\title{
Béla Soltész
}

\section{Migration and Diaspora Policies for Development in Latin America}

PhD Thesis 
Corvinus University of Budapest

Institute for International Studies

Supervisor: Prof. Attila Melegh PhD

(C) Béla Soltész, 2016. All rights reserved. 
Corvinus University of Budapest

Doctoral School of International Relations

International and Security Studies Subprogramme

Migration and Diaspora Policies for Development in Latin America

$\mathrm{PhD}$ Thesis

Soltész, Béla László

Budapest, 2016. 


\section{Table of contents}

0. Introduction

1. Migration, development and the state: a theoretical overview

1.1. The migration-development nexus in social sciences

1.1.1. Disciplinary approaches in the study of migration

1.1.2. Conceptual approaches in the study of development 31

1.1.3. Development in migration theory: the 'migration- 36 development nexus'

1.1.4. Challenge or opportunity? Migration and 41 development in an evaluative framework

1.1.4.1. Challenges and opportunities for the 43 country of destination

1.1.4.2. Challenges and opportunities for the 45 country of origin

1.2. Operationalizing the migration-development nexus: the 48 concept and role of migrant remittances

1.2.1. Six 'circles' of remittance definitions 49

1.2.1.1. Household remittances 50

1.2.1.2. Investment remittances 56

1.2.1.3. Community remittances 59

1.2.1.4. Social remittances 60

1.2.2. Effects of remittances on the micro and macro level 61

1.2.2.1. Public versus private allocation 62

1.2.2.2. Wellbeing versus development 64

1.2.2.3. Micro versus macro level effects 67

1.2.3. Remittances and the state 70

1.3. Diaspora and the state: transnational policies for 74 development

1.3.1. Diaspora, transnationalism and the state: a conceptual 76 overview 
1.3.2. Policymaking in the 'emigration state'

1.3.3. Diaspora policies for development: items of a 'policy 86 toolkit'

1.3.4. Evaluating the hypotheses, part 1: The conceptual 90 level

2. The Latin American diaspora: processes and institutions

2.1. The formation of the Latin American diaspora 93

2.1.1. The background of Latin American emigration trends 93

2.1.1.1. Coloniality and migration history in Latin 93 America

2.1.1.2. Demographic and economic trends in 96 Latin America

2.1.1.3. The social and political environment of 103 migration in Latin America

2.1.2. Trends and patterns of emigration and remittance 110 flows in Latin America

2.1.2.1. Trends of emigration in Latin America 110

2.1.2.2. Remittance flows in Latin America 120

2.1.2.3. Patterns of emigration in Latin America 125

\subsection{Diaspora institutions in Latin America 133}

2.2.1. Migration and diaspora on the Latin American 133 political agenda

2.2.1.1. The migration issue on the Latin 133 American political agenda

2.2.1.2. The birth of diaspora politics and diaspora 138 policies in Latin America

2.2.2. The institutional setting for diaspora policymaking in 142 Latin America

2.2.2.1. Specialized Diaspora Units in Latin 142 American governmental structures

2.2.2.2. Other governmental units involved in 153 
diaspora policymaking in Latin America

2.2.3. Outreach and activities of diaspora institutions in 157 Latin America

2.2.3.1. Consultation mechanisms between Latin 157 American governments and the diaspora

2.2.3.2. Activity areas of Latin American Diaspora 160 Units

2.2.4. Evaluating the hypotheses, part 2: The institutional 164 level

3.1. A framework for the analysis of diaspora policies

3.1.1. The opening of windows of opportunity

3.1.2. The 'deal' approach: political resources and 176 economic resources

3.1.3. Transnational spaces of policymaking

3.1.4. Setting up a framework for analysis of diaspora policies

3.2. Extending Latin American consular activities

3.2.1. The transformation of Latin American diplomatic and consular agendas

3.2.2. Extended consular activities and their implications on development in Latin America

3.2.3. Case study: the Mexican Consular ID

3.3. Fostering return migration and diaspora investment in 197 Latin America

3.3.1. Return migration to Latin America: why and how 198 migrants would go back?

3.3.2. Return migration programmes in the institutional 201 structure of Latin American governments

3.3.3. Case Study: The Ecuadorian Cucayo Fund 
3.4. Matching funds to community projects in Latin America 214

3.4.1. Latin American migrant associativism in the country 215 of destination

3.4.2. Migrant associations as development actors in Latin 220 America

3.4.3. Case study: the Mexican "3xI” Programme 224

3.5. Latin American diaspora networks 229

3.5.1. The highly qualified emigrants' role in Latin 230 American development

3.5.2. Diaspora networks for knowledge transfer to Latin 234 America

3.5.3. Case study: the Colombian Red Caldas and 237 Colombia Nos Une networks

3.6. Comparative analysis of Latin American diaspora policies 242

3.6.1. The policy window 243

3.6.2. The policy deal 246

3.6.3. The policy mechanism 248

3.6.4. The policy impact 251

3.6.5. The policy lifespan 256

3.6.6. Evaluating the hypotheses, part 3: The policy level 258

4. Conclusions and questions for further research 262

5. Annex: Diaspora Unit Survey among Latin American 272 Governments [DUS 2014-2015]

6. Bibliography 335

7. List of related publications of the author 358 


\section{List of tables, graphs and other illustrations}

\section{Tables}

Table 1. Migration and Diaspora Policies for Development in 20 Latin America: the structure of the thesis

Table 2. Evaluating the migration-development nexus: a 38 historical overview

Table 3. Evaluating the migration-development nexus: a 40 thematic overview

Table 4. Possible developmental effects of (im)migration for 43 countries of destination

Table 5. Possible developmental effects of (e)migration for 45 countries of origin

Table 6. Six 'circles' of remittance definitions 50

Table 7. Discrepancies between economic performance 52 indicators in remittance-recipient countries: three cases

Table 8. Discrepancies between the purchasing power of 53 remittances: four cases

Table 9. Types of remittances services by legal background, 56 provider, price and accessibility constraints

Table 10. Official (international) development assistance or 64 government-led development programme versus migrant remittances

Table 11. 'Wellbeing' versus 'development' approach of 66 remittances use

Table 12. International average salary income comparison: 67 Average nominal and PPP net monthly wages in USD in three Latin American countries and the United States

Table 13. The diaspora's economic resources from the 82 perspective of the state (of origin) 
Table 14. The state (of origin)'s political resources from the 83 perspective of the diaspora

Table 15. The country of origin's tools for diaspora engagement 88 policies

Table 16. Visa regimes for Latin American citizens 106

Table 17. Net Migration Rate in Latin American countries per 5- 111 year periods

Table 18. Emigrant stock from Latin American countries, total 112 values and as compared to usually resident population (\%) (2013)

Table 19. Latin American immigrant stock in the top 20113 destination countries (total values and percentage in total stock, 2014)

Table 20. Inflow of remittances to Latin America (total and as \% 120 of GDP, in current million USD, 2013)

Table 21. A possible categorization of Latin American countries 128 based on their level of development

Table 22. A possible categorization of Latin American countries based on the effectiveness of their governance

Table 23. A possible categorization of Latin American countries based on the relative economic importance of their diaspora

Table 24. A possible categorization of Latin American countries based on the economic importance of their diaspora and the governmental capabilities for diaspora policymaking

Table 25. Double citizenship regimes and extraterritorial voting 140 rights in Latin America

Table 26. Laws and policy documents outlining migration and/or 144 diaspora policies in Latin America

Table 27. Specialized institutional bodies responsible for 147 immigration and emigration/diaspora issues in each Latin American country 
Table 28. Main characteristics of specialized institutional bodies 151 responsible for emigration/diaspora issues in each Latin American country

Table 29. Migration- and diaspora-related interministerial 154 consultative units in Latin America

Table 30. Consultation mechanisms between Latin American 158 consulates abroad and members of the diaspora

Table 31. Main activity fields of the Diaspora Units

Table 32. Mexico's main federal government programmes 162 aiming the diaspora

Table 33. Background for diaspora policies and achievements in 165 diaspora policies compared

Table 34. Overview of the structure of policy areas, remittance 168 types and case studies of Chapter 3.

Table 35. Levels of action and channels of policymaking in 179 diaspora politics

Table 36. Diplomatic and consular activities of the country of 188 origin in order to address the needs of the diaspora

Table 37. Consular identification cards issued by Latin American 190 countries

Table 38. Returnee ideal types according to their supposed 200 effects on development and their policy needs

Table 39. Types and examples of return migration incentives in 202 Latin America

Table 40. Tax exemptions for returning migrants in Latin 204 America

Table 41. Fostering return migration through agreements: the 205 case of Uruguay

Table 42. Fostering return migration through comprehensive 206 programmes: the case of Ecuador, Colombia and Peru (2011)

Table 43. Policy consequences of the reorganization of the 214 Ecuadorian institutional framework related to return 
migration

Table 44. Ideal types of migrant organizations and their possible 219 benefits to the government of the country of origin

Table 45. Activities of migrant associations for the development 223 of the country of origin and their cooperation with the governmental level

Table 46. Development contribution models from the highly 233 skilled diaspora members to the country of origin

Table 47. Scientific networks for Latin American diasporas, 235 administered from the country of origin

Table 48. Policy window of four selected Latin American 243 diaspora policies

Table 49. Policy deal of four selected Latin American diaspora 246 policies

Table 50. Policy mechanism of four selected Latin American 248 diaspora policies

Table 51. Policy impact of four selected Latin American diaspora 251 policies

Table 52. Policy lifespan of four selected Latin American 256 diaspora policies

Table 53. Hypothesis 1: "None of the developmentally relevant 263 diaspora policies of Latin American governments can change the ongoing migratory trends significantly"

Table 54. Hypothesis 2: "Diaspora policies of Latin American 265 governments create a transnational space in which developmentally positive economic and social transfers can take place"

Table 55. Hypothesis 3: "Latin American governments as well as the diaspora can obtain political, economic and symbolical benefits from diaspora policies" 


\section{Graphs}

Graph 1. Left: Population growth rate, Right: rate of urban 98 population. Both sides for three reference countries (Argentina, Guatemala and Mexico) and Latin American average.

Graph 2. GDP per capita (in current USD) for three reference 100 countries (Argentina, Guatemala and Mexico), Latin American average and world average.

Graph 3. Share of industry in GDP (full line) and unemployment 101 rate (dotted line) in Latin America (top left), Argentina (top right), Mexico (bottom left) and Guatemala (bottom right).

Graph 4. Assessment of the development of Latin American 104 countries, survey results, 2000-2013.

Graph 5. Trust in the state and in the public administration in 105 Latin American countries (2013)

Graph 6. Plans about moving abroad, survey results (2003-2013) 108

Graph 7. Share of destination countries/regions for Latin 118 American emigration (2013)

Graph 8. Diversity of destinations for Latin American emigrants 119 (by country of origin, 2013)

Graph 9. Remittances as a percentage of the GDP of Latin 121 American countries (in current total USD, 2013)

Graph 10. Inflow of remittances to Latin America, 1970-2014

Graph 11. Remittance inflows to and FDI in Latin America (top left), Mexico (top right), Argentina (bottom left) and Guatemala (bottom right) 
Maps

Map 1. Relative and absolute values of the emigrant stock of 114 Latin American countries

Map 2. Share of destination countries/regions for Latin 116 American emigration in the total emigrant stock of countries of origin (2013)

\section{Case Study Overview Template and Tables}

$\begin{array}{lll}\text { Template 1. } & \text { Framework for the case studies } & 182\end{array}$

Case Study Overview Table 1. The Mexican Consular ID 192

Case Study Overview Table 2. The Ecuadorian Cucayo Fund 208

Case Study Overview Table 3. The Mexican “3x1” Programme 224

Case Study Overview Table 4. The Colombian "Red Caldas" and 237

"Colombia Nos Une" networks 
"In August 2000, the [Peruvian migrant] groups were visiting the pueblo [i.e. their hometown in Peru, the municipality of Huachac] to take part in the annual celebrations of the district's Patron Saint (Santo Domingo de Guzmán). The mayor invited the leaders of each migrant club to attend a special meeting at the municipality to discuss ideas for local development projects and to suggest particular projects for which each group would be responsible. The interest was great and many of the leaders and key "movers" from the three migrant groups arrived with ideas for priority projects.

However, in putting forward their priorities, each revealed their own ideas of what "development" entailed. All showed interest in maintaining links and strengthening their own internal solidarity as migrant clubs, but in the end their ideas for local projects diverged strikingly.

The Italian group [i.e. the migrants from Huachac who lived in Italy] opted to fund an up-to-date telecommunications center in Huachac with a central telephone exchange and internet booths for public use. This they saw as a practical way of strengthening their ties with family and friends back home, thus making it easier for family members to make calls or send emails from the village.

The American "Huacquinos" [i.e. the migrants from Huachac who lived in the United States] chose the idea of building a commercial center modeled on some U.S. type of mall or gallery of shops and service centers, including restaurants, grocers, and stationery shops.

And those from Lima [i.e. the migrants from Huachac who lived in Lima, Peru] argued for an Instituto Superior [i.e. a high school] that would fill a major gap in the provision of educational courses and vocational training for the young of the municipality. This, they argued, would better prepare them for obtaining skilled and professional jobs. The argument was of course premised on the notion that it was principally through education that one achieved social mobility, just as they themselves had done in the 1960s and 1970s. Yet, in arguing this in 2000, they chose to ignore the fact that, in the 1980s and 1990s, most professionals in Peru had in fact suffered a real decline in their incomes and purchasing power.

(...) [T] hese contrasting development narratives expose the self-images of each group and how they envisage the needs of the village. At the end of the meeting, each migrant group was required to pledge itself to collect a certain sum of money earmarked for a specific local development project. These offers were then recorded formally in the Libro del Oro (the village financial ledger) as a way of sealing the agreements."

(Long, N. [2008], p. 56, citing Tamagno, C. [2003], pp. 315-330) 


\section{Acknowledgements}

I would like to take the opportunity to thank the professional support of my supervisor at the Corvinus University of Budapest, Attila Melegh; my supervisors at the University of Chile (Santiago, Chile) and the Mexiquense College (Toluca, Mexico) where I spent 1-1 semester as an exchange student in the 2010/2011 school year, Horst Nitschack and Paolo Riguzzi, respectively; the researchers of the Mexico State University (Toluca, Mexico), Norma Baca and Francisco Herrera, to whom I could join on their fieldwork in the migrant-sending communities of Tonatico, Las Vueltas and Pachuquilla in May-June 2011; and my colleagues at the Hungarian Central Statistical Office and the Demographic Research Institute, with whom I was working on the "SEEMIG - Managing Migration and its Effects in South East Europe" project between 2012 and 2014. A special acknowledgement is for the government officials of ten Latin American countries who participated in my Diaspora Unit Survey. I am also very grateful to Zsanna Puzsér for her patience and support. 


\section{Introduction}

\section{Topic}

This $\mathrm{PhD}$ thesis analyzes the policies pursued by Latin American governments in order to obtain developmentally useful contributions from their diaspora, i. e. from emigrants who were born in Latin America but live elsewhere.

In the thesis, I conceptualize and examine (numbers in brackets indicate chapters):

(1.1) the understanding of developmental effects of migration in the literature,

(1.2) economic contributions of migrants (remittances), and

(1.3) policies that can capture, enhance or orientate these contributions.

I observe how Latin American countries were:

(2.1) affected by mass emigration, and

(2.2) building institutions to tackle with this process.

Finally I analyze, with case studies, four relevant policy areas:

(3.2.) Extended consular activities for facilitating remittance flows,

(3.3.) Investment programmes for returning migrants,

(3.4) Matching funds programmes for community remittances, and

(3.5) Diaspora networks for knowledge transfer.

Case studies are built around a common structure, presented in (3.1) and compared in (3.6).

\section{Relevance and novelty of the thesis}

Middle- and lower-middle income countries all around the globe are getting increasingly affected by outward migration processes. While it is debated whether the overall effects of mass emigration are harmful, neutral or beneficial to their development, it is sure that several mechanisms exist to design and implement policies that capture economic contributions from emigrants and channel them to local development projects. 
Systematic research on migration policies and their institutional background is a rather new area of studies, and the literature focuses mostly on immigration, not on emigration policies. This thesis is among the rather limited number of works that observe the issue from the perspective of the government of a country from where a large number of people emigrate.

The novelty of this thesis is that it analyses, in a common conceptual framework, the different policies that Latin American countries have implemented in order to get some developmentally useful economic input from their diaspora. While many analyses exist on parts of the topic, these are generally written focusing on a given country or region, or on an aspect other than policymaking.

The thesis is, therefore, an evaluative synthesis of the possibilities of the government of a country with significant emigration rate and with a growing diaspora. Although it contains only Latin American cases, it can be understood as a source of information and inspiration for scholars and policymakers in the field of diaspora policies in other regions of the world, including Hungary the whole Central and South Eastern European region. See the "Questions for further research" chapter (4.2) at the end of the thesis.

\section{Hypotheses}

The hypotheses I intend to prove in this thesis suppose that, although policies for obtaining developmentally useful contributions from emigrants are conceived in Latin America with the promise of reducing emigration through development projects,

(H1) none of these policies can change the ongoing migratory trends significantly, but

(H2) they create a transnational space in which developmentally positive economic and social transfers can take place, of which

(H3) the government of the country of origin as well as the diaspora can obtain political, economic and symbolical benefits.

To prove these hypotheses, the social, political and institutional environment of Latin American diaspora policies is described from a theoretical (Chapter 1.) and empirical-institutional (Chapter 2.) approach - the latter containing the analysis of the migration processes and the institutional evolution of the diaspora policy 
frameworks. Then, through concrete policy cases (Chapter 3.), the relationship of these policies is presented with $(\mathrm{H} 1)$ the migratory trends, $(\mathrm{H} 2)$ the transnational belongings of migrants who contributed, and the $(\mathrm{H} 3)$ benefits that both counterparties can gain out of these interactions.

Hypotheses are evaluated three times in the text, at the end of every chapter. In Chapter 1.3.4 they are contrasted to the findings on the conceptual level, while Chapter 2.2.4 deals with the institutional level and Chapter 3.6.6 with the policy level, respectively. These three chapters are brought together in a final Conclusion in Chapter 4.

\section{Data sources}

The thesis relies on statistical data, primary sources and secondary sources of information and theoretical works of renowned scholars.

Most of the statistical data are retrieved from databases of the World Bank and the United Nations. The commensurability of data from different sources is checked. Data on migrant stocks and flows are given using the country of birth approach.

Primary sources of information include legal documents and the results of a survey, to be referred as Diaspora Unit Survey [DUS, 2014-2015]. For the latter, I sent out a questionnaire for all Latin American governments through their embassies accredited to Hungary. Ten countries provided information. The compilation of the responses is presented at the end of the thesis, in the Annex.

Secondary sources of information include project evaluations, fieldwork relates, research reports and other texts written by scholars and practitioners about the specific policies presented and analyzed in the thesis. When it was necessary, news articles and government website information were also consulted.

Finally, theoretical works include texts from internationally renowned scholars (mainly from the English-speaking academia) and local authors (from the countries where the analyzed policies are implemented). A balance of sources in English and in Spanish was sought when compiling the bibliography, completing the list with Hungarian authors when possible. 
Table 1. Migration and Diaspora Policies for Development in Latin America: the structure of the thesis

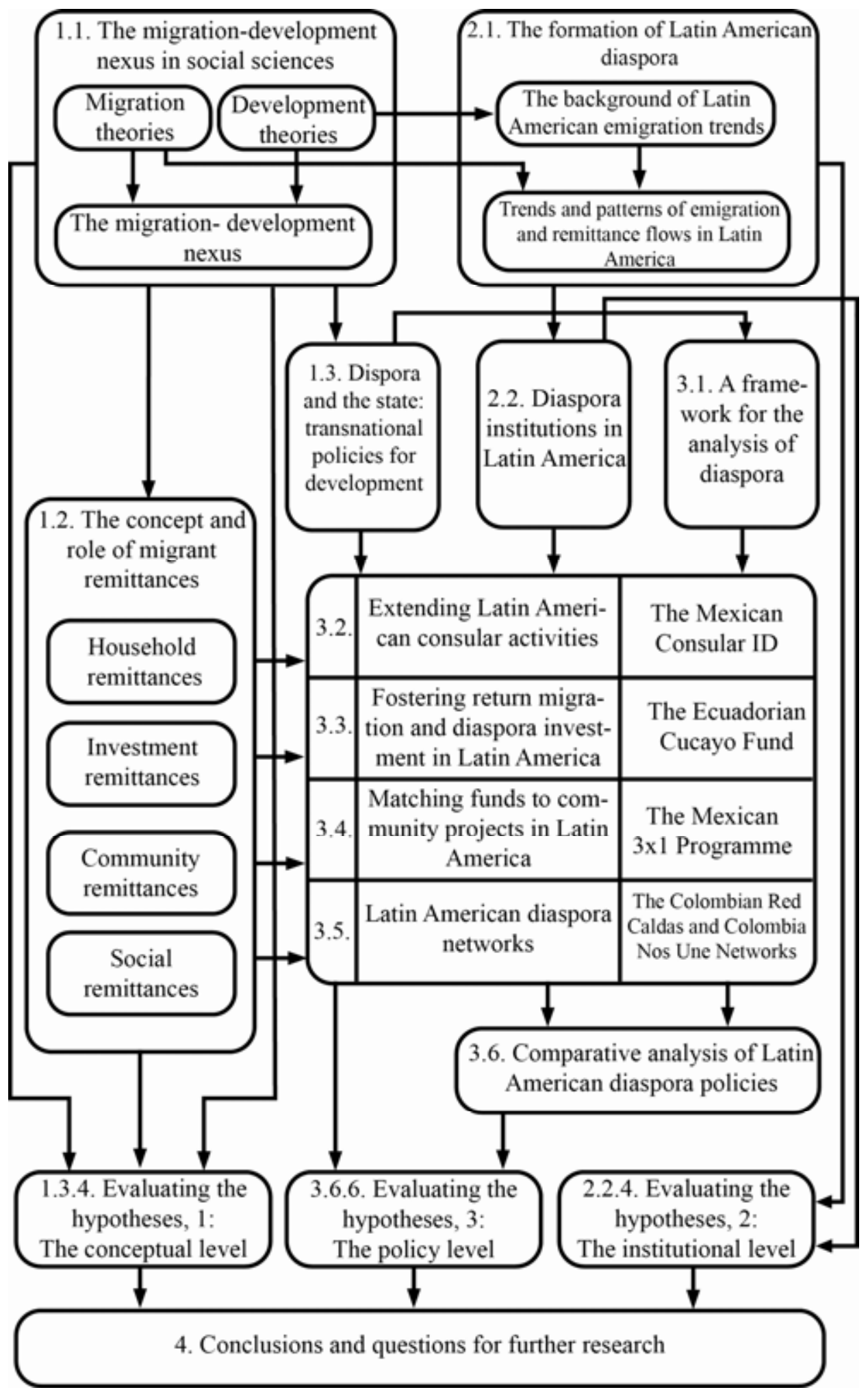




\section{Methodology and structure}

The thesis relies on literature analysis, the analysis of primary sources (statistical data and survey data) and the comparative analyses of policy cases within a framework built from different relevant conceptual notions found in the migration and development literature.

The three chapters of the thesis (numbers in brackets refer to chapters) contain threads of arguments leading: (1) from the general theories concerning migration and development through the features and effects of remittances to the possibilities of the governments of countries of origin to design and implement policies to address the topic; (2) from the overall trends of migration and remittance flows in Latin America to the institutional and policy settings of Latin American countries regarding diaspora policies, (3) from the identified developmental challenges of mass emigration to concrete policies, programmes and projects in Latin America.

The thesis builds a conceptual framework relying heavily on theoretical works of two researchers of the International Migration Institute at University of Oxford: Hein de Haas [2008; 2010; 2011] and Alan Gamlen. [2006; 2008, 2010, 2014]

Chapter 1 summarizes what migration theory says about the 'migrationdevelopment nexus' using de Haas's analysis of the developmental discourse [2008]. Developmental effects are presented in a challenges versus opportunities framework and one part thereof (opportunities for the country of origin) is chosen for further analysis, as the main field of diaspora policies for development. The main 'opportunity' for countries of origin, the concept of 'remittances' is presented in details, in a model of 'six circles of remittances definitions'. After that, it is described how these transfers can be reached by policies, using Gamlen's notion of "extending rights" and "extracting obligations" [2006], from the point of view of the government of the country of origin.

Chapter 2 describes the historical, demographic, economic, social and political background of emigration from Latin America, followed by the presentation of the actual emigration trends (and their effects to Latin American societies), in order to present the historical circumstances under which policymaking got its start. Then, the relative importance of the emigration issue and the governmental 
capacities to implement policies are assessed, in order to analyze the capabilities of the given government to tackle with the issue. Finally, an institutional history of the formation of Diaspora Units within Latin American governments (the Ministries of Foreign Affairs, more precisely) and the analytical presentation of the most important laws, institutions, mechanisms and an overview of the main fields of activity completes the picture.

Concrete public policies and case studies are analyzed in Chapter 3. They are selected as a function of their relevance on development: the four policy areas which were defined and described by Gamlen [2006] and which could be connected to the four types of remittances described in 1.2, are in the focus of the analysis (see Table 15).

Analysis for each policy area follows a similar logic: first, theoretical notions and concepts are cleared. Second, all relevant public policies of the given category, that can be found in Latin America, are presented in a taxative way. Third, a relevant case study on a concrete policy programme is exposed.

The four policy areas and the case studies are the following:

- Special consular activities: "Matrícula Consular" or Consular ID Card, Mexico.

- Investment programmes: "Cucayo Fund" matching funds scheme for returning migrants, Ecuador.

- Remittance capture programmes: "3x1" matching funds scheme for collective remittances, Mexico.

- Knowledge transfer programmes: "Red Caldas" and "Colombia Nos Une" scientific and business networks, Colombia.

Case studies were chosen with the objective of showing the most representative piece of their kind for each policy. Also, they represent four types of remittances involved: household, investment, community and social remittances, respectively.

The formative period of each concrete policy is analyzed according to Kingdon's concept of "policy windows" [Kingdon, 1984], while the evaluation of their basic idea (in other words, the 'deal' between the state and the migrants) relies 
on Gamlen's “extending rights - extracting obligations" dichotomy. Policy mechanisms are presented in a flowchart where six different types of actors are presented. Finally, policy evaluation is elaborated in a retrospective way for the achievements of these policies since their introduction, and their perspectives for further development are also assessed.

A comparative analysis closes Chapter 3, in which the four case studies are compared, following the structure of their template.

Final conclusions are drawn in Chapter 4, feeding from the three evaluative chapters of the hypotheses: Chapter 1.3.4 for the findings on the conceptual level, Chapter 2.2.4 for the institutional level and Chapter 3.6.6 for the policy level, respectively.

\section{Main findings}

Through evaluating the three hypotheses on the three analytical levels (conceptual, institutional and policy level), the following statements can be made:

(H1): "None of the developmentally relevant diaspora policies of Latin American governments can change the ongoing migratory trends significantly" can be declared as valid on the concrete policy level. Theoretically, a well-managed, well-funded, well-focused government unit could implement diaspora policies which have a significant impact on the migratory flows, i.e. retaining or bringing back more people through diaspora-driven development programmes. In the practice, however, no Latin American country has been able to do this: no significant change in emigration stock or flows could be identified through the implementation of diaspora policies.

(H2): "Diaspora policies of Latin American governments create a transnational space in which developmentally positive economic and social transfers can take place" is valid in all three levels of analysis. Countries identified as 'engaged' and 'capable' for undertaking diaspora policy activities for development, have created Diaspora Units, diaspora councils and several concrete outreach programmes. The 'transnational space' came into being and was filled with content. Increase in (household, investment, community and social) remittances has been identified in all four policy areas and case studies, respectively. 
(H3): "Latin American governments as well as the diaspora can obtain political, economic and symbolical benefits from diaspora policies” can also be declared as valid, with the restriction that the diaspora has less 'objective' benefits from the cooperation, than the government of the country of origin. While the latter can calculate with more consumption to be taxed, and more additional sources for financing institutions or meso level actors that otherwise would need transfers from the central budget, members of the former will receive legal and administrative help at the consulates, if needed, and assistance for the return if they wish to do so. Otherwise, the benefits they have from cooperating are mostly symbolical.

(4.): A fourth, cross-cutting finding is that among Latin American countries, it is not the countries with the highest emigration rate are those which have created the largest diaspora institutions and the most overarching policies. There is a group of countries with high emigration rate but with low governmental capacities (e.g. Bolivia, Honduras) where no significant diaspora institutions and policies were created. Another group of countries had the government capacities, but the emigration issue was not seen as very relevant, thus diaspora institutions and policies were also not created - or were created only for specific groups, such as the highly skilled emigrants (e.g. Brazil, Chile). Finally, a group of countries with medium to high emigration rate and medium governmental capacities created the most innovative and robust diaspora institutions and policies (e.g. Mexico, Ecuador).

\section{Definitions and delimitations}

The title of this thesis is "Migration and Diaspora Policies for Development in Latin America", in which the concepts are defined as follows:

By migration, if not indicated otherwise, emigration is understood here, i. e. migratory flows from Latin American countries to other countries ${ }^{1}$, most importantly to the United States and Spain. Intra-regional migration (between different Latin

\footnotetext{
1 The term 'country of origin' is used for a country where a migrant was born (country of birth approach), and 'country of destination' stands for the country where the migrant lives (country of usual residence approach). If a Mexican person migrates to the United States, Mexico is the country of origin and the United States is the country of destination. These terms are used consequently this way, even in the case of remittances and migrant investments, when flows of people and money are opposite, i. e. the money comes from the 'country of destination' and goes to the 'country of origin'.
} 
American countries) is included in the topic, while internal or domestic migration (within the boundaries of a given Latin American country) is not included.

By diaspora, the totality of the migrants are understood, i.e. the people who were born in a given Latin American country and live in another country, regardless of their citizenship and legal status (documented or undocumented). In other words, migrants are counted according to the country of birth approach. Accordingly, members of the 'second generation' (i. e. the children of migrants) are not considered as migrants, although they might fall under the scope of certain diaspora policies. In these cases, their inclusion to the concept of diaspora is explicitly mentioned in the text.

By policies, institutionalized and regularly implemented measures are understood, while 'diaspora policies' stand for policies which are managed by the government of the country of origin and aims at the diaspora. Other measures by other actors (e.g. NGOs, international organizations, companies) are not included.

By development, quantifiable material dimensions of the enhancement of individual human capabilities are understood. Non-quantifiable and non-material dimensions are not included.

Finally, by Latin America, the Spanish- and Portuguese-speaking sovereign nations of the Americas are understood, 19 countries altogether (see 2.1.). A special emphasis is given to countries with high emigration rate and active policymaking on diaspora affairs, most importantly Mexico, Ecuador, Peru and Colombia.

Regarding the delimitations of the time period of the analysis, it covers approximately 25 years, between the structural adjustments of the late 1980s and the present (2015, or until the latest point of available data).

Regarding the delimitations of the disciplinary field, this thesis belongs to the realm of Political Sciences - International Relations, more precisely, as it covers governmental activities which aim at subjects who usually reside on the territory of other sovereign countries. However, as these policies are not always including the government of the country where migrants live, it is more precise to speak about transnational, rather than international policymaking in these cases (see 1.3.). Besides Political Sciences, the thesis relies heavily on Political Economy on one side and Social Anthropology on another. Economic indicators and anthropological relates are both used when appropriate. 
Regarding the analytical content, the thesis does not discuss migration theory, nor development theory in details. Instead, it covers the intersection of the two domains - the so-called 'migration-development nexus'. The thesis does not contain quantitative analysis of the developmental effects of migration and remittances. Instead, it focuses on the formation of political institutions and organized governmental activities (the so-called 'diaspora policies'). 


\section{Migration, development and the state: a theoretical overview}

\subsection{The migration-development nexus in social sciences}

Migration as a social phenomenon is as old as humanity itself. The study of migration is also an old concern for social scientists. However, with the diversification of social sciences, each discipline has fixed its own focus and methodology to interpret and to analyze the migratory phenomena.

The same can be said to the concept and study of development. Human societies have always pursued to develop themselves in order to achieve an everdistant ideal state of things. Following the Enlightenment, however, an economic approach became common to conceptualize and, later, to measure development ruling out other, non-material approaches. Despite this, different currents within Development Economics have framed and understood the root causes, processes and objectives of development.

Understanding the migration-development nexus is, therefore, a function of understanding the disciplinary plurality of Migration Studies and the conceptual plurality of Development Studies. In the following, both study areas are described briefly with the objective of finding the right scope and approach for the purposes of the present thesis. Next, the 'migration-development nexus' is presented, as an increasingly discussed field of study on its own right. Finally, the thematic content of the 'migration-development nexus debates' is synthesized in the form of a matrix of positive and negative developmental effects of migration, both for countries of origin and countries of destination.

\subsubsection{Disciplinary approaches in the study of migration}

International migration is a complex phenomenon that has been approached by practically all branches of social sciences. Theorizing migration is, therefore, an intellectual bridge-building between different disciplines. Depending on the concrete question, one can easily arrive to different realms. The root causes of migration are mostly investigated by Economics, while the concrete migratory process and the 
inclusion or exclusion of migrants in the country of destination is a field of study of Sociology and Anthropology. Regulating migratory flows is a problem that belongs to Law and Political Sciences, while the long-term developmental effects of migration are observed by scholars of Demography and, again, Economics. Finally, History and Geography also have their say when it comes to concrete spatial and historical analysis. [Massey et al, 1993; Brettel - Hollifield, 2008; de Haas 2008]

Disciplinary plurality also means a plurality of focus. First, Economics and Demography are interested in the overall process of migration and have a rationalist approach, seeing the individual migratory decision as a utility-maximizing behaviour. Migration is seen as a macro-level process that is a sum of individual responses to a developmental challenge, that is, the difference in wages and living standards between different countries. Impacts of migration on the population's size, structure and economic performance are the main concerns.

Second, Sociology and Anthropology have a structuralist rather than a rationalist approach. As opposed to neoclassical Economics' micro and macro theories that focus on labour supply and demand, several theories stemming from sociologists and anthropologists underline the embeddedness of migration in a wider societal context. The network theory and the cumulative causation theory, for instance, see migration as part of an adaptation process of the individual to the structures of inclusion and exclusion, rather than an economically rational choice. The main concern of these currents of thought is how migrants can be incorporated to the country of destination and what social and cultural challenges does it imply.

Third, Law and Political Sciences have an institutional approach, focusing on the state and its institutions that define the outlines for regulating migration. Questions of sovereignty and control are in play, i. e. how undesired migrants can be kept out and desired migrants can be let in, in an otherwise liberal state that respects the civil rights of the individuals who stay in its territory. This approach is a normative one, and is linked to the concept of security, understanding migration as a challenge for legislation, police and border patrol bodies. In many ways, the refugee question also belongs to this realm.

Besides History and Geography (most importantly Zelinsky [1973]), it was the economics' approach that prevailed ever since migration appeared as an object of research for social sciences. Following a well-known synthesis on migration theories [Massey et al, 1993], it can be stated that neoclassic economic theory on factor 
supply and demand was the first comprehensive theory applied for international migration. [Sjaastad, 1962; Todaro, 1969, 1976] In general, neoclassical theory saw migrants as profit-maximizing, fully rational individuals (micro theory) and countries as internally homogeneous units of wage levels, between which migration would work as a driver for equilibrium. A radical shift from this approach, the New Economy of Labour Migration [Taylor, 1986; Stark - Taylor, 1991] put the focus on the household as the unit of analysis, understanding migration as a coordinated coping mechanism with uncertainties for a group of people, rather than the outcome of individual cost-benefit analyses. Still, it remained within the Economics paradigm, and so did Piore's [1979] dual labour market theory (although the latter incorporated the notion of social structures beyond economic stratification).

Sociology and Anthropology came into the picture in the late 1980s [Taylor, 1986; Massey, 1990] with network theory and institutional theory. Not independently of the economic growth and the rising of living standards in Western Europe and the United States, and the comparative decline of many postcolonial nations, understood by Wallerstein's world system theory [1979] as a core-periphery opposition, the demand for physical workers resulted in an ethnically more heterogeneous inflow of immigrants, many times following postcolonial (Western Europe) or neocolonial (United States) structures of domination. Even though the whole process was intended to be temporary and strictly labour-driven, as Swiss novelist Max Frisch put it in an oft-quoted sentence, "we asked for workers and we got people instead." [cited by Hollifield, 2006, p. 183] Many guest workers stayed in the country of destination and a permanent non-Western immigrant population started to evolve in all Western countries. The 'second generation' issue also appeared, i. e. those children of immigrant ancestry who were born there but were, in many ways, treated as foreigners because of their appearance or cultural characteristics.

Given the circumstances described above, a change in perspectives became necessary. While the general approach to migration was predominantly economic, in the 1970s and 1980s it adopted a societal tone. Originally, the postcolonial immigration was treated in an "assimilationist" framework, while guest workers faced "differential exclusion." [Schierup et al, 2006, pp. 41-42] That is, workers from the ex-colonies were perceived as culturally non-different, while guest workers were implicitly excluded from the spheres of society that were not directly related to work. These approaches became unsustainable, and gave rise to multiculturalism, an 
ideological project translated to public policies that aimed to accept immigrant groups and grant them equal social and cultural rights. [Kymlicka, 1995]

Western European governments slowed down the recruitment of foreign labour as a consequence of the 1973 oil crisis and a very similar process took place in the United States where the Bracero programme, the major framework providing landowners with cheap seasonal workers from Mexico, was unilaterally finished already in 1964, and restrictions were gradually implemented in the following decade. From this point on, the migration issue started to gain a third (security) perspective, with the above mentioned concerns on sovereignty and border control. This perspective became predominant with the growing instability of the economic bases of Western welfare regimes towards which immigration, however, kept on going due to family reunification. [Castles - Miller, 2009]

Another, equally or more important feature of the 1990s was that immigration flows to the Western world became detached from the previous "historical ties". The neoliberal economic model became prevalent in the majority of the world's countries and free trade and foreign investment contributed to the "uprooting of people" [Sassen, 2006, p. 600], i. e. global competition broke the backbone of local economies in many developing countries, unemployment rates skyrocketed, and many people saw migration as the only way out from misery. In the meantime, immigration legislation became extremely strict in the United States (especially after the 9/11 attacks in 2001), the Bush administration's "axis of evil" discourse fuelled anti-Muslim (and anti-Third World, for that matter) sentiments, and the threat of infiltrating aliens became a part of the American and the European political discourses, serving as a base for practiques of orientalism in a Saidian sense towards immigrants [see Said, 1977] and a wave of racism/xenophobia. [Castles - Miller, 2009]

Political Sciences (including International Relations) have, with an expression of sociologist Theda Skocpol, "brought the state back in" [Skocpol, 1985], i. e. set the focus on the interests and capacities of the state (and its constitutive elements: the bureaucracy, the political parties etc.) regarding the management of international migration. In many cases the interest of political scientists - especially in the realm of Security Studies - turned towards migration due to the perceived internal and external threats and the apparent failures of border control and social integration. A notorious case is Samuel Huntington's “Who Are We? The Challenges to America's 
National Identity" [Huntington, 2004] which portrays immigration - especially Hispanic immigration - to the United States as a threat to national identity and security, urging the state to take actions to prevent the supposed negative effects of this challenge. A significant stream of literature followed Huntington's line.

However, another current started to emphasize the role of states from a different perspective: namely, their responsibility to tackle the root causes of migration at the countries of origin, in order to make migration 'pressure' decrease on both sides of the process, i.e. in the countries of origin and in the countries of destination. The "migration-development nexus" as coined in a paper of Sørensen et al [2002], set the scope at the intersection of Migration Studies and Development Studies and, at the same time, opened the path for an approach which is also followed by this thesis - namely, the perspective of the country of origin of migrants.

In the following, the relevant currents of the (equally broad and complex) development literature are presented briefly, in order to conceptualize "development" for the purposes of this thesis, i.e. the analysis of development-related Latin American diaspora policies.

\subsubsection{Conceptual approaches in the study of development}

The concept of development has been central to many areas of thought, focusing on different aspects of the concept. Besides its individual spiritual and psychological layers of meaning, 'development', when applied to human societies, is mostly related to economic concepts, such as living standards, production and growth.

While theorizing on economic development is as old as the discipline of Economics itself, being already present in Adam Smith's Wealth of Nations, Development Economics as a separate field of study emerged only after World War II. In their classical work, Todaro and Smith define it as "[t]he study of how economies are transformed from stagnation to growth and from low-income to highincome status, and overcome the problems of absolute poverty." [2011, p. 8.]

Beyond the narrow 'economical' scope, the focus of 'Development Studies' includes research on the "social system", i.e. "[t]he organizational and institutional structure of a society, including its values, attitudes, power structure, and traditions" [Todaro - 
Smith 2011, p. 13.] Still, Economics is the lead discipline. Therefore, contrary to Migration Studies, Development Studies is firmly rooted within Economics.

However, when defining 'development' as a concept, even economists feel the urge to include constituent parts of the definition from outside the strictly delimited realm of Economics. Perhaps the best-known approach is Amartya Sen's classical definition of development as "the process of expanding the substantive freedoms that people enjoy" [Sen, 1999, p. 3], i.e. it is not income, utility or status that counts, but what a person does (or can do), which might be strikingly different from what could be deduced from economic indicators. In Sen's notion on "human capabilities", it is "the ability of human beings to lead lives they have reason to value and to enhance the substantive choices they have" [Sen, 1997, p. 1959] that counts as development. Thus, not material production or the growth thereof is what counts, but the "freedoms" and "capabilities" people enjoy as its consequence. Based on Sen's approach, Todaro and Smith give a synthesis definition of development as "[t]he process of improving the quality of all human lives and capabilities by raising people's levels of living, self-esteem and freedom". [2011, p. 5.]

Later on, Sen went even further. Another theoretical work of his, elaborated with Joseph Stiglitz and Jean-Paul Fitoussi [2009], includes happiness and other personal aspects of human existence in a broader concept of "subjective well-being", such as "cognitive evaluations of one's life, happiness, satisfaction, positive emotions such as joy and pride, and negative emotions such as pain and worry." [Stiglitz et al, 2009, p.16.]

For the purposes of this thesis, 'development' is understood as a substantially economic term, in line with Todaro and Smith's synthesis definition cited above, although accepting the relevance of the enhanced definition of the Stiglitz-SenFitoussi Commission. Within the realm of Economics, however, no single current of thought can or should be chosen as "the" followed approach. With the benefit of hindsight, it can be stated that Development Economics must be eclectic, due to the heterogeneity of the 'developing world' itself and the complexity of the 'development process'.

Historically speaking, there have been at least six different currents within Development Economics that are worth mentioning. First, in the general optimism of the 1950s it was believed that developing countries will sooner or later go through the same "linear stages of growth" that developed countries had already gone 
through. Most importantly, Walt W. Rostow and his eponymous theory [1960] held this view, while another approach, the Harrod-Domar model [see Hagemann, 2009] set a relationship in which the growth rate of production is a direct function of national savings and an inverse function of the national capital-output ratio, thus reducing the problem to a simple equation of capital allocation.

Contrary to what these models anticipated, i.e. that sooner or later every poor country would become richer, in the 1960s and 1970s very few postcolonial nations showed signs of stable and equitative growth. The enthusiasm of post-WWII times and decolonization thus started to fade and give place to doubts. The second current of Development Economics therefore emphasized the importance of industrialization and "beneficial" development patterns to follow, as opposed to remaining stuck in the low productivity rate of subsistence economies. Using modern economic theory and statistical analysis, the Lewis two-sector model [first described in Lewis, 1954] understood development as a transition to an industrial mode of production in which the surplus labour from the traditional (agricultural) sector is transferred to the modern (industrial) sector, leading to growth in wages, production and standards of living. In another set of analyses by Hollis B. Chenery [1979], referred as "Patterns of development", the 'typical' patterns of successful modernization were identified and theorized. While more sophisticated than the linear models, these approaches also viewed development as a primarily endogenous subject, with very little influence of the surrounding international context.

The third strand of thought, however, took a revolutionary stance. The "dependency" theories based their arguments on the unequal and exploitative relations of the world economy as a source for the lack of development. In contrast to the previous current, dependency theorists conceptualized "underdevelopment" as opposed to "backwardness", as they did not accept neither the premise of the linear stages, nor the endogenous nature of development (or lack thereof). Instead, they saw the underdevelopment of the "Third World" as a direct (and simultaneous) consequence of the development of the "First World". In a highly unequal international system (of which the "Second", i.e. the state socialist block was seen as absent or isolated), the exploitation of the "periphery" by the "core" (in Wallersteinian terms), was understood as the main reason for the continued bad economic performance of poor countries. It had a large effect on Latin American social sciences, as many of the leading scholars of this current - Andre Gunder Frank 
[1966, 1969], Oswaldo Sunkel [1969], Theotonio dos Santos [1970], Raúl Prebisch [1982] - came from, or lived in the region (see chapter 1.1.3.).

This approach was defied by a fourth one, the so-called "neoclassical counterrevolution" which took place in the 1980s, seeing uneven development or stagnation as a consequence of market distortions and coordination failures. It was influenced by the bad performance of those developing countries that tried to pursue economic policies of import substitution or partial or total autarky. On a theoretical level, public choice theory [Grindle - Thomas, 1991] and free market analysis brought the focus back from the international system to the domestic stock and capital markets, based on the Solow neoclassical growth model [1956, for an analysis of its afterlife see Hagemann, 2009] or works of scholars as Deepak Lal [1985], Béla Balassa [1989] and Jagdish Bhagwati [1993], among others. On a policy level, it had its main (domestic) recommendations synthesized in the shortlist known as the "Washington Consensus" by John Williamson [1990], arguing for trade and exchange rate liberalization, cutbacks of public spending and privatization as key pieces for economic development.

Fifth, the 1990s and 2000s brought an eclectic approach of mainstream publications deliberately using elements of the former three currents of thought. While neoclassical (or neoliberal) economic theories remained in the centre of the academic discourse, many development economists adapted notions from outside this current - or from outside the realm of Economics, as seen in the cases of the Sen-Stiglitz-Fitoussi Commission's approach above. Development 'Studies' has, therefore, became more appropriate to denominate all these currents, as its scope and concerns spilled over the traditional boundaries of Economics as a discipline. Among those who still remain within, a set of studies see development failures as coordination failures, but not only regarding the market processes but also concerning institutions, values and so forth. A new interpretation of the classical "stages of growth" can be seen in "multiple equilibria" models [Kehoe et al, 1992], while another approach - rather a decision-making tool than a theory in itself - the Hausmann-Rodrik-Velasco "Growth Diagnostics Decision Tree" [2007] describes a possible practical use of hybrid theories, i.e. using economic policies of different theoretical background in function of different concrete policy challenges.

Sixth and finally, in the millennium years, and not independently of the growing importance of anti-globalization movements, a vocal minority of "post- 
development" critics started to argue that the very concept of development itself was an Eurocentric and capitalism-biased invention. Scholars of this current - most importantly, Wolfgang Sachs [1992], Arturo Escobar [1995] and Gilbert Rist [1997] - sustain that the development process is therefore socially constructed and guided by Western interests of economic and political domination. Post-development theorists therefore focus on informal, hybrid, non-Western forms of economic, social and cultural patterns of lifestyles and exchange mechanisms.

Given its policy-oriented nature, this thesis relies mostly on texts from the fifth, eclectic strand of literature. On the other hand, as the third, "dependency" current has had very strong effects on Latin American social sciences, theories and concepts from this set of authors are also observed. But for an operational notion of development, a focus on development policy institutions and processes is also required.

Development policy has the main goals as defined by Todaro and Smith [2011, pp. 22-23] in: 1) increasing the availability of basic life-sustaining goods, 2) raising the levels of living through higher income, better education and greater attention to human values, and 3) expanding the range of economic and social choices available to individuals and societies. On an international scale, the United Nations Development Programme (UNDP, founded in 1965), is a key actor in development policies worldwide, while the Organization for Economic Co-operation and Development's Development Assistance Committee (OECD DAC, founded in 1961) is a key actor in international cooperation for development. The former has set a broad framework of measuring and programming development assistance through the Millennium Development Goals (MDG), while the latter, containing most of the developed donor countries, set a target of spending $0.7 \%$ of their Gross National Product to development purposes. [IDA, 2007]

However, neither the MDG nor the $0.7 \%$ target succeeded, as donor stated did not donate as much as it had been expected. Another initiative, the World Trade Organization's Doha "Development" round of negotiations (2001-2008) shipwrecked after failing to reach a compromise on one of the most important points, agricultural import rules. [Cho, 2010] Critiques of the unequal world system (in a Wallersteinian / dependency theory sense) as well as innovative market-based proposals surged in political discourses, NGO agendas and academic publications. From the latter group, a compilation with the title of "New Sources of Development Finance" [Atkinson, 
2004] deserves a special attention, as it is one of the first comprehensive works which put in one framework all the possible "new" sources of funding that could "help" the developing world. These include Tobin tax, environmental tax, a global lottery and - remittances. [Solimano, 2004] It is therefore in this framework of disciplinary plurality and a rather practical need of finding new sources of development finance that migrant remittances made it into the focus of Development Studies.

In the following, the intersection area of Migration Studies and Development Studies - the so-called "migration-development nexus" - is presented.

\subsubsection{Development in migration theory: the "migration-development nexus"}

As described above, both 'migration' and 'development' (as theoretical concepts as well as parts of a broader process of global social change) have been in the centre of scholarly debates for decades, if not centuries, although with varying intensity, scope and embeddedness into political discourse(s). The "migrationdevelopment nexus", however, has become central to academic discourse, resulting in a boom of academic publications, only in the past 10-15 years. The term itself refers to the effects of migration on development. The effects of development on migration is a different issue, i. e. what level of development leads to what level of immigration or emigration. [de Haas, 2008] The latter question is interrelated to the former (which is the broad topic of the present thesis), however, it will not treated separately here.

The concept itself is, nonetheless, historically, politically and economically charged. Historically, because the supposed positive or negative effects of migration have always been shaping the economic development of countries of origin and countries of destination, thus it is really difficult (or even misleading) to draw consequences or to theorize based on the processes and data of a relatively short period of time. Politically, because - as described above - the idea appeared in a framework of insufficient funding for development cooperation, holding the promise of 'resolving' parts of the problem, i.e. no additional spending need to be made by international donor countries on aid transfers, as migrant remittances will make the acute global inequalities decrease on the long run. And economically, because the migration-development nexus was conceptualized around remittances, which in turn 
were conceptualized as development transfers, not as private and taxed individual savings (see Chapter 1.2. for details).

It is in this perspective that the migration-development nexus should be understood: as an intellectual consequence of several different theoretical shifts that social sciences underwent during the second half of the 20th century which, in turn, were not independent from global political and economic processes. Thus, while appearing as a relatively new field of study, the overviews of the 'migration' and 'development' literature presented in 1.1.1. and 1.1.2. make it clear that the migration-development nexus carries in itself all the disciplinary, historical and (geo)political contradictions that are separately present in the two fields of which it is a field of intersection.

Writings on the effects of migration on development are usually conceptualized in a challenges-versus-opportunities framework, with a very strong desire to draw a balance. Is migration, all in all, good or bad for development? Also, for whom? For countries of origin on the macro level, countries of destination on the macro level, individual migrants or their households, or non-migrants? An interesting feature of the literature on migration and development is the ever-changing overall evaluation of the process. Historical currents, conceptual frameworks, ideological currents, scope and methodology of research are all important factors that influence the final evaluation.

As described above, the post-world war classical theories that were relevant in this intersection field regarded migration as a factor price equalization process, but they did describe a hypothetical ideal world and not what really was happening. Then, a 'black legend' narrative of post/neocolonial dependency and brain drain appeared in the late 1960s and in the 1970s. With the 'neoclassical counterrevolution' in Development Economics and neoliberal policy currents of the Washington Consensus in the late 1980s, the possible linkages of migration and development as a field of research largely disappeared from the foreground of scientific interest. However, in the second half of the 1990s it made an impressive return, resulting in a boom of the number and the complexity of publications, and has been one of the key research areas in Migration Studies ever since. This is especially interesting having in mind the rather negative perception of migration that the 'security studies' approach of migration was transmitting. 
It should be noted as well, that in Latin America the overall assessment of the migration-development nexus has been following a somewhat different dynamics. Given the fact that, historically speaking, the Latin American intelligentsia has been more left-leaning than its North American and Western European counterparts, critical remarks have always been very present in the local scientific discourses. The dependency theory, an essentially Latin American current of thought, appeared almost a decade before concepts as brain drain would have found their way into the mainstream discourse with the authors cited above. [Gunder Frank, 1966; Dos Santos, 1970; Prebisch, 1982] Also, the migration-development nexus has never disappeared from sight in Latin American social sciences and its impressive comeback in the late 1990s to the Western Academia was preceded by a large number of, although methodologically somewhat obsolete, Latin American publications. This 'intellectual' lag was the consequence of the "lost decade", i. e. the dictatorships that were flourishing in most Latin American countries in the late 1970s and the early 1980s, forcing a great number of scholars into exile and hindering the evolution of analytical and critical social sciences throughout Latin America. [Devlin - Ffrench-Davis, 1995; Urquidi, 2005]

Hein de Haas [2008, p. 2] in his overview of the global narratives of the migration-development nexus displays a simple table on how these scholarly narratives have been changing over time, which I completed with the relevant additional notes on Latin American historical and intellectual background. The migration-development nexus as a research area in the Latin American context can be summarized, from a historical point of view, as follows:

Table 2. Evaluating the migration-development nexus: a historical overview

\begin{tabular}{|c|c|c|}
\hline Historical events & $\begin{array}{l}\text { Mainstream social } \\
\text { sciences }\end{array}$ & $\begin{array}{l}\text { Latin American social } \\
\text { sciences }\end{array}$ \\
\hline $\begin{array}{l}1945 \text { Foundation of the } \\
\text { United Nations }\end{array}$ & \multirow{3}{*}{$\begin{array}{l}\text { Development and } \\
\text { migration optimism. Neo- } \\
\text { classical equilibrium } \\
\text { perspective. Harris-Todaro } \\
\text { model }\end{array}$} & \multirow{2}{*}{$\begin{array}{l}\text { Development and } \\
\text { migration optimism, rise } \\
\text { of critical voices. } \\
\text { Prebisch-Singer theorem }\end{array}$} \\
\hline $\begin{array}{l}1948 \text { Foundation of OAS } \\
\text { and CEPAL }\end{array}$ & & \\
\hline 1959 Cuban revolution & & $\begin{array}{l}\text { Dependency theory. } \\
\text { CEPAL's structuralism. }\end{array}$ \\
\hline
\end{tabular}




\begin{tabular}{|c|c|c|}
\hline & & $\begin{array}{l}\text { Development and } \\
\text { migration pessimism }\end{array}$ \\
\hline $\begin{array}{l}1973 \text { Global oil crisis and } \\
\text { Chilean coup d'etat }\end{array}$ & \multirow{2}{*}{$\begin{array}{l}\text { Development and } \\
\text { migration pessimism. } \\
\text { Dependency, brain drain }\end{array}$} & \multirow[t]{2}{*}{$\begin{array}{l}\text { Lost decade, exile of } \\
\text { intellectuals }\end{array}$} \\
\hline $\begin{array}{l}1982 \text { Falkland war and } \\
\text { Latin American debt } \\
\text { crisis }\end{array}$ & & \\
\hline 1989 Fall of Berlin Wall & \multirow{2}{*}{$\begin{array}{l}\text { New approaches (New } \\
\text { Economics of Labour } \\
\text { Migration, } \\
\text { Transnationalism) }\end{array}$} & Structural adjustments \\
\hline $\begin{array}{l}1994 \text { Foundation of } \\
\text { NAFTA }\end{array}$ & & \multirow{3}{*}{$\begin{array}{l}\text { Boom in publications, } \\
\text { mixed but generally more } \\
\text { negative than positive } \\
\text { evaluation }\end{array}$} \\
\hline $\begin{array}{l}2001 \text { Terrorist attacks on } \\
\text { New York }\end{array}$ & \multirow{2}{*}{$\begin{array}{l}\text { Boom in publications, } \\
\text { methodological } \\
\text { heterogeneity, both } \\
\text { pessimistic and optimistic }\end{array}$} & \\
\hline $\begin{array}{l}2008 \text { Unfolding of global } \\
\text { financial crisis }\end{array}$ & & \\
\hline
\end{tabular}

Source: Hein de Haas [2008, p.2.] and own compilation

Besides historical categorization, a rather clear distinction can be made on the opposing views on the thematic content of texts concerning migration and development. As de Haas notes it [2008, p. 23], the debate on whether the overall effects of migration on development are positive or negative, "has remained somehow under-theorized and largely disconnected from more general debates". As a broad statement, we can say that the neo-classical equilibrium perspective and its later offsprings are rather optimistic about the development effects of migration, while the dependency theory and neo-Marxist (or post-development) approaches are rather pessimistic. Hybrid approaches are balancing between these two extremes.

Also, the scope of the research and the (geographic and disciplinary) location of the researcher seem to be substantial. From the 1970s onwards, the neo-classical and Marxist grand theories have become challenged by fieldwork evidence that either approved or disapproved the general narratives. Several field studies were conducted by (mostly North American) anthropologists and sociologists in Latin American (mostly Mexican) villages from where large parts of the population had emigrated. In the 1990s a generation of Latin American migration anthropologists appeared, most notably in Mexico (University of Zacatecas, Colegio de México, 
Colegio de la Frontera Norte) but also elsewhere in Latin America (Institute of Peruvian Studies, University of Chile etc.). [Imaz, 2010] In parallel, economists and geographers were conducting research on migration and development, using demographic and macroeconomic data, generally while living and working in the United States, either at universities or at international institutions (United Nations, World Bank, IMF etc).

The difference in the scope and the physical/intellectual location of the researchers led to different evaluations. As de Haas put it, "anthropologists and sociologists seemed the most pessimistic, while geographers and economists tended towards a more moderate stance" [de Haas, 2008, p. 31.], to which I would add that living in Latin America while conducting the research also seems to increase the possibility of a pessimistic approach. To sum up, being 'on the spot' induces a focus on the negative side of the migration-development nexus, while watching it from 'outside' and 'above' makes the balance more positive.

The migration-development nexus as a research area in the Latin American context can be summarized, from a thematic point of view, as follows:

Table 3. Evaluating the migration-development nexus: a thematic overview

\begin{tabular}{|l|l|l|}
\hline $\begin{array}{l}\text { Overall scientific } \\
\text { standpoint }\end{array}$ & Migration optimists & Migration pessimists \\
\hline Current of thought & Neo-classical & Structuralist \\
\hline Field of study & Economy, Geography & Anthropology, Sociology \\
\hline Scope & Macro & Micro \\
\hline $\begin{array}{l}\text { Residence during the } \\
\text { research }\end{array}$ & $\begin{array}{l}\text { United States, Western } \\
\text { Europe }\end{array}$ & Latin America \\
\hline Narrative & Modernization & Disintegration \\
\hline $\begin{array}{l}\text { Balance of resource } \\
\text { transfers }\end{array}$ & Net North-South transfer & Net South-North transfer \\
\hline $\begin{array}{l}\text { Effect on human } \\
\text { capital }\end{array}$ & Brain gain & Brain drain \\
\hline Effect on equality & More equality & More inequality \\
\hline Use of remittances & Investment & Consumption \\
\hline
\end{tabular}




\begin{tabular}{|l|l|l|}
\hline $\begin{array}{l}\text { Overall structural } \\
\text { change }\end{array}$ & Development & Dependency \\
\hline Migration prospects & Less migration & More migration \\
\hline
\end{tabular}

Source: Hein de Haas [2008, p.24.] and own compilation

The main problem in evaluating the migration-development nexus is therefore the incommensurability of the findings. In other words, what can we say, if for every migration-optimist paper, written by a North American, published by the World Bank, relying on macroeconomic data and using econometric methods, there is a migration-pessimist one, written by a Latin American, published by a Mexican university, using fieldwork evidence collected through anthropological observation?

The question is obviously impossible to answer in a plausible way. We need to limit ourselves to a descriptive study of what developmental effects can be traced and how many people are concerned, understanding development from Amartya Sen's capabilities approach, not forgetting the fact that migration itself is also a substantive freedom in order to improve one's livelihood options.

\subsubsection{Challenge or opportunity? Migration and development in an evaluative framework}

The question whether migration is a challenge or an opportunity for development, must be formed in a way that it would include both sides: countries of origin and countries of destination of migrants. Development in migration theories are usually conceptualized from a clear economic/materialist standpoint, taking the aggregate amount of remittances and/or its proportional value related to the Gross Domestic Product (GDP) or to the Gross National Income (GNI) as the key indicator. Following Hein de Haas's overview [2010] on how migration theories deal with the issue of development, it can be stated that development and migration are seen as substitutes by the classical and neoclassical economic theory. They regard migration as the establishing process of a spatial-economic equilibrium in which migrant labour goes in one direction and capital, through migrant remittances, go to the other.

However, migration is "a strongly patterned process because people's individual choices are constrained by structural factors such as social stratification, market access, power inequalities as well as cultural repertoires affecting 
preferences." [de Haas, 2010, p. 5] These 'distorting' patterns that hinder the equilibrium are actually so relevant that the neoclassical theory in itself cannot explain the direction, volume and composition of the specific migratory processes. The New Economy of Labour Migration takes a step forward in this respect, placing the household as the unit in the focus, instead of the individual, making it a useful framework to understand the guest workers' and debt migrants' motivations, who are not seeking individual benefits but are obliged to provide money for their families thus, no full access to information nor legal possibilities do exist for making a rational choice. Other theories, such as the cumulative causation theory or the network theory address this problem by accepting that migrants are relying mostly on their personal networks to choose their destination (that may or may not be the best choice in formal cost-benefit terms), while world systems theory focuses on the historical-geographical dependent relations between countries of origin and countries of destination as a key determinant of the establishment of migration corridors. [Massey et al, 1993]

Most migration theories are, nonetheless, operating on a micro level of analysis: they try to understand why a single migrant departs from the country of origin, and not what happens with the country of origin with every single migrant who departs. But when it comes to draw the balance on the national level, i.e. whether migration is a challenge or an opportunity for a given country, it becomes clear that the national utility function regarding migration is not the sum of the individual migrants' utility functions: migration also affects those who do not migrate.

Therefore, in the following tables, an overview of key factors is presented on the macro level: namely, challenges and opportunities in countries of origin and countries of destination. Table 4 and 5 summarize a wide range of statements (see references in the subsequent two chapters) that are shared by certain circles of migration researchers and that might be valid in certain particular settings. Obviously, not all the elements listed here are equally important for every country however, the main features of most individual local designs are included in this table.

Also, for analytical purposes, a distinction between short and long run is made in tables 4 and 5. "Short run" is conceptualized as being a direct consequence of the movement of people, their first encounter with the labour market and social welfare systems of the country of origin, their absence from the country of 
destination and the remittances they start to send back home once they have the possibility to do so. "Long run", in turn, is understood as the consequence of the existence of a stable diaspora, i.e. migrants who have been living in the country of destination for a longer period in time, partially or fully integrated to the host society and raising the 'second generation', i.e. locally born children who might, or might not feel identified to the country of origin of their parents, but, at the end of the day, they are not 'migrants' themselves, but 'natives' to a country shaped by immigration.

\subsubsection{Challenges and opportunities for the country of destination}

Table 4. Possible developmental effects of (im)migration for countries of destination

\begin{tabular}{|c|c|c|}
\hline & Positive & Negative \\
\hline $\begin{array}{l}\text { Short } \\
\text { Run }\end{array}$ & $\begin{array}{l}\text { - Extra human capital and } \\
\text { contribution to GDP (brain gain) } \\
\text { - Contribution to the social } \\
\text { welfare system (migrant workers) } \\
\text { - Decreasing unemployment in } \\
\text { DDD (dirty, dangerous, } \\
\text { degrading) jobs } \\
\text { - Consumption of local goods } \\
\text { by migrants }\end{array}$ & $\begin{array}{l}\text { - Decrease of wages and loss of } \\
\text { employment for the non-migrants } \\
\text { with 'migrant jobs' } \\
\text { - Pressure on the social welfare } \\
\text { system (in connection with refugee } \\
\text { and family reunification issues) } \\
\text { - Possible infiltration of } \\
\text { terrorists and/or criminals }\end{array}$ \\
\hline $\begin{array}{l}\text { Long } \\
\text { Run }\end{array}$ & $\begin{array}{l}\text { - Cultural diversity as a source } \\
\text { for innovation (e. g. ethnic } \\
\text { niches) } \\
\text { - Demonstration effect on } \\
\text { countries of origin (international } \\
\text { prestige) } \\
\text { - Increasing trade with } \\
\text { countries of origin }\end{array}$ & $\begin{array}{l}\text { - } \text { Marginalization of immigrants } \\
\text { in economic and social terms } \\
\text { - Deskilling: Immigrants } \\
\text { usually take jobs that require lower } \\
\text { qualifications } \\
\text { - Integration 'traps' } \\
\text { - } \quad \text { Fundamentalism (immigrants } \\
\text { or second generation) } \\
\text { - Xenophobia (in host society) }\end{array}$ \\
\hline
\end{tabular}

Source: own compilation, for references see 1.1.3.1 and 1.1.3.2.

On the short run, the most important benefit of migration for the country of destination is that it receives a (generally) young adult population whose costs of healthcare and education were paid by another country, resulting in a net transfer of human capital. Immigrants, besides dynamizing the country of destination's economy with their work and consumption, also have positive structural effects on 
the economy. They fill in the gaps in the labour market that the natives would not, given the DDD (dirty, dangerous, degrading) nature of many of these jobs, while unemployment decreases in the country of origin. Highly skilled migrants may enjoy better professional opportunities in the country of destination and, again, a more competitive wage, a part of which can be translated as remittances or even as investment. [Borjas, 2006]

On the long run, there are benefits that do not stem from the differences of wages but from the cultural background, most importantly, entrepreneurial culture. Scholars who represent the integration approach emphasize that cultural diversity is a value in itself, both in societal and economical terms. Multiculturalism, in the sense of public policies described above, favoured the formation of ethnic enterprises, ranging from Chinese retail stores to Mexican fast food restaurants. The term "ethnic enterprises" was coined by Ivan Light in the 1970s [Light, 1972], drawing on Edna Bonacich's "middleman minorities" theory. [Bonacich, 1973] According to Zhou [2004], a larger concept, "ethnic economies" is more adequate, which in turn can refer to either "ethnic enclave economies" where the entrepreneurs have a clientele constituted by their co-ethnics, or "middleman minorities" proper, who serve a larger, majority (or other minority) spectrum of customers. Ethnic entrepreneurship is covering a niche in the country of destination's market, which provides a stable living for the migrant and their kins.

On the less sunny side of migratory processes, a major developmental challenge is that migrants are willing to accept lower wages and worse working conditions than natives. On the short run, this causes an overall lowering of salaries in the types of jobs that are normally taken by immigrants. As migration is very much a network-dependent issue, migrants of a given ethnicity may 'crowd out' natives (and competing immigrant groups) from certain occupational areas. In a study on what happens to natives who lose their jobs because of competition with immigrants that they finally lose, Cattaneo et al [2013] found that on the macro level the native population moves towards an upper segment of the labour market through personal networks or subsidized training courses. In this respect, competition with immigrant workers pushes natives upwards which, if they succeed, might be seen as a win-win outcome. However, this is not always the case on the micro level.

Security concerns also rise from the challenge that migration poses on the idea of national sovereignty and border control. A 'welfare chauvinism' of the 
population of developed countries, together with the post-9/11 fear from radical Islam and terrorism, immigration is often perceived as a dreadful process in which potential criminals and rent-seekers enter the country. It also denounces the limited ability of a liberal state to control who is entering to and staying in its territory.

On the long run, therefore, ethnicization of lower-skilled jobs can lead to segregation and (often religious) extremism on the immigrant side, and to frustration and xenophobia on the side of those natives who cannot re-invent their professional identity once their original job was 'taken by immigrants'. [Boubtane et al, 2011] This can happen despite the fact that many migrants work in job areas for which they are overqualified. Not using existing skills and expertise is known as 'brain waste', and is a joint outcome of many factors ranging from qualifications unfamiliar to the employers and no local work experience, to the lack the language proficiency and simple racism. [Sumption, 2013] Also, some occupations require licensing or registration, while in others a strong labour union can block the access of immigrants to specific jobs. This is a lose-lose situation.

Ghettoization of immigrants is therefore a produce of marginalization due to legal and economic constraints, although in many cases a xenophobic narrative depicts it as a proof for their 'cultural' inability to integrate into the host society. [Stolcke, 1995] A large number of problems may actually stem from a hiding population that does not seek contact with any 'authority', not even the healthcare system, due to which migrants sometimes get accused in public discourse as possible disease spreaders. Criminality is also directly related to undocumented migratory status, as people with no valid documents can only work in the shadow economy, sometimes trading with illicit goods (drugs, weapons, human smuggling etc.).

\subsubsection{Challenges and opportunities for the country of origin}

Table 5. Possible developmental effects of (e)migration for countries of origin

\begin{tabular}{|c|c|c|}
\hline & Positive & Negative \\
\hline $\begin{array}{l}\text { Short } \\
\text { Run }\end{array}$ & $\begin{array}{l}\text { - Financial and social } \\
\text { remittances } \\
\text { - Decreasing unemployment } \\
\text { - Ensuring human rights } \\
\text { and/or } \\
\text { preventing humanitarian crisis }\end{array}$ & $\begin{array}{l}\text { - Loss of public money invested } \\
\text { in education (brain drain) } \\
\text { - Lack of professionals in the } \\
\text { skill areas affected by emigration, } \\
\text { e.g. healthcare workers (care } \\
\text { drain) }\end{array}$ \\
\hline
\end{tabular}




\begin{tabular}{|l|l|l|}
\hline & & $\begin{array}{l}\bullet \quad \text { Pressure on the social welfare } \\
\text { system (lower share of taxpayers) }\end{array}$ \\
\hline Rong & $\begin{array}{l}\bullet \text { Mobility channel and/or } \\
\text { empowerment for the socially } \\
\text { marginalized groups } \\
\bullet \quad \text { Growing competitiveness of } \\
\text { the education system and } \\
\text { student performance } \\
\bullet \quad \text { Favourable change in } \\
\text { gender relations } \\
\bullet \quad \text { Establishment of } \\
\text { transnational diaspora networks } \\
\text { and advocacy groups }\end{array}$ & $\begin{array}{l}\bullet \quad \text { Remittance dependency } \\
\text { (financial, social) and lack of } \\
\text { innovation } \\
\bullet \quad \text { Decreasing total fertility rate } \\
\bullet \quad \text { Disarticulation of migrant- } \\
\text { sending societies } \\
\bullet \quad \text { Political passivity due to the } \\
\text { 'exit option' }\end{array}$ \\
\hline
\end{tabular}

Source: own compilation, for references see 1.1.3.1 and 1.1.3.2.

On the short run, for the countries of origin the most important opportunity that migration entails is that migrants can work for a better wage. Most migratory movements are primarily economically-driven, and the surplus money that stems from the difference of the wages between the two countries, is conceived by the migrant as the net benefit of migration. Saved money is spent back home as remittances, a flow of private money transfers that in 2012 exceeded 500 billion USD worldwide. [Migration and Remittances Factbook, 2011, p. 26]

In the country of origin, family members can live off the remittances, which is a private salary, and as such, it can be spent as a locally earned salary would be: either on non-durable and durable consumer goods, or saved for investment. In any way, foreign currency arrives to the economy, an amount of money that otherwise would not have been generated and directed to the country of origin. And, as the migrant's family members spend the money, they generate additional economic activity, a phenomenon known as the multiplier effect. Remittances are also more resistant to crisis than FDI, as their main driving force is not economic rationale but solidarity.

It is also important to mention the case of humanitarian crises where migration as an exit (refugee) option can help ensuring human rights and/or preventing catastrophes. In cases of natural disasters, wars or persecution of given groups of the society, leaving the country can actually save people's lives. The refugee condition has blurry borders, and in many cases it is difficult to separate it 
from economic motivations. Less abrupt motivations for leaving also include climate change, one of the key drivers of migration in the future according to many forecasts. [IOM, 2008]

On the long run, migrants can 'make it' in the country of destination and become owners of large sums of money that can affect positively their country of origin in several ways. According to Manuel Orozco's "5 T-model" it is trade, transportation, telecommunication, transfer of remittances and tourism between the countries of origin and destination that yields business opportunities for the ethnic entrepreneur, and a development potential for the country of origin (see 1.2. for a critical evaluation). [Orozco, 2005]

The weaving of transnational networks can also empower women, ethnic, religious or sexual minorities, or other marginalized or dissident social groups in the country of origin who can either become a migrant and thus enhancing their human capabilities, or benefiting from "social remittances". This term, coined by Peggy Levitt, comprises "normative structures, ideas, values, and beliefs", "systems of practice" and "social capital" (see also 1.2.). [Levitt, 2001] According to this theory, successful migrants can be agents for change in their country of origin. Although not every belief and social practice in the countries of destination are undoubtedly positive, it can be said that richer societies generally cherish self-realization values, in contrast to poorer societies based on survival values [Inglehart - Baker, 2000], therefore the impact of migrants can help the economic-organizational structure of these societies to move towards the former, if the economic conditions are given.

Regarding the negative effects of emigration, on the short run the key issue to handle is the loss of human capital. In the first years of children's life they get education, housing, food, clothes etc. which are difficult to measure in exact financial terms but it is evident that the family and the state spends money to bring up the child while the child doesn't contribute to neither the family's nor the state's budget. Migration in this respect is a loss: the loss of contributors to the state budget (taxpayers) and the loss of professionals in key skill areas, which further burdens the development of the country of origin.

Remittances, although being the principal gain from migration and a counterbalance of the loss of human capital, are not always benefiting the local economy. In many cases, they are spent under conditions of dependency that, both as an economic and a psychological condition, leads the members of the migrant- 
sending household to spend the remittances on consumer goods made in the country of destination. This certainly is the case in societies where migration has a strong symbolic context. Defining whether remittances are spent on locally produced goods - and consequently having an important spillover effect - is a function of the local economy's structure. In many countries of origin, transnational companies possess the majority of the consumer goods' market, eventually taking back the surplus to the country from where the migrant has been sending money back home. [Sørensen, 2004]

On the long run, when emigration becomes a standard way to deal with challenges in a society, prospective migrants hold very high expectations about 'making it' abroad. This is mainly because societies of origin have a distortioned view of countries of destination. It is so because, firstly, media presents the United Stated and Western Europe as the land of plenty, where streets are paved with gold, and secondly, migrants themselves confirm this myth when in contact with nonmigrant co-nationals, otherwise they would face cognitive dissonance. [Glick Schiller - Fouron, 2001]. This way, an 'emigration society' comes into being, with negative features such as the political passivity due to the easy 'exit option', and the decreasing of the total fertility rate, as a large share of migrants are young adults who need to postpone their child-bearing and, if they settle down in the country of destination, their children will grow up there, which further worsens the age structure of the country of origin. Societies can, therefore, experience many disarticulating tendencies appearing when emigration is on the rise. [Delgado et al, 2009]

In the following, one specific (although crucial) part of the picture, the concept and role of migrant remittances is chosen for further analysis, as remittances are the most operational notion for understanding the different types of transfers through which development takes place.

\subsection{Operationalizing the migration-development nexus: the concept and role of migrant remittances}

As seen above, migration has plenty of positive and negative effects, both to the countries of origin and to the countries of destination. In the following, the focus is set on the 'left column' of the migration-development matrix presented in Table 5, 
i. e. the opportunities which are open for a country of origin of migrants. While many of these features such as the decreasing unemployment, the opening of mobility channels and/or the empowerment for the socially marginalized groups, and especially the favourable change in gender relations are very relevant for development, it is usually the various notions of 'remittances', i. e. money, goods or skill transfers that is usually used as the key operational concept for 'measuring' developmental effects. This is also in line with the policymakers' main concerns.

Of the several topics listed above, therefore, the analysis conceptualizes 'developmental' effects around financial and social remittances. After a set of definitions, the effects of remittances are described, followed by an overview of how remittances can - or cannot - be a target for policymakers eager to find new sources of income for the state budget.

Examples are taken from economic and anthropological case studies on Latin American remittance mechanisms.

\subsubsection{Six"circles" of remittance definitions}

Remittances are international private money transfers that are related to migration, i. e. the flow of the money is contrary to the flow of people and it is a direct consequence thereof. Most of the developmental effects of migration can be conceptualized around remittances; however, the literature is somewhat fuzzy with regards to what is considered as 'remittances'. In my interpretation, there are six different 'circles' of transfers that we can understand as remittances, and the broader the definition is, the harder it gets to describe them in a quantitative way. In order to organize the often contradictory approaches to the concept of remittances, I elaborated a cumulative model in which six definitions are given, each of them containing the totality of the fields covered by the previous definitions.

In the following I present this hierarchized set of definitions for the different categories of remittances, starting from the narrowest (workers' remittances according to the IMF's Balance of Payments Manual) and arriving to the broadest (including also social remittances, i. e. the ideas, practices, identities and social capital that flow from receiving to country of origin communities). At each stage I also give an interpretation of these definitions. 
Table 6: Six 'circles' of remittance definitions

Definition A: workers' remittances

Definition B: Definition A + compensation of employees + migrant transfers

Definition C: Definition B + (estimated amount of) unrecorded transfers

Definition D: Definition C + migrant investments

Definition E: Definition D + collective transfers

Definition F: Definition E + (non-quantifiable amount of) non-material transfers

Note: for each definition, the cost of remitting should be subtracted from the total value.

Source: own compilation based on MIF [2012], IMF Balance of payments manual [2008], Goldring [2003], Guarnizo [2003], Levitt [2001], Levitt-Lamba [2011], Ghosh [2006].

In order to incorporate the notion of 'circle of beneficiaries' to the model, I distinguish four types of remittances: household (Definitions A-C), investment (Definition D), community (Definition E) and social (Definition F).

The theoretical overview on remittance types has the objective of summarizing conceptual notions which will be the base for analysis in Chapter 3 of this thesis. Chapter 3.2 will be built around the concept of household remittances; Chapter 3.3 around investment remittances; Chapter 3.4 around community remittances and Chapter 3.5 around social remittances.

\subsubsection{Household remittances}

The narrowest interpretation of remittances (Definition A) is the workers' remittances that figures in the "Current transfers" part of a country's Current Account. The International Monetary Fund defines workers' remittances as "current transfers by migrants who are employed in new economies and considered residents there. (A migrant is a person who comes to an economy and stays, or is expected to stay, for a year or more.)" [IMF, 2008, paragraph 302] If a person does not spend an entire year in another country, will not be counted as a migrant, and the eventual money transfers to the country of origin will be accounted as compensation of employees in the Income part of the Current Account, defined as "wages, salaries, and other benefits, in cash or in kind, and includes those of border, seasonal, and other nonresident workers (e. g., local staff of embassies)." [IMF, 2008, paragraph 
169] On the other hand, if a person who has been living in another country for more than one year, but the money they send goes to their own bank account at the country of origin, this amount is not accounted as workers' remittance but as migrant transfers, in the "Capital transfers" part of the Capital and Financial Account. Generally, this means one, large-sum transfer that a migrant sends back to the country of origin before moving back, or in order to invest in a business or to buy a property. [MIF, 2012] These latter two categories, together with Definition A, put up the Definition B of remittances, which is, for many reasons, the most convenient one for quantitative analysis.

Definition B is thus what common sense would understand under the concept of remittances, although it contains three separate financial categories. Differences between the narrow Definition A and the broader Definition B can be significant. For example, in 2011, Brazil received 1.97 billion US dollars in workers' remittances, 0.58 billion in compensation of employees and 2.05 billion in migrant transfers). Therefore, the amount of 'remittances' received by Brazil is 1.97 billion US dollars according to Definition A, while it is 4.6 billion according to Definition B. The latter is what publications would usually use for 'remittances' without explicit technical definitions. [MIF, 2012]

However, if we take these three separate financial categories as an aggregate amount of 'remittances', we might arrive to false conclusions as the social dynamics that induces these three types of flows is different. For example, if migrant transfers are on the rise, it is possibly because return migration is increasing and the stock of migrants is getting smaller, while if workers' remittances are rising, it might be because the stock of migrants is growing. [MIF, 2012]

Also, when it comes to measuring the net size of remittances and their share in a country's budget, a problem arises with the economic indicators. The Gross Domestic Product (GDP) is the best-known and most widely accepted indicator for the size and performance of the economy of a country. However, the Gross National Income (GNI) is considered by the expert community as a better indicator to show the income which is indeed available to the people who live in the given country. As opposed to GDP, the GNI includes the wages earned by cross-border workers (as well as capital incomes such as repatriated profits and dividends, etc.) in the IMF's Systems of National Accounts these latter are called Net Primary Incomes (NPI). 
GNI, on the other hand, does not include the remittances of those who live and work abroad for more than one year (classified as Net Secondary Incomes, NSI). In other words, GNI contains what is the difference between Definition A and B, but it does not contain what belongs under Definition A. A third indicator, the Gross National Disposable Income (GNDI) shows both, as it includes both NPI and NSI. Unfortunately, GNDI is not easily available in databases. The OECD calculates it for its members and for major non-member countries, so there are data, for example, for Mexico. Also, for the purposes of a study, the same data were calculated by the authors on small, remittance-dependent countries, including Honduras and El Salvador. [Capelli - Vaggi, 2014] Values are shown in the following table.

Table 7. Differences between economic performance indicators in remittancerecipient countries: three cases

\begin{tabular}{|l|l|l|l|l|l|l|}
\hline & $\begin{array}{l}\text { GDP } \\
\text { (M USD) }\end{array}$ & NPI & GNI & NSI & GNDI & GNDI/GNI \\
\hline Mexico & $1,157,646$ & $-17,244$ & $1,140,402$ & 22,974 & $1,173,760$ & 1.02 \\
\hline $\begin{array}{l}\text { El } \\
\text { Salvador }\end{array}$ & 23,054 & -632 & 22,422 & 3,841 & 26,263 & 1.17 \\
\hline Honduras & 17,426 & -973 & 16,453 & 3,107 & 19,572 & 1.19 \\
\hline
\end{tabular}

Source: Capelli - Vaggi [2014]

As it can be seen, the smaller and more remittance-dependent a country is, discrepancies among the three values tend to be larger. Also, as remittances add up to GNDI on the positive side, GNDI values for these countries are bigger than GNI values, due to the fact that the latter includes the capital incomes such as repatriated profits and dividends on the negative side, which is quite an important sum in open Latin American economies with lots of US-based companies operating on their territory. Also, it shows how remittances are counterbalancing the outflow of capital due to profit repatriation by transnational companies. [Capelli - Vaggi, 2014]

For these reasons, although GNI is a more accurate indicator for the size of a country's budget, in most of the Latin American remittance-receiving countries GDP is closer to the actual amount of Gross National Disposable Income (GNDI). For practical reasons, therefore, GDP is more convenient for comparing the remittances data with (at least in these countries). 
Furthermore, two other features of these types of remittance flows shall be taken into account in order to define their real value, namely the exchange rate and the inflation. Except for some countries that have their currencies pegged to the US dollar or using the US dollar instead of it, such as Ecuador or Panama, exchange rate fluctuations can largely change the purchasing power of the remittances, and so does inflation. From a receiver's point of view, the best case is when the exchange rate of the national currency is getting worse vis-à-vis the US dollar and the inflation rate is low. Accordingly, if the exchange rate of the national currency is getting better vis-àvis the US dollar and the inflation rate is high, it is the worst case for a family living off remittances.

Table 8 shows, based on 2010-2011 country level data, to what extent these circumstances are important.

Table 8. Discrepancies between the purchasing power of remittances: four cases

\begin{tabular}{|c|c|c|c|c|c|c|c|}
\hline & \multicolumn{2}{|l|}{ Inflation } & \multicolumn{4}{|c|}{$\begin{array}{l}\text { Annual remittances growth rate (\%), } 2010 \text { to } \\
2011\end{array}$} \\
\hline & & high & low & Country & $\begin{array}{l}\text { In } \\
\text { USD }\end{array}$ & $\begin{array}{l}\text { In local } \\
\text { currency }\end{array}$ & $\begin{array}{l}\text { Adjusted for } \\
\text { inflation }\end{array}$ \\
\hline \multirow{4}{*}{$\begin{array}{l}\text { Exchan- } \\
\text { ge rate } \\
\text { vis-à-vis } \\
\text { USD }\end{array}$} & \multirow[t]{2}{*}{ better } & \multirow{2}{*}{$\begin{array}{l}\text { Para- } \\
\text { guay }\end{array}$} & \multirow[t]{2}{*}{ Chile } & Chile & 7.5 & 1.8 & -1.0 \\
\hline & & & & Argentina & 6.5 & 12.5 & 3.2 \\
\hline & \multirow[t]{2}{*}{ worse } & \multirow{2}{*}{$\begin{array}{l}\text { Argen- } \\
\text { tina }\end{array}$} & \multirow{2}{*}{$\begin{array}{l}\text { Mexi- } \\
\text { co }\end{array}$} & Paraguay & 9.1 & -4.1 & -11.3 \\
\hline & & & & Mexico & 6.9 & 20.9 & 17.5 \\
\hline
\end{tabular}

Source: own compilation based on MIF [2012], p. 20.

On the left side of Table 8, four countries are shown, all of them representing a logical position in the exchange rate / inflation matrix. On the right side, the first column of data represents the growth rate of the remittances (definition B) from 2010 to 2011 in US dollars, the currency in which the decisive amount of this sum of money was generated. The second column shows the values of the first column adjusted with the change of the exchange rate, while the third column shows the values of the second column, adjusted with the inflation rate of the respective country. It can be seen clearly that even if the average migrant from these four countries increased the amount of the remitted money, the purchasing power of this sum varies wildly, showing an almost $30 \%$ of difference in the extreme cases of Paraguay and Mexico that is entirely due to macroeconomic reasons and as such, means an external variable for migrants' economic behaviour. 
Even at this stage of the analysis (i. e. still at the second-narrowest Definition B), it is clear that a statement as 'remittances to Latin America have risen with 7\%' has little analytical value. One should take into account: 1) the changes in the internal share of the three constitutive categories, 2) the changes in the exchange rate between the currency of the country of destination (USD, EUR, GBP etc.) and the country of origin (Mexican peso, Argentine peso etc.), 3) the inflation rate in the country of origin.

The next circle of definition for remittances is Definition $\mathrm{C}$, adding the estimated amount of unrecorded transfers to the previously described categories. From a methodological point of view, it is calculated by IMF, World Bank or national statistical institutes taking the (exact) amount of remittances according to Definition B, and multiplied by a coefficient that they find realistic. This coefficient is defined through surveys and anthropological fieldwork experience, thus remittances according to Definition $\mathrm{C}$ (and in the following, broader circles of Definition D and E) are estimations and not exact data.

Varying according to migration corridor, year, legal category of migrants and sectors of employment, the percentage of the money sent back to the country of origin via informal channels can reach the $40 \%$ of the total. An unrecorded transfer can be everything that does not pass through a bank account or a person-to-person money transfer operator such as Western Union. Unrecorded transfers include cash or in-kind gifts handed personally by migrants upon their visit to the country of origin, or by friends, relatives and other acquaintances who travel from the country of destination to the country of origin. As far as the amount of these remittances does not exceed the official limitations of taking cash through the respective border, they are not illegal, however, migrants often use these channels because their stay in the country of destination is illegal and as such, they cannot open a bank account.

The costs of remitting through these unrecorded channels are usually higher than the recorded channels. This is why most experts stand for "banking the unbanked", i. e. channeling the remittances into the banking system through providing access to bank accounts on both sides of the process. [Ghosh, 2006]

Remittances go through a variety of channels which can be named as 'remittance service providers' or 'remittance agencies', being either legally established financial companies - money transfer operators, MTOs - or informal mechanisms (see Table 8). Legal remittance agencies can be large, multinational 
firms as Western Union or MoneyGram, or smaller, migrant-run enterprises that meet the legal requirements for providing the service of transferring money and holding back a part of it as the company's profit. Big companies are known for operating with very high transaction fees that may reach $15 \%$ to $25 \%$ of the total amount, given the fact that most migrants remit small sums on a monthly basis instead of transferring a lump sum once or twice a year, and transaction fees tend to have a stable minimum amount which is quite high. Also, in the post-2001 securitization of international money transfers, the US government security measures against the financing of terrorist cells raised the administrative burdens on remittance agencies, making Western Union, MoneyGram and other big companies raise their fees on international transfers, while some smaller remittance agencies went into bankruptcy. [Acosta et al, 2008]

Illegal remittance agencies, in turn, are by nature free of government supervision, a condition that makes them very attractive for many migrants for several reasons. First, because undocumented migrants, who have a (quite reasonable) suspicion to fill in any official form, are likely to avoid legal remittance agencies. Second, even if migrants would use official channels, this would mean an important loss if there are discrepancies between official and real (black market) exchange rates. It is the case, for example, in Venezuela, where one US dollar would officially buy 198 bolívares fuertes using the SIMADI exchange rate (the official one for private cash exchange $)^{2}$ as of September 2015, but in the black market the exchange rate would be one to 757. [DolarToday.com, 2015] Legal remittance agencies are, of course, obliged to use the official exchange rate, therefore a large part of remittances to this country arrives in cash, and through illegal channels. Third, if the commodities market is not well-developed enough in the country of origin, a sort of semi-legal enterprises may come into existence, as in the case of Ecuador. Immigrants in Spain can buy household utensils in Spain and pay in euros, but these objects will not be shipped to the buyer, but to their family members or kins in Ecuador. These items are often smuggled, therefore avoiding taxation in both countries. [Moré, 2009]

\footnotetext{
${ }^{2}$ As of September 2015, there are three official exchange rates in Venezuela, all of which are completely detached from (black) market realities.
} 
Table 9 synthesizes the different technical options for sending remittances through formal or informal channels.

Table 9. Types of remittances service by legal background, provider, price and accessibility constraints

\begin{tabular}{|c|c|c|c|c|}
\hline $\begin{array}{l}\text { Type of } \\
\text { service }\end{array}$ & $\begin{array}{l}\text { Legal } \\
\text { background }\end{array}$ & Provider & Price & $\begin{array}{l}\text { Accessibility } \\
\text { constraints }\end{array}$ \\
\hline $\begin{array}{l}\text { Physical } \\
\text { delivery of } \\
\text { cash }\end{array}$ & $\begin{array}{l}\text { Legal, as long } \\
\text { as it does not } \\
\text { exceed the } \\
\text { permitted } \\
\text { maximum } \\
\text { amount; Illegal } \\
\text { if it does exceed } \\
\text { the limit }\end{array}$ & $\begin{array}{l}\text { Informal } \\
\text { providers and } \\
\text { courier } \\
\text { services }\end{array}$ & $\begin{array}{l}\text { Difficult to } \\
\text { monitor and } \\
\text { quantify due to } \\
\text { informal } \\
\text { nature of the } \\
\text { service }\end{array}$ & $\begin{array}{l}\text { Lowest: No identification } \\
\text { or reporting requirements } \\
\text { and arguably few } \\
\text { constraints } \\
\text { to amounts }\end{array}$ \\
\hline $\begin{array}{l}\text { Delivery of } \\
\text { goods to } \\
\text { country of } \\
\text { origin, paid } \\
\text { in country of } \\
\text { destination }\end{array}$ & $\begin{array}{l}\text { Semi-legal, } \\
\text { using legal } \\
\text { loopholes }\end{array}$ & $\begin{array}{l}\text { Informal } \\
\text { connection of } \\
\text { formal retail } \\
\text { stores and } \\
\text { formal } \\
\text { delivery agents }\end{array}$ & $\begin{array}{l}\text { Usually higher } \\
\text { than buying the } \\
\text { same good on } \\
\text { market prices }\end{array}$ & $\begin{array}{l}\text { Low: Usually no } \\
\text { identification required }\end{array}$ \\
\hline $\begin{array}{l}\text { Cash-to-cash } \\
\text { transfer by } \\
\text { remittance } \\
\text { agencies }\end{array}$ & $\begin{array}{l}\text { Legal, if the } \\
\text { agency operates } \\
\text { legally (and } \\
\text { holds all the } \\
\text { certificates) }\end{array}$ & $\begin{array}{l}\text { Money } \\
\text { transfer } \\
\text { operators }\end{array}$ & $\begin{array}{l}\text { Usually the } \\
\text { highest among } \\
\text { formal } \\
\text { remittance } \\
\text { service providers }\end{array}$ & $\begin{array}{l}\text { Low: Identification } \\
\text { usually } \\
\text { required only for large } \\
\text { sum transactions, } \\
\text { foreign IDs are } \\
\text { accepted. }\end{array}$ \\
\hline $\begin{array}{l}\text { Account-to- } \\
\text { cash }\end{array}$ & Legal & $\begin{array}{l}\text { Financial } \\
\text { institution with } \\
\text { disbursing } \\
\text { agent in } \\
\text { country of } \\
\text { origin }\end{array}$ & $\begin{array}{l}\text { Usually cheaper } \\
\text { than many } \\
\text { money transfer } \\
\text { operators }\end{array}$ & $\begin{array}{l}\text { High: Requires that } \\
\text { sender has a bank } \\
\text { account. }\end{array}$ \\
\hline $\begin{array}{l}\text { Account-to- } \\
\text { account }\end{array}$ & Legal & $\begin{array}{l}\text { Financial } \\
\text { institutions } \\
\text { only }\end{array}$ & $\begin{array}{l}\text { Cheapest: it can } \\
\text { be zero due to } \\
\text { cross-selling of } \\
\text { other financial } \\
\text { services }\end{array}$ & $\begin{array}{l}\text { Highest: Requires that } \\
\text { both sender and recipient } \\
\text { have bank accounts }\end{array}$ \\
\hline
\end{tabular}

Source: own compilation based on Cirasino et al [2008], p.311. and Moré [2009]

More details on household remittances and their sending mechanisms (in concrete cases and in the present, between the United States and Mexico) will be presented in Chapter 3.2.

\subsubsection{Investment remittances}

The next circle of remittance definitions, Definition D, contains also migrant investments in durable goods, dwelling or land in the country of origin. Technically, 
a migrant pays its price of purchase, usually being there personally at the act of purchase, when returning to the country of origin. This 'return' can be short-term or long-term, in the latter case meaning that the migrant moves back definitely to the country of origin and ceases to be a migrant. Short-term return, in contrast, means that a migrant on a holiday visits their family in the country of origin, and while being there, uses the opportunity to carry out the purchase.

It is clear, and several surveys have proved it, that the poorer a migrantsending household is, the larger part of the total amount of remittance will be spent on food and basic livestock. However, if a household is already better-off, and remittances are an additional, and not the main (or the only) source of income, then investments are more likely to be made from the conveniently lumped sums of transfers received as an extra income, on top of the day-by-day local earnings.

Nonetheless, there are important differences between countries, regions and social groups. A comparative anthropological study [Baby-Collin et al, 2008] has shown that while in several Bolivian villages almost $60 \%$ of the remittances were used for productive purposes (mainly buying land), in Mexican villages it was only 15\%. Three conclusions were made: first, land has a greater symbolic value in Bolivia; second, Mexican emigration is more 'structural' and the rate of returnees is lower, thus they prefer to invest in the country of destination; and third, among Mexicans there were more migrants in undocumented status who gained less money than their documented fellows. From a developmental point of view it is also not clear whether buying land is beneficial or not if there would be other options to spend that money.

Furthermore, considering durable goods bought from remittances as an investment is also problematic in developmental terms, as in many cases these items come from the county of destination and even if they are bought locally, the retail stores are located in the big cities and owned by multinational companies (e.g. WalMart), thus smaller villages do not enjoy any 'spillover effect', as the money is not spent neither locally, nor on locally produced goods.

A broader perspective also includes the trade of goods and the additional economic activities that are brought to existence due to migration. Manuel Orozco's "5 T"-model comprises trade and other, migration-related and economically beneficial activities during which the country of origin receives money from migrants in the country of destination, the five T's being: trade, transportation, 
telecommunication, transfer of remittances and tourism between the two countries. According to Orozco, all these consequences of migration yield business opportunities for local entrepreneurs and a development potential for the country of origin. [Orozco, 2005]

Trade might appear as out of context here but it should be understood within Zhou's [2004] concept of "ethnic economies" which are supposed to fuel the trade of "ethnic" goods, such as traditional food, clothing or handicrafts. In other words, a migrant does not 'give' money to their family members or countrymen but engages them in a mutually beneficial exchange of goods which would have not taken place without migration. Migrants can buy products of the country of origin and sell them in the country of destination: either to other members of the migrant community or to the host society.

One must be more than skeptical with this approach. What Orozco calls "ethnic" or "nostalgic trade" is by no means an automatic demand enhancer for local economies back in the country of origin. A fieldwork in East Harlem, New York [Valenzuela, 2001] found that most Mexican-owned shops were restaurants, taquerías $^{3}$ or grocery stores, which either sold inexpensive food products imported from Mexico, or used US-produced ingredients such as beef, tomato or corn. Serving 'Mexican' food in the United States does not mean that the food is actually coming from Mexico, or that somebody in Mexico has received a significant amount of money for it.

Regarding transportation, telecommunication and tourism, Orozco's idea is the same: namely, that the total amount of monetary benefits from emigration should be taken into account, not only remittances or investments. Thus, every dollar that a migrant spends on traveling back and forth, paying telephone bills or internet access to their family members, or taking their new friends from the country of destination to visit their country of origin, should be added to the total sum of money transfers.

Investment remittances will be presented in details in Chapter 3.3.

\footnotetext{
${ }^{3}$ Eateries selling Mexican fast food (tacos).
} 


\subsubsection{Community remittances}

Definition E includes community remittances (also known as collective remittances), i. e. the outcome of fundraising activities carried out by migrant (or hometown) associations in the country of destination and sent to the country of origin as a donation of charity gift. Community remittances are, therefore, larger sums of money sent on a case-by-case basis, whenever there is a project or a special occasion that makes migrants urged and willing to donate money to the country, region or municipality they are coming from. Natural disasters can be a driver for charity on the national level, while hometown associations can capture donations aiming at a concrete investment in the municipality of origin. In any case, community remittances come from an association in the country of destination and go to a community (or a larger group of individuals) in the country of origin. While their monetary value is dwarfed by household and investment remittances (Definitions AD), their symbolic and social value might be very important.

Hometown associations are formal or informal groupings founded and run by migrants from a specific sending location at a specific receiving location, for example the San Antonio Social Club in Paterson, United States, the members of which are all migrants from San Antonio de Cocha, a municipality in Peru. [Ávila, 2003] Given the network basis of migration, it is not unusual that a large number of migrants from a Latin American town or county can be found in a particular town or neighbourhood in the United States or Europe. Conditioned by associational culture both in the sending and the country of destination, these associations can assume several tasks, including the fundraising for a specific objective related to the hometown. Associational culture (and the legal consequences thereof) in the country of destination is closely related to the possibilities of sending community remittances: while in the United States self-help organizations are very common, and fundraising is their daily routine, in other migrant destinations, such as Spain, associations are historically more tied to religion and culture and they rarely collect money. Migrants in Spain are therefore more likely to found cultural associations, as the legal framework is more appropriate for these, and they might not be able to send money to a Latin American country. [Aparicio Gómez, 2011]

Generally, migrant associations do not have a high budget, but they have two serious developmental advantages over individual remittances. The first is that, 
unlike individual remittances that usually arrive month by month, community remittances come at once and resolve one specific problem. Second, they do not pursue the objectives of one specific person or a household, but that of the whole community.

Churches can also generate community remittances. As Levitt [2007] puts it, "Migrant and nonmigrant followers of particular saints, deities, or religious teachers also belong to imagined global communities of connection." Many Latin American migrants go back to their locality of origin at least once a year, to the day of the patron saint, and they often raise funds for religious or charity purposes. Churches perform various important activities such as education, healthcare or psychological help towards the most vulnerable. These activities would not be carried out without the sense of solidarity that the church provides to its members who live outside the specific migrant-sending area.

Chapter 3.4 will deal with the issue of community or collective remittances in details.

\subsubsection{Social remittances}

The broadest definition of remittances, Definition F, adds the immaterial "social remittances" to the previously described elements. The term was coined by Peggy Levitt who meant "normative structures, ideas, values, and beliefs", "systems of practice "and "social capital" under this label. [Levitt, 2001] Originally, the author was referring to these assets on the individual level, showing the ideal type of a successful (rich) returning migrant who brings from the country of destination a new, fresh look on the problems of its home country, and the (allegedly) more development-oriented values and practices, and also the social ties to other rich migrants, making them an ideal actor to initiate deep transformations in the migrantsending community. Later [Levitt - Lamba, 2011] she focused on migrant associations, given the fact that an individual rarely has the force to transform a whole community, while associations can do an important work, as for example in the Dominican context, where it was the migrant associations that took on topics that were previously taboo, such as teenage pregnancy, reproductive health and AIDS awareness, and brought a high valuation of culture, sports and recreation, and the culture of fundraising by campaigns. 
Although one must be careful with the model of migrants transferring values as not every belief and social practice in the United States is undoubtedly positive, it can be said that richer societies generally cherish self-realization values, in contrast to poorer societies based on survival values [See Inglehart - Baker, 2000], therefore the impact of migrants can help these societies to move towards the former, if the economic conditions are given. Migrant associations can provide a model for nonmigrants to organize themselves along values that previously were considered deviant but in a better-off economic context are necessary to be adopted. Also, certain forms and contents of knowledge can be transferred, as it will be analyzed later, in Chapter 3.5.

\subsubsection{Effects of remittances on the micro and macro level}

From this point on, 'remittances' will be used according to Definition C, meaning 'household remittances' that comprise the recorded data on workers' remittances, compensation of employees and migrant transfers, and the estimated amount of regular but unrecorded transfers. Broader definitions would include transfers that are difficult to measure and very few publications dare to publish estimations on their monetary value.

The crucial point in the migration and development literature about remittances is whether the sum of the various developmental effects they have on the micro and the macro level is positive or negative. As already mentioned in 1.1.4.1., labour migration is driven by wage inequalities between countries, and the surplus purchasing power that stems from earning a wage in one country and spending it in another, is conceived by migrants and their households as the net benefit of migration. As also described in the previous chapter, the money that migrants do not spend or invest in the country of destination is sent to the country of origin as remittances.

The flow of private money transfers quantifiable as household remittances exceeds 500 billion US dollars worldwide. In Latin America, Mexico is the biggest recipient of remittances in absolute terms, receiving 22.5 billion dollars as of 2011, followed by Brazil, Guatemala, Colombia and El Salvador. Regarding the importance of remittances for the national economy, the remittances/GNI ratio is more telling: $19 \%$ of the Gross National Income is made up by remittances in tiny 
Honduras, $17.3 \%$ in El Salvador and $11.8 \%$ in Guatemala, while for larger countries this ratio is lower, even if in absolute terms they receive way more remittances: $2.6 \%$ in Mexico, $1.8 \%$ in Colombia and only $0.3 \%$ in Brazil (see 2.1.1. for further details). [Migration and Remittances Factbook, 2011]

No wonder that many scholars and policymakers have seen remittances from the early 2000s onwards as a panacea for developmental inequalities between the global North and South. Migrant remittances are the only North-to-South flow of capital that has been increasing constantly and aside from a small backdrop, remained resilient to the global financial crisis as well. Even before the unfolding of the crisis in 2008, remittances doubled the amount of all official development assistance (ODA) and were roughly equal to FDI and portfolio investments in lowand lower-middle income countries around the world, and since then remittances' absolute value and share in the total of flows has kept on growing. [Migration and Remittances Factbook, 2011]

However, remittances are different from ODA and corporate investments. As opposed to ODA, remittances are private flows of money, more precisely small amounts of hard-earned money, over which the state or any public body has very little control and disposal. In the following, therefore, remittances will be compared to international public developmental transfers. Then, a 'wellbeing' versus 'development' comparison will follow, showing that remittances are, as opposed to private (domestic or foreign) investments, mostly of a consumption-oriented nature, and they are not spent according to a productive/entrepreneurial capitalist rationality. Finally, a micro versus macro comparison will complete the picture, the former showing the cost-benefit function of an individual migrant and its household back home, and the role of remittances within, while the latter will present two other features of remittance transfers, the first being the human capital loss versus remittances gain dichotomy, and the latter, the financial consequences of foreign currency inflows to the macroeconomic performance of the country of origin.

\subsubsection{Public versus private allocation}

In a comparative analysis of ODA and remittances, Eversole [2005] concluded that the difference between the two should be understood having in mind the perspective of "poor people themselves, not how development institutions 
conceptualize development for them, but how these people actually implement, and succeed in achieving, development - the pursuit of improved well-being - given the opportunities within their reach." [Eversole, 2005, p. 310.] This is a very important notion, because political and scholarly discourse is often focused on whether remittances are used in a productive way or not, i. e. does their use lead to further economic activities or are they spent on consumer goods and leisure.

Some scholars and policymakers hold that ODA and government-led development programmes are better for achieving developmental aims than remittances, as they are more focused on macro level objectives, have a better understanding of economic and social processes and have a focus on poverty alleviation, while migrants and their household members tend to spend their earnings on unproductive consumer goods, often driven by prestige considerations, and their spending do not "trickle down" to non-migrant households. [de Haas, 2009]

Other scholars and policymakers, on the other hand, argue that remittances are a private salary by definition, and their only special feature is that they were earned in another country, thus migrants and their household members will spend it on whatever they want to, adding that the very fact that it is the 'poor people' themselves who can decide on what to do with a sum of money that arrives to a poor region or settlement, and not the government, is a value in itself. [Sorensen, 2004; Eversole, 2005]

Another important position is that of the "post-development" current which emphasizes that even though poor people's self-determination in this matter is a positive feature, no substantial and sustainable development can be based on migrant remittances, not because migrants are selfish and consumerist but because world systemic reasons (economic dependency, structural constraints) will lead to capital outflows and continued outward migration from poor areas. [Escobar, 1995; Rist, 2003]

Main elements of the ODA/government-led development versus migrant remittances debate are synthesized in the table below. 
Table 10. Official (international) development assistance or government-led development programme versus migrant remittances

\begin{tabular}{|c|c|c|}
\hline & $\begin{array}{l}\text { Official (international) } \\
\text { development assistance or } \\
\text { government-led } \\
\text { development programmes }\end{array}$ & Migrant remittances \\
\hline Source of money & $\begin{array}{l}\text { Government of the country or of } \\
\text { another country (ODA) }\end{array}$ & Migrant worker abroad \\
\hline $\begin{array}{l}\text { Destination of } \\
\text { money }\end{array}$ & $\begin{array}{l}\text { Development project and its } \\
\text { administration }\end{array}$ & Household of the migrant worker \\
\hline Channel & Official & Private \\
\hline $\begin{array}{l}\text { Decision } \\
\text { allocation }\end{array}$ & $\begin{array}{lcr}\begin{array}{l}\text { Political, formal, based } \\
\text { political } \\
\text { indicators }\end{array} & & \text { on } \\
\text { agreements } & \text { and } \\
\end{array}$ & $\begin{array}{l}\text { Individual, informal, based on } \\
\text { subjective ranking of priorities of the } \\
\text { household }\end{array}$ \\
\hline $\begin{array}{l}\text { Positive aspects (in } \\
\text { the literature) }\end{array}$ & $\begin{array}{l}\text { - } \quad \text { Macro-level approach } \\
\text { - } \quad \text { Planned developmental } \\
\text { strategy } \\
\text { - } \quad \text { Focus on economic } \\
\text { activities, poverty alleviation, job } \\
\text { creation and reduction of } \\
\text { inequalities }\end{array}$ & $\begin{array}{l}\text { - Free decision of the people } \\
\text { involved, based on their needs and } \\
\text { subjective assessment of welfare } \\
\text { objectives } \\
\text { - Multiplier effect in the local } \\
\text { community } \\
\text { - Private income resilient to crisis }\end{array}$ \\
\hline $\begin{array}{l}\text { Negative aspects } \\
\text { (in the literature) }\end{array}$ & $\begin{array}{l}\text { - } \quad \text { Lack of knowledge on local } \\
\text { needs and constraints } \\
\text { - Political-bureaucratical } \\
\text { conditioning of the allocation } \\
\text { - Probability of corruption } \\
\text { - } \quad \text { Prestige investments and } \\
\text { "white elephants" } \\
\text { - Human capacities are used } \\
\text { for administration instead of } \\
\text { technical work }\end{array}$ & $\begin{array}{l}\text { - } \quad \text { Sustaining obsolete and } \\
\text { dependent economic structures } \\
\text { - } \quad \text { Prestige consumption and } \\
\text { unproductive spending of the income } \\
\text { - } \quad \text { Culture of living off remittances } \\
\text { instead of working locally } \\
\text { - } \quad \text { Growth of inequalities } \\
\text { - } \quad \text { Growth of consumer prices }\end{array}$ \\
\hline
\end{tabular}

Source: own compilation based on Escobar [1995], Rist [2003], Sorensen [2004], Solimano [2004], Eversole [2005] and Delgado et al. [2009]

\subsubsection{Wellbeing versus development}

Another possible approach is the wellbeing/welfare (bienestar) ${ }^{4}$ versus development (desarrollo) dichotomy. The key theorist of the concept of wellbeing or well-being, Partha Dasgupta [1995] argues that the notions of decent living conditions, balanced nutrition and lack of psychological stress factors are of basic importance, thus they should be given the same importance as development, not as opposed to, but complementing the notion of development (somewhat similar to, although reaching a bit further than the "capabilities" approach by Amartya Sen, published a couple of years later). Wellbeing is usually understood on a micro

\footnotetext{
${ }^{4}$ The Spanish noun bienestar can be translated to English either as "wellbeing" or as "welfare".
} 
(individual or household) level, while welfare refers to the macro level of societywide mechanisms. In the case of (household) remittances, therefore, wellbeing is the relevant expression.

Sociological evidence shows that migrants from lower-middle income countries with weak social protection system not only pursue gains and increased income through migration but they also regard it as a coping mechanism with negative external factors such as an unexpected illness. Alejandro Canales Cerón [2008] remarked that remittances are often covering 'emergency' expenses, in cases of illness, material damage, indebtedness or even a social obligation such as the 'quince años" ${ }^{5}$, of a female child, thus being out of the scope of making economically rational choices. The term 'choice' itself might be inappropriate. Raúl Delgado Wise and his research team, among many others, made a point on how remittances are generated: under precarious conditions, often in clandestine employment and exploitation; and how they are spent: conditioned by marginalized social position and in underdeveloped areas with very few alternatives for any economic activity. [Delgado Wise et al, 2009]

Based on this notion, i.e. seeing migration as a coping mechanism with threats to the household's wellbeing, rather than as a long-term strategy for development through savings and investment, Canales thus suggests to treat wellbeing and development separately. The first concept (bienestar) belongs to the household realm and it has the objectives of any household with or without migrant relatives, i. e. sustaining the material circumstances that would permit the members of the given household to maintain healthy and satisfactory living conditions. The second (desarrollo), belongs to the productive/entrepreneurial capitalist realm and has profit-maximizing objectives, containing also the probability of cutting back on economically unproductive activities, which makes no sense in the household approach. A somewhat modified overview of Canales's model is presented in the following.

\footnotetext{
${ }^{5}$ The 15th birthday of a female child which is celebrated throughout Latin America almost as exuberantly as a wedding. It has the objective of 'presenting' the young lady to the society, i.e. as a possible bride-to-be for pretenders.
} 
Table 11. 'Wellbeing' versus 'development' approach of remittances use

\begin{tabular}{|c|c|c|}
\hline & 'Wellbeing' approach & 'Development' approach \\
\hline Remittances' recipient & $\begin{array}{l}\text { Household (as a group of } \\
\text { people united by family, } \\
\text { kinship and/or emotional ties) }\end{array}$ & $\begin{array}{l}\text { Business (can be a family } \\
\text { business as well, but members } \\
\text { are united by economic } \\
\text { rationale) }\end{array}$ \\
\hline Circle of recipients & Given & Can be changed \\
\hline $\begin{array}{l}\text { Remittances are } \\
\text { complementary to: }\end{array}$ & $\begin{array}{l}\text { Locally earned wages, rents } \\
\text { and other family incomes }\end{array}$ & $\begin{array}{l}\text { Public, domestic private, or } \\
\text { foreign private investment }\end{array}$ \\
\hline $\begin{array}{l}\text { Balance achieved through } \\
\text { remittances }\end{array}$ & Income-spending & Savings-investment \\
\hline $\begin{array}{l}\text { Money is typically spent } \\
\text { to: }\end{array}$ & $\begin{array}{l}\text { - Direct consumer goods } \\
\text { and services } \\
\text { - } \quad \text { Durable consumption } \\
\text { goods, including housing } \\
\text { - Savings for future } \\
\text { consumer goods and services } \\
\text { - } \quad \text { Emergency cases: health- } \\
\text { related and other unforeseen } \\
\text { expenses } \\
\text { - Education } \\
\text { - Social celebrations and } \\
\text { family ceremonies (quince } \\
\text { años, weddings, baptisms, } \\
\text { funerals, etc.) }\end{array}$ & $\begin{array}{l}\text { - Fixed capital, working } \\
\text { capital, reinvestments, tax } \\
\text { payments } \\
\text { - Land, buildings and } \\
\text { machinery, consumables, } \\
\text { livestock } \\
\text { - Deposits in banks, cash } \\
\text { pools, loans } \\
\text { - Productive infrastructure, } \\
\text { communication and transport } \\
\text { - Public goods, social } \\
\text { infrastructure }\end{array}$ \\
\hline $\begin{array}{l}\text { Direct consequences of } \\
\text { remittance transfer }\end{array}$ & $\begin{array}{l}\text { Increased level of wellbeing, } \\
\text { more stable economic basis for } \\
\text { a healthy and satisfactory life } \\
\text { for household members }\end{array}$ & $\begin{array}{l}\text { Creation of jobs, purchase of } \\
\text { local economic assets }\end{array}$ \\
\hline $\begin{array}{l}\text { Indirect consequences of } \\
\text { remittance transfer }\end{array}$ & $\begin{array}{l}\text { Multiplier effect through } \\
\text { consumption (the money which } \\
\text { is spent locally, benefits local } \\
\text { economy), and/or growth of } \\
\text { inequality between migrant and } \\
\text { non-migrant households }\end{array}$ & $\begin{array}{l}\text { Stability of the local economy } \\
\text { through sustaining the value of } \\
\text { immobiliary and paying taxes }\end{array}$ \\
\hline
\end{tabular}

Source: Canales [2008], own synthesis based on the tables on p.14 and p.21 and other notions in the text

It can be seen that critiques regarding the 'unproductive' or 'dependent' nature of living off remittances are dismantled by separating a different 'wellbeing' and 'development' approach. However, it assesses only a micro level of effects of remittances, leaving aside macrostructural constraints for achieving either 'wellbeing' or 'development', on one side, and macroeconomic effects of remittances inflow, in another. A macro level approach is therefore needed to complete what is presented above. 


\subsubsection{Micro versus macro level effects}

A third possible approach to assess the role of remittances in development is the conceptual divide between micro and macro level effects. The elements described in the previous, 'wellbeing' versus 'development' dichotomy are essentially micro level factors, while the 'private' versus 'public' approach is dealing with both micro and macro level effects from an essentially macro level perspective. However, as remittances are basically foreign hard currency pouring into the national economy (which is a very positive feature at first sight), the financial imbalance can be the source of a number of negative consequences on the macro level.

On the micro level, it is the migrant's own cost-benefit balance that counts. The possible gains, as it has already been mentioned, come from the differences in wages between the country of origin and the country of destination. Nonetheless, there is an opportunity cost of migration: except for situations of massive unemployment, people who decide to migrate could have held a position in the country of origin, the salary of which (in PPP) should be subtracted from the amount of the salary in the country of destination, in order to get the net gain of migration.

The following table presents wage gaps for the United States and three Latin American countries in selected professions.

Table 12. International Average Salary Income Comparison: Average nominal and PPP net monthly wages in USD in three Latin American countries and the United States (2006)

\begin{tabular}{|l|l|l|l|l|l|l|l|}
\hline & $\begin{array}{l}\text { Brazil } \\
\mathbf{1 : 1}\end{array}$ & $\begin{array}{l}\text { Brazil } \\
\text { PPP }\end{array}$ & $\begin{array}{l}\text { Mexico } \\
\mathbf{1 : 1}\end{array}$ & $\begin{array}{l}\text { Mexico } \\
\text { PPP }\end{array}$ & $\begin{array}{l}\text { Peru } \\
\mathbf{1 : 1}\end{array}$ & $\begin{array}{l}\text { Peru } \\
\text { PPP }\end{array}$ & USA \\
\hline Engineer & 1481 & 3687 & 1081 & 1562 & 1176 & 2560 & $\mathbf{4 7 1 0}$ \\
\hline Professor & 790 & 1968 & 1059 & 1655 & 691 & 1599 & $\mathbf{4 6 3 8}$ \\
\hline Teacher & 299 & 745 & 651 & 1018 & 474 & 1097 & $\mathbf{4 0 5 5}$ \\
\hline Nurse & 650 & 1766 & 534 & 834 & 528 & 1149 & $\mathbf{3 1 6 8}$ \\
\hline Miner & 295 & 747 & 368 & 584 & 226 & 531 & $\mathbf{2 6 9 4}$ \\
\hline Car mechanic & 239 & 649 & 401 & 626 & 198 & 458 & $\mathbf{2 5 2 6}$ \\
\hline Office clerk & 376 & 1021 & 486 & 759 & 476 & 1102 & $\mathbf{1 9 2 1}$ \\
\hline Salesperson & 199 & 504 & 300 & 468 & 376 & 871 & $\mathbf{1 8 7 6}$ \\
\hline Bus driver & 306 & 762 & 389 & 609 & 140 & 325 & $\mathbf{1 5 9 4}$ \\
\hline Chambermaid & 122 & 332 & 261 & 408 & 159 & 347 & $\mathbf{1 2 5 1}$ \\
\hline
\end{tabular}

Source: own compilation based on data retrieved from WorldSalaries.org [2006] 
The table above shows that a Mexican nurse, if she decides to migrate to the United States and finds a job in her field, will receive a salary which is six times higher in absolute terms and almost four times higher regarding its purchase power. The difference of the two salaries (minus the difference of the cost of living) in purchase power terms is the net gain of migration and it can be sent back home as remittances. However, as Delgado and his co-authors [2009] note it, immigrant wages are generally way lower than a native would earn for the same position, and non-monetary additional benefits are almost nonexistent, especially if the migrant is undocumented. Also, a very large share of the salary is spent locally in the country of destination, let aside the costs of travel (including the coyote, or human trafficker, for the undocumented) and all those costs that come with a marginalized social position and lack of social capital. The figures in the table also show that in many cases, deskilling or brain waste can also be the outcome: if there are no options for working as a nurse, working as a salesperson is still an economically reasonable option for a Mexican nurse in the United States.

On the macro level, however, the picture is different. Two approaches are relevant here: the human capital and the financial approach. Regarding human capital, the point is that even if the balance of costs and benefits is positive for an individual migrant, the balance on the macro level is not the sum of these individual balances. Delgado et al. [2009] showed that Mexico is in fact a net human capital exporter to the United States: the average state spending of the Mexican state in terms of education and healthcare, on an average Mexican citizen until the point when they enter the labour market, multiplied with the flow number of Mexican immigrants to the United States per year, is nearly the double of the yearly amount of remittances from the United States to Mexico. This phenomenon, more narrowly known as the brain drain (for the tertiary educated) frames the remittances issue very differently. [Didou, 2009]

The picture must be completed with three other notions. The first is while the 'loss' of human capital is counted once, remittances keep on arriving to the country of origin from the moment when the migrant becomes able to save some money. Under conditions of underdevelopment and unemployment, a country can benefit more from its citizens working abroad and sending remittances, than staying at home being unemployed or underpaid. This was the starting point for many 'labourexporting' countries when they entered the migration arena. 
Second, many migrants keep on studying after leaving the country of origin. Actually, higher education is one of the key drivers for young people: they want to study in a country where standards are better and titles are more renowned than in their home country. In this case, the difference between the wages of a worker without this qualification, and the wage that the migrant with the qualification actually receives, is an additional source of more remittances that would have not come into existence without migration. The same applies to the migrants' productivity after returning to the country of origin, if they decide to do so. [Helliwell - Putnam, 1999]

As many research results show that migrants are likely to return to the country of origin after a while, the third notion is the nature of return. There are many options: the returnee can be economically active or passive, they can bring home savings or arrive with an empty hand, they can come back to stay or they will migrate again when conditions will require it. Human capital loss is therefore not definitive, but 'brain drain' might turn to 'brain circulation', or even 'brain gain' if a migrant has learnt useful things as described in the second notion. These three notions soften the 'human capital loss' approach, although the balance is still more likely to be negative than positive. Chapter 3.3. of this thesis deals with the issue of return migration, while Chapter 3.5. makes a point on brain drain.

The second macro level aspect, not discussed until now, is the financial consequences of foreign currency inflow. According to Martínez Pería et al. [2008], there are many positive aspects of money arriving through the banking system to otherwise 'unbanked' societies: first, if recipients want to minimize the costs of remitting, they are obliged to use the banking system, which 'paves the way' for them to gain access to other financial products and services. Second, banks might also build on remittances as backing for loans, thus dynamizing the credit market in an environment with lack of funds and resource gaps. Third, banks' loanable funds can grow as a result of deposits generated by remittances flows. Fourth, as remittances usually arrive as lump sums, recipients are more likely to store them in banks.

On the other hand, negative effects can also be present. First, remittances can help to relax the recipients' financing constraints, thus leading to a lower demand for credit and dampening the credit market development. Second, remittances might be immediately consumed and never reaching the banking system, or third, people 
might not trust financial institutions and prefer to keep their money away from them, these latter two cases meaning an increased demand for cash.

Besides these effects on the financial system, the real exchange rate also gets affected by the fact that huge sums of foreign currency arrive to local residents' bank account, but they will be spent in local currency. With the exception of those Latin American countries that are using the US dollar as a de facto national currency, remittances need to be exchanged from dollar to the national currency, and not only real exchange rate changes can alter the purchase power of remittances (see Table 8) but also vice versa. Increased demand for a national currency leads to its overvaluation vis-à-vis the dollar, and the so-called Dutch disease phenomenon appears: inflationary pressure becomes massive for most of the domestic nontradable goods, and locally produced goods lose price competitiveness because of the overvalued national currency and decrease of exports, possibly leading to the loss of jobs and even more emigration. [López et al, 2008]

\subsubsection{Remittances and the state}

As explained above, remittances are of a somewhat controversial nature but they have important positive effects both on the micro and the macro level. At a first glance and from a governmental perspective, they seem to be a very valuable resource, as they are a direct inflow of money from abroad that might act as a substitute for resources of the central budget. No wonder that governments in lower and lower-middle income countries have started to focus on these massive inflows of money.

However, remittances are not an easy target. Not only they are difficult to conceptualize and measure (as seen above) - they are also nearly impossible to tax. They appear in the form of unpredictable investments in unpredictable places, either in line with a general governmental plan for economic, social and spatial development, or completely unrelated to it. They can even be transferred to (or captured by) the opposition and ending up in implicit or direct financing of antigovernment activities.

As remittances usually arrive as small amounts of private transfers from abroad, the government never sees them in one sum, if not in the statistical tables. They cannot be taxed because any attempt on this matter would immediately drive 
remittances to informal or semi-formal channels. As a matter of fact, why would they be subject to any sort of income tax? They have already been taxed in the country of destination, and if for some reason they have not (having been earned in the black market), the country of origin still does not have the right to put an income tax on them. [Rédei, 2007]

Governments, however, have not always been scrupulous about taxing remittances, regardless of the justifiability of doing so. In 2007, for example, Bolivia put a $1 \%$ tax on all incoming private money transfers to the country, the overwhelming majority of which were migrant remittances from Spain, Argentina and other countries of destination for Bolivian migrants. Nonetheless, a public outcry and a sudden drop in the use of formal channels made Evo Morales's government back away from it, first by lifting the tax for transfers under 1,000 US dollars and then by abolishing it completely. Similar were the results when Colombia introduced a tax of $1.25 \%$. [Remesas.org, 2008]

While income tax on remittances might not be a viable idea, if the inflowing money is spent locally, then the income from value added taxes will increase. In case of VAT-biased taxation, which is the case in many developing countries, the government budget might gain back more on value added taxes on remittances being spent, than what it loses on not being able to put any income tax on remittances. On the long run, it means that tax burden on durable goods will make their price grow, and at a given point it will be a cheaper option for migrants to bring them directly from the country of destination whenever they return for a visit, instead of sending remittances for family members who would buy these goods in the country of origin. This is exactly what happened to household electrical appliances and personal computers in Mexico. [Cirasino et al, 2008]

Construction is another activity where remittances are usually involved and it could also be taxed. Building huge houses from remittances, for example, is a wellknown feature of local communities with a strong and recent emigration, as many migrants want to show off their recently acquired wealth and they start to build grandiose homes, even if they actually do not live in those buildings but keep on working abroad. However, in Latin America traditionally there is no tax on real estate - with the exception of an approximately 1-2\% of acquisition tax on the sale value of the property, depending on the country. Taxing 'migrant' homes would be highly discriminatory and rather difficult to carry out. [Cirasino et al, 2008] 
To sum up, remittances are basically out of range for the usual taxation mechanisms of the state - they can only be tapped indirectly, via value added taxes, but only to a certain point. Also, they are not really sensible to government planning on what sort of development models should be followed overall or in certain geographical areas. As migration is a highly clustered and network-related process, it can happen that one village has plenty of huge houses, paved roads and a modern school, while the neighbouring one lacks all of these features. This is the case, for example, in the mountain villages southwest to Mexico City, where those communities with many migrants abroad have a reasonably high standard of living, while the others live in poverty. [Baca, 2009]

The same applies for social groups: remittances go to family members and kins, thus ethnic differences will be stressed if there are significant differences in the migration patterns of the ethnic groups. As migration needs an initial investment of money for buying the plane ticket or to pay for the coyote ${ }^{6}$, it is the better-off ethnic or kinship group which will be able to send its members to work abroad. This is what happened to the - already rather wealthy - indigenous people of Otavalo, Ecuador, who were merchants, as opposed to the poorer farmers of the region, belonging to other indigenous groups. Through remittances and new business connections, otavaleños became even more affluent than they used to be, while the living standards of the other indigenous groups did not change significantly. [Ljungkvist, 2011]

These notions are important because the inflow of remittances might be a challenge for economic, social and regional development policies. Very poor countries obviously cannot do anything but accept the resulting unequal development as a given, but lower-middle income countries (as the majority of Latin American nations) can aim at making complementary investments where remittances do not reach. This, in turn, would mean abandoning those villages where wealthy migrants have their families left behind, but otherwise the municipality (and the public services for which it is responsible) are in a chronic lack of funds.

This is why many countries with an uneven emigration landscape and a significant inflow of remittances - most importantly Mexico - started to adapt an approach of co-funding, in which migrant associations are involved as donors for

\footnotetext{
${ }^{6}$ Human trafficker.
} 
development projects that are in line with the government's development goals. Chapter 3.4 of this thesis describes and analyzes these efforts.

However, in many cases migrants send money home for a certain public purpose which does not necessarily please the government. Both the Farabundo Martí National Liberation Front (FMLN) in El Salvador and the Revolutionary Armed Forces of Colombia (FARC) allegedly received donations from migrants in the United States, as it was stated in the post-9/11 securitization of remittance channels. [Ramsey, 2012] Also, the bitter relation between Chávez's and Maduro's Venezuela and its diaspora is related to the funding that the latter has been sending to the opposition in the country. Obviously, it is in the government's interest to block these transfers. Nonetheless, as they usually come in cash, it is almost impossible to stop them, as all law enforcement can be blocked with the sufficient amount of dollars.

An interesting case is that of the Dominican Republic. Dore et al. [2003] describe how politics in this country became driven by migrant money. Both of the two big parties of current Dominican politics, the leftist PRD and the centrist PLD were founded in New York's Washington Heights neighbourhood. The democratic transition concluded with the 1996 elections in which both big parties collected around $10-15 \%$ of the total cost of their campaign from Dominicans living abroad. What is more, the president-elect, Leonel Fernández had grown up in New York, and one of his first measures was to authorize double citizenship, the most important objective of the Dominican community in the United States. Remittances, in a very direct way, were successful in achieving a political goal.

Transnationalization of the political arena through migrant fundraising for political parties in the country of origin is a phenomenon in other Latin American countries as well. This is one of the source areas of diaspora engagement policies, which are described and analyzed in this thesis, beginning with a theoretical overview of the concept of the diaspora as such and the transnational policymaking from a country of origin perspective. As 'individual migrants' have become a coherent 'diaspora', so have isolated government attempts of tapping the flow of household, investment, collective and social remittances become a coherent set of 'diaspora policies'. 


\subsection{Diaspora and the state: transnational policies for development}

Migration at first sight is a process in which people move from one country to another because they find it a reasonable solution for the challenges they are facing in their lives, whatever these challenges may be. The very narrow interpretation of the term 'migration' is, therefore, the act of leaving the country of origin and arriving to the country of destination. Immediate antecedents, the circumstances and the immediate consequences of migrating are usually included in this interpretation, which usually loses sight of the migrants once they are integrated into the society of the country of destination.

Integration, while being a widely discussed term, is usually operationalized in terms of reaching a certain legal status (citizenship or permanent residence permit), labour market status (stable job) and the acquisition of cultural and social skills for being able to interact with members of the host society (at least medium-level language proficiency, knowledge and respect of the basic traditions and customs of the country of destination).

Regarding its psychological and interpersonal projections, social sciences use the terms 'assimilation' (for migrants who come to resemble the members of the host society in cultural and social behaviour) and 'acculturation' (as an adaptation strategy of whole societal groups, including the majority group, to the simultaneous existence of different cultures within one political/geographical unit.

Conceptual or methodological questions of the complex issue of migrant integration, assimilation and acculturation are not included in the topic of this thesis, for key concepts and problems see Portes - Böröcz [1989], Portes - Zhou [1993], Alba - Nee [1997], Berry [1997], Eriksen [2007], Ager - Strang [2008], Schwartz et al [2010]. For questions of research methodology and indicators, see Huddleston et al [2011], OECD [2012], Sik [2012] and Kováts [2013].

Countries of destination have been dealing with the above mentioned issues mostly within the policy framework known as 'multiculturalism'. As migrant integration does not (usually) lead to perfect assimilation and cultural traits of the migrant groups remain significant even in the case of the second and the third generations, many liberal Western states have declared themselves to be multicultural. The term 'multicultural' originally designed countries with several 'indigenous' nationalities, even if in very different social and political contexts: 
Canada, Belgium, Yugoslavia, the Soviet Union, and so forth. To a certain extent, every country in the world is multicultural. However, multiculturalism as an active policy framework is more than the simple recognition of this fact: it actively pursues the dignification of the different cultures that constitute a country.

Over the years, multiculturalism has had ambiguous effects: while achieving a lot in symbolic terms, in most countries it failed to change the economic and social causes of the exclusion mechanisms which led to the reproduction of inequalities among ethnic or cultural groups. Multiculturalism as an ideology or a political practice is also out of the scope of this thesis: for further information, see Kymlicka [1995], Žižek [1997], Hesse [2000], Parekh [2002] and Hasmath [2011].

While fundamentally important in Migration Studies, theories and policy implications of migrant integration, assimilation, acculturation and multiculturalism are not treated here in details because they have been conceived and applied from the perspective of the country of destination, i.e. where migrants arrive and are supposed to be integrated. The topic of this thesis, however, falls under the scope of diaspora research, which is understood from the perspective of the country of origin.

As already described in Chapter 1.1.1, Migration Studies have a massive bias towards the perspective of the country of destination. This is not surprising, firstly because the social and policy challenges are more substantial where people actually are, and not where people are absent, and secondly, because countries of destination are usually richer and have a more abundant production of academic and policy papers than countries of origin which are usually poorer and less developed in this respect.

As a consequence, the following Chapter 1.3. is conceptualized around the 'diaspora' literature which has the perspective of the country of origin and focuses on the co-nationals or co-ethnics living abroad, in function of the connections they have with the 'motherland'. Rather awkwardly, this literature is also dominated by Western scholars who have been theorizing about the issue in general, while 'local' scholars (i. e. those who were born and still live in countries of origin of migrants) have been acting as transmitters of local knowledge, focusing on individual countries as 'case studies'. Global hierarchies of knowledge production are as present in this field of research as in any others in social sciences.

The first part of Chapter 1.3. presents a conceptual overview of diasporas, their possible linkages to the state, and the concept of transnationalism, i.e. the 
research focus which surpasses the 'methodological nationalism' and recognizes the simultaneousness of multiple belongings. Then, considerations on policymaking follow, regarding the general and particular possibilities of the government of a country of origin in the area of diaspora policies. Finally, a feedback on the three hypotheses of this thesis closes the Chapter 1.3. and the whole Chapter 1.

\subsubsection{Diaspora, transnationalism and the state: a conceptual overview}

The term diaspora derives from the Greek "to sow or scatter from one end to the other" and is generally defined as "a self-identified ethnic group, with a specific place of origin, which has been globally dispersed through voluntary or forced migration." [Vertovec, 2006, p.3] In its classical meaning, it was used for historical communities of given nationalities living permanently detached from their home territories, most importantly the Jewish, the Greek and the Armenian diaspora. Curiously, European colonists were never understood as a 'diaspora', even if the Spanish and Portuguese Creoles in Latin America, or the British or Dutch inhabitants of South Africa were always a numerical minority in the areas where they were permanently living.

Using the term 'diaspora' in the context of South-to-North migration began in the late 1980s. [Tóth, 2006] It was mostly due to a growing awareness of migrant communities as actors in the political life of their countries of origin, at times in favour of, at other times against what Western governments were allied to. The renovated interest in diaspora research can therefore be traced in the political and scientific discourse as a certain way of re-discovering a feature of human societies that has been there for centuries if not for millennia: exile or mass emigration of a group of people from a country, and their subsequent attempts to remain in connection with the happenings back home. [Kunz, 2010]

However, if every migrant group is dubbed as 'diaspora', the term loses its analytical value. Terms as Cohen's "catastrophic diaspora" or "victim diaspora" [1997] for war-ravaged groups such as the Palestinian, or Armstrong's "mobilized diaspora" [1976] for tight-knit and upward mobile East Asian nationalities, began to spread in the scientific community, resulting in what Brubaker calls the "'diaspora' diaspora' - a dispersion of meanings of the term ['diaspora'] in semantic, conceptual and disciplinary space.” [Brubaker, 2005, p.1] 
'Diaspora' therefore makes most sense when it is defined as a group of migrants in the country(ies) of destination who are able and willing to maintain ties with the country of origin, in order to make things happen in a way they find as favourable. If this is 'good' or 'bad' for the government of the country of origin, depends on the concrete circumstances. But it is rather likely that a conflict of values, opinions and interests will be present: after all, these people left the country for a reason.

The first influential work focusing on modern (migrant) diasporas' political involvement in their home countries' affairs was Benedict Anderson's analysis on what he called "long-distance nationalism", i. e. support of (ultra)nationalist groups by the diaspora. [Anderson, 1998] This political approach gives a narrower scope on diasporas than what is defined by Brubaker's three criteria (dispersion, homeland orientation and boundary-maintenance): diasporas are seen as agents of political action in the country of origin, even if they are physically absent. [Brubaker, 2005]

This sort of politics (still with a focus on migrants/diaspora and not the state as an agent) received the "transnational" epithet. Transnationalism as a social and political concept is equally difficult to define as the concept of diaspora, but it can be understood broadly as a set of political actions and social exchanges that occur between citizens and governments belonging to different states. As opposed to "international", transnational politics was first described by Phillip Jessup in the 1950s [Jessup, 1956], the main difference being the direct involvement of nongovernmental actors in the social and political life of another country in the case of transnational relations, while international relations are usually between two governments (as the representatives of their respective "nations").

In an overview, Waldinger [2013, pp. 757-760] presents how this concept has had "an honorable career", encompassing Raymond Aron's notion on "transnational society" as social practices that cross borders and Nye and Keohane's "transnational relations" as political actions that cross state boundaries and are not controlled by national governments. More directly linked to the migrant experience, Nina Glick Schiller's "transnational ways of being" and "ways of belonging" [2001] described the livelihood strategies (in the former case) and emotional relationships (in the latter) that migrants keep with their countries of origin and destination. Finally, Peggy Levitt [2001] substitutes the concept of a supposedly homogeneous 
"transnationalism" with a set of "transnational practices" that occur in an erratic and less intense manner.

Transnational spaces thus have the common feature that they involve many elements that are not directly and necessarily linked to the state apparatus of the country of origin. Diasporas generally come into being without the help and support of any government - actually, as already mentioned, the rulers of the country of origin are sometimes the main reason why citizens feel urged to leave the country. Transnational practices that emerge between migrants, on one hand, and their relatives and friends who did not emigrate, on the other, are also likely to appear spontaneously.

What can the overall position of the government of a country of origin be with regards to the fact that citizens are moving abroad? Two categorizations are worth citing, the first being elaborated by Miguel Ángel Centeno [2005]. Capabilities and restrictiveness define the two axes of migration-related policymaking, resulting in the following ideal types for countries of origin ${ }^{7}$ :

- The "frustrated guardian" state, with willingness to restrict emigration but without sufficient means (either economic or police and military) to do so;

- The "paper-walled" state, which does not want to restrict that its citizens go abroad, nor it would be able to hold them back;

- The "stockholder" state, which also does not put restrictions to its emigrant citizens, although it would have the capacities to do so, but it rather uses these capacities to capitalize on the diaspora; and

- The "iron-curtained" state, which wants to restrict the emigration of its citizens and it is successful in doing so.

Centeno's nomenclature is particularly expressive, as it synthesizes capabilities and aspirations in one single notion. "Frustrated guardian" states as well as "iron-curtained" states are understood as possessive, oppressive entities which treat their citizens as property which is likely to be 'lost', once they make it to go abroad. The latter is successful in holding them back, while the former is not, and it

\footnotetext{
7 For the sake of completeness, the four ideal types of countries of destination should also be mentioned, that are, according to Centeno, 1. the "open borders" state that does not restrict the entry of foreigners nor it would be able to do so, 2. the "split-minded" state that would like to be restrictive but it is incapable to do so, 3. the "fortified castle" state that pursues a restrictive immigration policy and it is able to implement it properly, and 4. the "good neighbour" state that would have the means to restrict immigration but is is not willing to do so.
} 
causes a frustration in the government which usually materializes in patriotic outbursts, calling outward migrants as 'traitors'. In the Latin American context, Cuba could be seen as an "iron-curtained" state until rather recently, while the current Venezuelan government can be dubbed as a "frustrated guardian".

On the other hand, there are two ideal types of states which do not restrict the outflow of their citizens, either because they don't care (the "paper-walled" states) or they find it economically or politically beneficial (the "stockholder" states). However, the group of "paper-walled states" should be split into two, very different positions. First, there are the countries who cannot really do anything as they do not have the means to hold people back (and neither do they worry about it, as the “frustrated guardians" would). Small Central American nations, such as Nicaragua or Guatemala could be examples for this stance. Second, there are larger, liberal countries whose sheer size makes them relaxed about the outward migration of thousands of citizens: Brazil can be cited here. Finally, "stockholder" states are those who let people go but they want to profit from it. These are the countries who actively pursue the creation of diaspora policies: Mexico, Ecuador, Peru and Colombia, among others.

The second relevant categorization of the possible attitudes of the government of the country of origin towards the diaspora was set by Alan Gamlen [2006]. While less poetic than Centeno's nomenclature, perhaps it is more operational in terms of focusing on what happens after the migrants have already left the country. Gamlen's categories are the following [2006, p. 21.]:

- The "exploitative" states that only "extract obligations without extending rights", i. e. pursuing an agenda in which most items are related to what a migrant is supposed to do after leaving the country of origin;

- The "generous" states that are the exact opposite of the previous category, $i$. e. states that grant rights and provide benefits to migrants without expecting concrete actions from the diaspora - in other words, they "extend rights without extracting obligations"; and

- The "engaged" states that actively pursue to both "extend rights" and "extract obligations".

To these three categories found in Gamlen's text, I find that a logical fourth position should be added, which I would call: 
- The "neglective" states, i. e. those states that do not actively engage themselves in negotiations with the diaspora. There can be many reasons for this: lack of interest (the diaspora is small and/or the country is rich), lack of understanding (the government and the diaspora are ideologically opposed to each other) or lack of capabilities (the country is very poor and has no means to engage itself in - often costly - diaspora politics). This latter position is, however, dubious, because of the migrants' agency: migrants as agents can take the initiative if the state cannot, which is actually the case with many underdeveloped countries.

Although the character of a state's diaspora policy is not necessarily linked to its geographic, cultural or economic attributes, interesting remarks can be made by observing Gamlen's cross-tables [Gamlen, 2006, p. 9 and p. 19] in which the author compares the main diaspora policy measures of 73 countries. According to these tables, the "engaged" countries include mainly large or middle-sized medium-income states from around the globe, such as Turkey, India, China, Mexico or Argentina, and also some richer countries as Australia and New Zealand, and poorer ones like Morocco, Eritrea or Haiti. One of the author's main statements is that "engagement" to the diaspora issue is not a consequence of a country's regional belonging, i. e. neighbouring states can have diaspora policies of quite different intensity. However, it seems that "exploitative" and "generous" states are more clustered: in the first group mainly Asian and Middle Eastern countries like Taiwan, Sri Lanka or Israel can be found, while in the second group, European and Latin American countries appear, such as Italy, Croatia or Colombia. Finally, the states that I call "neglective" include countries as diverse as the Netherlands, Chile, Russia and Venezuela.

Centeno's and Gamlen's categorizations seem to correlate in many points, the latter also having the benefit of relying on a large set of empirical data. On one hand, it seems that governments of richer and/or large countries do not really see the necessity to get engaged in diaspora policies, while countries with a significant political tension with the diaspora might not want to establish this kind of links. In both cases, governments will not do much about the issue.

On the other hand, there are governments of countries with significant emigration who would like to do something, and if they have the means to do so (i.e. they are not too weak, divided, poor etc.), policies will be created in order to keep in touch with members of the diaspora. Whether these policies serve to "extract 
obligations" or to "extend rights", depends on the concrete political context. However, for a meaningful diaspora policy, both features should be present.

In the following, the "emigration state" will be conceptualized, using the expression by Gamlen in another paper [2008]. This can be related to Centeno's "stockholder" state or the "engaged" state in Gamlen's 2006 text. The policymaking process in the 'emigration state' is understood as a negotiation and a 'deal' in which the diaspora provides resources (mostly of an economical nature), while the government provides other types of resources (mostly of a political nature).

\subsubsection{Policymaking in the 'emigration state'}

Why would a state want to become "engaged"? What are the drivers of the state apparatus of the country of origin to try to get in touch with the diaspora? The most evident answer is because the diaspora has resources. Given the largely economic nature of today's migratory processes, and the spectacular growth in remittance flows, countries of origin are becoming more and more dependent on the money that their citizens are earning abroad. With all the developmental potential that remittances (can) have (see 1.2.3.), governments of countries of origin are motivated to invent ways of "diaspora engagement" because of the opportunity to capitalize on these resources. [Vertovec, 2005; Gamlen, 2006, 2010, Délano-Gamlen 2014]

The rationale for migrants to accept the hand of the government of their country of origin is a more complex issue. Being citizen of only the country of origin means, naturally, that any sort of bureaucratic process a migrant is subject to, must go through the consulate, and the country of origin can provide a sort of legal protection to its citizen abroad. However, this is not the case with those migrants who obtained citizenship of the country of destination. An important notion is that, given the circumstances of everyday life and international law, the country of destination can do much more for a migrant than the country of origin. The rule is, therefore, that migrants are more likely to get engaged in political and social actions in the former than in the latter, and they are highly motivated in obtaining citizenship in the country of destination, while not necessarily appreciating the citizenship of the country of origin. [Waldinger, 2013] 
Tables 13 and 14 synthesize the 'resources' that the state and the diaspora yield for each other. In a very simplistic dichotomy it can be said that migrants have economic resources at their disposal, while the state has political resources. This situation is a good starting point for negotiations between the state and the diaspora, which at a given point might conclude in a 'deal', that is, a consensual setting of procedures and/or institutions. Agency, i. e. the capabilities for articulating goals and taking actions in order to implement them, is very different on the two sides, given the fact that the state (despite its internal divisions in terms of levels and units of governance) is a unitary actor, while the diaspora, by definition, is diverse and dispersed in space.

Putting together two, similarly structured tables on what the state and the diaspora might benefit from this 'deal' has the danger of comparing apples and oranges. What individual waged workers can 'do' for their country of origin through migration is by no means on the same scale as what a state's consular service can do for a given migrant. However, as it will be also exposed later on, in the discursive field this 'quid pro quo' understanding is very much present on both sides: migrant representatives and state officials often refer to what migrants 'do' for the state and vice versa, which justifies this symmetric approach.

Table 13. The diaspora's economic resources from the perspective of the state (of origin)

\begin{tabular}{|l|l|l|l|}
\hline $\begin{array}{l}\text { Migrant activity } \\
\text { field }\end{array}$ & $\begin{array}{l}\text { Added value of } \\
\text { migration }\end{array}$ & $\begin{array}{l}\text { Resources from the perspective of the } \\
\text { state (of origin) }\end{array}$ \\
\cline { 2 - 4 } & $\begin{array}{l}\text { If the migrant } \\
\text { returns to the } \\
\text { country of origin }\end{array}$ & $\begin{array}{l}\text { If the migrant does } \\
\text { not return to the } \\
\text { country of origin }\end{array}$ \\
\hline $\begin{array}{l}\text { Individual } \\
\text { waged worker }\end{array}$ & Higher wage & $\begin{array}{l}\text { Repatriation of } \\
\text { savings }\end{array}$ & $\begin{array}{l}\text { Remittances (Definition } \\
\text { C) }\end{array}$ \\
\hline $\begin{array}{l}\text { Entrepreneur } \\
\text { and/or highly } \\
\text { qualified } \\
\text { professional }\end{array}$ & $\begin{array}{l}\text { Higher wage } \\
\text { Business } \\
\text { opportunity/niche } \\
\text { Professional } \\
\text { development }\end{array}$ & $\begin{array}{l}\text { Investment } \\
\text { Know-how transfer } \\
\text { Education } \\
\text { R\&D }\end{array}$ & $\begin{array}{l}\text { Investment } \\
\text { Trade } \\
\text { Professional networks } \\
\text { Lobbying power }\end{array}$ \\
\hline $\begin{array}{l}\text { Migrant } \\
\text { association }\end{array}$ & $\begin{array}{l}\text { Organized nationals } \\
\text { abroad }\end{array}$ & - & $\begin{array}{l}\text { Lobbying power } \\
\text { Agenda setting power } \\
\text { Fundraising capabilities }\end{array}$ \\
\hline
\end{tabular}

Source: own compilation 
Table 14. The state (of origin)'s political resources from the perspective of the diaspora

\begin{tabular}{|l|l|l|l|}
\hline State policy & $\begin{array}{l}\text { Added value of } \\
\text { ftate action }\end{array}$ & $\begin{array}{l}\text { Resources from the perspective of the } \\
\text { diaspora }\end{array}$ \\
\cline { 3 - 4 } & $\begin{array}{l}\text { If the migrant } \\
\text { returns to the } \\
\text { country of origin }\end{array}$ & $\begin{array}{l}\text { If the migrant does } \\
\text { not return to the } \\
\text { country of origin }\end{array}$ \\
\hline $\begin{array}{l}\text { Diplomacy and } \\
\text { consular } \\
\text { service }\end{array}$ & $\begin{array}{l}\text { Agreements with the } \\
\text { country of destination } \\
\text { on legal terms of } \\
\text { migration, legal } \\
\text { assistance and } \\
\text { protection }\end{array}$ & - & $\begin{array}{l}\text { Processing of official } \\
\text { procedures related to the } \\
\text { country of origin } \\
\text { Support in administrative } \\
\text { issues regarding the } \\
\text { residence in the country } \\
\text { of destination } \\
\text { Protection of human and } \\
\text { cultural rights abroad }\end{array}$ \\
\hline $\begin{array}{l}\text { Citizenship and } \\
\text { voting rights }\end{array}$ & $\begin{array}{l}\text { Migrant participation } \\
\text { in the politics of the } \\
\text { country of origin (right } \\
\text { to vote and to be } \\
\text { elected) }\end{array}$ & $\begin{array}{l}\text { Representation of } \\
\text { diaspora issues and } \\
\text { interests in the legislature } \\
\text { of the country of origin }\end{array}$ \\
\hline Social policy & $\begin{array}{l}\text { State-funded } \\
\text { programmes to help in } \\
\text { certain aspects of } \\
\text { migration-related life } \\
\text { situations }\end{array}$ & $\begin{array}{l}\text { State-funded } \\
\text { programmes for return } \\
\text { migration } \\
\text { Transferability of } \\
\text { social allowances (if } \\
\text { relevant) }\end{array}$ & $\begin{array}{l}\text { Protection of social } \\
\text { rights and interests } \\
\text { abroad }\end{array}$ \\
\hline
\end{tabular}

Source: own compilation

As it is shown above, the list of possible topics in which a state-diaspora 'deal' could be achieved, is quite long. However, it is always a matter of particular circumstances and decisions whether in the agenda of state-diaspora talks the majority of items come from the first or the second table. The important point is that both parties of a possible 'deal' have something to offer.

This is where policymaking can have its start. Nonetheless, policymaking on emigration - and concerning citizens who are physically absent - is not as obvious as policymaking with subjects who are physically present. What we know about policymaking in general is therefore not always applicable here. Even 'migration policies' as an object of research has been, for decades, synonymous with research on 'immigration policy'. [Tóth, 2010] This “receiving-country bias of migration research" [de Haas, 2011, p. 13] has already been presented above.

But what is migration policy, or 'emigration policy' in this case, anyway? Hein de Haas [2011, p. 26] points out two key sources of confusion that must be kept 
in mind in order to avoid analytical errors. The first is rather simple (though often overlooked): while states are definitely key actors in determining the characteristics of international migratory flows, usually it is not their 'migration policy' that counts but several 'non-migration' policies that make people want to immigrate to or emigrate from a given country. Overall economic performance and developmental level are the most obvious determinants, but labour market demands, tax systems and social welfare transfers (and eligibility for them) also have a crucial role, either as a 'push' or a 'pull' factor. Contrary to this, 'migration policies' can be (and, indeed, are) of a rather marginal relevance. Even the most important piece of this body of policies, i. e. visa and entry policy and its enforcement by armed forces, has a limited strength when it comes to major structural determinants. To cite the most obvious case: the United States spends millions of dollars on border patrol, however, the wage gap between this country and Mexico is so enormous that thousands of Mexicans risk their lives every day by crossing the border, no matter how dangerous and defying it might be. Highly restrictive 'migration policy' in this case is overwritten by the structural demand for unskilled labour, a result of several "nonmigration policies'.

The second source of confusion identified by de Haas is more complex. Described in another paper [Czaika - de Haas, 2011], a theory of "three policy gaps" aims to highlight the discrepancies between stated and achieved 'policy' objectives. First, a "discourse gap" stands between the politicians' statements and the concrete policies. Second, the "implementation gap" is the disparity between policy documents and their implementation. Third, the "efficacy gap" is the difference between the aimed and the actual changes of migration flows through the implementation of the given policy measure. Politicians' discourses are important, therefore, not because they are actual 'policy goals': in this case, statements on 'zero immigration' or 'diaspora-driven development' on the side of the country of destination and the country of origin, respectively, could be taken as benchmarks, and thus every policy would be a rotund failure. However, policies stem from these discourses, even though they are filtered by interest groups (discursive gap) before they take the shape of a concrete policy document. Only this document could be a valid benchmark to measure the extent of the implementation of the measures included in it (implementation gap), and their effectiveness in achieving the aims that were set (efficacy gap). 
Defining a policy and its effectiveness or the lack thereof is a complex process. In a conceptual paper on immigrant integration policies, Niessen and Huddleston [2007] present an evaluation framework that, besides originally stated goals (with indicators), observes laws and enforcement processes, technical and financial support, facilitation and other related services. Also, it is not only the programme effectiveness, but also its cost-effectiveness and technical efficiency that need to be assessed. The authors overtly state that "public policies (...) can be benchmarked provided that they are broken down into policy objectives, inputs, process, activities, outputs, outcomes and impact." [Niessen - Huddleston, 2007, p. 11]

As one might expect, this is not the case with emigration policies. As opposed to a coherent, well-conceived single policy paper with all the criteria mentioned above, emigration policies are "a constellation of institutional and legislative arrangements and programmes that come into being at different times, for different reasons, and operate across different timescales at different levels within homestates." [Gamlen, 2006, p. 4] Furthermore, many of these measures are conditioned by the country of destination, thus lying beyond the sovereignty of the country of origin. The term 'policy' therefore does not stand for an exact and well-defined state strategy and thus a systematic evaluation of their effectiveness is close to the impossible.

One can, nonetheless, have an overall assessment on whether a given policy has been successful or not. A popular way in emigration policy evaluation is to collect a showcase of 'good practices' such as IOM's background paper titled "The Future of Diaspora Policy" [Agunias, 2010] did, and presenting them as models to follow. The problem with this approach is twofold. First, almost each of these policies is a result of an organic and somewhat spontaneous development that cannot easily be transplanted to other social and political contexts. Second, even the 'good practices' contain counterproductive elements and they evolve with time, often to a less advantageous direction. Using existing diaspora policy measures as benchmarks can be problematic, albeit still one of the most realistic ways for evaluation.

In the following, an overview of the possibilities of existing diaspora policies is presented, following the 'tools' identified by Gamlen [2006] and clustered into conceptual categories. As the scope of this thesis is on development-related policies, 
the focus is set on those items of the diaspora policy 'toolkit' that have relevance for development.

\subsubsection{Diaspora policies for development: items of a 'policy toolkit'}

Relying on Foucault's notion of the three types of state-citizen relationship that enable the state to exercise power, namely the relations of power, relationships of communication and finalized activities, Gamlen distinguishes three realms in which a state can conduct its activities towards the diaspora. Relationships of communication come first, constructing an inclusive discourse on the nation which comprises (a constructed image of) the diaspora, and communication channels for distributing news, information and entertainment content, tailored for the needs of those who live abroad. It is followed by the foundation of diaspora-related institutions (specialized bodies within the government structure) that make possible the exercise of power through the consulates as government outlets that are becoming more and more diversified in their activities and in their strategies and channels of outreach. Finally, concrete activities forge the notion of a "transnational citizenship" which is supposed to tie together the citizens of a country, no matter where they actually live. Based on this notion, the state can start to extend rights to and extract obligations from its non-resident citizens. [Gamlen, 2006, p. 5]

Although it is a very useful conceptual framework, there are two major shortcomings with Gamlen's approach. The first is also noted by the author himself when relating to Robert C. Smith's notion of "thin membership". As opposed to citizenship which is a constitutionally defined category, and as opposed to sovereignty which is based on the (territorial) monopoly of violence, the 'belonging' to the diaspora (and, through the diaspora, to the country of origin) is a blurrier phenomenon. In an analysis of different Mexican-American hometown associations in the United States, Smith [2006] draws a scale from "thin" to "thick" membership, in which individual migrants can deliberately choose their position, replying or not to the country of origin's outreach attempts, on one hand, and taking part or not in civil society activities related to the country of origin, on the other. Even in the case of a highly engaged state with a plethora of activities aimed at the diaspora, individual migrants can always stay away from it if they wish to do so for some reason, of which the political disaccord is the most obvious one. 
The second point where Gamlen's framework needs to be enhanced is what I call the 'agency' issue. State-diaspora relations are often presented as if the state were necessarily the proactive actor who takes the initiative. However, it is not always the case. As it has been mentioned above, weak and/or poor states do not have the means to engage the diaspora - it is the diaspora that holds out its hands to help the country. A very prominent example is that of El Salvador, where the central government laid in ruins after the civil war, but the diaspora was very well organized and it had an umbrella organization in the United States, the Salvadoran-American National Network that put through several important fundraising campaigns for El Salvador, financed business network meetings and funded study grants. Diasporas, therefore, can be very active even without the faintest government attempt to get them engaged. [Portes et al, 2003, p.112]

Finally, although it is not a critique on Gamlen's typology but a stress on a feature that is not sufficiently emphasized in his account, the awareness of the 'quid pro quo' nature of the diaspora policy measures is essential. A central idea of Chapter 1.3.1. of this thesis is that relations between the state and the diaspora are conceptualized from both sides as negotiations which conclude in a 'deal', favourable for both sides or not, but in which participants expect to obtain something: generally, the state pursues economic resources, while the diaspora wishes to obtain benefits of a political nature. This approach shall be incorporated as a cross-cutting feature in the typology of state actions toward the diaspora.

Table 15 summarizes Gamlen's typology of the "tools" of a country of origin for conceiving and carrying out its diaspora engagement policies. Tools with a high relevance for development are highlighted. Another possible typology can be found in Bakewell [2008] ${ }^{8}$.

\footnotetext{
${ }^{8}$ These are: Pre-departure, Ongoing Support, Support for Migrants' Integration, Maintaining Links with "Home Country", Support for Return, Migration and Development, Migrant Associations. This is also a clear and logical typology, however, it is built from a migrant lifecycle perspective, i. e. the supposed stages of a migrant's life and the governmental response to each. I have chosen to base my argument on Gamlen's typology because the latter reflects more the governmental perspective and stresses the 'deal'-like nature of many of these policies.
} 
Table 15. The country of origin's tools for diaspora engagement policies

\begin{tabular}{|c|c|c|}
\hline Policy field & Concrete policy tool & $\begin{array}{l}\text { Relevance } \\
\text { for } \\
\text { development }\end{array}$ \\
\hline Communication & $\begin{array}{ll}- & \text { Inclusive rhetoric and symbols (transnational } \\
\text { concept of the nation) } \\
-\quad \text { Cultural promotion } \\
- & \text { Media outreach, information in native language } \\
- & \text { Conferences and conventions }\end{array}$ & $\begin{array}{l}\text { low } \\
\text { low } \\
\text { medium } \\
\text { low }\end{array}$ \\
\hline $\begin{array}{l}\text { Institution- } \\
\text { building }\end{array}$ & $\begin{array}{ll}- & \text { Ministerial level agency for diaspora affairs } \\
- & \text { Dedicated (and specially trained) bureaucracy } \\
\text { - } & \text { Special consular activities (for concrete policy } \\
\text { goals) } & \\
- & \text { Transnational networks } \\
\end{array}$ & $\begin{array}{l}\text { medium } \\
\text { medium } \\
\text { high } \\
\text { medium } \\
\end{array}$ \\
\hline $\begin{array}{l}\text { Extending } \\
\text { rights }\end{array}$ & $\begin{array}{ll} & \text { Dual nationality } \\
- & \text { Right to vote } \\
- & \text { Parliamentary representation (for the diaspora) } \\
- & \text { Can run for office } \\
\text { - } & \text { Welfare protection }\end{array}$ & $\begin{array}{l}\text { medium } \\
\text { low } \\
\text { low } \\
\text { low } \\
\text { medium }\end{array}$ \\
\hline $\begin{array}{l}\text { Extracting } \\
\text { obligations }\end{array}$ & $\begin{array}{l}\text { - Mandatory payment (expatriate tax or tax on } \\
\text { remittances) } \\
-\quad \text { Remittance capture programmes } \\
\text { - } \quad \text { Investment programmes (returning migrants or } \\
\text { joint ventures) } \\
-\quad \text { Knowledge transfer programmes }\end{array}$ & $\begin{array}{l}\text { high } \\
\text { high } \\
\text { high } \\
\text { high }\end{array}$ \\
\hline
\end{tabular}

Source: Gamlen [2006, pp. 9 and 19.] and own compilation

In Table 15, I have added an extra column to Gamlen's concepts, evaluating the relevance of the given policy from the perspective of development. With this, it becomes clear that different policy tools serve for different purposes. Communication, for example, can be moderately important for development as media outreach and information in native language, provided by the consular offices of the country of origin, can help migrants (especially the most vulnerable ones) to overcome their difficulties in the country of destination. By knowing their rights and opportunities, they might be more successful in reaching their objectives and, very importantly, send more money back home. Other communication-related activities have a less direct effect on development: inclusive rhetoric and symbols, cultural promotion, conferences and conventions may help to strengthen emotional ties to the country of origin, but they are not explicitly related to the topic of development.

Institution-building is a bit more relevant in this topic than communication. While informing migrants living detached from the circulation of news and opportunities is an important task, for carrying out any development-related diaspora policy a stable institutional background is a must have. Any regular governmental 
activity that addresses the members of the diaspora needs to count with a central planning unit (most conveniently located within the Ministry of Foreign Affairs), a regular consultation framework with other ministries and with the associations of the diaspora, the latter being formalized in a way to ensure representativeness through a transnational consultation mechanism. All this institutional setup needs to be filled with skilled staff within the central unit and at the consulates, where front-office work takes place. And, most importantly, the key objective of the institution-building process is to carry out special consular activities which aim at providing services to the diaspora in a way that complements the services they receive (or not) in the country of destination. One concrete action, the issuance of a special, consular ID which enables migrants with an irregular status to open bank accounts (thus being able to send remittances with lower commission fees) is presented in Chapter 3.2.3. as being a representative case for this set of actions.

Extending rights of citizenship to the diaspora is one half of the thematic content of the diaspora policymaking. This is the 'political benefits' side of the 'deal'. Migrants permanently living outside their country of origin can keep their citizenship (or even gain it back, if previously lost) and they can vote in the presidential elections. What is more, in some cases the diaspora has its own seats in the parliament, with migrant MPs representing geographical regions outside the country's borders. This also means that living abroad on a permanent basis does not prevent a citizen from running for office. In other cases, several entitlements for welfare protection are provided for migrants, whenever they go back to the country of origin. These are very important measures and they are very beneficial for the diaspora. However, the 'deal' for the government of the country of origin is not this (unless migrant voters are very likely to vote to the party which is in office) but the obligations which can be extracted from the diaspora.

Extracting obligations is therefore of an essentially economic nature. While extending rights is a political action, the other half of the 'deal' is organized around remittances - either of the household, community, investment or social kind. The most simple form of such an obligation is (or would be) a mandatory payment which is ordered for being outside the country (i.e. an expatriate tax or a tax on remittances - see 1.2.3.). Less direct and more feasible attempts to tap the purse of the diaspora include remittance capture programmes, investment programmes (either for returning migrants or for founding joint ventures where diaspora members and entrepreneurs 
or state agencies of the country of origin are participating) and knowledge transfer programmes (or scientific networks). These policy areas are in the main focus of this thesis: therefore, Chapter 3.3.3 deals with the case study of a government fund for non-refundable loans and technical assistance for returning migrants who would like to set up their own businesses; Chapter 3.4.3 presents a co-funding programme in which the government triples the amount of community remittances sent by the diaspora for specific development projects; finally, Chapter 3.5.3 describes a scientific network of migrant scholars and researchers which was aiming at conceiving and implementing development projects in the country of origin using their expertise and professional connections obtained in the country of destination.

All the activities mentioned above and synthesized in Table 15 are the items of the 'toolkit' of diaspora engagement policies. From their varying relevance for development, it can be understood that many measures are implemented not because the state has an immanent need to do so, but because the diaspora expects to have some political benefits from cooperating with the state and providing economic resources for developmental objectives. This shows the relevance of understanding the items of an existing diaspora policy framework as the outcome of a 'deal' in which not only the state has had its interests materialized, but also the diaspora has gained important benefits.

Chapter 3 of this thesis will be based on the conceptual overview shown above. Out of the five measures identified as of high relevance for development in Table 15, the mentioned four will be analyzed in details, with a case study for each. The fifth, mandatory payment is left out because no Latin American country has a tax on expatriates, and even though some countries have tried to put a tax on remittances, this turned out to be a failure as it only increased the share of informal remittance flows.

Also, the four policy areas will be coupled with the four different types of remittances, as described in Chapter 1.2.

\subsubsection{Evaluating the hypotheses, part 1: The conceptual level}

At the end of Chapter 1 which presents the theoretical background of this thesis, it is worth to look back at the hypotheses set in the beginning. To what extent 
have these hypotheses been validated by what theories hold about the possibilities of diaspora policies?

Hypothesis (H1) claims that none of these policies can change the ongoing migratory trends significantly. As seen in 1.1.1, 1.1.2. and 1.1.3, scholarly assessment of the 'migration-development nexus' is rooted in several major strands of literature, the most important being the neoclassical and the dependency/world system approaches. According to the first, migration can be beneficial for countries of origin through factor price equalization, transfer of money and know-how, and as a consequence, it can promote development and diaspora policies can act as catalyzers for the process. According to the second, however, migration is a transfer of human capital from developing to developed countries, and migrant labour is primarily beneficial for countries of destination, not for countries of origin. Remittances (in all their complexity described in 1.2.1 and 1.2.2.) are therefore nothing more but a meager wage earned under precarious conditions and detached from the economy of the country of origin, which further aggravates the dependency, and diaspora policies cannot do anything about it.

At this point, no justice can be made, as both standpoints are very ideological. However, it is clear that while diaspora policies have (modest but existing) capabilities to enhance the development potential of remittances (and therefore making the entire process more beneficial for the people involved), it does not necessarily reduce outward migration. Just to point out the most obvious feature: if prospective migrants receive more money and better education through remittances, they might be more likely to migrate, as they will be more successful in planning and carrying out the journey and finding a job upon their arrival. What policies can do about it, is still to be discussed in the following chapters. However, it can be said based on 1.3.2. that usually a 'policy impact' is not the same as political discourses or overall political objectives would aim to reach: it is much less. Thus it seems more likely (on the theoretical level, at least), that diaspora policies cannot change overall trends in migration, in line with (H1).

Regarding Hypothesis (H2), it states that diaspora policies create a transnational space in which developmentally positive economic and social transfers can take place. This is certainly the case if we understand the flow of remittances (including all six definitions thereof, as described in 1.2.1.) as a fundamentally positive feature. In 1.2.3. the possibilities of a state regarding remittances were 
presented, and it was shown that there are many ways to enhance their volume and positive impact. There are tools to be used (see 1.3.3.) in order to create transnational spaces for information exchange or for the implementation of development-related projects on a transnational level. Well-designed institutions and policies are crucial in order to achieve this, and the following chapters will go into details regarding both. At the theoretical level, however, it can be stated that $(\mathrm{H} 2)$ is valid.

While the concept and the agency of the diaspora it is still a problematical issue (see 1.3.1.), elements of a possible 'deal' between the government and the diaspora are present on the theoretical level (see Tables 13 and 14 in 1.3.2.) and they can be operationalized (see Table 15 in 1.3.3.). Hypothesis (H3) holds that the government of the country of origin as well as the diaspora can obtain political, economic and symbolical benefits from such a deal, and based on what has been identified in 1.3.2. and 1.3.3, it is very likely that there is a bias towards economic benefits on the side of the government of the country of origin, and towards political benefits on the diaspora's side. This will also be further examined in the following chapters, but on a theoretical level it can be stated that both parties can obtain benefits, thus (H3) can also be regarded as valid at this point of the analysis.

To sum up, on the conceptual level (H1) and (H3) cannot be assessed in a satisfactory way - although it is likely that they are valid - while (H2) can be regarded as valid.

In the following, the data and trends of Latin American migration will be presented, followed by the description and analysis of the creation of diasporarelated institutions in the countries which have been most affected by mass emigration. 


\section{The Latin American diaspora: processes and institutions}

Chapter 2 presents an overview of the historical, demographic, economic, political and social background of migration flows from Latin America, followed by a general analysis of the migration trends and patterns of the countries of the region. Based on this, a dynamic analysis is undertaken on the evolution of diaspora policies in the main countries of origin. Starting with an introduction of the political background of the issue, diaspora institutions are presented, primarily based on information collected through a survey (see the Annex of this thesis). Specific programmes and projects are also presented, when relevant.

Chapter 2 ends with a feedback on the hypotheses of this thesis, observed on the 'institutional' level, in Chapter 2.2.4.

\subsection{The formation of the Latin American diaspora}

In 2.1, the background and the morphology of Latin American emigration trends are presented with the purpose of setting up a framework of challenges and capabilities, within which migration and diaspora policies are being conceived.

Main findings on the background factors are summarized at the end of 2.1.1.3, while a tentative categorization of Latin American countries according to their emigration features is delineated in 2.1.2.3.

\subsubsection{The background of Latin American emigration trends}

\subsubsection{Coloniality and migration history in Latin America}

Migration theories - as presented in 1.1.1. - usually take two factors for granted. First, that migration occurs when people are pursuing an objective and they think that it could be reached in another country - be it economic, political or security-related. Second, this 'another' country which becomes their country of destination, scores better in these topics than their country of origin. 
However, this was not the case in most of the migration processes that shaped the demographic, social, cultural and economic landscape of Latin America ${ }^{9}$. Colonialism and neocolonialism created and sustained structures of oppression, exclusion and dependency. Most of the ancestors of present-day Latin Americans did not cross the Atlantic Ocean in a way that would be explainable in the framework of major migration theories. It is worth to resume the immigration history of Latin American societies from the perspective of coloniality, in order to point out some peculiarities that have their effect also on the present-day emigration processes. [Quijano, 2000; Mignolo, 2005; for the concept of coloniality as a social system see also Böröcz, 2001 and Melegh, 2006]

First and foremost, indigenous societies in the Americas were occupied and destroyed by Spanish, Portuguese, English, French and Dutch conquerors who, in turn, founded settlements with the primary objective of producing raw materials and exporting them to the metropole of their colonial empires. All colonial powers imported African slaves in order to provide the colonies with labour force. Between the $16^{\text {th }}$ and the $19^{\text {th }}$ centuries, the whole territory of the American continent was transformed into slaveholder colonies which followed a very different operational logic to those 'sovereign' countries that migration theories usually are built on. African immigration was forced and it meant absolutely no improvement for the 'immigrants' in any aspect of their lives. European immigration was officially promoted and it held the promise of a leap forward on the class ladder: landless peasants became landlords, small noblemen became rulers of immense territories. Whiteness, while having no value in itself and in Europe, became the most valuable asset in the colonies. [Radcliffe - Westwood, 1996]

These features are important because highly unequal societies came into being where race was the most important structuring force. Latin America especially the Portuguese colonies - experienced a high level of interbreeding between races, as opposed to North America, where racial boundaries were stricter.

\footnotetext{
${ }^{9}$ As already mentioned in the introduction, by Latin America, the Spanish- and Portuguese-speaking sovereign nations of the Americas are understood throughout the thesis, i. e. Argentina, Bolivia (Plurinational State of), Brazil, Chile, Colombia, Costa Rica, Cuba, Dominican Republic, Ecuador, Guatemala, Honduras, Mexico, Nicaragua, Panama, Paraguay, Peru, Uruguay and Venezuela (Bolivarian Republic of). Other countries and territories often counted to Latin America as French Creole-speaking Haiti and non-sovereign Puerto Rico are not inclued in this analysis, and neither are English- and Dutch-speaking sovereign countries of the Americas.
} 
However, this mestizaje or mestiçagem ${ }^{10}$ did not mean a democratization in racial terms, as it was understood centuries later. [Freyre, 1933] From the viewpoint of migration history, mestizo, black and indigenous population did not leave the colonies, while whites went back and forth between the Iberian Peninsula and Latin America. "To make the Americas" (hacer las Américas) was the expression in Spanish to express a huge (material) gain or success in a business, as many colonists saw the colonial adventure as a way to grow rich, but then they would go back to the metropole. In this respect, it was a 'classical' migrant expectation, with the difference of arriving to the top, and not to the bottom of the society of the country of destination, as most migrants would do. And for those who settled down there and never returned to Europe, the 'motherland' kept on being a reference point, as the colonial elites received their formation at the universities of the Iberian Peninsula, most importantly in Salamanca and Coimbra. [Galeano, 1973]

The $19^{\text {th }}$ century brought changes in three respects. First, Latin American countries gained independence and the former creole $^{11}$ colonial elites became national elites. Second, external reference points (and export destinations) were shifted from impoverished Spain and Portugal to wealthy Britain, France and United States. Third, slavery was abolished, and in order to keep providing the plantations, mines and factories with workers, indentured labour migrants were hired from poorer regions of Europe (Italy, Southwest Germany, Poland, Austro-Hungarian Empire) and Asia (China, Japan). Spaniards and Portuguese also joined to this "new immigration', although no longer in a privileged colonial position but as ordinary immigrants. [Szilágyi, 2003; Anderle, 2008]

Immigration to Latin America was no longer "making the Americas" as it would have been in colonial times, but it still meant a good opportunity to become rich. Those countries with a significant 'white' immigration became the most prosperous in the late $19^{\text {th }}$ century: Argentina, Uruguay, Chile and (the southern part of) Brazil. Native and mestizo population, and black ex-slaves (in Brazil), however, remained stuck in poverty. Countries with a large indigenous and mestizo population (such as Mexico, Peru or Ecuador) did not receive many white immigrants at the

\footnotetext{
10 Spanish and Portuguese words for cross-breeding, mestizo/a and mestiço/a being the terms for mixed-race people in the respective languages.

${ }^{11}$ White person of Spanish or Portuguese descent, but already born in the Americas.
} 
time, as there was no such transformation in rural economies as in the previously mentioned countries. [Moreno Figueroa, 2010]

The third (and smallest) wave of immigration to Latin America was related to World War II and its consequences. Exiled groups immediately before and after the war arrived to the region (mostly Jewish and Poles in the first group, Germans, Croatians and Hungarians in the second one) between the late 1930s and the late 1950s. Latin America was no longer an attractive destination but a convenient hideaway, with the exception of Venezuela, which experienced an economic boom thanks to petroleum industry. By 1960, however, white immigration to Latin America practically stopped. [Radcliffe - Westwood, 1996]

All these remarks are important because the big Latin American shift from being an immigration to an emigration region (see below) happened in a way that was conditioned by the ethno-racial background of the population. White/creole population had different migration history, and also different assets and different capabilities for migrating than darker-skinned mestizo, black or indigenous population. These differences are difficult to trace in aggregate data, however, they are very important when it comes to policymaking. It can be stated that there is an embedded white upper/middle class migration pattern in Latin American emigration flows, together with the much larger, conventional South-to-North unskilled labour migration flow, the latter being typical to the Wallersteinian "outer rim" or labour periphery. It is only in a handful of 'white' or 'whiter' countries (most importantly Argentina, Uruguay and Chile) that the first pattern is more significant, however, it is very much present in the other countries as well, in the case of the highly skilled emigrants.

In the following, basic economic, demographic and migration data are presented. Notions of coloniality in social structures and migration should be taken into account when interpreting these data.

\subsubsection{Demographic and economic trends in Latin America}

Beyond the 'colour' issue, studying Latin American population development is essential for understanding the migration phenomenon. Over the past half century, the dynamism of population growth and urbanization created a large and 
geographically mobile social group which could send many of its members abroad if economic and political conditions also were stimulating.

Currently [UNPD, 2015a], the region is home to 634 million citizens and approximately 600 million usually resident ${ }^{12}$ inhabitants, being slightly less populous than Europe and approximately twice as populous as North America (without Mexico). Population has doubled in 41 years, scoring 318 millions in 1974, which is approximately the same pace in which the world's total population has doubled itself. Population growth rate peaked in the 1960-1965 period at $2.76 \%$ (the aggregate population growth rate of the world also peaked in that period, at $2.2 \%$ ), and it has been declining ever since. Population growth rate for the whole region has been $1.12 \%$ for the 2010-2015 period. Of the two most populous countries, Brazil (208 million in 2015) experienced a significantly lower growth rate than the average (0.91\%), while Mexico (127 million in 2015) showed a significantly higher rate at 1.37\%. Most Latin American countries score between these two values, with the exception of smaller Central American countries that show higher rates, and three countries (Cuba, El Salvador and Uruguay) whose population growth rate is significantly lower. [UNPD, 2015b]

The share of young (15-34 years old) adults did not change substantially over the past six decades. While in 1950 this age group accounted for the $32.9 \%$ of the population, it has remained close to this value over the years, peaking at $35.8 \%$ in 1995 and currently scoring $33.7 \%$ (as of 2015). This is an important remark because it shows an evenly distributed population growth, i.e. not culminating into a 'hump' of excess population in the age group which is most likely to emigrate. [UNPD, 2015c]

The share of urban population, however, has grown massively. In the period of available data (1960-2014, World Bank, 2015h), the rate of urban population for Latin America as a whole has grown from $49,6 \%$ to $79,2 \%$. Individual countries have shown a similar rate of growth. The most urbanized country of the region, Argentina has increased its rate of urban population from $74 \%$ to $91 \%$, while the least urbanized one, Guatemala, has grown from $31 \%$ to $51 \%$. The mid-range Mexico

\footnotetext{
${ }^{12}$ I.e. not living abroad on a permanent basis. The difference of the two is the 30-million stock of emigrants.
} 
experienced a somewhat faster pace of growth, from $51 \%$ to $79 \%$ between 1960 and 2014.

Graph 1 shows the evolution of the rate of urban population for these three countries (taken as reference countries for 'developed', 'mid-range' and 'undeveloped') and the Latin American average on the right, while on the left the above mentioned population growth rate appears for the same three countries and for the whole region.

Graph 1. Left: Population growth rate, Right: rate of urban population. Both sides for three reference countries (Argentina, Guatemala and Mexico) and Latin American average.
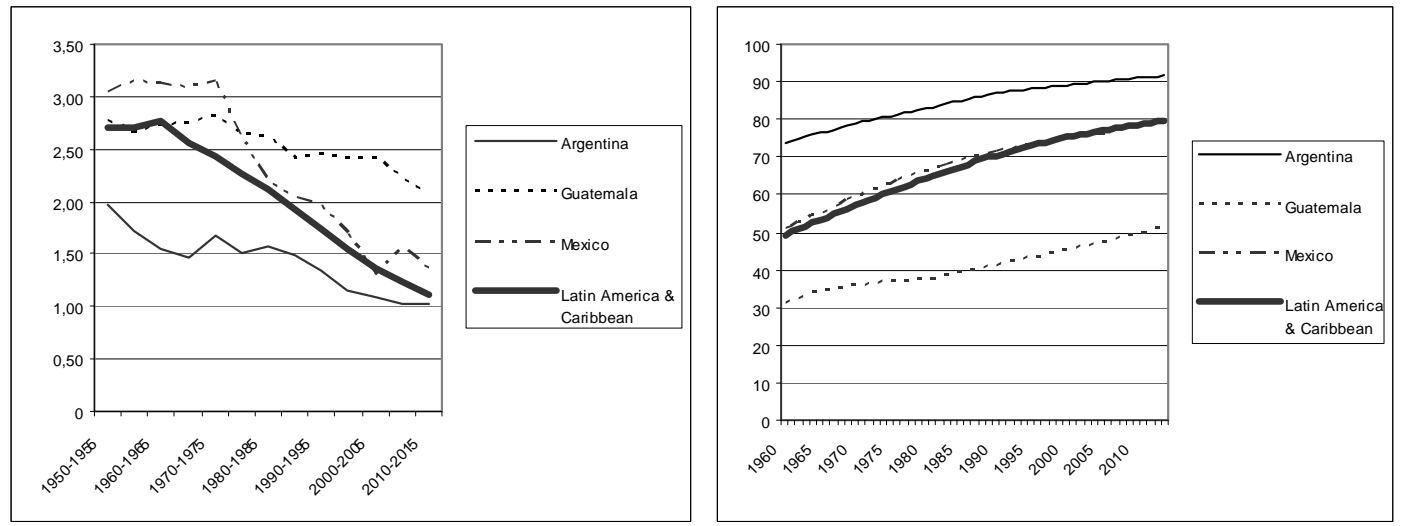

Source: Left: United Nations Population Database [2015b], Right: World Bank [2015h]

Latin American population therefore has shown a stable and dynamic development, with no substantial deviations from global trends over the past five or six decades. This should be noted because it reveals that sudden emigration waves of the 1990s (see 2.1.2.) did not have a primary root cause in demography. Even if there was a rather large, young and urban segment of the population that could migrate, it did not actually leave because of a demographic pressure, as population development was neither uneven nor sudden. Causes were primarily economic, and have remained so ever since.

Economic development (or lack thereof) can be analyzed based on indicators, most importantly the GDP. ${ }^{13}$ Historically, and with the exception of early $20^{\text {th }}$

${ }^{13}$ GDP data (in current USD) shown in this thesis are extracted from the World Bank database, however, the Maddison Database [2013] has been consulted for longer-term (1800-2013) historical 
century Argentina, all Latin American countries have always had a lower GDP per capita value than their former metropole, Spain (according to the Maddison database that traces back historical records until 1800). The same applies to Portugal which, no matter how impoverished it became in the early $20^{\text {th }}$ century, has always had a higher GDP per capita value than Brazil. However, due to the social structure that remained largely colour-based even after independence, European descendants in Latin America enjoyed a reasonably higher standard of living than average Spaniards and Portuguese in Spain and Portugal, respectively. [Solimano - Tokman, 2008] Many Spaniards and Portuguese therefore chose to migrate to these countries, despite the common sense understanding of migration as a flow of people heading towards countries with a higher GDP value. This is one of the reasons why the notion of coloniality is important in a longue durée analysis of Latin American migration patterns.

When comparing GDP data of Latin American countries with countries that later became countries of destination for their emigrants (Mexico with the United States, Peru and Argentina with Spain, Brazil with Portugal etc.), it can be seen that the already existing gaps became wider in the time period which Latin American economic history calls "the lost decade", covering more or less the 1980s. Macroeconomic shocks like the 1982 Mexican "Tequila crisis", the Argentinean recession in the late 1980s or the "Fujishock" in Peru in 1990 definitely contributed to the growth of these gaps, but these events were already preceded by long periods of stagnation. [Devlin - Ffrench-Davis, 1995; Urquidi, 2005] In other words, most of the Latin American economies had 'stuck in time', while the United States and Southwest Europe experienced a period of dynamic growth. This helps to explain the sudden nature of emigration waves from many Latin American countries in the 1990s (see more details below).

Graph 2 shows the GDP per capita values (in current USD) of the above mentioned three reference countries (Argentina, Guatemala and Mexico) compared to the Latin American and world average GDP per capita values. Shocks threw back Argentina $(1989,2001)$ and Mexico $(1982,1994)$ below the world average, while

data, the latter being displayed in 1990 Geary-Khamis dollars. In order to avoid confusions, Maddison data are not shown here numerically. 
poor Guatemala has remained poor, slowly getting further down from the world average.

Graph 2. GDP per capita (in current USD) for three reference countries (Argentina, Guatemala and Mexico), Latin American average and world average.

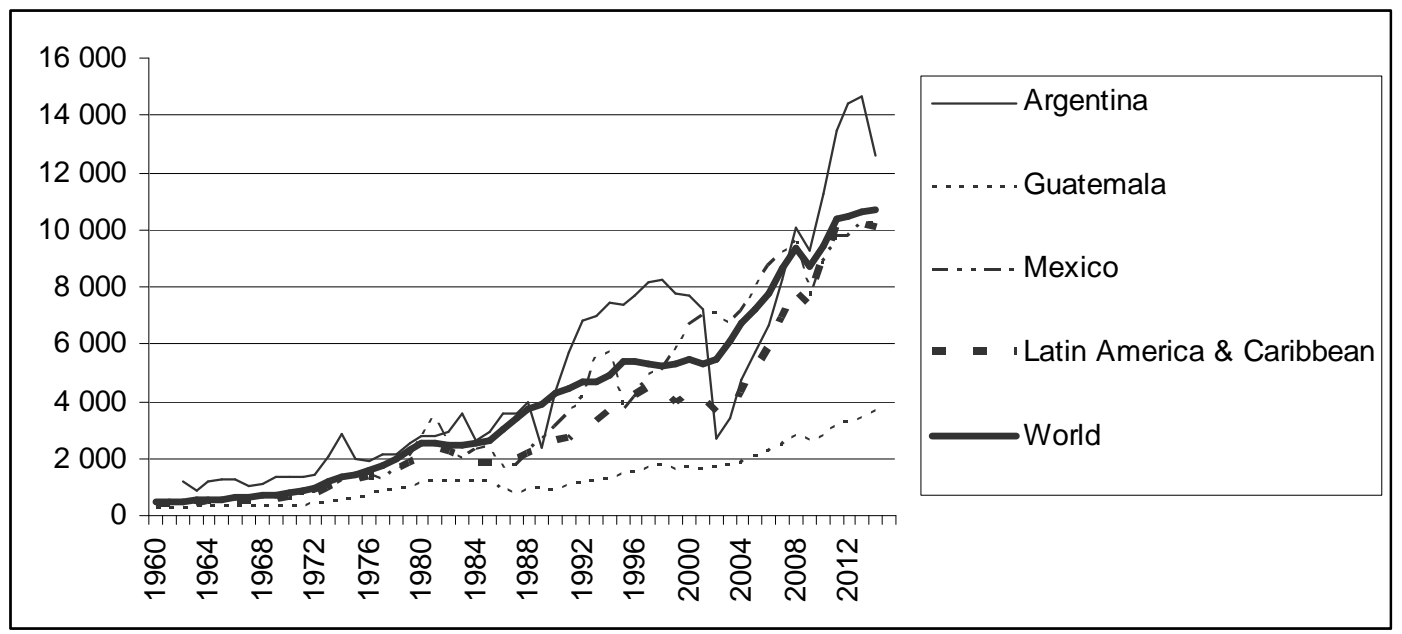

Source: World Bank [2015b]

Regarding the sectorial distribution of the GDP, the share of industry is the most telling. Until the 1980s, several Latin American countries followed the path of "import substitution industrialization", hoping to cope with worsening terms of trade for their export, dominated by raw materials. While these efforts have certainly yielded important results, by the end of the 1970s state investments became unsustainable due to high oil prices (as external factors) and low productivity (as internal factors). In the 1980s Latin America submerged into an acute debt crisis that paralyzed many economies. [Devlin - Ffrench-Davis, 1995; Urquidi, 2005]

The economic policy answer to these problems was a series of structural adjustments. Structural adjustment is a common denomination for different measures echoing the neoliberal reform agenda of the late 1980s and summarized most prominently in John Williamson's article on the "Washington Consensus". [Williamson, 1990] These reforms tried to assess the failures of the import substitution industrialization and the debt crisis, and although they contributed to macroeconomic stability, their social costs were extremely high, leading to decreasing social security, increasing unemployment and - massive emigration. 
Drastic reforms were implemented in Mexico in 1988, in Argentina and Venezuela in 1989, and in Peru and Brazil in 1990. [Urquidi, 2005] Some of these reforms were extremely brutal, such as the "Fujishock" in Peru, while others, although smoother at the beginning, had very long-lasting structural consequences, the most well-known being Mexico's joining to the NAFTA in 1994. [Dingemans - Ross, 2012] Stateowned firms were privatized and staff decreased, social transfers were cut back and precarity became widespread, free trade agreements were signed and increased competition decimated local enterprises. Regular unemployment rose, and the most convenient solutions for many Latin Americans were either turning to the precarious/grey/black economy or going abroad. [Sokoloff - Robinson, 2003].

Graph 3 shows how the sudden decline of the share of industry in the GDP was followed by the rise of unemployment.

Graph 3. Share of industry in GDP (full line) and unemployment rate (dotted line) in Latin America (top left), Argentina (top right), Mexico (bottom left) and Guatemala (bottom right).
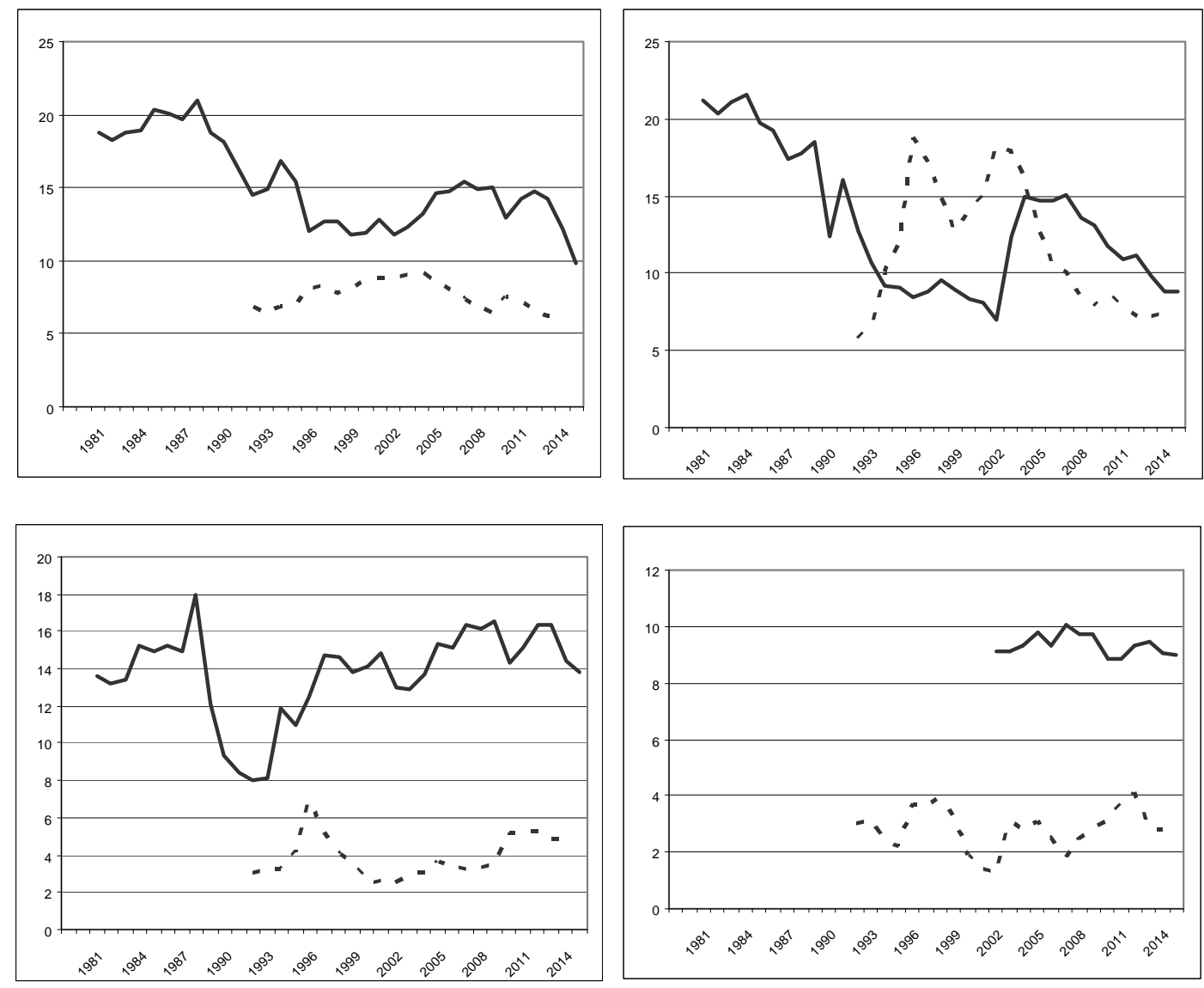

Note: For visualization purposes, industry data are decreased with 20, i.e. a $30 \%$ of industry in GDP is shown on the same scale as a 10\% unemployment rate. Source: World Bank [2015d, 2015g] 
Given the nature of privatizations, FDI arrived mostly as portfolio investment (see 2.1.2.2.) and did not help to create new jobs instead of those that were lost due to the adjustments. In Mexico, however, the ratification of the North American Free Trade Agreement (NAFTA) in 1994 facilitated the outsourcing of labour-intensive parts of the production chain of American companies, especially in the automobile and the garment industry, to the northern borderlands of Mexico, giving birth to thousands of maquiladoras ${ }^{14}$. Nonetheless, these new job opportunities could not make up with the massive decrease of rural employment (as NAFTA had a disastrous effect on Mexican agriculture), let alone the bankruptcy of Mexican firms in those sectors of the industry that also have been affected negatively by North American competition. [Stiglitz, 2002]

Structural adjustments are therefore the main reason why emigration from Latin America skyrocketed in the 1990s. It must also be mentioned that not all 'emigration' countries show a high rate of unemployment (see Guatemala's low rates, but also in Mexico only 3.2\% of the recent migrants are reported to had been unemployed before leaving to the United States). However, these figures must be treated with precaution. As these countries do not have general subsidies for the unemployed, and large share of the workers are employed in the informal or semiformal economy, the border between being either employed or unemployed is way blurrier than it would be in, say, a European welfare state.

Informality and precarious employment drew the social context in which emigration processes originate in Latin America. As the structural adjustments did not lead to long-term enhancing of the labour market, meaningful job options remained scarce in countries of origin. It was under these circumstances that the massification of emigration started and migratory networks solidified between countries of origin and destination. [Durand - Massey, 2010]

\footnotetext{
${ }^{14}$ Maquiladoras are assembly plants that import raw material from the United States to Mexico, and export assembled goods back to the United States in an intra-company manner. Even though maquiladora activity has boomed Mexican exports, this is mainly a statistical fata morgana, as they are not linked with other sectors of Mexican economy, therefore having little or no effect on Mexico's economic development. Low taxing on maquiladoras reduces the state's incomes, while in terms of employment, they generally offer low wages, and worker protection or labour union activity is practically nonexistent in most of them, making maquiladoras a not-so-attractive alternative for jobless, prospective migrants.
} 


\subsubsection{The political and social environment of migration in Latin America}

While largely of an economic nature, root causes of emigration have also included political features - more so in the past than in the present. Political migration has been present ever since Latin American polities were formed. 'Exile', however, was only a necessity for the most prominent - white or creole - politicians and their closest circle in case of political changes unfavourable for them. From Simón Bolívar himself to José Martí or Fidel Castro, a common feature of Latin American political and intellectual careers was a period in exile to a neighbouring country or overseas - mainly to the United States, England, France or Spain. [Sznajder - Roniger, 2007] On the other hand, exile due to political reasons was respected by potential countries of destination to that extent that Latin America is the region of the world where asylum at diplomatic missions is taken the most seriously. In the Latin American political tradition, embassies count as de facto territories of the country of origin and asylum seekers should not be extradited to the host country, a tradition canonized in various conventions from the 1928 Havana Convention through the 1933 Montevideo Convention till the OAS's 1954 Caracas Convention on Diplomatic Asylum [OAS, 1954].

Politics became a massive factor for emigration as masses themselves became politicized. Fidel Castro's victory in 1959, the coups d'état in Argentina, Chile and Uruguay in the 1970s and the civil or guerrilla wars in Colombia, Peru, Nicaragua, Guatemala and El Salvador had major effects on uprooting the population. With the end of guerrilla violence and the transition to electoral democracy in all Latin American countries (except Cuba), political factors lost their importance. Nonetheless, economic hardships are often closely related to politics, and economically motivated migration can also be interpreted in political terms. It has been the case of higher- and middle-class Cubans, and it is currently the case of higher- and middle-class Venezuelans. Not surprisingly, these are two countries with the most difficult state-diaspora relations in Latin America, as it will be exposed later. [López Segrera, 2011]

While the debt crises and dictatorships of "lost decade" are over, most Latin Americans are not really satisfied with how things are going. As of 2013, there were only two countries in the region where the majority of citizens found that the country was developing (Ecuador and Panama). Five years earlier, there were also only two, 
but different ones (Brazil and Colombia). In the following, a series of interesting public opinion poll data is presented, taken from the largest survey of its kind, Latinobarómetro [2013]. Graph 4 shows how Latin Americans assessed the development of their country in 2000, 2008 and 2013.

\section{Graph 4. Assessment of the development of Latin American countries, survey} results, 2000-2013.

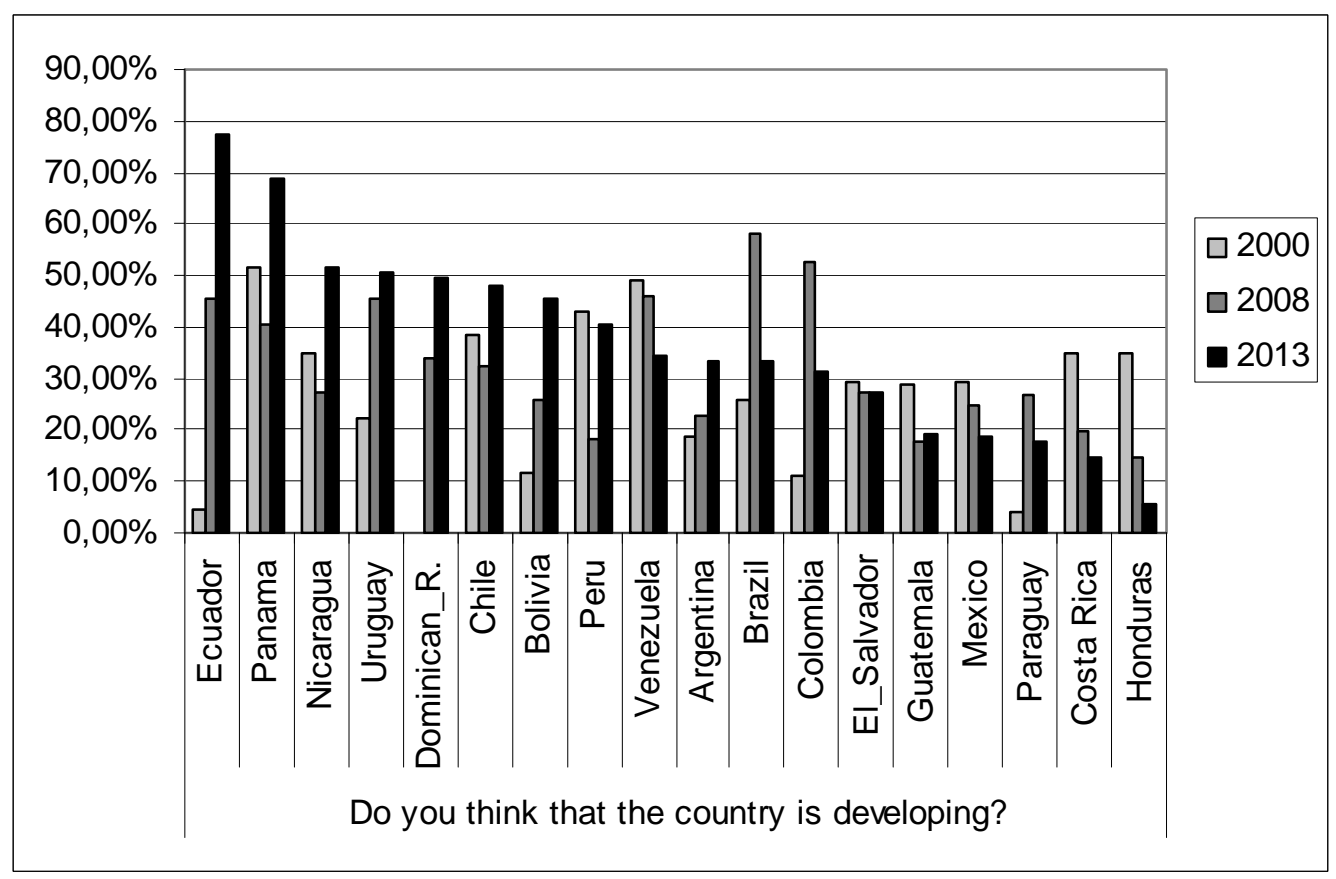

Source: Latinobarómetro [2013]

Discontent is also present towards the political system. The lack of stable democratic institutions has had severe hindering effects on Latin American development, most importantly because of the risk of personal interventions of the country's top leader(s). Latin American political life has seen many sorts of personalistic way of exercising power: military dictatorships [Huneeus, 2000], rightand left-wing populisms [Weyland, 2001; Spanakos, 2011] and regimes of delegative democracy. [O'Donnell, 1993] Policymaking has always been subject to frequent changes, in line with the current political views and/or interests of the president of the country.

As a consequence of its historical background, many Latin American citizens hold a rather unfavourable opinion on the state apparatus of their country. The disbelief in any sort of state action is especially marked in countries like Nicaragua, 
Honduras, the Dominican Republic, Guatemala and Peru, all of them being major countries of origin of migrants. This social attitude hinders the feasibility of social reforms and the implementation of development policies (including the diaspora policies which will be analyzed later). Graph 5 shows the low levels of trust in the state and in the public administration in Latin American countries. [Latinobarómetro, 2013]

Graph 5. Trust in the state and in the public administration in Latin American countries (2013)
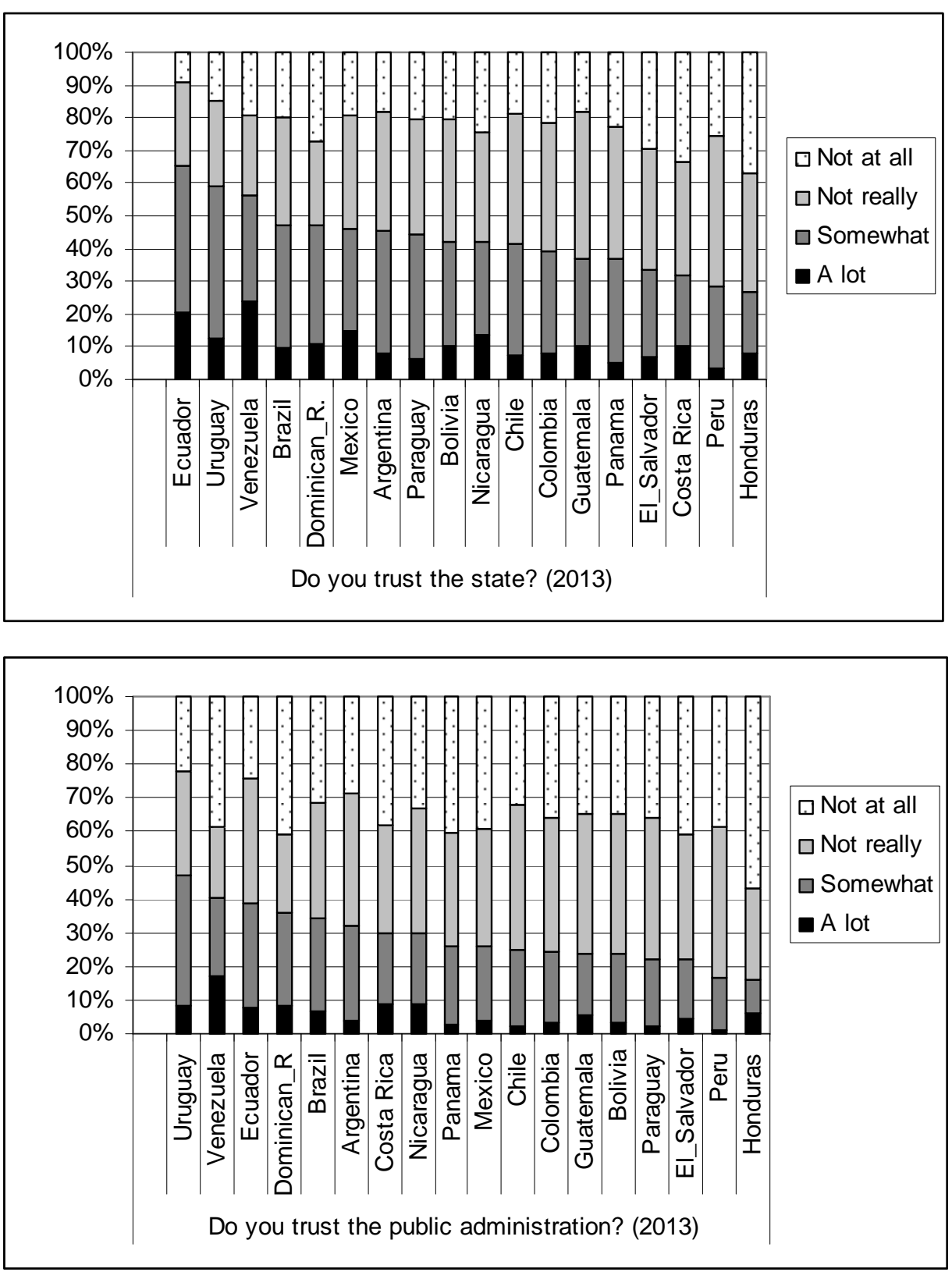

Source: Latinobarómetro [2013] 
Furthermore, there are other political factors that are conditioning migration and they are not within a government's sphere of action and authority. Most importantly, terms of traveling abroad are defined by countries of destination by imposing different visa regimes on prospective visitors - or migrants. With the exception of Chile, no Latin American country's citizens can travel without visa to the United States and Canada, and other main countries of destination for Latin American migrants also hold a selective regime, in general allowing the visa-free entry of citizens of middle-income countries, while requiring visa from those coming from lower income countries. Cuban citizens need a visa for almost every major country in the world, while Bolivian, Dominican and various Central American country nationals also have to face restrictions. On the other end of the continuum, citizens of Mercosur countries, Mexico and Costa Rica can enter to all major destination countries (except the United States and Canada). [IATA, 2015] Table 16 summarizes these regulations.

Table 16. Visa regimes for Latin American citizens (2015)

\begin{tabular}{|c|c|c|c|c|c|c|c|c|}
\hline $\begin{array}{l}\text { Passport } \\
\text { holders from } \\
\text { (vertical) can } \\
\text { enter without } \\
\text { visa to } \\
\text { (horizontal) }\end{array}$ & Mercosur & $\begin{array}{l}\text { Andean } \\
\text { Commu- } \\
\text { nity }\end{array}$ & Mexico & $\begin{array}{l}\text { Schen- } \\
\text { gen Area }\end{array}$ & Japan & UK & $\begin{array}{l}\mathrm{US}+ \\
\text { Cana- } \\
\mathrm{da} \\
\end{array}$ & Other \\
\hline Argentina & $\mathrm{X}$ & $\mathrm{X}$ & $\mathrm{X}$ & $\mathrm{X}$ & $\mathrm{X}$ & $\mathrm{X}$ & & $\begin{array}{l}\text { IL, KO, NZ, } \\
\text { RU, TR, ZA }\end{array}$ \\
\hline Bolivia, P. S. & $\mathrm{X}$ & $\mathrm{X}$ & & & & & & IE, TR, ZA \\
\hline Brazil & $\mathrm{X}$ & $\mathrm{X}$ & $\mathrm{X}$ & $\mathrm{X}$ & & $\mathrm{X}$ & & $\begin{array}{l}\text { IL, KO, NZ, } \\
\text { RU, TR, ZA }\end{array}$ \\
\hline Chile & $\mathrm{X}$ & $\mathrm{X}$ & $\mathrm{x}$ & $\mathrm{X}$ & $\mathrm{X}$ & $\mathrm{X}$ & $\mathrm{X}$ & $\begin{array}{l}\text { IL, KO, NZ, } \\
\text { RU, TR, ZA }\end{array}$ \\
\hline Colombia & $\mathrm{X}$ & $\mathrm{X}$ & $\mathrm{X}$ & & & & & $\begin{array}{l}\text { IL, KO, RU, } \\
\text { TR }\end{array}$ \\
\hline Costa Rica & $\mathrm{X}$ & $\mathrm{X}$ exc PE & $\mathrm{X}$ & $\mathrm{X}$ & $\mathrm{X}$ & $\mathrm{X}$ & & $\begin{array}{l}\text { IL, KO, TR, } \\
\mathrm{ZA}\end{array}$ \\
\hline Cuba & & & & & & & & EC, RU \\
\hline $\begin{array}{l}\text { Dominican } \\
\text { Republic }\end{array}$ & & & & & $\mathrm{X}$ & & & $\begin{array}{l}\text { CO, EC, IL, } \\
\text { KO, TR }\end{array}$ \\
\hline Ecuador & $\mathrm{X}$ & $\mathrm{X}$ & & & & & & $\begin{array}{l}\text { IL, KO, RU, } \\
\text { TR, ZA }\end{array}$ \\
\hline El Salvador & $\mathrm{X}$ exc VE & $\mathrm{X}$ exc PE & & $\mathrm{X}$ & $\mathrm{X}$ & $\mathrm{X}$ & & $\mathrm{IL}, \mathrm{KO}, \mathrm{TR}$ \\
\hline Guatemala & $\mathrm{X}$ & $\mathrm{X}$ exc PE & & $\mathrm{X}$ & $\mathrm{X}$ & $\mathrm{X}$ & & $\begin{array}{l}\text { IL, KO, RU, } \\
\text { TR }\end{array}$ \\
\hline Honduras & $\mathrm{X}$ exc VE & $\mathrm{X}$ & & $\mathrm{X}$ & $\mathrm{X}$ & $\mathrm{X}$ & & $\begin{array}{l}\text { IL, KO, TR, } \\
\text { RU }\end{array}$ \\
\hline Mexico & $\mathrm{X}$ & $\mathrm{X}$ & $\mathrm{X}$ & $\mathrm{X}$ & $\mathrm{X}$ & $\mathrm{X}$ & & $\begin{array}{l}\text { IL, KO, NZ, } \\
\text { TR }\end{array}$ \\
\hline Nicaragua & $\begin{array}{l}\mathrm{X} \text { exc BR, } \\
\mathrm{VE}\end{array}$ & & & $\mathrm{X}$ & & $\mathrm{X}$ & & $\begin{array}{l}\text { EC, KO, } \\
\text { RU, TR }\end{array}$ \\
\hline
\end{tabular}




\begin{tabular}{|c|c|c|c|c|c|c|c|}
\hline Panama & $\mathrm{X}$ & $\mathrm{X}$ & $\mathrm{X}$ & $\mathrm{X}$ & & $\mathrm{X}$ & $\begin{array}{l}\text { IL, KO, RU, } \\
\text { TR, ZA }\end{array}$ \\
\hline Paraguay & $\mathrm{X}$ & $\mathrm{X}$ & $\mathrm{X}$ & $\mathrm{X}$ & & $\mathrm{X}$ & $\begin{array}{l}\text { IL, KO, RU, } \\
\text { TR, ZA }\end{array}$ \\
\hline Peru & $\mathrm{X}$ & $\mathrm{X}$ & $\mathrm{X}$ & & & & $\begin{array}{l}\text { IL, KO, RU, } \\
\text { TR, ZA }\end{array}$ \\
\hline Uruguay & $\mathrm{X}$ & $\mathrm{X}$ & $\mathrm{X}$ & $\mathrm{X}$ & $\mathrm{X}$ & $\mathrm{X}$ & $\begin{array}{l}\text { IL, KO, RU, } \\
\text { NZ, TR, ZA }\end{array}$ \\
\hline $\begin{array}{l}\text { Venezuela, R. } \\
\text { B. }\end{array}$ & $\mathrm{X}$ & $\mathrm{X}$ & $\mathrm{X}$ & $\mathrm{X}$ & & & $\begin{array}{l}\text { KO, RU, } \\
\text { TR, ZA }\end{array}$ \\
\hline
\end{tabular}

Abbreviations: BO: Bolivia, BR: Brazil, CO: Colombia, EC: Ecuador, IE: Ireland, IL: Israel, IN:

India, KO: South Korea, PE: Peru, PY: Paraguay, RU: Russia, TR: Turkey, UY: Uruguay, ZA: South Africa

Source: Own compilation based on IATA Timatic Web as of October 2015

http://www.iata.org/publications/Pages/timaticweb-travel-requirements.aspx

The most obvious feature of the overview of the visa regimes is that the United States holds a very restrictive visa regime towards Latin America. While for many years it actively sought for seasonal workers - for example in the framework of the Bracero ${ }^{15}$ programme (1942-1964) with Mexico - prospective Latin American migrants are no longer welcome in North America. Restrictions became especially high after 2001. Therefore, as the first-best country of destination became so difficult to reach (in a legal way), the popularity of other possible destinations increased most importantly Europe. [Garzón, 2007; Tedesco, 2008]

In the 1990s and the early 2000s, a booming economy in Southwest Europe (Spain, Italy and Portugal) demanded many low-skilled workers, mostly in the shadow economy, and Latin Americans - mostly Ecuadorians and Peruvians headed towards this region. Visa requirements were consequently tightened for nationals of these countries. A similar thing happened with Brazilians and Peruvians of Japanese descent, who started to move to Japan in large numbers, until Japan decided to require visa from them. [Goto, 2006]

Finally, some nearby Latin American countries are still there for those who have been rejected from everywhere else. Within the different Latin American integration mechanisms (MERCOSUR, Andean Community etc.) there are no visa requirements and people can move freely, by showing their national ID cards. Intraregional migration, as the third-best option, has always been important in Latin America, and visa regimes help to keep this pattern alive. [Solimano - Tokman, 2008; Gindling, 2009]

\footnotetext{
15 The term bracero means seasonal agriculture worker in Spanish.
} 
Nonetheless, migration potential in most Latin American societies is not extremely high. Despite the unfavourable public opinion on the general development perspectives and on the political-bureaucratical apparatus, Latinobarómetro's surveys did not show a very decided willingness among the members of these societies to leave. Yet, there have been outstandingly high values, for example in the Dominican Republic where, in 2008, two out of three respondents wanted to emigrate. The average is, however, around one out of five, and it shows a slight decrease with time. Whether it means that most Latin Americans became reconciled to lower-thanexpected standards of living, or that those who wanted to leave already did so, is subject to debates. Still, it can be said that in Latin America, migration potential is regular, with an obvious - but not too harsh - difference between poorer and richer countries, the latter scoring around $15 \%$ and the former, around $25 \%$.

\section{Graph 6. Plans about moving abroad, survey results (2003-2013)}

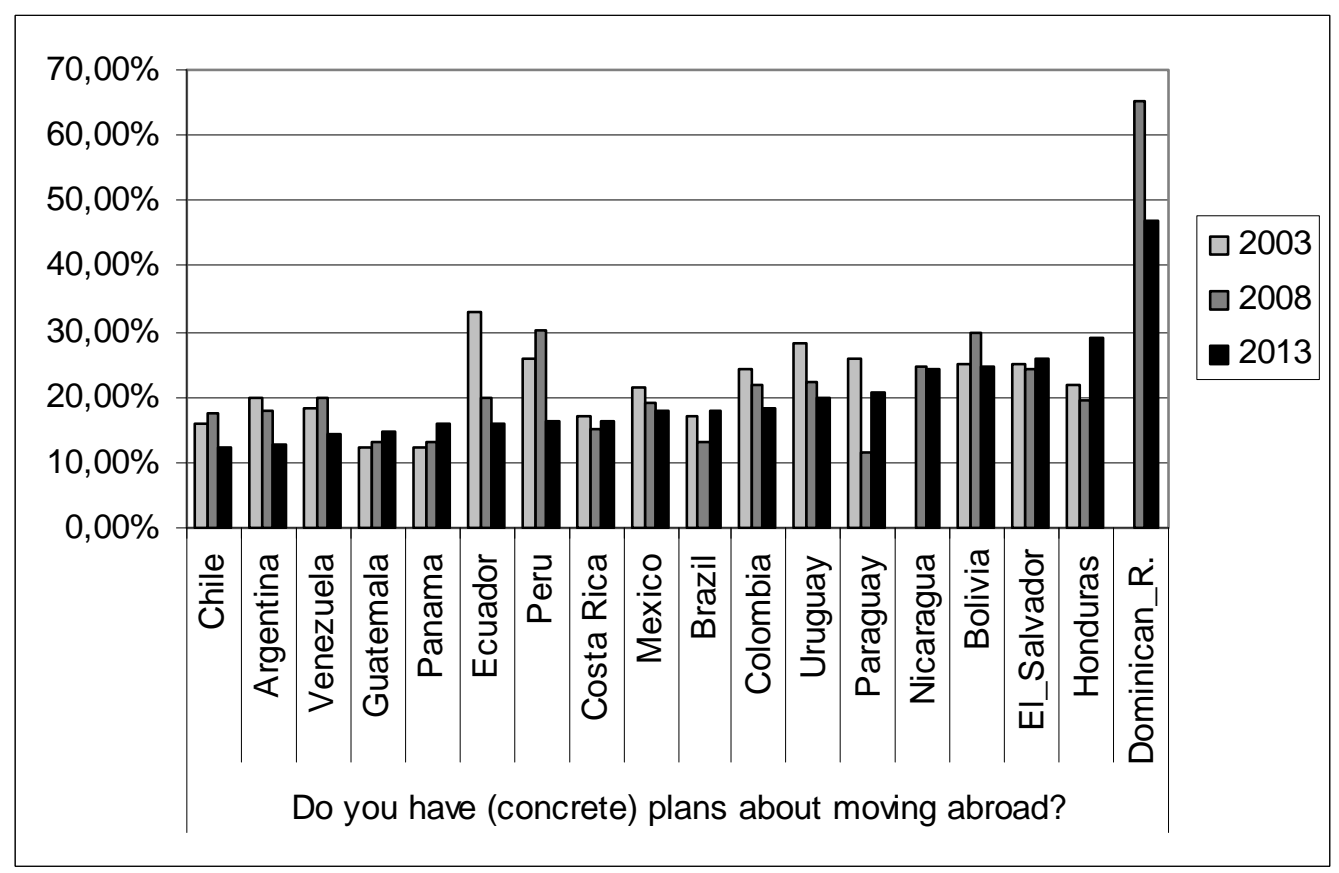

Source: Latinobarómetro [2013]

To sum up what has been said in 2.1.1., trends and patterns of Latin American emigration (and remittance flows) have a historical, demographic, economic, political and social background which can be summarized highlighting the following features: 
- Due to the colonial past, Latin American societies are highly unequal, and the most important factor of distinction is race. If migrating, richer and better educated 'whites' can pass almost unnoticed in white middle class environments of the countries of destination, while lower-class, coloured migrants cannot.

- In general, Latin American countries with a higher share of 'white' population are richer. This is the case of the 'Southern Cone', namely Argentina, Uruguay, Chile and the Southern part of Brazil. Most 'whites' in these countries, however, are not descendants of the 'masters' of colonial times, as their ancestors came as free settlers in the late $19^{\text {th }}$ or early $20^{\text {th }}$ century. Based on these relatively close ties to many European countries, 'whites' can claim a simplified procedure of residence permit and citizenship there. The same applies to Japanese descendants and Japan.

- While most Latin American countries experienced a dynamic population growth and a massive urbanization process, it did not exceed the world average, and it was neither sudden nor unbalanced. By the beginning of the 1990s there was a large (but not extremely large) segment of population who was young, urban and mobile.

- Latin American economies experienced a long period of stagnation in the 1980s, known as the "lost decade", during which the gap between the region and the developed countries grew significantly. The 1973 oil crisis led to a debt crisis, as indebted Latin American countries could not keep on paying their debt services. This, in turn, dried out the resources of a developmentalist industry policy, known as import substitution industrialization. Finally, drastical structural adjustments were implemented in the late 1980s and early 1990s, causing a dramatic collapse of the industry and the rise of unemployment.

- $\quad$ Political factors were more important during the Cold War than after 1990. While communist takeover in Cuba, guerrilla wars in Central America, Colombia and Peru, and military coups in most of the South American countries had caused refugee crises, after 1990 it was mostly the economic hardships that led to massive emigration. The cases of Cuba and Venezuela 
are more complex in this respect, as economic problems are interpreted within a political framework.

- Latin American public opinion is rather unfavourable regarding the general development prospects of the respective countries, as well as regarding the competence and honesty of statesmen and public administrators. A significant - although not very large - share of the population has concrete plans to move abroad. However, these plans are conditioned by restrictive visa regime of the first-best country of destination (the United States), leading to the increased popularity of other possible destinations among prospective migrants - most importantly Europe and some nearby Latin American countries.

Having in mind these features, the trends of migration and remittance flows, as well as the observable general patterns of Latin American migration are presented in the following.

\subsubsection{Trends and patterns of emigration and remittance flows in Latin America}

\subsubsection{Trends of emigration in Latin America}

An overall turn in migration trends is well traceable using the net migration rate as an indicator. [Melegh, 2013] As mentioned before, Latin America was a region of net immigration for approximately 450 years, although most of this time migration was either forced or administered within a framework of colonial oppression, very differently from what is understood as 'international migration' in our times (see 2.1.1.1). Net migration rate for the whole continent turned negative in the late 1950s, yet showing important regional differences. By 1950, net migration rate was negative in 10 out of 19 Latin American countries, and for four more countries it was around zero (see Table 18). Main immigration countries, such as Argentina, Venezuela, Brazil and Uruguay gradually lost their attractiveness, partly because the countries of origin of former migration flows (mainly Southwest Europe) experienced economic growth, and partly because economic hardships and political imbalances made these countries less and less attractive for prospective migrants - 
however, immigrants kept on arriving from neighbouring countries. [Radcliffe Westwood, 1996]

Mass emigration flows occurred due to economic and political shocks (see 2.1.1.2 and 2.1.1.3), many of which can be identified in Table 17, such as Fidel Castro's coming to power in 1959, the coup d'état in Uruguay in 1973 or the Mexican debt crisis in 1982. What definitely turned the tide was, however, the wave of structural adjustments that swept through Latin America in the late 1980s and early 1990, and the consequences thereof. [López Segrera, 2011]

In the meantime, however, a handful of 'success stories' are also present, i. e. countries that due to their good economic performance (and also to the hectic situation of their neighbours) became small regional hubs of inward migration, such as Costa Rica, Chile and Panama. The majority of Latin American countries are nonetheless sending more migrants than they receive, as it can be seen in Table 17 .

Table 17. Net Migration Rate in Latin American countries per 5-year periods

\begin{tabular}{|l|rrrrrrrrrrrr|}
\hline \multirow{1}{*}{ Country } & 1950 & 1955 & 1960 & 1965 & 1970 & 1975 & 1980 & 1985 & 1990 & 1995 & 2000 & 2005 \\
\hline Argentina & 1955 & 1960 & 1965 & 1970 & 1975 & 1980 & 1985 & 1990 & 1995 & 2000 & 2005 & 2010 \\
Bolivia & 3 & 1 & 1 & 1 & 2 & -2 & 1 & 1 & 0 & 0 & -1 & -1 \\
Brazil & -2 & -2 & -2 & -2 & -2 & -1 & -2 & -2 & -3 & -2 & -3 & -3 \\
Chile & 2 & 0 & 0 & 0 & 0 & 0 & 0 & 0 & 0 & 0 & -1 & -1 \\
Colombia & -1 & -1 & -1 & -1 & -2 & -1 & -1 & -1 & 1 & 1 & 0 & 0 \\
Costa Rica & -2 & -3 & -3 & -3 & -2 & -2 & -2 & -1 & -1 & -1 & -1 & -1 \\
Cuba & 0 & 0 & 0 & 0 & 0 & 2 & 2 & 2 & 4 & 7 & 4 & 3 \\
Dominican R. & -1 & -2 & -5 & -6 & -4 & -3 & -5 & -1 & -2 & -3 & -3 & -3 \\
Ecuador & -2 & -2 & -2 & -3 & -3 & -3 & -3 & -3 & -3 & -3 & -3 & -3 \\
El Salvador & 0 & 0 & 0 & 0 & 0 & 0 & 0 & 0 & 0 & 0 & -1 & -1 \\
Guatemala & -6 & -4 & -1 & -3 & -5 & -9 & -10 & -11 & -9 & -14 & -12 & -9 \\
Honduras & 0 & 0 & -1 & -2 & -4 & -7 & -7 & -7 & -8 & -7 & -5 & -3 \\
Mexico & 1 & 1 & 1 & -6 & -3 & -2 & -3 & -3 & -5 & -6 & -5 & -3 \\
Nicaragua & -1 & -1 & -2 & -2 & -3 & -3 & -5 & -3 & -2 & -4 & -5 & -4 \\
Panama & -2 & -1 & -1 & -2 & -3 & -4 & -6 & -8 & -5 & -6 & -8 & -7 \\
Paraguay & -3 & -2 & -2 & -2 & -1 & -1 & -1 & -1 & 0 & 1 & 1 & 1 \\
Peru & -10 & -8 & -7 & -6 & -4 & -3 & -1 & -1 & -1 & -2 & -2 & -1 \\
Uruguay & 0 & 0 & 0 & 0 & 0 & 0 & -1 & -2 & -3 & -3 & -5 & -5 \\
Venezuela & 1 & 2 & 0 & -2 & -10 & -4 & -2 & -2 & -1 & -2 & -6 & -3 \\
\hline LatinAmerica & 6 & 5 & 1 & 1 & 6 & 6 & 1 & 1 & 0 & 0 & 0 & 0 \\
\hline Source: United & $\mathbf{0}$ & $-\mathbf{1}$ & $-\mathbf{- 1}$ & $-\mathbf{1}$ & $-\mathbf{1}$ & $\mathbf{- 1}$ & $-\mathbf{2}$ & $\mathbf{- 2}$ & $\mathbf{- 1}$ & $\mathbf{- 2}$ & $\mathbf{- 2}$ & $\mathbf{- 2}$ \\
\hline
\end{tabular}

\footnotetext{
${ }^{16}$ See also World Bank [2015e]
} 
Regarding the current situation, the single largest country of origin of migrants in Latin America is Mexico, and almost every Mexican migrant is in the United States. This is the most important feature in the whole Latin American migration issue, as Mexicans add up for almost the half of the total Latin American emigrant stock (including intraregional migrants), and a bit more than the half of those who are outside Latin America (see details in Tables 18 and 19). Very far from Mexico's 13.2 million stock of emigrants, Colombia holds the second place with 2.4 million and Brazil comes third with 1.8 million emigrants. Data for all Latin American countries are shown below.

Table 18. Emigrant stock from Latin American countries, total values and as compared to usually resident population (\%) (2013)

\begin{tabular}{|c|c|c|c|}
\hline \multicolumn{2}{|c|}{$\begin{array}{l}\text { Emigrant stock from Latin } \\
\text { American countries (total) }\end{array}$} & \multicolumn{2}{|c|}{$\begin{array}{l}\text { Emigrant stock as compared to } \\
\text { usually resident population }(\%)\end{array}$} \\
\hline Mexico & 13212419 & El Salvador & 25,06 \\
\hline Colombia & 2448385 & Cuba & 12,99 \\
\hline Brazil & 1769639 & Paraguay & 11,92 \\
\hline El Salvador & 1526093 & Dominican R. & 11,58 \\
\hline Cuba & 1476344 & Nicaragua & 11,02 \\
\hline Peru & 1373387 & Mexico & 10,68 \\
\hline Dominican R. & 1190441 & Uruguay & 9,88 \\
\hline Ecuador & 1144408 & Honduras & 8,40 \\
\hline Guatemala & 1049865 & Bolivia & 7,35 \\
\hline Argentina & 980580 & Ecuador & 7,31 \\
\hline Paraguay & 770441 & Guatemala & 6,69 \\
\hline Bolivia & 764862 & Colombia & 5,17 \\
\hline Honduras & 659606 & Peru & 4,49 \\
\hline Nicaragua & 655117 & Panama & 3,94 \\
\hline Venezuela & 630686 & Chile & 3,44 \\
\hline Chile & 604008 & Costa Rica & 2,77 \\
\hline Uruguay & 336741 & Argentina & 2,31 \\
\hline Panama & 149952 & Venezuela & 2,08 \\
\hline Costa Rica & 130364 & Brazil & 0,87 \\
\hline \begin{tabular}{|l|} 
Total \\
\end{tabular} & 30873338 & Total & 5,16 \\
\hline
\end{tabular}

As seen in Table 18's right column, it is not only the absolute numbers that count. While from the perspective of the country of destination, the sheer flow or stock number of migrants already tells a story, from the point of view of the country of origin it is the ratio of emigrants to the total population that is primordial. Tiny El 
Salvador is heading this list with 25\%, followed by Cuba (13\%), Paraguay (11.9\%) and the Dominican Republic (11.6\%).

Table 18 (above) and Map 1 (below) therefore show the emigrant stock data both as absolute figures and as percentages of the usually resident population. On Map 1 the scale of grey shows the ratio of the emigrant stock to the population, while the font size of the name of the country refers to the absolute number of emigrants.

Table 19 shows these top 20 countries of destination in decreasing order regarding the absolute number of stock (left) and the share of Latin American immigrants within the total of the respective country of destination (right).

Table 19. Latin American immigrant stock in the top 20 destination countries (total values and percentage in total stock, 2014)

\begin{tabular}{|c|c|c|c|}
\hline \multicolumn{2}{|c|}{$\begin{array}{l}\text { Latin American immigrant stock } \\
\text { in: (top } 20 \text { destinations) }\end{array}$} & \multicolumn{2}{|c|}{$\begin{array}{l}\text { Share of Latin American } \\
\text { immigrants in total stock in: }(\%)\end{array}$} \\
\hline United States & 21118851 & Paraguay & 91,46 \\
\hline Spain & 2219946 & Costa Rica & 89,12 \\
\hline Argentina & 1508061 & Venezuela & 80,91 \\
\hline Venezuela & 947642 & Argentina & 79,97 \\
\hline Italy & 630069 & Bolivia & 77,97 \\
\hline Japan & 441245 & Chile & 77,64 \\
\hline Canada & 380060 & Ecuador & 72,32 \\
\hline Costa Rica & 373948 & United States & 46,13 \\
\hline Chile & 309154 & Spain & 34,33 \\
\hline Ecuador & 259860 & Brazil & 30,43 \\
\hline Brazil & 182490 & Portugal & 18,95 \\
\hline Paraguay & 169937 & Japan & 18,10 \\
\hline Portugal & 169359 & Mexico & 14,21 \\
\hline France & 165409 & Italy & 11,01 \\
\hline Mexico & 156774 & Canada & 5,22 \\
\hline United Kingdom & 125247 & Switzerland & 4,86 \\
\hline Australia & 123925 & France & 2,22 \\
\hline Germany & 120548 & Australia & 1,92 \\
\hline Bolivia & 120303 & United Kingdom & 1,60 \\
\hline Switzerland & 113404 & Germany & 1,22 \\
\hline
\end{tabular}


Map 1. Relative and absolute values of the emigrant stock of Latin American countries

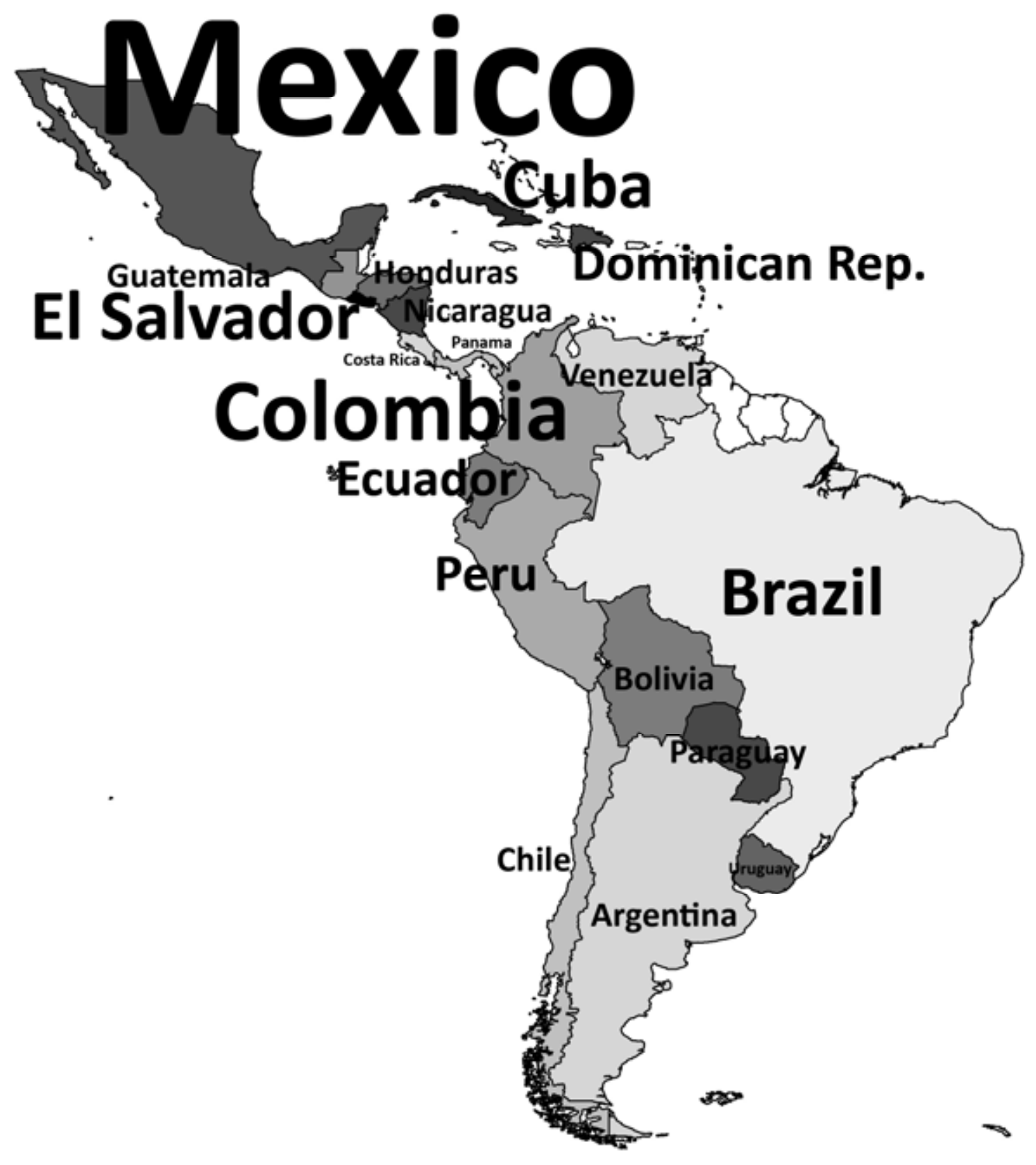

Source: Own compilation based on the data from United Nations [2013] displayed in Table 18. 
Regarding the destinations for Latin American migrants, the United States is by far the most important one, being the number one destination in 12 out of 19 cases and the number two in four further cases. The second destination is Spain (figuring three times as first and seven times as second most important), while the third one is Argentina (first destination for three countries and second for one more). In the top 20, there are nine countries in Latin America, seven in Europe, the two countries of North America (excluding Mexico), one in Asia and one in Australia.

A closer look to the data reveals three important features. First, migration between neighbouring countries is very significant in Latin America. This is obviously the case of the United States and Mexico, the largest migration corridor in the world (see below), but also between Argentina and its neighbours. Historically speaking, Latin American nations did not have strict border control regimes (in the most extreme cases it was not even clear where the actual borders were running), and many times the population did not have a profound belonging to the territory (most European and Asian immigrants arrived with the idea of earning some money and then going back, although most of them did not succeed in the latter). [McDonogh, 2009] In cases when labour-intensive economies (or latifundia with a seasonally increasing demand of labour, such as in the case of crop harvesting) have been separated from their labour suppliers by a rather porous international border, seasonal workers have arrived from the latter to the former ever since these borders were traced. Later on, these short-distance cross-border flows peaked with civil wars, such as in the cases of Colombian, Peruvian or Nicaraguan peasants fleeing to neighbouring countries because of the clashes between the army and the guerrilla. Currently, limitrophe migration is relatively important in many Central American border regions, the Nicaragua-Costa Rica border being the most prominent. All these elements add up to the large stocks of migrants from neighbouring countries in almost every Latin American country. [Gindling, 2009]

Second, the United States is the single most important country of destination for Latin America, not only for Mexico, with which it shares a long border, but also for eleven other countries. It is especially important for Central America and the Spanish Caribbean (see below), from where the overwhelming majority of migrants arrive to the United States (while South America shows a more heterogeneous picture regarding destinations). 
Map 2. Share of destination countries/regions for Latin American emigration in the total emigrant stock of countries of origin (2013)
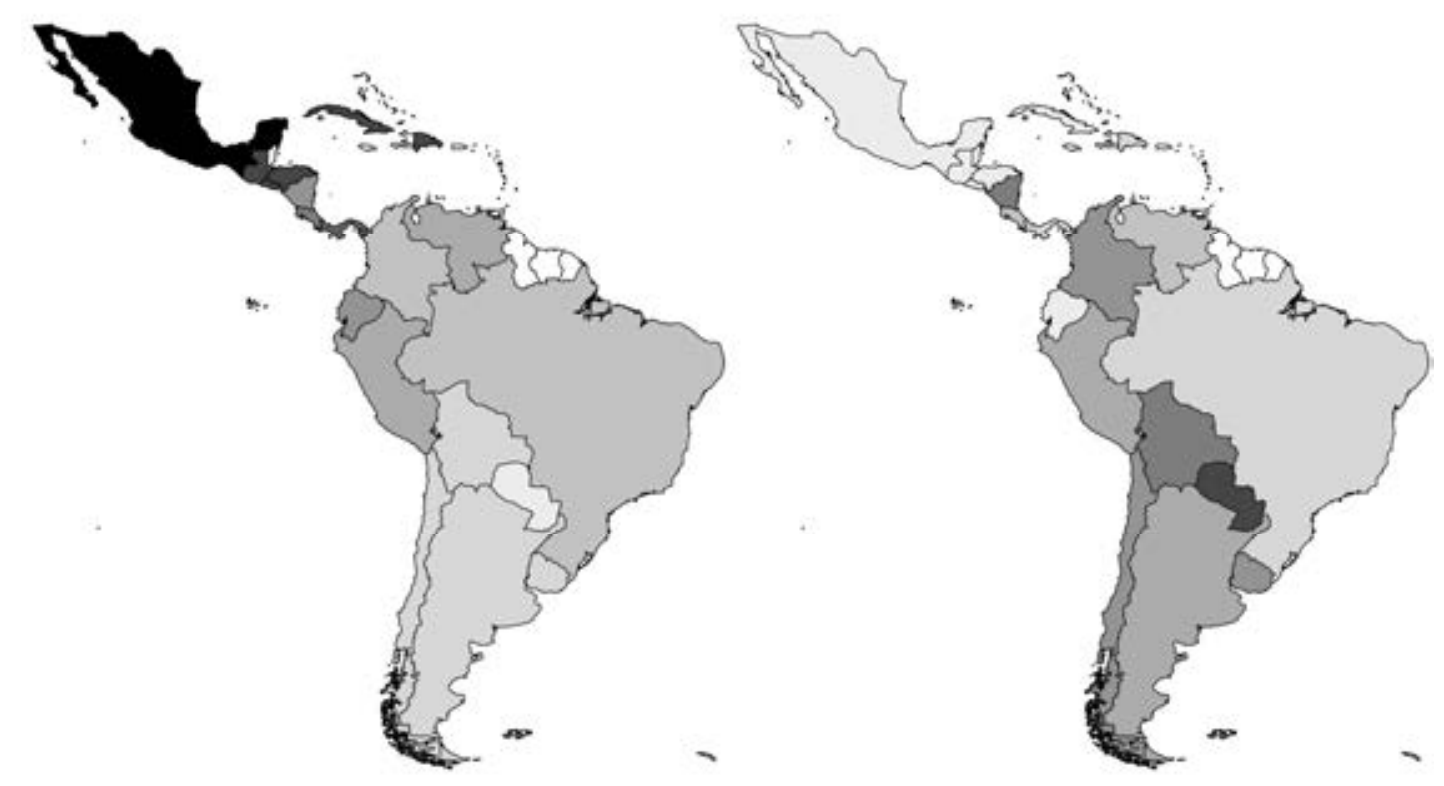

United States

Latin America
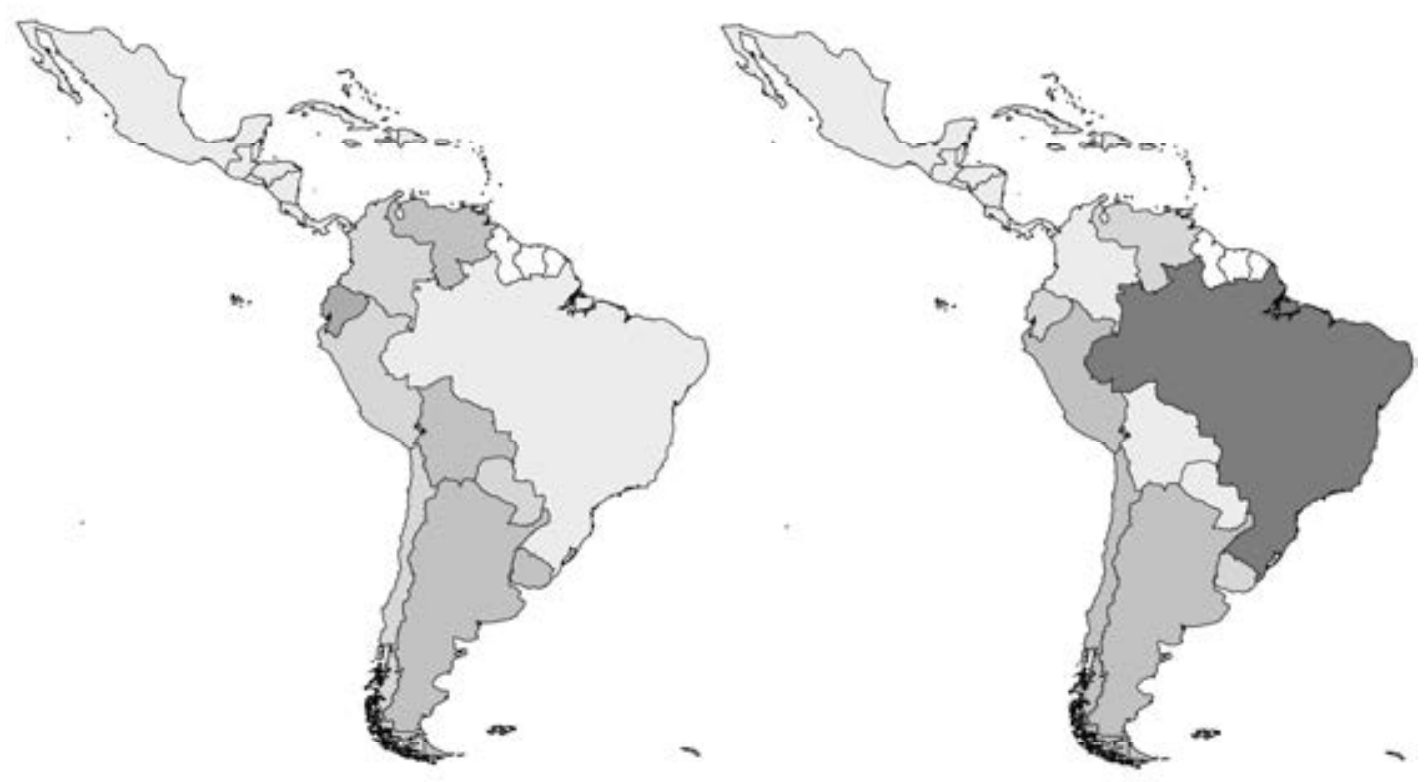

Spain

Other

Source: Own compilation based on United Nations [2013] 
The reason of the popularity of the United States is obvious: an incredible difference in wages and living standards, the need for cheap labour, a (relative) geographic proximity and the well-established networks of co-ethnics are all important factors for keeping the Latin America - United States migration system alive. [Durand - Massey 2003; 2010]

Third, the importance of Spain as a destination is also worth noting. While 'postcoloniality' is not directly relevant to Spanish- and Portuguese-speaking Latin American countries in a way that it is decisive for the Anglophone Caribbean, former colonial ties are still present. Even if political independence was achieved in the 19th century, language and cultural proximity are mentioned by many Latin American migrants as an influential factor for choosing the former metropole as the country of destination. However, this is only one part of the story. Durand and Massey [2010] have a notion of "transgenerational" migrants which applies for Spanish and Portuguese descendants in Latin America, but also for Italian descendants in Argentina and Uruguay, Jewish descendants in Argentina and Japanese descendants in Brazil and Peru. These people have a simplified access for residence permits in Spain, Portugal, Italy, Israel and Japan, respectively, based on their ancestors who had been citizens of these countries. Immigration policymakers in Spain, Portugal, Italy, Israel and Japan have explicitly favoured the descendants of their former nationals over other immigrants, thus giving rise to large communities of Latin American immigrants. Japan is a particularly interesting case, as it is a rather closed country for prospective immigrants, however, it facilitated the entry of many Japanese-Brazilians, the so-called dekasegi. [Goto, 2006; Garzón, 2007; Deligdisch, 2008, Letenyei, 2008; Lilón, 2010]

Map 2 and Graph 7 show the above mentioned features. On Map 2, the same data are visualized in a cartographic way. The scale of grey shows the percentage of emigrants from a given country going to the country (or region) shown below each map. Darker tones mean higher percentage. 
Graph 7. Share of destination countries/regions for Latin American emigration (2013)

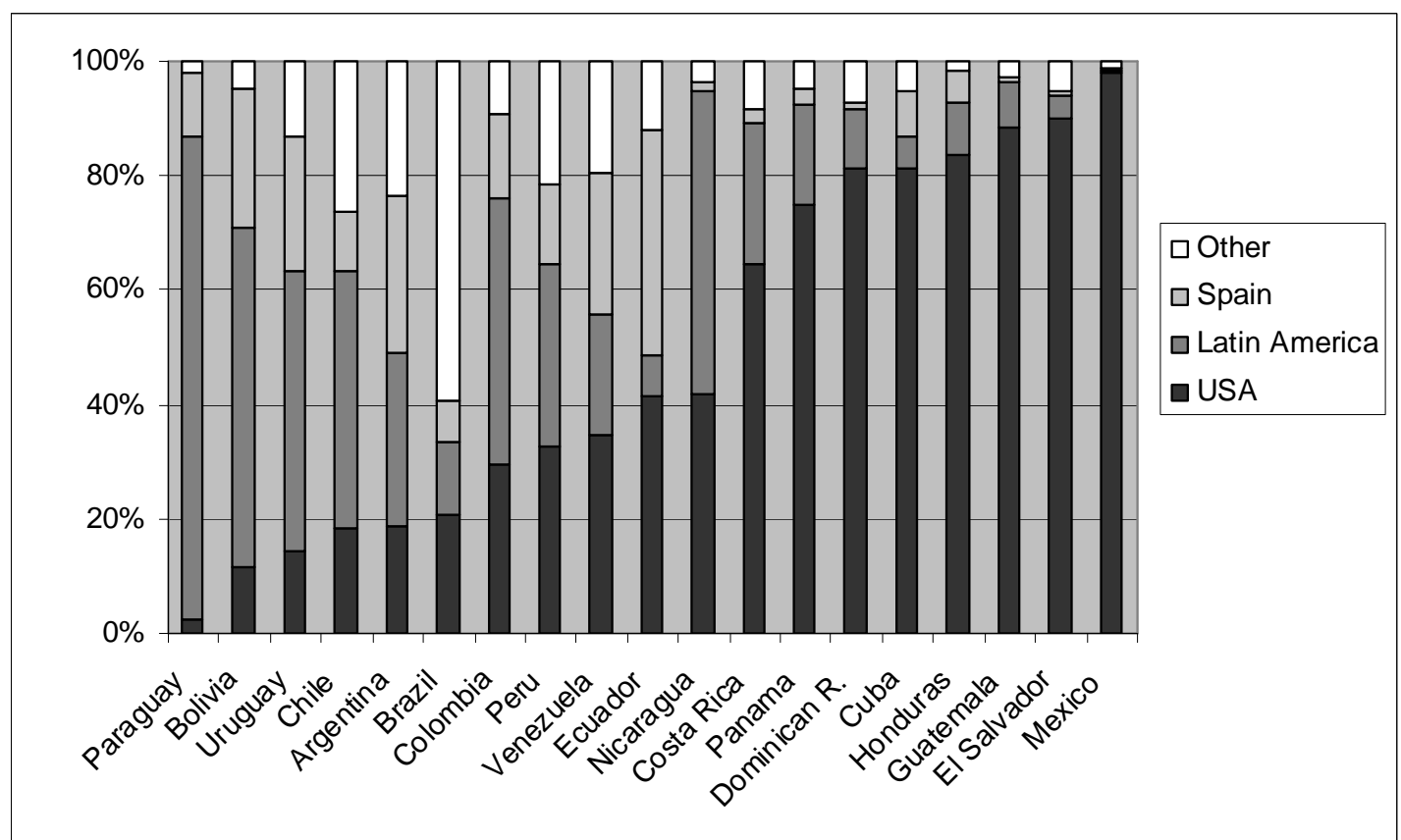

Source: United Nations [2013]

Diversity of destinations is an interesting feature which needs to be observed on a general level and beyond the concrete countries of destination. For the purposes of this thesis, i.e. analyzing diaspora policies, it is important to know how concentrated the diaspora is. In the case of Latin American countries, migrants are usually heading to few countries. For 9 out of 19 countries, more than the half of the diaspora lives in one single country (the United States, for that matter, with the exception of Paraguay which sends the majority of its migrants to Argentina). Concentration is extreme in the case of Mexico, from where $98 \%$ of all migrants have gone to the other side of the Rio Grande ${ }^{17}$. Top three destinations together add up for the $80 \%$ of the total stock of emigrants in 11 out of the 19 Latin American countries.

On the other hand, there is a rather diverse set of countries of destination in the case of Brazil, where the three major countries of destination combined hardly reach the half of the emigrant stock. Also, it is a rather unusual country group, containing Japan and Portugal besides the United States in the top three. In the

\footnotetext{
${ }^{17}$ River that runs on (a part of) the United States - Mexico border.
} 
further seven countries of Brazilian migrants' top ten destinations, one Latin American, one Asian and five European countries appear. Other countries of significant diversity of destinations include Argentina, Chile, Peru, Colombia, Venezuela and Ecuador, all of which countries have at least one European and one Latin American country of destination for their migrants in the top five, besides the ubiquitous United States. The interesting feature is that all of the Latin American countries with a higher diversity of destinations are in South America, while countries with one single major migration destination are in Central America and the Caribbean (with the exception of Paraguay).

\section{Graph 8. Diversity of destinations for Latin American emigrants (by country of} origin, 2013)

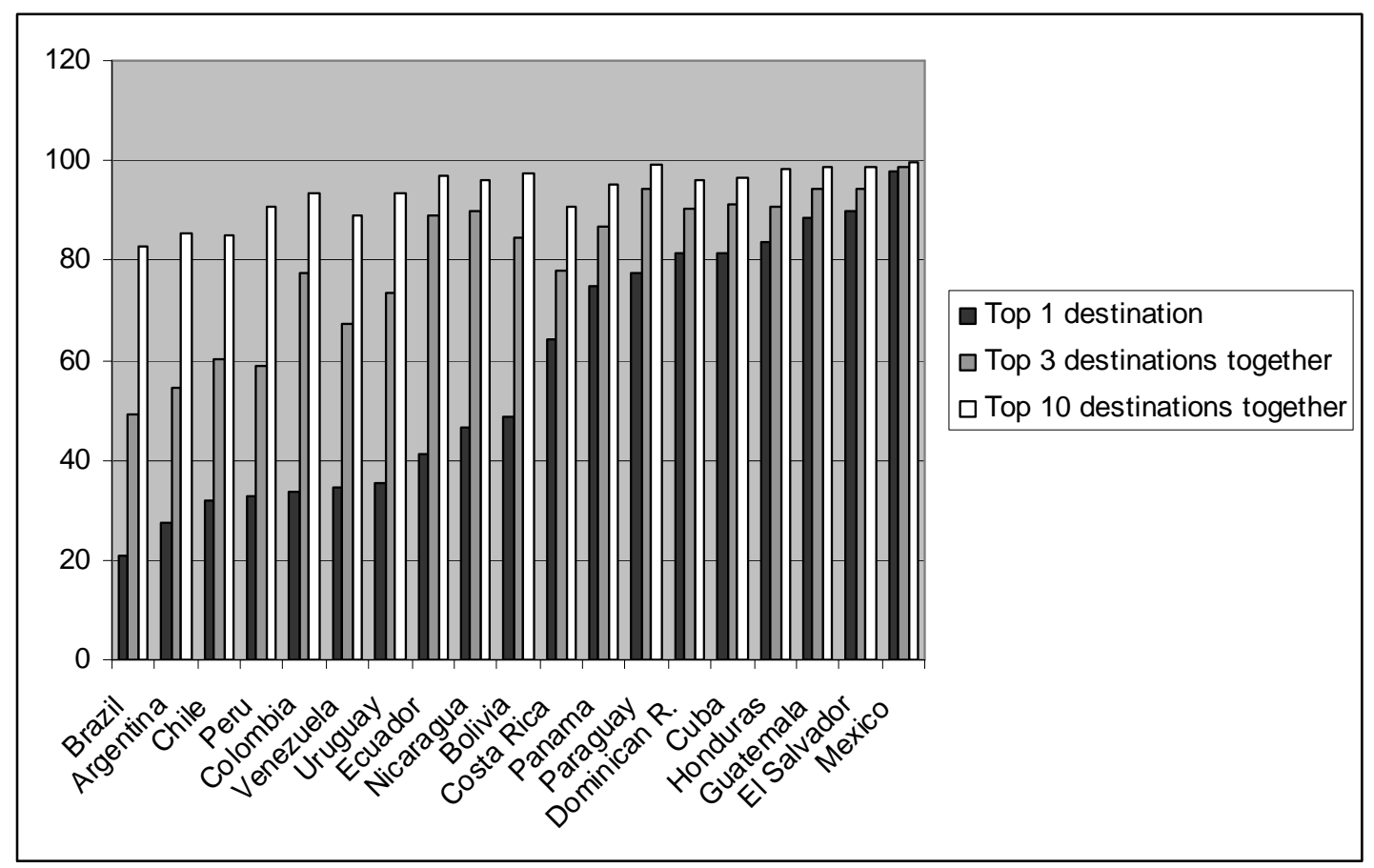

Source: Own calculation based on United Nations [2013]

Needless to say, this affects policymaking in a fundamental way. In the case of Mexico, Central America and the Caribbean, 'diaspora' policy of a government is basically a negotiation with its largest trading partner and political ally, the United States. South American countries, on the other hand, have a broader set of partners to deal with, including fellow Latin American countries (which usually offer visa-free travel and other benefits to their nationals) and Western European welfare states. 
This condition can make diaspora policy more checkered and diverse - for better or for worse.

\subsubsection{Remittance flows in Latin America}

As it has been described above, the largest stock of emigrants belongs by far to Mexico (nearly 12 million), followed by a group of larger (Colombia, Brazil, Peru) and smaller (El Salvador, Cuba, Ecuador etc.) countries. A similar ranking can be made for remittances. Mexico is the largest remittance receiver, not only in Latin America but in the whole world. Other countries with a significant diaspora follow Mexico, with Guatemala coming second, followed by Colombia, El Salvador and the Dominican Republic. Table 20 shows the absolute values of remittances in (current) US dollars and the percentage of this value in their nominal GDP (in which remittances are not included).

Table 20. Inflow of remittances to Latin America (total and as \% of GDP, in current million USD, 2013)

\begin{tabular}{|c|c|c|c|}
\hline \multicolumn{2}{|c|}{$\begin{array}{l}\text { Remittances (total, in current } \\
\text { million USD, 2013) }\end{array}$} & \multicolumn{2}{|c|}{$\begin{array}{l}\text { Remittances as \% of GDP (total } \\
\text { current, 2013) }\end{array}$} \\
\hline Mexico & 23022 & Honduras & $16,95 \%$ \\
\hline Guatemala & 5379 & El Salvador & $16,37 \%$ \\
\hline Dominican R. & 4485 & Guatemala & $9,99 \%$ \\
\hline Colombia & 4449 & Nicaragua & $9,97 \%$ \\
\hline El Salvador & 3971 & Dominican R. & $7,33 \%$ \\
\hline Honduras & 3136 & Bolivia & $3,93 \%$ \\
\hline Peru & 2707 & Ecuador & $2,60 \%$ \\
\hline Brazil & 2537 & Paraguay & $2,05 \%$ \\
\hline Ecuador & 2458 & Mexico & $1,82 \%$ \\
\hline Bolivia & 1201 & Peru & $1,34 \%$ \\
\hline Nicaragua & 1081 & Costa Rica & $1,21 \%$ \\
\hline Costa Rica & 596 & Colombia & $1,17 \%$ \\
\hline Paraguay & 591 & Panama & $1,06 \%$ \\
\hline Argentina & 533 & Uruguay & $0,21 \%$ \\
\hline Panama & 451 & Brazil & $0,11 \%$ \\
\hline Chile & 136 & Argentina & $0,09 \%$ \\
\hline Uruguay & 122 & Chile & $0,05 \%$ \\
\hline Venezuela & 120 & Venezuela & $0,03 \%$ \\
\hline
\end{tabular}

Source: World Bank [2015f] 
As seen in Table 20, the remittances these countries receive have a very different impact on their economy. Colombia and the Dominican Republic both received around 4.5 billion USD in 2013, however, this figure is the $1.2 \%$ of the GDP of the former country, and the $7.3 \%$ of the GDP of the latter. It is clear that when it comes to analysis, relative importance of emigration and remittances are more telling than absolute numbers.

The amount of remittances received, as a percentage of the nominal GDP of each country is visualized in Graph 9:

\section{Graph 9. Remittances as a percentage of the GDP of Latin American countries} (in current total USD, 2013)

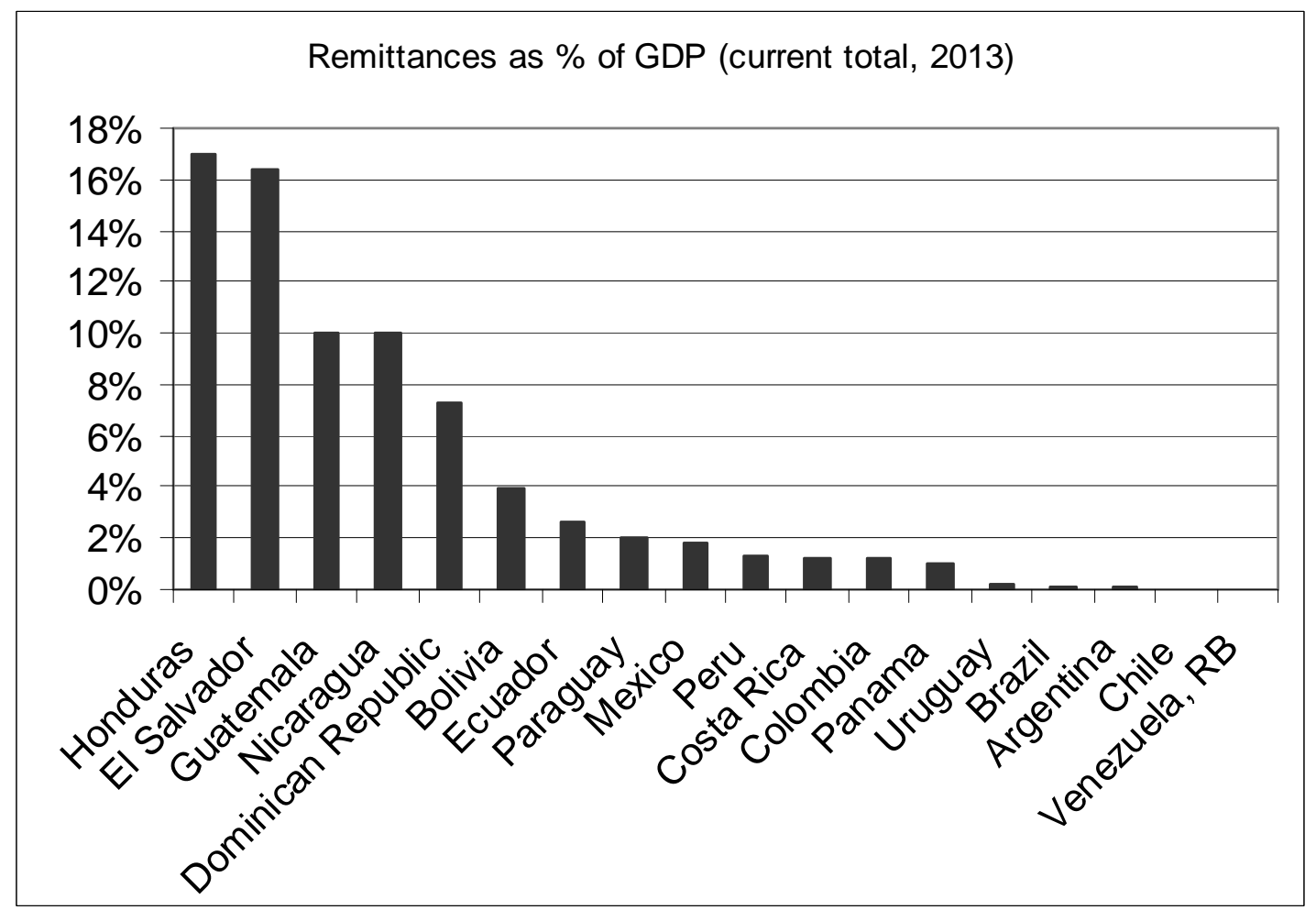

Source: World Bank [2015c, 2015f]

The development of remittance inflow trends is also very important. As a general feature, it can be said that the inflow of remittances started to rise significantly in the late 1990s, however, there have been differences according to the migration history of each country. As remittances are countercyclical - they increase when the overall economic performance in a country decreases - it is no wonder that 
they peaked in 2008, topping over an astronomical amount of 60 billion US dollars (in current value). With the passing of the crisis, they started to decrease sharply.

Historically, Mexico has received around two thirds of the total inflow of remittances to Latin America, while in the mid-2000s its share decreased, mainly because of the growth of other - most importantly Central American - migrant communities in the United States. In the past few years, Mexico's share is growing once again, given that the Mexican community is by far the largest and the most established, meaning that millions of Mexicans would stay in the United States and send money back to Mexico regardless of the current state of affairs in the world economy. [Hiskey - Orces, 2010]

In the following, remittance inflows are shown from 1970 till 2014 in four separate graphs. Separation has been necessary for practical visual reasons. The first shows the Latin American total amount of remittances and the amount received by Mexico. The second one shows the next three countries - Guatemala, Colombia and the Dominican Republic; the third one displays the data of the following six, while the fourth one shows the last seven.

\section{Graph 10. Inflow of remittances to Latin America, 1970-2014, USD/year}

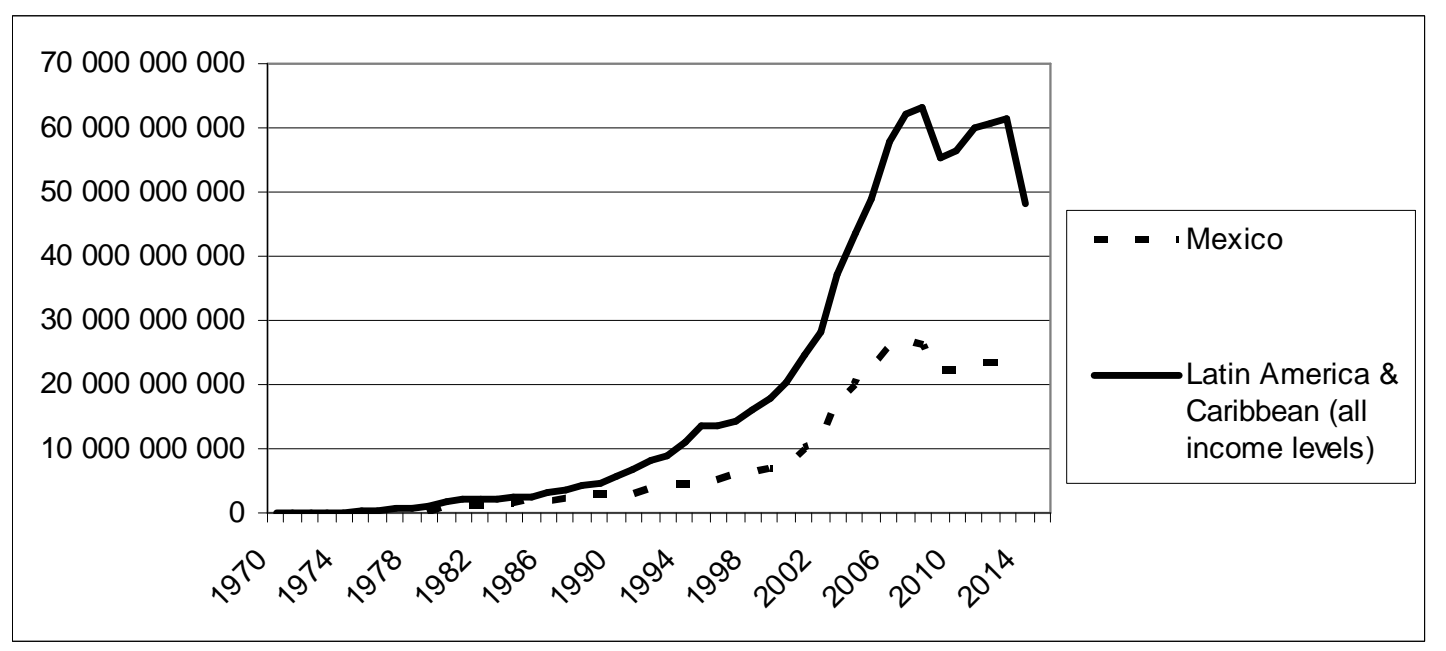



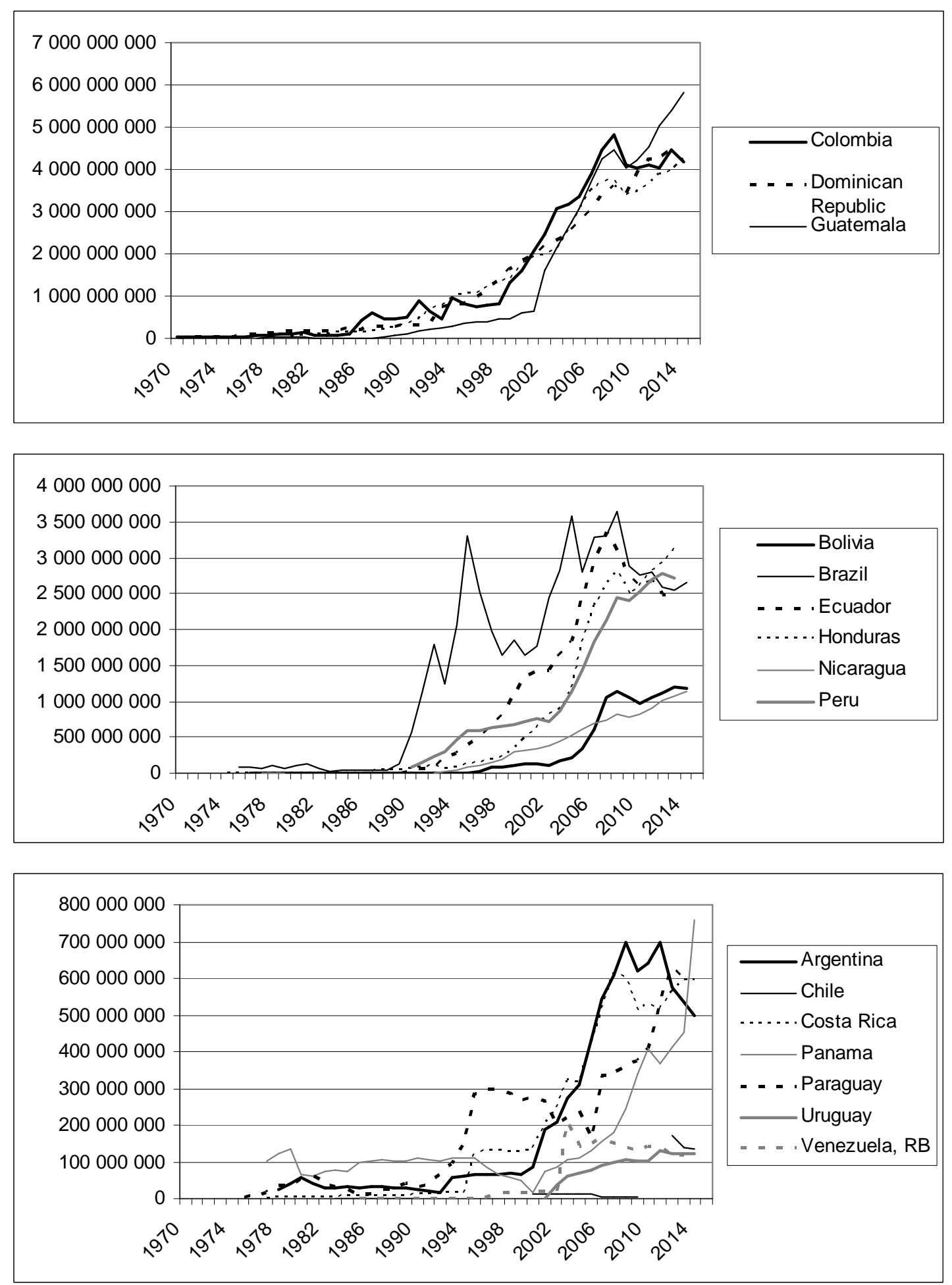

Source: World Bank [2015f]

Another relevant aspect is the relation of remittances and foreign direct investment. In many ways, they are the two sides of the same story. As Latin American countries opened to the world economy, FDI started to arrive in large dimensions. However, much of these flows were portfolio investments, and they 
aimed at the privatization of previously state-owned firms. Upon acquisition, many of these newly privatized companies reduced the scope of their operation and dismissed a large share of their employees. All-Latin American aggregate data (top left on Graph 10) show that FDI and remittance inflows started to increase at the same time, in the mid-1990s, and while the amount of FDI was way larger, it also proved to be way more volatile than remittances which - in line with all the characteristics described in Chapter 1.2. - have been, at the end of the day, a more resilient source of income for the region.

However, there are important differences between countries. Taking the three countries of reference which have already been used for this purpose in 2.1.2.1 Argentina, Mexico and Guatemala - we can see three very different national trajectories. Argentina (bottom left on Graph 10), as hectic as it might have been, experienced a huge inflow of FDI but emigration did not reach dramatic levels. Consequently, remittances have increased but they have not reached the dimensions of FDI. Mexico (top right), in turn, has sent millions of workers to the United States as structural adjustments and trade within the NAFTA uprooted large segments of the population, and remittances and FDI have had, by average, the same amount. Finally, Guatemala (bottom right), as a typical small and poor Central American nation, hardly received any FDI, thus the increase of remittances is not the consequence of the inflow of FDI into the economy and its destabilizing effect on the labour market, but of the overall lack of funds for economic activities.

To sum up, remittances have had and increased role in Latin American economic development, although in different ways in different countries. They might be large in absolute numbers but negligible as compared to the total GDP - or vice versa. Also, they might have evolved as a coping mechanism with the lack of funds, or on the contrary, they have appeared exactly because the inflow of FDI destroyed the previously existing livelihoods of people.

In the following, an attempt is made to synthesize the different features of migration and remittance flows into meaningful patterns or categories, in order to provide a reference point for the analysis of diaspora policies and their capabilities and constraints. 
Graph 11. Remittance inflows (dotted line) to and FDI (continuous line) in Latin America (top left), Mexico (top right), Argentina (bottom left) and Guatemala (bottom right)
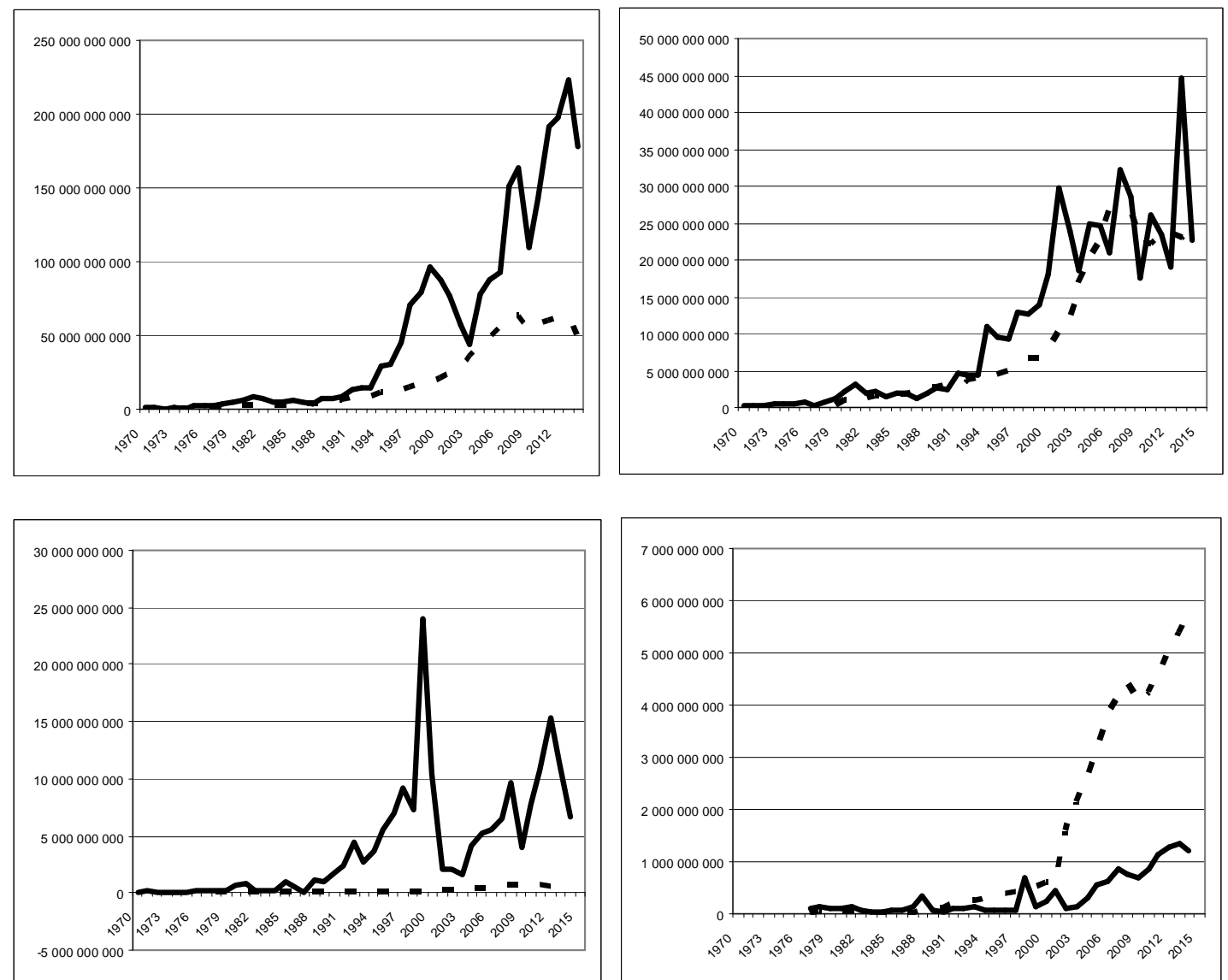

Source: Own compilation based on World Bank [2015 a, 2015f]

\subsubsection{Patterns of emigration in Latin America}

How could all the features described in Chapter 2.1 be contracted into comparable and internally coherent categories? The answer is not easy, as arguably there are many factors that need to be taken into account.

For the purposes of this thesis, the most important question is this: "How can the government of the country of origin can obtain developmentally important contributions from the diaspora?" In order to give an answer, the elements of the question, i.e. concerning the "development", the "government" and the "diaspora" need to be conceptualized around oppositions or scales, in a way that they could 
serve as the base of building categories - or, at least, patterns - that would help the forthcoming analysis.

Development, as already exposed above, can be conceptualized around many indicators, the most convenient of which are GDP and GNI ${ }^{18}$. In this respect, a categorization of the World Bank is relevant, which defines low-income economies as those with a GNI per capita of 1,045 USD or less in 2014; middle-income economies as those with a GNI per capita of more than 1,045 USD but less than 12,736 USD; and high-income economies as those with a GNI per capita of 12,736 USD or more. Lower-middle-income and upper-middle-income economies are further distinguished, being separated at a GNI per capita value of 4,125 USD. [World Bank, 2014]

According to this categorization, there are three country groups in Latin America (as no "low-income" country can be found in the region:

- Lower-middle (1,046 - 4,125 USD): Bolivia, El Salvador, Guatemala, Honduras, Nicaragua;

- $\quad$ Upper-middle (4,126 - 12,736 USD): Brazil, Colombia, Costa Rica, Cuba, Dominican Republic, Ecuador, Mexico, Panama, Paraguay, Peru;

- $\quad$ High $(12,736$ USD < ) Argentina, Chile, Uruguay, Venezuela.

These categories can be a good starting point, however, there are other indicators to take into account. For an analysis with a focus on development, the HDI (Human Development Index) is also fundamental. According to the latest Human Development Report, there are four categories: Very high (HDI 0.8-1), High (HDI 0.7 - 0.799), Medium (HDI $0.55-0.699)$ and Low $(0-0.549)$. As in the case of the GNI-based four categories, there is no Latin American country in the lowest-ranking group. The division is therefore the following: [UNDP, 2014]

- $\quad$ Very high (HDI 0.8-1): Argentina, Chile, Cuba;

- $\quad$ High (HDI 0.7 - 0.799): Brazil, Colombia, Costa Rica, Dominican Republic, Ecuador, Mexico, Panama, Peru, Uruguay, Venezuela

- Medium (HDI 0.55 - 0.699): Bolivia, El Salvador, Guatemala, Honduras, Nicaragua, Paraguay.

By combining these two categorizations, it can be said that Argentina and Chile are definitely on the highest rank, and Uruguay (with a HDI of 0.79) can also

\footnotetext{
${ }^{18}$ Differences between the two and applicability of both have been discussed in Chapter 1.2.
} 
be added to the top three. Following these three, there are two 'uneasy' countries: Venezuela (with high GNI and high HDI) and Cuba (with upper-middle GNI and very high HDI). Uneasiness in these cases means that as opposed to the 'developed' countries of the three Southern Cone countries, neither Venezuela nor Cuba can be full-heartedly dubbed as 'developed': Venezuela owes its high GNI to its petroleumbased economy, while Cuba's high HDI is shadowed by the scarcity of consumption goods and the restrictions of personal freedom.

To these two countries, Brazil should be added. Development of Brazil has been a contested issue for decades: the huge country has been nicknamed as "Belindia" [Taylor - Bacha, 1976], making a reference to the fact that a part of its population enjoys the living standards of Belgium, while the large majority lives on an income level resembling to that of India. Therefore, Brazil scores lower in GNI per capita and HDI values than the Southern Cone countries and Venezuela, but due to its sheer size (and to the fact that Brazilian middle and higher classes comprise tens of millions of people), it should be separated from the rest of 'mid-range' countries.

'Mid-range', in this respect, means an upper-middle GNI and a high HDI. This is the case of Colombia, Costa Rica, Dominican Republic, Ecuador, Mexico, Panama and Peru. Most of these countries are, as already observed before, important countries of origin for large stocks of emigrants - perhaps with the exception of Costa Rica and Panama. Mexico is obviously on a different scale than the other countries in this group, however, as opposed to Brazil, there is no justification for treating it separately, as neither geographical nor income features are that diverse as in the Brazilian case.

Finally, countries with a lower-middle income and medium human development include Bolivia, El Salvador, Guatemala, Honduras and Nicaragua. Paraguay can also be added to this group, despite having a slightly higher GNI than the others. The common feature of these countries is the (relatively) small size (with the exception of Bolivia) and the underdeveloped economy, based on the export of raw materials.

A developmental classification of Latin American countries can therefore be sketched as follows: 
Table 21. A possible categorization of Latin American countries based on their level of development

\begin{tabular}{|l|l|}
\hline Category & Countries \\
\hline High development & Argentina, Chile, Uruguay \\
\hline Asymmetrical high development & Brazil, Cuba, Venezuela \\
\hline Medium development & $\begin{array}{l}\text { Colombia, Costa Rica, Dominican } \\
\text { Republic, Ecuador, Mexico, Panama, } \\
\text { Peru }\end{array}$ \\
\hline Low development & $\begin{array}{l}\text { Bolivia, El Salvador, Guatemala, } \\
\text { Honduras, Nicaragua, Paraguay }\end{array}$ \\
\hline
\end{tabular}

Source: own compilation based on World Bank [2014] and UNDP [2014].

The next issue to be assessed is the question of governance. Very much related to the question of development, Latin American governments have different capacities and capabilities for conceiving, designing and implementing public policies. For the present analysis, this notion has to be completed with the specific aspect of whether these governments are capable of making policies towards the diaspora, i.e. if there are severe hindering factors that would make these attempts unviable.

The most convenient indicators in this respect are the World Bank's series of "Worldwide Governance Indicators" (WGIs) which measure six key dimensions of governance, from 1996 onwards: Voice and Accountability, Political Stability and Lack of Violence, Government Effectiveness, Regulatory Quality, Rule of Law, and Control of Corruption. While WGIs are widely contested and criticized, they are still the most overarching indicators for quantifying the overall quality of governance.

For the purposes of this thesis, and in order to answer the question set above, it is the Government Effectiveness Index (GEI) which seems to be the most telling. As of 2014, Latin American countries had the following scores (the best possible score being 2.5, the worst possible score being -2.5): [World Bank, 2015i]

- $\quad 1-1.5$ : Chile;

- $\quad 0.5-1$ : none;

- $\quad 0-0.5$ : Costa Rica, Mexico, Panama, Uruguay;

- $\quad-0.5-0$ : Argentina, Brazil, Colombia, Cuba, Dominican Republic, Ecuador, El Salvador, Peru; 
- $\quad-1-0.5$ : Bolivia, Honduras, Nicaragua, Paraguay;

$-\quad-1.5-1$ : Venezuela.

While many of the country scores seem to correlate with developmental scores, it is interesting to observe those that are very different. Among the richer countries, Argentina scores bad and Venezuela, extremely bad, while among the mid-range countries, Costa Rica, Mexico and Panama have a better score. It is also important to contrast these (externally conceived and measured) scores with the Latinobarómetro poll data presented in Graph 6. According to these, people have much more trust in public administration and in the state in general in various countries, than what the World Bank would say about their effectiveness. For example, trust is rather high in the case of Venezuela, Ecuador and the Dominican Republic, while they score below zero on effectiveness according to the World Bank. On the other hand, people assess rather negatively the state and the public administration in Chile and in Costa Rica, and very negatively in Peru, while they score high(er) on effectiveness according to the World Bank.

For the present purposes, however, these notions are only incorporated to the extent that the extremely good scores of Chile and the extremely bad scores of Venezuela are compensated with their rather negative and rather positive public image, respectively, taking them closer to the rest of the countries. Table 22 shows this slightly modified categorization according to the World Bank's Government Effectiveness Index (GEI):

Table 22. A possible categorization of Latin American countries based on the effectiveness of their governance

\begin{tabular}{|l|l|}
\hline Category & Countries \\
\hline High effectiveness of governance & $\begin{array}{l}\text { Chile, Costa Rica, Mexico, Panama, } \\
\text { Uruguay }\end{array}$ \\
\hline Intermediate effectiveness of governance & $\begin{array}{l}\text { Argentina, Brazil, Colombia, Cuba, } \\
\text { Dominican Republic, Ecuador, El } \\
\text { Salvador, Peru }\end{array}$ \\
\hline Low effectiveness of governance & $\begin{array}{l}\text { Bolivia, Honduras, Nicaragua, Paraguay, } \\
\text { Venezuela }\end{array}$ \\
\hline
\end{tabular}

Source: own compilation based on World Bank GEI [2015i]

It has to be added that there are two countries where significant political discrepancies exist between the government and the diaspora: Cuba and Venezuela. 
In these two cases it is predictable that overall government effectiveness will be deteriorated when it comes to possible cooperation with the diaspora. As Venezuela already scores low, it affects the medium score of Cuba, which is arguably low instead.

Finally, the size and the distribution of the diaspora should be categorized, together with its economic importance for the country of origin, based on the net amount of remittances they send, and more importantly, the ratio of this amount to the country's GDP. This has already been calculated and presented in 1.2.2.2, therefore it should only be organized here into plausible categories.

Regarding the emigrant stock as compared to usually resident population, Latin American countries can be distributed into three groups of approximately equal size:

- 10\% - 25.1\%: Salvador, Cuba, Paraguay, Dominican Republic, Nicaragua, Mexico;

- 5\%-9.9\%: Uruguay, Honduras, Bolivia, Ecuador, Guatemala, Colombia;

- $\quad 0.8 \%$ - 4.9\%: Peru, Panama, Chile, Costa Rica, Argentina, Venezuela, Brazil.

Regarding remittances, groups can be formed according to the ratio of remittances as compared to the total amount of GDP:

- 4-17\%: Honduras, El Salvador, Guatemala, Nicaragua, Dominican Republic;

- 1 -3.9\%: Bolivia, Ecuador, Paraguay, Mexico, Peru, Costa Rica, Colombia, Panama;

- $\quad 0-0.9 \%$ : Uruguay, Brazil, Argentina, Chile, Venezuela.

Relative importance of emigration for a country can therefore be summarized based on these two features. Most of the countries belong to the same 'range' according to both categorizations. There are cases when the diaspora appear to be more important regarding its size than regarding the proportional amount of remittances they send (Paraguay, Mexico, Uruguay), while opposite cases (Guatemala, Honduras, Peru, Panama, Costa Rica) also occur. In general, remittances data seemed to be more telling about the importance of the diaspora, thus this has been the base for categorization. As there is no reliable remittances data for Cuba, it has been classified according to the size of its diaspora, to the first category. 
Table 23. A possible categorization of Latin American countries based on the relative economic importance of their diaspora

\begin{tabular}{|l|l|}
\hline Category & Countries \\
\hline Very important & $\begin{array}{l}\text { Cuba, Dominican Republic, El Salvador, } \\
\text { Guatemala, Honduras, Nicaragua }\end{array}$ \\
\hline Rather important & $\begin{array}{l}\text { Bolivia, Colombia, Costa Rica, Ecuador, } \\
\text { Mexico, Panama, Paraguay, Peru }\end{array}$ \\
\hline Rather unimportant & $\begin{array}{l}\text { Argentina, Brazil, Chile, Uruguay, } \\
\text { Venezuela }\end{array}$ \\
\hline
\end{tabular}

Source: own compilation based on United Nations [2013] and World Bank [2015f]

Based on these three categorizations, a lot can be said about the importance and the capabilities of the diaspora policy issue in each country. By assigning numerical values to the categories, we could foresee how motivated decision makers will be to handle the issue, and how successful they will be. The logical maximum of points would therefore go to countries with low development level, high governance effectiveness and high economic importance of the diaspora. On the other hand, the logical minimum would go to countries which enjoy a high development, have a very ineffective government and the diaspora is economically unimportant.

It is obvious that these are nonsense combinations, as high development level usually correlates with higher effectiveness of the government and with lower level of economic importance of the diaspora, and accordingly, lower development level implies lower effectiveness of government and higher level of economic importance of the diaspora. Actually, when looking at the Tables 21, 22 and 23, we can identify clusters of countries that show these features. For example, Chile is a good example for the former case, and Honduras for the latter.

Therefore, it seems to be reasonable to draw three 'patterns' of emigration and diaspora, seen from the perspective of their possible implications for diaspora policymaking. These patterns are summarized in Table 24 . 
Table 24. A possible categorization of Latin American countries based on the economic importance of their diaspora and the governmental capabilities for diaspora policymaking

\begin{tabular}{|l|l|l|l|l|}
\hline Pattern & $\begin{array}{l}\text { Development } \\
\text { level }\end{array}$ & $\begin{array}{l}\text { Governance } \\
\text { effectiveness }\end{array}$ & $\begin{array}{l}\text { Economic } \\
\text { importance of } \\
\text { the diaspora }\end{array}$ & Countries \\
\hline $\mathbf{1}$ & High & $\begin{array}{l}\text { High or } \\
\text { intermediate }\end{array}$ & Low & $\begin{array}{l}\text { Argentina, Brazil (2), } \\
\text { Chile, Uruguay }\end{array}$ \\
\hline $\mathbf{2}$ & Intermediate & Intermediate & Intermediate & $\begin{array}{l}\text { Bolivia (3), Colombia, } \\
\text { Costa Rica, Ecuador, } \\
\text { Mexico, Panama, } \\
\text { Paraguay (3), Peru }\end{array}$ \\
\hline $\mathbf{3}$ & Low & $\begin{array}{l}\text { Low or } \\
\text { intermediate }\end{array}$ & High & $\begin{array}{l}\text { Dominican Republic (2), } \\
\text { El Salvador, Guatemala, } \\
\text { Honduras, Nicaragua }\end{array}$ \\
\hline $\mathbf{4}$ & Asymmetrical & Low & Controversial & Cuba, Venezuela \\
\hline
\end{tabular}

Numbers in brackets show that the given country could arguably be classified to another category. Source: own compilation, see details at Tables 21,22 and 23.

What has been summarized in Table 24 is a preliminary assessment on the importance of the diaspora in the economical and social processes of each Latin American country - based on the overall development level of the country, the absolute and relative size of the diaspora itself and of the remittances they send home - and on the general effectiveness of the governmental activities of the given country. By these factors, four patterns have been identified, three of which are logical positions in an 'importance - capabilities matrix'. Pattern 1 marks the position of 'lower importance' (i.e. of the diaspora) and 'high capabilities' (i.e. for policymaking). Pattern 2 stands for 'intermediate importance' and 'intermediate capabilities', while pattern 3 is for 'high importance' and 'low capabilities'. Pattern 4, however, covers two 'outlier' countries, Venezuela and Cuba, in which cases neither the development level, nor the capabilities of diaspora policymaking can be 'matched' to the rest of the countries, due to their different political systems. It is therefore expected that they will show different features regarding their diaspora policies as well. 


\subsection{Diaspora institutions in Latin America}

In the following, the institutional history of Latin American 'diaspora affairs' is presented, focused on the issues that are crucial for their birth, functioning and impact: namely, the political capital of the diaspora, the institutional frameworks for their creation and the areas where activities have been undertaken.

\subsubsection{Migration and diaspora on the Latin American political agenda}

\subsubsection{The migration issue on the Latin American political agenda}

As it has been summarized in 2.1, in the Latin American context 'migration' meant, for centuries, 'immigration'. If a Latin American country had migrationrelated policies, it meant policies of immigration and settlement, with few, although notable exceptions as Mexico. Latin American countries were effectively encouraging the immigration of (mainly white) colonists through immigration agents in the 19th century, based on a population politics premise summarized by Argentine president F. D. Sarmiento as "gobernar es poblar" (to govern is to populate). The idea consisted in providing immigrants land for free, thus distant and sparsely populated areas of Latin American countries could contribute to the nation's unity and wealth. [Solimano - Allendes, 2007]

In line with the 'coloniality' of Latin American migration history, exposed in 2.1.1.1 and relevant even after the independence of Latin American nations, this 'internal colonization' took place largely at the expense of outlawed indigenous populations. Settlement policies were substantially racist in nature, and shaped by the notion of Eugenics: criollo elites expected to strengthen their domination over the indigenous (or Negro) peasantry through a conscious 'whitening' of the population. When white immigration became massive enough, this strategy was very successful indeed, like in the Chilean case where English, German, French and Croatian immigrants took part in the process of the conquest of the South (from the Mapuche tribes), and lots of their descendants made their way into the Chilean elite and middle class. Hence, the migration-development nexus was, throughout Latin American history, related to a process of nation-building administered by the criollo elite. [Solimano - Tokman, 2008] 
As also mentioned in 2.1.1.1, emigration presents an opposite case in ethnic and class terms. In many Latin American countries, emigrants have been - and, by large, still are - lower-class people of colour, and their departure was dismissed, if not encouraged by governments. If Latin American countries had a policy on outward migration, it was conceived under the assumption of temporariness, namely, that excessive workforce can cross the border on a temporary basis, for a limited period of time, and bringing the revenues of their work back to the home country. Overseas employment is still seen to some extent as a mean of getting rid of people who could not be useful for the country.

The bilateral treaty between the United States and Mexico on seasonal workers, the Bracero Programme (1942-1964) was the only one large-scale legal migration mechanism between a Latin American country and the main country of destination. The government of the United States suspended the programme unilaterally in 1964 and it did not seek to have similar treaties with any Latin American country after this date. [Délano, 2011]

An opposite tendency appeared in the 1970s when the rise of dictatorships made intellectuals and politically involved workers flee from oppression and reprisal. These emigrants were seen by the state as potential enemies: they could not return, their citizenship was taken away, and - in some cases, of which the Operation Condor became the most notorious - these regimes actually tried to localize and kill them abroad. Intellectuals and leftist union members fled Argentina, Chile and Uruguay, arriving mostly to Western Europe (Sweden, France etc.) and to a lesser extent, Australia and Mexico. 'Exiled opposition' was a vocal adversary of the rightwing military regimes, and their staunch leftist standpoint induced a rather problematic relationship between the country of origin and the diaspora even after the democratic transition, especially in the case of Chile. [Sznajder - Roniger, 2007]

The Cuban diaspora is (structurally) somewhat similar to the emigrants from the Southern Cone, as they also left the country in a situation of political turmoil and as an opposition to the regime - obviously, their political sympathies are diametrically opposed to Argentinean and Chilean exiliados. Following Fidel Castro's arrival to power, several waves of mass emigration (most notably in 1980 and in 1994) led to the formation of a large, tight-knit and politically active Cuban diaspora, mostly in Miami, Florida. [Portes - Bach, 1985] After the lifting of travel restrictions for Cubans by Raúl Castro, the emigration has seen a new rising tide. The 
Cuban government is rather precautious with the Cuban-American community, as they are openly anti-Castroists and the radical wing of the Cuban-American lobby has had a decisive share in maintaining the United States' embargo against Cuban goods and products. From 1995 onwards, the United States has followed the socalled "wet foot, dry foot" policy towards rafters who try to get to Florida through the Strait of Florida: Cubans who are caught on the water (i. e. with "wet feet") are sent home, while those who make it to the shore ("dry feet") can remain in the United States - a benefit that no other Latin American irregular immigrant group enjoys. [López Segrera, 2011]

After the end of the Cold War and with the hardships of the structural adjustments of the early 1990s, another trend emerged. Many underachieving Latin American governments treated emigrants as 'traitors' who had left the country when the country would have needed them, therefore no longer considering them part of the political community - this was the case of Peru after the "Fujishock" that, while restoring macroeconomic stability, led to the drastically quick pauperization of important segments of the population. Also, Ecuador and Colombia experienced large-scale outmigration due to economic and political instability, and political leaders could not do anything else but to criticize them publicly for doing so. [Cárdenas - Mejía, 2008; Berg, 2010; Vega, 2011]

By the end of the 1990s, many Latin American governments had to realize that a large part of the country's population has moved abroad and they are not willing to return, even if political oppression or extreme economic hardships have ended. Reanimating the contact with the diaspora emerged as a new goal, while, with the gradual restriction of United States's (and, later, European) immigration policies, advocating of undocumented immigrants' right to enter and stay in these countries also became an issue. Together with the wish to attract emigrants' remittances and investment, these are the aims of present-day Latin American governments towards their diaspora.

In the current context, the government of a Latin American country of origin is basically interested in that its migrant citizens can enter safely and legally to the country of destination, have their rights respected there, have their requirements met to become economically successful, and still they maintain their contacts with their household members in the country of origin, so the latter can get financial contributions. Once the government of a country of origin decides to build policies in 
order to achieve these goals, they will start being gradually included in the agenda of the Ministry of Foreign Affairs of each country.

Achieving these goals, however, is not easy. As immigration is being increasingly seen by the main countries of destination as a problem, and not as a way to meet labour market demands (and a natural consequence of the liberalization of all markets, except that of labour), immigration policies are becoming more and more restrictive. These policies are also seen as a fundamental part of national sovereignty, making them a bilateral issue between each country of origin and destination. Mexico and the most Central American countries from which migration aims almost exclusively the United States, have little space for manoeuvre: they must negotiate with this specific country, and from an extremely subordinated position.

From the 1990s onwards, control and criminalization of migrants in the Mexico - United States and the Central America - United States migratory systems became more thorough than ever before. [Portes - Bach, 1985; Alba, 1999; Escobar et al, 1999] This had four important effects on migrant behaviour. First, as crossing the border has become way too risky, once undocumented migrants made their way to the United States, they preferred not to go back to Mexico, even if they could not manage to find a satisfactory job. The dynamic, demand-led migratory flows have therefore become more rigid, resulting in a 'stuck' population of undocumented Mexicans willing to accept any miserable job offer. As a consequence, wages saw a drastic polarization: while documented migrants' wages were slowly rising, undocumented migrants' wages decreased. Second, undocumented migrants have started to form an underclass of outcasts, having no access to formal labour market, higher education or healthcare, let alone political representation or labour union membership. [Tuirán, 2000] Third, due to the difficulties of crossing the border, undocumented migrants would not get involved in any transnational activities, like the trade of goods, further reducing their opportunities to make a decent living, while the prolonged absence weakened their ties with their place of origin. In this aspect the 'hard' immigration policies seem to have got a result which is exactly the opposite of the original objectives, namely, to reduce the stock of undocumented migrants. Given the circumstances, undocumented Mexicans would prefer to stay in the United States, expecting to get, sooner or later, the necessary documents. In the meantime, they get rooted in this particular outlaw existence, and if the undocumented period becomes too long, they gradually lose the opportunities of 
going back to Mexico, as family and kinship ties may fade with time. Fourth, the cleavage between documented and undocumented migrants splits the Mexican population in the United States in two, sometimes hostile groups that are in a clear conflict of interests, leading to severe problems for any comprehensive policymaking on migratory issues. [Capetillo-Ponce, 2007]

Other countries that have a significant population in Europe have had to face with different problems. While the United Stated had tightened its already strict rules of entry, European countries, most importantly Spain, allowed Latin American citizens to enter the country without visa. Also, at the time a booming economy in Spain demanded many low-skilled workers, mostly in the shadow economy, and Latin Americans (most importantly Ecuadorians but also Bolivians, Dominicans and Colombians) were welcome as they spoke the same language as locals. Italy also became popular with Andean and Argentinean migrants. However, the global economic crisis hit Spain very heavily from 2008 onwards and many migrants returned to Latin America or moved to third countries. Parallelly to the economic problems, European politics towards Latin American immigrants also became more restrictive. [Arteta - Oleas, 2008; Tedesco, 2008]

The only migration channel that still stands open is that of regional migration, which is facilitated by geography and a sense of solidarity among Latin American nations and manifested in the MERCOSUR's and the Andean Community's common regulations. For this reason, while governments of Latin American countries are rather unsuccessful in trying to negotiate migration issues with North American or European governments, they are rather active (and successful) in handling the same issue with their Latin American counterparts. The MERCOSUR's Residence Agreement approved in Brasília in 2002, and the Plan of Action for the Statute of MERCOSUR Citizenship, as well as the initiatives adopted in the context of the Union of South American Nations (UNASUR) and the South American Migration Conference (CSM) - all three currently under negotiation - are very important steps towards an area of free circulation in Latin America. The Central America-4 (CA-4) Border Control Agreement (signed in 2006 between El Salvador, Guatemala, Honduras and Nicaragua) is also a good example for joint governmental efforts towards the free movement of people. [Ceriani, 2013] 


\subsubsection{The birth of diaspora politics and diaspora policies in Latin America}

As it has already been mentioned, mainstream political discourse in Peru during the Fujimori presidency in the 1990s treated emigrants as 'traitors' who leave the country in hard times, even if it would need their work and support. However, in the 2000s an important turn occurred, as Alberto Toledo, a former migrant himself, won the elections in 2001 and started to treat the diaspora issue as one of the most crucial for the country. A specialized body was created within the Ministry of Foreign Affairs for the "Peruvian Communities Abroad" (Comunidades Peruanas en el Exterior) first as a subsecretariat in 2001, then as a secretariat in 2005. Consulates were urged to organize meetings with diaspora representatives that were later institutionalized as diaspora councils under the protection of the consulate (Consejos de Consulta Consular). Toledo called Peruvian migrants the "Quinto Suyo", or "Fifth country", making a reference to the Inca Empire (which was named in Quechua language "Four countries"). The next president, Alan García declared 18 October the "Peruvian Abroad Day" in order to honour the diaspora, and making statements of appreciation to the Peruvian migrant community is a must for every politician running for office ever since, as they are a pool of 3 million potential voters and important contributors to Peruvian economy through remittances. [Berg Tamagno, 2005; Berg, 2010]

This story is particularly telling about how diaspora politics came into being in Latin America. Most importantly, diaspora politics is not the same as diaspora policies, however, the latter would hardly exist without the former. Diaspora politics, already mentioned in Chapter 1.3, is understood here as a regular political activity involving political actors of the country of origin (political parties, presidential candidates, etc.) and formal and informal groups of migrants in the country of destination (migrant associations, informal circles, etc.). Following the logical framework of a 'deal' between the government (or political actors willing to take the power) and the diaspora (or groups thereof), exposed in Chapter 1.3, it is a usual practice in electoral democracies that political actors meet, negotiate with and promise benefits for the members of every possible interest group, hoping to have their votes in the elections. The diaspora should be no exception to that: this is why diaspora politics exists. 
However, the 'diaspora vote' is somewhat different from the vote of other interest groups, such as 'the agricultors' or 'the landless peasants'. First and foremost, they are physically absent. Depending on the laws and regulations of each country, citizens living abroad on a permanent basis and with no registered address in the country of origin, may or may not vote in the elections. Second, even if they may, sometimes it is really difficult for them to cast their votes personally at the consulate of the country of origin, which might be very far away from the place where they live. Third, even if the diaspora is a group with some common needs and interests, they are not necessarily one single "interest group", and fourth, they might not even care about politics in their country of origin any longer, as they expect to have their problems solved by the country of destination instead. [Gamlen, 2006, 2014]

Vocal diaspora groups have nonetheless tried to have their say ever since Latin American emigration has started to gain a significant dimension. Members of the exiled political opposition of the military governments in the 1970s were therefore limited in the legal means to intervene in the political life of the country that they had left behind, thus voting rights were suspended (regardless of whether elections were actually held or not) and if emigrants received the citizenship of their country of destination, it automatically meant the loss of the citizenship of the country of origin. Restrictions on double citizenship have been in force in many Latin American countries, typically in those that suffered a military regime, as in the case of Argentina, Chile or Panama. [Poletti, 2007]

Regarding the right to vote, nowadays the majority of Latin American countries allow their citizens to vote on presidential elections, even if they live permanently abroad, but they have to go personally to the consulate in order to exercise this right. Exceptions to this general trend are right-restricting Chile, Cuba, El Salvador and Uruguay on one hand, as they do not provide this right to their citizens; and right-extending Colombia, Dominican Republic, Mexico and Peru (see below).

Table 25 summarizes the main features of double citizenship regimes and extraterritorial voting rights in Latin America. Most of the information has been compiled based on the "Diaspora Unit Survey" [DUS, 2014-2015] which I conducted with the Diaspora Units of the Ministries of Foreign Affairs of ten Latin American countries as part of the research for this thesis (see originals in Annex 1). 
Table 25. Double citizenship regimes and extraterritorial voting rights in Latin America

\begin{tabular}{|c|c|c|c|}
\hline Country & \begin{tabular}{|l} 
Double \\
citizenship (in \\
case of obtaining \\
second \\
nationality, does \\
the first one \\
remain vigent) \\
\end{tabular} & $\begin{array}{l}\text { Right to vote from } \\
\text { abroad (year when } \\
\text { ceded and type of } \\
\text { elections in which } \\
\text { they can } \\
\text { participate) }\end{array}$ & $\begin{array}{l}\text { Remarks (taken } \\
\text { from the Diaspora } \\
\text { Unit Survey) }\end{array}$ \\
\hline Argentina & $\begin{array}{l}\text { No (except bilateral } \\
\text { treaties, e. g. with } \\
\text { Spain) }\end{array}$ & $\begin{array}{l}\text { 1993, consulate, } \\
\text { presidential, } \\
\text { parliamentary }\end{array}$ & $\begin{array}{l}\text { In referendums only if } \\
\text { explicitly stated by the } \\
\text { election authority }\end{array}$ \\
\hline Bolivia & Yes & $\begin{array}{l}\text { 1984, consulate, } \\
\text { presidential }\end{array}$ & \\
\hline Brazil & Yes & $\begin{array}{l}\text { 1965, consulate, } \\
\text { presidential }\end{array}$ & $\begin{array}{l}\text { If a Brazilian citizen is } \\
\text { inscripted on the electoral } \\
\text { list, the "transit vote" rule } \\
\text { is applied, as if he/she } \\
\text { were a tourist outside } \\
\text { Brazil } \\
\end{array}$ \\
\hline Chile & $\begin{array}{l}\text { No (except bilateral } \\
\text { treaties, e. g. with } \\
\text { Spain) }\end{array}$ & no & $\begin{array}{l}\text { The Law Nr. } 20.748 \\
\text { allowing the right to vote } \\
\text { for the Chilean diaspora } \\
\text { has been passed, by the } \\
\text { next presidential election } \\
\text { (in 2017) it should be } \\
\text { applied. } \\
\end{array}$ \\
\hline Colombia & Yes & \begin{tabular}{|l}
1961 , consulate, \\
presidential, \\
parliamentary (upper \\
house), one special MP \\
at the lower house
\end{tabular} & $\begin{array}{l}\text { Vote is counted to the } \\
\text { upper house. Referendums: } \\
\text { depends on the concrete } \\
\text { case. }\end{array}$ \\
\hline Costa Rica & Yes & $\begin{array}{l}\text { 2014, consulate, } \\
\text { presidential }\end{array}$ & \\
\hline Cuba & No & no & \\
\hline \begin{tabular}{|l|} 
Dominican \\
Republic
\end{tabular} & Yes & \begin{tabular}{|l}
1997, consulate, \\
presidential, \\
parliamentary (upper \\
house), from 2011 \\
migrants send 7 MPs to \\
the lower house \\
\end{tabular} & \\
\hline Ecuador & Yes & $\begin{array}{l}\text { 2002, consulate, } \\
\text { presidential }\end{array}$ & Vote is facultative. \\
\hline El Salvador & Yes & no & \\
\hline Guatemala & Yes & $\begin{array}{l}\text { From 2015, consulate, } \\
\text { presidential }\end{array}$ & \\
\hline
\end{tabular}




\begin{tabular}{|c|c|c|c|}
\hline Honduras & $\begin{array}{l}\text { No (except bilateral } \\
\text { treaties, e. g. with } \\
\text { Spain) }\end{array}$ & $\begin{array}{l}\text { 2001, consulate, } \\
\text { presidential }\end{array}$ & \\
\hline Mexico & Yes & $\begin{array}{l}\text { 2006, postal, } \\
\text { presidential (from } 2012 \\
\text { also governor in } \\
\text { Distrito Federal, } \\
\text { Michoacán and Morelos } \\
\text { states) }\end{array}$ & \\
\hline Nicaragua & $\begin{array}{l}\text { No (except bilateral } \\
\text { treaties, e. g. with } \\
\text { Spain and Central } \\
\text { American countries) }\end{array}$ & $\begin{array}{l}2000, \text { consulate, } \\
\text { presidential (in the } \\
\text { practice, however, it is } \\
\text { rarely performed, due to } \\
\text { lack of funding and } \\
\text { administrative capacity) }\end{array}$ & \\
\hline Panama & No & 2009, postal, presidential & \\
\hline Paraguay & Yes & $\begin{array}{l}\text { From } 2018 \text { (approved by } \\
\text { a } 2011 \text { referendum) }\end{array}$ & \\
\hline Peru & Yes & $\begin{array}{l}\text { 1998, consulate (internet } \\
\text { voting mechanism is } \\
\text { under testing), } \\
\text { presidential, } \\
\text { parliamentary } \\
\text { (extraterritorial MPs } \\
\text { from 2010) }\end{array}$ & $\begin{array}{l}\text { The feasibility of a special } \\
\text { extraterritorial electoral } \\
\text { district is under testing. }\end{array}$ \\
\hline Uruguay & Yes & $\begin{array}{l}\text { no (invalid referendum } \\
\text { in 2009) }\end{array}$ & $\begin{array}{l}\text { A Law Proposal has been } \\
\text { submitted to the } \\
\text { Parliament in September } \\
2014 \text { by the government, } \\
\text { still not approved. }\end{array}$ \\
\hline Venezuela & Yes & $\begin{array}{l}\text { 1997, consulate, } \\
\text { presidential }\end{array}$ & \\
\hline
\end{tabular}

Source: Own compilation based on the Diaspora Unit Survey [2014-2015], Nohlen et al [2007], Poletti [2007], Didou [2009], Castillo [2010] and Vargas [2011] and, if relevant, the website of each institution.

The 'standard' is that citizens of Latin American countries living abroad on a permanent basis can maintain the citizenship of their country of origin even after obtaining the citizenship of their country of destination. Also, they can participate in the presidential elections of their country of origin (but not on other, local or referendum-type elections), if they go personally to the consulate of the country of origin. This is the case of Bolivia, Brazil, Costa Rica, Ecuador, Guatemala and Venezuela.

However, there are countries which are more restrictive. Regarding the double citizenship, there are countries which deny it altogether (Cuba and Panama) or recognize it only in the case if there is a special bilateral treaty with the country 
involved (Argentina, Chile, Honduras and Nicaragua, all of which have an agreement with Spain on recognizing double citizenship with that particular country).

There are also countries that do not restrict double citizenship but they restrict the right to vote for migrants who live abroad on a permanent basis. This is currently the case with two countries from the previous group (Chile and Cuba) and with three others (El Salvador, Paraguay and Uruguay). However, two of these five (Chile and Paraguay) have already adopted a law allowing the diaspora vote in the next presidential elections (2017 and 2018, respectively).

Finally, there are countries which are more 'liberal' regarding the political participation of the diaspora. Mexico allows postal voting and Peru and Ecuador are testing the feasibility of internet voting. And there are a handful of countries which provide migrants not only with the right to vote but also with the right to be voted to. Colombia, the Dominican Republic and Peru have migrant members of the parliament. This means that there are 'extraterritorial' electoral districts: in the Dominican parliament there are MPs who represent the voters of the district of Florida or New York. [Nohlen et al, 2007; Vargas, 2011]

Within these different frameworks of diaspora politics, it can be expected that diaspora policies have also developed showing different features. The following chapter presents the legal and institutional framework of diaspora policies, their outreach and their concrete scope(s) of activity.

\subsubsection{The institutional setting for diaspora policymaking in Latin America}

\subsubsection{Specialized Diaspora Units in Latin American governmental structures}

Traditionally, citizens of a country who are abroad are entitled to consular protection, in line with many international agreements, the most important being the Vienna Convention on Consular Relations [1963], which followed the other important, related agreement, the Vienna Convention on Diplomatic Relations [1961].

With the massification of emigration from Latin American countries, however, governments had to face with the challenge of having tens or hundreds of thousands of citizens in one consular district and for a staff of less than ten people. Especially in the case of elections, when migrants lined up in long queues in front of 
the consulates to cast their votes, it became clear that consulates need a reinforcement in order to be able to carry out all the activities they are supposed to do (procedures of passports and visas, assisting citizens who got in trouble abroad, public notary procedures etc). This is a quantitative challenge which could (or should) have been tackled by the increase in staff, budget and consular units (districts) in the areas with a large diaspora.

Nonetheless, there are qualitative challenges as well. Migrants are not travelers or tourists but permanent residents of the country of destination where especially if they do not hold a residence permit - they are subject to unfavourable treat. Therefore, consulates should deal with issues of legal advice, law enforcement, negotiating issues of social security and helping in an eventual return migration. All these qualitative changes need a legal and an institutional foundation. [Gamlen, 2006]

Regarding the legal framework, all countries have a general Migration Law which might or might not deal with emigrant issues, but sometimes the legal instruments regulating the Foreign Service contain the legal instruments for dealing with the diaspora. In other occasions, separate laws or decrees are issued to deal with specific topics, most importantly return migration (see Table 26).

Regarding the institutional framework, there are many examples how a 'Diaspora Unit' (understood from here onwards as a specialized institutional unit department, division etc. - which has the main objective of dealing with the issues of the diaspora) came into being within the framework of the respective Ministry of Foreign Affairs. In many occasions, there have already existed an 'Immigration Unit' within the respective Ministry of Interior. Usually, these two units are linked with a coordination mechanism (regular meetings etc.) but they work separately, as the circle of population they cover is different. Immigration Units are also larger and better equipped with legal and financial instruments for their operation. For a comparative overview of Immigration and Emigration Units, see Table 27. For a more detailed presentation of Emigration Units, see Table 28.

The creation of emigration-related institutional or interinstitutional units or strategic lines of action is therefore presented in various steps, starting with the legal instruments and policy documents on which they are based. These are summarized in the following Table 26. 
Table 26. Laws and policy documents outlining migration and/or diaspora policies in Latin America

\begin{tabular}{|c|c|}
\hline Country & Relevant laws and policy documents \\
\hline Argentina & $\begin{array}{l}\text { Migration Law ( } \mathrm{N}^{\mathrm{o}} 25.871 \text {, in 2004) } \\
\text { New Argentine Migratory Policy (Nueva Política Migratoria argentina, NPMA, } \\
\text { on immigration only, in 2003) }\end{array}$ \\
\hline Bolivia & Migration Law ( $\mathrm{N}^{\mathrm{o}} 370$, in 2013$)$ \\
\hline Brazil & $\begin{array}{l}\text { Alien Statute Law }\left(\mathrm{N}^{\circ} 6815, \text { in 1980) }\right. \\
\text { Proposal for a Migration Law, Bill (Projeto de Lei) 288/2013 }\end{array}$ \\
\hline Chile & Decree-Law on Alien Affairs ( $\mathrm{N}^{\circ} 1094$, in 1975) \\
\hline Colombia & $\begin{array}{l}\left.\text { Law on the National Migration System( } \mathrm{N}^{\circ} 1465 \text {, in } 2011\right) \\
\text { Law on Return Migration }\left(\mathrm{N}^{\circ} 1565 \text {, in } 2012\right) \\
\text { Decree on the National Intersectorial Commission on Migration }\left(\mathrm{N}^{\mathrm{o}} 1239 \text {, in }\right. \\
2003) \\
\text { Decree on the Modification of the Structure of the Ministry of Foreign Affairs } \\
\left(\mathrm{N}^{\circ} 3355 \text {, in 2009) }\right. \\
\text { Integral Migration Policy (Politica Integral Migratoria, Document } \mathrm{N}^{\mathrm{o}} 3603 \\
\text { CONPES, in 2009) }\end{array}$ \\
\hline Costa Rica & $\begin{array}{l}\text { Law on Migration and Alien Affairs }\left(\mathrm{N}^{\circ} 8764 \text {, in 2010) }\right. \\
\text { "Integral Migratory Policy" (Política Migratoria Integral) document by the } \\
\text { National Council of Migration (in 2013) }\end{array}$ \\
\hline Cuba & Decree-Law on Migration $\left(\mathrm{N}^{\circ} 302\right.$, in 2013$)$ \\
\hline $\begin{array}{l}\text { Dominican } \\
\text { Republic }\end{array}$ & Migration Law ( $\mathrm{N}^{\mathrm{o}} 285$, in 2004) \\
\hline Ecuador & $\begin{array}{l}\text { Migration Law (in 2005, modified several times) National Plan on Ecuadorians } \\
\text { Abroad } \\
\text { (Plan Nacional de Ecuatorianos en el Exterior, in 2001) } \\
\text { National Plan on Human Development for Migrations (Plan Nacional de } \\
\text { Desarrollo Humano para las Migraciones 2007-2010, in 2007) } \\
\text { Plan of Return for the Ecuadorian Migrant (Plan de Retorno para el Migrante } \\
\text { Ecuatoriano, in 2008) } \\
\text { Proposal for a Law on Human Mobility (Proyecto de Ley de Movilidad Humana) } \\
\text { Proposal for an Organic Law on Protection and Equality of Rights of Ecuadorian } \\
\text { Migrants Residing Abroad } \\
\text { (Ley Orgánica de Protección e Igualdad de Derechos de los Migrantes } \\
\text { Ecuatorianos Residentes en el Exterior) }\end{array}$ \\
\hline El Salvador & $\begin{array}{l}\text { Migration Law (in 1959) } \\
\text { Special Law for the Protection and Development of the Salvadorian Migrant } \\
\text { Person and his/her Family } \\
\text { (Ley Especial para la Protección y Desarrollo de la Persona Migrante } \\
\text { Salvadoreña y su Familia, in 2011) } \\
\text { Institutional Policy of Protection and Linkage for the Migrant Salvadoreans } \\
\text { (Política Institucional de Protección y Vinculación para los Salvadoreños } \\
\text { Migrantes, in 2014) }\end{array}$ \\
\hline Guatemala & Migration Law (in 1999) \\
\hline Honduras & $\begin{array}{l}\text { Law on Migration and Alien Affairs (Decree } \mathrm{N}^{\circ} 208 \text {, in 2003) } \\
\text { Law on the Protection of Migrant Hondurans and their Families (Ley de } \\
\text { Protección de los Hondureños Migrantes y sus Familiares, Decree } \mathrm{N}^{\circ} \text {, in 2013) }\end{array}$ \\
\hline Mexico & $\begin{array}{l}\text { Migration Law (in 2011) } \\
\text { Decree creating the Institute of Mexicans Abroad (Decreto por el que se crea el } \\
\text { Instituto de los Mexicanos en el Exterior, con el carácter de órgano } \\
\text { administrativo desconcentrado de la Secretaría de Relaciones Exteriores, }\end{array}$ \\
\hline
\end{tabular}




\begin{tabular}{|c|c|}
\hline & $\begin{array}{l}\text { D.O.F. } 16 \text { abril 2003, in 2003) } \\
\text { Proposal for a Law on Attention to and Protection of Mexicans Abroad } \\
\text { (Proyecto de Ley de Atención y Protección de los Mexicanos en el Exterior) }\end{array}$ \\
\hline Nicaragua & $\begin{array}{l}\text { Migration Law ( } \mathrm{N}^{\circ} 761, \text { in 2011) } \\
\text { Special Law on [Return] Migration Incentives (Ley especial de Incentivos } \\
\text { Migratorios, } \mathrm{N}^{\circ} 535, \text { in 2005) } \\
\text { Proposal for a Law on Attention to and Protection of the Nicaraguan Migrant } \\
\text { Abroad (Proyecto Ley de atencion y proteccion al migrante nicaraguense en el } \\
\text { exterior) }\end{array}$ \\
\hline Panama & $\begin{array}{l}\text { Decree-Law on the National Migration Service (Decreto-Ley que crea el } \\
\text { Servicio Nacional de Migración, la Carrera Migratoria y dicta otras } \\
\text { disposiciones, in 2008) }\end{array}$ \\
\hline Paraguay & Migration Law ( $\mathrm{N}^{\circ} 978$, in 1996) \\
\hline Peru & $\begin{array}{l}\text { Migration Law (Legislative Decree } \mathrm{N}^{\circ} \text { 1236, in 2015) } \\
\text { Law on the Consultative Councils of Peruvian Communities Abroad (Ley de los } \\
\text { Consejos de Consulta de las Comunidades Peruanas, Law N }{ }^{\circ} 29495 \text {, in 2012) } \\
\text { Law on the Economic and Social Reinsertion of the Returned Migrant (Ley de } \\
\text { reinserción económica y social del migrante retornado, } N^{\circ} 30001 \text {, in 2013) } \\
\text { Resolutions of the Minister of Foreign Affairs No.1197 of } 2002 \text { and No. } 0687 \text { of } \\
2004\end{array}$ \\
\hline Uruguay & Law on Migration and Return $\left(\mathrm{N}^{\circ} 18.250\right.$, in 2008$)$ \\
\hline Venezuela & $\begin{array}{l}\text { Law on Alien Affairs and Migration }\left(\mathrm{N}^{\circ} 37.944 \text {, in 2004) }\right. \\
\text { Proposal for a Law of Repatriation of Goods of Venezuelans Abroad (Ley de } \\
\text { Repatriación de Bienes de venezolanos en el exterior) (or an emigrant tax) }\end{array}$ \\
\hline
\end{tabular}

Source: DUS [2014-2015] and governmental law collection websites

As it can be seen from Table 26, all Latin American countries have a Migration Law which usually deals with the terms and conditions of entry and stay of foreign citizens and the institutional competences of the different governmental units that deal with them. Many of these laws date back to the mid- $20^{\text {th }}$ century and they were often conceived under a military dictatorship. This is the case with the migration laws of Brazil and Chile, for example (although there are attempts in both countries to create a more modern migration law).

New migration laws entered into force in the past 10 years in Bolivia, Colombia, Costa Rica, Cuba, Ecuador, Mexico, Nicaragua, Panama, Peru, Uruguay, many of which make several references to the emigration and diaspora issue. Some of these countries also created specialized laws for a concrete topic within the emigration issue, the two most important being the protection of vulnerable migrant groups abroad (El Salvador and Honduras already have a law on this matter, while the legislation of Ecuador, Mexico and Nicaragua are debating over their respective law proposals) and return migration (Colombia, Nicaragua and Peru already have a law, Ecuador has a 'plan'). Some of the countries also have a law or a ministerial decree concerning the institutionalization of their Diaspora Unit: Colombia, Mexico and Peru counts with such a document. 
There are comprehensive policy papers on an 'integral' migration policy in five countries: Argentina, Colombia, Costa Rica, Ecuador and El Salvador. However, this enumeration can be misleading: Argentina's "New Argentine Migratory Policy" [2003] deals only with immigration issues, while significant countries of origin like Mexico or Peru do not count with one single document - nonetheless, they have important achievements on the policy level.

Meanwhile, as of 2015, roughly the half of Latin American countries still have little more achievement in the institutionalization of their diaspora-related activities than an administrative unit for visa issues for those citizens who reside abroad which sometimes issues an informative material for emigrants or prospective returnees. These countries (for example Bolivia, Panama or Paraguay) do not actively 'make policy' in institutional terms, conceiving migration primarily as an issue of documentation and public administration.

Others already have a specialized body for diaspora communities, even if only a few countries have a separate, higher level institutional unit within the Ministry of Foreign Affairs that deals with diaspora issues with a holistic approach (see Tables 27 and 28). Most importantly, it is Mexico that has a large apparatus for this sort of tasks, but also Ecuador and El Salvador are worth mentioning. Mexico's Institute for Mexicans Abroad (Instituto de los Mexicanos en el Exterior) will be presented in details below. Being more a paradigm shift than a simple agenda setting, institutionalization of the constant contact and assistance of a large number of citizens who live abroad have been a slow but important process in diaspora issues. [Didou, 2009; Délano, 2011; Vargas, 2011]

Parallelly, on the intergovernmental level, the Ministry of Foreign Affairs of most Latin American countries have been dedicating increased efforts to advocate migrants' rights, with migration becoming a basic issue in bilateral relations with the countries of destination. Cooperation with other countries of origin on international fora, as in the case of the quest for the ratification of United Nations' International Convention on the Protection of the Rights of All Migrant Workers and Members of Their Families, has also become an important point in the agenda.

In Table 27, the specialized institutional bodies responsible for immigration and emigration/diaspora issues are shown for each Latin American country. 
Table 27. Specialized institutional bodies responsible for immigration and emigration/diaspora issues in each Latin American country

\begin{tabular}{|c|c|c|}
\hline Country & $\begin{array}{l}\text { Institutional body for } \\
\text { immigration (Ministry of } \\
\text { Interior) }\end{array}$ & $\begin{array}{l}\text { Institutional body for } \\
\text { emigration (Ministry of Foreign } \\
\text { Affairs) } \\
\end{array}$ \\
\hline Argentina & $\begin{array}{l}\text { National Directorate of Migrations } \\
\text { (Dirección Nacional de Migraciones) }\end{array}$ & $\begin{array}{l}\text { Directorate of Argentines Abroad } \\
\text { (Dirección de Argentinos en el Exterior) }\end{array}$ \\
\hline Bolivia & $\begin{array}{l}\text { General Directorate of Migration } \\
\text { (Dirección General de Migración) }\end{array}$ & \\
\hline Brazil & $\begin{array}{l}\text { Department of Foreigners (within the } \\
\text { Ministry of Justice) (Departamento de } \\
\text { Estrangeiros) }\end{array}$ & $\begin{array}{l}\text { Division of Brazilian Communities } \\
\text { Abroad (Divisão das Comunidades } \\
\text { Brasileiras no Exterior, DBR) }\end{array}$ \\
\hline Chile & $\begin{array}{l}\text { Department of Migration and Alien } \\
\text { Affairs (Departamento de Migración } \\
\text { y Extranjería) }\end{array}$ & $\begin{array}{l}\text { Directorate for the Communities of } \\
\text { Chileans Abroad (Dirección para la } \\
\text { Comunidad de Chilenos en el Exterior, } \\
\text { DICOEX) }\end{array}$ \\
\hline Colombia & $\begin{array}{l}\text { General Direcorate of Migration } \\
\text { (Dirección General de Migración) }\end{array}$ & $\begin{array}{l}\text { Directorate of Consular and Migratory } \\
\text { Affairs and Citizen Service (Dirección } \\
\text { de Asuntos Consulares, Migratorios y de } \\
\text { Atención al Ciudadano) }\end{array}$ \\
\hline Costa Rica & $\begin{array}{l}\text { General Direcorate of Migration and } \\
\text { Alien Affairs (Dirección General de } \\
\text { Migración y Extranjería) }\end{array}$ & \\
\hline Cuba & $\begin{array}{l}\text { Direcorate of Immigration and Alien } \\
\text { Affairs (Dirección de Inmigración y } \\
\text { Extranjería) }\end{array}$ & $\begin{array}{l}\text { Nation and Emigration (Nación y } \\
\text { Emigración) }\end{array}$ \\
\hline $\begin{array}{l}\text { Dominican } \\
\text { Republic }\end{array}$ & $\begin{array}{l}\text { General Direcorate of Migration } \\
\text { (Dirección General de Migración) }\end{array}$ & \\
\hline Ecuador & $\begin{array}{l}\text { General Direcorate of Migration } \\
\text { (Dirección General de Migración) }\end{array}$ & $\begin{array}{l}\text { Viceministry of Human Mobility } \\
\text { (Viceministerio de Movilidad Humana) }\end{array}$ \\
\hline El Salvador & $\begin{array}{l}\text { General Direcorate of Migration and } \\
\text { Alien Affairs (Dirección General de } \\
\text { Migración y Extranjería) }\end{array}$ & $\begin{array}{l}\text { Viceministry of Foreign Affairs for } \\
\text { Salvadorans Abroad (Viceministerio de } \\
\text { los Asuntos Exteriores para los } \\
\text { Salvadoreños en el Exterior) } \\
\end{array}$ \\
\hline Guatemala & $\begin{array}{l}\text { General Direcorate of Migration } \\
\text { (Dirección General de Migración) }\end{array}$ & $\begin{array}{l}\text { General Directorate of Consular and } \\
\text { Migratory Affairs (Dirección General } \\
\text { de Asuntos Consulares y Migratorios) }\end{array}$ \\
\hline Honduras & $\begin{array}{l}\text { Direcorate of Migration and Alien } \\
\text { Affairs (Dirección de Migración y } \\
\text { Extranjería) }\end{array}$ & \\
\hline Mexico & $\begin{array}{l}\text { National Institute of Migration } \\
\text { (Instituto Nacional de Migración) }\end{array}$ & $\begin{array}{l}\text { Institute for Mexicans Abroad } \\
\text { (Instituto de los Mexicanos en el } \\
\text { Exterior) }\end{array}$ \\
\hline Nicaragua & $\begin{array}{l}\text { General Direcorate of Migration and } \\
\text { Alien Affairs (Dirección General de } \\
\text { Migración y Extranjería) }\end{array}$ & \\
\hline Panama & $\begin{array}{l}\text { National Migration Service (Servicio } \\
\text { Nacional de Migración) }\end{array}$ & \\
\hline Paraguay & $\begin{array}{l}\text { General Direcorate of Migrations } \\
\text { (Dirección General de Migraciones) }\end{array}$ & \\
\hline
\end{tabular}




\begin{tabular}{|l|l|l|} 
Peru & $\begin{array}{l}\text { National Superintendence of } \\
\text { Migrations (Superintendencia } \\
\text { Nacional de Migraciones) }\end{array}$ & $\begin{array}{l}\text { General Directorate of Peruvian } \\
\text { Communities Abroad and Consular } \\
\text { Affairs (Dirección General de } \\
\text { Comunidades Peruanas en el Exterior y } \\
\text { Asuntos Consulares) }\end{array}$ \\
\hline Uruguay & $\begin{array}{l}\text { National Direcorate of Migration } \\
\text { (Dirección Nacional de Migración) }\end{array}$ & $\begin{array}{l}\text { Directorate of Linkages (Dirección de } \\
\text { Vinculación) }\end{array}$ \\
\hline Venezuela & $\begin{array}{l}\text { Direcorate of Migration and Border } \\
\text { Zones (Dirección de Migración y } \\
\text { Zonas Fronterizas) }\end{array}$ & \\
\hline
\end{tabular}

Source: DUS [2014-2015] and website of each institution.

The largest and oldest Diaspora Unit, the Institute of Mexicans Abroad (Instituto de los Mexicanos en el Exterior, IME) was created in 2000, when a landslide victory of the PAN party ousted the long-time ruler PRI party from power. Migrants' right to vote had been an issue for decades and the constitution was changed to provide Mexicans abroad with the right to vote on presidential elections at the consulates in 1997. Diaspora vote was favouring the PAN party, and the president-elect, Vicente Fox made an important gesture towards migrants, naming Juan Hernández, a charismatic diaspora community leader as the first president for the newly-created IME. It became an autonomous institution within the Ministry of Foreign Affairs, coordinating diaspora politics on two levels: the interministerial (macro) and the migrant organization (meso) level. The latter is operationalized in the form of the CCIME (Advisory Council), a periodically meeting assembly of electing 105 representatives through five different procedures: from MexicanAmerican organizations, from the federal government, one from each state government, from the IME and ten special advisors (experts). The objective of the whole structure is to keep the diaspora in regular and institutional contact with the Mexican government. [Escobar Latapí, 2008]

Other Latin American countries also have their diaspora policy framework, although on a more moderate scale. The three Andean countries with developed institutions in this respect (Colombia, Ecuador and Peru) are worth mentioning, while MERCOSUR countries are not placing a real emphasis on the issue. Some of the Central American nations also have diaspora policies in high regard, however, their budget constraints make it very difficult to actively pursue their policy objectives. Focusing on the institutionally more developed cases, I present the three Andean states in detail, followed by one MERCOSUR and one Central American case, respectively. 
Similar to Mexico, Peru also created its first diaspora institution after the electoral victory of a president backed by many migrant voters - Alejandro Toledo. The entity (now called General Directorate of Peruvian Communities Abroad and Consular Affairs) belongs to the Ministry of Foreign Affairs and it administrates several programmes of human rights protection, cultural and educational vinculation and productive vinculation, the latter being explicitly focused on remittances and named after Toledo's aforementioned metaphor as the Quinto Suyo programme. Regarding interministerial coordination, a regular roundtable meeting is held between several ministries on migration management, and the field is planned to be elevated to a vice-ministerial level. [Vega, 2011]

Ecuador created two special units for diaspora affairs within its Ministry of Foreign Affairs in 2000, the Directorate General for Supporting Ecuadorians Abroad, and the Subsecretariat of Migratory Affairs. After the electoral victory of the Bolivarian left and president Rafael Correa in 2007, these were merged in a new institution, the National Secretariat of Migrants (SENAMI). This new institution coordinated the elaboration of the first comprehensive strategy on the issue, the National Plan of Human Development for Migration 2007-2010. [Araujo Eguiguren, 2009] Later, SENAMI and the Ministry of Foreign Affairs fusioned in a ministry called Foreign Affairs and Human Mobility.

Colombia saw several waves of violent civil war and drug mafia activity, thus the governmental activities were focused on protecting the victims of criminal cases. In 1995, an Interministerial Committee for Assistance for Colombians Abroad was created (see below), completed with a working group for preventing human trafficking, especially that of women. In the meantime, forced migration (mostly internal but also limitrophe) became a crucial issue in the conflict-ridden country, and in 1998 a National Plan for Integral Assistance for the Population Displaced by Violence was created, together with a special governmental fund to cover the expenses of the activities. In the early 2000s, the internal armed conflict became manageable, however, in the previous decade a large diaspora was formed abroad from those Colombians who, either voluntarily or by force, had left the country. Because of this, migration and diaspora issues shifted from conflict management and legal protection issues to the diaspora and development area, as also seen in the cases above with Mexico, Peru and Ecuador. In 2003, a National Development Plan 2003- 
2006 was adopted, and the next development plan (2007-2010) continued this approach. [Araujo - Eguiguren, 2009]

Three out of the five MERCOSUR countries (Argentina, Brazil, Uruguay) and Chile also have a specialized body within their Ministry of Foreign Affairs. In Argentina, it is called the Directorate of Argentines Abroad. It focuses on the repatriation of the highly skilled, or those who face economic, social or health difficulties and they apply for this voluntary return with government assistance. Other MERCOSUR countries are also focused on these two issues, and Brazil, Uruguay and Venezuela also have programmes for the highly skilled, and so does Chile, however there is no special focus on the remittance-sending 'average' migrant workers in any of these countries. [Buira, 2006]

Finally, small Central American countries usually do not have the governmental capacities to pursue an active diaspora policy, but in some cases the diaspora organizes itself to that extent that they 'reach out' for their country of origin. It is especially so in cases of natural disasters or other humanitarian actions that overwrite bitter social cleavages and memories or civil wars and other violent clashes, due to which many of the diaspora members actually left the country. This has been the case with El Salvador, which created the Viceministry of Foreign Affairs for Salvadorans Abroad in 2004, when president Elías Antonio Saca came to power. The Salvadoran diaspora was very active when the country's governance shipwrecked as the consequence of the ongoing civil war, and they started to operate many charity and education programmes way before 2004. The creation of a Viceministry and the regular president-diaspora meetings was only the officialization of an existing diaspora activity. [Nosthas, 2006] Other Central American nations also had some minor efforts to reach out for the diaspora but El Salvador is the most developed in this respect.

Table 28 summarizes the main characteristics of Diaspora Units within each Ministry of Foreign Affairs in Latin America. 
Table 28. Main characteristics of specialized institutional bodies responsible for emigration/diaspora issues in each Latin American country

\begin{tabular}{|c|c|c|c|}
\hline Country & Specialized Diaspora Unit & Founded (year) & $\begin{array}{l}\text { Staff } \\
\text { (approx.) }\end{array}$ \\
\hline Argentina & $\begin{array}{l}\text { Directorate of Argentineans Abroad } \\
\text { (Dirección de Argentinos en el } \\
\text { Exterior), within the General Directorate } \\
\text { of Consular Affairs (Dirección General } \\
\text { de Asuntos Consulares) }\end{array}$ & & $7-10$ employees \\
\hline \multicolumn{4}{|l|}{ Bolivia } \\
\hline Brazil & 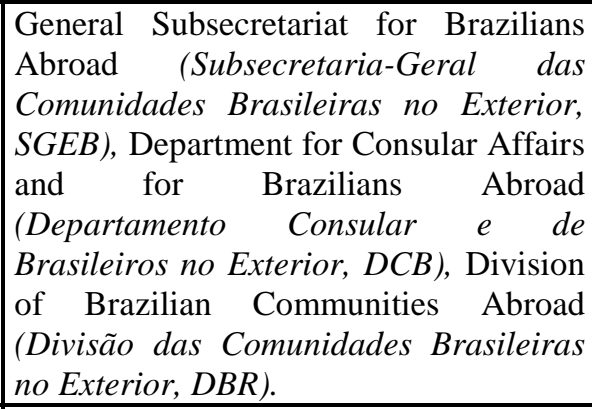 & $\begin{array}{|lr|}\text { The } & \text { General } \\
\text { Subsecretariat } & \text { for } \\
\text { Brazilians } & \text { Abroad } \\
\text { (SGEB) was } & \text { created } \\
\text { in 2007. } & \\
\end{array}$ & $\begin{array}{l}\text { Approx. } \quad 10 \\
\text { employees } \\
\text { (SGEB, DCB and } \\
\text { DBR) }\end{array}$ \\
\hline Chile & $\begin{array}{l}\text { Directorate for the Community of } \\
\text { Chileans Abroad (Dirección para la } \\
\text { Comunidad de Chilenos en el Exterior, } \\
\text { DICOEX), within the General } \\
\text { Directorate of Consular Affairs and } \\
\text { Immigration } \\
\text { (Dirección General de Asuntos } \\
\text { Consulares y de Inmigración, } \\
\text { DIGECONSU) of the Ministry of } \\
\text { Foreign Affairs. The DICOEX is divided } \\
\text { in two Subdirectorates: of Development } \\
\text { (de Desarrollo) and of Operations (de } \\
\text { Operaciones). }\end{array}$ & 2000 & $\begin{array}{l}14 \text { employees: } \\
\text { one director, two } \\
\text { subdirectors, one } \\
\text { secretary, nine } \\
\text { professional } \\
\text { employees and an } \\
\text { auxiliary } \\
\text { employee. }\end{array}$ \\
\hline Colombia & $\begin{array}{l}\text { Directorate of Consular and Migratory } \\
\text { Affairs and Citizen Service (Dirección } \\
\text { de Asuntos Consulares, Migratorios y de } \\
\text { Atención al Ciudadano) }\end{array}$ & $\begin{array}{l}\text { No data on when did } \\
\text { the Directorate adopt } \\
\text { the "Migratory" } \\
\text { element in its name. }\end{array}$ & Variable \\
\hline Costa Rica & $\begin{array}{l}\text { Directorate of External Service } \\
\text { (Dirección de Servicio Exterior) }\end{array}$ & 1962 & 20 employees \\
\hline \multicolumn{4}{|l|}{ Cuba } \\
\hline \multicolumn{4}{|l|}{$\begin{array}{l}\text { Dominican } \\
\text { Republic }\end{array}$} \\
\hline Ecuador & $\begin{array}{l}\text { A whole Viceministry (of Human } \\
\text { Mobility, Viceministerio de Movilidad } \\
\text { Humana) is in charge of the diaspora } \\
\text { affairs. In the other half of the Ministry } \\
\text { of Foreign Affairs (the Cancillería), } \\
\text { there are also related units, such as the } \\
\text { Directorate of Travel Documents } \\
\text { (Dirección de Documentos de Viaje), the } \\
\text { Subsecretariat of the Ecuadorian } \\
\text { Migrant Community (Subsecretaria de } \\
\text { la Comunidad Ecuatoriana Migrante), } \\
\text { the Directorate of Consular Affairs }\end{array}$ & $\begin{array}{l}\text { The } \\
\text { Secretariat of the } \\
\text { Migrant (Secretaría } \\
\text { Nacional } \\
\text { Migrante, SENAMI) } \\
\text { was merged into the } \\
\text { Ministry of Foreign } \\
\text { Affairs in } 2013 \text { and } \\
\text { now it is called the } \\
\text { Viceministry } \\
\text { Human Mobility. of }\end{array}$ & Variable \\
\hline
\end{tabular}




\begin{tabular}{|c|c|c|c|}
\hline & (Dirección de Asuntos Consulares), etc. & & \\
\hline \multicolumn{4}{|l|}{ El Salvador } \\
\hline Guatemala & $\begin{array}{l}\text { General Directorate of Consular and } \\
\text { Migratory Affairs (Dirección General } \\
\text { de Asuntos Consulares y Migratorios) }\end{array}$ & $\begin{array}{l}2003, \text { by enhancing } \\
\text { the scope of action of } \\
\text { the Directorate of } \\
\text { Consular Affairs }\end{array}$ & $\begin{array}{l}37 \text { employees } \\
\text { (for the whole } \\
\text { Directorate, not } \\
\text { only for the } \\
\text { diaspora issue) } \\
\end{array}$ \\
\hline \multicolumn{4}{|l|}{ Honduras } \\
\hline Mexico & $\begin{array}{l}\text { Institute of Mexicans Abroad (Instituto } \\
\text { de los Mexicanos en el Exterior, IME) }\end{array}$ & 2000 & $\begin{array}{l}46 \text { employees plus } \\
\text { one special } \\
\text { consular } \\
\text { employee at every } \\
\text { consulate } \\
\end{array}$ \\
\hline \multicolumn{4}{|l|}{ Nicaragua } \\
\hline \multicolumn{4}{|l|}{ Panama } \\
\hline \multicolumn{4}{|l|}{ Paraguay } \\
\hline Peru & 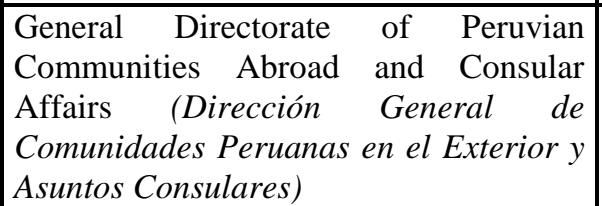 & & \\
\hline Uruguay & $\begin{array}{l}\text { Directorate of Linkages (Dirección de } \\
\text { Vinculación), but other units are also } \\
\text { involved, such as the Office of Return } \\
\text { and Welcome (Oficina de Retorno y } \\
\text { Bienvenida), the Office of Assistance to } \\
\text { the Compatriot (Oficina de Asistencia al } \\
\text { Compatriota) or the Centre of Citizen } \\
\text { Service, all of which are in a daily } \\
\text { contact with the Directorate of Linkages. }\end{array}$ & $\begin{array}{l}\text { The Directorate of } \\
\text { Linkages was created } \\
\text { in } 2005 \text {, before which } \\
\text { it was the Directorate } \\
\text { of Consular Affairs } \\
\text { that had been in } \\
\text { charge of the issue. }\end{array}$ & $\begin{array}{l}\text { There are } 3 \\
\text { employees at the } \\
\text { Directorate of } \\
\text { Linkages. }\end{array}$ \\
\hline Venezuela & & & \\
\hline
\end{tabular}

Source: DUS [2014-2015], marked with bold, and website of each institution.

Regarding the institutional autonomy of the Diaspora Units, there is a wide range from a Viceministry (Ecuador) or a separate Institute (Mexico) through a separate directorate (Argentina, Chile, Peru, Uruguay) or a directorate with diaspora affairs included in its name (Colombia, Guatemala) to countries where there is no separate unit but a general directorate of consular affairs (Costa Rica and others). Obviously, this affects the capabilities of each Diaspora Unit.

Regarding their size, the numbers of employees should be interpreted in function of the size of the country and of the diaspora, on one hand, and the institutional autonomy of the Diaspora Unit, on the other. Autonomous Diaspora Units range from a staff of 46 in the case of Mexico, through mid-range units as 14 in the Chilean or 10 in the Brazilian case, to small units such as the 3 employees of 
the Diaspora Unit in Uruguay. On the other hand, institutional design makes it difficult to tell how many employees actually work on the issue if the unit is not sufficiently delimitated, as in the case of Colombia or Guatemala. No answer was received from Ecuador and Peru in this respect, although it might have been a larger number as well.

While autonomy and size of Diaspora Units are important features, it is also crucial to analyze how these are embedded in the internal structure of the state bureaucracy. Therefore, in the following, an overview of the interinstitutional contacts of the Diaspora Units within the government is presented.

\subsubsection{Other governmental units involved in diaspora policymaking in Latin America}

Diaspora Units are the central elements in giving shape to the political and social ambitions towards an active governmental approach to the affairs of the diaspora, nonetheless, it is clear that their staff size and their organizational role does not enable them to deal with every issue related to the diaspora. Or, better said, they can deal with every issue, but they cannot resolve every problem on their own. Hence, there is a necessity to work together with other governmental units that might have a different profile and focus, but which are also involved in the broader topic of migration.

The standard governmental solution for coping with an overarching problem is to create a mechanism of regular meetings between the representatives of every ministry and specialized government unit which might be concerned. This can be institutionalized in the form of a 'commission', 'committee' or 'council' which has a permanent secretariat (normally within the institutional unit which is most related to the topic) and it can be given formal or informal power over decisions in the topic. Obviously, as it is an intra-governmental body, no significant debates will take within this committee over principles or (represented) interest of voters. Rather, it will focus on pragmatic solutions for problems that are already on the agenda. [Gamlen, 2006, 2014]

Many Latin American countries have had committees or councils on migration issues. Nonetheless, as already have been mentioned several times, 'migration' stood for 'immigration' or even 'settlement' for decades, if not centuries, 
thus in the case of those institutional units which have already existed before the massification of the emigration in the 1990s, the focus of their activities have gradually shifted from immigration to emigration. Whether it meant the founding of a new institutional body, or only the scope and constitution of the traditional 'Migration Council' changed, depends on the historical context of each country.

Currently existing, migration- and diaspora-related interministerial commissions, committees or councils in Latin America are summarized in Table 29.

Table 29. Migration- and diaspora-related interministerial consultative units in

\section{Latin America}

\begin{tabular}{|c|c|c|}
\hline Country & $\begin{array}{l}\text { Commission, } \\
\text { Committee or } \\
\text { Council }\end{array}$ & Background and members \\
\hline \multicolumn{3}{|l|}{ Argentina } \\
\hline \begin{tabular}{|l|} 
Bolivia \\
\end{tabular} & $\begin{array}{l}\text { National Council for } \\
\text { Migrations (Consejo } \\
\text { Nacional de } \\
\text { Migraciones) }\end{array}$ & $\begin{array}{l}\text { Created in } 2013 \text { by the Law No. } 370 \text { on Migration, it is } \\
\text { presided by the Minister of Foreign Affairs and its } \\
\text { members are the (representatives of ) Ministers of } \\
\text { Governance; Labour, Employment and Social Welfare. Its } \\
\text { secretariat is the National Directorate of Migration. }\end{array}$ \\
\hline Brazil & $\begin{array}{l}\text { National Council for } \\
\text { Immigration } \\
\text { (Conselho Nacional } \\
\text { de Imigração) }\end{array}$ & $\begin{array}{l}\text { Created in } 1993 \text { by the Decree No. 840, it is presided by } \\
\text { the Minister of Labour and Employment and its members } \\
\text { are the (representatives of) Ministers of Justice; Foreign } \\
\text { Affairs; Agriculture; Science and Technology; } \\
\text { Development, Industry and Foreign Trade; Health; } \\
\text { Education; five representatives of Labour Unions, five } \\
\text { representatives of Employers and one representative of the } \\
\text { scientific community. }\end{array}$ \\
\hline Chile & \begin{tabular}{|l|} 
Interministerial \\
Committee for the \\
Chilean Community \\
Abroad $\quad$ (Comité \\
Interministerial para \\
la Comunidad Chilena \\
en el Exterior)
\end{tabular} & $\begin{array}{l}\text { Created in } 2009 \text { by the MFA Decree No. 139, it is } \\
\text { presided by the Subsecretary of Foreign Affairs, and its } \\
\text { members are the representatives of the Ministries of } \\
\text { Foreign Affairs; Interior; Finance; Economy; } \\
\text { Development and Reconstruction; Social Development; } \\
\text { Education; Justice; Labour and Social Welfare; Health; } \\
\text { Housing and Urbanism; the General Secretariat of the } \\
\text { Presidency; and the General Secretariat of the } \\
\text { Government. }\end{array}$ \\
\hline Colombia & \begin{tabular}{|l|} 
Intersectorial National \\
Commission of \\
Migration (Comisión \\
Nacional \\
Intersectorial de \\
Migración)
\end{tabular} & $\begin{array}{l}\text { Created in } 2003 \text { and reformulated in } 2009 \text { within the } \\
\text { framework of the Integral Policy for Migration (Política } \\
\text { Integral Migratoria-PIM), it is presided by the Minister of } \\
\text { Foreign Affairs and its members are the Ministers (or their } \\
\text { representatives) of Interior and Justice; National Defense; } \\
\text { Social Protection; Commerce, Industry and Tourism; the } \\
\text { directors (or their representatives) of the Administrative } \\
\text { Department of Security; the National Department of } \\
\text { Planning; the Colombian Institute for the Development of } \\
\text { Higher Education; the Colombian Institute of Educational } \\
\text { Credits and Technical Studies Abroad; and the director of } \\
\text { Consular Affairs ad Colombian Communities Abroad in } \\
\text { the Ministry of Foreign Affairs. }\end{array}$ \\
\hline
\end{tabular}




\begin{tabular}{|c|c|c|}
\hline Costa Rica & $\begin{array}{l}\text { National Council of } \\
\text { Migration (Consejo } \\
\text { Nacional de } \\
\text { Migración) }\end{array}$ & $\begin{array}{l}\text { Created in 1952, it is presided by the Minister of } \\
\text { Governance and Police, and its members are the Ministers } \\
\text { of Foreign Affairs and Cult; Labour and Social Security; } \\
\text { National Planning and Economic Policy; Health; } \\
\text { Education; the Director of Migration and Alien Affairs; } \\
\text { the Executive Presidents of the Costa Rican Institute of } \\
\text { Tourism; and the Costa Rican Social Insurance Fund; and } \\
\text { two representatives of civil society organizations related to } \\
\text { the topic of migration, assigned by the Ombudsman of } \\
\text { Citizens' Rights. }\end{array}$ \\
\hline \multicolumn{3}{|r|}{ ( } \\
\hline $\begin{array}{l}\text { Dominican } \\
\text { Republic }\end{array}$ & $\begin{array}{l}\text { National Council for } \\
\text { Dominican } \\
\text { Communities Abroad } \\
\text { (Consejo Nacional } \\
\text { para las Comunidades } \\
\text { Dominicanas en el } \\
\text { Exterior) }\end{array}$ & $\begin{array}{l}\text { Created in } 2006 \text { by the Decree No. 618-06, it is presided } \\
\text { by the Minister of Foreign Affairs and its members are the } \\
\text { (representative of) the Ministers of Economy, Planning } \\
\text { and Development; Culture; Education; Higher Education, } \\
\text { Science and Technology; Industry and Trade; Public } \\
\text { Health and Social Assistance; Labour; Tourism; and the } \\
\text { Director of the General Directorate of Migration. }\end{array}$ \\
\hline Ecuador & \begin{tabular}{|l} 
Consultative Council \\
of the Migration \\
Policy (Consejo \\
Consultivo de Política \\
Migratoria)
\end{tabular} & $\begin{array}{l}\text { Created in } 2004 \text { by the Codification } 23-454 \text { of the Law of } \\
\text { Alien Affairs, it is presided by the General Director of } \\
\text { Alien Affairs and its members are the (representative of) } \\
\text { the National Director of Migration Affairs; the Director of } \\
\text { Migration Affairs of the Ministry of Foreign Affairs and } \\
\text { the Judiciary Consultant of the National Directorate of } \\
\text { Alien Affairs (as of 2004). }\end{array}$ \\
\hline \multicolumn{3}{|l|}{ El Salvador } \\
\hline \begin{tabular}{|c|} 
Guatemala \\
\end{tabular} & $\begin{array}{l}\text { National Council of } \\
\text { Migration (Consejo } \\
\text { Nacional de } \\
\text { Migración) }\end{array}$ & $\begin{array}{l}\text { The Article } 9 \text { of the Migration Law (1999) created the } \\
\text { National Council of Migration, presided by the Minister of } \\
\text { Governance and its members are the Minister of Foreign } \\
\text { Affairs; the General Director of Migration; the General } \\
\text { Director of the Guatemalan Institute of Tourism; and the } \\
\text { Attorney General of the Nation. }\end{array}$ \\
\hline \multicolumn{3}{|l|}{ Honduras } \\
\hline Mexico & $\begin{array}{l}\text { National Council for } \\
\text { the Mexican } \\
\text { Communities Abroad } \\
\text { (Consejo Nacional } \\
\text { para las Comunidades } \\
\text { Mexicanas en el } \\
\text { Exterior) } \\
\end{array}$ & $\begin{array}{l}\text { Created in } 2003 \text { as a consultative body but never had a } \\
\text { meeting. }\end{array}$ \\
\hline \multicolumn{3}{|l|}{ Nicaragua } \\
\hline \multicolumn{3}{|l|}{ Panama } \\
\hline \multicolumn{3}{|l|}{ Paraguay } \\
\hline \begin{tabular}{|l|} 
Peru \\
\end{tabular} & $\begin{array}{l}\text { Permanent } \\
\text { Multisectorial } \\
\text { Commission } \\
\text { "Intersectorial } \\
\text { Working Group for } \\
\text { Migration } \\
\text { Management" } \\
\text { (Comisión } \\
\text { Multisectorial } \\
\text { Permanente "Mesa de } \\
\text { Trabajo Intersectorial } \\
\text { para la Gestión } \\
\text { Migratoria") }\end{array}$ & $\begin{array}{l}\text { Created in 2011, it is presided by the Minister of Foreign } \\
\text { Affairs and its members are the representatives of the } \\
\text { Presidency of the Council of Ministers; the Ministries of } \\
\text { Labour and Promotion of Employment; Interior; } \\
\text { Education; the Woman and of Social Development; } \\
\text { Production; Justice; the Public; Health; the Supervision } \\
\text { Authorities (superintendencia) of Migrations; Tax } \\
\text { Administration; Banking and Assurance Companies; the } \\
\text { Office of Normalization of Previsions; the National } \\
\text { Penitentiary Institute; the Social Security of Health; the } \\
\text { Integral Security of Health; the MIVIVIENDA Fund [of } \\
\text { housing]; and the National Institute of Statistics and } \\
\text { Informatics. }\end{array}$ \\
\hline
\end{tabular}




\begin{tabular}{|l|l|l|} 
Uruguay & $\begin{array}{l}\text { National Board of } \\
\text { Migrations (Junta } \\
\text { Nacional de } \\
\text { Migraciones) }\end{array}$ & $\begin{array}{l}\text { Created in } 2008 \text { by the Law } \mathrm{N}^{\circ} 18.250 \text { (which actualized a } \\
\text { previous law dating from 1930), it is presided by the } \\
\text { Minister of Foreign Affairs and its members are the } \\
\text { Ministers of Interior; Labour and Social Security; Social } \\
\text { Development and a representative of the Population } \\
\text { Department of the Presidency of the Republic. Its work is } \\
\text { assessed by the Consultative and Advisory Council on } \\
\text { Migration Affairs (Consejo Consultivo Asesor en } \\
\text { Migraciones, CCAM), whose members represent the civil } \\
\text { society and the various groups of immigrants. }\end{array}$ \\
\hline Venezuela & & \\
\hline
\end{tabular}

Source: DUS [2014-2015] and institutional websites.

As it can be seen from Table 29, there are Councils with a large history, such as the Costa Rican one, which was founded in 1952. It is also remarkable because it integrates the representatives of the civil society among its members (a feature which can be seen in the case of only one more Latin American country - Uruguay). The rest of the countries have only governmental units in their migration-related councils or committees. The Ministries of Foreign Affairs; Interior; and the representative of the President / Head of Government are always present in such an institution. The first is presiding over emigration-related consultative bodies, while the second or third is in charge of leading the immigration-related committees or councils. Other possible members range from Ministries of Labour, Education, Economy and Health as almost compulsory invitees, while there are more unusual members in some cases, such as the Institute of Tourism (Costa Rica, Guatemala), the National Penitentiary Institute (Peru) or the Ministry of National Defense (Colombia). Nonetheless, the setting of the membership of a migratory council or committee is within the sovereignty of every government, and no general rules exist on it. Historical reasons (including the history of the institutions involved) might account for the size and constitution of these consultative units.

In conclusion, there is a more or less general institutional framework for diaspora policies which include a specialized Diaspora Unit (within the consular department of the Ministry of Foreign Affairs, and which might grow and gain institutional autonomy in function of the size and importance of the diaspora), a network of the consulates abroad (working together with the central unit in migration-related issues) and an interministerial committee which involves all the governmental bodies that are considered relevant, and which is presided by the minister who is in charge for 'migration' affairs in general. However, the 
institutional framework of diaspora policies is larger than the government realm: it has to involve its subjects - i.e. the diaspora. In the following, therefore, the outreach and the concrete activities of the diaspora policies are presented.

\subsubsection{Outreach and activities of diaspora institutions in Latin America}

\subsubsection{Consultation mechanisms between Latin American governments and the diaspora}

To stay in line with Peru's new government approach to the diaspora cited in Chapter 2.2.1.2, Peruvian diplomats often had more difficulties in making themselves understood with poor and indigenous Peruvian migrants than with fellow diplomats from other countries. Their case highlights not only the obstacles that diaspora policymakers should be aware of in a country of postcolonial and highly unequal society, but also the importance of regular meetings between the consular and diplomatic corps, on one side, and the representatives of the diaspora, on the other.

However, this is not an easy task, and not only because of the cultural and status differences between diplomats and migrants. There are obvious obstacles caused by geography, i.e. the simple fact that embassies or consulates might be at a significant distance from migration hubs, and migrants cannot regularly attend to meetings with the diplomats. Also, politics might come into the picture: if there are sharp contrasts between the 'ruling' party of a country and the majority of the diaspora (which is very likely, given that political motivations could have taken part, even if indirectly, in sending the migrants off from the country). Furthermore, the 'diaspora' itself can be divided along ethnic, economic, religious or other fault lines. Chapter 3.4.1 deals with the question of the "plurifragmentation" of the diaspora in details. [Guarnizo, 2006]

Therefore, the good relationship of the consular and diplomatic staff with the leaders of the (several, and sometimes antagonistic) groups of migrants is crucial in preparing the ground for successful policymaking. Building mutual understanding and trust is a 'soft' element in the process, but its importance is beyond discussion. Top-down approach has to be avoided, while a cautious listening to existing problems can help things moving forward: hence the reason of bringing together a 
'council' in which supposedly every interested person or group can have its say. In the past years, consultative councils have been set up in the consulates and embassies of several Latin American countries. Some of them (such as Colombia, Guatemala, Mexico, Peru or Uruguay) even have a legal document (law or ministerial decree) circumscribing the scope of activities of these councils (see Table 30).

In the DUS, the Peruvian respondent defined the objectives of the Consultative Councils as "creating a space for dialogue and cooperation with the consular office, through identifying and resolving the problems which affect directly the Peruvian community [abroad], such as: tasks of protection and assistance to our citizens abroad, development of linkages to the nation, promotion of the culture, insertion to the society of the country of origin and participation in the activities that the Consular Office would realize in order to benefit the Peruvian community [abroad] or to foster humanitarian involvement in Peru." [DUS Peru, 2014]

As it can be seen from this quote, dialogue, protection and humanitarian involvement can all fit in the scope of activities of the Consultative Councils, showing that on one side, migrants can hope to have their legal and administrative problems solved by participating in the work of the councils - while on the other side, the government can expect to have, sooner or later, financial transfers coming from the diaspora towards one or more developmentally important areas of intervention.

Table 30 summarizes the existing consultation mechanisms (councils, working groups etc.) based on the Diaspora Unit Survey.

Table 30. Consultation mechanisms between Latin American consulates abroad and members of the diaspora.

\begin{tabular}{|c|c|c|}
\hline Country & $\begin{array}{l}\text { Council or } \\
\text { Working Group }\end{array}$ & Background and members \\
\hline \multicolumn{3}{|l|}{ Argentina } \\
\hline \multicolumn{3}{|l|}{ Bolivia } \\
\hline Brazil & \begin{tabular}{|l|} 
Council of \\
Representatives of \\
Brazilians Abroad \\
(Conselho de \\
Representantes de \\
Brasileiros no \\
Exterior, CRBE) \\
\end{tabular} & $\begin{array}{l}\text { It is a meeting of the representatives of Brazilian } \\
\text { communities living in different parts of the world. It exists } \\
\text { since } 2010 \text { and as of } 2014 \text {, it contained } 49 \text { local councils. }\end{array}$ \\
\hline
\end{tabular}




\begin{tabular}{|c|c|c|}
\hline \multicolumn{3}{|l|}{ Chile } \\
\hline Colombia & & $\begin{array}{l}\text { The Integral Migration Policy has been adopted based on a } \\
\text { consultation process with communities of Colombians } \\
\text { abroad. It is not known whether the consulting mechanism } \\
\text { with these communities has been formalized since then. }\end{array}$ \\
\hline \begin{tabular}{|c|} 
Costa Rica \\
\end{tabular} & & No such mechanisms. \\
\hline \multicolumn{3}{|l|}{ Cuba } \\
\hline $\begin{array}{l}\text { Dominican } \\
\text { Republic }\end{array}$ & $\begin{array}{l}\text { Consultative Councils } \\
\text { of the Presidency of } \\
\text { the Dominicans } \\
\text { Abroad (Consejos } \\
\text { Consultivos de la } \\
\text { Presidencia de los } \\
\text { Dominicanos en el } \\
\text { Exterior, CCPDE) }\end{array}$ & $\begin{array}{l}\text { Actually there are } 21 \text { of them, in all of the important } \\
\text { centres of the Dominican diaspora. }\end{array}$ \\
\hline Ecuador & & $\begin{array}{l}\text { The Ecuadorians living abroad can form organizations and } \\
\text { councils and they contact the Ecuadorian consulates, but } \\
\text { no formal mechanism exists. }\end{array}$ \\
\hline \multicolumn{3}{|l|}{ El Salvador } \\
\hline \begin{tabular}{|l|} 
Guatemala \\
\end{tabular} & \begin{tabular}{|l} 
"Consular Tables" \\
(Mesas Consulares)
\end{tabular} & $\begin{array}{l}\text { Regular meetings called "Consular Tables" are being held } \\
\text { at the Guatemalan consulates in the United States. }\end{array}$ \\
\hline \multicolumn{3}{|l|}{ Honduras } \\
\hline Mexico & $\begin{array}{l}\text { Consultative Council } \\
\text { of the Institute of } \\
\text { Mexicans Abroad } \\
\text { (Consejo Consultivo } \\
\text { del Instituto de los } \\
\text { Mexicanos en el } \\
\text { Exterior) } \\
\end{array}$ & $\begin{array}{l}\text { In all the } 56 \text { consular districts of Mexico in the United } \\
\text { States and Canada, diaspora members can apply for } \\
\text { Council Membership for } 2 \text { years. Up to } 7 \text { members in each } \\
\text { consular district can receive the help of the consulates for } \\
\text { realizing a project. } \\
\text { As of October 2015, } 167 \text { projects are running in } 40 \\
\text { consular districts. }\end{array}$ \\
\hline \multicolumn{3}{|l|}{ Nicaragua } \\
\hline \multicolumn{3}{|l|}{ Panama } \\
\hline \multicolumn{3}{|l|}{ Paraguay } \\
\hline Peru & $\begin{array}{l}\text { Consultative Councils } \\
\text { (Consejo de Consulta) }\end{array}$ & $\begin{array}{l}\text { Consultative Councils can be set up at the seat of a } \\
\text { consular district by migrants residing in the consular } \\
\text { district, independently of their legal status. Functioning of } \\
\text { these Councils is regulated by the Resolutions of the } \\
\text { Minister of Foreign Affairs No. } 1197 \text { of } 2002 \text { and No. } \\
0687 \text { of } 2004 \text {, and the Law } \mathrm{N}^{\circ} 29495 \text { of } 2012 \text { on the } \\
\text { Consultative Councils of the Peruvian Communities } \\
\text { Abroad (Ley de los Consejos de Consulta de las } \\
\text { Comunidades Peruanas en el Exterior). }\end{array}$ \\
\hline Uruguay & $\begin{array}{l}\text { Consultative Councils } \\
\text { (Consejos } \\
\text { Consultivos) }\end{array}$ & $\begin{array}{l}\text { Consultative Councils can be set up and work with the } \\
\text { consulates of Uruguay according to Law } \mathrm{N}^{\circ} 18.250 \text {, } \\
\text { however, they are autonomous and not regulated by the } \\
\text { Government of Uruguay. }\end{array}$ \\
\hline Venezuela & & \\
\hline
\end{tabular}

Source: DUS [2014-2015] and the website of the Dominican CCPDE.

Regular meetings are important for setting the stage to further cooperation.

As the Colombian respondent put it, the country's Integral Migration Policy had been 
adopted based on a consultation process with communities of Colombians abroad. However, it is not known whether the consulting mechanism with these communities has been formalized since then.

In the following, an overview is presented on the activities undertaken and/or coordinated by the Diaspora Unit of each Latin American country.

\subsubsection{Activity areas of Latin American Diaspora Units}

Based on the laws and strategic documents summarized in Table 26, Diaspora Units are 1) pursuing their own activities as specialized units within the respective Ministry of Foreign Affairs, contributing to the successful operation of the foreign service towards the diaspora (through the central office and through the consulates), and 2) coordinating the diaspora-related work of other governmental bodies (ministries, specialized institutions etc).

In this chapter both activity areas are presented, starting with the first, i.e. the own activities of the Diaspora Units. These are summarized in the following table, and remarks of the respondents of the DUS regarding these activities are cited below.

Table 31. Main activity fields of the Diaspora Units

\begin{tabular}{|l|l|}
\hline Activity & $\begin{array}{l}\text { Diaspora Units that undertake } \\
\text { this activity }\end{array}$ \\
\hline Organizing events and cultural activities for citizens abroad & $\begin{array}{l}\text { Colombia, Costa Rica, Ecuador, } \\
\text { Uruguay }\end{array}$ \\
\hline $\begin{array}{l}\text { Organizing events and social activities for helping citizens } \\
\text { abroad }\end{array}$ & $\begin{array}{l}\text { Brazil, Colombia, Ecuador, Peru, } \\
\text { Uruguay }\end{array}$ \\
\hline $\begin{array}{l}\text { Organizing events and social activities for helping citizens } \\
\text { in the country of origin, with the participation of the } \\
\text { diaspora }\end{array}$ & Ecuador, Uruguay \\
\hline $\begin{array}{l}\text { Promoting that diaspora members invest in the country of } \\
\text { origin }\end{array}$ & $\begin{array}{l}\text { Colombia, Ecuador } \\
\text { Other activities (see below) }\end{array}$ \\
\hline
\end{tabular}

Source: DUS [2014-2015]

As remarks to the question on their activities, Diaspora Units mentioned a wide range of activities. However, given the fact that many times their activities are embedded in the work of the Department of Consular Affairs, within which they operate, a significant share of their activities are the same as any consular department would undertake: assisting citizens who got in trouble abroad, identity document 
procedures, visa procedures, public notary procedures, legal help, etc. There is a focus on vulnerable groups, victims of aggression or subjects to deportation in the case of some Diaspora Units, for example the Ecuadorian one. [DUS Ecuador, 2014]

In other occasions, Diaspora Units provide specific help for the consulates in providing them common material and know-how on how to negotiate with the country of destination in specific issues, many of which have a clear relevance for development. The Division of Brazilian Communities Abroad, for example, provides Brazilian consulates with assessment in the following issues:

- Procedures regarding the Unemployment Guarantee Investment Fund (FGTS), a fund available for Brazilians who recently became unemployed (either in Brazil or abroad);

- Negotiations with the country of destination for bilateral agreements on social security and mutual recognition of titles and professional habilitation documents;

- Preparation and realization of the National Exam for Certificating Competences of Youth and Adults Abroad (Exame Nacional para Certificação de Competências de Jovens e Adultos no exterior) which allows that migrants who did not finish school in Brazil could get a title based on an equivalency examination. [DUS Brazil, 2014]

Many times, Diaspora Units also assist in the building of communities within the diaspora, on one hand, and the establishment of linkages between these communities and the consulates, on the other. This has been mentioned by respondents from Chile, Guatemala, Uruguay and Peru, the latter which also made a reference to the economic dimension of these activities, stating that their objective is to "promote the linkage of Peruvians [abroad] to Peru from a productive perspective, at the same time fostering the beneficial insertion of our communities into the societies of destination”. [DUS Peru, 2014]

Besides their own activities, however, Diaspora Units also act as the coordinators of many other programmes or policies. This is stressed with the fact that many of these Diaspora Units also operate as the permanent background institution for the regular coordination mechanisms (commissions or committees, see 2.2.2.2) between the respective Ministry of Foreign Affairs and the other relevant institutional actors. For example, this is the case of Chile's Directorate for the 
Communities of Chileans Abroad (DICOEX), which has the function of the Technical Secretariat of the Interministerial Committee for the Chilean Community Abroad. [DUS Chile, 2014]

Of all Latin American countries, Mexico has by far the largest number of institutionalized programmes for diaspora affairs. As it can be seen from Table 32, a wide range of programmes exists, and all of them belong to the specific ministry (called secretaría in Mexican Spanish). Coordination of these different programmes is made by the Institute for Mexicans Abroad (Instituto de los Mexicanos en el Extranjero, IME). Main programmes are summarized in Table 32, the IME's own programmes are written in bold.

Table 32. Mexico's main federal government programmes aiming the diaspora

\begin{tabular}{|c|c|c|c|c|}
\hline & Category & Objective & Programmes & $\begin{array}{l}\text { Host } \\
\text { Institution }\end{array}$ \\
\hline 1. & $\begin{array}{l}\text { Protection } \\
\text { and } \\
\text { informatio } \\
n\end{array}$ & $\begin{array}{l}\text { Maintaining the } \\
\text { physical and } \\
\text { heritage integrity } \\
\text { of migrants, } \\
\text { providing } \\
\text { information about } \\
\text { their rights and } \\
\text { obligations. }\end{array}$ & $\begin{array}{l}\text { - Information days (Jornadas } \\
\text { Informativas) } \\
\text { "Paisano" Programme for } \\
\text { protecting migrants on a visit to } \\
\text { Mexico } \\
\text { "Beta Groups" for protecting } \\
\text { migrants (Grupos Beta de } \\
\text { Protección a Migrantes) } \\
\text { Repatriation of Minors (Menores } \\
\text { Repatriados) }\end{array}$ & $\begin{array}{l}\text { SRE/IME } \\
\text { SEGOB/INM } \\
\text { SEGOB/INM } \\
\text { SEGOB/INM }\end{array}$ \\
\hline 2. & Education & $\begin{array}{l}\text { Promoting and } \\
\text { assuring the } \\
\text { educational } \\
\text { attention for } \\
\text { migrant children } \\
\text { and youth who } \\
\text { have had education } \\
\text { both in Mexico and } \\
\text { the United States, } \\
\text { aiming a high } \\
\text { quality, equitative } \\
\text { and inclusive } \\
\text { education. }\end{array}$ & $\begin{array}{l}\text { Financial Education Programme } \\
\text { for Mexican Migrants (Programa } \\
\text { de Educación Financiera para } \\
\text { Migrantes Mexicanos) } \\
\text { Network of Mexican Talents } \\
\text { (Red de Talentos Mexicanos) } \\
\text { Binational Migrant Education } \\
\text { Programme (Programa Binacional } \\
\text { de Educación Migrante México- } \\
\text { Estados Unidos, under various } \\
\text { denominations) }\end{array}$ & $\begin{array}{l}\text { SRE/IME } \\
\text { SEP }\end{array}$ \\
\hline 3. & Health & $\begin{array}{l}\text { Offering healthcare } \\
\text { for migrant } \\
\text { families, providing } \\
\text { preventive } \\
\text { information, } \\
\text { offering access to } \\
\text { healthcare at the } \\
\text { place of origin, } \\
\text { during the } \\
\text { migratory process } \\
\text { and at the place of } \\
\text { destination. }\end{array}$ & $\begin{array}{l}\text { - "Windows of Health" } \\
\text { (Ventanillas de Salud) } \\
\text { "Go Healthy, Come Back Healthy" } \\
\text { (Vete Sano Regresa Sano) } \\
\text { Popular Health Insurance for } \\
\text { Migrant Families (Seguro Popular } \\
\text { de Salud para Familias Migrantes) } \\
\text { Repatriation of Sick Citizens } \\
\text { (Repatriación de Connacionales } \\
\text { Enfermos) }\end{array}$ & $\begin{array}{l}\text { SRE/IME } \\
\text { SS } \\
\text { SS } \\
\text { SS }\end{array}$ \\
\hline
\end{tabular}




\begin{tabular}{|c|c|c|c|c|}
\hline 4. & $\begin{array}{l}\text { Promotion } \\
\text { and } \\
\text { diffusion }\end{array}$ & $\begin{array}{l}\text { Promoting } \\
\text { Mexican } \\
\text { entrepreneurial } \\
\text { organizations and } \\
\text { Mexican } \\
\text { jobseekers in other } \\
\text { countries. }\end{array}$ & $\begin{array}{l}\text { Council for Business Promotion } \\
\text { with Mexican and Hispanic } \\
\text { Communities [in the U.S.] } \\
\text { (Consejo para la Promoción de } \\
\text { Negocios con las Comunidades } \\
\text { Mexicanas e Hispanas) } \\
\text { Agreement on cooperation in } \\
\text { labour affairs in North America } \\
\text { (Acuerdo de cooperación laboral } \\
\text { de América del Norte, ACLAN) } \\
\text { Programme for Temporary } \\
\text { Migrant Workers (Programa de } \\
\text { Trabajadores Migratorios } \\
\text { Temporales) }\end{array}$ & $\begin{array}{l}\text { STPS } \\
\text { STPS }\end{array}$ \\
\hline 5. & Retention & $\begin{array}{l}\text { Implementing } \\
\text { projects that } \\
\text { improve social } \\
\text { conditions at the } \\
\text { place of origin, } \\
\text { promoting better } \\
\text { life conditions both } \\
\text { in an individual } \\
\text { and in a collective } \\
\text { approach. }\end{array}$ & $\begin{array}{l}\text { 3x1 Programme for Migrants } \\
\text { (Programa } 3 \times 1 \text { para Migrantes) } \\
\text { Productive Options Programme } \\
\text { (Programa Opciones Productivas) }\end{array}$ & $\begin{array}{l}\text { SEDESOL } \\
\text { SEDESOL }\end{array}$ \\
\hline
\end{tabular}

Source: Own compilation based on Palma Martínez and Ángeles Jiménez [2009] and DUS Mexico [2015]. Abbreviations: IME: Institute of Mexicans Abroad (within SRE, the Ministry of Foreign Affairs), INM: National Institute of Migration (within SEGOB, the Ministry of Governance), SEP: Ministry of Education, SS: Ministry of Health, SRE: Ministry of Foreign Affairs, STPS: Ministry of Labour, SEDESOL: Ministry of Social Development.

In other countries, main fields of activities might be similar (for a conceptual overview, Table 15 in 1.3.3. is the point of reference), although not as developed as in the case of Mexico. Ecuador, for example, has many programmes focusing on communication and return migration, most of which will be presented in Chapters 3.2 and 3.3, respectively. The latter include programmes of education at distance (with the Ministry of Education), repatriation of sick migrants (Programa Voy por $T i$, with the Ministry of Health), real estate bonds (Bono de la vivienda, with the Ministry of Urban Development and Housing) etc.

Others, such as Uruguay focus on the highly qualified migrants, having programmes such as the "I am Uruguay" (Soy Uruguay) programme for knowledge networks in the diaspora, and the Circulation Programme for Highly Qualified Uruguayans (Programa de Circulación de Uruguayos Altamente Capacitados, CUAC). These will be presented in details in Chapter 3.5.

To sum up, Diaspora Units operate and coordinate a wide range of development-related activities which have already had a significant institutional and 
project-level history. The most relevant examples will be presented and analyzed in details in the following chapter.

\subsubsection{Evaluating the hypotheses, part 2: The institutional level}

In Chapter 2, the main line of thought has been the evaluation of the background for policymaking in diaspora affairs (2.1.) and the actual achievements in legal and institutional terms (2.2.). Hence, at the end of this overview a short balance can be drawn on whether hypotheses have been correct and applicable on the institutional level.

Main findings on the importance of the diaspora and the overall development level (as correlating variables) and effectiveness of governance (as an inversely correlating variable) are shown on the left side of Table 33. These follow the categorizations of Tables 21, 22 and 23, respectively. For every category shown in the mentioned table, a number is assigned, in line with the previous logical assessment of the potential effects of belonging to a given category on the conditions and capabilities for creating effective diaspora policies. In other words, 0 is assigned for the options which promise low level of diaspora policymaking (high level of development, ineffective governance, low economic importance of the diaspora), 2 for the opposites of these three stances and 1 for the intermediate categories. Obviously, one of these three values is very likely to be an opposite of the other two, therefore medium stances might mean higher importance of migration but lower capacities for policymaking, on the other way round. Scores from these three features are summed up in a 'Score B' where B stands for 'background'.

On the right hand side of Table 33, there are the main findings regarding the actual achievements in diaspora policymaking. 'Citizenship and vote' makes a reference to the overall restrictiveness or liberal stance of a country concerning the double citizenship and the right to vote of the diaspora (as summarized in Table 25), with 2 points being assigned to the liberal stance, 0 to the restrictive and 1 to the intermediate positions). 'Laws' refer to the complexity of legal and policy framework of the diaspora issue (specialized laws and decrees; and policy documents are both worth 1-1 points), while 'Institutions' stand for the institutional framework, in which a 'smaller' Diaspora Unit is coded as 1 point and a larger, or institutionally 
more autonomous unit (Institute, Viceministry) is coded as 2 points. The total of these three columns is summed up in a 'Score A' where A stands for 'achievements'.

Table 33 therefore summarizes all main findings of Chapter 2.

Table 33. Background for diaspora policies and achievements in diaspora policies compared

\begin{tabular}{|c|c|c|c|c|c|c|c|c|c|}
\hline & $\begin{array}{l}\text { Develop- } \\
\text { ment }\end{array}$ & $\begin{array}{l}\text { Gover- } \\
\text { nance }\end{array}$ & $\begin{array}{l}\text { Diaspora } \\
\text { Imp. }\end{array}$ & \begin{tabular}{|l} 
Score \\
B
\end{tabular} & $\begin{array}{l}\text { Citizen- } \\
\text { ship, vote }\end{array}$ & Laws & $\begin{array}{l}\text { Institu- } \\
\text { tions }\end{array}$ & $\begin{array}{l}\text { Score } \\
\text { A }\end{array}$ & Match \\
\hline Argentina & 0 & 1 & 0 & 1 & 1 & 1 & 1 & 3 & + \\
\hline Bolivia & 2 & 0 & 1 & 3 & 1 & 0 & 0 & 1 & - \\
\hline Brazil & 0 & 1 & 0 & 1 & 1 & 0 & 1 & 2 & $\mathrm{O}$ \\
\hline Chile & 0 & 2 & 0 & 2 & 0 & 0 & 1 & 1 & $\mathrm{O}$ \\
\hline Colombia & 1 & 1 & 1 & 3 & 2 & 2 & 0 & 4 & $\mathrm{X}$ \\
\hline Costa Rica & 1 & 2 & 1 & 4 & 1 & 1 & 0 & 2 & - \\
\hline Cuba & 0 & 1 & 2 & 3 & 0 & 0 & 0 & 0 & - \\
\hline Dominican R & 1 & 1 & 2 & 4 & 2 & 0 & 0 & 2 & - \\
\hline Ecuador & 1 & 1 & 1 & 3 & 1 & 2 & 2 & 5 & + \\
\hline El Salvador & 2 & 1 & 2 & 5 & 1 & 2 & 2 & 5 & $X$ \\
\hline Guatemala & 2 & 1 & 2 & 5 & 1 & 0 & 0 & 1 & - \\
\hline Honduras & 2 & 0 & 2 & 4 & 1 & 1 & 0 & 2 & - \\
\hline Mexico & 1 & 2 & 1 & 4 & 2 & 1 & 2 & 5 & $X$ \\
\hline Nicaragua & 2 & 0 & 2 & 4 & 1 & 1 & 0 & 2 & - \\
\hline Panama & 1 & 2 & 1 & 4 & 1 & 0 & 0 & 1 & - \\
\hline Paraguay & 2 & 0 & 1 & 3 & 1 & 0 & 0 & 1 & - \\
\hline Peru & 1 & 1 & 1 & 3 & 2 & 1 & 1 & 4 & $X$ \\
\hline Uruguay & 0 & 2 & 0 & 2 & 1 & 0 & 1 & 2 & $\mathrm{O}$ \\
\hline Venezuela & 0 & 0 & 0 & 0 & 1 & 0 & 0 & 1 & $\mathrm{O}$ \\
\hline
\end{tabular}

Source: Own compilation. Values are based on Tables 21, 22, 23, 25, 26, 28.

The far right column of Table 33 is titled as 'Match' because it evaluates how Scores A and B for each country are related. Coding is as follows:

O 0 or 1 points of difference, low score (0-3)

$\mathrm{X} \quad 0$ or 1 points of difference, high score (4-6)

- $\quad$ More than 1 points of difference, A is lower than B

$+\quad$ More than 1 points of difference, $\mathrm{A}$ is higher than $\mathrm{B}$

These four categories can be translated into the following categories:

O It was expected that these countries will have a lower level of institutionalization of diaspora policies, because the issue is not so relevant for them, and the expectations turned to be correct. These countries are: Brazil, Chile, Uruguay and Venezuela. 
$\mathrm{X}$ It was expected that these countries will have a higher level of institutionalization of diaspora policies, because the issue is very relevant for them, and the expectations turned to be correct. These countries are: Colombia, El Salvador, Mexico, Peru.

These countries have a lower level of institutionalization of diaspora policies, than it could have been expected based on the importance of their diaspora. These countries are: Bolivia, Costa Rica, Cuba, Dominican Republic, Guatemala, Honduras, Nicaragua, Panama, Paraguay.

$+\quad$ These countries have a higher level of institutionalization of diaspora policies, than it could have been expected based on the importance of their diaspora. These countries are: Argentina and Ecuador.

The interesting feature in the above grouping is that the first three categories largely overlap with the three profiles set up in Table 24, at the end of Chapter 2.1. Pattern 1 in Table 24, is almost the same as the country group marked with $\mathrm{O}$ in Table 33. Pattern 2 overlaps with the X group, and pattern 3, with the - group. The two controversial members of pattern 4 and the two 'over-achievers' of the + group are different.

What does this prove? Basically, it demonstrates that the patterns identified regarding the background of diaspora affairs are more or less the same as the patterns of institutional achievements in legal and policy matters about the diaspora. There are countries which could do a lot but they are not interested (Pattern 1, mark O), countries for which the topic is important and they have done a lot (Pattern 2, mark $\mathrm{X}$ ) and countries for which the topic is important but they could not achieve too much (Pattern 3, mark -).

Going back to the hypotheses, (H1) states that none of these policies can change the ongoing migratory trends significantly. On the institutional level - which is evaluated here - it can be said that countries with a significant outmigration but with low governmental effectiveness or capacities do not even reach the level of institutionalization which would be sufficient to create policies. Others, which have created specific laws, institutions and policies, institutionally are able to deal with the problem. It cannot be said, however, whether they will succeed to change migratory trends or not - it remains to be answered on the concrete, policy level. 
(H2) states that diaspora policies can create a transnational space in which developmentally positive economic and social transfers can take place. This is certainly the case on the institutional level, as the 'liberal' regimes of double citizenship and voting rights, the founding and enhancement of the Diaspora Units, the councils of diaspora members at the consulates and the concrete outreach programmes are all creating the 'transnational space', on one hand, and its 'content' or 'transfers' on the other, which can be found within this space. Whether these transfers are developmentally positive, or they are not much more than information, news, symbolical acts or other, developmentally unimportant contents, it should also be answered based on the findings of the concrete policy level.

Finally, (H3) states that the government of the country of origin as well as the diaspora can obtain political, economic and symbolical benefits from the existence of these social and economic transfers. When it comes to diaspora politics, symbolical benefits abound. But beyond recognizing the importance of the diaspora, the specific laws and the outreach programmes are very likely to yield other benefits as well. Legal help, repatriation help, enhanced capabilities for resolving administrative issues are all possible sources of political benefits for the diaspora, while more active linkages and a more likely future repatriation of economic and/or human capital can probably materialize in economic benefits for the country of origin. Diaspora Units are very important in fostering these transfers, as they explicitly came into being for improving the channels of these transfers.

To sum up, on the institutional level hypotheses (H2) and (H3) seem to be valid, while (H1) cannot really be assessed. It will be evaluated on the next level of analysis, the level of policies, which comes next in Chapter 3. 


\section{Analysis of diaspora policies in Latin America}

Chapter 1 overviewed the theoretical background of development-related migration and diaspora policies, while Chapter 2 presented how migratory processes were followed by the evolution of the institutional framework in Latin American governments for conceiving and implementing related policies. In Chapter 3, policy areas and concrete policies will be presented and analyzed in a common framework.

Progressive, transnational policies were conceived and implemented mostly in the countries identified in Chapter 2.2. as the 'engaged' ones. These are not the richest, nor the poorest countries in the region, but those of lower-middle income (e.g. Mexico, Ecuador, Colombia). In the next chapter I will focus on the four policy areas identified as most relevant for the development of the country of origin, based on Gamlen [2006], and presented in Table 15.

These four broad emigration policy areas correlate with the cumulative definitions of remittances (Definitions C, D, E and F), displayed in Table 6.

Table 34 summarizes the logical structure of Chapter 3.

Table 34. Overview of the structure of policy areas, remittance types and case studies of Chapter 3.

\begin{tabular}{|l|l|l|l|}
\hline Chapter & $\begin{array}{l}\text { Policy area } \\
\text { (see table 15) }\end{array}$ & $\begin{array}{l}\text { Remittance type } \\
\text { addressed } \\
\text { (see Table 6) }\end{array}$ & Case study \\
\hline 3.2. & $\begin{array}{l}\text { Special consular } \\
\text { activities (for } \\
\text { concrete policy goals) }\end{array}$ & $\begin{array}{l}\text { Household remittances } \\
\text { (Definition C) }\end{array}$ & $\begin{array}{l}\text { "Matrícula Consular" } \\
\text { or Consular ID Card, } \\
\text { Mexico }\end{array}$ \\
\hline 3.3. & $\begin{array}{l}\text { Investment } \\
\text { programmes } \\
\text { (returning migrants or } \\
\text { joint ventures) }\end{array}$ & $\begin{array}{l}\text { Investment remittances } \\
\text { (Definition D) }\end{array}$ & $\begin{array}{l}\text { "Cucayo Fund", } \\
\text { Ecuador }\end{array}$ \\
\hline 3.4. & $\begin{array}{l}\text { (Collective) } \\
\text { remittance capture } \\
\text { programmes }\end{array}$ & $\begin{array}{l}\text { Collective remittances } \\
\text { (Definition E) }\end{array}$ & $\begin{array}{l}\text { "3x1 Programme" } \\
\text { matching funds } \\
\text { scheme, Mexico }\end{array}$ \\
\hline 3.5. & $\begin{array}{l}\text { Knowledge transfer } \\
\text { programmes }\end{array}$ & $\begin{array}{l}\text { Social remittances } \\
\text { (Definition F) }\end{array}$ & $\begin{array}{l}\text { "Red Caldas" and } \\
\text { "Colombia Nos Une" } \\
\text { networks, Colombia }\end{array}$ \\
\hline
\end{tabular}

Source: own compilation 
Analysis for each policy area follows a similar logic: first, a conceptual overview situates the policy field. Second, all relevant public policies of the category found in Latin America during the research are presented in a taxative and analytical way. Third, a relevant case study of a concrete policy programme goes into details regarding its creation, functioning and impact. The formative period of each concrete policy is presented according to Kingdon's conceptual framework on "policy windows" [Kingdon, 1984], while the evaluation of their achievements relies on Gamlen's "extending rights - extracting obligations" dichotomy [2006] and Czaika and de Haas's "gaps" identified in the formation of migration policies [2011].

\subsection{A framework for the analysis of diaspora policies}

Diaspora policies, as defined in the introduction of this thesis as "policies which are managed by the government of the country of origin and aim at the diaspora" and conceptualized in Chapter 1.3.2, around key texts of Gamlen [2006] and Czaika - de Haas [2011, p. 20], the latter which identifies a series of "gaps" in the implementation of a given policy. It is clear that the analysis of a policy should focus on how public opinion and public discourses were distilled in policies (historical approach), but also on how these policies affected the migratory processes (impact approach). Czaika and Haas add a third point to this dichotomy: how the policies (on paper) were actually implemented (in reality). These are the three gaps that the authors identify: the "discourse gap" between the politicians' statements and the concrete policies; the "implementation gap" between policy documents and their implementation; and the "efficacy gap" between the aimed and the actual changes of migration flows through the implementation of the given policy measure.

This is a good starting point for a policy analysis framework, however, it has to be expanded is several ways. First, the "policy gap" needs to be operationalized by identifying how "discourses" and "opinions" are transformed into policies. Chapter 3.1.1 presents six different theories on the creation of a public policy, out of which Kingdon's [1984] analytical framework will be chosen for further analysis.

The 'coalition of interests' upon which a policy relies will be conceptualized as a 'deal' between the government of the country of origin and the diaspora. Alan Gamlen's [2006] notion, already presented in 1.3.3., the "Extending rights" versus "Extracting obligations" dichotomy summarizes the possible assets of each 
counterparty (for the government: expatriate tax or tax on remittances, remittance capture programmes, investment programmes for returning migrants or joint ventures, and knowledge transfer programmes; for the diaspora: to receive increased human, social and welfare rights protection, the right to have dual nationality, to vote, to run for office, to have parliamentary representation, etc.). These are the possible bases of a 'deal': different government benefit items of this list will be detailed in Chapters 3.2, 3.3, 3.4 and 3.5. More details on the 'deal' approach will be presented in 3.1.2.

Furthermore, an analysis of the actors and the transnational space of negotiations should be added to the framework. While the focus of this thesis is on the Diaspora Unit of the government of the country of origin, policymaking is a process of different actors on different levels. Main actors are 1) the government of the country of origin, 2) the diaspora's leaders, 3) migrants in the country of destination, and 4) the beneficiaries of the development policies, in the country of origin. Very importantly, 5) the civil society of the country of origin and 6) the government of the country of destination can also be involved. Table 35 and the rest of Chapter 3.1.3 present the complexity of actors in play and the possible linkages and interactions among them. This will also partially explain the possible "implementation gaps", as conflicting interests might arise.

Then, an impact assessment should be added. Following Kahan's [2008] expression, a summative, retrospective analysis is undertaken, as in the case of these diaspora policies, originally set goals and benchmarks are not available. Therefore, besides general information (nature and structure of its managing authority, yearly budget, number of beneficiaries and average benefit per beneficiary), there are two main focus points: the impact of the policy on local development and on migratory flows. This is presented in details in 3.1.4.

Finally, the notion of temporality should be added: how the policy evolved since its creation and what are the perspectives that it has for the future (in case it is still operating). This will be present in every case study, as they will be narrated following the chronology of the events, thus at the end of the description these two notions will be added.

In the following, the elements of the analytical framework described above will be presented in details, to be summarized in Template 1. 


\subsubsection{The opening of windows of opportunity}

Public policies are created in order to address significant social challenges, and in Latin America, outward migration is certainly one of these challenges. Policymaking, however, is not an automatic process. There are many competing theories on how policies are created in order to address a challenge, and how policy changes do (or do not) occur. Relying on Sarah Stachowiak's [2009] categorization, although changing the order of their presentation, in the following I summarize the six major theories on the creation of public policies:

- "Power Politics" aka Power Elites Theory (Mills),

- "Large Leaps", aka Punctuated Equilibrium Theory (Baumgartner and Jones),

- "Grassroots" Theory (Alinsky, Biklen).

- “Coalition” Theory aka Advocacy Coalition Framework (Sabater),

- "Policy Windows" (Kingdon),

- "Messaging and Frameworks" (Tversky and Kahneman),

The most classical way of understanding policy change is perhaps the paradigm in which politics in general and concrete policies in particular are the outcome of conflicting interests between individuals and elite groups who are in a constant struggle for power. The "Power Politics" theory, applied for policy theory by C. Wright Mills' seminal book, The Power Elites [1956], among others, understands public policy as a conscious creation of mechanisms which are beneficial for those power elites and powerful individuals that created them. This approach has a perfectly rational, fully informed decision-maker in mind, who relies on the opinion of experts and acts either directly or indirectly (through the political structure) in order to remain in power which, in democratic terms, means that policies will be designed to benefit the interest groups that elevated the decisionmaker to power.

A somewhat more nuanced, but still governance-focused approach can be found in Baumgartner and Jones' [1993] analysis on agenda setting, who understand the inclusion of new elements in the political agenda and, consequently, in policymaking, as a paradigm shift in a Kuhnian [1962] sense. This theory views 
decision-makers as more passive and less informed actors, by nature more interested in maintaining the status quo. In this approach, thinking about and defining an issue shifts from the previous frameworks of understanding, either because the issue gets attention due to a crisis, or new actors get involved, and suddenly (hence the "Large Leaps" notion) the governance bodies are forced to include the new issue in the agenda and build a structured set of institutional responses (i. e. a policy) to it.

Very different from the above two, a "Grassroots" theory evolved in the 1970s, linked to the counterculture and protest movements of the decade, which views power, politics and concrete policies as changeable and dynamic, in which society can take part by joint action to achieve social change. Saul Alinsky's book, Rules for Radicals [1971], followed by Biklen's handbook for community organizing [1983] understood power as a function of people's obedience which, in turn, can be challenged by conscious organizing efforts that reflect on people's wishes for change. Policies are therefore changeable though internally coherent, popular action.

Again, a more nuanced approach within this current of thought evolved over time. Sabatier [1999] views policy change as a function of the coalition-building between groups, as opposed to the "people" in Alinsky's rather homogeneous approach. The advocacy "Coalition" theory emphasizes the importance of coordinated activities of societal groups holding the same core beliefs or values, and interested in the changing of the current policy regime in a given field. When agreement is reached on how to frame a problem and from which direction it should be approached to resolve it, an advocacy coalition can be set up, within which strong internal coordination mechanisms evolve based on the shared values, serving as the backbone of the societal conglomerate which will push for change in an own dynamics.

Finally, two comprehensive models tried to include both the societal and governance perspectives. One of these is Kingdon's [1984] model of "Policy Windows" which sees policy change as an outcome of different drivers that come together in a favourable moment, a "window of opportunity". This model theorizes different "streams", i. e. currents of issues and understandings in the discourse, linked to different circles of stakeholders, which, in a relatively short period and under a unique constellation of external circumstances, come into an interplay and, even if in a somewhat aleatory way, they form a novel understanding of the issue, 
transformed into policies based on this shared understanding that came into being among stakeholders when the window of opportunity was open.

Another comprehensive model is developed by Tversky and Kahneman [1981] which emphasizes the importance of "Messaging and Frameworks". As opposed to the previously presented notions operating with the assumption that people make rational decisions and choices by evaluating costs and benefits from an individual or group perspective, and then choosing the most beneficial or least harmful option, this approach, drawing on evidence from psychological experiences, holds that people develop different preferences according to the ways in which issues or options were presented and framed to them. This approach, linked to poststructuralism in many ways, understands policy change as the change of preferences induced by the change of the discourse upon them which is, in turn, a consequence of framing and presenting a given issue.

For the purposes of the present analysis, obviously, one of these competing approaches needs to be chosen. Policymaking on emigration and development in Latin America, to my understanding, is neither a sequence of conscious and internally coherent governmental actions, nor the outcome of coordinated popular struggle for change. The first four theories in the list would be applicable for 'classical' policy areas such as labour rights or access to welfare services, in which the topic is central to the political agenda and there are significant groups of people who - either as voters or as protesters - are, or might be mobilized. However, the diaspora is not present. They do not march on the streets, nor are they present in systems of education, healthcare and so on. It would be difficult to understand diaspora politics (and policies) as an outcome of a 'classical' political conflict of interests.

Thus, a comprehensive model is preferable. From the list of above, I have chosen Kingdon's "Policy Windows" or Agenda Setting model, because it theorizes policy change as the somewhat random outcome of several factors in interplay at a specific moment of time, which fits better to the concrete stories of the creation of diaspora policies in Latin America (almost always linked directly to a change in the presidency of the country of origin). While Tversky and Kahneman's “Messaging and Frameworks" grabs very well the changing and instable nature of public preferences, it implicitly counts with a mediatized arena of discursive politics, which might not be the case in the case of diaspora politics, where mass media outreach is 
way less important than in the case of 'domestic' party politics. Therefore, it is Kingdon's "Policy Windows" theory which I will use in the following, in order to present how policies on emigration and development were conceived and implemented in Latin America.

In his classic book, Agendas, Alternatives and Public Policies, Kingdon [1984] describes three different "streams" that flow in time, largely independent from each other: "problems", "politics" and "policy". In the present case, "problem" is outward migration, "politics" is party politics shaped by the election cycle, and "policy" is the set of measures that a government can implement in order to minimize the societal damage and to make potential benefits out of the process. According to Kingdon, policy changes occur when these streams meet, i. e. problems get the political elite's attention and policy solutions are coupled with them. The latter can be done only in a relatively short time period, called by Kingdon a "policy window" of opportunity that is open only while problems are perceived as urging and no other policy solutions are implemented. Howlett [1998] classifies these "policy windows" as 1) "routine", 2) "discretionary", 3) "spillover problem" and 4) "random problem". In the first case, regular and predictable events such as elections open a window of opportunity for policy proposals. In the second, individual political actors define the ways in which policy windows open and close. In the third, a policy change in a related topic leads to the opening of a policy window, while in the fourth, unforeseen events such as accidents push an issue to the focus of public attention.

In the case of policymaking on emigration and development in Latin America, the "problem stream" was gaining strength already in the late 1980s and 1990s, however, the policies described in the following only had their launch in the 2000s. Following Kingdon's argument, this lagging was due to the lack of policy windows, i. e. moments when political actors were ready to "do something" with the issue, and they also had existing schemes to use (from the "policy stream"). If Howlett's classification is used, policy windows that emerged were of a "discretionary" nature: charismatic politicians shaped the flow of policymaking on the issue. However, these policy windows had also a "routine" element, as an increased awareness on migrant-related issues was due to electoral campaigns.

It is interesting, nonetheless, that Latin American presidential candidates campaigning with these issues initiated different kinds of policy changes upon their election. Leonel Fernández in the Dominican Republic, Vicente Fox in Mexico, 
Alejandro Toledo in Peru and Rafael Correa in Ecuador had several migrant-related issues in the focus of their victorious campaigns in 1996, 2000, 2001 and 2007, respectively. However, Fernández and Toledo moved towards the political inclusion of the diaspora, Correa put the emphasis on development and return policies, while Fox's focus was the protection of migrant rights abroad and development projects in the migrants' home communities, co-funded by the migrants themselves. Using the concepts of Kingdon's theory, "policy windows" were similar, only the nature of the "policy stream" was different. Leonel Fernández, for instance, had been a migrant himself in New York, and the support that he was receiving from the Dominican diaspora in the United States, both in financial and organizational terms, was crucial in order to achieve the electoral victory. A well-organized, wealthy Dominican diaspora with its own policy agenda pushed Fernández towards a constitutional reform that provided diaspora members representation in the Dominican parliament; i. e. extraterritorial circumscriptions were created for Dominican voters residing in New York, Florida, and so on. [Dore et al, 2003; Vargas, 2011]

Very differently from the Dominican case, Mexican immigrants in the United States are rather poor and they are organized on a hometown basis, i. e. instead of a single Mexican-American political community, the diaspora is structured around hometown associations (HTAs) that have a very local agenda: to protect their own rights in the United States, and to finance development projects in their hometown in Mexico, such as paving roads or renovating the church. This pattern was so widespread in some Central-Western Mexican states that, as it will be described in the following, matching fund schemes were initiated in the state of Zacatecas as early as 1986. When Fox won the elections in 2000, the "policy stream" included very different elements from those that Fernández had to face in the Dominican Republic four years before. Mexican migrants did not want representation in the Mexican parliament, but they did want protection of their rights in the United States and cooperation of the Mexican state in the local development of their hometown. The different, already existing patterns are, to my understanding, the reason why Mexico's diaspora policy moved in one direction, and that of the Dominican Republic, to another. [Soto - Velázquez, 2006] 


\subsubsection{The 'deal' approach: political resources and economic resources}

As it has already been described in chapter 1.3.1. and synthesized in Tables 13 and 14, the diaspora has economic resources that, from the perspective of the state (of origin) are seen as an asset, while the state (of origin) can yield political resources for diaspora. Some elements from the first category are remittances (Definition C) or repatriation of savings through investment, know-how transfer, trade, fundraising capabilities and lobbying power in the country of destination, while in the second category, elements as agreements with the country of destination on legal terms of migration, legal assistance and protection, support in administrative issues, protection of human, social and cultural rights in the country of destination, participation in the politics of the country of origin (right to vote and to be elected) state-funded programmes to help in certain aspects of migration-related life situations or for return migration can be found (see Tables 13 and 14 for details).

It is therefore justifiable to understand the policymaking process between the state (of origin) and the diaspora as a bargaining where the former actor has mostly political assets in play and the latter, mostly economic ones. Both actors are interested in obtaining assets that they are short of: the diaspora is a fragmented group of people of different legal statuses and levels of integration to the society (and, as a consequence, to the political decision-making) of the country of destination, while the government of the country of origin is trying to manage social challenges in a low-middle income country with deep structural problems and chronic shortage of capital. Therefore I assume that migrants in general and migrant associations in particular are aware of the importance of their economic contribution to their country of origin's economy, and they find it fair and justifiable to expect that the government of the country of origin would provide them with benefits of a political nature, that could be materialized either in the country of origin, in the country of destination or in both. To come back to Alan Gamlen's [2006] notion already presented in 1.3.3., the "Extending rights" versus "Extracting obligations" dichotomy, for every policy item that aims at capturing remittances or other asset transfers, coming from the diaspora (expatriate tax or tax on remittances, remittance capture programmes, investment programmes for returning migrants or joint ventures, and knowledge transfer programmes), migrants can and indeed do expect political gestures and/or benefits (the right to have dual nationality, to vote, to run for 
office, to have parliamentary representation, and to receive some sort of human, social and welfare rights protection from the government of their country of origin (see Table 13).

This assumption on a state-diaspora 'deal', however, needs some conceptual clarification. First and foremost, the 'diaspora' or the 'migrant community' is a fiction, while the 'government of the country of origin' is a very real institution. Regarding legal and sociological characteristics, therefore, the bargaining process and the 'deal' is rather unequal: it does not happen between the governments of two sovereign states, but between the government of a sovereign state and a wide range of small, non-governmental organizations - for example, there are more than 3000 Mexican migrant associations in the United States. [Orozco - Rouse 2007] These associations are legally registered and operating in the territory of another sovereign state, moreover, the majority of the members of these organizations has, as a consequence of their still existing citizenship ties, a subordinate relationship with this government, even though territorially speaking, they are not under its jurisdiction. There is, therefore, an inequality of actors embedded in the transnational character of the policymaking process.

Second, the overwhelming majority of remittances and other capital and knowledge transfers occur on the micro level, between individual migrants and their household members in the country of origin, thus these transfers only appear in the international balance of payments, not among the country's budget income categories. In other words, migrants are citizens who do not contribute to the economy of the country of their citizenship through taxes (neither income nor value added taxes) but they provide a practically untaxable income to their household members, who in turn are usually economically inactive and reside in disadvantaged geographic areas. Migrants therefore cannot use the strongest card that they have in their hands, i. e. not sending remittances if the government of their country of origin will not provide them a benefit that they would like to obtain, as they would not harm the government but their family members with such a manoeuvre. At the same time, however, governments have practically no means to reach these money flows. While some Latin American governments struggling with budget deficit may find it an easy solution to tax remittances for budget balancing, as it has been the case in Colombia $(0.4 \%)$, Bolivia (1\%) and Brazil (0.38\%), this practice is problematic, as it serves as a counter-incentive to use official (legal) channels for remittances. [Solimano, 2003] 
If we take into account that an average Colombian emigrant sends a monthly amount of 350 USD back home, we find that the Colombian state could have the revenue of a yearly 16.8 USD per migrant, but if in search of this revenue the state pushed migrant towards illegal remittance channels, it would definitely not worth it. To sum up, taxing remittances in not a good idea and governments are aware of it: in 2006, Latin American states declared in the Montevideo Compromise on Migration and Development that remittances are regarded as a fundamental tool for development and will abstain from putting obstacles to their inflow. [SEGIB, 2006] The room for policymaking on and around remittances is therefore concentrated on the facilitation of private flows, and the matching funds schemes for investment and community remittances which, in turn, represent a very small share of the total of the remittances flows.

Third, 'political' benefits can be very diverse. All in all, migrants are a group of citizens (of the country of origin) who, just as any other well-defined group of citizens, can be the actor or the subject of political bargaining. As it has been the case in many Latin American election campaigns, most notably that of Peru and the Dominican Republic, political parties can rally for migrant votes and/or donations, just as they rally for those of any other social groups, e. g. women, small entrepreneurs or agricultural workers. From a political party perspective, migrants are nothing more than a specific, hard-to-reach and politically passive group of potential voters. Also, many of the important political struggles related to the migrant experience - most notably, for residence permits - are beyond the reach of any political party of the country of origin, as this issue is within the competence of another sovereign country. Once again, the most important political objective of the diaspora cannot be solved by the government of the country of origin. [Castillo, 2010]

\subsubsection{Transnational spaces of policymaking}

Once the "policy window" opens, policymakers pick the elements for a policy from a set of available practiques already present in the society (policy stream), and a 'deal' is made between the different actors. In the diaspora policy case, these practiques are transnational in nature, thus policies involve natural and institutional actors existing under the jurisdiction of different sovereign countries. Main actors in 
play are 1) the government of the country of origin, 2) the diaspora's leaders, 3) migrants in the country of destination, and 4) the beneficiaries of the development policies, in the country of origin. Very importantly, 5) the civil society of the country of origin can also be involved in the partnership. Finally, 6) the government of the country of destination is also present in the mechanism, either as a facilitator, an opposer or a laissez-faire observer of the policy activities between the other actors. (see Table 35).

Table 35. Levels of action and channels of policymaking in diaspora politics Level Country of destination Transnational space Country of origin

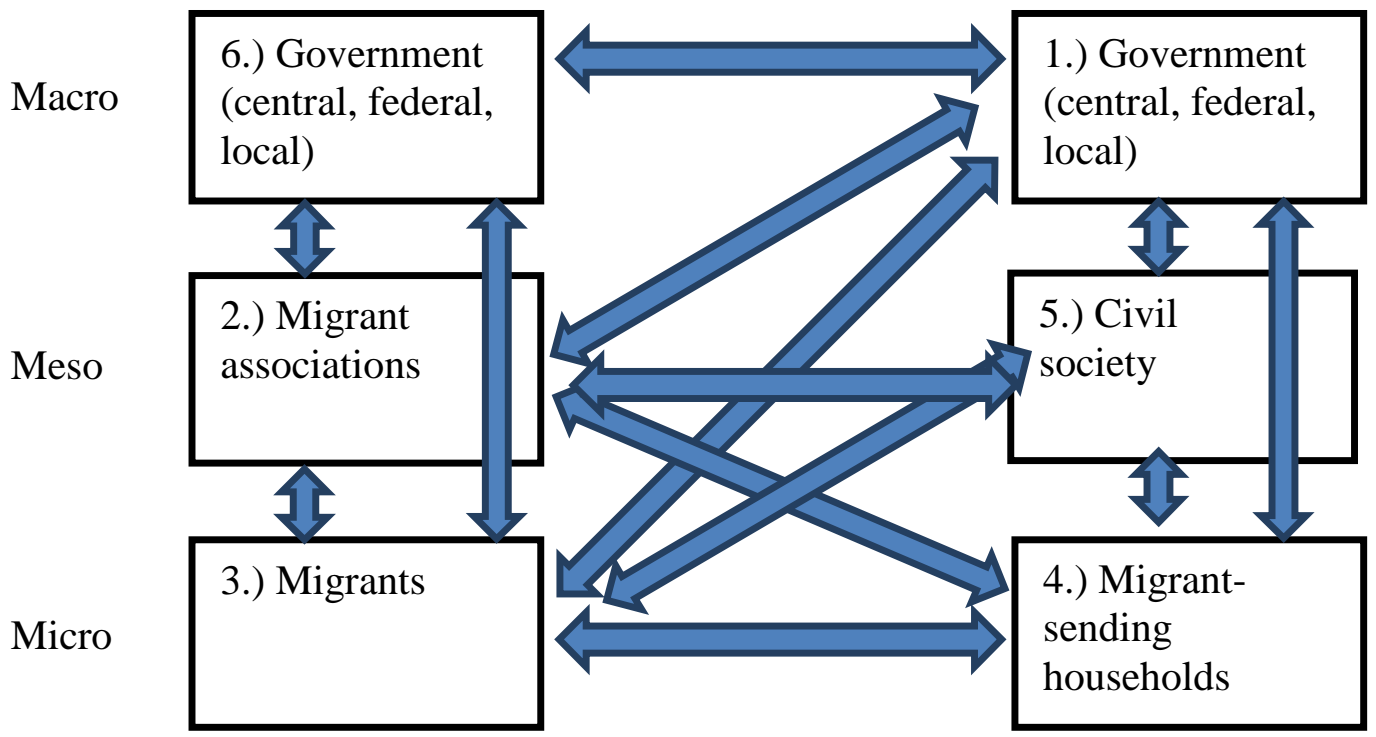

Source: own compilation.

In Table 35, actors are grouped in two according to the country where they operate. Policymaking, however, happens mostly in a transnational space between the two countries, i. e. policy actions happen over the borders. There are five different actors in play:

1.) Government of the country of origin (either central, federal or local),

2.) Migrant associations,

3.) Individual migrants,

4.) Migrant-sending households in the country of origin,

5.) Civil society in the country of origin,

6.) Government of the country of destination (either central, federal or local). 
Other actors on the meso level, such as money transfer operators, companies, labour unions or political parties in both countries could also be involved in the scheme, however, functionally they would not change the overall picture. The possible role of each actor in the process in dynamic terms is also important, as they can be initiating, facilitating, or opposing the process (or abstaining from it), while in terms of exchange they can be giving and receiving assets. [Gamlen, 2006, 2008] In the case studies, the placement and width of the arrows will symbolize these interactions.

Table 35 also shows that there are many possible channels in diaspora politics, and the analysis in the following will be aware of that. Concrete policies nonetheless use only some of these channels, and there is usually a triangle in their centre, as migrants (or diaspora associations) are targeted by the government in order to provide benefits for the communities where they households are located, in the country of origin. The base of these policies is therefore a resource that migrants generate, and the government of the country of origin helps with matching funds, administrative means or technical assistance, to enhance the positive societal impacts of the use of these resources. In general, it can be stated that the more concrete a resource transfer is, the bigger is the benefit, but at the same time, the smaller is the circle of beneficiaries. To cite three examples from the case studies that will follow, out of 1) a family business set up in Ecuador by a returning migrant, with $50 \%$ nonrefundable state grant, 2) the paving of a road in Mexico, co-financed by migrants in 25\%, and 3) an anti-malaria health campaign in Colombia, designed by Colombian scientists living abroad, the first one gives a big help for a small circle of people, the last one gives a small help for a large circle of people, and the second one being somewhere in between the two.

The government of the country of origin therefore must decide on the scope of its policies when it comes to actual policy design. Usually, Latin American governments have the political image impact in high regard: as it will be shown in the following, many policies are producing 'success stories' for the media, however, they lack the funding that would be necessary for a considerable impact. This is an important notion because in many times, governments present these policies as if they could substantially reduce emigration, while most of them are arguably unable to do so. The last and most important element of the analytical framework has to be, therefore, an evaluation of the overall effectiveness and impact of the analyzed policies regarding migration and development. 


\subsubsection{Setting up a framework for analysis of diaspora policies}

In the favourable cases when a policy window opens (politicians can incorporate feasible policy solutions from the transnational civil society's organized groups to their own agenda and institutionalize these solutions in form of policies), a policy deal is made (stakeholders give what they have and receive what they are lacking), and a policy mechanism is set up (stakeholders become parts of an institutionalized network where tasks and responsibilities are defined and accepted, and where possible adversaries of the mechanism are overcome or neutralized), the policy comes into being. But what do they actually achieve? Evaluation of outcomes must be framed in a way that their effects on society can be assessed.

Kahan [2008] distinguishes between 1) Preliminary Evaluation of either needs or resources that would define ex ante the purpose, scope and outreach of a given policy (to be implemented), 2) Formative or Process Evaluation that tells how a project is operating, and whether it is working out as and for what it was planned, 3) Outcome Evaluation that sees strictly the extent to which a project has achieved the outcomes it set at the beginning, 4) Summative Evaluation that examines broadly the overall effectiveness and impact of a project, and 5) Economic Evaluation that assesses the relationship between project costs and project outcomes in the form of a cost-effectiveness study.

The present thesis will examine four concrete policies that are related to the migration-development nexus. Thus, it must assess whether migration and development, treated as separate concepts, were modified in any way. As these policies are currently existing, consolidated policies, it is possible to evaluate them either in a formative (2) or a summative (4) way. I choose the latter option because the time horizon is broad enough for a retrospective analysis, while originally set goals and benchmarks are not available. Therefore, besides general information (nature and structure of its managing authority, yearly budget, number of beneficiaries and average benefit per beneficiary), there are two main points to focus on in the evaluation: impact of the policy on local development and on migratory flows. Finally, while a cost-effectiveness study would exceed the limits of the present thesis, the relative significance of each policy will be presented in a comparison to other related socioeconomic indicators. 
In order to give a common outline for the case studies to be described in the following (the Mexican Consular ID in 3.2.3, the Ecuadorian Cucayo Fund in 3.3.3, the Mexican 3x1 Programme in 3.4.3. and the Colombian Red Caldas and Colombia Nos Une Networks in 3.5.3.), the following template will be used, containing every aspect described above in chapter 3.1.

\section{Template 1. Framework for the case studies}

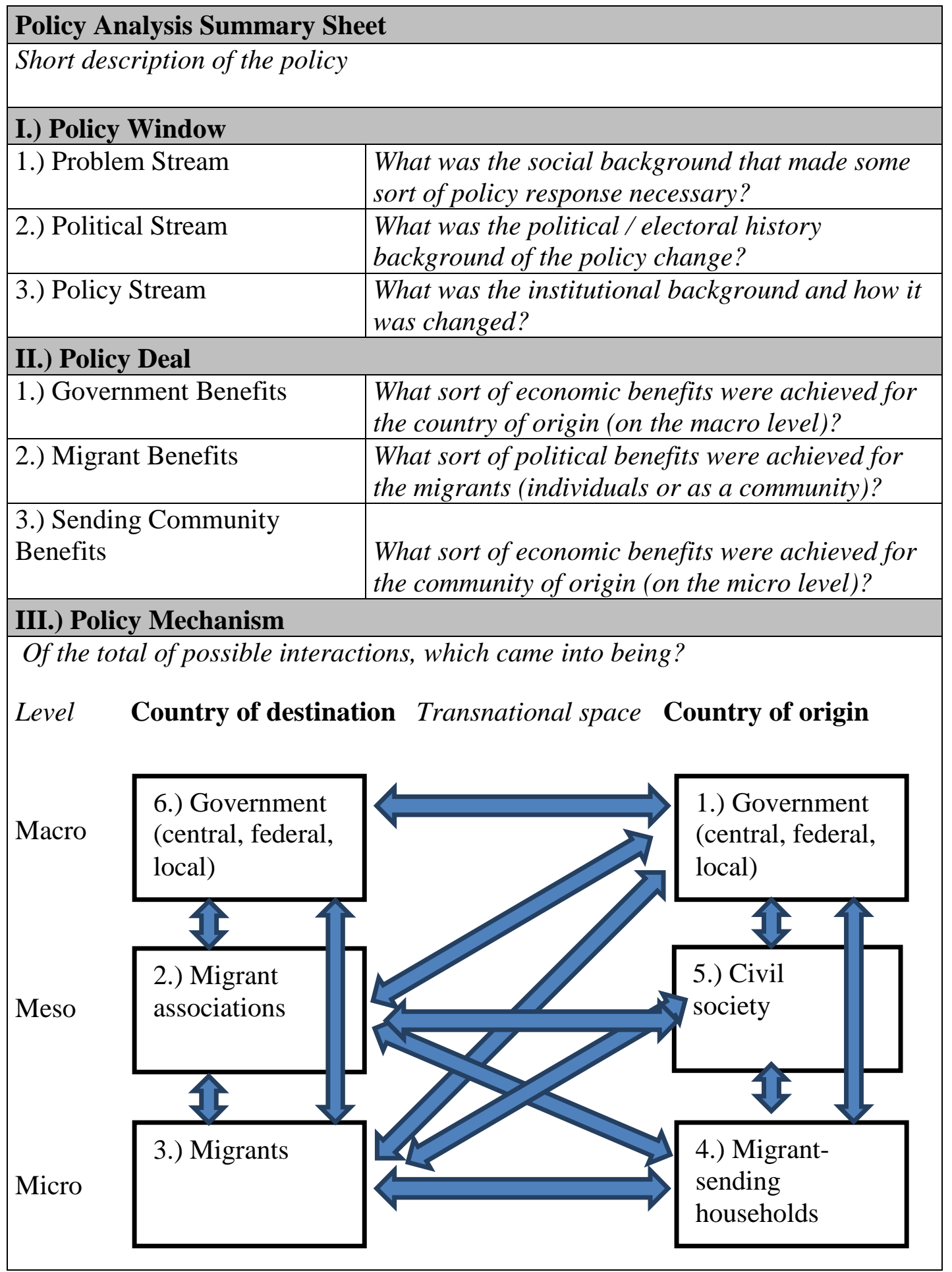




\begin{tabular}{|c|c|}
\hline $\begin{array}{l}\text { 1.) Government (Country of } \\
\text { origin) }\end{array}$ & $\begin{array}{l}\text { What is the role of the actor in the process in } \\
\text { dynamic terms (initiating, facilitating, opposing, } \\
\text { giving, receiving, abstaining)? }\end{array}$ \\
\hline 2.) Migrant associations & $\begin{array}{l}\text { What is the role of the actor in the process in } \\
\text { dynamic terms (initiating, facilitating, opposing, } \\
\text { giving, receiving, abstaining)? }\end{array}$ \\
\hline 3.) Migrants & $\begin{array}{l}\text { What is the role of the actor in the process in } \\
\text { dynamic terms (initiating, facilitating, opposing, } \\
\text { giving, receiving, abstaining)? }\end{array}$ \\
\hline $\begin{array}{l}\text { 4.) Migrant-sending } \\
\text { households }\end{array}$ & $\begin{array}{l}\text { What is the role of the actor in the process in } \\
\text { dynamic terms (initiating, facilitating, opposing, } \\
\text { giving, receiving, abstaining)? }\end{array}$ \\
\hline $\begin{array}{l}\text { 5.) Civil society (Country of } \\
\text { origin) }\end{array}$ & $\begin{array}{l}\text { What is the role of the actor in the process in } \\
\text { dynamic terms (initiating, facilitating, opposing, } \\
\text { giving, receiving, abstaining)? }\end{array}$ \\
\hline $\begin{array}{l}\text { 6.) Government (Country of } \\
\text { destination) }\end{array}$ & $\begin{array}{l}\text { What is the role of the actor in the process in } \\
\text { dynamic terms (initiating, facilitating, opposing, } \\
\text { giving, receiving, abstaining)? }\end{array}$ \\
\hline \multicolumn{2}{|l|}{ IV.) Policy Impact } \\
\hline 1.) Managing Authority & $\begin{array}{l}\text { What sort of institutional body manages the } \\
\text { policymaking and how it is embedded in the } \\
\text { broader policy context? }\end{array}$ \\
\hline 2.) Budget & $\begin{array}{l}\text { What is the yearly and overall budget for } \\
\text { implementing the policy? }\end{array}$ \\
\hline 3.) Number of Beneficiaries & $\begin{array}{l}\text { How many people benefits directly and indirectly } \\
\text { from the policy? }\end{array}$ \\
\hline $\begin{array}{l}\text { 4.) Average Benefit per } \\
\text { Beneficiary }\end{array}$ & $\begin{array}{l}\text { What (and, if quantifiable, how much money) is } \\
\text { the average benefit of a participant? }\end{array}$ \\
\hline $\begin{array}{l}\text { 5.) Impact on Local } \\
\text { Development }\end{array}$ & $\begin{array}{l}\text { To what extent has the policy contributed to the } \\
\text { development of the communities of origin? }\end{array}$ \\
\hline 6.) Impact on Migratory Flows & $\begin{array}{l}\text { To what extent has the policy contributed to the } \\
\text { outflow of migrants from the communities of } \\
\text { origin? }\end{array}$ \\
\hline 7.) Relative Significance & $\begin{array}{l}\text { How can the above }(I V / 2,3,4,5,6) \text { indicators } \\
\text { related to the total of the respective migration- } \\
\text { related indicators/phenomena of the country of } \\
\text { origin? }\end{array}$ \\
\hline \multicolumn{2}{|l|}{\begin{tabular}{|l|} 
V.) Policy Lifespan \\
\end{tabular}} \\
\hline $\begin{array}{l}\text { 1.) Timeline of } \\
\text { implementation }\end{array}$ & $\begin{array}{l}\text { How were the different policy elements } \\
\text { implemented? What was the dynamics of the } \\
\text { process? }\end{array}$ \\
\hline 2.) Perspective & $\begin{array}{l}\text { What is the future that can be expected for this } \\
\text { policy in particular, and for the policy area in } \\
\text { general? }\end{array}$ \\
\hline
\end{tabular}

Source: own compilation. 
Case studies were chosen with the objective of showing the most representative piece of their kind for each policy. Two Mexican cases appear because, without any doubt, Mexico is the country in Latin America with the broadest set of diaspora policies. Regarding the new approach for consular activities, it is Mexico that has reached the most concrete results, and a showpiece of these efforts is the "Matrícula Consular". The other featured Mexican policy, the " $3 \times 1$ Programme" is perhaps the most famous textbook example of matching funds programmes for community remittances, not only in Latin America but also worldwide. Ecuador's "Cucayo Fund" was chosen among several others that would have been relevant as well, for example Peru's similar programme, but the Ecuadorian case has arguably been the most developed in terms of funding and technical assistance mechanisms. Finally, Colombia's two consequent attempts of building a diaspora network for the highly skilled, "Red Caldas" and "Colombia Nos Une" together put up a story of two decades with its highlights and lowlights, being the oldest of its kind in Latin America.

In the following chapters (3.2 to 3.5), the four main areas of diaspora policymaking, identified as relevant for development, will be presented, containing a general overview of the question, an overview of existing Latin American policies and a detailed case study analysis for each of these areas.

\subsection{Extending Latin American consular activities}

With the emigration boom, Latin American diplomatic and consular services faced the urgent necessity to handle the needs of a huge and vulnerable population that suddenly appeared in their consular district. In order to achieve this, traditional consulates had to be transformed into a sort of transnational public service hub for migrant rights advocacy, or at least, a multi-purpose service centre for the migrant population that, either because of its irregular migratory status or because of its deficient integration, could not access these services in the country of destination.

As it has been mentioned already, this was especially difficult for Latin American diplomatic and consular staff, given the fact that the diplomatic career was typically reserved for the members of the wealthiest (white) families who had no connection with the daily problems of the poor and (usually) darker-skinned, 
illiterate and/or undocumented migrants. However, as mass migration became a political issue and a subject of partisan debates, haute société Latin American foreign service members suddenly saw themselves obliged to organize information days and other diaspora outreach activities for that sort of people who they would have never met back in their home countries. [Golte, 2007]

Anthropologist Javier Ávila [2003] counts how disastrous the first encounters were between Peruvian migrants and consulate staff in Paterson, New Jersey, home of one of the largest Peruvian migrant communities in the United States. Migrants felt themselves uncomfortable in the elegant building of the consulate, and they were ashamed to speak in their sociolinguistic register (some of them were not even native Spanish- but Quechua-speakers) that was very different from the consul's eloquent Spanish. They did not even understand what they were supposed to "consult". The first thing that they asked was to change the customer service room at the consulate, as officers were sitting behind a small window placed conveniently for the sitting officer but customers had to bend over to speak, feeling somewhat humiliated. The consulate building was later remodeled, the customer service room became an open space, and the consulate slowly became a hub for migrant community life, with consuls regularly participating in the annual "Peruvian Parade", a real working-class festivity on the streets of Paterson.

Having in mind this very telling story on what does it mean to "reshape consular activity", in the following I present the changes in the consular agendas from a developmental point of view, i.e. how these activities can, or could be beneficial for the development of the country of origin.

\subsubsection{The transformation of Latin American diplomatic and consular agendas}

For any sort of diaspora policymaking, the key piece is the diplomatic and consular network of the country of origin in the country of destination. This usually means one embassy (with a consular department) in the capital city and a couple of other consulates in the main cities of the country. If there are several consulates, the territory of the country is divided in consular districts, and each citizen of the country of origin should turn to the consulate of their own consular district. The competences, rights, obligations and usual activities of diplomatic and consular 
services are described in two international conventions, the Vienna Conventions on Diplomatic Relations [1961] and on Consular Relations [1963], respectively.

The presence of a large and recent diaspora in the consular district is not something that the signatories to these two conventions originally had in mind. New types of diplomatic and consular activities therefore have to go beyond what the Vienna Conventions described - however, they have to respect the sovereignty of the country of destination. In legal terms, therefore, diplomatic and consular offices have no extra powers delegated, while in administrative and policy terms, they have to face with an increased workload and a diversified set of activities to undertake. This extension of consular activity is therefore a unilateral process, not necessarily mirrored by the administrative units of the country of destination.

Theoretically, this extended scope can be conceptualized in three ways. First, as a specific branch of public diplomacy; second, as 'intermestic' affairs (i.e. between international and domestic); and third, as a set of services that the government of the country of origin offers to its citizens as if they were in its own territory. In the following, the conceptual content and the applicability of these three approaches to the concrete activity or policy fields will be presented.

First, public diplomacy [Richmond, 2008] is usually understood as a communicational activity in which the diplomatic service reaches out to the public opinion in order to inform and influence it, either in controversial issues, or as part of a general communicational campaign to show the country of origin as an important political and trade partner and as an appealing destination for investment and tourism. As opposed to 'high' diplomacy, public diplomacy is not focused on achieving legally binding agreements with governmental units, but on communication, marketing and shaping the public opinion.

In the case of extended consular activities for the diaspora, the concept might be relevant as the means (informative events and materials, media appearances, online communication channels) are similar, and the objectives are partially related. However, it is not the population of the country of destination but the diaspora that should be reached, and communicational activities should not transmit broad and general messages, but very concrete information related to the everyday needs of the diaspora. Understanding extended consular activities as a sub-branch of public diplomacy is therefore only partially applicable. 
Second, the theory of 'intermestic' affairs [for the term, see Barilleaux, 1985], as the entanglement of domestic and international factors in international relations was elaborated by James Rosenau and further developed in Robert Putnam's [1988] theory of the 'two level games'. This approach sees foreign policy activities as the outcome of interests of and pressures from different domestic groups in a country that push the government towards a specific stance in foreign policy and, at the same time, the achievements of a government in foreign policy feed back to the interests and pressures on the domestic level.

The diaspora is, by nature, a social group very much interested in certain foreign policy goals, the most important being the liberalization of immigration and residence legislation in the country of destination. However, their 'belonging' is somewhat controversial: they are citizens of the country of origin but they might (or might not) want to obtain the citizenship of the country of destination. If they goals were achieved, the country of origin would gave its ties weakened to that specific population (and maybe new waves of emigration would arise). Also, lobbying for liberalization of immigration laws is a rather tough exercise in most countries with a significant immigrant population. Nonetheless, the relevance of the 'intermestic' approach is rather high.

Third, extended consular activities [Gamlen, 2006] can be understood not as a field of diplomacy but as a gradual and need-driven extension of services that the consulate provides as a representative of the government of the country of origin, rather independently from the fact that both the administrative staff and the beneficiaries of the services are physically located outside the country of origin. Or, better said, the consulate acts as a complementary provider of services in all those areas where the migrant population cannot (fully) benefit from the services provided by the country of destination.

This approach appears to be the most fruitful for the purposes of the present analysis, especially if we try to collect all the activities that Latin American consulates undertake for their diasporas. The most developed array of activities is, of course, that of Mexico. A study [Laglagaron, 2010] sets up four categories for what Mexican consulates do in diaspora issues in the United States:

- Supporting leadership from within the Mexican migrant community;

- Improving education for migrant children and adults; 
- Providing health care for migrants;

- Promoting formal banking \& improving the financial literacy of migrants.

To these categories, others can be added, based on cases found in the activity list of other Latin American consulates:

- Facilitating pension transfers to the country of origin;

- Facilitating the acceptance of diplomas and academic degrees

[Colombianosune.com, 2015]

When looking at concrete cases, it can be seen that many Latin American countries have signed bilateral agreements with specific governmental bodies of the countries of destination in the above mentioned topics. This is certainly an achievement of the diplomatic corps. However, on the level of day-by-day work, it is the consular officers' merit that they have put a content to these activity areas especially in the United States where central regulations are often lacking and state or municipal level regulations exist on many issues related to social security and assistance.

An important distinction is therefore to be made, according to the counterparty of the given activity. Consular and diplomatic missions can provide services unilaterally, with no authority, organization or business involved from the country of destination - nonetheless, constraints of funding, capacity and expertise put serious limits to unilateral activity. For assessing diaspora needs in a meaningful way, Latin American diplomats have sought to establish mechanisms with state institutions in the country of destination, while consulates have done an intense networking and lobbying activity on the 'ground' level, including municipal and private actors (see below).

Table 36 presents a general overview on activities of the diplomatic and consular service of the country of origin in order to address the needs of the diaspora.

Table 36. Diplomatic and consular activities of the country of origin in order to address the needs of the diaspora

\begin{tabular}{|l|l|l|l|}
\hline Area & Activity & Actor & Counterparty \\
\hline Legal status & $\begin{array}{l}\text { Lobbying for liberalization of } \\
\text { immigration laws }\end{array}$ & Embassy & $\begin{array}{l}\text { Ministry of Interior, } \\
\text { Legislative Bodies }\end{array}$ \\
\cline { 2 - 4 } & Protecting victims of violence & Consulate & $\begin{array}{l}\text { Local police bodies, local } \\
\text { courts }\end{array}$ \\
\cline { 2 - 4 } & $\begin{array}{l}\text { Lobbying for a modus vivendi } \\
\text { for migrants on the local level }\end{array}$ & Consulate & $\begin{array}{l}\text { Municipality, Local } \\
\text { institutions, local } \\
\text { businesses }\end{array}$ \\
\hline
\end{tabular}




\begin{tabular}{|c|c|c|c|}
\hline \multirow[t]{2}{*}{ Education } & $\begin{array}{l}\text { Facilitating the recognition of } \\
\text { diplomas and academic degrees }\end{array}$ & \multirow{2}{*}{$\begin{array}{l}\text { Embassy } \\
\text { Consulate } \\
\text { Consulate }\end{array}$} & \multirow{2}{*}{$\begin{array}{l}\text { Ministry of Education } \\
\text { Local institutions } \\
\text { none }\end{array}$} \\
\hline & $\begin{array}{l}\text { Own programmes for adult } \\
\text { education, language courses etc. }\end{array}$ & & \\
\hline Health & $\begin{array}{l}\text { Facilitating the access of migrants } \\
\text { to healthcare services }\end{array}$ & $\begin{array}{l}\text { Embassy } \\
\text { Consulate }\end{array}$ & $\begin{array}{l}\text { Ministry of Health / Social } \\
\text { Security } \\
\text { Local institutions }\end{array}$ \\
\hline $\begin{array}{l}\text { Labour and } \\
\text { pension }\end{array}$ & $\begin{array}{l}\text { Promoting legal employment } \\
\text { opportunities and pension transfers }\end{array}$ & Embassy & $\begin{array}{l}\text { Ministry of Labour / Social } \\
\text { Security }\end{array}$ \\
\hline \multirow[t]{2}{*}{ Remittances } & $\begin{array}{l}\begin{array}{l}\text { Promoting safe } \\
\text { channels for remittances }\end{array} \\
\end{array}$ & Consulate & $\begin{array}{l}\text { Banks and monetary } \\
\text { service providers }\end{array}$ \\
\hline & Providing financial information & Consulate & none \\
\hline
\end{tabular}

Source: own compilation.

In the following, two specific fields of activity will be chosen for further analysis, both of which are marked with bold in Table 36. These are "Lobbying for a modus vivendi for migrants on the local level" and "Promoting safe and legal channels for remittances". The reason of picking these two is their high relevance for the development on the country of origin on one hand, and the novel means for networking and lobbying on the consular level, on another.

Regarding the developmental dimension, operationalized around the concept of remittances (which is the main focus of this thesis), it is clear that earning decent wages and sending remittances through secured channels should be the two key goals for any related policy approach. Nonetheless, the first factor is mostly beyond the scope of the foreign service of the country of origin: wages are determined by the labour market, and the access to it, and while diplomats may lobby for recognition of titles and improved work conditions, it is the employer who has the last word. It is especially so in the case of migrants in an irregular legal status, who are the most vulnerable (and least paid) group in the labour market. Therefore, many consular officers started to lobby on lower levels of decision-making: instead of the federal or state level, they started to court employers, banks and local service providers. The case study in 3.2.3 will show this process in details. Also, this is the reason why the consular level networking and lobbying activities are chosen for further analysis.

In the following, Latin American consular identification mechanisms (as a strategy of coping with the economic and social marginalization of migrants in an irregular legal status) and financial education on remittances (as a way to increase the amount of money that actually arrives to the country of origin) are presented. 


\subsubsection{Extended consular activities and their implications on development in}

\section{Latin America}

Consulates can provide important help for migrants in remitting their savings to the country of origin. Technically, remittances can go through specialized remittance agencies (such as Western Union or MoneyGram) or through bank accounts. Remittance agencies (remesadoras) are usually more expensive, both in terms of commission (a basic fee between 3 and 10 US dollars, plus a percentage of the remitted amount) and exchange rate. However, migrants in an irregular legal status had no other option but to use these providers, as they could not open a bank account.

From 2003 onwards, in a campaign pioneered by Mexican consulates, more and more banks in the United States agreed to accept consular identification documents for opening a bank account. Consular IDs are identity cards comparable to passports but issued outside the territory of the country of origin, thus migrants do not need to leave the country of destination if they want to have one. For many migrants in irregular legal status this is the only identification document they have, therefore its value is unquestionable. [Délano, 2011] The case of the Mexican matrícula consular will be presented in details in 3.2.3 as a case study. Many other Latin American countries followed Mexico's example: as of 2015, ten countries issue consular IDs for migrants and two more are in the process of introducing them. Seven countries have no consular ID card (most of them are countries identified in 2.2 as not engaged to diaspora politics).

Table 37 summarizes the available information on Latin American consular ID cards.

Table 37. Consular identification cards issued by Latin American countries

\begin{tabular}{|l|l|l|l|}
\hline Country & $\begin{array}{l}\text { Name of consular } \\
\text { ID card (if exists) }\end{array}$ & Country & $\begin{array}{l}\text { Name of consular ID } \\
\text { card (if exists) }\end{array}$ \\
\hline Argentina & matrícula consular & Guatemala & $\begin{array}{l}\text { tarjeta de identificación } \\
\text { consular }\end{array}$ \\
\hline Bolivia & - & Honduras & (in process of introduction) \\
\hline Brazil & $\begin{array}{l}\text { matrícula de cidadão } \\
\text { brasileiro }\end{array}$ & Mexico & matrícula consular \\
\hline Chile & - & Nicaragua & $\begin{array}{l}\text { tarjeta de identidad } \\
\text { consular }\end{array}$ \\
\hline Colombia & tarjeta de registro consular & Panama & - \\
\hline Costa Rica & - & Paraguay & - \\
\hline
\end{tabular}




\begin{tabular}{|l|l|l|l|}
\hline Cuba & - & Peru & tarjeta consular \\
\hline Dominican R. & localizador de archivo & Uruguay & tarjeta consular \\
\hline Ecuador & matrícula consular & Venezuela & - \\
\hline El Salvador & (in process of introduction) & & \\
\hline
\end{tabular}

Source: Agunias - Newland [2012], Radiolaprimerisima.com [2013], Elpais.com.uy [2014],

Departamento19.hn [2015]

As it will be exposed in the case study, it was only after the US Department of Treasury announced in 2002 that consular ID cards could be accepted as valid, government-issued identification, that matrículas and tarjetas consulares started to be accepted in US banks and migrants - including those without a residence permit could open bank accounts. Still, given the low level of financial literacy and difficulties on the other side of the remittance channel (i.e. household members also have no bank account), remittance agencies enjoy a continued popularity (although their commissions have lowered considerably, given the competition with commercial banks).

Consulates fulfill an important task in convincing banks to accept the consular ID. Also, they promote financial literacy through informative material, lectures and courses. In the case of Mexico, they are the information providers of a central information-collecting mechanism on the costs of using each and every remittance channel from their consular district. The mechanism is administered from Mexico, and it is called the Federal Attorney for Consumers' Rights (Procuradoría Federal del Consumidor, PROFECO). it publishes weekly the data for commissions and exchange rates for three major agencies (Western Union, MoneyGram, United States Postal Service) if remitting an average amount (300 USD) from every large city of the United States (commissions may vary from city to city). Consulates help in compiling the information and the Paisano Programme (of the Ministry of Interior) is contributing to distribute the information within family members in Mexico. [PROFECO, 2015]

Another Mexican government agency, the National Commission for the Protection and Defense of Users of Financial Services (Comisión Nacional para la Protección y Defensa de los Usuarios de Servicios Financieros, CONDUSEF), compiles detailed infosheets on different modalities of remittance-sending (immediate, 24 hours, cash-to-cash, cash-to-account etc.). An online calculator is 
supposed to help migrants (Remesamex), however, it did not work at the time of research (October 2015). Infosheets were nonetheless available on the website of the Institute of Mexicans Abroad and consulates' websites displayed a link to it. According to the latest (2015 Q1), an amount of 200 USD, if transferred through Western Union in cash-to-cash and in less than one hour, had a commission of 13.58 USD, being the most expensive of its kind, while the cheapest agency was Viamericas, with a commission of 6.32 USD, also cash-to-cash, delivering the next day. [CONDUSEF, 2015] For further information on the issue, see the case study in 3.2.3.

Other consular activities less directly related to development in the country of origin will not be treated here in details. It has to be mentioned, however, that health and education programmes have a very important effect on assessing needs of the migrant community, and thus strengthening the linkages of the diaspora and the country of origin. Consultative Councils (see 2.2.3.) are a valuable tool for achieving this. Also, community development in the diaspora and the fostering of the creation of diaspora or hometown associations (HTAs) is on the extended consular agenda: these will be analyzed in 3.4. in relation to the community remittances and the development projects (co)financed by migrants.

In the following, the emblematic consular ID case, that of Mexico, is presented using the framework described in 3.1.

\subsubsection{Case study: the Mexican Consular ID}

\section{Case Study Overview Table 1. The Mexican Consular ID}

\section{The Mexican "Matrícula Consular" or Consular Identity Document}

In order to provide undocumented Mexican migrants with an identity document that they could use for accessing healthcare facilities, obtaining a driver's license and, very importantly, opening bank accounts, Mexican consulates started to issue the so-called "Matrícula Consular" ID cards. Although it caused a controversy among anti-immigration political circles, many private entities, especially banks accepted it, because they were not interested in their client's migratory status - they wanted to make business. Thus, migrants could transfer remittances safely and with a lower margin for intermediaries, increasing the amount of money that actually reached their family members.

\section{I.) Policy Window}

\begin{tabular}{|l|l} 
1.) Problem Stream & Undocumented migrants have no access to health facilities,
\end{tabular} banks, they are afraid to cooperate with the police.

A pro-migrant government is elected in Mexico, extreme security measures are implemented in the US after 9/11, the

2.) Political Stream Mexican government wants to 'help' and finds allies in local governments and companies. 


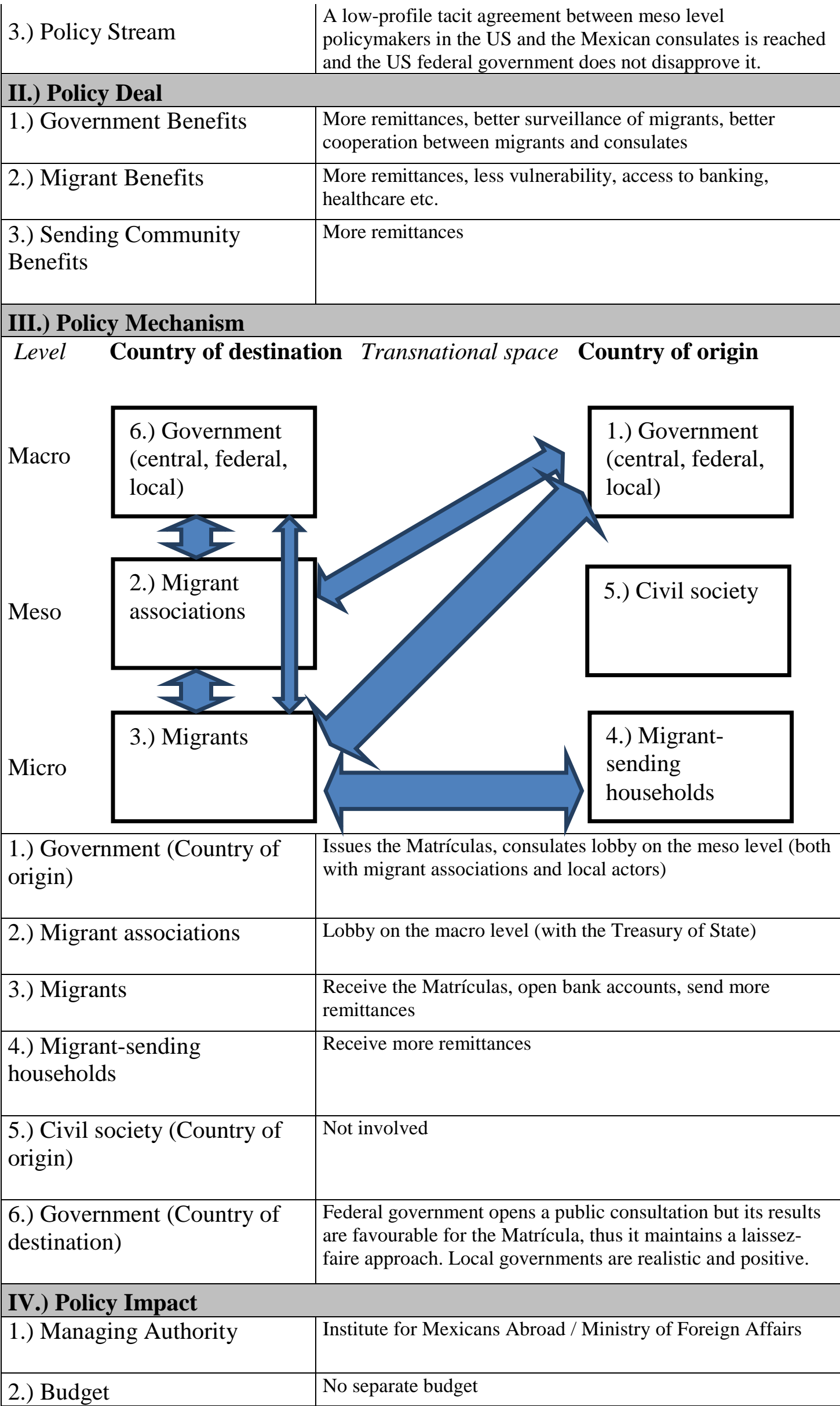




\begin{tabular}{|l|l|}
\hline 3.) Number of Beneficiaries & Approx. 4 million \\
\hline $\begin{array}{l}\text { 4.) Average Benefit per } \\
\text { Beneficiary }\end{array}$ & Approx. 420 USD per year \\
\hline $\begin{array}{l}\text { 5.) Impact on Local } \\
\text { Development }\end{array}$ & More remittances \\
\hline 6.) Impact on Migratory Flows & Difficult to measure, but possibly increasing \\
\hline 7.) Relative Significance & Medium \\
\hline V.) Policy Lifespan & $\begin{array}{l}\text { Implemented in 2001, upgraded in 2002. Public outcry in anti- } \\
\text { immigration circles in the US. The Department of Treasury } \\
\text { does not rule out the card (decision in late 2003). Low profile } \\
\text { consular activity since 2003 reaches an agreement with more } \\
\text { than the half of all commercial bank in the US since then. }\end{array}$ \\
\hline $\begin{array}{l}\text { 1.) Timeline of } \\
\text { implementation }\end{array}$ & $\begin{array}{l}\text { Matrículas were implemented by 9 more Latin American } \\
\text { countries. It has become an integral part of Mexican (and Latin } \\
\text { American) consular policy and it is likely to remain that way. }\end{array}$ \\
\hline 2.) Perspective
\end{tabular}

Source: Own compilation.

The Matrícula Consular is an identity card issued by Mexican consulates abroad, upon one 'reference' document that the applier presents for the consular officer. There is a wide range of reference documents accepted by the consulate, from Mexican electoral certificate card to the certificate of birth. The consulate issues the Matrícula which contains all the personal information that are necessary to prove the identity of a person (regardless of their migratory status).

This is not a Mexican invention, as the Vienna Convention on Consular Relations [1963] recognizes the consular ID as a legit form of documenting identity. However, originally it was used for those travelers who had their original identity documents lost or stolen. Mexican consulates had issued this sort of document since 1871. But it was only after the attacks of $9 / 11$ in 2001 that detentions and increased security measures led to many undocumented Mexican migrants being caught by US law enforcement personnel. [Délano, 2011]

Given the fact that the United States' administrative system is much more decentralized that European state administrations, there is no such thing as a central (federal) identity document and Americans usually identify themselves with a driving license or other document issued on the state level. Different states have different legislation for identity documents that are accepted for identification by the 
police or at the entrance of a public building, opening a bank account, or even to obtain a driving license. [González Gutiérrez, 2006]

Political impetus for a more proactive diaspora policy came, as it has already been mentioned, with the election of Vicente Fox as the president of Mexico in 2000. Fox had been governor of the state of Guanajuato, one of the most important migrant-sending areas of the country, and already in his inaugural speech, he stated that he wants to be the "president of 120 million Mexicans" (i. e. including the 11 million who live in the US).

The "original" version, issued in 2001, was very easy to forge; however, the next year a "high-security matrícula" was issued that had all the security elements of the Mexican federal ID (photo, fingerprint, special elements). [Escobar Latapí, 2008] The Mexican consulates, relying on their already existing local networks that they had been building from the 1990s onwards, started to lobby at local governments and companies, presenting the Matrícula as a reliable document for proving identity. Companies - especially banks - had been reluctant in the beginning, but they realized that if they accept the Matrícula, they might gain new clients. As Carlos González Gutiérrez, then-president of the Institute for Mexicans Abroad (IME) eloquently put it, "the invisible hand of the market is behind the strong will of local governments to find a practical, non-ideological modus operandi with regards to those citizens who live in the city or the county without a regular migratory status". [González Gutiérrez 2006, p. 191, own translation]

This was the period of financial expansion that preceded the 2008 economic crisis, banks were eager to discover new markets, and the approximately 5 million undocumented Mexican migrants certainly meant a new market for them. According to González Gutiérrez [2006], in three years, between late 2001 and mid-2004, only Wells Fargo opened 400,000 new bank accounts based on Matrículas as identity documents. It is estimated that in four years, a total of 4 million Mexicans received Matrículas, and their majority opened a bank account.

The development impact of this policy is beyond discussion. Remittances costs dropped significantly. While private money transfer operators worked with fees up to $20 \%$ of the total sending, transfer from bank account to bank account rarely exceeded the $2 \%$ of the sum, counting with an average 350 USD sending. [López et al, 2008] As of 2015, the cheapest remittance agency (Viamericas, see above) charges a fee of slightly more than $3 \%$. Thus, even if we assume that fees went down 
with an average 10\% (35 USD per month), and assuming that only the half of the effective Matrícula receivers started to send remittances through a bank account, the yearly gain from this policy is around a very conservative estimate of 840 million USD, but maybe more.

Naturally, adversaries of the policy appeared immediately. According to Délano [2011], anti-immigration circles stated that "fake ID cards" distributed by Mexican consulates are indeed a "de facto legalization" or "backdoor amnesty" for undocumented migrants. However, the Matrícula did not affect in any form the legal status of those who received it. Opponents then made a point on its low security standards, to which the Mexican government responded with increasing the security elements included and narrowing the circle of reference documents, to that extent that pro-immigration voices stated that it might not fulfill its original objective, as many undocumented migrants do not even have the documents to prove their identity for obtaining a Matrícula. [Alarcón, 2006]

On the federal level, it was the Department of Treasury of the United States that wanted to give a comprehensive answer to this challenge. In July 2003, a public consultation was opened in which the federal institution asked citizens whether they support or refuse the acceptation of Matrículas in banks. The Institute for Mexicans Abroad started an important mobilizing campaign between MexicanAmerican organizations for submitting positive feedback to the Department of Treasury. The campaign was successful, and $83 \%$ of the total of 24,000 opinions received was positive. The Department of Treasury thus announced that it will keep on permitting the acceptance of Matrículas for those commercial banks that are willing to accept it. [González Gutiérrez, 2006]

As of 2015, required personal data for opening a bank account in the United States, according to the Customer Identification Program (CIP) and under the United States of America Patriot Act are the following for non-U.S. citizens:

- A document proving the individual's name, date and place of birth,

- A document proving residence address (and mailing address if different).

If the individual is a non-U.S. person, all of the following that the individual possesses (minimum of one required):

- a U.S. taxpayer identification number; 
- a passport number and country of issuance, and alien identification card number;

- number and country of issuance of any other government-issued document evidencing nationality or residence and bearing a photograph or similar safeguard. [Keytlaw.com, 2015]

As address can be proved by a bill of electricity or water, Matrículas have become theoretically acceptable for all U. S. banks. However, many banks required additional documentation that migrants in an irregular legal status could not meet. According to the latest information by the Department of Treasury, out of the total of 569 banks currently operating in the United States, 304 accept the Matrícula, while 265 do not. Adversaries still exist, including a boycott movement with a website where individual information can be found on each existing bank in the U.S., whether it accepts the Matrícula or not [Bankofamericaboycott.com, 2015]

However, the democratic and decentralized political system of the United States made it possible to achieve this important contribution to remittances flows and development. Also, very importantly to the U.S. treasury, the Matrícula can be used to obtain an Individual Taxpayer Identification Number (ITIN) in order to pay federal income taxes. While the almost 6 million Mexican citizens, who live currently in the United States in an irregular legal status, did not receive neither a residence permit nor a U.S. identity document, they can open bank accounts, obtain drivers' license, pay taxes, access to basic healthcare institutions and even marry at Mexican consulates using the Matrícula. [Aguilar, 2015] Therefore, it seems to be a way to create a modus vivendi for migrants through extended consular activity.

\subsection{Fostering return migration and diaspora investment in Latin America}

Return migration is almost as crucial as remittances in developmentally oriented policymaking towards the diaspora. As already described in Chapter 1.2.1.2, investment remittances (Definition D in Table 6.) are a significant part of the total amount of financial transfers between the country of destination and the country of origin. Ideally, a 'migration lifecycle' ends when a wealthy, skillful migrant returns to their country/region/municipality of origin and invests their savings in a 
productive enterprise that can provide jobs to locals and thus contributing to the decrease of the migration pressure on the population - especially the youth.

While this is the dream of policymakers, migratory processes are not very likely to end this way. In the following, a conceptual overview and categorization of return migration takes place, followed by the presentation of policy approaches of Latin American governments towards the issue of return migration (including those attempts that come from other governments to 'send back' migrants). Finally, a case study is presented on a microfinancing mechanism for productive investments, the Ecuadorian "Cucayo" Fund, operating between 2008 and 2013.

\subsubsection{Return migration to Latin America: why and how migrants would go back?}

When and how do migrants decide to move back to their country of origin? Jorge Durand [2004] points out that explaining return migration is problematic on the basis of the 'migration theories', i.e. theories for the original migration decision, as they focus on the profit-maximizing, risk-minimizing or structural reasons that launch people on the migration track. However, return migration is not the inverse of the original migration decision. Wage differences, risk and structural factors may change, but they can remain intact as well, it is only the migrants' subjective assessment of circumstances or personal goals that might change and lead to voluntary return. Forced return is another issue which should be treated as a separate category.

Durand sets up a typology of five groups for return migration. The first one covers those migrants who, after a long time period spent abroad and with all of their savings, return to their country of origin with the purpose of living there for the rest of their lives. The majority are elderly people who finish their working career and remain inactive upon return, while a minor group keeps on working, starting a business with the capital gathered abroad. The second group is made up by those who, after a short and temporary phase of migration, return either because their permit has expired, or because they succeeded in obtaining the money or skills they wanted to, and they had originally planned migration as a one-dimensional project which should be finished after achieving the stated objectives. The third group is called "transgenerational" by Durand, as they are second-generation migrants who 
were already born in the country of destination but, for any of the different possible reasons, they decide to move to the country of origin of their parents. The fourth group covers the extradited, or those who were forced to leave due to their undocumented status and police arrest. Finally, the fifth group is for the "failed" (fracasado). These migrants could not 'make it', they neither became integrated members of the host society, nor did they become successful outsiders who could leave after saving a sufficient amount of money, but they decided to return to the country of origin in order to minimize losses.

In the Latin American context, Durand's typology is very important because it shows clearly that return migration is not necessarily a transfer of money and human capital from the country of origin perspective. The fourth and the fifth groups, i. e. the extradited and the failed, can even be a destabilizing factor, as in the case of the notorious Mara Salvatrucha gang, whose members, originally mostly Salvadorans living in California, continued their criminal activities after being forcefully repatriated to their Central American countries of origin. [Ramsey, 2012]

While the third, "transgenerational" category is not really relevant in Latin America (or, better said, it is relevant in the other way round, i. e. the second and third generation Spanish-, Italian- and Jewish-Argentines who migrated 'back' to the country of origin of their parents or grandparents - see 2.1.1), a great developmental potential lies in the first and the second categories, the economically successful longterm or short-term migrants who return.

Boundaries of the latter two categories are, nonetheless, rather blurry. Durand [2004, p. 105] quotes the bonmot of European policymakers of the 1980, stating that "nothing is so permanent than temporary migration". The individual cost-benefit analysis that supposedly fully rational migrants build their decision upon to stay longer than originally planned, has been a key area of study ever since. [Berninghaus - Seifert-Vogt, 1988]

It is arguable, therefore, to simplify Durand's five ideal types to a binary opposition understood from the perspective of the country of origin's government. On one hand, there are the 'net gain' returnees who bring back capital, skills and entrepreneurial know-how. On the other, 'net loss' returnees who need assistance and/or are a threat to national security. Governments of countries of origin are obviously interested in receiving more 'net gain' returnees than 'net loss' ones. 
However, most of the returnee groups are not easily classifiable as 'winners' or 'losers': their assets and weaknesses show a way more complex picture. Table 38 therefore makes an attempt to describe the returnee ideal types according to the 'success' of their migration project, their supposed effects on development and their specific needs that should be covered by public policies.

Table 38. Returnee ideal types according to their supposed effects on development and their policy needs.

\begin{tabular}{|c|c|c|c|}
\hline $\begin{array}{l}\text { Overall } \\
\text { assessment }\end{array}$ & $\begin{array}{l}\text { Returnee } \\
\text { category }\end{array}$ & Effects on development & Policy needs \\
\hline \multirow[t]{2}{*}{ Success } & Entrepreneur & $\begin{array}{l}\text { + Brings savings } \\
+ \text { Founds a business }\end{array}$ & $\begin{array}{l}\text { Market orientation, tax } \\
\text { exemption, microcredit, } \\
\text { grants }\end{array}$ \\
\hline & Pensioner & $\begin{array}{l}\text { + Brings savings } \\
\text { ? Not necessarily invests it } \\
\text { in a productive business }\end{array}$ & $\begin{array}{l}\text { Incentives for productive } \\
\text { investment, healthcare }\end{array}$ \\
\hline Failure & $\begin{array}{l}\text { 'Rejected' } \\
\text { returnee }\end{array}$ & $\begin{array}{l}\text { - Does not bring savings } \\
\text { nor skills } \\
\text { - May find it difficult to } \\
\text { get re-inserted again in the } \\
\text { local society }\end{array}$ & $\begin{array}{l}\text { Social and/or healthcare } \\
\text { programmes, labour } \\
\text { market orientation, } \\
\text { psychological aid }\end{array}$ \\
\hline \multirow[t]{3}{*}{ Ambiguous } & $\begin{array}{l}\text { Circular } \\
\text { migrant }\end{array}$ & $\begin{array}{l}+ \text { Brings some savings } \\
\text { (concrete goal) } \\
? \text { Will leave again if } \\
\text { money is needed }\end{array}$ & $\begin{array}{l}\text { Incentives for productive } \\
\text { investment, labour market } \\
\text { orientation }\end{array}$ \\
\hline & $\begin{array}{l}\text { Prospective } \\
\text { mother }\end{array}$ & $\begin{array}{l}\text { ? Brings savings or not } \\
+ \text { Will give birth to } \\
\text { children }\end{array}$ & $\begin{array}{l}\text { Healthcare, basic } \\
\text { education facilities, labour } \\
\text { market orientation }\end{array}$ \\
\hline & Caretaker & $\begin{array}{l}\text { ? Brings savings or not } \\
+ \text { Will take care of elderly } \\
\text { family members }\end{array}$ & $\begin{array}{l}\text { Social and/or healthcare } \\
\text { programmes }\end{array}$ \\
\hline
\end{tabular}

Source: own compilation.

As it can be seen in Table 38, categories are rather ambiguous, as 'developmental' effects are not always measurable in economic terms (in line with the content of Table 5). Actually, the main driving force behind the return can be emotional and/or family-related in many of cases. Returnees can decide to go back either because their parents need caretaking, or their elderly parents died and left a heritage which, completed with the migrants' savings, could serve as a base of further economic activities. Also, childbearing can be a main motivation to return to the place of origin where family members could help to the young parents. These are 
(or can be) developmentally positive stories, however, they are difficult to measure. [Wang - Fan, 2006]

Furthermore, sociocultural integration in the country of destination can affect negatively the likeliness of return, while structural integration through the labour market might leave it intact. Investments (or plans thereof), and personal ties to people in the country of origin affects positively the return ambitions' likeliness of being realized, thus there is a strong psychological drive behind return migration, not always describable in terms of economic rationality. [de Haas et al, 2009]

Therefore, from a policy perspective, it is important that governments of countries of origin build up a framework for return migration policies in which several 'profiles' can be handled, including the vulnerable deported migrant, the young entrepreneur, the pensioner or the child who has to take care of their elderly parents. Chapter 3.3.2 shows that many Latin American countries have conceived and implemented differentiated return migration policies for specific groups: however, the intensity and structural development of these policy activities vary wildly from country to country.

\subsubsection{Return migration programmes in the institutional structure of Latin American governments}

When it comes to policymaking on return migration, two important analytical questions have to be posed. The first is about the targeted returnee group, i. e. what sort of returnee ideal type is in the mind of the policymakers. As it is presented above in Table 38, different groups have different policy needs, and Latin American countries have very diverse policies in this respect. Argentina, for example, targets the most 'successful' and the most 'failed', Ecuador has a special focus on entrepreneurs and Mexico on circular migrants (see below). In terms of development, the entrepreneurial focus deserves a special attention, thus the case study in 3.3.3. will present a programme of this kind.

The second question is whether it is the country of origin, or the country of destination that initiates the return process. As immigration has become a sensible issue in most countries of destination, especially with the economic crisis, a rather open discourse began in politics on 'sending them back to where they came from'. Securitization of immigration policies and anti-immigrant legislative attempts are not 
a topic of this thesis, thus only those programmes will be mentioned that effectively seek reinserting returnees in the society and labour market of their country of origin, most notably Spain's and the IOM's initiatives.

Once the target group and the actor are defined, different areas and goals of policy interventions can be identified. In the following, an overview of return incentive policy patterns is presented, ranging from the assistance in the process of return to the subsidies for socio-economic reinsertion. Institutionally, the actor in these activities is the government of the country of origin, more precisely the Diaspora Unit within the Ministry of Foreign Affairs (see Chapter 2.2.) which manages or supervises the implemented policies. Different institutional and operational setups are presented below. The overview will be followed by a short presentation of return incentive programmes ran by other actors (international organizations, governments of countries of origin).

Table 39 summarizes the different types of return migration incentive policies, managed or coordinated by Diaspora Units. Most of these activities are focused on returnees who are supposed to bring back human and financial capital. Nonetheless, humanitarian aid for returnees in a vulnerable situation is also present in the list.

Table 39. Types and examples of return migration incentives in Latin America

\begin{tabular}{|l|l|l|}
\hline \multicolumn{2}{|l|}{ Return incentive } & Example \\
\hline \multicolumn{2}{|l|}{ Information material } & "Manual of Return", Chile \\
\hline Assistance in the process of return & Paisano Programme, Mexico \\
\hline $\begin{array}{l}\text { Subsidizing } \\
\text { the return }\end{array}$ & Humanitarian & "Indigent citizens" Programme, Argentina \\
\cline { 2 - 3 } & Highly skilled & RAÍCES, Argentina (see Chapter 3.5.2) \\
\cline { 2 - 3 } & Entrepreneur & Cucayo Fund, Ecuador (see Chapter 3.3.3) \\
\hline Tax exemptions upon return & Law N $N^{\circ}$ 30001, Peru \\
\hline Microcredit for starting a business & Cucayo Fund, Ecuador (see Chapter 3.3.3) \\
\hline Sectorial benefits and help & MFA agreements, Uruguay \\
\hline
\end{tabular}

Source: DUS [2014-2015], Buira [2006], Palma - Ángeles [2009], Moncayo [2011], Texidó Gurrieri [2012], Manual del Regreso [2013]

The basic piece of policy items that most Latin American countries have designed and implemented, is an informative material, available either online or in 
print form at the consulates, that help migrants to effectively plan and organize their journey back home. This sort of 'technical' help can be a simple listing of addresses and websites, as in the case of Brazil's or Bolivia's "Guide for the return", or a set of available funding opportunities for traveling and job seeking.

Chile's Manual of return [Manual del Regreso, 2013] is one of the most detailed: it contains around 300 pieces of concrete information in a 'questions and answers' format, organized in 10 thematic groups, ranging from citizenship and consular issues to schooling, social security and banking in Chile.

Besides providing information, several countries provide paid return opportunities - however, only for the highly skilled migrants, as an attempt to tackle with the challenges of brain drain. Argentina's RAICES programme is the largest of this kind, but Uruguay and Venezuela also have a framework for repatriating scientists. [Texidó - Gurrieri, 2012] This will be presented in 3.5.2, as it belongs to the specific topic of brain drain policies.

Argentina also has a programme for repatriating 'indigent' citizens (connacionales indigentes), i. e. those who for some reason remained without the sufficient means to return to their country of origin but they are willing to do so. [Buira, 2006] Similar 'emergency' programmes exist in other countries as well, for example in Mexico, where a programme covers the expenses of repatriation of ill migrants who have no access to a decent medical treatment in the United States. Furthermore, Mexico has a broad programme of protecting migrants who go back to their locality of origin, generally once a year, from the perils which they might face on the way (including the state's own corrupt officials). The Paisano programme is coupled with a healthcare programme as well, the "Go Healthy, Come Back Healthy" programme, which takes the opportunity of these visits to provide healthcare assistance to migrants. [Palma - Ángeles, 2009]

When it comes to the actual return of migrants, it is the repatriation of personal belongings and valuable objects (such as a car) that can be fostered by policies on tax exemptions. Taking returning migrants out of the scope of regular customs procedures is of a high developmental relevance, thus many Latin American countries have created incentives of this kind. Table 40 summarizes the information collected in the Diaspora Unit Survey [2014-2015]. 
Table 40. Tax exemptions for returning migrants in Latin America

\begin{tabular}{|c|c|}
\hline Country & $\begin{array}{l}\text { Legal basis and most important items with tax exemption (per } \\
\text { returning migrant) }\end{array}$ \\
\hline Argentina & \begin{tabular}{|l} 
Resolution $3109 / 11$ of the Federal Administration of Public Incomes \\
- A car (used) \\
- Personal belongings \\
- Items related to profession or investment \\
\end{tabular} \\
\hline \multicolumn{2}{|l|}{ Bolivia } \\
\hline Brazil & \begin{tabular}{|l} 
Resolution of the Ministry of Economy IN RFB n ${ }^{\circ} 1.361,2013$. \\
- $\quad$ Domestic items and furniture \\
- Items related to profession
\end{tabular} \\
\hline Chile & $\begin{array}{l}\text { - Domestic items and items related to profession, in a value of } 3000 \text { USD (if the } \\
\text { migrant spent 1-5 years abroad), } 5000 \text { USD (more than } 5 \text { years abroad) } \\
\text { - A car (new or used) }\end{array}$ \\
\hline Colombia & $\begin{array}{c}\text { Law } 1565 \text { (Law of return) } \\
\bullet \quad \text { Domestic items }\end{array}$ \\
\hline Costa Rica & - Domestic items \\
\hline \multicolumn{2}{|l|}{ Cuba } \\
\hline \multicolumn{2}{|l|}{$\begin{array}{l}\text { Dominican } \\
\text { Republic }\end{array}$} \\
\hline Ecuador & $\begin{array}{l}\text { Sistema 4x4: tax exemption for } 12 \text { packages of a total value not higher than } 2400 \text { USD } \\
\text { per year and per migrant. } \\
\text { In the case of definitive return: } \\
\text { - A car (used or new) } \\
\text { - Personal belongings } \\
\text { - Items related to profession or investment }\end{array}$ \\
\hline \multicolumn{2}{|l|}{ El Salvador } \\
\hline \multicolumn{2}{|l|}{ Guatemala } \\
\hline \multicolumn{2}{|l|}{ Honduras } \\
\hline Mexico & $\begin{array}{l}\text { "There is no distinction between migrant and non-migrant Mexican citizens" [DUS } \\
\text { Mexico, 2015] }\end{array}$ \\
\hline \multicolumn{2}{|l|}{ Nicaragua } \\
\hline \multicolumn{2}{|l|}{ Panama } \\
\hline \multicolumn{2}{|l|}{ Paraguay } \\
\hline Peru & \begin{tabular}{|l} 
Law $\mathrm{N}^{\circ} 30001$ on the Economic and Social Reinsertion of the Returning Migrant \\
- Domestic items \\
- A car (max. 30,000 USD value) \\
- Professional and investment items (max. 150,000 USD value) \\
\end{tabular} \\
\hline Uruguay & $\begin{array}{ll}\text { - } & \text { A car (used or new) } \\
\text { - } & \text { Personal belongings } \\
\text { Items related to profession }\end{array}$ \\
\hline Venezuela & \\
\hline
\end{tabular}

Source: DUS [2014-2015]

Furthermore, there are many issues in which a returning migrant (especially if they return to the county of origin after a long period of absence) needs assistance. This ranges from finding a job, a house, a school for the children, through 
administrative issues regarding social security and healthcare, to possible investments in economic activities. Diaspora Units can provide help in two ways: either as a coordinator of activities undertaken by other public bodies, or as administrators of their own programmes, with a separate budget. The first one seems to be more cost-effective, while the second one might have a bigger impact. Both approaches are presented below, the first through the example of Uruguay, while the second is through selected policy efforts from Colombia, Peru and Ecuador (the latter also including the programme analyzed in 3.3 .3 as a case study).

Uruguay's Diaspora Unit within the Ministry of Foreign Affairs is a good example for achieving results through agreements with other public bodies. According to the information obtained from DUS Uruguay [2014], the Ministry has agreements and cooperation mechanisms with the following entities:

Table 41. Fostering return migration through agreements: the case of Uruguay

\begin{tabular}{|c|c|}
\hline $\begin{array}{l}\text { Existing agreement of the Ministry of } \\
\text { Foreign Affairs of Uruguay with: }\end{array}$ & Subject of the agreement \\
\hline $\begin{array}{l}\begin{array}{l}\text { Administration of State Health Services } \\
\text { (ASSE) }\end{array} \\
\end{array}$ & Free healthcare service during one year \\
\hline Ministry of Housing (MVOTMA) & $\begin{array}{l}\text { Warrant for renting a flat; in cases of high } \\
\text { vulnerability, subvention to the rent }\end{array}$ \\
\hline Mortgage Bank of Uruguay (BHU) & $\begin{array}{l}\text { Warrant for buying a flat (on a case by case } \\
\text { basis) }\end{array}$ \\
\hline Post of Uruguay & $\begin{array}{l}\text { Transfer of remittances free of charge (from } \\
\text { Spain) to a real estate account at the Mortgage } \\
\text { Bank of Uruguay (BHU) }\end{array}$ \\
\hline Ministry of Labour and Social Security (MTSS) & $\begin{array}{l}\text { Distributing CVs among all Public Labour } \\
\text { Centres }\end{array}$ \\
\hline $\begin{array}{l}\text { Chambers of Business, Construction and } \\
\text { Industries }\end{array}$ & Distributing CVs \\
\hline $\begin{array}{l}\text { Faculty of Psychology of the University of the } \\
\text { Republic of Uruguay }\end{array}$ & $\begin{array}{l}\text { Psychological help for the 'involuntary' returnees } \\
\text { (deported or not admitted) }\end{array}$ \\
\hline Ministry of Social Development (MIDES) & $\begin{array}{l}\text { Providing vulnerable returnees with identity } \\
\text { documents }\end{array}$ \\
\hline $\begin{array}{l}\text { National Administration of } \\
\text { Telecommunications (ANTEL) }\end{array}$ & $\begin{array}{l}\text { Free phone chip (SIM card) with a charge of } 20 \\
\text { USD, reduced price for establishing landline } \\
\text { phone and broadband internet connection }\end{array}$ \\
\hline Workers' University of Uruguay (UTU) & Validation of skills acquired abroad \\
\hline State Insurance Bank (BSE) & $\begin{array}{l}\text { Discount on insurance of property }(20 \%) \text { and } \\
\text { vehicles }(15 \%)\end{array}$ \\
\hline
\end{tabular}

Source: DUS Uruguay [2014]

As it can be seen in Table 41, almost all main areas are covered by an agreement, which is a rather impressive achievement from a very small Diaspora Unit (The Office of Return and Welcome, see Table 28). On the other hand, 
effectiveness of these measures is out of scope for the Diaspora Unit: as the Ministry of Foreign Affairs is not directly involved in the day-by-day functioning of these services, these might or might not address properly the needs of returning migrants.

At the time of research (ending in 2015) there was only three countries that had a comprehensive policy framework to foster return and investment and they had a developed Diaspora Unit in the centre of their activities. Official assistance to resolve a wide range of legal and labour market issues is available in Colombia, Ecuador and Peru, and all three countries provided microcredit for investment until 2013. Furthermore, Peru also offered credits for buying immobiliary upon return. [Moncayo, 2011] Changes in the Ecuadorian model will be presented in the case study.

Incentive programmes of the three Andean countries with the most developed and comprehensive return migration policy framework in Latin America is presented in Table 42.

Table 42. Fostering return migration through comprehensive programmes: the case of Ecuador, Colombia and Peru (2011)

\begin{tabular}{|c|c|c|c|}
\hline \multirow{2}{*}{ Objective } & \multicolumn{3}{|c|}{ Programme name } \\
\hline & Ecuador & Colombia & Peru \\
\hline $\begin{array}{l}\text { Assistance for finding a } \\
\text { job }\end{array}$ & & $\begin{array}{l}\text { Plan of Return of the } \\
\text { National } \\
\text { Apprenticeship Service } \\
\text { (Servicio Nacional de } \\
\text { Aprendizaje) }\end{array}$ & $\begin{array}{l}\text { Special Programme } \\
\text { for Laboral } \\
\text { Reconversion } \\
\text { "Revalora Perú" }\end{array}$ \\
\hline $\begin{array}{l}\text { Tax exemption for } \\
\text { repatriating durable goods }\end{array}$ & $\begin{array}{l}\text { "Bienvenid@s a } \\
\text { Casa"Programme }\end{array}$ & $\begin{array}{l}\text { Law on Voluntary } \\
\text { Return }\end{array}$ & $\begin{array}{l}\text { Law on Migration } \\
\text { Incentives }\end{array}$ \\
\hline $\begin{array}{l}\text { Legal and administrative } \\
\text { assistance }\end{array}$ & $\begin{array}{l}\text { "Volver a Casa" } \\
\text { Programme }\end{array}$ & $\begin{array}{l}\text { Assistance programme } \\
\text { for Returning Migrants } \\
\text { and their Families }\end{array}$ & \\
\hline $\begin{array}{l}\text { Microcredit and/or non- } \\
\text { refundable grant for } \\
\text { investments }\end{array}$ & $\begin{array}{l}\text { "Cucayo" Fund, } \\
\text { "Banca del } \\
\text { Migrante" credits }\end{array}$ & $\begin{array}{l}\text { "Retorno Productivo } \\
\text { Positivo" Programme }\end{array}$ & $\begin{array}{l}\text { National SME } \\
\text { Register }\end{array}$ \\
\hline $\begin{array}{l}\text { Credit for buying } \\
\text { immobiliary }\end{array}$ & & & $\begin{array}{l}\text { "MIVIVIENDA" } \\
\text { Fund }\end{array}$ \\
\hline
\end{tabular}

Note: Ecuador's programmes have been reorganized in 2013. See case study in 3.3.3.

Source: Moncayo [2011, pp. 5-7]

Besides these efforts, it has been already mentioned that not only countries of origin, but countries of destination also have policies for repatriating migrants. Forced repatriation is not treated here, nor the "Voluntary Departure" option that the United States offers for migrants who are issued a removal order, but they can opt to 
go 'voluntarily' on their own expense, and avoid a final order of removal which might be coupled with a ban of re-entering the US in the following ten years. [Immigration Equality, 2014]

What indeed needs to be briefly presented here is the set of "noncoercive" or "pay-to-go" programmes that several Western European countries designed and implemented from the 1970s onwards. They have been addressing (mostly undocumented) migrant populations in order to convince them to go back voluntarily to their country of origin, offering them economic incentives on one hand, and the threat of forced removal, on the other. Being a 'carrot and stick' policy rather than a really 'voluntary' cooperation of migrants with the government, it has never achieved large-scale results. Reasons of moderate success include high costs, lack of will from the migrants' side to go back, and the high propensity of migrants who, later on, decide to migrate once again. [Black et al, 2011]

As a consequence of the financial crisis starting in 2008, all major Western European countries started a voluntary return programme, many of them operated by the International Organization for Migration's national branches. IOM programmes helped 9,400 Latin American citizens to return from Europe in the 2003-2010 period. The European Union also created the European Fund for Return, with a budget of 676 million euros for the 2008-2013 period. [Black et al, 2011; Texidó - Gurrieri, 2012]

A special case to be mentioned separately is the Plan of Voluntary Return (Plan del Retorno Voluntario) in Spain, as it is the most important country of destination for Latin Americans in Europe. Following 2008, Spanish economy practically collapsed, the construction and services sectors sagged, unemployment rate among migrants grew to $50 \%$ and tensions rose, thus the Zapatero government launched the Plan of Voluntary Return in 2009, which provided returning migrants with the amount of one year's unemployment subsidy and the costs of travel, with the condition of not going back to Spain in the forthcoming five years. Autonomous communities like Catalonia also had similar programmes. [Castillo, 2011; Ljungkvist, 2011] Problems have been similar to those described by Black et al [2011], i. e. low participation rate and high costs.

Despite many shortcomings, it created bilateral frameworks for cooperation and social benefit transfers with 20 countries, most notably with Ecuador, from where a case study is presented in the following. 


\subsubsection{Case Study: The Ecuadorian Cucayo Fund}

\section{Case Study Overview Table 2. The Ecuadorian Cucayo Fund}

\section{The Ecuadorian Cucayo Fund}

A government fund made it possible for individual returnees, or cooperatives/NGOs with migrant members to receive a non-reimbursable grant from the Ecuadorian state, coupled with technical assistance, in order to found productive enterprises in their localities of origin. The government received international aid for funding the programme. A 50\%-75\% of the cost of the project was covered by the migrants themselves, and the jobs they created were mostly filled by their family members and kins. The Fund existed between 2008 and 2013.

\section{I.) Policy Window}

1.) Problem Stream

Ecuadorian migrants who have saved some money abroad find it difficult to make a living as the countries of destination (mostly Spain and Italy) enter into economic recession. Parallelly, the country of origin would need investments but investors do not reach rural communities.

2.) Political Stream

Rafael Correa is elected as president in 2007. He campaigned with migrant-related issues. Spain and other European countries transfer considerable sums of money as development assistance, and they expect the reduction of migratory flows.

3.) Policy Stream

Co-development programmes are launched, focusing mostly on return migration and investment of migrant savings in rural areas, co-financed by the Ecuadorian government.

\section{II.) Policy Deal}

\begin{tabular}{|l|l|}
\hline 1.) Government Benefits & $\begin{array}{l}\text { Capturing migrant savings (50-75\%) for job-creating projects } \\
\text { and coping with international requirements for tackling the } \\
\text { emigration challenge. }\end{array}$ \\
\hline 2.) Migrant Benefits & $\begin{array}{l}\text { Receiving governmental non-reimbursable grants (25-50\%) for } \\
\text { a job-creating investment that benefits, first and foremost, the } \\
\text { family and closer social circle of the migrant. }\end{array}$ \\
\hline $\begin{array}{l}\text { 3.) Sending Community } \\
\text { Benefits }\end{array}$ & $\begin{array}{l}\text { Jobs are created, although mostly for the family and closer } \\
\text { social circle of the migrant. }\end{array}$
\end{tabular}

III.) Policy Mechanism

Level Country of destination Transnational space Country of origin

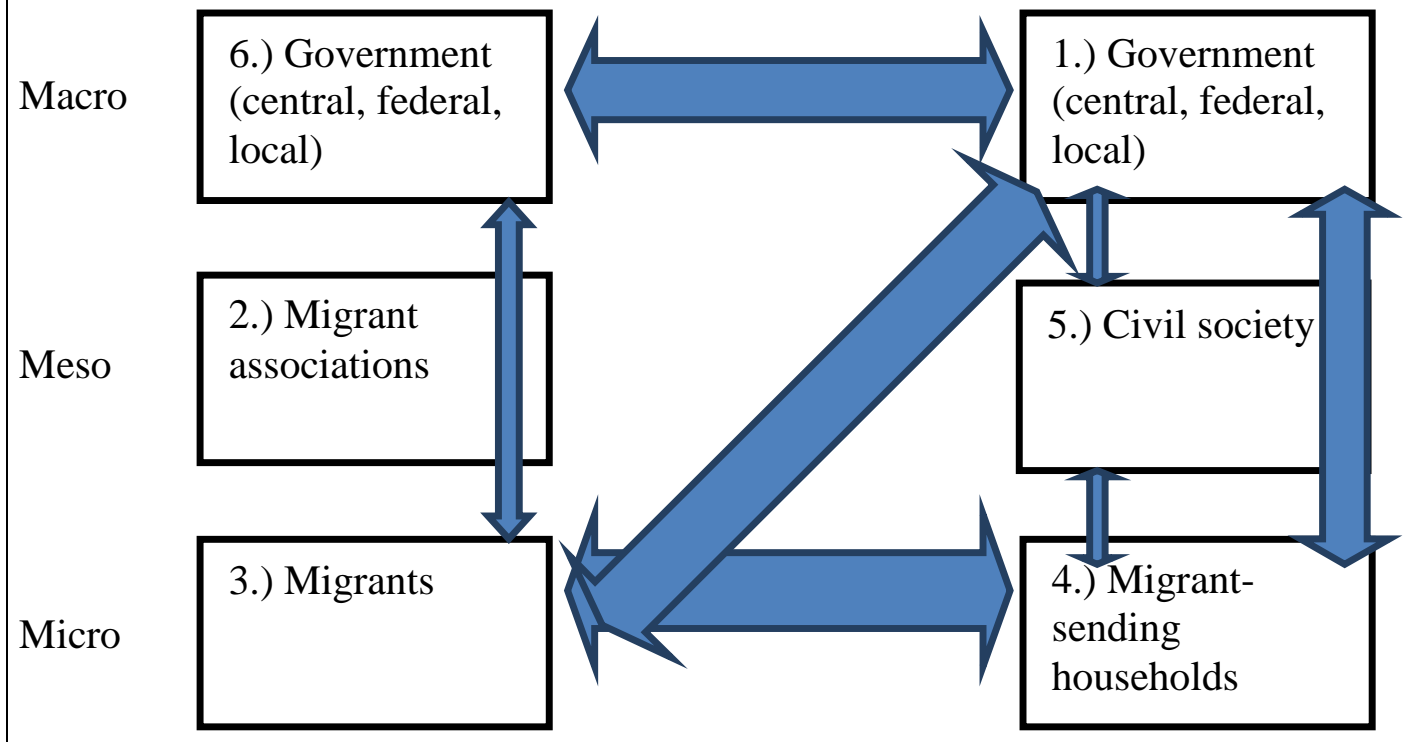




\begin{tabular}{|c|c|}
\hline $\begin{array}{l}\text { 1.) Government (Country of } \\
\text { origin) }\end{array}$ & $\begin{array}{l}\text { Provides a } 25-50 \% \text { non-reimbursable grant and technical } \\
\text { assistance for returning migrants if they invest it in productive } \\
\text { businesses. It receives international aid in the meantime, from } \\
\text { the government of the country of destination. }\end{array}$ \\
\hline 2.) Migrant associations & Negligible role. \\
\hline 3.) Migrants & $\begin{array}{l}\text { Apply for grants at the government of the country of origin and } \\
\text { if they win, they move back and found an enterprise. }\end{array}$ \\
\hline $\begin{array}{l}\text { 4.) Migrant-sending } \\
\text { households }\end{array}$ & Become employees of a newly created enterprise. \\
\hline $\begin{array}{l}\text { 5.) Civil society (Country of } \\
\text { origin) }\end{array}$ & $\begin{array}{l}\text { Becomes beneficiary and multiplier of benefits (cooperatives } \\
\text { etc.) }\end{array}$ \\
\hline $\begin{array}{l}\text { 6.) Government (Country of } \\
\text { destination) }\end{array}$ & $\begin{array}{l}\text { Facilitates (pushes forward) the efforts of the government of } \\
\text { the country of origin. Donates money. }\end{array}$ \\
\hline \multicolumn{2}{|l|}{ IV.) Policy Impact } \\
\hline 1.) Managing Authority & $\begin{array}{l}\text { SENAMI (Secretariat for Migrants at the Ministry of Foreign } \\
\text { Affairs) }\end{array}$ \\
\hline 2.) Budget & Approx. 2 million USD per year \\
\hline 3.) Number of Beneficiaries & Approx. 2100 per year \\
\hline $\begin{array}{l}\text { 4.) Average Benefit per } \\
\text { Beneficiary }\end{array}$ & 950 USD \\
\hline $\begin{array}{l}\text { 5.) Impact on Local } \\
\text { Development }\end{array}$ & High \\
\hline 6.) Impact on Migratory Flows & Moderate \\
\hline 7.) Relative Significance & Medium \\
\hline \multicolumn{2}{|l|}{ V.) Policy Lifespan } \\
\hline $\begin{array}{l}\text { 1.) Timeline of } \\
\text { implementation }\end{array}$ & $\begin{array}{l}\text { First implemented in 2008, it had its peak around } 2011 . \\
\text { Critiques were formulated on its high costs and narrow circle } \\
\text { of recipients. In 2013, a large-scale reorganization of the } \\
\text { Managing Authority (SENAMI) took place and the Cucayo } \\
\text { Fund ceased to exist. }\end{array}$ \\
\hline 2.) Perspective & $\begin{array}{l}\text { Although a good showcase of many success stories, it was too } \\
\text { costly and very few returnees did actually benefit from it. In } \\
\text { 2013, the Ecuadorian government shifted towards policies of } \\
\text { lower investment (but broader scope). }\end{array}$ \\
\hline
\end{tabular}

Source: own compilation.

The Cucayo Fund was created by the government of Ecuador in 2008, through restructuring the Fund of Aid, Savings and Inversion for Ecuadorian Migrants and their Families (Fondo de Ayuda, Ahorro e Inversión para los Migrantes Ecuatorianos y sus Familias) which had been existing since 2002. The creation of the Fund formed part of a broader change of direction in public policies 
initiated by president Rafael Correa who came into power in 2007. Before, the Ecuadorian government did not really take measures to tackle with mass emigration, but the Correa government made it explicit that 'bringing back' migrants and channeling their savings in productive investments is a priority. [Castillo, 2011]

Mass emigration from Ecuador had been the result of the economic collapse in 1998-1999, when Ecuadorian society experienced a dramatic drop in living standards. Between 1999 and 2003, approximately 1.5 million people left the country, most of them to Spain, and to a lesser extent, Italy. Although the European Union pressured Spain for limitations in accepting Ecuadorian migrants, family reunification was treated in a very liberal way at the time, and there were several amnesties (regularizations) for the undocumented. Remittances (which accounted for an average of 5.9\% of Ecuador's GDP between 2001 and 2008) started to decrease already in 2007, the year before the unfolding of the global economic crisis, as entire households were being transplanted to Spain. [Boccagni - Lagomarsino, 2009]

Ecuador's economy is largely based on oil revenues which were heavily fluctuating in the 2000s and remittances were increasingly topping them. In an ambiance of economic and political instability, Bolivarian left wing presidential candidate Rafael Correa mentioned migration among the top social issues in his campaign. Upon election, already in 2007, the institutional bases of a new and comprehensive diaspora policy were set, very much focused on attracting back migrants to Ecuador. The National Secretary for Migrants (Secretaría Nacional del Migrante, SENAMI), was created as a special administrative body, with its director ranking as a minister. It administered the network of "Ecuadorian Houses" (Casas Ecuatorianas) in the main countries and areas of destination for Ecuadorian migrants (United States, Spain, Italy, United Kingdom), which provided information and legal aid for its clients. It also managed the set of programmes for return migration: the "Welcome home” (Bienvenid@s a casa) programme published job offers, mitigated duty free import of personal goods and provided legal assistance for return.

Two of Bienvenid@s a casa's subprogrammes provided financial incentives for return, the Migrant Bank (Banca del Migrante) provides microcredit, while the Cucayo Fund (Fondo Cucayo, to be presented in details in the following) provided matching funds to investments and founding small enterprises. The third subprogramme, Human Talent (Talento Humano) supported Ecuadorian students abroad and maintained a network of professional information exchange among them 
and among high-qualified Ecuadorians in the diaspora. [Herrera, 2011; Ljungkvist, 2011]

President Correa's personal engagement might be a main reason why Ecuador has built up, only in a couple of years' time, one of Latin America's most solid institutional framework for diaspora policies. However, it does not explain why fostering return migration is so central in his efforts. It is rather a consequence of external factors, the most important being the global crisis that hit Spain very heavily (and it affected, to a lesser extent, other countries of destination as well) and the discourse and policymaking on return appeared, resulting in the Plan of Voluntary Return. It also has to be mentioned that the Ecuadorian community in Spain was among the freshest, and it was very poorly integrated to Spanish society, thus return seemed to be a feasible option for many of them. [Castillo, 2011; Ljungkvist, 2011]

The Cucayo Fund was under the administration of SENAMI. It received applications since late 2008, its budget for the first three years was 6.25 million US dollars, and it provided a single and not reimbursable subsidy for Ecuadorian citizens who had been living abroad for at least one year. Applications could be made with a business plan and there were four grant types:

- Small grant (500-2500 USD) for family enterprises, with 50\% own share,

- $\quad$ Large grant (2501-15000 USD) for family enterprises, with 75\% own share,

- $\quad$ Grant for cooperatives ( of a minimum of 5 members, of which at least 2 are returning migrants) which adds 1501-50000 USD to a 75\% of own funds,

- Grant for communities (for two returning migrants and an NGO), also with a grant of $1501-50000$ USD adding up to a $75 \%$ of own share.

Besides the grant, beneficiaries receive technical assistance from a mentor during 8 months. In the first two years of the programme's operation, SENAMI transferred 2.99 million USD for a total of 230 projects, to which migrants contributed with 11.43 million USD. The projects created 4283 new jobs, mostly in the area of agriculture (31\%), services (27\%), light industry (17\%) and tourism (14\%). Only the $5 \%$ of the enterprises went bankrupt in the first two years. [SENAMI, 2011; Moncayo, 2011]

Information available on the programme focused mostly on individual success stories. Typical cases include a family-run photocopy and graphics salon in Quito which received a 5000 USD grant to a 75\% of own share [Mena Erazo, 2009], 
a cooperative which bred guinea pigs (a delicacy in Ecuador) and out of which 17 families made a living [Observatorio, 2011], or a women's NGO for organic farming which provided work to 101 women. [Moncayo, 2011]. The Cucayo Fund did, without any doubt, make important contributions to local development and job creation through returning migrants' investments. There were, however, shortcomings as well.

First and foremost, the programme's budget was far from being sufficient to make a considerable impact. In two years, 4283 jobs were created, while the Ecuadorian diaspora counts 1.5 million members. Even though the Cucayo Fund was very popular among prospective returnees, only the $9 \%$ of the applications are approved, due to lack of funds. Furthermore, many applicants could not put the requested own share into the business, and/or they did not have the professional skills to start and manage it properly. Many migrants had not obtained any sort of professional skills abroad, as they do a very simple manual work. In an assessment made by Moncayo [2011], only 40\% of the applicants reported to had learnt the profession during the emigration years. And, finally, two thirds of the applicants admitted that they would have returned anyway, with or without the Cucayo Fund's grant, it was only a sort of 'last push' that made them go back to Ecuador.

Regarding implementation, answers Moncayo received were generally positive, although there were critiques in two points. First, criteria for selection were seen as arbitrary. Second, technical guidance and mentoring were seen many times as unsubstantial, and the developed business plans did not work out in reality. But in general, the programme was relatively well implemented. Impact, however, was a more controversial issue. Family businesses may not be the best form of enterprise for development subsidy grants, as they usually employ family members and kins only. Cooperatives and NGOs employ more people and on a more democratic basis, however, Cucayo Fund's grants were by large received by family businesses. It is also an important feature that a $40 \%$ of grantees saw it possible that, if the business went bankrupt, they would emigrate again. [Moncayo, 2011]

To sum up, the Cucayo Fund's matching funds scheme was working and it actually benefited people. The main concern was, however, its seemingly biased nature: it privilegized those, relatively better-off and more skilled migrants who would have returned anyway. It may served as the 'last push' for those migrants who were planning return migration, but it could hardly go beyond that. 
The Fund's political benefits were also important. As it has been mentioned, Ecuadorian public opinion was targeted by media articles on individual success stories. Out of the 9 news articles analyzed [Rosero, 2009; El Mercurio, 2010; El Comercio, 2009a, 2009b; El Ciudadano, 2011; Reyes, 2010; Mena Erazo, 2009, 2011; Expreso Latino, 2009], only one expressed concerns related to the programme which went beyond the fact that the funding was not sufficient. It seems, therefore, that small enterprises set up by returning migrants with matching funds from the Ecuadorian government are a very appealing example to be included in the government's PR agenda, and the same applies to the country of destination, Spain, which also called several times for cooperation in order to 'bring back' migrants and provide them jobs in productive enterprises. Cucayo Fund was therefore a 'success story' that could be very well presented in the media, both in Ecuador and in Spain, as a tool to reduce migration. While, certainly, this was not the case.

Either because it fulfilled its political objective of being a poster child for policies attracting back migrants from Spain, or because it was too expensive to maintain, the Cucayo Fund did not survive the reorganization of SENAMI in 2013. Upon the reelection of Rafael Correa in 2013, the Ministry of Foreign Affairs was renamed as the Ministry of Foreign Affairs and Human Mobility and SENAMI was upgraded to the level of Viceministry. With this, the 'diaspora' issue gained a symbolic recognition, however, there was no significant upgrading of the budget and financial incentives for returning migrants were stopped. On the other hand, two important achievements were made: first, the launching of the Prometeo programme for attracting highly skilled researchers to Ecuador (to be presented in Chapter 3.5.2) and a shift toward the model represented by Uruguay in Table 41, that is, coordinating rather than financing the incentive programmes for return migration. From 2013 onwards, the Viceministry of Human Mobility have reorganized its policymaking on return migration, and it is now operating as a coordinator of activities of other governmental bodies, not as a management authority of its own programmes. Table 43 summarizes these changes. 
Table 43. Policy consequences of the reorganization of the Ecuadorian institutional framework related to return migration

\begin{tabular}{|c|c|c|}
\hline Policy area & $\begin{array}{l}\text { SENAMI (2007- } \\
\text { 2013) }\end{array}$ & $\begin{array}{l}\text { Viceministry of Human } \\
\text { Mobility (2013-) }\end{array}$ \\
\hline $\begin{array}{l}\text { Assistance for finding a } \\
\text { job }\end{array}$ & & $\begin{array}{l}\text { "Bolsa de empleo" job fair (Ministry of } \\
\text { Labour) }\end{array}$ \\
\hline $\begin{array}{l}\text { Tax exemption for } \\
\text { repatriating durable } \\
\text { goods }\end{array}$ & $\begin{array}{l}\text { "Bienvenid@sa Casa" } \\
\text { Programme }\end{array}$ & $\begin{array}{l}\text { Agreement with the National Customs } \\
\text { Service }\end{array}$ \\
\hline $\begin{array}{l}\text { Legal and administrative } \\
\text { assistance }\end{array}$ & $\begin{array}{l}\text { "Volver a Casa" } \\
\text { Programme }\end{array}$ & $\begin{array}{l}\text { Capacitation programme for migrants } \\
\text { and their family members (Ecuadorian } \\
\text { Service of Professional Capacitation) }\end{array}$ \\
\hline $\begin{array}{l}\text { Microcredit and/or non- } \\
\text { refundable grant for } \\
\text { investments }\end{array}$ & $\begin{array}{l}\text { "Cucayo" Fund, } \\
\text { "Banca del Migrante" } \\
\text { Credits }\end{array}$ & \\
\hline $\begin{array}{l}\text { Credit for buying } \\
\text { immobiliary }\end{array}$ & & $\begin{array}{l}\text { Credit "Bono de la vivienda" (Ministry } \\
\text { of Urban Development and Housing) }\end{array}$ \\
\hline $\begin{array}{l}\text { Schooling assistance for } \\
\text { children }\end{array}$ & & $\begin{array}{l}\text { Agreement with the Ministry of } \\
\text { Education }\end{array}$ \\
\hline $\begin{array}{l}\text { Healthcare assistance for } \\
\text { returnees }\end{array}$ & & $\begin{array}{l}\text { Plan "Ecuador Saludable, Voy por Ti" } \\
\text { (Ministry of Public Health) }\end{array}$ \\
\hline
\end{tabular}

Source: Moncayo [2011, pp. 5-7] and DUS Ecuador [2014]

As it can be seen, every previous policy field is covered (and many new areas are introduced), with the exception of non-refundable grants. Even though the Cucayo Fund was a well-designed, well-managed programme, it was too costly to keep it running after its novelty factor ended and the international (mostly Spanish) attention waned. Policymaking on return migration in Ecuador shifted to more costeffective (although less focused) interventions [El Telegrafo, 2014].

\subsection{Matching funds to community projects in Latin America}

Migrants, just like any other social groups, tend to organize themselves in informal or formal groupings. The common origins, culture, traditions (from the country of origin) as well as the common social, economic and political interests (in the country of destination) make migrant associativism an immanent feature of the diaspora landscape. Diasporas are organized around specific associations with specific goals that may or may not be in direct connection with the country of origin. However, whatever their common activities might be, the very fact that they gather in associations strengthen the internal ties of the diaspora and helps migrants to 
overcome many challenges that otherwise would be difficult to tackle, such as social marginalization, lack of information and lack of personal contacts.

As opposed to other civil society organizations, migrant associations' spatiality is a problematic feature. As the notion of 'transnational' social spaces conceptualizes it, migrants are never fully 'territorialized' in one geographical location: they have, although to a varying extent, a simultaneous belonging of two societies, cultures and locations. [Portes et al, 2005] Common bases for group forming, therefore, are simultaneously linked to 'country of origin' and 'country of destination' issues.

From the perspective of the government of the country of origin, a good relationship with migrant associations can be beneficial in many ways. Obviously, they are convenient intermediaries of information for the members of the diaspora, but they can also organize social and cultural events, courses, information exchanges and debates, and so on. And, perhaps most importantly from the point of view of the development of the country of origin, they can raise funds for humanitarian, charity, or development projects, to be implemented in the country of origin: in line with Chapter 1.2.1.3, these "community remittances" (Definition E) can be valuable sources of local development in the migrants' hometowns.

In the following, the description of the basic features of migrant associations and their possible linkages to the government of the country of origin are presented, followed by an overview of Latin American attempts to channel community remittances for development projects. Finally, a case study presents the most famous initiative of its kind, the Mexican 3x1 Programme for Migrants.

\subsubsection{Latin American migrant associativism in the country of destination}

Whenever migrants come together in the country of destination, they are faced with the in-betweenness of their existence. They recognize each other's regional, ethnic, religious and socioeconomic belongings (that the society of the country of destination might not be able to do), while they also need to reflect on how they are proceeding in their individual life paths in the country of destination. The double binding of immigrant communities has always been a complex issue - in the Latin American case, a whole branch of research, the Chicana/o Studies deals with the topic (for a key text, see Anzaldúa [1987]). 
In line with this double binding, migrant organizations are always defined from both sides, to which the content of the associational activity might come as third, for example in the case of the Association of Businesspeople from Oaxaca, Mexico in Los Angeles (Asociación Oaxaqueña de Negocios en Los Ángeles). Locality of origin, actual location and focus of interest define the circle of possible membership: however, it is not defined, which one of these features is understood as the most important one.

The locality of origin versus actual location dichotomy of immigrant associativism often translates to a dichotomy of attitudes: there are associations which are more conservative and they focus on traditions, and there are associations which are more confrontative and they want to achieve something. A typology set by Schrover and Vermeulen [2005], labels migrant organizations either as "defensive" or "offensive", depending on their relationship with the (different levels of) government of the country of destination. Migrant associations or groups based on their common features that they brought from their country (or locality) of origin are usually "defensive", while associations or groups formed around the common situation that they are facing in the country (or locality) of destination are usually "offensive".

"Defensive" migrant associations include hometown associations (HTAs), ethno-religious associations, established or ad hoc groupings for organizing a cultural event related to ethno-national identity, and so on. They defend the common elements of the members' identity which are related very directly to historical, cultural, geographic or lifestyle features of the country of origin. As long as they accept the laws and behavioural norms of the country of destination, the overall governmental approach to these associations is positive, although somewhat paternalistic. HTAs can be rather important actors on the diaspora scenery: rural emigration from Latin American countries, especially from Mexico to the United States, is largely determinated by network effects. Thus, in most cases, Mexican villages of mass emigration have their 'counterparts' in the United States, where most of the emigrants are heading to. For example, villagers of Tonatico, Estado de México often refer to Waukegan, Illinois as a "second Tonatico", as the overwhelming majority of the village's emigrants live in that specific town. There is a "Tonatico Social Club" in Waukegan which organizes social and sport events, 
performs charity acts and celebrates important festivities for the community. [González Ortiz - Rivera, 2004]

"Offensive" migrant organizations are exactly the opposite. They are focused on their situation in the country of destination, and their demands towards the (different levels of) government. The League of United Latin American Citizens (established in 1929) was the first of its kind in the United States. Later, the Chicano Movement in the United States in the late 1960s became a prominent example of cooperation between different Mexican/Latino organizations that were generally offensive in nature and which had a very heterogeneous membership. The Mexican American Legal Defense and Educational Fund (MALDEF), founded in 1968, and the Comisión Femenil Mexicana Nacional are among the most well-known examples. Their raison d'être has been openly conflictive with the US government policies. [Muñoz, 2013]

Paradoxically, the more "defensive" a migrant organization is, the less it helps for its members' integration, as it is intrinsically turned towards the country of origin. Broader, "offensive" organizations and pan-Latino alliances, on the other hand, put their members on the scene of politics and policymaking in the country of destination. From the point of view of the government of the country of origin, it also means that different migrant organizations are useful partners for different purposes. HTAs can be partners for local development projects (see the case study on the $3 \times 1$ Programme in 3.4.3.), while broader, lobbying-oriented organizations can take part in campaigns, such as the pro-Matrícula consular campaign (see the case study in 3.2.3.).

Another key feature of migrant organizations is that there are internal fault lines among them that make it almost impossible for one single organization to effectively represent all members of the diaspora of a given nationality in a given country. In the case of larger countries, the smaller locality (county, region) is sometimes more appealing than the national belonging, and ethno-racial (indigenous, Afro-descendant etc.) groups can also form separate organizations. Guarnizo [2006] describes the "plurifragmentation" of the Colombian diaspora in the United States: Colombian migrant 'society' reproduces the multiple fault lines that divide Colombian society. These run between classes and political camps, for which Colombian migrants usually form particular and/or informal groups. These cooperate only if a major negative event, i. e. a natural disaster or other unforeseen happening 
occurs which is not charged politically. This latter can be linked to the migrant condition: if a Colombian-American falls victim to violence in the United States, the diaspora can stand up together, and so do they when it comes to fundraising for charity or to celebrate 20 July, the Colombian national holiday. Besides these connection points, the diaspora is fragmented and its members have more connection to their local peers in their respective status groups, than to fellow Colombians (see also 3.5.3.).

Finally, the relationship of the migrant organization with the government of the country of origin can also be friendly, neutral or openly hostile. The most notorious case is that of the Cuban diaspora: anti-Castroist Cuban migrants have been very active in lobbying for maintaining the US embargo against the island and to oust the current administration from power. As the Cuban diaspora is very concentrated geographically (in Florida), socioeconomically (middle or highermiddle class, urban and entrepreneurial) and shares a common political ideology (moderate or radical anti-Castroism), the diaspora is very well organized, the largest lobbying group being the Cuban American National Foundation. However, militant zest is fading: according to a longitudinal study, the diaspora has moved towards a modus vivendi with the Cuban regime. While in 1993 (when overthrowing the communist regime seemed to be the most feasible), $87 \%$ of Cuban migrants supported the embargo (73\% would even have approved a US-backed military intervention), as of 2008 only $45 \%$ reported to agree with maintaining the embargo (and 65\% saw it important to re-establish regular diplomatic ties between the two countries). [Blanco, 2011] While the Cuban case is the most prominent, there are other anti-government diaspora groups from other Latin American countries as well, such as anti-chavista Venezuelan groupings, or the Frente Oaxaqueño Binacional, a militant organization of indigenous migrants from the Mexican state of Oaxaca.

Political circumstances can, however, change in the country of origin, forcing migrant organizations to a new form of alignment. In the case of Central American republics ravaged by civil war in the 1980s and 1990s, migrant organizations were founded on the principles of mutual aid and solidarity. Salvadoran migrants, for example, built an extensive network of diaspora organizations, such as Carecen and El Rescate (later pulled together under an umbrella organization, the SalvadoranAmerican National Network) which helped the reconstruction of the country after the war with large fundraising campaigns, investment roundtables and scholarships. 
However, many of them stayed in the United States with a refugee status which was, following the peace agreements, revised by US authorities. The newly elected Salvadoran government was therefore pressed by the diaspora to lobby for maintaining the refugee status for its economically beneficial migrants. In other words, El Salvador's government had to convince US officials that it is still unable to protect its citizens, who otherwise send large amounts of money for charity programmes and regularly visit the country. [Nosthas, 2006]

Table 44 summarizes the above described features from the point of view of the government of the country of origin.

Table 44. Ideal types of migrant organizations and their possible benefits to the government of the country of origin

\begin{tabular}{|l|l|l|l|l|}
\hline Orientation & $\begin{array}{l}\text { Group } \\
\text { forming } \\
\text { feature }\end{array}$ & Denomination & Typical activities & $\begin{array}{l}\text { Possible } \\
\text { benefits to the } \\
\text { government of } \\
\text { the country of } \\
\text { origin }\end{array}$ \\
\hline Defensive & $\begin{array}{l}\text { Locality, } \\
\text { region }\end{array}$ & $\begin{array}{l}\text { Hometown } \\
\text { Associations } \\
\text { (HTAs) }\end{array}$ & $\begin{array}{l}\text { Self-help, maintenance } \\
\text { of already existing } \\
\text { social ties, organizing } \\
\text { events, fundraising }\end{array}$ & $\begin{array}{l}\text { Fundraising for } \\
\text { local development } \\
\text { projects }\end{array}$ \\
\cline { 2 - 5 } & $\begin{array}{l}\text { Ethnic, } \\
\text { religious } \\
\text { and/or } \\
\text { national } \\
\text { identity }\end{array}$ & $\begin{array}{l}\text { Cultural and } \\
\text { social } \\
\text { organizations }\end{array}$ & $\begin{array}{l}\text { Maintenance of } \\
\text { common identity } \\
\text { elements, forming a } \\
\text { broader network of } \\
\text { communication, } \\
\text { fundraising }\end{array}$ & $\begin{array}{l}\text { Fundraising for } \\
\text { actions on the } \\
\text { national level } \\
\text { (mostly in the } \\
\text { humanitarian / } \\
\text { charity realm) }\end{array}$ \\
\hline Offensive & $\begin{array}{l}\text { Problem in } \\
\text { the country } \\
\text { of } \\
\text { destination }\end{array}$ & $\begin{array}{l}\text { Advocacy groups } \\
\text { the country } \\
\text { of origin }\end{array}$ & $\begin{array}{l}\text { Assessing migrant } \\
\text { conditions and lobbying } \\
\text { for their improvement } \\
\text { in the country of } \\
\text { destination }\end{array}$ & $\begin{array}{l}\text { Lobbying for policy } \\
\text { change in the } \\
\text { country of } \\
\text { destination }\end{array}$ \\
\hline
\end{tabular}

Source: own compilation.

Governments of the country of origin can approach diaspora organizations in many ways. The most formalized is the creation of councils or committees, in which distinguished members of the diaspora, often as presidents or spokespersons of a specific association, can have their say. These councils have been presented in Chapter 2.2.3.1 (summarized in Table 30). As already stressed there, among the possible topics of interaction and joint work, humanitarian, charity or development 
activities, to be implemented in the country of origin, play an important role. In the following, an overview is presented on the possible frameworks of cooperation between the government and the migrant associations.

\subsubsection{Migrant associations as development actors in Latin America}

As displayed in Table 44, migrant associations have different standpoints towards the government of the country of origin and towards any sort of fundraising for, and financing of developmentally significant projects to be implemented in the country of origin. Logically, it is a "defensive" and "locality-based" association that is most likely to be a partner for the government in such an activity, as they are not adversaries in political terms, and they have a very strong sense of belonging to and responsibility for a specific location in the country of origin. Therefore, it is not a surprise that when it comes to 'collective remittances', hometown associations (HTAs) have the central role. The high spatial concentration of migrants from the same village in a specific US town, and their shared knowledge of what specific economic activity needs to be subsidized, would enable hometown associations to be the perfect investors in economic development projects.

However, this is usually not the case. Economic activities generally occur on a private basis in most Latin American countries. Emigrants would not subsidize private small or medium enterprises in the same way as the state would do so in a welfare economy, with the exception of two cases. First, if the subsidized enterprise and the emigrant community are linked by family or kinship ties, but this case does not fit in the stricto sensu HTA agenda, being rather a micro (household-) level money transfer than a collective remittance. Second, if kinship ties are not that strong, but it is known that the owner of the small enterprise is in need of help due to an illness, an unexpected death in the family or a natural hazard. Still, in these cases the main reason of the money transfer is not the expectative for economic growth but charity.

Therefore, pointing back to the wellbeing versus development dichotomy of Canales Cerón [2008] presented in 1.2.2., it has to be stated that HTA members, when thinking about community projects, they are thinking about bridges, roads, fountains, hospitals, schools, that are important as infrastructure for development, but not as primary job- or wealth-generating investments. Symbolical projects, such as 
the renovation of the local church, the cemetery or a shrine, are also rather frequent, as they show the spiritual belonging of migrants to the community.

This sort of local development initiatives has been embraced by the state in the framework of a comprehensive programme in two countries, Mexico and El Salvador. The first one has the " $3 \times 1$ " Programme operating since 2000 , which, on the other hand, builds upon existing mechanisms of matching funds that had been created already in the $1980 \mathrm{~s}$. The " $3 \times 1$ " Programme is a showpiece for development programmes using collective remittances, and it will be presented in details in 3.4.3. Here, therefore, the Salvadorian programme is presented.

El Salvador's “Unidos por la Solidaridad” (United by Solidarity) programme began operating in 2002. It came into being as a form of institutional framework for Salvadoran migrant organizations' aid activities (see 3.4.1.) which gained momentum after Hurricane Mitch's devastating effects on Central America in November 1998. Another helping factor was Francisco Flores's election as the president of El Salvador in March 1999, as he had economic recovery through diaspora involvement as central to his election programme. The "Unidos por la Solidaridad" programme has financed an average of 20-25 projects per year, defined and financed on a case-by-case basis, where Salvadoran migrant organizations had the initiative and financial input (just as in the case of the Mexican " $3 \times 1$ " programme). Matching funds was based on migrants' ideas on what sort of development projects should be implemented in El Salvador. If they managed to raise funds for it, the Salvadorian government also put its (equal or slightly larger) share to it - this is why it has been called 'matching funds'. In the first two years 4.5 million USD was raised by migrant organizations and it was matched by 7 million USD by a special fund of the Salvadoran government, administered by the Ministry of Foreign Affairs. Projects included the renovation of sewage systems, medical centres or road pavements. [Flores, 2011; Stefoni, 2011] For more details, see the case study in 3.4.3.

Another form of institutionalized cooperation between migrant associations and the government is when it is not the country of origin, but the country of destination that is involved through its official levels. Most importantly, cooperation schemes have been organized by the (different levels of the) Spanish Government. As opposed to the migrant organizations in the United States that receive no support at all from the U.S. government, migrant organizations in Spain were included in the 
government's development agenda since 2001, when the term 'co-development' (codesarrollo) was included in the integrated GRECO plan for migration management (2001-2004) and the subsequent plans for international cooperation for development. The term (codéveloppement in original) was coined in 1997 by French migration expert Sami Naïr, and it was meant to make a reference to the government's objective of including (co-opting) migrants from a given country of origin in the planning of their international cooperation activities for development towards that specific country. [Giménez et al, 2006]

In other words, very differently from the entirely bottom-up design of the Mexican and Salvadoran HTA matching funds scheme, those countries with a significant migrant community in Spain could count with the technical and financial help of the Spanish state, i. e. they were approached in a top-down way (and with available funds). Similarly to the Plan of Voluntary Return (see 3.3.2.), this 'window of opportunity' for migrant organizations was essentially an outcome of Spanish internal politics' matches, and not of immigrant activism. After the Zapatero government took office in 2004, co-development became a buzzword to tackle the effects of the unfolding of the massive immigration wave within the discursive framework of the left-wing government's culturally sensible migration policy approach.

An important feature is that governments of Latin American countries had little influence in these processes, as the main linkages were tied on the meso level, between municipalities or NGOs. The Plan Director enabled Spanish autonomous communities and NGOs to establish partnerships with Latin American counterparts and receive grants from the Spanish government to implement development projects. The twinning programme of the regions of Cañar (Ecuador) and Murcia (Spain); the Programa Pagesos Solidarios, for the development of the localities of origin of Colombian agricultural workers in Catalonia; and the Programa Junín Global, between the institutions of the county of Junín in Peru and the migrants from that region in Spain; are worth mentioning. The majority of these projects took place in Ecuador. [Cerezo, 2011; Flores, 2011]

Finally, a different kind of migrant organization involvement can be seen in the case of other countries where diaspora associativism is less hometown-based. Here, none of the two governments (neither the country of origin nor the country of destination) are involved. In a comparative research of Mexican, Dominican and 
Colombian migrant organizations in the U.S. by Portes et al [2005], it was shown that Dominican organizations are, in average, rather large and they own a considerable sum of money, especially because the two large political parties, the Revolutionary Dominican Party (PRD) and the Dominican Liberation Party (PLD) have their offsprings in the United States in the form of migrant organizations, channeling diaspora resources directly to Dominican party politics. Colombians, although party politics also plays a role, are fragmented according to class and place of (actual) residence. In the Colombian case, charity organizations are prominent, with Lions Club and a number of religious foundations as relevant examples. Given the particularities of these groups, biases exist in the distribution of the benefits (belonging to a certain religious group or party etc.) Neither in the Dominican nor in the Colombian case does a matching funds scheme exist.

Table 45 summarizes these three forms of migrant association involvement in the development of the country of origin.

Table 45. Activities of migrant associations for the development of the country of origin and their cooperation with the governmental level

\begin{tabular}{|l|l|l|l|l|}
\hline $\begin{array}{l}\text { Type of } \\
\text { cooperation }\end{array}$ & Initiator & $\begin{array}{l}\text { Counter- } \\
\text { part }\end{array}$ & Beneficiary & Examples \\
\hline $\begin{array}{l}\text { Matching funds } \\
\text { scheme }\end{array}$ & $\begin{array}{l}\text { Government of } \\
\text { country of } \\
\text { origin }\end{array}$ & $\begin{array}{l}\text { Migrant } \\
\text { association }\end{array}$ & $\begin{array}{l}\text { Community of } \\
\text { origin }\end{array}$ & $\begin{array}{l}\text { 3x1 Programme } \\
\text { (Mexico) } \\
\text { United by Solidarity } \\
\text { (El Salvador) }\end{array}$ \\
\hline Co-development & $\begin{array}{l}\text { Government of } \\
\text { country of } \\
\text { destination }\end{array}$ & $\begin{array}{l}\text { Migrant } \\
\text { association }\end{array}$ & $\begin{array}{l}\text { Community of } \\
\text { origin }\end{array}$ & $\begin{array}{l}\text { Cañar-Murcia co- } \\
\text { development } \\
\text { programme }\end{array}$ \\
\hline $\begin{array}{l}\text { Fundraising and } \\
\text { charity with no } \\
\text { governmental } \\
\text { participation }\end{array}$ & $\begin{array}{l}\text { Migrant } \\
\text { association }\end{array}$ & $\begin{array}{l}\text { Religious } \\
\text { association } \\
\text { Political party } \\
\text { etc. }\end{array}$ & $\begin{array}{l}\text { Specific group } \\
\text { of the } \\
\text { community of } \\
\text { origin }\end{array}$ & $\begin{array}{l}\text { Charity actions of the } \\
\text { Lions Club Colombia }\end{array}$ \\
\hline
\end{tabular}

Source: Own compilation, based on Portes et al [2005], Cerezo [2011] and Flores [2011].

To sum up, migrant associations can be important actors in sending community remittances, thus contributing to the development of the countries or localities from where they originate. However, government involvement (or the lack thereof) can significantly modify the outcome of their original charity intentions. In the following, a case study analyzes the best known matching funds scheme in Latin America, the Mexican “3x1” Programme. 


\subsubsection{Case study: the Mexican "3x1” Programme}

\section{Case Study Overview Table 3. The Mexican “3x1” Programme}

\section{III.) Policy Mechanism}

Level Country of destination Transnational space Country of origin

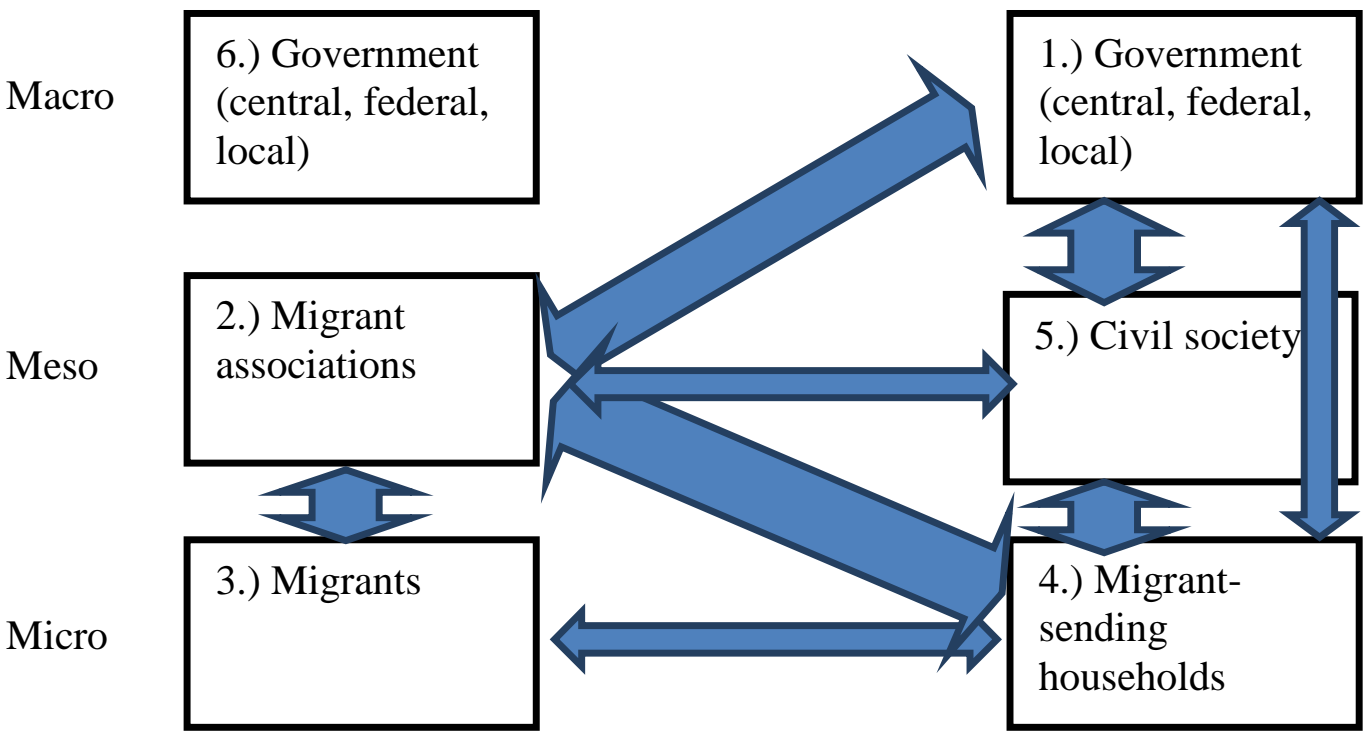

1.) Government (Country of $\quad$ Decides which migrant initiatives will be implemented and, origin) through its 3 levels, puts $75 \%$ in the project.

2.) Migrant associations 


\begin{tabular}{|c|c|}
\hline 3.) Migrants & Donate money for the project through the association. \\
\hline $\begin{array}{l}\text { 4.) Migrant-sending } \\
\text { households }\end{array}$ & Enjoy the benefits of the local development project. \\
\hline $\begin{array}{l}\text { 5.) Civil society (Country of } \\
\text { origin) }\end{array}$ & $\begin{array}{l}\text { Might participate in the decision-making, enjoy the benefits } \\
\text { of the local development project. }\end{array}$ \\
\hline $\begin{array}{l}\text { 6.) Government (Country of } \\
\text { destination) }\end{array}$ & Not involved. \\
\hline \multicolumn{2}{|l|}{ IV.) Policy Impact } \\
\hline 1.) Managing Authority & SEDESOL (Ministry of Social Development) \\
\hline 2.) Budget & 17 million USD (2013) \\
\hline 3.) Number of Beneficiaries & $30,000-50,000$ \\
\hline $\begin{array}{l}\text { 4.) Average Benefit per } \\
\text { Beneficiary }\end{array}$ & 425 USD \\
\hline $\begin{array}{l}\text { 5.) Impact on Local } \\
\text { Development }\end{array}$ & Medium \\
\hline 6.) Impact on Migratory Flows & Low \\
\hline 7.) Relative Significance & Medium \\
\hline \multicolumn{2}{|l|}{ V.) Policy Lifespan } \\
\hline $\begin{array}{l}\text { 1.) Timeline of } \\
\text { implementation }\end{array}$ & $\begin{array}{l}\text { Started as a pilot project, the } 3 \times 1 \text { Programme gained } \\
\text { popularity among migrants. Originally, it was presented as a } \\
\text { tool for local development - now, it is framed as a way of } \\
\text { engaging the diaspora. Despite critiques and controversies, it } \\
\text { keeps on operating. }\end{array}$ \\
\hline 2.) Perspective & $\begin{array}{l}\text { Being an innovative but more symbolic than job-creating } \\
\text { programme, it might remain at the current level, no serious } \\
\text { development of the programme can be expected. }\end{array}$ \\
\hline
\end{tabular}

Source: own compilation.

The precedents of the $3 \times 1$ Programme for Migrants (in the following, 3x 1 Programme) are non-governmental charity initiatives of migrant clubs from the state of Zacatecas (a traditional migrant-sending region) that from the 1960s onwards had been raising funds to help migrants in the United States in case of illness, and to implement social projects in their place of origin. It was in 1986 when PRI governor of Zacatecas, Genaro Borrego launched a matching funds programme, called the 1x1 
Programme, that completed the budget of such social projects with an equal amount. [Aparicio - Meseguer, 2009]

Even though there were only 28 projects implemented in this scheme until 1992, the idea received the attention of Mexico's president Carlos Salinas de Gortari, leading to the creation of the programme called International Solidarity among Mexicans, also known as the 2x1 Programme, where the state and the federation also put its part to the projects. However, it was only after PRD governor Ricardo Monreal entered office in Zacatecas that the programme became significant in terms of budget and the number of projects implemented. By 2002, in the state of Zacatecas, the total number of projects was 868, with an aggregate investment of 464 million pesos, and the scheme had been adapted by the states of Jalisco, Durango and Guanajuato, also in the Centre-West region. [Soto - Velázquez, 2006]

Under the term of Salinas, numerous programmes were set up to aim the growing Mexican migrant community in the United States, like the Paisano Programme and the Programme for Mexican Communities Abroad, under the Foreign Ministry and operated through Mexican consulates and cultural centres (see 3.2.3.). The Salinas administration, and also that of Vicente Fox, actively promoted the creation of Mexican HTAs that began to grew in number and membership, reaching a total of approximately 2,000 for 2006. [García de Alba et al, 2006]

Vicente Fox came to power in 2000 as the first non-PRI president since seven decades, but while he gave a new direction to Mexican politics in several ways, in migratory issues he was following Salinas's footsteps. Fox founded the Institute for Mexicans Abroad, and started the 3x1 Programme-Citizen Initiative in 2002, later renamed as the $3 \times 1$ Programme for Migrants. It has been operating in the whole territory of Mexico, involving the municipal governments' share in its budget. 3x1 therefore means that, in theory, for every peso that a HTA wishes to spend in a specific development project, the municipality, the state and the federal government also put their respective peso, therefore multiplying the original amount by four. [Aparicio - Meseguer, 2009]

The $3 \times 1$ Programme is administered by the Mexican Ministry of Social Development (SEDESOL), but the initiatives still come from the HTAs. Coordination is undertaken by the Mexican consulates abroad, supported by the Diaspora Unit at the Ministry of Foreign Affairs, the Institute of Mexicans Abroad (IME). A Committee of Validation and Attention to Migrants (COVAM), with 
representatives of all four parties involved, decides which projects will be implemented. The share of the federal government may be more than $25 \%$ if its social impact is expected to be outstanding, however, this occurs quite rarely. The total cost of each project cannot be more than 800,000 pesos. As it can be seen, the Mexican government dedicates important amounts for the programme that saw its budget being multiplied in ten years. [Baca, 2009]

Among the positive aspects of the programme, migrants' right to initiate projects is certainly the most important. Also, the (three levels of) government put a $75 \%$ of grant to it: for 2013, the federal budget was 55 million pesos (approximately 4.2 million US dollars), meaning that a possible pool of 17 million dollars was available together with the other three counterparts' share. [Reyes, 2013] The programme as a 'good practice' has been acknowledged in the international fora and it is often treated as a model for further development policies.

Anthropological relates on concrete cases show how negotiations were made and how projects were implemented. González Ortiz and Rivera Sánchez [2004] described the construction of a pedestrian bridge in Tonatico, State of Mexico, with the input $(31 \%)$ of the Club Social Tonatico in Waukegan, Illinois. Interviewees expressed dissatisfaction with the lack of information and coordination, informal management and personalization of leadership, but they were generally satisfied with the project. García de Alba et al [2006] evaluated the case of the pavimentation of the road leading to Apulco, Zacatecas, with $40 \%$ funding from the Club Guadalupano in Fort Worth, Texas. Locals did not really know about the project and there was a friction between migrants and the local community. However, those who participated, were content with the decision-making and the chosen project, considering it an important investment, although they suspected corruption. Finally, Romero Sánchez [2004] investigated how a fountain of drinking water was constructed in Lázaro Cárdenas, Tlaxcala, Mexico, even without the participation of a migrant association, as the municipality saw this opportunity as a good way to get $50 \%$ external funding, thus it paid the $25 \%$ share that migrants should have put into the project.

According to an external evaluator, three types of problems can be distinguished: 1) inherent, 2) economic and 3) political problems. An inherent problem of the programme is that its original objectives (poverty reduction, infrastructural development of geographically unfavoured localities) are not in line 
with the new geographies of Mexican migration. Most migrants heading to the United States do not stem from the poorest settlements, but more likely from those of low-middle or middle income (as reaching and crossing the border can be quite expensive). Moreover, the poorest municipalities might not be able to match the $75 \%$ of external funding with their own $25 \%$ share. The $3 \times 1$ programme thus shows a clear geographic bias towards these areas, not reaching sufficiently the poorest regions. [Sagarnaga, 2004]

Another inherent problem is that migrants' perceptions on the importance of projects might be different of the perceptions (and interests) of locals. Various researches mention that migrants prefer 'performative' projects, i. e. those that are big, majestic and/or can be seen by everybody, such as the renovation of the church (which has been, by far, the most popular choice for $3 \times 1$ projects), as opposed to drainage or sewage systems, for example. [García de Alba et al, 2006; Aparicio Meseguer, 2009]

The economic problem of the programme is very simple: the (three levels of the) Mexican government does not dispose of an amount of money that would substantially change migratory and developmental patterns. Even if a yearly amount of 17 million dollars is spent on local development projects, this adds up as slightly more than 1.5 dollar per inhabitant. Partly because of this, and partly because the above mentioned inherent problems, the original objectives of the " $3 \times 1$ " Programme have been modified with time: the "retention" element is no longer emphasized, while maintaining social ties has been put into the focus. This further stresses the 'performative' nature of the programme, already mentioned before. [Aparicio Meseguer 2012]

Finally, there are political problems as well, and these are the most complex. Aparicio and Meseguer [2009] claim that there is "a clear partisan bias in resource allocation: states and municipalities ruled by the Partido Acción Nacional (PAN) were systematically more likely to participate in the programme and receive more projects than their PRI (Partido Revolucionario Institucional) and PRD (Partido de la Revolución Democrática) counterparts. This, we posit, alerted of the political use of the $3 \times 1$ Programme as a tool by the federal government to reward PAN strongholds". [Aparicio and Meseguer, 2009, p. 11.] This is mostly because decisions on the projects are took by a simple majority vote, and all four counterparts delegate 3-3 members in a state (for migrant organizations and local governments, it is not 3 
members for each but altogether in a given state). If the state government and the federal government are of the same party, only one local or migrant representative must align to them, and majority vote is reached. [García de Alba et al, 2006]

As Aparicio and Meseguer [2012] conceptualize it, relying on Dixit and Londregan [1996], political parties seek the support or "swing" or "undecided" voters more than that of "core" voters who would support them anyway. As criteria for government support were loosely defined, the authors found that the grants were biased towards municipalities where Fox's party, the PAN held approximately the half of the votes in the last election, while in municipalities with overwhelming PAN support or with clear opposition preferences, proportionately less projects were granted.

Other (not partisan) political problems also might appear, between local governments and migrants. In the case of Tonatico, there were different HTAs, all of which were formed around a charismatic migrant. Personal sympathy or antipathy between the mayor and the migrant leaders was at least as important in the kick-off phase of the project, as higher politics. [González Ortiz - Rivera, 2004]

To sum up, the $3 \times 1$ Programme is one of the most innovative public policy solutions in Latin America for local development planning and investment through migrants' involvement. However, the character, location and total number of the projects make a rather limited impact in migration and development terms. Instead, transnational ties are strengthened through these projects and, in many ways, migrants remain symbolically connected to their hometown. Moreover, political deals often put migrants and politicians on the same platform, as both groups are interested in implementing 'attractive' projects that look good, instead of those which are useful but not that visible. Achievements should therefore evaluated on two levels: development impact (which might be rather humble) and identity/community level (which might be more significant).

\subsection{Latin American diaspora networks}

Understanding migration as a gain or loss of human capital is a key feature of most theoretical and policy-focused approaches in the migration-development literature. And when it comes to measure, or at least, to categorize the amount of 
human capital, it is the educational attainment that comes up as the most convenient variable.

Emigration of the highly skilled - the so-called brain drain - is seen by most researchers and policymakers as the most painful loss, as in developing countries there is a constant shortage in the top segment of the labour market. However, these shortages are also present (although on a different scale) in developed countries where wages might be incomparably higher, let alone the better professional and technical environment - thus, there is a constant pulling effect for the highly skilled.

As it is exposed below, 'retaining' the best and brightest is not a viable option for poorer countries, and 'attracting them back' is also questionable in cost-benefit terms. Luckily, not all is lost: highly skilled migrants might contribute to the development of the country of origin by several modalities of 'social remittances' (Definition F, as described in Chapter 1.2.1.4). In order to access to their social and cultural capital, the government of the country of origin, through its Diaspora Unit, can establish a network of regular information exchanges, known in the related literature as 'diaspora networks'.

Diaspora networks can be the base of knowledge transfer programmes, thus contributing directly to development. This is, nonetheless, a difficult task. The Colombian case study in 3.5.3 shows the challenges and opportunities of such a mechanism.

\subsubsection{The highly qualified emigrants' role in Latin American development}

From the 1970s onwards, global distribution of industries and items of the production chain has led to the migration of production, followed by the migration of workers. Technology- and knowledge-intensive industries generally kept on evolving in developed countries, while labour-intensive industries were relocated to developing countries. Also, the gap in wages and professional perspectives between the two country groups was increasing, especially with the acceleration of globalization in the 1990s. A consequence of these processes has been the robust brain drain, or migration of the highly skilled, that many developing countries experienced.

Governments of developing countries tried to tackle with the challenges that these processes meant to their economies. According to Brown [2002, p. 167], two 
major types of policies could be identified: "retaining" and "attracting back" policies. The first set of efforts aim to retain prospective migrants with prescribing a compulsory period of working in the country of origin or taxing those who leave; or with a more positive approach, offering benefits for those who, upon graduation, start working in the country of origin. The second set of policies is targeting those who already migrated, and offer them tax exemptions, legal assistance, favourable loans or concrete jobs if they move back. For the highly skilled, it can be said that only the largest developing countries could afford to comprehensively plan and implement any of the two policy models: China, India and South Korea have extensive programmes to turn 'brain drain' into 'brain circulation'. Smaller and poorer countries usually cannot offer the same level of professional quality and perspectives that the country of destination, thus even if a governmental programme would pay a wage high enough to "attract back" a skilled migrant, professional reasons might pull them back again, sooner or later, to the country of destination.

Indeed, migration of the highly skilled is not a simple "loss" of human capital for the country of origin, for two reasons. First, the quality of higher education and the specialization of careers available are many times insufficient, and if talented students wish to pursue further studies, the only way to do so is to move to another country. In this case the knowledge and skills they achieve in the country of destination would not have been generated without migrating. Second, individual migrants usually show loyalty and willingness to 'help' their country of origin. Even if they live and work abroad, they have an internal driving force which makes them willing to contribute to the development of the country they left behind. This latter phenomenon, coupled with the spreading of information technology, made it possible to several countries from the late 1990s onwards to design and implement new types of public policies. Brown [2002, p. 170] calls it the "diaspora option", which, instead of retaining or attracting back the highly skilled, accepts the situation and tries to build up "intellectual or scientific networks" of communication, on an easily accessible online platform, in order to channel the intellectual capacities of the highly skilled migrants towards development projects (in terms of education, manufacturing or trade) that would be implemented in the country of origin.

There are several Latin American countries which tried to attract back migrants, most notably Argentina, through the RAICES programme (see details below). Other countries tried to rely on the "diaspora option" and they created 
channels and fora for information exchange with and among diaspora members, having in mind developmental goals. [Didou, 2009]

The underlying idea of diaspora networks is that successful migrants or descendants of migrants, who do not wish to return to the country of origin, would re-discover their "ethnic" belonging, involving their country of origin in the course of the activities that made them successful. By creating transnational spaces in which solidarity is the main appeal, these emigrants can provide capital or knowledge for the country of origin, or raising funds and awareness in specific issues related to it, in the country where they actually live. However, in the case of the first generation, that is, people who actually migrated, resentments may exist towards the country they left for some reason, while the second or third generation is more likely to have an identity that is fundamentally that of the country in which they grew up, making their contributions rather limited. It is therefore not automatic for a citizen of the United States of, say, Colombian ancestry, to want to make investments or to participate in joint research programmes in Colombia. [Didou, 2009]

The evidence, however, seems to show that highly skilled expatriates are willing to send "social remittances" (see Chapter 1.2.1.4). if they are asked to do so. According to Meyer [2007, p. 9.], motivations might include "guilt feeling of having left and 'made fortune' away; activist commitment or sentimental remembering; opportunities to keep in touch with relatives; expectations about professional developments; social or entrepreneurial expansion; occasion of international connections and cooperation agencies support; etc." Any of these motivations, or a combination of various, can make a highly skilled migrant to cooperate with the government of the country of origin.

Relying on theories on how social and human capital are interconnected, [Helliwell - Putnam, 1999] Meyer argues that networking opportunities are appealing for experts in a given professional field, however, their opportunity costs of being involved in a non-profitable venture is high. This means that highly skilled expatriates are relatively easy to get involved in a transnational network mechanism (especially if it goes through internet), but they are difficult to be kept active, as their time is scarce and they might 'exit' if they see no point in remaining connected to the network. On the other hand, "identity expression" is found to be an important retaining force: Meyer's analysis of Colombian and South African diaspora networks' communication revealed that appealing to patriotism has been successful 
to settle problematic issues and to keep experts involved despite their previous attempts to leave. [Meyer, 2007]

But what sort of knowledge capital does the diaspora yield for the country of origin? Kusnetsov [2007] makes difference between a technological knowledge and a policy knowledge, the latter referring to the know-how of putting ideas in practice. Both are crucial to extract developmentally useful outputs from the cooperation. Also, successful cooperation needs a very engaged and competent diaspora member (a padrino or 'godfather' in Kusnetsov's term) on one side, and an institutionalized (and also competent) secretariat for the bureaucratic work in the country of origin.

If all these conditions are met, concrete knowledge transfer can take place, without the highly skilled expatriate(s) effectively moving back to the country of origin. Although making experts return temporarily, the "diaspora option" means that experts continue to live abroad. Thus, in Table 46 it is presented, based on Kusnetsov's categories, how highly skilled migrants can contribute to the development of their country of origin.

Table 46. Development contribution models from the highly skilled diaspora members to the country of origin

\begin{tabular}{|l|l|}
\hline Model & Description \\
\hline "Top executives" & $\begin{array}{l}\text { Expatriate top executives in major multinationals influence investment } \\
\text { decisions to place operations within the company to the country of origin. }\end{array}$ \\
\hline $\begin{array}{l}\text { "Knowledge } \\
\text { outsourcing" }\end{array}$ & $\begin{array}{l}\text { Successful diaspora members who 'made it' abroad, provide outsourcing } \\
\text { contracts to firms back home. }\end{array}$ \\
\hline $\begin{array}{l}\text { "Mentoring" or } \\
\text { "Venture capital" }\end{array}$ & $\begin{array}{l}\text { Technical and financial inputs from the diaspora to develop and finance } \\
\text { commercially viable projects. }\end{array}$ \\
\hline $\begin{array}{l}\text { "Investment } \\
\text { facilitation" }\end{array}$ & $\begin{array}{l}\text { Diaspora members with personal knowledge on the reality of the country of } \\
\text { origin act as facilitators in cross-border investor networks. }\end{array}$ \\
\hline $\begin{array}{l}\text { "Identifying } \\
\text { niches" }\end{array}$ & $\begin{array}{l}\text { Diaspora members identify niches in the country of destination and translate } \\
\text { these opportunities into business projects for the firms of the country of } \\
\text { origin. }\end{array}$ \\
\hline $\begin{array}{l}\text { "Brain } \\
\text { circulation" }\end{array}$ & $\begin{array}{l}\text { Renowned scholars and technical experts receive disciples from the country } \\
\text { of origin for a period of time. }\end{array}$ \\
\hline \multicolumn{2}{|l|}{ Source: Kusnetsov [2007, pp. 24-25.] }
\end{tabular}

Internal and external conditions for networking, however, are very different in each Latin American country. It is obvious that not all items in Kusnetsov's typology are equally reachable for policymakers. "Top executives" do not abound, 
and relocating entire phases of the production chain within the company or through outsourcing to Colombia is rarely achievable only because a top executive is Colombian. Mid-range companies, however, may want to invest or facilitate investment in the country of origin of the owner/top manager. This has been the case of ChileGlobal, a successful initiative of Chilean expatriate entrepreneurs to relocate parts of their productive activity to Chile, backed by the Chilean government. The success of this initiative has been, nonetheless, closely tied to the favourable overall business climate in Chile for foreign investment. [Kusnetsov, 2007]

Business forums, nonetheless, can always be organized by Diaspora Units, in cooperation with consulates, chambers of commerce and associations of a given industry. These are usually high-profile events - many times connected to an award ceremony - where symbolical recognition of a distinguished member of the diaspora is supposed to strengthen their ties to the country of origin.

For academics, it is usually a joint research project, a visiting scholarship, an online course taught through Skype, or other forms of involvements that are sought, for which the expert does not have to leave their well-paid job at a prestigious university or research institution. In the following, both groups (academics and businesspeople) will be briefly presented in their function of being partners for networking attempts of the Diaspora Units of their countries of origin.

\subsubsection{Diaspora networks for knowledge transfer to Latin America}

Focusing on successful businesspeople and academic researchers of migrant background in order to channel their possible inputs to developmental projects, migrant-sending Latin American countries have created different types of mechanisms to contact and engage them. In Mexico, for example, the Institute of Mexicans Abroad organizes a wide range of activities within the framework of the Red Global MX programme, from conferences and seminars to the funding of longdistance education and scholarships, in order to strengthen ties with Mexicans and descendants of Mexicans, mainly living in the United States. Colombia's Red Caldas (see case study in 3.5.3.) created partnerships between Colombian researchers abroad and at home, while Chile's DICOEX draws on the revival of Chilean identity among descendants of Chilean emigrants who fled the country during the years of Pinochet's dictatorship and became successful abroad. In all cases, the target group 
of these activities is seen as an asset for the country of origin to explore. It must be mentioned that non-governmental initiatives, like the Red Mundial de Científicos Peruanos (Worldwide Web of Peruvian Scientists) also came into existence. [Didou, 2009; Texidó - Gurrieri, 2012, DUS 2014-2015]

Usually, Latin American attempts have focused on the possibilities of establishing contacts with highly skilled diaspora members in a "mentoring", "facilitating", "identifying niches" or "brain circulation" approach, the latter including also the objectives of 'bringing back' experts, temporarily or permanently, to the country of origin. Scientific network building and investment facilitation have been the two most important directions of government activities.

Scientific networks differ from investment facilitation in their nature of focusing on individuals who work in the academic sphere, rather than on higherranking managers or business owners. The former are more accessible in the country of origin / country of destination relationship for the government attempts than the latter, as voluntary sharing of technological and scientific expertise is more a question of individual engagement than larger-scale investment. In the following, scientific networks are presented in Table 47. As of 2015, eight Latin American countries had institutionalized mechanisms that can be viewed as such.

Table 47. Scientific networks for Latin American diasporas, administered from the country of origin

\begin{tabular}{|c|c|c|}
\hline Country & Name of network & Objectives \\
\hline Argentina & RAICES & $\begin{array}{l}\text { Information exchange, database for CVs and } \\
\text { research projects, job offers, subsidies for return }\end{array}$ \\
\hline Chile & hileGlobal & Information exchange, networking \\
\hline Ecuador & Prometeo & $\begin{array}{l}\text { Establishing contacts with academics and researchers } \\
\text { abroad (not only Ecuadorians) and offering them } \\
\text { project grants }\end{array}$ \\
\hline El Salvador & Talento en el exterior & Information exchange, networking \\
\hline \multirow[t]{2}{*}{ Colombia } & $\begin{array}{l}\text { Red Caldas (1992- } \\
\text { 2001) }\end{array}$ & Information exchange, networking, planning projects \\
\hline & $\begin{array}{l}\text { Colombia Nos Une } \\
(2003-)\end{array}$ & $\begin{array}{l}\text { Setting up thematic (scientific, cultural, business) } \\
\text { networks, planning projects }\end{array}$ \\
\hline Mexico & Red Global MX & $\begin{array}{l}\text { Information exchange, networking, partnership } \\
\text { projects between peer institutions }\end{array}$ \\
\hline Uruguay & CUAC & $\begin{array}{l}\text { A forum for outstanding Uruguayans (migrants and } \\
\text { non-migrants) in the scientific, business or cultural } \\
\text { life }\end{array}$ \\
\hline Venezuela & TALVEN & Information exchange, networking \\
\hline
\end{tabular}

Source: Own compilation based on DUS [2014-2015], Didou [2009, p. 47], Texidó - Gurrieri [2012, pp. 38-42.] 
The first Latin American scientific network was the Colombian Red Caldas, which was later transformed into the Colombia Nos Une programme (see case study in 3.5.3.). The largest one is the Argentinean RAICES programme, which has already been mentioned in 3.3.2, as it aims 'bringing back' successful migrants, rather than only connecting them to an online space of information exchange. An interesting approach can be detected in Uruguay's CUAC initiative, as it links migrants with non-migrants in the same professional field. [Didou, 2009]

It is worth mentioning that the circle of countries which have this kind of policies is somewhat different to those which have implemented policies for return and investment. In the former group, the majority belongs to the middle-income MERCOSUR bloc, while in the latter, lower-middle income Andean countries can be found, with Colombia (and Mexico) appearing in both. It is not surprising that countries of a certain level of research and development infrastructure find it feasible to effectively 'bring back' skilled migrants, while countries of a lower level of development cannot really calculate with this. In the latter case, job creation for (mostly unskilled) local workers through return migration and investment has been a more realistic objective. [Texidó - Gurrieri, 2012] An interesting case is that of Ecuador, which shifted perspectives, focusing more and more on the highly skilled, and not on the entrepreneurs (see case study in 3.3.3).

For the case study in 3.5.3, the subsequent Colombian Red Caldas and Colombia Nos Une networks have been chosen because of their long history which began before the 'information revolution'. Therefore, the history of the network reflects on how the technical possibilities for information exchange evolved with time. Also, its funding and its domestic and international institutional embeddedness changed over time, while the original objectives have been maintained ever since. 


\subsubsection{Case study: the Colombian Red Caldas and Colombia Nos Une networks}

\section{Case Study Overview Table 4. The Colombian "Red Caldas" and "Colombia Nos Une" networks

The Colombian "Red Caldas" and "Colombia Nos Une" networks

A network of e-mail lists, administered by PhD students on state scholarship, attempts to reach Colombian scientists abroad and channel their ideas and knowledge into developmentally useful joint projects, co-founded by the country where the scientist resides, and the Colombian government. Later, for financial and technical reasons, the network disintegrates and becomes refounded in the framework of an investment-facilitating and communication programme. It receives external (French and EU) funding, but instead of networking and incubation, in becomes characterized by a top-down style of information sharing on available funding opportunities.

\section{I.) Policy Window}

\begin{tabular}{|l|l|}
\hline 1.) Problem Stream & $\begin{array}{l}\text { Many Colombian scientists left the country and received } \\
\text { prestigious jobs abroad, while Colombian universities and } \\
\text { local governments did not have qualified personnel for } \\
\text { development planning. }\end{array}$ \\
\hline 2.) Political Stream & $\begin{array}{l}\text { Following a longer period of guerrilla and drug cartel } \\
\text { violence, a new constitution is adopted in 1991 under } \\
\text { president Gaviria. A moment of national reconstruction } \\
\text { enthusiasm' is reached (before new conflicts rise in the late } \\
\text { 1990s). }\end{array}$ \\
\hline 3.) Policy Stream & $\begin{array}{l}\text { Individual scientists are approached by a government-run } \\
\text { agency to join to a network of common project planning and } \\
\text { implementation. Scientists generally receive the idea } \\
\text { positively. }\end{array}$ \\
\hline
\end{tabular}

II.) Policy Deal

\begin{tabular}{|l|l|}
\hline 1.) Government Benefits & $\begin{array}{l}\text { Planning, technical assistance and partial funding of } \\
\text { development projects, access to intellectual networks }\end{array}$ \\
\hline 2.) Migrant Benefits & Not too much, mostly symbolical recognition \\
\hline $\begin{array}{l}\text { 3.) Sending Community } \\
\text { Benefits }\end{array}$ & $\begin{array}{l}\text { A) experts: learn about up-to-date technological } \\
\text { innovations, become linked to international knowledge } \\
\text { networks } \\
\text { population: depending on the concrete project }\end{array}$ \\
\hline
\end{tabular}

\section{III.) Policy Mechanism}

\section{Level Country of destination Transnational space Country of origin}

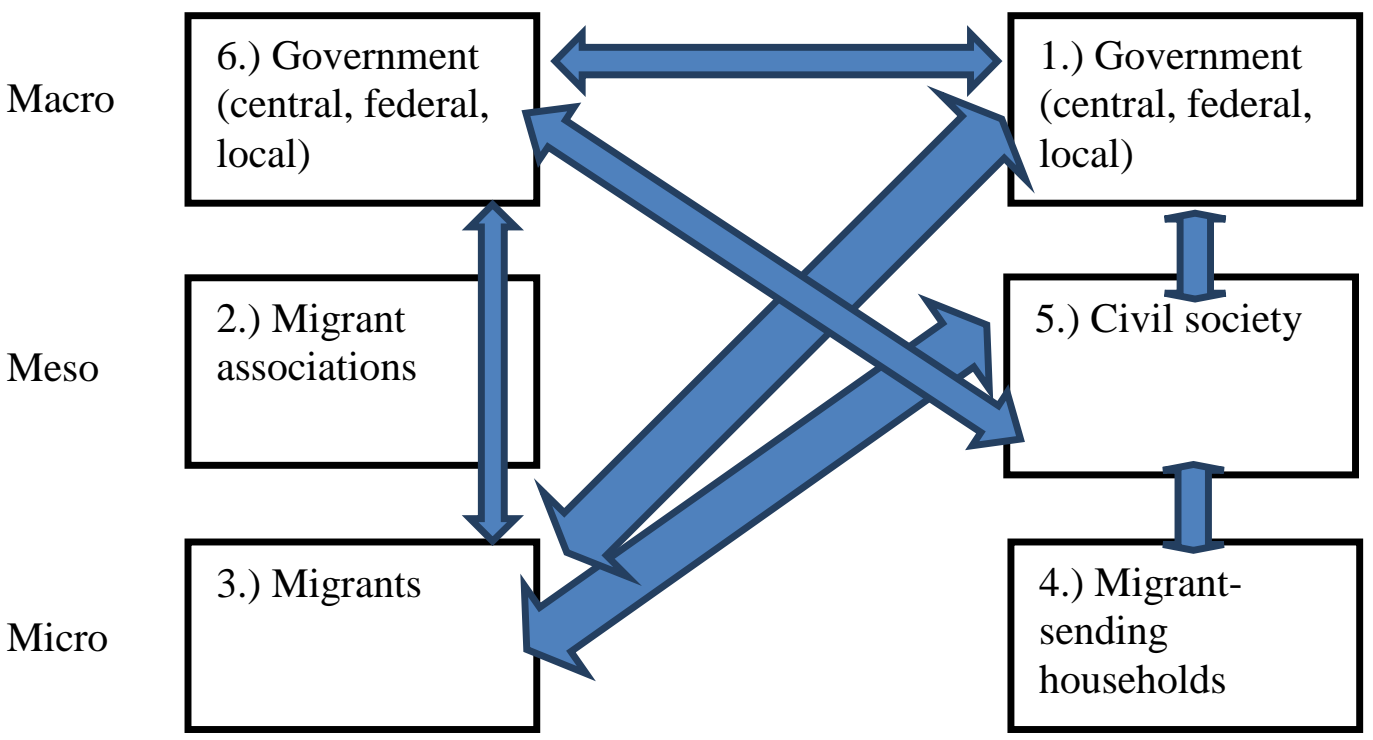




\begin{tabular}{|c|c|}
\hline $\begin{array}{l}\text { 1.) Government (Country of } \\
\text { origin) }\end{array}$ & $\begin{array}{l}\text { Initiates regular knowledge exchange with (individual) } \\
\text { highly skilled migrants in the form of a communication } \\
\text { network, provides a secretariat for project development. }\end{array}$ \\
\hline 2.) Migrant associations & Not involved. \\
\hline 3.) Migrants & $\begin{array}{l}\text { Highly skilled migrants share knowledge and elaborate ideas } \\
\text { for development projects, try to receive funding. }\end{array}$ \\
\hline $\begin{array}{l}\text { 4.) Migrant-sending } \\
\text { households }\end{array}$ & Indirect benefits, depending on the project. \\
\hline $\begin{array}{l}\text { 5.) Civil society (Country of } \\
\text { origin) }\end{array}$ & $\begin{array}{l}\text { Beneficiary institutions in the country of origin (schools, } \\
\text { research centres etc.) get involved in cutting edge } \\
\text { technological and scientific projects. }\end{array}$ \\
\hline $\begin{array}{l}\text { 6.) Government (Country of } \\
\text { destination) }\end{array}$ & Donates money (through bilateral mechanisms). \\
\hline \multicolumn{2}{|l|}{ IV.) Policy Impact } \\
\hline 1.) Managing Authority & Ministry of Foreign Affairs \\
\hline 2.) Budget & n.d. \\
\hline 3.) Number of Beneficiaries & n.d. \\
\hline $\begin{array}{l}\text { 4.) Average Benefit per } \\
\text { Beneficiary }\end{array}$ & n.d. \\
\hline $\begin{array}{l}\text { 5.) Impact on Local } \\
\text { Development }\end{array}$ & Small \\
\hline 6.) Impact on Migratory Flows & None \\
\hline 7.) Relative Significance & Small \\
\hline \multicolumn{2}{|l|}{ V.) Policy Lifespan } \\
\hline $\begin{array}{l}\text { 1.) Timeline of } \\
\text { implementation }\end{array}$ & $\begin{array}{l}\text { Red Caldas was a pioneer initiative in the early } 1990 \text { s when } \\
\text { thematic e-mail lists were a new and more efficient } \\
\text { alternative to traditional information exchange mechanisms } \\
\text { (paper-based publications, telephone calls). Its popularity } \\
\text { and impact peaked around } 1994 \text {, after which financial } \\
\text { problems hindered the further evolution. In the times of the } \\
\text { revolutionary changes in online communication, the network } \\
\text { quickly became obsolete. } \\
\text { Reorganized in } 2003 \text {, the Colombia Nos Une web platform } \\
\text { became once again an up-to-date hub for skilled emigrants. } \\
\text { Due to lack of funding and loose focus, it became marginal } \\
\text { and unsubstantial once again. }\end{array}$ \\
\hline 2.) Perspective & $\begin{array}{l}\text { None, at its present form its impact is very limited. With no } \\
\text { significant information content, it is of little interest for } \\
\text { (skilled) migrants. }\end{array}$ \\
\hline
\end{tabular}

Source: own compilation. 
Colombia was the first Latin American country which started to organize its highly skilled diaspora members in an online scientific network. The Caldas Network (Red Caldas), named after a Colombian scientist, was conceived and implemented in 1991, when internet was still very far from being a part of everyday life. Technically speaking, the network was an overlapping series of e-mail lists which were administered by Colombian consulates' technical staff, while members and content were added by Colombian scientists who lived in the given country. As internet gained terrain and commercial use, these e-mail lists were developed in nodes (nodos) or online fora of project development ideas. Colombian experts and highly skilled workers could accede to these nodes and check what the discussion was about, and they could add their own ideas. It was an explicit goal to plan and implement projects that would help Colombia in any way. Several success stories are mentioned in an analysis [Chaparro et al, 2004]: the Switzerland node was the forum for developing an anti-malaria campaign for Colombia's Pacific region, with the cooperation of the experts of the Universities of Bogotá and Lausanne, while the Belgium node brought together professors from the universities of Louvain and Tolima to develop a curriculum for the industrial automation MSc in the latter institution. The Colombian state helped the work of the nodes with an average of 70 scholarships per year, i. e. Colombian PhD students who studied abroad, received a monthly stipend from the Colombian state if they administered and coordinated the Red Caldas's nodes.

Colombian emigrant scientists were brought to the programme by voluntarism and patriotism: it was only the administrating $\mathrm{PhD}$ students who received any sort of remuneration. An interesting feature of the Colombian diaspora is the "plurifragmentation" [Guarnizo, 2006] already mentioned in 3.4.1, due to which Colombian migrants, especially the highly skilled, found themselves isolated from their compatriots and online networks were a good opportunity to re-connect themselves and to contribute to a patriotic objective. According to Chaparro et al [2004], however, this enthusiastic voluntarism could be translated to a concrete developmental project only if two conditions were met. First, a tandem of "scientific directors" was needed, one abroad and one in Colombia, both of which understood the importance and technical details of the project, and both of which had the personal engagement to spend long working hours on designing and monitoring it. Given this feature, projects were generally conceived by highly skilled emigrants and 
implemented by the universities where they had worked before emigration, or based on other personal relationships. Second, financing had to be resolved: the Colombian government only provided co-financing and applicable sources needed to be found by Colombian diaspora members (often backed by the consulates). However, different criteria and cycles of financing, as well as scientists' limited capacities for administrative work, made it impossible in many cases to submit a successful application.

The Red Caldas was, therefore, hindered by internal contradictions. Even this way, in its heydays between 1995 and 1997 it helped to conceive and implement hundreds of successful projects. This has been its drawback as well: the Colombian government explicitly stated that 'success' meant 'successful projects implemented', even though information exchange in itself was a very important plus for Colombian universities. Another source of problems was financing: while scholarships were available for node administrators, the network operated smoothly, but when the programme budget was cut back drastically in 1998 due to the country's internal problems, the Colombian counterparts could no longer put their share to the project budgets even if the foreign institutions were ready to provide a grant. Finally, there were many management problems: for example, scientists did not really understand the administrative requirements, while bureaucrats in the Colombian state administration did not understand the scientific content of the project proposals and they could not contribute effectively to the mitigation between possible partner institutions. Also, the system was limited to the academic sphere and business actors could not be involved, and the technical realization became obsolete for the late 1990s: as networks grew, new messages multiplied and many scientists stopped to follow them do to their large number and undifferentiated nature. Technical reconfiguration became necessary but there was no budget available. [Chaparro et al, 2004]

Given all these features, the Red Caldas became disintegrated by 2001, and regular communication among members vanished. In 2003 the Colombian government decided to restructure it radically: the new umbrella programme received the name of Colombia Nos Une (Colombia Unites Us) and it was designed not only for the highly skilled, but also for the middle class migrants who had become an economically very important group, as Colombian migration became massive. In 2005 and 2006, Colombia Nos Une addressed all major Colombian diaspora 
organizations in the United States and Europe, most importantly Spain. The aforementioned distrust was present among Colombians, but officials of the programme designed "working tables" in different topics (science, labour, business, health) in which organizations could participate and give their inputs. Through the programme, the Colombian government managed to elaborate migratory agreements with seven departments and two cities, all of them major sending areas, to include diaspora members in the drafting process of their development plans. [Escobar, 2012]

Red Caldas's structure of nodes and e-mail lists was abandoned and a virtual platform was established in 2007. As of now, four subprogrammes or 'axis' (ejes) exist (science, trade, culture and community), in which communication is segmented according to topics and e-mails are only sent from the central administration once in a given period, in the form of newsletters. The network was re-branded as Vinculación de colombianos altamente reconocidos en el exterior (Contacting highly renowned Colombians abroad), thus including the notion of 'valuable' diaspora without mentioning skills or education. [Redescolombia.org, 2012]

However, this has been a very different situation regarding communication channels, than it was in the early 1990s: a strong competition from other social networks and social media made it less popular that expected. Also, possible users did not see distinctive benefits in using Colombia Nos Une's platform instead of other, popular online communication channels. By 2012, it has been transformed to an information hub for the highly skilled diaspora where content was generated by Colombian government officials, rather than experts in the diaspora, who usually came back to the site to check whether new funding opportunities are available rather than to propose own project ideas. [Escobar, 2012]

It must be mentioned that networking activities under the aegis of the Colombia Nos Une programme are not exclusively financed by the Colombian State. The CIDESAL programme (Création d'incubateurs de diasporas des savoirs pour l'Amérique Latine, Creation of Incubators for Latin American Scientific Diasporas) was created in 2008 by the French IRD (Institut de Recherche pour le Développement, Research Institute for Development), and financed in a large share by the European Union and the government of France. Besides Colombia, Argentina and Uruguay also take part in the programme. [Proyecto Cidesal, 2008] 
Colombia Nos Une in its present form (2015) is little more than an information website for several, poorly interconnected projects ran by different institutional bodies of the Colombian government and in which skilled migrants can participate. There is one subpage dedicated to "outstanding Colombians abroad" (Colombianos destacados en el exterior, http://www.colombianosune.com/ejes/cde) that operates as a thematic news feed, collecting news related to famous Colombians who live outside the country (2-3 a day).

Unsuccessful experience is also an experience: it shows how considerable efforts were invested into a policy area (first in the 1990s, then in the mid-2000s) that lost most of its appeal with the information revolution and the popularization of web 2.0. Government officials without an access to a considerable budget can do little more than reblogging the news on activities of other institutional or private actors, or individual success stories. As a mechanism, it did not turn out to be a good practice for the Information Age.

\subsection{Comparative analysis of Latin American diaspora policies}

The comparative analysis of the four selected case studies is presented in Chapter 3.6. Its objective is to summarize the findings in a systematic way, in order to define generally valid features of Latin American diaspora policies, based on the concrete cases that were analyzed in depth.

Based on the theoretical framework set up in 3.1 and on the Case Study Overview Tables 1-4 in chapters 3.2.3, 3.3.3, 3.4.3 and 3.5.3, respectively, here the constituent parts of each Case Study Overview Table are transformed into crosstables that observe the four case studies simultaneously for each question or feature.

3.6.1 presents how the 'policy window', as conceptualized by Kingdon [1984], has opened in all four cases. 3.6.2 describes the 'deal' between the government of the country of origin and the diaspora, in a sense of 'extending rights' and 'extracting obligations', as described by Gamlen [2006]. 3.6.3 presents the policy mechanism and the role of each actor in the four cases, while 3.6.4 assesses the impact of the given policy intervention. These two chapters follow the logic of the "gaps" of policymaking described by Czaika and de Haas [2011]. Finally, 3.6.5 
assesses the temporal dimension of the policies and gives a general assessment regarding their future evolution.

After the systematic presentation of all relevant features of the analyzed policies, Chapter 3.6.6 evaluates the hypotheses of this thesis on the policy level. These hypotheses were set up at the beginning of this thesis and they were evaluated on the theoretical level (in Chapter 1.3.4) and on the conceptual level (2.2.4).

\subsubsection{The policy window}

Table 48 summarizes the findings of each analyzed Latin American diaspora policy case, regarding their creation, in line with Kingdon's [1984] "policy window" approach.

\section{Table 48. Policy window of four selected Latin American diaspora policies}

\begin{tabular}{|c|c|c|}
\hline $\begin{array}{l}\text { Streams of the } \\
\text { Policy Window }\end{array}$ & Policy & Observations \\
\hline \multirow[t]{4}{*}{$\begin{array}{l}\text { I/1.) Problem } \\
\text { Stream }\end{array}$} & $\begin{array}{l}\text { Matrícula } \\
\text { Consular }\end{array}$ & $\begin{array}{l}\text { Undocumented migrants have no access to health } \\
\text { facilities, banks, they are afraid to cooperate with the } \\
\text { police. }\end{array}$ \\
\hline & Cucayo Fund & $\begin{array}{l}\text { Ecuadorian migrants who have saved some money } \\
\text { abroad find it difficult to make a living as the countries } \\
\text { of destination (mostly Spain and Italy) enter into } \\
\text { economic recession. Parallelly, the country of origin } \\
\text { would need investments but investors do not reach } \\
\text { rural communities. }\end{array}$ \\
\hline & $3 x 1$ Programme & $\begin{array}{l}\text { Migrant-sending localities lack basic infrastructure, } \\
\text { government funds are scarce to finance them. }\end{array}$ \\
\hline & $\begin{array}{l}\text { Red Caldas and } \\
\text { Colombia Nos } \\
\text { Une }\end{array}$ & $\begin{array}{l}\text { Many Colombian scientists left the country and } \\
\text { received prestigious jobs abroad, while Colombian } \\
\text { universities and local governments did not have } \\
\text { qualified personnel for development planning. }\end{array}$ \\
\hline \multirow[t]{4}{*}{$\begin{array}{l}\text { I/2.) Political } \\
\text { Stream }\end{array}$} & $\begin{array}{l}\text { Matrícula } \\
\text { Consular }\end{array}$ & $\begin{array}{l}\text { A pro-migrant government is elected in Mexico, } \\
\text { extreme security measures are implemented in the US } \\
\text { after } 9 / 11 \text {, the Mexican government wants to 'help' and } \\
\text { finds allies in local governments and companies. }\end{array}$ \\
\hline & Cucayo Fund & $\begin{array}{l}\text { Rafael Correa is elected as president in } 2007 . \mathrm{He} \\
\text { campaigned with migrant-related issues. Spain and } \\
\text { other European countries transfer considerable sums of } \\
\text { money as development assistance, and they expect the } \\
\text { reduction of migratory flows. }\end{array}$ \\
\hline & $3 x 1$ Programme & $\begin{array}{l}\text { New president in Mexico (Vicente Fox) picks a } \\
\text { successful regional programme and elevates it to the } \\
\text { federal level. }\end{array}$ \\
\hline & $\begin{array}{l}\text { Red Caldas and } \\
\text { Colombia Nos } \\
\text { Une }\end{array}$ & $\begin{array}{l}\text { Following a longer period of guerrilla and drug cartel } \\
\text { violence, a new constitution is adopted in } 1991 \text { under } \\
\text { president Gaviria. A moment of 'national } \\
\text { reconstruction enthusiasm' is reached (before new } \\
\text { conflicts rise in the late 1990s). }\end{array}$ \\
\hline
\end{tabular}




\begin{tabular}{|l|l|l|}
\hline $\begin{array}{l}\text { I/3.) Policy } \\
\text { Stream }\end{array}$ & $\begin{array}{l}\text { Matrícula } \\
\text { Consular }\end{array}$ & $\begin{array}{l}\text { A low-profile tacit agreement between meso level } \\
\text { policymakers in the US and the Mexican consulates is } \\
\text { reached and the US federal government does not } \\
\text { disapprove it. }\end{array}$ \\
\cline { 2 - 3 } & $\begin{array}{l}\text { Cucayo Fund } \\
\text { mo-development programmes are launched, focusing } \\
\text { savings in rural areas, co-financed by the Ecuadorian } \\
\text { government. }\end{array}$ \\
\hline 3xl Programme & $\begin{array}{l}\text { The programme receives proposals from migrant } \\
\text { organizations and local governments and implements } \\
\text { local development projects. It is presented as a } \\
\text { 'retaining' element for prospective migrants, although } \\
\text { it is not. }\end{array}$ \\
\hline & $\begin{array}{l}\text { Red Caldas and } \\
\text { Colombia Nos } \\
\text { Une }\end{array}$ & $\begin{array}{l}\text { Individual scientists are approached by a government- } \\
\text { runency to join to a network of common project } \\
\text { planning and implementation. Scientists generally } \\
\text { receive the idea positively. }\end{array}$ \\
\hline
\end{tabular}

Source: own compilation.

I/1.) Problem Stream. As described in Chapter 2.1, mass emigration caused serious problems for Latin American countries. Workforce, skills and money was lacking on the local level in the country of origin, while there were integration problems (no access to public services, marginalization on the labour market etc.) in the country of destination. As migration processes from Latin America in the 1990s and early 2000s were rather robust and sudden, management of the issue was insufficient on both sides of the migratory channel.

Understanding emigration as a "problem", however, was not such a mainstream approach in the 1990s and early 2000s as it is in the mid-2010s. Under the laissez-faire premises of the neoliberal structural adjustments, emigration was seen either as the labour side of a factor equalization process or as an escape valve for a structurally rooted excess of low-skilled labor force (see Chapter 1.1). Framing the emigration issue as a problem was very much connected to the opposition forces in party politics, as it is seen in these concrete cases as well (I/2).

I/2.) Political Stream. A basic feature in all four cases is that a new president, from a political party previously in opposition, was elected. In the case of Mexico, it is the same election (the victory of Vicente Fox and the PAN in 2000) that launched both activities analyzed here. Interestingly, ideological belongings did not really seem to matter: Fox was on the centre-right, Gaviria (Colombia) on the centreleft, and Correa (Ecuador) on the left of the political spectrum. What might have been important, however, is taking up the emigration issue as a proof of bad management of the previous government. This was very easy in Colombia where 
desperate guerrilla warfare was going on, but Ecuador's spectacular economic crash that followed the 1998-1999 banking crisis was also a cause of widespread civil discontent. In the case of Mexico, it was the corrupt and obsolete governance of the ruling PRI party that was to blame for economic hardships and mass emigration.

The idea of change, therefore, has been the main element in pulling the political stream closer to the other two. Similar processes can be identified in other Latin American countries as well, such as in the case of the election of Alejandro Toledo in Peru (2001) and Leonel Fernández in the Dominican Republic (1996).

I/3.) Policy Stream. A "hands-on approach" can be observed in all four cases. (Newly elected) governments did not wait for external actors (most importantly the government(s) of the country(ies) of destination) but designed and implemented policies unilaterally. This might be the result of the new government that took over the administration, restructured it according to their needs and created Diaspora Units (such as the Institute for Mexicans Abroad in 2000) which, in turn, needed to present own programmes of outreach for the diaspora, in order to demonstrate their raison d'être. This is definitely the case with Ecuador's SENAMI as well, while the Colombian case is less obvious, as no separate unit was created.

The policy design might have been influenced by another factor, namely, the restrictive turn in the immigration policies of the countries of destination. The Matrícula Consular was a direct consequence of the post-9/11 policy changes in the U.S, while the $3 \times 1$ Programme and the Cucayo Fund were presented (originally) framed as programmes that are able to retain or turn back migration flows. As it has been shown, their communication gradually shifted from these (unsustained) statements. In the Colombian case, connection to the countries of destination was less direct.

To sum up, 'policy windows' in the cases of analyzed Latin American diaspora policies opened because "problems" related to emigration objectively grew, on one hand, and were conceptualized as problems, on the other; "political" actors saw a good topic in it to thematize the discourse and eventually won the elections with an agenda that contained the promise of tackling the problems of emigration; and "policy" activities were implemented, together with their new institutional frameworks, mostly in order to show engagement to the issue towards domestic voters, but also towards the governments of the countries of destination of emigrants, who started to become worried about the large immigration flow. 


\subsubsection{The policy deal}

Table 49 summarizes the findings of each analyzed Latin American diaspora policy case, regarding the 'deal' between the government and the diaspora, and also for the sending community (locality of origin), following Gamlen's [2006] approach of "extending rights" and "extracting obligations".

Table 49. Policy deal of four selected Latin American diaspora policies

\begin{tabular}{|c|c|c|}
\hline Deal features & Policy & Observations \\
\hline \multirow{4}{*}{$\begin{array}{l}\text { II/1.) } \\
\text { Government } \\
\text { Benefits }\end{array}$} & $\begin{array}{l}\text { Matrícula } \\
\text { Consular }\end{array}$ & $\begin{array}{l}\text { More remittances, better surveillance of migrants, } \\
\text { better cooperation between migrants and consulates }\end{array}$ \\
\hline & Cucayo Fund & $\begin{array}{l}\text { Capturing migrant savings }(50-75 \%) \text { for job-creating } \\
\text { projects and coping with international requirements for } \\
\text { tackling the emigration challenge. }\end{array}$ \\
\hline & $3 x 1$ Programme & $\begin{array}{l}\text { Extra funding for local development projects, } \\
\text { involvement of migrants in local activities. }\end{array}$ \\
\hline & $\begin{array}{l}\text { Red Caldas and } \\
\text { Colombia Nos } \\
\text { Une }\end{array}$ & $\begin{array}{l}\text { Planning, technical assistance and partial funding of } \\
\text { development projects, access to intellectual networks. }\end{array}$ \\
\hline \multirow{4}{*}{$\begin{array}{l}\text { II/2.) Migrant } \\
\text { Benefits }\end{array}$} & $\begin{array}{l}\text { Matrícula } \\
\text { Consular }\end{array}$ & $\begin{array}{l}\text { More remittances, less vulnerability, access to banking, } \\
\text { healthcare etc. }\end{array}$ \\
\hline & Cucayo Fund & $\begin{array}{l}\text { Receiving governmental non-reimbursable grants (25- } \\
50 \% \text { ) for a job-creating investment that benefits, first } \\
\text { and foremost, the family and closer social circle of the } \\
\text { migrant. }\end{array}$ \\
\hline & $3 x 1$ Programme & Prestige and social capital in the locality of origin. \\
\hline & $\begin{array}{l}\text { Red Caldas and } \\
\text { Colombia Nos } \\
\text { Une }\end{array}$ & Not too much, mostly symbolical recognition \\
\hline \multirow{4}{*}{$\begin{array}{l}\text { II/3.) Sending } \\
\text { Community } \\
\text { Benefits }\end{array}$} & $\begin{array}{l}\text { Matrícula } \\
\text { Consular }\end{array}$ & More remittances \\
\hline & Cucayo Fund & $\begin{array}{l}\text { Jobs are created, although mostly for the family and } \\
\text { closer social circle of the migrant. }\end{array}$ \\
\hline & $3 x 1$ Programme & Local development projects implemented. \\
\hline & $\begin{array}{l}\text { Red Caldas and } \\
\text { Colombia Nos } \\
\text { Une }\end{array}$ & $\begin{array}{l}\text { Experts: learn about up-to-date technological } \\
\text { innovations, become linked to international knowledge } \\
\text { networks } \\
\text { Population: depending on the concrete project }\end{array}$ \\
\hline
\end{tabular}

Source: own compilation.

II/1.) Government Benefits. As conceptualized in 1.3.3, the government of a country of origin expects mostly economic benefits from increased cooperation with the diaspora, while the diaspora's possible benefits are mostly of a political nature. In the four cases analyzed, at the end of the day there was more remittances (household, investment, community or social) flowing in than there would have been without 
doing anything. This is definitely a big achievement and it shows that the diaspora is indeed a source for development in the country of origin.

However, the diaspora is not a barrel of money to be tapped. Involvement of the government of the country of origin in all its complexity needs a lot of resources - among them, economic ones (see point IV/2. on the budget). Investments into consular and Diaspora Unit staff are also a considerable cost. Still, on the benefit side, there are significant inflows to counterbalance these investments. From a government perspective, these are extra incomes for families or for meso level actors (municipalities, educational institutions etc.) that will have more disposable income (which, in turn, can be burdened with tax on consumption in the first case or can be seen as a complementary for low funding from the central budget). Direct benefits, however, only appear at the households or meso level actors (see II/3).

II/2.) Migrant Benefits. As opposed to the benefits of the (government of the) country of origin, it is less evident to what extent migrants benefit from the analyzed policies. In the case of Matrículas, there are obvious benefits (not from holding the Matrículas in themselves but having them accepted in banks, public attorney offices and so on, which are the results of additional efforts by the consulates). In the other cases, however, it is less so: The Cucayo Fund benefits the returnees (who, therefore, cease to be migrants, and it has no additional benefit for the rest of the diaspora), while the $3 \times 1$ Programme and the Red Caldas / Colombia Nos Une provides little more than symbolic recognition for diaspora members who have been willing to help their country or community of origin with their time, work and money.

From the perspective of the diaspora, political resources of the government of the country of origin are therefore best channeled into extended consular activities. Other mechanisms of assisted return, matching funds and diaspora networks rarely benefit migrants in a direct way.

II/3.) Sending Community Benefits. The sending communities, i.e. the localities where migrants come from, can benefit from the 'deal' between the government of the country of origin and the diaspora as recipients of different forms of remittances (household, investment, collective or social). What has been presented for II/1, applies here as well: diaspora policies for development can provide additional income for households and institutions. It is, however, only in the case of the Cucayo Fund that benefits go further of the remittances received: by helping the 
creation of a microenterprise, the Cucayo Fund was an important contribution to the self-subsistence of the community. Others (including the $3 \times 1$ Programme, which usually does not create jobs on the long run) do not help community members in producing their own income.

To conclude, governments and sending communities can have significant benefits from development-related diaspora policies: the latter in a direct way (through receiving incoming money), while the former in an indirect way (through taxes on consumption and by having additional sources of income for meso level actors that otherwise would need that money from the central budget). Meanwhile, the diaspora has a very reduced circle of benefits, mostly of an administrative nature and connected to the consulates. The rest of the activities analyzed here only provide them with symbolical rewards.

\subsubsection{The policy mechanism}

Table 50 summarizes the findings of each analyzed Latin American diaspora policy case, regarding the participants of the policy mechanism.

Table 50. Policy mechanism of four selected Latin American diaspora policies

\begin{tabular}{|c|c|c|}
\hline $\begin{array}{l}\text { Mechanism } \\
\text { participants }\end{array}$ & Policy & Observations \\
\hline \multirow{4}{*}{$\begin{array}{l}\text { III/1.) } \\
\text { Government } \\
\text { (Country of } \\
\text { origin) }\end{array}$} & $\begin{array}{l}\text { Matrícula } \\
\text { Consular }\end{array}$ & $\begin{array}{l}\text { Issues the Matrículas, consulates lobby on the meso } \\
\text { level (both with migrant associations and local actors) }\end{array}$ \\
\hline & Cucayo Fund & $\begin{array}{l}\text { Provides a } 25-50 \% \text { non-reimbursable grant and } \\
\text { technical assistance for returning migrants if they } \\
\text { invest it in productive businesses. It receives } \\
\text { international aid in the meantime, from the government } \\
\text { of the country of destination. }\end{array}$ \\
\hline & $3 x 1$ Programme & $\begin{array}{l}\text { Decides which migrant initiatives will be implemented } \\
\text { and, through its } 3 \text { levels, puts } 75 \% \text { in the project. }\end{array}$ \\
\hline & $\begin{array}{l}\text { Red Caldas and } \\
\text { Colombia Nos } \\
\text { Une }\end{array}$ & $\begin{array}{l}\text { Initiates regular knowledge exchange with (individual) } \\
\text { highly skilled migrants in the form of a communication } \\
\text { network, provides a secretariat for project } \\
\text { development. }\end{array}$ \\
\hline \multirow{4}{*}{$\begin{array}{l}\text { III/2.) Migrant } \\
\text { associations }\end{array}$} & $\begin{array}{l}\text { Matrícula } \\
\text { Consular }\end{array}$ & Lobby on the macro level (with the Treasury of State) \\
\hline & Cucayo Fund & Negligible role. \\
\hline & $3 x 1$ Programme & $\begin{array}{l}\text { Raise funds for a local development project, apply for } \\
\text { funding and put } 25 \% \text { in the project. }\end{array}$ \\
\hline & $\begin{array}{l}\text { Red Caldas and } \\
\text { Colombia Nos } \\
\text { Une }\end{array}$ & Not involved. \\
\hline III/3.) Migrants & $\begin{array}{l}\text { Matrícula } \\
\text { Consular }\end{array}$ & $\begin{array}{l}\text { Receive the Matrículas, open bank accounts, send more } \\
\text { remittances }\end{array}$ \\
\hline
\end{tabular}




\begin{tabular}{|c|c|c|}
\hline & Cucayo Fund & $\begin{array}{l}\text { Apply for grants at the government of the country of } \\
\text { origin and if they win, they move back and found an } \\
\text { enterprise. }\end{array}$ \\
\hline & $3 x 1$ Programme & Donate money for the project through the association. \\
\hline & $\begin{array}{l}\text { Red Caldas and } \\
\text { Colombia Nos } \\
\text { Une }\end{array}$ & $\begin{array}{l}\text { Highly skilled migrants share knowledge and elaborate } \\
\text { ideas for development projects, try to receive funding. }\end{array}$ \\
\hline \multirow{4}{*}{$\begin{array}{l}\text { III/4.) Migrant- } \\
\text { sending } \\
\text { households }\end{array}$} & $\begin{array}{l}\text { Matrícula } \\
\text { Consular }\end{array}$ & Receive more remittances \\
\hline & Cucayo Fund & Become employees of a newly created enterprise. \\
\hline & $3 x 1$ Programme & Enjoy the benefits of the local development project. \\
\hline & $\begin{array}{l}\text { Red Caldas and } \\
\text { Colombia Nos } \\
\text { Une }\end{array}$ & Indirect benefits, depending on the project. \\
\hline \multirow{4}{*}{$\begin{array}{l}\text { III/5.) Civil } \\
\text { society } \\
\text { (Country of } \\
\text { origin) }\end{array}$} & $\begin{array}{l}\text { Matrícula } \\
\text { Consular }\end{array}$ & Not involved \\
\hline & Cucayo Fund & $\begin{array}{l}\begin{array}{l}\text { Becomes beneficiary and multiplier of benefits } \\
\text { (cooperatives etc.) }\end{array} \\
\end{array}$ \\
\hline & $3 x 1$ Programme & $\begin{array}{l}\text { Might participate in the decision-making, enjoy the } \\
\text { benefits of the local development project. }\end{array}$ \\
\hline & $\begin{array}{l}\text { Red Caldas and } \\
\text { Colombia Nos } \\
\text { Une }\end{array}$ & $\begin{array}{l}\text { Beneficiary institutions in the country of origin } \\
\text { (schools, research centres etc.) get involved in cutting } \\
\text { edge technological and scientific projects. }\end{array}$ \\
\hline \multirow[t]{4}{*}{$\begin{array}{l}\text { III/6.) } \\
\text { Government } \\
\text { (Country of } \\
\text { destination) }\end{array}$} & $\begin{array}{l}\text { Matrícula } \\
\text { Consular }\end{array}$ & $\begin{array}{l}\text { Federal government opens a public consultation but its } \\
\text { results are favourable for the Matrícula, thus it } \\
\text { maintains a laissez-faire approach. Local governments } \\
\text { are realistic and positive. }\end{array}$ \\
\hline & Cucayo Fund & $\begin{array}{l}\text { Facilitates (pushes forward) the efforts of the } \\
\text { government of the country of origin. Donates money. }\end{array}$ \\
\hline & $3 x 1$ Programme & Not involved. \\
\hline & $\begin{array}{l}\text { Red Caldas and } \\
\text { Colombia Nos } \\
\text { Une }\end{array}$ & Donates money (through bilateral mechanisms). \\
\hline
\end{tabular}

Source: own compilation.

III/1.) Government (Country of origin). Regarding the mechanism of the policies analyzed here, governments of the country of origin are by definition in focus. Their involvement is coupled with a wide range of activities (issuing documents, providing technical assistance, providing legal assistance, maintaining a system of applications and evaluations, funding projects, lobbying and maintaining a system of communication and outreach. As this thesis has been focused on government activities, these have been presented in details in 2.2 and the respective parts of Chapter 3.

III/2.) Migrant associations. As opposed to the government of the country of origin, the 'diaspora' is not an unitary (or, at least, a hierarchically coordinated) actor, but a loose network of individuals and organizations. Migrant associations are in the core of the diaspora, and diaspora policies often have associations as their counterparties. However, from the four cases analyzed, it is only the $3 \times 1$ Programme 
in which migrant associations have a crucial role. In the case of the Matrícula, diaspora organizations were important in lobbying, but after the positive decision of the Treasury of State, their importance vanished. In the case of the Cucayo Fund and the Red Caldas / Colombia Nos Une, counterparties of the government of the country of origin were individual migrants, not migrant associations. This is an important point concerning the sustainability of a programme, therefore the non-inclusion of migrant associations might be identified as a weak point in the cases where the policy had major shortcomings and ceased to operate.

III/3.) Migrants. In all four cases analyzed, individual migrants have been the key actors to keep policies working. They open bank accounts and send more remittances through obtaining Matrículas; they move back to the country of origin with their savings and found an enterprise; they donate money for matching funds projects through an association, and they are willing to share their knowledge and elaborate ideas for development projects (also, they even try to receive funding in the country of destination). It is therefore the (individual) migrant activity that keeps policies operating.

III/4.) Migrant-sending households. A rather passive role is assigned to household in the four cases analyzed: they receive more remittances and enjoy the benefits of the eventual investment or community project.

III/5.) Civil society (Country of origin). As households, civil society organizations are also not very active in the analyzed cases. However, there were some cases in the experience of the Cucayo Fund (when cooperatives received funding), the $3 \times 1$ Programme (when migrant associations worked closely with organizations or informal groups in the locality of origin) and the Red Caldas (when development projects were conceived and implemented jointly, having a highly skilled migrant on one side and a department of a Colombian university or research institution on the other side), when it was the meso level of the country of origin that had the significant share in the project. As a remark, it can be added to point III/2 that the meso level should be more involved in policies in order to ensure more outreach and sustainability.

III/6.) Government (Country of destination). Governments of the country of destination have been either absent or benevolently distant in the four cases analyzed, sometimes donating some money to keep the projects running. As the scope of these case studies were set in policies where the government of the country of origin has 
the lead role, it does not mean that they are passive in the migration and development agenda, only that they have a different approach (e.g. their own agenda of codevelopment) which is not described here in details.

To sum up, differentiated and proactive approach of the governments of the countries of origin brought the four analyzed policy cases into life. They were relatively successful in engaging and mobilizing the diaspora - however, there have been an asymmetry between the two sides involved. The 'diaspora' side of the cooperation has been mostly understood as individual migrants who apply for and take part in the offered activities or mechanisms. More involvement from meso level actors (migrant associations, civil society and non-governmental institutions in the country of origin) might have provided extra resources for the analyzed policies (with the exception of the $3 \times 1$ Programme which relies on them).

\subsubsection{The policy impact}

Table 51 summarizes the findings of each analyzed Latin American diaspora policy case, regarding their impact, in line with Czaika and de Haas's [2011] theory of the three "policy gaps".

Table 51. Policy impact of four selected Latin American diaspora policies

\begin{tabular}{|l|l|l|}
\hline $\begin{array}{l}\text { Impact } \\
\text { Features }\end{array}$ & Policy & Observations \\
\hline $\begin{array}{l}\text { IV/1.) } \\
\text { Managing }\end{array}$ & $\begin{array}{l}\text { Matrícula } \\
\text { Consular }\end{array}$ & $\begin{array}{l}\text { Institute for Mexicans Abroad / Ministry of Foreign } \\
\text { Affairs }\end{array}$ \\
\cline { 2 - 3 } & Cucayo Fund & $\begin{array}{l}\text { SENAMI (Secretariat for Migrants at the Ministry of } \\
\text { Foreign Affairs) }\end{array}$ \\
\cline { 2 - 3 } & 3xl Programme & SEDESOL (Ministry of Social Development) \\
\cline { 2 - 3 } & $\begin{array}{l}\text { Red Caldas and } \\
\text { Colombia Nos } \\
\text { Une }\end{array}$ & Ministry of Foreign Affairs \\
\hline IV/2.) Budget & $\begin{array}{l}\text { Matrícula } \\
\text { Consular }\end{array}$ & No separate budget \\
\cline { 2 - 3 } & Cucayo Fund & Approx. 2 million USD per year \\
\cline { 2 - 3 } & 3xl Programme & 17 million USD (2013) \\
\cline { 2 - 3 } & $\begin{array}{l}\text { Red Caldas and } \\
\text { Colombia Nos } \\
\text { Une }\end{array}$ & n.d. \\
\hline $\begin{array}{l}\text { IV/3.) Number } \\
\text { of Beneficiaries }\end{array}$ & $\begin{array}{l}\text { Matrícula } \\
\text { Consular }\end{array}$ & Approx. 4 million \\
\cline { 2 - 3 } & Cucayo Fund & Approx. 2100 per year \\
\cline { 2 - 3 } & 3xl Programme & 30,000-50,000 \\
\cline { 2 - 3 } & Red Caldas and & n.d. \\
\hline
\end{tabular}




\begin{tabular}{|c|c|c|}
\hline & $\begin{array}{l}\text { Colombia Nos } \\
\text { Une }\end{array}$ & \\
\hline \multirow{4}{*}{$\begin{array}{l}\text { IV/4.) Average } \\
\text { Benefit per } \\
\text { Beneficiary }\end{array}$} & $\begin{array}{l}\text { Matrícula } \\
\text { Consular }\end{array}$ & Approx. 420 USD per year \\
\hline & Cucayo Fund & 950 USD \\
\hline & $3 x 1$ Programme & 425 USD \\
\hline & $\begin{array}{l}\text { Red Caldas and } \\
\text { Colombia Nos } \\
\text { Une }\end{array}$ & n.d. \\
\hline \multirow{4}{*}{$\begin{array}{l}\text { IV/5.) Impact } \\
\text { on Local } \\
\text { Development }\end{array}$} & $\begin{array}{l}\text { Matrícula } \\
\text { Consular }\end{array}$ & More remittances \\
\hline & Cucayo Fund & High \\
\hline & $3 x 1$ Programme & Medium \\
\hline & $\begin{array}{l}\text { Red Caldas and } \\
\text { Colombia Nos } \\
\text { Une }\end{array}$ & Small \\
\hline \multirow{4}{*}{$\begin{array}{l}\text { IV/6.) Impact } \\
\text { on Migratory } \\
\text { Flows }\end{array}$} & $\begin{array}{l}\text { Matrícula } \\
\text { Consular }\end{array}$ & Difficult to measure, but possibly increasing \\
\hline & Cucayo Fund & Moderate \\
\hline & $3 \times 1$ Programme & Low \\
\hline & $\begin{array}{l}\text { Red Caldas and } \\
\text { Colombia Nos } \\
\text { Une }\end{array}$ & None \\
\hline \multirow[t]{4}{*}{$\begin{array}{l}\text { IV/7.) Relative } \\
\text { Significance }\end{array}$} & $\begin{array}{l}\text { Matrícula } \\
\text { Consular }\end{array}$ & Medium \\
\hline & Cucayo Fund & Medium \\
\hline & $3 x 1$ Programme & Medium \\
\hline & $\begin{array}{l}\text { Red Caldas and } \\
\text { Colombia Nos } \\
\text { Une }\end{array}$ & Small \\
\hline
\end{tabular}

Source: own compilation.

IV/1.) Managing Authority. Three out of the four policies analyzed here are (or have been) managed by the Diaspora Unit within the Ministry of Foreign Affairs, and the fourth - the $3 \times 1$ Programme, managed by the Ministry of Social Development - have also worked in close cooperation with the Institute of Mexicans Abroad since its start. However, with time the Ecuadorian Cucayo Fund - managed by the SENAMI - ceased to exist, and new programmes for return migration are not managed, only coordinated by the Viceministry of Human Mobility. The Red Caldas / Colombia Nos Une Networks became obsolete and unsubstantial with time. Among the four policy activities, it is only the issuance of the Matrícula Consular which keeps on existing within the Ministry of Foreign Affairs and fulfilling well its duties - yet, the day-by-day work is done by consulate staff as part of their duties at the consulates, thus it is no longer an 'active' policy but a tried and streamlined regular item on the to-do list.

Therefore, it is worth to ask whether it is a good idea to have the Diaspora Unit within the Ministry of Foreign Affairs as the Managing Authority of a diaspora 
policy. Initially, perhaps yes - as the complex expertise needed for designing a policy is (or should be) there. However, with time it should be outsourced for other units within the government - or even to externals - who are more knowledgeable on the topic of the policy. Agreements between the Ministry of Foreign Affairs and other entities (see Table 41 for the case of Uruguay and Table 43 on how the Ecuadorian return migration incentive activities were delegated to other institutions) might be a good following if the policy has already been operating for a couple of years.

IV/2.) Budget. A crucial factor in the shortcomings or limitations of all of the four policies analyzed here, budget is the Achilles heel of policymaking in a developing country. Not only the amount but also the calculabity of the budget is important, i.e. for planning it is important to know whether the same or an even larger sum of money will be available next year, to be applied for under the same conditions. This has been the case for the 3x1 Programme, while for the Cucayo Fund apparently it came as a surprise for many that after 2012, there was no new call in 2013 and the programme started without any successor. [El Telegrafo, 2014]

Regarding the size of the budget, it is obvious: 2 million USD per year for the Cucayo Fund (2011) and 17 million USD for the 3x1 Programme (2013) is not a large sum if it is compared to the size of the diaspora of the two respective countries. It is not negligible either (see point IV/4 for the average number of beneficiaries). Still, no significant impact can be expected without a drastical expansion of the Diaspora Unit budget - which is not very likely, given the nature of the issue.

The Matrícula Consular and the Red Caldas / Colombia Nos Une apparently never had a separate budget line within the budget of the respective Ministry of Foreign Affairs.

IV/3.) Number of Beneficiaries. A cost-benefit analysis would certainly choose the Matrícula as the most cost-effective of the four diaspora policy interventions. Although their additional cost (on top of other consular activities) cannot be calculated, they have a price as well, to be paid by the migrant (27 USD at the time of research) which is supposed to cover most of the expenses of the consular unit in terms of extra working time. Approximately 4 million people benefited from the Matrícula between its introduction and 2013.

The Cucayo Fund, while being substantial and complex assessment to returning migrants' needs, had its weakest point at its narrow coverage: 
approximately 10 thousand people benefited from it during its existence (2000 per year), from the Ecuadorian diaspora that is well over a million. The 3x1 Programme, in turn, has benefited between 30 and 50 thousand people in one year (2013). Nonetheless, 'benefit' from a community project is not the same as a nonreimbursable government investment to a private property.

The Red Caldas / Colombia Nos Une, with the development projects mentioned in 3.5.3, had indirect effects on beneficiaries that are not quantifiable.

IV/4.) Average Benefit per Beneficiary. If we count the gains on sending remittances at lower prices, which have been a consequence of introducing the Matrícula, each card holder has enjoyed a net decrease of approximately 420 USD in the additional costs of sending money home during one year (and so on, let alone the overall drop in the prices of remittance agencies). Moreover, this 'money' is not a government investment but a decrease of the private remittance agencies.

The other three policy activities supposed an active financial involvement of the government of the country of origin. With an average amount of 950 USD per person, benefiting from the Cucayo Fund was a considerable grant. Also, an average of 425 USD per person for a rural community in Mexico through the 3x1 Programme is also an important sum. Yet, the matching fund nature of these programmes (and that of the Red Caldas / Colombia Nos Une, for which no data were found) means that migrant contribution for development can only be channeled if the (different levels of) government also put their share to it - maybe at the expense of other, omitted investments, as in the cases found in the 3x1 Programme by Aparicio and Meseguer [2009, 2012].

IV/5.) Impact on Local Development. Among the four, it is the Cucayo Fund that had most impact on local development, helping to create approximately 10 thousand micro- and small enterprises during its five years of existence. The $3 \times 1$ programme, although the number of its beneficiaries is way larger, has had an effect on development through the increase of living standards. The other two policy activities had indirect effects.

Very importantly, there is an opposition of scope and impact here. The narrower the focus of a development policy is, the bigger will its impact be. This is why the other two policy activities are not quantifiable on the local level - still, the increased amount of remittances received through the Matrícula, or the positive 
effects of an achievement of the Red Caldas (such as malaria pills) are not to be neglected.

IV/6.) Impact on Migratory Flows. A crucial question, also in the focus of this thesis, is whether these developmental policies can have an impact on migration flows - namely, can they bring such a development which would make emigration levels decrease. The answer is a rotund no. None of the four policies analyzed here have the dimensions, nor the potential, to significantly reduce outward migration. The Matrícula Consular - otherwise a successful tool in developmental terms - can even increase the migrant stock (or slow down its decrease) as it reduces the likeliness of wanting or needing to return to Mexico.

The Cucayo Fund, as it was presented, could bring back mostly those migrants who would have returned anyway - and, even if it had its local successes, it could not arrive to a scale when its impact would have been significant. Addressing 10 thousand migrants from a diaspora of 1.15 million people means that it would have needed a budget 115 times bigger to address everybody.

The $3 \times 1$ Programme, although it considerably increases the living standards in a village if the project is well conceived, it does not create jobs on the long run. Furthermore, by linking migrants to the community, it keeps the possible migratory channels alive and accessible. This does not mean that it is 'bad' for development: from communities of high migration rate, smooth channels for going away and coming back might be as beneficial as retaining, or even better than that. Yet, reducing migration flows is not very likely through the investments of the community remittances type.

Finally, development projects implemented through Red Caldas and Colombia Nos Une could be important, but their sporadical nature did not enable them to have any impact on emigration processes.

IV/7.) Relative Significance. All in all, three out of the four cases can be rated as of medium significance - policies which have had an impact for given groups of beneficiaries in different points of space or time, but they did not lead to systemic change. The fourth, the Red Caldas / Colombia Nos Une was even less important, being a particular initiative for a particular group of people, leading to sporadical results.

In conclusion, the analyzed Latin American diaspora policies for development are important in some ways, but there are no wonder substances for the 
complex challenges of emigration. Yet, all four are able to link migrants to their countries or communities of origin in a way that is, to varying extent, beneficial to the members of these communities. In the highlights and lowlights experienced by the people involved in these four policy activities, budget is certainly the major constraint, followed by problems of management skills / capacities and conceptual issues. By the latter, it is understood that while these policies will help to increase the inflow of different kinds of remittances - household, investment, community and social - they will not decrease neither the absolute numbers of the emigrant stock, nor the root drivers of emigration.

\subsubsection{The policy lifespan}

Table 52 summarizes the findings of each analyzed Latin American diaspora policy case, regarding its lifespan and perspectives for the future (and for further applicability).

Table 52. Policy lifespan of four selected Latin American diaspora policies

\begin{tabular}{|c|c|c|}
\hline $\begin{array}{l}\text { Lifespan } \\
\text { features }\end{array}$ & Policy & Observations \\
\hline \multirow[t]{4}{*}{$\begin{array}{l}\text { V/1.) Timeline } \\
\text { of } \\
\text { implementation }\end{array}$} & $\begin{array}{l}\text { Matrícula } \\
\text { Consular }\end{array}$ & $\begin{array}{l}\text { Implemented in } 2001 \text {, upgraded in } 2002 \text {. Public outcry } \\
\text { in anti-immigration circles in the US. The Department } \\
\text { of Treasury does not rule out the card (decision in late } \\
\text { 2003). Low profile consular activity since } 2003 \text { reaches } \\
\text { an agreement with more than the half of all commercial } \\
\text { bank in the US since then. }\end{array}$ \\
\hline & Cucayo Fund & $\begin{array}{l}\text { First implemented in 2008, it had its peak around } 2011 . \\
\text { Critiques were formulated on its high costs and narrow } \\
\text { circle of recipients. In 2013, a large-scale } \\
\text { reorganization of the Managing Authority (SENAMI) } \\
\text { took place and the Cucayo Fund ceased to exist. }\end{array}$ \\
\hline & $3 x 1$ Programme & $\begin{array}{l}\text { Started as a pilot project, the } 3 \times 1 \text { Programme gained } \\
\text { popularity among migrants. Originally, it was } \\
\text { presented as a tool for local development - now, it is } \\
\text { framed as a way of engaging the diaspora. Despite } \\
\text { critiques and controversies, it keeps on operating. }\end{array}$ \\
\hline & $\begin{array}{l}\text { Red Caldas and } \\
\text { Colombia Nos } \\
\text { Une }\end{array}$ & $\begin{array}{l}\text { Red Caldas was a pioneer initiative in the early } 1990 \mathrm{~s} \\
\text { when thematic e-mail lists were a new and more } \\
\text { efficient alternative to traditional information exchange } \\
\text { mechanisms (paper-based publications, telephone } \\
\text { calls). Its popularity and impact peaked around 1994, } \\
\text { after which financial problems hindered the further } \\
\text { evolution. In the times of the revolutionary changes in } \\
\text { online communication, the network quickly became } \\
\text { obsolete. } \\
\text { Reorganized in 2003, the Colombia Nos Une web } \\
\text { platform became once again an up-to-date hub for }\end{array}$ \\
\hline
\end{tabular}




\begin{tabular}{|c|c|c|}
\hline & & $\begin{array}{l}\text { skilled emigrants. Due to lack of funding and loose } \\
\text { focus, it became marginal and unsubstantial once } \\
\text { again. }\end{array}$ \\
\hline \multirow[t]{4}{*}{$\begin{array}{l}\text { V/2.) } \\
\text { Perspective }\end{array}$} & $\begin{array}{l}\text { Matrícula } \\
\text { Consular }\end{array}$ & $\begin{array}{l}\text { Matrículas were implemented by } 9 \text { more Latin } \\
\text { American countries. It has become an integral part of } \\
\text { Mexican (and Latin American) consular policy and it is } \\
\text { likely to remain that way. }\end{array}$ \\
\hline & Cucayo Fund & $\begin{array}{l}\text { Although a good showcase of many success stories, it } \\
\text { was too costly and very few returnees did actually } \\
\text { benefit from it. In } 2013 \text {, the Ecuadorian government } \\
\text { shifted towards policies of lower investment (but } \\
\text { broader scope). }\end{array}$ \\
\hline & $3 \times 1$ Programme & $\begin{array}{l}\text { Being an innovative but more symbolic than job- } \\
\text { creating programme, it might remain at the current } \\
\text { level, no serious development of the programme can be } \\
\text { expected. }\end{array}$ \\
\hline & $\begin{array}{l}\text { Red Caldas and } \\
\text { Colombia Nos } \\
\text { Une }\end{array}$ & $\begin{array}{l}\text { None, at its present form its impact is very limited. } \\
\text { With no significant information content, it is of little } \\
\text { interest for (skilled) migrants. }\end{array}$ \\
\hline
\end{tabular}

Source: own compilation.

V/1.) Timeline of implementation. Regarding the distribution of crucial moments or periods of the lifespan of a policy, there are four rather different trajectories, suggesting that there is difficult to identify common features in this respect. The Matrícula was a bold intervention in 2001/2002, causing a major scandal. However, after the peak of public outcry, in slowly 'blended in' to the other activities of the consular network, becoming part of the everyday routine.

The Cucayo Fund had a lifespan of five years - covering President Rafael Correa's first term - an it was a popular, yet expensive showcase of success stories to be presented for the public, both at home and abroad. After Correa's second victory, the institutional framework for migration and diaspora policies was upgraded, and while the area gained importance, this particular policy ceased to exist.

The 3x1 Programme shows a gradual evolution in size and, parallelly, a decrease in expectations. Its budget is slowly but constantly increasing, however, it is no longer seen as a way to tackle with developmental problems and thus, ultimately, reduce emigration, but to keep migrants connected to their locality of origin through jointly implemented projects.

Finally, the Red Caldas was a well-functioning system when technology was at that stage of development (e-mail lists), and then felt into decay. Then, it was reorganized, once again according to the developmental stage of the era (web portal). Once again, it quickly became obsolete with the arrival of the web 2.0, and with no significant funding - neither in terms of webpage administration, nor in terms of 
meaningful information to be distributed through this channel - the network vanished away.

V/2.) Perspective. The Matrícula Consular is very likely to exist until immigration laws will substantially change in the United States - that is, for a long time. Other innovative policy methods using the administrative capabilities of Mexican consulates is to be expected - many of them are already existing (see Table 32). The Cucayo Fund was closed and apparently the Ecuadorian government follows the model presented in Table 41 for Uruguay - namely the outsourcing of the activities of the Diaspora Unit through agreements - which might be a more effective way to operate, in cost-benefit terms. The $3 \times 1$ Programme is expected to keep on operating in the same scale as it is right now, perhaps involving the private sector (there have been attempts to include them, in a ' $4 \times 1$ pilot' but it is still under testing). Finally, the Colombia Nos Une webpage might be redesigned one day, although it is not clear what sort of content should it have in order to attract the interest of skilled Colombians abroad.

To sum up, individual policy pathways have been very different, and so are the perspectives. Maybe the only common point is that evolution of diaspora policies leads to directions outside the diaspora policy realm. What was conceived as a diaspora policy, might (or should) become a sectorial policy in which one of the target groups are the migrants, i.e. a group whose special needs come from the fact that they are not present physically. However, with the introduction of online platforms for interaction with the government, many of these obstacles can be solved if willingness, budget and trust are not lacking.

\subsubsection{Evaluating the hypotheses 3: the policy level}

In the following, the evaluation of the initial hypotheses take place, this time on the policy level. This completes the series of evaluating the hypotheses on the three levels of analysis (of which the conceptual level was assessed in Chapter 1.3.4 and the institutional level, in Chapter 2.2.4).

From the three hypotheses of this thesis, (H1) states that none of the developmentally relevant diaspora policies of Latin American governments can change the ongoing migratory trends significantly. As shown in point IV/6. in 
Chapter 3.6.4, the four case studies (which, in turn, had been selected as being representative of their kind) have different impacts, however, none of them has a significant effect on the emigration trends, i.e. retaining prospective migrants or bringing them back from the country of destination.

The top three reasons for this are the following. First, all policy initiatives need to run on an insufficient budget (in the case of the Ecuadorian return programme, as it was presented above, a budget 115 times bigger would have been necessary to assess all the diaspora), described in point IV/2. Second, there is and adverse effects on the migration flows: out of the four cases analyzed, the most costeffective in terms of developmental effects, the Mexican Matrícula Consular, is very likely to have contributed to the growth, or at least the slower decrease of the emigrant stock, as it provided migrants in an irregular legal status with a document of multiple use, thus reducing the counterincentives for migrating (or for staying abroad longer than expected). Third, there is a divergence in interests, in the sense that neither the government of the country of origin, nor the diaspora is interested in substantially reducing the number of the emigrant stock, if economic nor labour market conditions do not change for better - rather, it is more convenient to let people go and earn money, so they can send (a part of) it back as remittances. Indeed, 'retaining' prospective emigrants have been on the agenda of countries of destination, not on that of countries of origin. Even in the case of the highly skilled, as presented in Chapter 3.5.1, Latin American countries did not have the means to effectively prevent them from emigrating or bringing them back in significant numbers.

Furthermore, none of the policy cases identified but not covered by the four case studies show considerably different features. As presented in 3.2.2, many Latin American consulates distribute consular ID cards and undertake other activities with an indirect developmental impact (healthcare, education, community building), however, none of these explicitly aims at facilitating return migration. It is the return incentives laws and programmes presented in 3.3.2 that have such an objective, but as it has been shown - they are complementary measures for people who have already decided to move back, facilitating them in doing so, and not initiatives that address people who otherwise would never think about going back. Identified matching funds projects (3.4.2) and diaspora networks (3.5.2) - other than those that 
appear in the case studies - have no significant effect on the volume of emigration or return migration either.

Yet, this does not mean that from a developmental perspective these policies are useless. (H2) states that these policies create a transnational space in which developmentally positive economic and social transfers can take place, and this can be validated both by the case study descriptions and the overview of other identified policy activities. In all four policy areas analyzed, there is a type of remittance flow that can be clearly identified and which - if the policy's other features, such as budget constraints or weak management do not hinder it - tend to grow as the policy is implemented.

Regarding the case studies, the Matrícula Consular helped migrants in irregular legal status to access to the banking system, thus reducing the costs of sending household remittances with a rough estimation of 425 USD per year. The Cucayo Fund helped approximately 10 thousand returning migrants in investing their savings in Ecuador. The 3x1 Programme has been running for 15 years, currently benefitting between 30 and 50 thousand people per year in rural communities where infrastructure projects are being undertaken using community remittances. Finally, the Red Caldas and the Colombia Nos Une networks, while active, contributed to the flow of knowledge between the diaspora and the country of origin.

Other policy attempts, not covered by the case studies but identified in Chapters 3.2.2, 3.3.2, 3.4.2 and 3.5.2, have also created flows of household, investment, community and social remittances, respectively. While costeffectiveness, outreach, impact and other relevant factors might not be optimal in most cases, it is beyond discussion that diaspora policy activities do create or broaden transnational spaces and channels for these flows of remittances.

The third hypothesis, (H3) states that the government of the country of origin as well as the diaspora can obtain political, economic and symbolical benefits from this cooperation. As presented in points II/1. and II/2 in Chapter 3.6.2, there are indeed many economic (and some political) benefits for the government, while for the diaspora the (mostly political/legal) benefits are not that evident.

As remittances are not really available for income taxing, the benefits of a government in increasing the volume of (different types of) remittances through diaspora policies are indirect. First, the extra inflow of remittances (excluding the non-quantifiable social remittances) generates further consumption that can be 
tapped with a value added tax (see also Chapters 1.2.1 and 1.3.3). Second, remittances can be seen as a substitute for government investments in infrastructure or social services - to varying extents, three out of the four cases analyzed (with the exception of the Matrículas) can show achievements of this kind.

Perhaps as importantly as in the case of economic benefits, the government of the country of origin also has political and symbolical benefits from running a diaspora policy activity. As identified in Chapter 3.6.1 (points I/1, I/2 and I/3), the policies analyzed came into being as a 'response' to the 'problem' of emigration which, in turn, was very much framed in an opposition-party political discourse. Taking up the diaspora issue has become a political move that could benefit political parties which, in turn, started to implement policies on the topic, once elected. A common feature of all four case studies is that 'doing something' with the diaspora has been a part of an election-winning political agenda.

However, the 'diaspora' benefits from the 'deal' are less evident. With the exception of the Matrícula Consular when a relatively simple and cheap (27 USD) procedure provides migrants in an irregular legal status with a reasonably useful identity document, the rest of the policies analyzed here suppose a significant spending of money, time or efforts. The 3x1 Programme and the Red Caldas / Colombia Nos Une projects provided little else than symbolical recognition for all this, while the Cucayo Fund provided a considerable grant - in case the migrant would go back to the country of origin, in which opportunity costs (of staying further) should be deduced from the equation.

It is, therefore, another 'benefit' that acts as driver for migrants in most cases: namely, the psychological reward for helping those who are in need. It can be narrated in a national, local, humanitarian, religious, kinship or other framework, yet the basic content is the same. Migrants, who left a part of their social and cultural identity 'pending' through migration, are given a way to reinforce their ties with those who are still 'on the ground'. Diaspora policies therefore serve migrants in a rather symbolic but very important way, by reinforcing their identity through involvement in doing something useful for those who are left behind.

To sum up, all three hypotheses have been found valid on the policy level, with the remark to (H3) that 'benefits' for the diaspora are of a basically symbolical nature. 


\section{Conclusions and questions for further research}

\subsection{Conclusions}

The topic of this $\mathrm{PhD}$ thesis has been the analysis of the policies pursued by Latin American governments in order to obtain developmentally useful contributions from their diaspora, i. e. from emigrants who were born in Latin America but live elsewhere.

The structure of the thesis has been built around three levels of analysis, on which the hypotheses were examined. The hypotheses formulated in the introduction stated that:

(H1) none of the developmentally relevant diaspora policies of Latin American governments can change the ongoing migratory trends significantly, but

$(\mathrm{H} 2)$ they create a transnational space in which developmentally positive economic and social transfers can take place, of which

(H3) the government of the country of origin as well as the diaspora can obtain political, economic and symbolical benefits.

Hypotheses have been assessed on three levels: on the conceptual, the institutional and the policy level. The chapters of this thesis were following this triple division: the social, political and institutional environment of Latin American diaspora policies has been described from a theoretical (Chapter 1.) and institutional (Chapter 2.) approach - the latter containing the analysis of the migratory processes as well - followed by an overview of policy fields and case studies on concrete policy mechanisms (Chapter 3.)

Chapter 1 contained notions on the understanding of developmental effects of migration in the literature (1.1), the economic contributions of migrants (remittances) (1.2), and policies that can capture, enhance or orientate these contributions (1.3). Chapter 2 described how Latin American countries were affected by mass emigration (2.1), and how they could (or could not) build institutions to tackle with this process. Finally, Chapter 3 presented four diaspora policy areas, which have been selected as the most relevant from a developmental perspective. These were: special or enhanced consular activities (3.2), investment and other assistance programmes for returning migrants (3.3), community remittance capture programmes (3.4) and knowledge 
transfer and diaspora network programmes (3.5). Also, they were conceptually connected to four types of remittances: household, investment, community and social remittances, respectively. Each of these subchapters had a general, a taxative (Latin American) and a case study part. Case studies were built around a common structure, presented in (3.1) and compared in (3.6).

In line with the triple division of the structure, every chapter ended with an assessment of the hypotheses on the given level. In Chapter 1.3.4 they were contrasted to the findings on the conceptual level, while Chapter 2.2.4 dealt with the institutional level and Chapter 3.6.6 with the policy level, respectively.

The concluding part of the thesis thus follows this division of $3 \times 3$, i.e. the findings about the three hypotheses, observed on three levels of analysis. Tables 53, 54 and 55 summarize the main findings on each level, as described in their respective chapters (1.3.4, 2.2.4 and 3.6.6).

Table 53. Hypothesis 1: "None of the developmentally relevant diaspora policies of Latin American governments can change the ongoing migratory trends significantly"

\begin{tabular}{|l|l|l|}
\hline $\begin{array}{l}\text { Level of } \\
\text { analysis }\end{array}$ & Valid & Main findings \\
\hline Conceptual & $(?)$ & $\begin{array}{l}\text { 'Migration-development nexus' (Chapter 1.1): the neoclassical } \\
\text { approach is positive, while the dependency/world system } \\
\text { approach is negative towards its possibilities (and, thus, the } \\
\text { reduction of emigration) } \\
\text { Remittances (in all their complexity described in Chapter 1.2) } \\
\text { can have a development effect, although on a conceptual level it } \\
\text { is not clear whether it balances the loss of human capital through } \\
\text { emigration, neither if they reduce emigration on the long run. } \\
\text { While diaspora policies have (modest but existing) capabilities to } \\
\text { enhance the development potential of remittances, this does not } \\
\text { necessarily reduce outward migration. }\end{array}$ \\
\hline Institutional & $(?)$ & $\begin{array}{l}\text { Many Latin American countries with a significant outmigration } \\
\text { but with low governmental effectiveness or capacities do not } \\
\text { even reach the level of institutionalization which would be } \\
\text { sufficient to create policies for tackling the issue of outmigration. } \\
\text { Others, which have created specific laws, institutions and } \\
\text { policies, institutionally are able to deal with the problem. It } \\
\text { cannot be said, however, whether they will succeed to change } \\
\text { migratory trends or not. } \\
\text { See Table 24 in Chapter 2.1.2. for the categorization and the } \\
\text { place of each country in this framework. }\end{array}$ \\
\hline Policy & Yes & $\begin{array}{l}\text { As shown in Chapter 3.6, the four case studies (which, in turn, } \\
\text { had been selected as being representative of their kind) have } \\
\text { different impacts, however, none of them has a significant effect } \\
\text { on the emigration trends, i.e. retaining prospective migrants or } \\
\text { bringing them back from the country of destination. }\end{array}$ \\
\hline
\end{tabular}




\begin{tabular}{|l|l|l|}
\hline & $\begin{array}{ll}\text { The top three reasons for this are the following: } \\
\text { 1) }\end{array}$ & $\begin{array}{l}\text { All policy initiatives need to run on an insufficient budget. } \\
\text { There can be an adverse effects on the migration flows. }\end{array}$ \\
& 3) & $\begin{array}{l}\text { There is a divergence in interests: it might be more convenient to } \\
\text { let people go and earn money, instead of retaining them, so they } \\
\text { can send (a part of) it back as remittances. }\end{array}$ \\
\hline
\end{tabular}

Source: own compilation.

Despite its difficult conceptualization (as the 'migration-development nexus' is a highly contested issue in the literature), it can be said that different types of remittance flows exist, and these flows can be addressed by public policies. Remittances are usually seen as developmentally positive inflows of (financial and human) capital which, partially or fully, counterbalance the losses of (financial and human) capital that were caused by the emigration of working-age people. On the conceptual level, however, it is widely debated whether a migration-led development model would ever reach a stage of less outward migration, i.e. if on the long run the government of the country of origin can, or could, reduce migration through enhancing the development potential of household, investment, community and social remittances.

On the institutional level, it has been shown that poor governmental capacities and the (perception of) inability to tackle with the issue makes the diaspora policy issue absent or only sporadically present in the institutional framework of many Latin American countries that have a high emigration rate. Others, while they have the means and capacities, are on a higher economic level and therefore they do not perceive emigration as a primordial issue - these countries could, but do not develop complex institutions for the diaspora. Finally, there is a group of countries which are heavily affected by emigration and they also have the capacities to build institutions that could tackle the issue of emigration. It is not sure, however, that having an institutional framework will lead to effective policies which, in turn, could substantially change the ongoing migration trends.

On the policy level, the assessment of (H1) is way more explicit. None of the policies analyzed (neither in the overview of existing Latin American policies nor in the concrete case studies) had the dimension, funding and outreach that would have been necessary to effectively reduce outward migration or start an important return migration wave. Indeed, some interventions might even increased the likeliness to emigrate or to stay abroad. Neither was it an obvious goal of policymakers: 
governments of countries of origin have had more interest in maintaining linkages and broadening the channels for remittances, than reducing the emigrant stock (or the growth thereof).

In conclusion, (H1) can be declared as valid on the concrete policy level, while it does not necessarily mean that on the conceptual and on the institutional level there are no considerable points which would contradict this. Theoretically, a better-managed, better-funded, differently focused government activity could implement policies which have a significant impact on the migratory flows, i.e. retaining or bringing back more people through diaspora-driven development programmes. In the practice, however, no Latin American country has been able to do this.

Table 54. Hypothesis 2: "Diaspora policies of Latin American governments create a transnational space in which developmentally positive economic and social transfers can take place"

\begin{tabular}{|c|c|c|}
\hline $\begin{array}{l}\text { Level of } \\
\text { analysis }\end{array}$ & Valid & Main findings \\
\hline Conceptual & Yes (?) & $\begin{array}{l}\text { - Yes, if we understand the flow of remittances (including all six } \\
\text { definitions thereof, as described in 1.2.1.) as a fundamentally } \\
\text { positive feature. In 1.2.3. the possibilities of a state regarding } \\
\text { remittances were presented, and it was shown that there are many } \\
\text { possible ways to enhance their volume and positive impact. } \\
\text { There are tools to be used (see 1.3.3.) in order to create } \\
\text { transnational spaces for information exchange or for the } \\
\text { implementation of development-related projects on a } \\
\text { transnational level. Well-designed institutions and policies are } \\
\text { crucial in order to achieve this. At the theoretical level, however, } \\
\text { it can be stated that }(\mathrm{H} 2) \text { is valid. }\end{array}$ \\
\hline Institutional & Yes & $\begin{array}{l}\text { - 'Liberal' regimes of double citizenship and voting rights, the } \\
\text { founding and enhancement of the Diaspora Units, the councils of } \\
\text { diaspora members at the consulates and the concrete outreach } \\
\text { programmes are all creating the 'transnational space', on one } \\
\text { hand, and its 'content' or 'transfers' on the other, which can be } \\
\text { found within this space. } \\
\text { - Whether these transfers are developmentally positive, or they are } \\
\text { not much more than information, news, symbolical acts or other, } \\
\text { developmentally unimportant contents, it depends of the concrete } \\
\text { policy level. }\end{array}$ \\
\hline Policy & Yes & $\begin{array}{l}\text { - In all four policy areas analyzed, there is a type of remittance } \\
\text { flow that can be clearly identified and which - if the policy's } \\
\text { other features, such as budget constraints or weak management } \\
\text { do not hinder it - tend to grow as the policy is implemented. } \\
\text { - Regarding the case studies: } \\
\text { - The Matrícula Consular helped migrants in irregular legal } \\
\text { status to access to the banking system, thus reducing the costs } \\
\text { of sending household remittances with a rough estimation of }\end{array}$ \\
\hline
\end{tabular}




\begin{tabular}{|l|l|}
\hline & 425 USD per year. \\
& - The Cucayo Fund helped approximately 10 thousand returning \\
& migrants in investing their savings in Ecuador. \\
- & The $3 \times 1$ Programme has been running for 15 years, currently \\
& benefiting between 30 and 50 thousand people per year in rural \\
& communities where infrastructure projects are being \\
undertaken using community remittances. & - The Red Caldas and the Colombia Nos Une networks, while \\
active, contributed to the flow of knowledge between the \\
diaspora and the country of origin. \\
Other policy attempts, not covered by the case studies but \\
identified in Chapters $3.2 .2,3.3 .2,3.4 .2$ and 3.5 .2 , have also \\
created flows of household, investment, community and social \\
remittances, respectively. \\
While cost-effectiveness, outreach, impact and other relevant \\
factors might not be optimal in most cases, it is beyond \\
discussion that diaspora policy activities do create or broaden \\
transnational spaces and channels for these flows of remittances.
\end{tabular}

Source: own compilation.

When conceptualizing transnational spaces in which developmentally positive economic and social transfers occur, it is important to decide on whether remittances can be understood as such. This thesis took a positive stance, understanding household, investment, community and social remittances as beneficial for development, thus making the 'migration-development nexus' operational around these flows. Analysis of the 'engaged' or 'emigration' state has shown that the government of the country of origin has a complex 'toolkit' at its disposal, of which there are several policy items that can be used for enhancing the amount and development potential of remittances.

Regarding the institutions, a history of institution building has been presented in which the root causes and consequences of mass emigration were addressed by 'politics' and the, by 'policies' (having the necessary gaps among them). The inclusion of the diaspora in the political life of the country of origin, and the founding and enhancement of the Diaspora Units, the diaspora councils and the concrete outreach programmes have indeed created a 'transnational space' in the case of those Latin American countries that had the willingness and the capabilities to do so. Whether the 'content' of the 'transfers' within these transnational spaces have been beneficial for development, is somewhat disputable, but - as stated above - this thesis has taken remittances as a generally positive feature.

Taken as beneficial, increase in (different types of) remittances has been identified in all four policy areas and case studies. Obviously, the detailed case analyses have shown many imperfections of these policies, but to say that there 
exists a transnational space (framed by these policies) and there is a more or less constant flow of remittances within these frames, are valid statements.

To sum up, (H2) is valid in all three levels of analysis, although the conceptual level only refers to the theoretical feasibility of the creation of transnational spaces and developmentally positive flows. Yet, as a whole, $(\mathrm{H} 2)$ appears to be the best proven of the three hypotheses of this thesis.

Table 55. Hypothesis 3: "Latin American governments as well as the diaspora can obtain political, economic and symbolical benefits from diaspora policies"

\begin{tabular}{|c|c|c|}
\hline $\begin{array}{l}\text { Level of } \\
\text { analysis }\end{array}$ & Valid & Main findings \\
\hline Conceptual & (?) & $\begin{array}{l}\text { - There are possible benefits on both sides, while - based on what } \\
\text { has been identified in } 1.3 .2 \text {. and } 1.3 .3-\text { it is very likely that there } \\
\text { is a bias towards economic benefits on the side of the } \\
\text { government of the country of origin, and towards political } \\
\text { benefits on the diaspora's side. }\end{array}$ \\
\hline Institutional & Yes & $\begin{array}{l}\text { - Beyond recognizing the importance of the diaspora, the specific } \\
\text { laws and the outreach programmes are very likely to yield other } \\
\text { benefits as well. Institutional legal help, repatriation help, } \\
\text { enhanced capabilities for resolving administrative issues are all } \\
\text { possible sources of political benefits for the diaspora, while more } \\
\text { active linkages and a more likely future repatriation of economic } \\
\text { and/or human capital can probably materialize in economic } \\
\text { benefits for the country of origin. } \\
\text { Diaspora Units are very important in enhancing these mutual } \\
\text { benefits, as they explicitly came into being for improving the } \\
\text { channels of these transfers. }\end{array}$ \\
\hline Policy & Yes & $\begin{array}{l}\text { - As presented in points II/1. and II/2 in Chapter } 3.6 .2 \text {, there are } \\
\text { indeed many economic (and some political) benefits for the } \\
\text { government, while for the diaspora the (mostly political/legal) } \\
\text { benefits are not that evident. } \\
\text { - Perhaps as importantly as in the case of economic benefits, the } \\
\text { government of the country of origin also has political and } \\
\text { symbolical benefits from running a diaspora policy activity. As } \\
\text { identified in Chapter } 3.6 .1 \text { (points } \mathrm{I} / 1, \mathrm{I} / 2 \text { and I/3), taking up the } \\
\text { diaspora issue could benefit political parties which, in turn, } \\
\text { started to implement policies on the topic, once elected. } \\
\text { However, the 'diaspora' benefits from the 'deal' are less evident. } \\
\text { With the exception of the Matrícula Consular, the rest of the } \\
\text { policies analyzed here suppose a significant spending of money, } \\
\text { time or efforts. The } 3 \times 1 \text { Programme and the Red Caldas / } \\
\text { Colombia Nos Une projects provided little else than symbolical } \\
\text { recognition for all this, only the Cucayo Fund provided a } \\
\text { considerable grant. } \\
\text { It is, therefore, another 'benefit' that acts as driver for migrants in } \\
\text { most cases: the psychological reward. Diaspora policies might } \\
\text { therefore serve migrants in a rather symbolic but very important } \\
\text { way, by reinforcing their identity through involvement in doing } \\
\text { something useful for those who are left behind. }\end{array}$ \\
\hline
\end{tabular}

Source: own compilation. 
A conceptual understanding of the diaspora policymaking as the outcome of the favourable encounter of political, problem and policy 'streams', on one hand, and the 'deal' between the government of the country of origin and the diaspora, from which both counterparties might have their benefits, has the analytical value of identifying the drivers behind the creation, functioning and eventual decline of a given diaspora policy. On the theoretical level, it has been said that the government has mostly political and legal resources to 'offer' for the members of the diaspora, such as protection or services, while the resources of the diaspora are mostly economic in nature - which, if sent back to the country of origin, can be conceptualized under the different categories of remittances.

This theoretical approach has been contrasted to the institutional realities of the Diaspora Units and consulates of the countries of origin. Apparently, a large share of their activities are beneficial for the diaspora: institutional legal help, repatriation help, enhanced capabilities for resolving administrative issues are all possible sources of political benefits, while more active linkages and a more likely future repatriation of economic and/or human capital can probably materialize in economic benefits for the country of origin. Institutionally speaking, therefore, there are many possible beneficial items on the agenda.

However, on the concrete policy level it turns out that there is an important bias towards the benefits of the country of origin. While the inflow of remittances benefit the local communities, and the active diaspora engagement can be seen by voters as an important political activity - hence bringing popularity to the government - developmentally related diaspora policies in general build on the drivers of philanthropy, charity, responsibility etc. among migrants. Most of the policies suppose an involvement of migrants in development activities that is not fueled by an economic or political rationale, but a rather altruist inner drive. Yet, symbolic rewards exist and many migrants hold it in high esteem.

In conclusion, $(\mathrm{H} 3)$ can also be declared as valid, with the restriction that the diaspora has less 'objective' benefits from the cooperation, than the government of the country of origin. While the latter can calculate with more consumption to be taxed, and more additional sources for financing institutions or meso level actors that otherwise would need transfers from the central budget, members of the former will receive legal and administrative help at the consulates, if needed, and assistance for 
the return if they wish to do so. Otherwise, the benefits they have from cooperating are mostly symbolical.

\subsection{Questions for further research}

Among many possible directions for further research, there are two important questions that can be defined as the most relevant at the end of this thesis. These are the following:

1. Which are the further, developmentally relevant Latin American diaspora policy actors and activities, not covered by this thesis?

2. How could these experiences be used for conceiving and implementing developmentally relevant diaspora policies in other parts of the world - especially in Central and Eastern Europe?

For the first question, there are many good answers. This thesis has limited itself to the collection and analysis of those policies in which the main actor was the government of a Latin American country, and the target or beneficiary group were the individual migrants or migrant associations. The analysis was focused on the creation, organization and activities of the 'Diaspora Units', i.e. specialized institutional units within the respective Ministries of Foreign Affairs of the countries of origin. As such, there have been many actors and activities that were left out or mentioned only sideways. Among them, the most important are the following:

- Governments of the countries of destination. While they were included in the actor list of the policy mechanisms, they only came into the picture in this analysis when there were involved in policies pursued by the governments of the countries of origin. However, the migration-related development plans and the whole concept and practice of "co-development" could be rightfully included in the analysis.

- $\quad$ Specialized International Organizations. Most importantly, the International Organization for Migration (IOM), which has its own development programmes, including the Transfer of knowledge through expatriate nationals (TOKTEN), which might be a more scale-optimal solution for managing the challenges of brain drain than individual nation state attempts. The United Nations' Development Programme 
(UNDP) the Office of the United Nations High Commissioner for Refugees (UNHCR), and the OECD DAC are also relevant actors in the field.

- Integration Mechanisms. Treated separately from other (thematic) international organizations, regional integrations are also important actors in Latin American politics and policies. 'Endogenous' integrations as the MERCOSUR, the UNASUR, the CAN, the ALBA and the CELAC all have had their say in the area of migration and development. As mentioned in this thesis as well, the South American Migration Conference (CSM) - currently under negotiation - can be a very important step towards an area of free circulation in Latin America. Also, other integration mechanisms - most importantly the Organization of American States and the European Union - should be involved in the analysis.

- Subnational levels of governance. Municipalities have been mentioned in this thesis only in the framework of rural development, while large cities abound in Latin America - many of them being regional hubs of immigration and source of emigration at the same time. Also, regional governments (most importantly in the case of federal states, such as Mexico and Brazil) can have their own diaspora policies - the Mexican 3x1 Programme, analyzed here, was born indeed as a regional programme in the Mexican state of Zacatecas.

- Non-governmental organizations and other non-profit institutions. Civil society has also been mentioned sideways, but their transnational linkages and developmental activities would deserve a separate analysis. 'Classical' NGOs of international development in the countries of destination, as well as trade unions, churches, charity organizations etc. should be included in further research.

- $\quad$ Political parties. Given the importance of transnational and diaspora politics in the creation of transnational and diaspora policies, the activities of political parties is also an important point.

- $\quad$ Business actors. Last but not least, for-profit actors, companies, investors are key elements in any sort of development financing mechanisms if the government in itself cannot cover all the expenses (which is usually the case). The role of privatepublic partnerships and corporate social responsibility initiatives are crucial to be included in a further analysis. 
For the second question, it is important to highlight two features. First, many emigration countries in the world have conceived and implemented diaspora-driven development policies, and some of them achieved considerable results. For evaluating the lessons learnt from the Latin American diaspora policies and the applicability of the result in other regions of the world, it is important to compare them to diaspora policies found in China, India, the Philippines, Morocco, Nigeria, Armenia, Israel, New Zealand and Turkey, among many others.

Second, if we would like to use the results of this thesis as a source of possible inputs for Hungary and the Central and Southeast European region, the basic differences between the two regions should be assessed from the perspective of their effects on migration patterns, migration legislation and spaces for independent policymaking. Most importantly, a further research should address the following factors:

- The economic and social differences between Latin America and Central and South Eastern Europe, with a special focus on demography and labour market structure;

- The effects of the European Union's space of free movement (the Schengen Area), which is a major difference when compared to the Latin America - United States migration corridor; and

- $\quad$ The effects of the structural and regional development funds of the European Union which, although providing a massive financial source for developmentally important government investments in Central and South Eastern Europe, do not cover the area of diaspora policies, thus hindering the formation of a unified 'migration and development' approach as seen in Latin America.

Despite the obvious differences, emigration trends in Central and South Eastern Europe show many parallel features to those of Latin America, and policy solutions might also be similar. There are examples for this: Slovakia already has a diaspora knowledge transfer programme and Moldova, a remittance capture programme, the latter being designed very much in the manner of the Mexican " $3 \times 1$ " matching funds scheme.

I consider that a comparative analysis of Latin American and Central and South Eastern European diaspora policy solutions for development would be a very fruitful path for further research. 


\section{Annex}

Diaspora Unit Survey among Latin American Governments [DUS, 2014-2015]

- DUS Argentina (received on 17 November 2014)

- DUS Brazil (received on 6 November 2014)

- DUS Chile (received on 13 October 2014)

- DUS Colombia (received on 7 May 2015)

- DUS Costa Rica (received on 3 October 2014)

- DUS Ecuador (received on 14 October 2014)

- DUS Guatemala (received on 16 April 2015)

- DUS Mexico (received on 16 October 2015)

- DUS Peru (received on 30 September 2014)

- DUS Uruguay (received on 1 November 2014) 
Encuesta sobre las actividades del Gobierno de Argentina para mantener contactos con ciudadanos argentinos residentes en el exterior

\author{
Por: Licenciado Béla Soltész \\ Universidad Corvinus de Budapest, Hungria \\ Escuela de Doctorado en Relaciones Internacionales \\ Título de la tesis de doctorado: "Migración, políticas de diáspora y desarrollo en América Latina"
}

Cuestionario enviado el 21 de septiembre de 2014

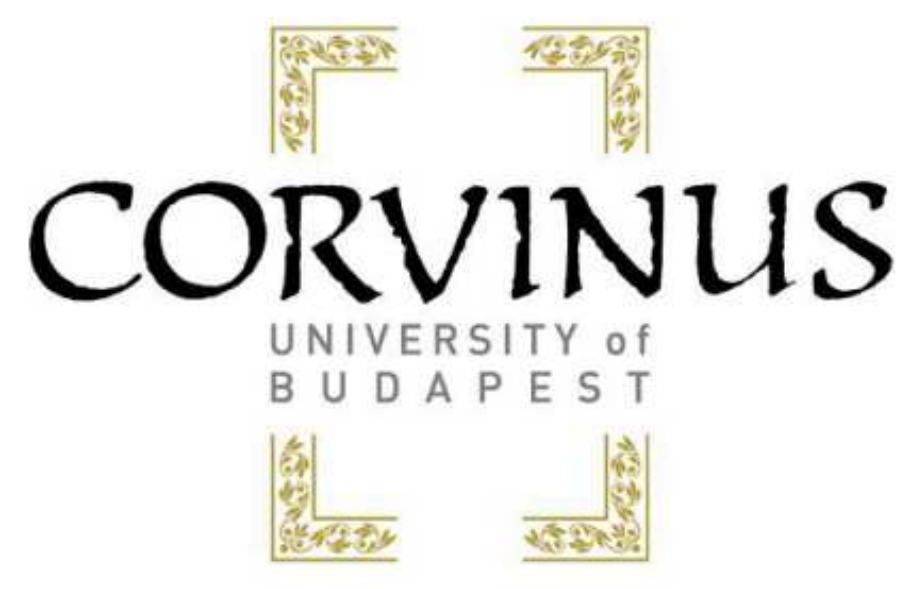


Estimado/a Señor/a:

Con la presente encuesta le solicito información sobre algunas actividades que lleva a cabo el Gobierno de la República Argentina para mantener contactos con sus ciudadanos en el exterior.

La encuesta tiene el único objetivo de recoger información para mi tesis de doctorado que se trata de políticas de diáspora que promueven el desarrollo en América Latina. Es un tema en el cual Hungría puede aprender mucho de los gobiernos latinoamericanos. Para llenar el cuestionario se necesitarán unos 20 minutos aproximadamente, y con ello Usted ayudará mucho en desarrollar mi tesis y en facilitar el intercambio de conocimiento entre nuestros paises.

En la encuesta, "argentinos en el exterior", "diáspora" y "migrantes" se entienden como conceptos sinónimos para el grupo de personas de origen argentino que viven fuera de Argentina de manera permanente.

\section{Participación en elecciones desde el exterior}

1.1. Por favor, marque con una $\mathbf{X}$ entre las paréntesis donde corresponda.

Los ciudadanos de la República Argentina residentes en el exterior de manera permanente,

( $\mathbf{X}$ ) pueden participar en las elecciones presidenciales, pero solo en persona en los consulados.

( ) pueden participar en las elecciones presidenciales, en persona en los consulados o por vía postal.

( ) pueden participar en las elecciones parlamentarias, y votar a un diputado que representa a los ciudadanos en el exterior.

( $\mathrm{X}$ ) pueden participar en las elecciones parlamentarias, y votar a una lista de partido.

( ) pueden participar en referendums.

( ) no pueden participar en ningún tipo de elecciones.

Otras observaciones (por favor indique): Los ciudadanos argentinos residentes en el exterior pueden participar en elecciones parlamentarias. En el caso de referendums, podrán o no participar, de acuerdo al llamado realizado por el P.E.N.

\section{Beneficios económicos para la diáspora}

2.1. Por favor, marque con una $\mathbf{X}$ entre las paréntesis donde corresponda.

Los ciudadanos de la República Argentina residentes en el exterior de manera permanente, al volver a Argentina, tienen derecho a:

( ) exención fiscal si deciden invertir en el país (en caso afirmativo, por favor indique cómo): 
( $x$ ) exención aduanera en importaciones y exportaciones (en caso afirmativo, por favor indique cómo): RESOLUCION GENERAL NRO 3109/11 DE LA ADMINISTRACION FEDERAL DE INGRESOS PUBLICOS, REFERENTE A LOS ARTICULOS $15^{\circ} \mathrm{Y} 103^{\circ}$ DEL DECRETO NRO. 616/10, REGLAMENTARIO DE LA LEY 25.871

( ) trato preferencial si deciden invertir en el país (en caso afirmativo, por favor indique cómo):

( ) subvenciones estatales si deciden invertir en el país (en caso afirmativo, por favor indique cómo):

( ) otros beneficios (en caso afirmativo, por favor indique cuáles):

2.2. ¿Existen programas de desarrollo implementados por el Gobierno de Argentina en los cuales participan argentinos residentes en el exterior?

(Tengo conocimiento de: Programa RAÍCES. ¿Existen otros? En caso afirmativo, por favor indique su nombre y una descripción muy breve o un enlace para una página web con más información):

\section{Instituciones relacionadas a la diáspora}

3.1. Dentro del Ministerio de Relaciones Exteriores y Culto de la República Argentina, ¿cuál es la unidad que se encarga de los asuntos de la diáspora?

La Dirección General de Asuntos Consulares - Dirección de Argentinos en el Exterior

3.2. ¿Aproximadamente cuántas personas trabajan en esta unidad?

$7-10$ personas

3.3. En su presente forma, ¿en qué año fue fundada esta unidad? Antes de esto, ¿qué unidad se encargaba de este tema?

3.4. ¿Cuáles son las actividades principales de esta unidad? Por favor, ponga una $\mathbf{X}$ entre las paréntesis donde corresponda.

( ) Organizar eventos y programas culturales para los argentinos en el exterior

( ) Organizar eventos y programas sociales que ayudan a los argentinos en el exterior 
( ) Organizar eventos y programas sociales que ayudan a los argentinos que están en Argentina, con la participación de los argentinos en el exterior

( ) Fomentar que los argentinos en el exterior inviertan en Argentina

( ) Otros, por favor indique:

Se debe tener en cuenta que la República Argentina desde su formación se consitutyó escencialmente como un país receptivo de inmigración. En la relación con la migración argentina en el exterior, las funciones de relacionamiento - a traves de la Cancilleria Argentina - es llevada a cabo principalmente por la DIGAC - DIARE. Las funciones de los Consulados argentinos en el exterior, quienes ejecutan las directivas recibidas. Las funciones de los Consulados puede verse en:

https://www.mrecic.gov.ar/node/246241

3.5. ¿Existe un consejo consultivo sobre el tema de las migraciones en Argentina, en el cual, fuera del Ministerio de Relaciones Exteriores y Culto, participan otros ministerios e instituciones? (En caso afirmativo, por favor indique cuáles, y a partir de qué año existe este consejo):

La Dirección Nacional de Migracines es el organismo encargado de la aplicación de la Ley 25.871. ) Es un organismo descentralizado actuante en la órbita del Ministerio del Interior y Transporte de la Nación.

3.6. ¿Existen consejos consultivos con las organizaciones de argentinos en el exterior, en los cuales los migrantes pueden discutir los temas que consideren importantes, con miembros del cuerpo diplomático de Argentina? (En caso afirmativo, por favor indique en qué paises, y a partir de qué año existen estos consejos):

\section{El futuro de la política de diáspora}

4.1. Según su opinión, ¿cuáles serían las actividades más importantes que el Gobierno de la República Argentina podría hacer para mejorar sus contactos con los ciudadanos argentinos en el exterior? Qué se necesitaría para desarrollar estas actividades?

Muchas gracias por su contribución a mi trabajo. Por favor, envíe el cuestionario rellenado a mi correo electrónico: soltesz.bela@gmail.com.

Le agradecería si pudiera enviarmelo hasta el 20 de octubre de 2014.

Atentamente, 


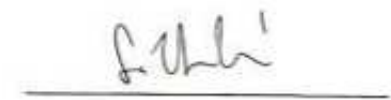

\section{Licenciado Béla Soltész}

Universidad Corvinus de Budapest, Hungría

Escuela de Doctorado en Relaciones Internacionales 
Questionário sobre as atividades do governo brasileiro para manter contactos com os cidadãos brasileiros residentes no exterior

\section{Por: Béla Soltész}

Universidade Corvinus de Budapeste, Hungria

Escola de Doutoramento em Relações Internacionais

Título da tese de doutorado: "Migração, políticas da diáspora e o desenvolvimento na América Latina"

Questionário postado em 2 de outubro de 2014

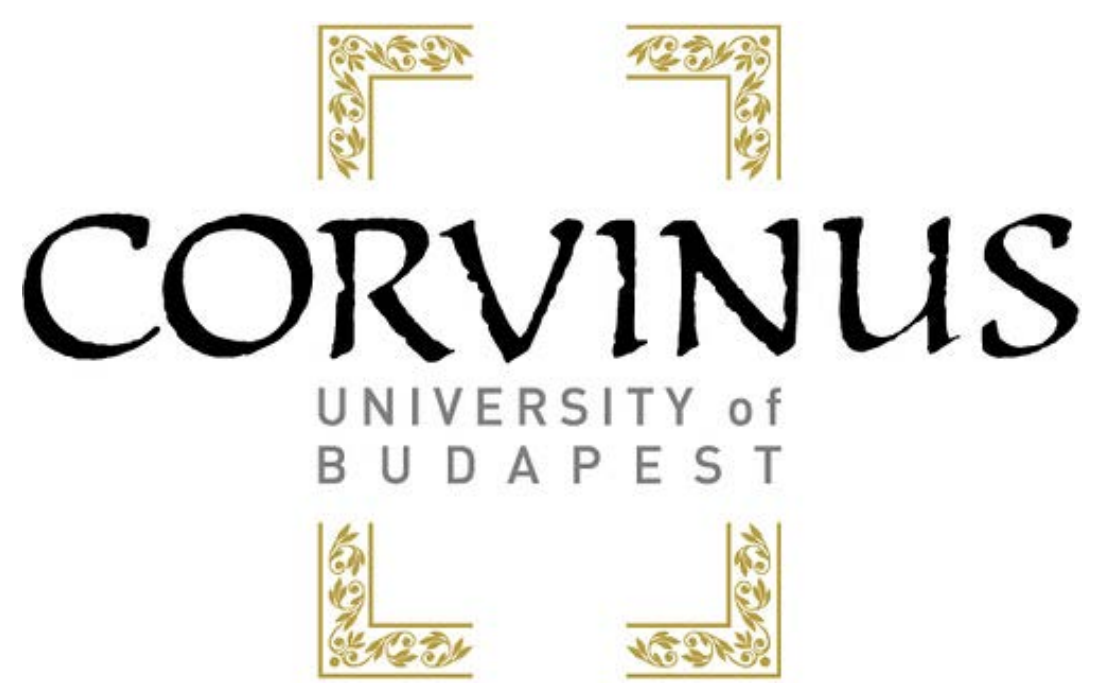


Caro/a Senhor/a:

Com esta pesquisa solicito algumas informações sobre as atividades realizadas pelo Governo do Brasil para manter contato com os seus cidadãos no exterior.

A pesquisa tem o único propósito de reunir informações para a minha tese que é sobre as políticas da diáspora que promovam o desenvolvimento na América Latina. É um assunto no qual a Hungria pode aprender muito dos governos latinoamericanos. Para preencher o questionário, demora-se uns 20 minutos, e com isso Você poderia ajudar muito no desenvolvimento da minha tese e para facilitar o intercâmbio de conhecimentos entre nossos países.

Na pesquisa, "os brasileiros no exterior", "diáspora" e "migrantes" são entendidos como conceitos sinônimos para o grupo de pessoas de ascendência brasileira que vivem fora do Brasil permanentemente.

\section{Participação nas eleições no exterior}

1.1. Marque com um $\mathrm{X}$ entre os suportes onde aplicáveis.

Os cidadãos da República Federativa do Brasil residentes no exterior permanentemente,

( $\mathrm{X}$ ) Podem participar nas eleições presidenciais, mas apenas em pessoa nos consulados.

( ) Podem participar nas eleições presidenciais, em pessoa nos consulados ou por via postal.

( ) Podem participar das eleições parlamentárias, e votar em um deputado que representa os cidadãos no exterior.

( ) Podem participar das eleições parlamentárias, e votar em uma lista partidária.

( ) Podem participar em referendos.

( ) Não é possível participarem em qualquer eleição.

Outros comentários (indicar): O voto no Brasil é obrigatório. Assim, os cidadãos brasileiros maiores de 18 anos residentes no exterior também devem cumprir suas obrigações eleitorais (alistamento e voto, por exemplo). Essas obrigações, no entanto, são facultativas para os maiores de 16 e menores de 18 anos, para os maiores 
de 70 anos e para os analfabetos. Observe-se que a apresentação de certidão eleitoral de quitação de suas obrigações eleitorais é requisito para a emissão de passaporte, no Brasil e no Exterior.

No Brasil, existe o "voto em trânsito" para presidente, que ocorre quando um eleitor, acaso esteja fora de seu domicílio eleitoral no dia das eleições, vota em seção eleitoral de outra cidade, desde que tenha feito a solicitação previamente junto à Justiça Eleitoral para votar em trânsito. Ainda não é possível votar em trânsito para cidadãos inscritos em seções eleitorais no Brasil e que viajam ao exterior no dia das eleições presidenciais; contudo, o sentido contrário é possível: cidadãos que estejam inscritos em seção eleitoral no exterior podem votar em trânsito no Brasil. (http://www.tse.jus.br/eleitor/eleitor-no-exterior)

\section{Benefícios económicos para a diáspora}

2.1. Marque com um X entre os suportes onde aplicáveis.

Os cidadãos da República Federativa do Brasil residentes no exterior permanentemente, retornando ao Brasil, têm direito a:

( ) Isenção de impostos se eles decidirem investir no país (em caso afirmativo, indicar como):

( $\mathrm{X}$ ) Isenção aduaneira na importação e exportação (em caso afirmativo, indicar como): qualquer viajante, brasileiro ou estrangeiro residente no País, que tiver permanecido no exterior por período superior a um ano e retornar em caráter definitivo, tem direito à isenção relativa aos seguintes bens, novos ou usados: Móveis e outros bens de uso doméstico; e Ferramentas, máquinas, aparelhos e instrumentos, necessários ao exercício de sua profissão, arte ou ofício individualmente considerada (deve ser comprovada a atividade desenvolvida pelo viajante no exterior). http://www.receita.fazenda.gov.br/aduana/Viajantes/ViajanteSituacaoEspecial.htm ( ) Um tratamento preferencial, se decidem investir no país (em caso afirmativo, indicar como):

( ) Subsídios estatais, se decidem investir no país (em caso afirmativo, indicar como):

( ) Outros benefícios (se sim, por favor especifique): 
2.2. Existem programas de desenvolvimento implementados pelo Governo do Brasil em que participam os brasileiros residentes no exterior?

(Em caso afirmativo, por favor digite o seu nome e uma breve descrição ou um link para um site com mais informações.?)

\section{Instituições relacionadas com a diáspora}

3.1. No âmbito do Ministério das Relações Exteriores da República Federativa do Brasil, qual é a unidade que é responsável pelos assuntos da diáspora?

Subsecretaria-Geral das Comunidades Brasileiras no Exterior (SGEB), Departamento Consular e de Brasileiros no Exterior (DCB), Divisão das Comunidades Brasileiras no Exterior (DBR).

3.2. Mais ou menos, quantas pessoas trabalham nesta unidade?

Cerca de 10 pessoas. (inclui gabinete SGEB, DCB e DBR)

3.3. Na sua forma actual, em que ano foi fundada esta unidade? Antes disso, o qual unidade era responsável por isso?

A Subsecretaria-Geral das Comunidades Brasileiras no Exterior (SGEB) foi criada em 2007.

3.4. Quais são as principais atividades desta unidade? Por favor, coloque um X entre parênteses, quando aplicável.

( ) Organizar eventos e programas culturais para os brasileiros no exterior

( $\mathrm{X}$ ) Organizar eventos e programas sociais que ajudam os brasileiros no exterior

( ) Organizar eventos e programas sociais para ajudar os brasileiros que estão no Brasil, com a participação dos brasileiros no exterior

( ) Incentivar os brasileiros no exterior para investirem no Brasil

( ) Outro, especifique: Auxiliar na prestação de serviços que beneficiem a comunidade brasileira no exterior, como a solicitação de saque do FGTS no exterior; negociação de Acordos Bilaterais de Previdência Social; negociação de Acordos de Reconhecimento Recíproco de Documentos de Habilitação; coordenação dos 
Conselhos de Cidadãos e de Cidadania com o CRBE para discussão acerca de políticas públicas e melhorias para a diáspora brasileira; realização do Exame Nacional para Certificação de Competências de Jovens e Adultos no exterior, permitindo que jovens que interromperam seus estudos básicos possam obter diploma de conclusão do ensino fundamental e ensino médio.

3.5. Existe um conselho consultivo sobre a questão da migração no Brasil, na qual, fora do Ministério das Relações Exteriores, outros ministérios e instituições envolvidas? (Se sim, por favor, liste e indique de que ano existe este conselho):

3.6. Há conselhos consultivos com organizações de brasileiros no exterior, em que os migrantes podem discutir questões que consideram importantes, membros do corpo diplomático do Brasil? (Se sim, por favor indique quais os países e, a partir de que ano existem):

Sim, existe o Conselho de Representantes de Brasileiros no Exterior (CRBE), que é a reunião de Conselhos das comunidades brasileiras nas diferentes localidades no mundo. O CRBE existe desde 2010. Atualmente, reúne 49 Conselhos das comunidades brasileiras em países nos cinco continentes, além de outros Conselhos de Cidadãos e de Cidadania que surgiram desde então.

(http://brasileirosnomundo.itamaraty.gov.br/associativismo-e-politicas-para-ascomunidades/CRBE)

\section{O Futuro da Política de Diáspora}

4.1. Na sua opinião, quais são as atividades mais importantes que o governo brasileiro poderia fazer para melhorar os contactos com os cidadãos brasileiros no exterior? O que seria necessário para desenvolver estas atividades?

\section{Bibliografia}

BRASIL. Ministério das Relações Exteriores. Subsecretaria-Geral das Comunidades Brasileiras no Exterior. Diplomacia Consular, 2007 a 2012. Brasília: Fundação Alexandre de Gusmão, 2012. Disponível em: < 
http://www.brasileirosnomundo.itamaraty.gov.br/diplomacia-consular-2007-a-2012final.pdf>

FIRMEZA, George Torquato. Brasileiros no exterior. Brasília : Fundação Alexandre de Gusmão, 2007. Disponível em: < http://funag.gov.br/loja/download/536-Brasileiros_no_Exterior.pdf>

BRASIL. Ministério das Relações Exteriores. Subsecretaria-Geral das Comunidades Brasileiras no Exterior. Portal Brasileiros no Mundo: http://brasileirosnomundo.itamaraty.gov.br/

BRASIL. Ministério das Relações Exteriores. Subsecretaria-Geral das Comunidades Brasileiras no Exterior. Portal do Retorno: http://retorno.itamaraty.gov.br/

Muito obrigado pela sua contribuição para o meu trabalho. Por favor, envie o questionário preenchido para o meu e-mail: soltesz.bela@gmail.com.

Eu apreciaria se você poderia enviá-lo para mim, até o dia 20 de outubro de 2014. Com os melhores cumprimentos,

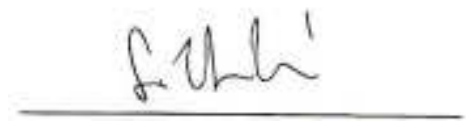

Bacharel Béla Soltész

Universidade Corvinus de Budapeste, Hungria

Escola de Doutoramento em Relações Internacionais 


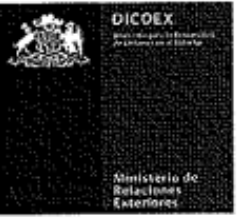

MINISTERIO DE RELACIONES EXTERIORES

DIRECCIÓN GENERAL DE ASUNTOS CONSULARES Y DE INMIGRACIÓN

DIRECCION PARA LA COMUNIDAD DE CHILENOS EN EL EXTERIOR

Santiago, 8 de octubre de 2014

Señor,

Béla Soltész,

Universidad Corvinus,

Budapest, Hungría.

Presente.

Estimado señor Soltész,

Deseo agradecer vuestro interés por desarrollar temas relativos a la comunidad de chilenos residentes en el exterior en su trabajo de tesis doctoral.

En relación al requerimiento de información que ha elevado por intermedio de nuestro Consulado en Budapest, me es grato comentarle:

\section{1.- Participación en elecciones desde el exterior}

Con fecha 3 de mayo de 2014, se publicó la Ley º.748 en el Diario Oficial, la que consagró el derecho de ejercicio del sufragio para los ciudadanos chilenos que se encuentran fuera del país, en elecciones primarias presidenciales, para Presidente de la República y en plebiscitos nacionales. Actualmente se está trabajando en elaborar el proyecto de Ley Orgánica Constitucional que regulará tanto el proceso de inscripción como la modalidad de sufragio en el exterior.

El objetivo es que los ciudadanos chilenos residentes en el exterior puedan ejercer su derecho a sufragio en las elecciones de 2017.

\section{2.- Beneficios económicos para la diáspora}

Derechos aduanales

Los chilenos que retornan de manera definitiva al país, pueden ingresar:

Menaje de casa adquirido en el extranjero.

Las condiciones de internación dependen del tiempo que la persona haya permanecido fuera del país:

- Chilenos que retornan y que han estado en el extranjero por más de 6 meses, pero menos de-1-año, pueden importar hasta_US $\$ 500$. FOB de enseres de casa usados, además de sus efectos personales.

Edificio José Miguel Carrera, Teatinos 180. Telèfono +56228274200 . Santiago / Chile 


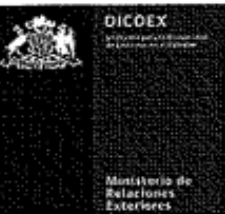

MINISTERIO DE RELACIONES EXTERIORES

DIRECCIÓN GENERAL DE ASUNTOS CONSULARES Y DE INMIGRACIÓN DIRECCIÓN PARA LA COMUNIDAD DE CHILENOS EN EL EXTERIOR

- Chilenos que retornan y que han estado en el extranjero más de 1 año y menos de 5 años, se les permite importar hasta US\$ 3.000.- FOB de enseres de casa y/o útiles de trabajo usados, además de sus efectos personales.

- Chilenos que retornan y que han estado en el extranjero más de 5 años, pueden importar hasta US\$ 5.000.- FOB de enseres de casa y/o útiles de trabajo usados, además de sus efectos personales.

Un automóvil nuevo o usado

Los chilenos que hayan permanecido en el extranjero durante un año o más y que durante el último año no hayan ingresado a Chile por más de treinta días (continuos o discontinuos), tienen derecho a importar un sólo vehículo por persona mayor de 18 años, independiente de su actividad. Dicho vehículo puede ser nuevo o usado, y debe pagar la totalidad de los derechos de aduana e impuestos a la importación.

Equipaje o efectos personales con fines no comerciales, bajo las mismas condiciones que un turista.

\section{3.- Instituciones relacionadas a la diáspora}

La Dirección para la Comunidad de Chilenos en el Exterior (DICOEX) es la encargada de fortalecer la vinculación y la asociatividad de las comunidades de chilenos y chilenas en el exterior, para avanzar en la participación ciudadana que los ayude en la preservación de la identidad, la inclusión en el quehacer y progreso nacional, así como en la inserción en sus países de residencia.

Igualmente, fomenta los lazos entre los nacionales residentes en el exterior con las 69 Embajadas y 108 Consulados de Chile. DICOEX, además, ejerce la Secretaría Técnica del Comité Interministerial para la Comunidad Chilena en el Exterior.

Jerárquicamente depende de la Dirección General de Asuntos Consulares y de Inmigración (DIGECONSU) del Ministerio de Relaciones Exteriores. Se estructura sobre la base de dos Subdirecciones: Subdirección de Desarrollo y Subdirección de Operaciones. Su staff está integrado por catorce personas: un Director, dos Subdirectores, una secretaria, nueve funcionarios profesionales $y$ un funcionario auxiliar.

Fue creada en el año 2000 por mandato del ex presidente de la República Ricardo Lagos Escobar.

El Comité Interministerial para la Comunidad Chilena en el Exterior se creó mediante Decreto $\mathrm{N}^{\circ}$ 139 (M.RR.EE) del 1 de septiembre de 2009. Su objetivo es asesorar a los Ministerios y servir de instancia de coordinación entre ellos respecto de las políticas públicas destinadas a la vinculación y desarrollo de los nacionales residentes en el extranjero, a través de la promoción y ejercicio de los derechos humanos, ciudadanos, sociales y culturales de sus integrantes. 
MINISTERIO DE RELACIONES EXTERIORES

DIRECCIÓN GENERAL DE ASUNTOS CONSULARES Y DE INMIGRACION

El Comité es presidido por el Subsecretario de Relaciones Exteriores e integrado por representantes de los Ministerios de Relaciones Exteriores, Interior, Hacienda, Secretaría General de la Presidencia, Secretaría General de Gobierno, Economía, Fomento y Reconstrucción, Desarrollo Social, Educación, Justicia, Trabajo y Previsión Social, Salud y Vivienda y Urbanismo.

En espera de que los antecedentes aportados sean de utilidad para su investigación, le saluda muy atentamente,

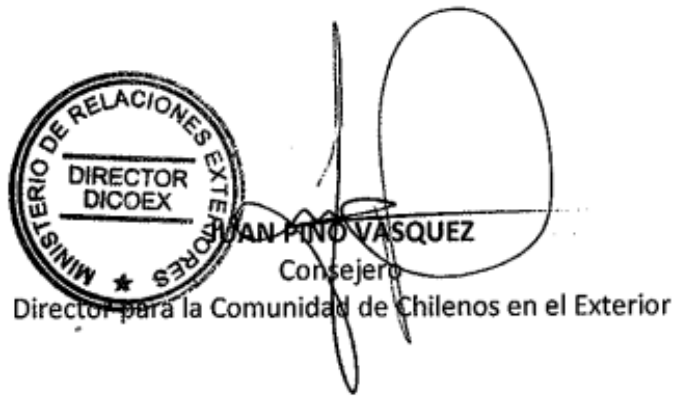

Edificio José Miguel Carrera, Teatinos 180. Teléfono +56228274200 . Santiago / Chile 
Encuesta sobre las actividades del Gobierno de la República de Colombia para mantener contactos con ciudadanos colombianos residentes en el exterior

\section{Por: Licenciado Béla Soltész}

Universidad Corvinus de Budapest, Hungría

Escuela de Doctorado en Relaciones Internacionales

Título de la tesis de doctorado: "Migración, políticas de diáspora y desarrollo en América Latina”

Cuestionario enviado el 21 de septiembre de 2014

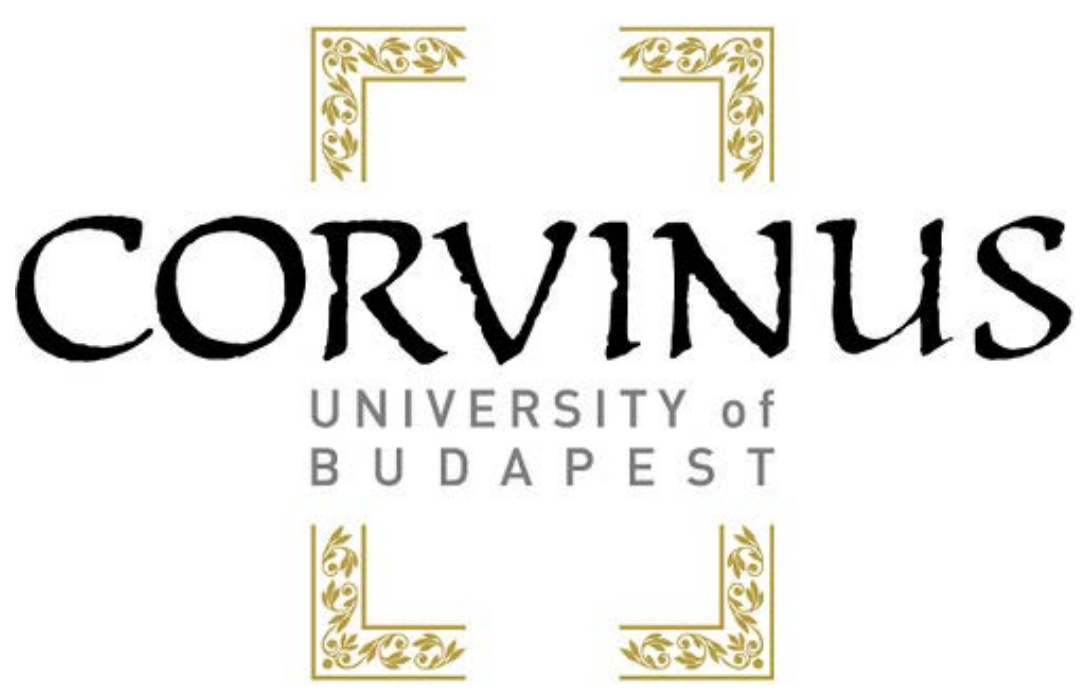


Estimado/a Señor/a:

Con la presente encuesta le solicito información sobre algunas actividades que lleva a cabo el Gobierno de Colombia para mantener contactos con sus ciudadanos en el exterior.

La encuesta tiene el único objetivo de recoger información para mi tesis de doctorado que se trata de políticas de diáspora que promueven el desarrollo en América Latina. Es un tema en el cual Hungría puede aprender mucho de los gobiernos latinoamericanos. Para llenar el cuestionario se necesitarán unos 20 minutos aproximadamente, y con ello Usted ayudará mucho en desarrollar mi tesis y en facilitar el intercambio de conocimiento entre nuestros países.

En la encuesta, "colombianos en el exterior", "diáspora" y "migrantes" se entienden como conceptos sinónimos para el grupo de personas de origen colombiano que viven fuera de Colombia de manera permanente.

\section{Participación en elecciones desde el exterior}

1.1. Por favor, marque con una $\mathbf{X}$ entre las paréntesis donde corresponda.

Los ciudadanos de la República de Colombia residentes en el exterior de manera permanente,

( $\mathrm{x}$ ) pueden participar en las elecciones presidenciales, pero solo en persona en los consulados.

( ) pueden participar en las elecciones presidenciales, en persona en los consulados o por vía postal.

( $\mathrm{x}$ ) pueden participar en las elecciones parlamentarias, y votar a un diputado que representa a los ciudadanos en el exterior.

( $\mathrm{x}$ ) pueden participar en las elecciones parlamentarias, y votar a una lista de partido.

( ) pueden participar en referendums.

( ) no pueden participar en ningún tipo de elecciones.

Otras observaciones (por favor indique): En colombia los diputados son los representantes a las Asambleas Departamentales, por lo tanto se entiende que la opción seleccionada hace referencia a Parlamentarios (Senadores y Representantes a 
la Cámara). Por otra parte, siendo los referendos mecanismos extraordinarios, no se puede responder de manera general.

\section{Beneficios económicos para la diáspora}

2.1. Por favor, marque con una $\mathbf{X}$ entre las paréntesis donde corresponda.

Los ciudadanos de la República de Colombia residentes en el exterior de manera permanente, al volver a Colombia, tienen derecho a:

( $\mathrm{x}$ ) exención fiscal si deciden invertir en el país (en caso afirmativo, por favor indique cómo): En el marco de la ley 1565 (Ley del retorno), hay ciertas exenciones fiscales e incentivos tributarios y de otra naturaleza de acuedo al tipo de retorno.

( $\mathrm{x}$ ) exención aduanera en importaciones y exportaciones (en caso afirmativo, por favor indique cómo): Existe la posibilidad de importar un menaje en el marco de la ley 1565 .

( ) trato preferencial si deciden invertir en el país (en caso afirmativo, por favor indique cómo):

( ) subvenciones estatales si deciden invertir en el país (en caso afirmativo, por favor indique cómo):

( $\mathrm{x}$ ) otros beneficios (en caso afirmativo, por favor indique cuáles): En el marco de la ley 1565, hay acompañamiento del Estado para radicarse nuevamente en Colombia, de acuerdo al tipo de retorno varía el tipo de apoyo.

2.2. ¿Existen programas de desarrollo implementados por el Gobierno de Colombia en los cuales participan colombianos residentes en el exterior?

(Tengo conocimiento de: Programa Colombia Nos Une y Plan de Retorno Positivo. ¿Existen otros? En caso afirmativo, por favor indique su nombre y una descripción muy breve o un enlace para una página web con más información):

Favor aclarar a qué se refiere con „programas de desarrollo”, Existen programas de Promoción de Comunidades Colombianas en el Exterior, mediante la presentación de proyectos por parte de los Consulados en beneficio de la comunidad. A través de los medios virtuales cualquier ciudadano puede participar en los foros y programas a nivel nacional. Ver Gobierno en Linea. 


\section{Instituciones relacionadas a la diáspora}

3.1. Dentro del Ministerio de Relaciones Exteriores de la República de Colombia, ¿cuál es la unidad que se encarga de los asuntos de la diáspora?

La Dirección de Asuntos Consulares, Migratorios y de Atención al Ciudadano.

3.2. ¿Aproximadamente cuántas personas trabajan en esta unidad?

Es algo que varía, lo desconocemos y por lo tanto habría que trasladar la consulta a la Dirección.

3.3. En su presente forma, ¿en qué año fue fundada esta unidad? Antes de esto, ¿qué unidad se encargaba de este tema?

Siempre ha existido una Dirección de Asuntos Consulares, sus áreas de acción y énfasis y por lo tanto su nombre. Para datos exactos habria que consultar a la Direccion.

3.4. ¿Cuáles son las actividades principales de esta unidad? Por favor, ponga una $\mathbf{X}$ entre las paréntesis donde corresponda.

( $\mathrm{x}$ ) Organizar eventos y programas culturales para los colombianos en el exterior

( $\mathrm{x}$ ) Organizar eventos y programas sociales que ayudan a los colombianos en el exterior

( ) Organizar eventos y programas sociales que ayudan a los colombianos que están en Colombia, con la participación de los colombianos en el exterior

( $\mathrm{x}$ ) Fomentar que los colombianos en el exterior inviertan en Colombia

( $\mathrm{x}$ ) Otros, por favor indique: La Dirección de Asuntos Consulares, Migratorios y de Asuntos Consulares se encarga de coordinar el funcionamiento de todos los consulados de Colombia en el mundo. Por lo tanto, las funciones son múltiples y relacionadas con todas las actividades de los consulados, para citar algunas: Asistencia a los connacionales en el exterior, trámite de documentos de identidad 
para colombianos, trámite de visados para extranjeros, actuaciones notariales, cooperación judicial, etc.

3.5. ¿Existe un consejo consultivo sobre el tema de las migraciones en Colombia, en el cual, fuera del Ministerio de Relaciones Exteriores, participan otros ministerios e instituciones? (En caso afirmativo, por favor indique cuáles, y a partir de qué año existe este consejo):

En el marco de la Política Integral Migratoria-PIM, y el documento CONPES 3603 de 2009 existe la Comisión Nacional Intersectoria de Migración. Para más información ver: http://www.cancilleria.gov.co/colombia/migration/policy y http://www.cancilleria.gov.co/colombia/migration/policy/commission

3.6. ¿Existen consejos consultivos con las organizaciones de colombianos en el exterior, en los cuales los migrantes pueden discutir los temas que consideren importantes, con miembros del cuerpo diplomático de Colombia? (En caso afirmativo, por favor indique en qué países, y a partir de qué año existen estos consejos):

La PIM se formuló en consulta con las comunidades de connacionales residentes en el exterior. Desconocemos si estas consultas se han formalizado a partir de ese momento. Se deberia hacer la consulta a la Dirección de Asuntos Consulares, Migratorios y de Servicio al Ciudadano.

\section{El futuro de la política de diáspora}

4.1. Según su opinión, ¿cuáles serían las actividades más importantes que el Gobierno de Colombia podría hacer para mejorar sus contactos con los ciudadanos colombianos en el exterior? Qué se necesitaría para desarrollar estas actividades?

Formalizar protocolos como el Registro Consular, el cual actualmente es voluntario. El registro es el punto de partida para establecer una comunicación entre los consulados colombianos y nuestros connacionales. Los consulados siempre pueden 
aprovechar mayores recursos para mejorar sus actividades, siendo el recurso humano el mas importante.

Muchas gracias por su contribución a mi trabajo. Por favor, envíe el cuestionario rellenado a mi correo electrónico: soltesz.bela@gmail.com.

Le agradecería si pudiera enviarmelo hasta el 20 de octubre de 2014.

Atentamente,

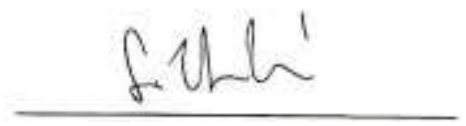

Licenciado Béla Soltész

Universidad Corvinus de Budapest, Hungría

Escuela de Doctorado en Relaciones Internacionales 
Encuesta sobre las actividades del Gobierno de la República de Costa Rica para mantener contactos con ciudadanos costarricenses residentes en el exterior

\section{Por: Licenciado Béla Soltész}

Universidad Corvinus de Budapest, Hungría

Escuela de Doctorado en Relaciones Internacionales

Título de la tesis de doctorado: "Migración, políticas de diáspora y desarrollo en América Latina”

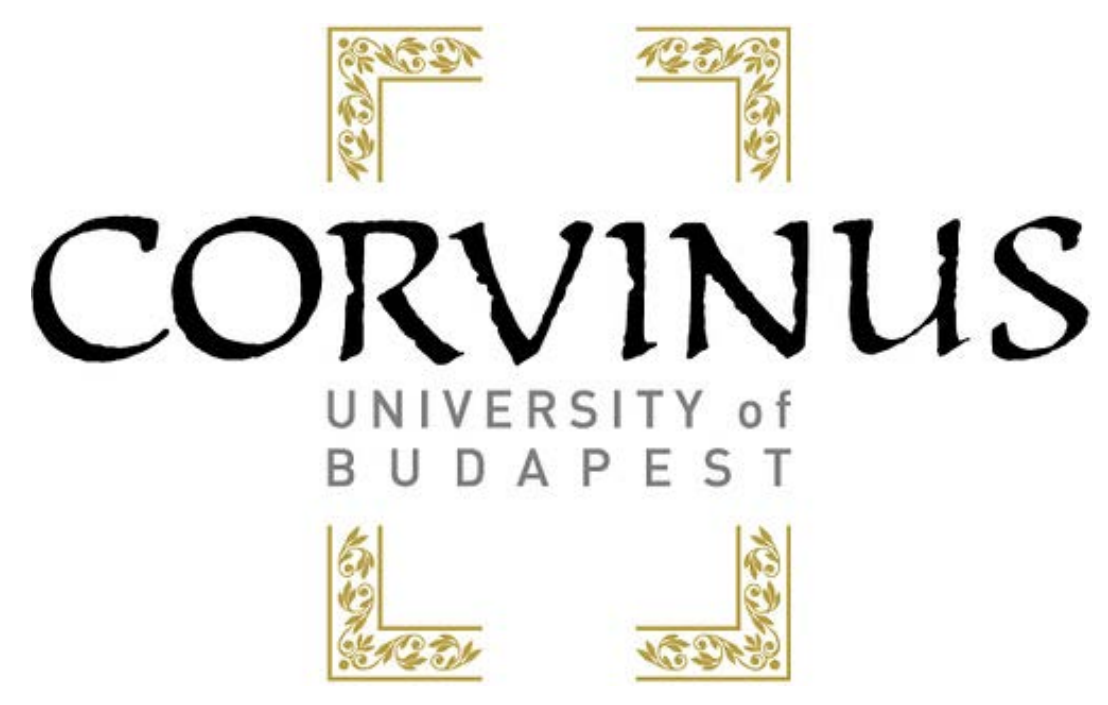


Estimado/a Señor/a:

Con la presente encuesta le solicito información sobre algunas actividades que lleva a cabo el Gobierno de Costa Rica para mantener contactos con sus ciudadanos en el exterior.

La encuesta tiene el único objetivo de recoger información para mi tesis de doctorado que se trata de políticas de diáspora que promueven el desarrollo en América Latina. Es un tema en el cual Hungría puede aprender mucho de los gobiernos latinoamericanos. Para llenar el cuestionario se necesitarán unos 20 minutos aproximadamente, y con ello Usted ayudará mucho en desarrollar mi tesis y en facilitar el intercambio de conocimiento entre nuestros países.

En la encuesta, "costarricenses en el exterior", "diáspora" y "migrantes" se entienden como conceptos sinónimos para el grupo de personas de origen costarricense que viven fuera de Costa Rica de manera permanente.

\section{Participación en elecciones desde el exterior}

1.1. Por favor, marque con una $\mathbf{X}$ entre las paréntesis donde corresponda.

Los ciudadanos de la República de Costa Rica residentes en el exterior de manera permanente,

( $\mathrm{X}$ ) pueden participar en las elecciones presidenciales, pero solo en persona en los consulados.

( ) pueden participar en las elecciones presidenciales, en persona en los consulados o por vía postal.

( ) pueden participar en las elecciones parlamentarias, y votar a un diputado que representa a los ciudadanos en el exterior.

( ) pueden participar en las elecciones parlamentarias, y votar a una lista de partido.

( X ) pueden participar en referendums.

( ) no pueden participar en ningún tipo de elecciones.

Otras observaciones (por favor indique): 


\section{Beneficios económicos para la diáspora}

2.1. Por favor, marque con una $\mathbf{X}$ entre las paréntesis donde corresponda.

Los ciudadanos de la República de Costa Rica residentes en el exterior de manera permanente, al volver a Costa Rica, tienen derecho a:

( ) exención fiscal si deciden invertir en el país (en caso afirmativo, por favor indique cómo):

( $\mathrm{X}$ ) exención aduanera en importaciones y exportaciones (en caso afirmativo, por favor indique cómo): Exención en la importación de su menaje de casa, ropa y artículos de uso personal.

( ) trato preferencial si deciden invertir en el país (en caso afirmativo, por favor indique cómo):

( ) subvenciones estatales si deciden invertir en el país (en caso afirmativo, por favor indique cómo):

( ) otros beneficios (en caso afirmativo, por favor indique cuáles):

2.2. ¿Existen programas de desarrollo implementados por el Gobierno de Costa Rica en los cuales participan costarricenses residentes en el exterior?

No.

\section{Instituciones relacionadas a la diáspora}

3.1. Dentro del Ministerio de Relaciones Exteriores de la República de Costa Rica, ¿cuál es la unidad que se encarga de los asuntos de la diáspora?

Dirección de Servicio Exterior.

3.2. ¿Aproximadamente cuántas personas trabajan en esta unidad?

20 personas. 
3.3. En su presente forma, ¿en qué año fue fundada esta unidad? Antes de esto, ¿qué unidad se encargaba de este tema?

1962.

3.4. ¿Cuáles son las actividades principales de esta unidad? Por favor, ponga una $\mathbf{X}$ entre las paréntesis donde corresponda.

( X ) Organizar eventos y programas culturales para los costarricenses en el exterior

( ) Organizar eventos y programas sociales que ayudan a los costarricenses en el exterior

( ) Organizar eventos y programas sociales que ayudan a los costarricenses que están en Costa Rica, con la participación de los costarricenses en el exterior

( ) Fomentar que los costarricenses en el exterior inviertan en Costa Rica

( ) Otros, por favor indique:

3.5. ¿Existe un consejo consultivo sobre el tema de las migraciones en Costa Rica, en el cual, fuera del Ministerio de Relaciones Exteriores, participan otros ministerios e instituciones? (En caso afirmativo, por favor indique cuáles, y a partir de qué año existe este consejo):

Consejo Nacional de Migración, creado en 1952 e integrado por:

1) El ministro o la ministra de Gobernación y Policía, quien lo presidirá.

2) El ministro o la ministra de Relaciones Exteriores y Culto.

3) El ministro o la ministra de Trabajo y Seguridad Social.

4) El ministro o la ministra de Planificación Nacional y Política Económica.

5) El ministro o la ministra de Salud.

6) El ministro o la ministra de Educación.

7) El director o la directora general de Migración y Extranjería.

8) El presidente ejecutivo o la presidenta ejecutiva del Instituto Costarricense de Turismo.

9) El presidente ejecutivo o la presidenta ejecutiva de la Caja Costarricense de Seguro Social. 
10) Dos personas representantes de las organizaciones de la sociedad civil, vinculadas al tema

migratorio, nombradas por la Defensoría de los Habitantes, según se establezca en el Reglamento de esta Ley.

3.6. ¿Existen consejos consultivos con las organizaciones de costarricenses en el exterior, en los cuales los migrantes pueden discutir los temas que consideren importantes, con miembros del cuerpo diplomático de Costa Rica? (En caso afirmativo, por favor indique en qué países, y a partir de qué año existen estos consejos):

No.

\section{El futuro de la política de diáspora}

4.1. Según su opinión, ¿cuáles serían las actividades más importantes que el Gobierno de Costa Rica podría hacer para mejorar sus contactos con los ciudadanos costarricenses en el exterior? Qué se necesitaría para desarrollar estas actividades?

Son necesarias mayores y mejores políticas focalizadas en los costarricenses de la diáspora.

Muchas gracias por su contribución a mi trabajo. Por favor, envíe el cuestionario rellenado a mi correo electrónico: soltesz.bela@gmail.com.

Le agradecería si pudiera enviarmelo hasta el 20 de octubre de 2014. Atentamente,

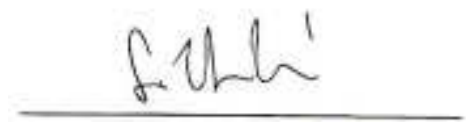

Licenciado Béla Soltész

Universidad Corvinus de Budapest, Hungría

Escuela de Doctorado en Relaciones Internacionales 
Encuesta sobre las actividades del Gobierno de la República de Ecuador para mantener contactos con ciudadanos ecuatorianos residentes en el exterior

\section{Por: Licenciado Béla Soltész}

Universidad Corvinus de Budapest, Hungría

Escuela de Doctorado en Relaciones Internacionales

Título de la tesis de doctorado: "Migración, políticas de diáspora y desarrollo en América Latina”

Cuestionario enviado el 21 de septiembre de 2014

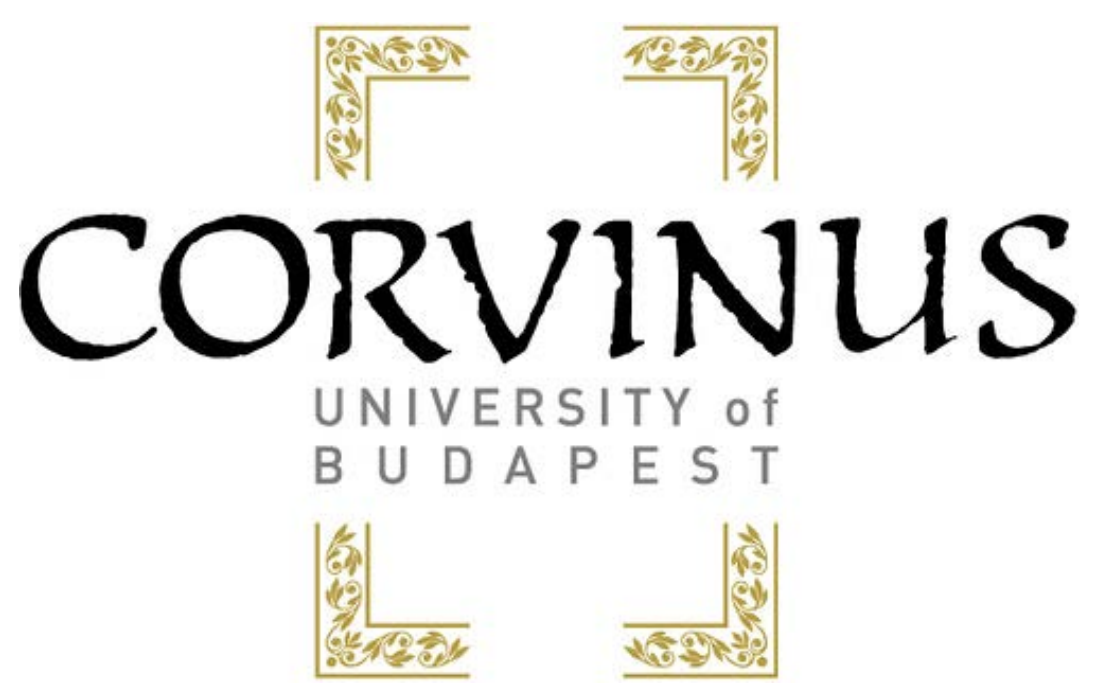


Estimado/a Señor/a:

Con la presente encuesta le solicito información sobre algunas actividades que lleva a cabo el Gobierno de Ecuador para mantener contactos con sus ciudadanos en el exterior.

La encuesta tiene el único objetivo de recoger información para mi tesis de doctorado que se trata de políticas de diáspora que promueven el desarrollo en América Latina. Es un tema en el cual Hungría puede aprender mucho de los gobiernos latinoamericanos. Para llenar el cuestionario se necesitarán unos 20 minutos aproximadamente, y con ello Usted ayudará mucho en desarrollar mi tesis y en facilitar el intercambio de conocimiento entre nuestros países.

En la encuesta, "ecuatorianos en el exterior", "diáspora" y "migrantes" se entienden como conceptos sinónimos para el grupo de personas de origen ecuatoriano que viven fuera de Ecuador de manera permanente.

\section{Participación en elecciones desde el exterior}

1.1. Por favor, marque con una $\mathbf{X}$ entre las paréntesis donde corresponda.

Los ciudadanos de la República de Ecuador residentes en el exterior de manera permanente,

( $\mathrm{X}$ ) pueden participar en las elecciones presidenciales, pero solo en persona en los consulados.

( $\mathrm{X}$ ) pueden participar en las elecciones presidenciales, en persona en los consulados o por vía postal.

( $\mathrm{X}$ ) pueden participar en las elecciones parlamentarias, y votar a un diputado que representa a los ciudadanos en el exterior.

( $\mathrm{X}$ ) pueden participar en las elecciones parlamentarias, y votar a una lista de partido.

( $\mathrm{X}$ ) pueden participar en referendums.

( ) no pueden participar en ningún tipo de elecciones.

Otras observaciones (por favor indique): Para los(as) ciudadanos(as) ecuatorianos(as) residentes en el exterior el voto es facultativo, en las las elecciones seccionales ( candidatos para Alcalde, Prefecto, Consejos Provinciales) en la República del 
Ecuador los ecuatorianos(as) residentes en el exterior no están considerados en los padrones.

\section{Beneficios económicos para la diáspora}

2.1. Por favor, marque con una $\mathbf{X}$ entre las paréntesis donde corresponda.

Los ciudadanos de la República de Ecuador residentes en el exterior de manera permanente, al volver a Ecuador, tienen derecho a:

( $\mathrm{X}$ ) exención fiscal si deciden invertir en el país (en caso afirmativo, por favor indique cómo):

( $\mathrm{X}$ ) exención aduanera en importaciones y exportaciones (en caso afirmativo, por favor indique cómo): Ciudadanos ecuatorianos residentes en el exterior que constan en el registro consular no pagarán arancel de 42 dólares para envíos de paquetería de uso personal dentro del sistema 4X4. Para tal efecto, tendrán un límite de 12 envíos o 2400 dólares al año, lo que ocurra primero

( $\mathrm{X}$ ) trato preferencial si deciden invertir en el país (en caso afirmativo, por favor indique cómo):

( $\mathrm{X}$ ) subvenciones estatales si deciden invertir en el país (en caso afirmativo, por favor indique cómo):

( $\mathrm{X}$ ) otros beneficios (en caso afirmativo, por favor indique cuáles): Cuando un ciudadano(a) ecuatoriano(a) que ha vivido en el exterior y desea regresar definitivamente al Ecuador tiene la opción de llevar su Menaje de casa, equipo de trabajo y un automóvil, con la exoneración de impuestos.

2.2. ¿Existen programas de desarrollo implementados por el Gobierno de Ecuador en los cuales participan ecuatorianos residentes en el exterior?

(Tengo conocimiento de: Programa "Bienvenid@s a Casa”, "Banco del Migrante" y "Fondo Cucayo”. ¿Existen otros? En caso afirmativo, por favor indique su nombre y una descripción muy breve o un enlace para una página web con más información):

Los programas que usted conoce estuvieron a cargo de la Ex Secreataría del Migrante, los cuales fenecieron. 
Actualmente el Viceministerio de Movilidad Humana se encarga de coordinar conjuntamente con varias instituciones del estado los siguientes programas:

MENAJE DE CASA, VEHÍCULO Y EQUIPO DE TRABAJO EXENTO DE IMPUESTOS - SERVICIO NACIONAL DE ADUANA

ACCESO AL SISTEMA EDUCATIVO NACIONAL - MINISTERIO DE EDUCACION

PROGRAMA DE CAPACITACIÓN PARA LAS PERSONAS MIGRANTES Y SUS FAMILIAS - SERVICIO ECUATORIANO DE CAPACITACION PROFESIONAL

PLAN ECUADOR SALUDABLE, VOY POR TI - MINISTERIO DE SALUD PUBLICA

BONO DE LA VIVIENDA - MINISTERIO DE DESARROLLO URBANO Y VIVIENDA

BOLSA DE EMPLEO - MINISTERIO DE RELACIONES LABORALES

AFILIACIÓN VOLUNTARIA - INSTITUTO ECUATORIANO DE SEGURIDAD SOCIAL

Para mayor información en el siguiente enlace (http://cancilleria.gob.ec/serviciosinterinstitucionales/)

RETORNO E INTEGRACION DE LA PERSONA MIGRANTE EN EL ECUADOR http://cancilleria.gob.ec/acompanamiento-en-el-retorno-al-pais/

\section{Instituciones relacionadas a la diáspora}

3.1. Dentro del Ministerio de Relaciones Exteriores y Movilidad Humana de la República de Ecuador, ¿cuál es la unidad que se encarga de los asuntos de la diáspora?

(Tengo conocimiento de la creación del Viceministerio de Movilidad Humana y, en su seno, la Subsecretaría de la Comunidad Ecuatoriana Migrante. ¿Existe más información accesible acerca de estas unidades, fuera de lo que se puede leer en http://cancilleria.gob.ec/integracion-de-la-senami-al-nuevo-vice-ministerio-demovilidad-humana/ ? En caso afirmativo, por favor dé una descripción muy breve o un enlace para una página web con más información): 
En el siguiente link http://cancilleria.gob.ec/movilidad-humana/, encontrará las gestiones y beneficios que realiza el Viceministerio de Movilidad Humana, conjuntamente con las Embajadas ecuatorianas y diferentes instituciones nacionales, en favor de los residentes en el exterior.

En la Cancillería también hay otras Unidades que se encargan de los asuntos de la diáspora como la Dirección de Documentos de Viaje, Subsecretaria de la Comunidad Ecuatoriana Migrante, Dirección de Asuntos Consulares, ect.

3.2. ¿Aproximadamente cuántas personas trabajan en estas unidades?

No se podría especificar, pero el personal está capacitado para ejercer las funciones de ayuda a la Comunidad ecuatoriana

3.3. En su presente forma, ¿en qué año fue fundada estas unidades? Antes de esto, ¿qué unidad se encargaba de este tema?

La Secretaría Nacional del Migrante, mediante Decreto Nro. 20, de 10 junio de 2013, pasó a formar parte del Ministerio de Relaciones Exteriores y ahora se llama Viceministerio de Movilidad Humana.

3.4. ¿Cuáles son las actividades principales de estas unidades? Por favor, ponga una $\mathbf{X}$ entre las paréntesis donde corresponda.

( X ) Organizar eventos y programas culturales para los ecuatorianos en el exterior ( $\mathrm{X}$ ) Organizar eventos y programas sociales que ayudan a los ecuatorianos en el exterior

(X) Organizar eventos y programas sociales que ayudan a los ecuatorianos que están en Ecuador, con la participación de los ecuatorianos en el exterior ( X ) Fomentar que los ecuatorianos en el exterior inviertan en Ecuador ( $\mathrm{X}$ ) Otros, por favor indique: Coordinar efectivamente con las Embajadas y Consulados del Ecuador en el Exterior, especialmente en casos de vulnerabilidad (Deportados, problemas intrafamiliares, problemas jurídicos, etc).

Los actos culturales y sociales para los ecuatorianos en el exterior, le corresponde organizar a cada Embajada del Ecuador, en base al presupuesto asignado. 
3.5. ¿Existe un consejo consultivo sobre el tema de las migraciones en Ecuador, en el cual, fuera del Ministerio de Relaciones Exteriores y Movilidad Humana, participan otros ministerios e instituciones? (En caso afirmativo, por favor indique cuáles, y a partir de qué año existe este consejo):

Otras Instituciones del Estado como por ejemplo la Secretaria Nacional de Comunicación Social, tiene el periodico digital el Ciudadano (http://www.elciudadano.gob.ec/), la revista Diplomacia Ciudadana revista bimestral del Ministerio de Relaciones Exteriores, así como „La Hora del migrante”, un programa radial que busca informar y sensibilizar sobre la realidad migratoria.

El Ministerio de Inclusión Económica y Social ofrece un servicio a favor de la Ninez y la Familia en el Ecuador y a la Comunidad Migrante en el exterior.

3.6. ¿Existen consejos consultivos con las organizaciones de ecuatorianos en el exterior, en los cuales los migrantes pueden discutir los temas que consideren importantes, con miembros del cuerpo diplomático de Ecuador? (En caso afirmativo, por favor indique en qué países, y a partir de qué año existen estos consejos):

Los ecuatorianos residentes en el exterior pueden formar Organizaciones, Consejos, para que organicen eventos culturales, sociales, deportivos, etc. Las Embajada y Consulados del Ecuador les informan de las gestiones realizadas y de la situación migratoria o política del país. Además reciben Asesoría Legal gratuita en, casos de vulnerabilidad, hipotecas, etc.

\section{El futuro de la política de diáspora}

4.1. Según su opinión, ¿cuáles serían las actividades más importantes que el Gobierno de Ecuador podría hacer para mejorar sus contactos con los ciudadanos ecuatorianos en el exterior? Qué se necesitaría para desarrollar estas actividades?

En el mes de enero 2014, la Cancillería implementó el sistema Consulado Virtual, que es una herramienta incluida en la página web del Ministerio de Relaciones 
Exteriores y Movilidad Humana, que permite al usuario solicitar, requerir y gestionar los diferentes servicios que las oficinas Consulares ofrecen.

Para crear un usuario nacional nos dirigimos al navegador de Internet, que sea de preferencia del usuario, aunque se recomienda utilizar Google Chrome.

Digitar www.consuladovirtual.gob.ec

Aparece el sitio web en cuestión donde el usuario se dirigirá seguidamente a la parte derecha del portal para referenciar el mensaje "Si usted es USUARIO NUEVO, por favor regístrese Aquî" y dar clic en "Ecuatoriano".

Además, el Viceministerio de Movilidad Humana, inauguró las oficinas de la Unidad de Consejería Virtual la cual brinda atención, asesoramiento y consejería sobre temas consulares y migratorios a través del uso de herramientas tecnológicas sobre mensajes de texto, chat, mensajes de correo electrónico; así como llamadas telefónicas gratuitas con la línea 1800-cancillería, en Ecuador, España, Canadá y Estados Unidos. Mientras que los ciudadanos desde otros países pueden comunicarse realizando llamadas vía internet, las 24 horas

Todas las Embajadas y Consulados del Ecuador en el exterior, están implementado las redes sociales (Facebook, Twitter, Página Web), para dar una mayor cobertura de información.

Finalmente, el Gobierno ecuatoriano busca vincular a investigadores extranjeros y ecuatorianos de alto nivel académico, residentes en el exterior, que puedan aplicar a nivel local su experiencia en actividades de investigación y conocimientos en temas especializados para lograr la apropiación y generación de conocimientos científicos de calidad en el territorio nacional en áreas prioritarias de desarrollo, por lo que están vigentes los siguientes Proyectos:

-PROYECTO "PROMETEO", DE LA SECRETARIA DE EDUCACION SUPERIOR CIENCIA TECNOLOGIA E INNOVACIÓN (http://prometeo.com.ec/).

-YACHAY Ciudad del Conocimiento (http://www.yachay.gob.ec/), -UNIVERSIDAD IKIAM, UNIVERSIDAD REGIONAL AMAZONICA

Muchas gracias por su contribución a mi trabajo. Por favor, envíe el cuestionario rellenado a mi correo electrónico: soltesz.bela@gmail.com.

Le agradecería si pudiera enviarmelo hasta el 20 de octubre de 2014.

Atentamente, 


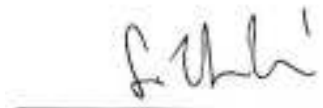

Licenciado Béla Soltész

Universidad Corvinus de Budapest, Hungría

Escuela de Doctorado en Relaciones Internacionales 
Encuesta sobre las actividades del Gobierno de la República de Guatemala para mantener contactos con ciudadanos guatemaltecos residentes en el exterior

\section{Por: Licenciado Béla Soltész}

Universidad Corvinus de Budapest, Hungría

Escuela de Doctorado en Relaciones Internacionales

Título de la tesis de doctorado: "Migración, políticas de diáspora y desarrollo en América Latina”

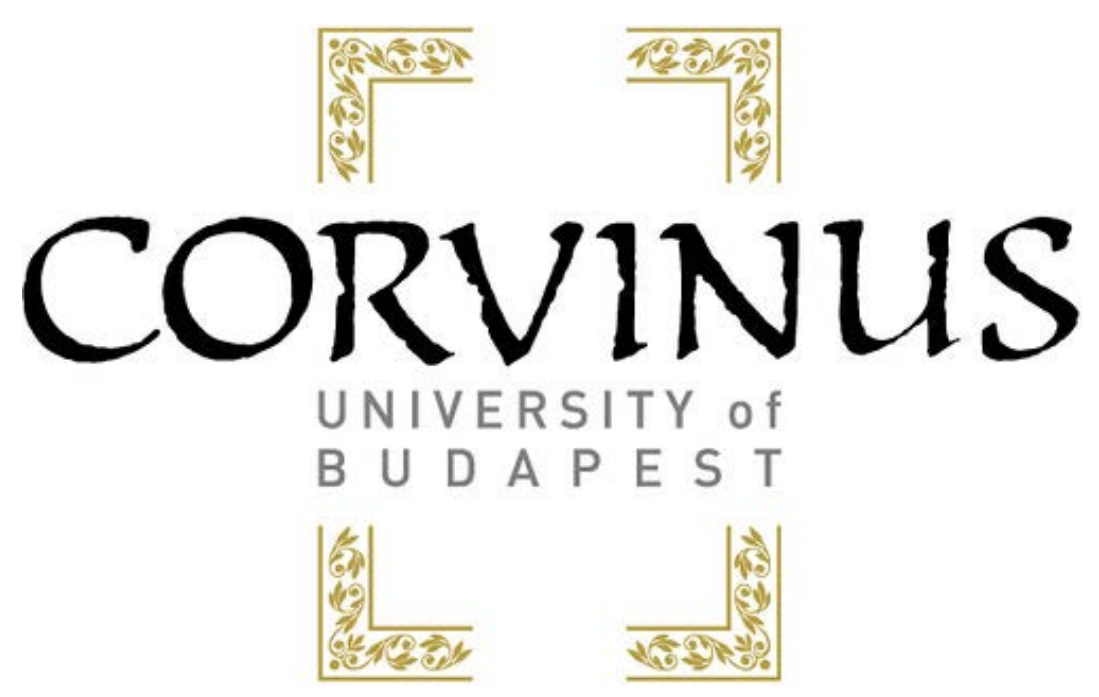


Estimado/a Señor/a:

Con la presente encuesta le solicito información sobre algunas actividades que lleva a cabo el Gobierno de Guatemala para mantener contactos con sus ciudadanos en el exterior.

La encuesta tiene el único objetivo de recoger información para mi tesis de doctorado que se trata de políticas de diáspora que promueven el desarrollo en América Latina. Es un tema en el cual Hungría puede aprender mucho de los gobiernos latinoamericanos. Para llenar el cuestionario se necesitarán unos 20 minutos aproximadamente, y con ello Usted ayudará mucho en desarrollar mi tesis y en facilitar el intercambio de conocimiento entre nuestros países.

En la encuesta, "guatemaltecos en el exterior", "diáspora" y "migrantes" se entienden como conceptos sinónimos para el grupo de personas de origen guatemalteco que viven fuera de Guatemala de manera permanente.

\section{Participación en elecciones desde el exterior}

1.1. Por favor, marque con una $\mathbf{X}$ entre las paréntesis donde corresponda.

Los ciudadanos de la República de Guatemala residentes en el exterior de manera permanente,

( ) pueden participar en las elecciones presidenciales, pero solo en persona en los consulados.

( ) pueden participar en las elecciones presidenciales, en persona en los consulados o por vía postal.

( ) pueden participar en las elecciones parlamentarias, y votar a un diputado que representa a los ciudadanos en el exterior.

( ) pueden participar en las elecciones parlamentarias, y votar a una lista de partido.

( ) pueden participar en referendums.

( $\mathrm{X}$ ) no pueden participar en ningún tipo de elecciones.

Otras observaciones (por favor indique): 


\section{Beneficios económicos para la diáspora}

2.1. Por favor, marque con una $\mathbf{X}$ entre las paréntesis donde corresponda.

Los ciudadanos de la República de Guatemala residentes en el exterior de manera permanente, al volver a Guatemala, tienen derecho a:

( ) exención fiscal si deciden invertir en el país (en caso afirmativo, por favor indique cómo):

( ) exención aduanera en importaciones y exportaciones (en caso afirmativo, por favor indique cómo):

( ) trato preferencial si deciden invertir en el país (en caso afirmativo, por favor indique cómo):

( ) subvenciones estatales si deciden invertir en el país (en caso afirmativo, por favor indique cómo):

( ) otros beneficios (en caso afirmativo, por favor indique cuáles):

2.2. ¿Existen programas de desarrollo implementados por el Gobierno de Guatemala en los cuales participan guatemaltecos residentes en el exterior?

En el caso específico de Estados Unidos, puede citarse la existencia del Consejo Asesor del Consejo Nacional de Atención al Migrante (CONAMIGUA) y las Mesas Consulares. A través del Consejo Asesor de CONAMIGUA, los líderes comunitarios guatemaltecos residentes en Estados Unidos asesoran al Consejo Nacional respecto de aquellas actividades para fortalecer la organización comunitaria y mantener un vínculo fluido de comunicación entre la Comunidad y los Consulados de Guatemala acreditados en ese país.

Asimismo, las Mesas Consulares se reúnen en todas las ciudades en las que Guatemala cuenta con un Consulado General en los Estados Unidos. En ellas se abordan cuestiones de coyuntura respecto del tema migratorio (tales como los avances en el asunto de la Reforma Migratoria; los programas de Acción Ejecutiva tales como DACA y DAPA ) y para acordar acciones concretas a desarrollar en beneficio de la comunidad migrante. 


\section{Instituciones relacionadas a la diáspora}

3.1. Dentro del Ministerio de Relaciones Exteriores de la República de Guatemala, ¿cuál es la unidad que se encarga de los asuntos de la diáspora?

Dirección General de Asuntos Consulares y Migratorios

3.2. ¿Aproximadamente cuántas personas trabajan en esta unidad?

37 personas

3.3. En su presente forma, ¿en qué año fue fundada esta unidad? Antes de esto, ¿qué unidad se encargaba de este tema?

La Dirección General de Asuntos Consulares y Migratorios fue creada en el año 2003, siendo la Dirección de Asutnos Consulares la encargada de este tema anteriormente.

3.4. ¿Cuáles son las actividades principales de esta unidad? Por favor, ponga una $\mathbf{X}$ entre las paréntesis donde corresponda.

( ) Organizar eventos y programas culturales para los guatemaltecos en el exterior

( ) Organizar eventos y programas sociales que ayudan a los guatemaltecos en el exterior

( ) Organizar eventos y programas sociales que ayudan a los guatemaltecos que están en Guatemala, con la participación de los guatemaltecos en el exterior

( ) Fomentar que los guatemaltecos en el exterior inviertan en Guatemala

( $\mathrm{X}$ ) Otros, por favor indique:

La Dirección General de Asuntos Consulares y Migratorios es la responsable de ejecutar, desde su sede y a través de los consulados generales, consulados, secciones consulares de las misiones diplomáticas, y consulados honorarios, la protección de los intereses del Estado, y de las personas naturales o jurídicas guatemaltecas en el exterior, incluyendo a las comunidades de connacionales que residen fuera del país. 
Es la responsable, asimismo, de atender los asuntos migratorios de su competencia y de la correcta aplicación en el extranjero, de la Ley de Migración y su Reglamento.

3.5. ¿Existe un consejo consultivo sobre el tema de las migraciones en Guatemala, en el cual, fuera del Ministerio de Relaciones Exteriores, participan otros ministerios e instituciones? (En caso afirmativo, por favor indique cuáles, y a partir de qué año existe este consejo):

En el Artículo No. 9 de la Ley de Migración, se crea el Consejo Nacional de Migración el cual se integra de la forma siguiente:

1) El Ministro de Gobernación, quien lo preside;

2) El Ministro de Relaciones Exteriores;

3) El Director General de Migración, quien fungirá como Secretario Ejecutivo;

4) El Director General del Instituto Guatemalteco de Turismo - INGUAT-; y,

5) El Procurador General de la Nación.

3.6. ¿Existen consejos consultivos con las organizaciones de guatemaltecos en el exterior, en los cuales los migrantes pueden discutir los temas que consideren importantes, con miembros del cuerpo diplomático de Guatemala? (En caso afirmativo, por favor indique en qué países, y a partir de qué año existen estos consejos):

Las Mesas Consulares realizadas en los Consulados de Guatemala acreditados en los Estados Unidos brindan la oportunidad para el intercambio de información a través de las organizaciones de migrantes.

\section{El futuro de la política de diáspora}

4.1. Según su opinión, ¿cuáles serían las actividades más importantes que el Gobierno de Guatemala podría hacer para mejorar sus contactos con los ciudadanos guatemaltecos en el exterior? Qué se necesitaría para desarrollar estas actividades?

El futuro de la política diáspora y las actividades que el gobierno debe desarrollar para fortalecer esta dinámica dependerán, en gran medida, del cambio que se 
produzca en la Ley Electoral y de Partidos Políticos en torno a la posibilidad de permitir el voto en el extranjero. Por la otra, la apertura de nuevas oficinas de atención consular para brindar los servicios de documentación, de asistencia y de protección consular a un mayor número de connacionales.

Muchas gracias por su contribución a mi trabajo. Por favor, envíe el cuestionario rellenado a mi correo electrónico: soltesz.bela@gmail.com.

Le agradecería si pudiera enviarmelo hasta el 20 de octubre de 2014.

Atentamente,

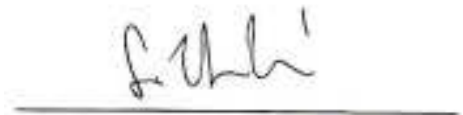

Licenciado Béla Soltész

Universidad Corvinus de Budapest, Hungría

Escuela de Doctorado en Relaciones Internacionales 
Encuesta sobre las actividades del Instituto de los Mexicanos en el Exterior

\section{Por: Licenciado Béla Soltész}

Ex-becario de la Secretaría de Relaciones Exteriores en México (2011, el Colegio Mexiquense)

Universidad Corvinus de Budapest, Hungría

Escuela de Doctorado en Relaciones Internacionales

Título de la tesis de doctorado: "Migración, políticas de diáspora y desarrollo en América Latina”

Cuestionario enviado el 14 de septiembre de 2015

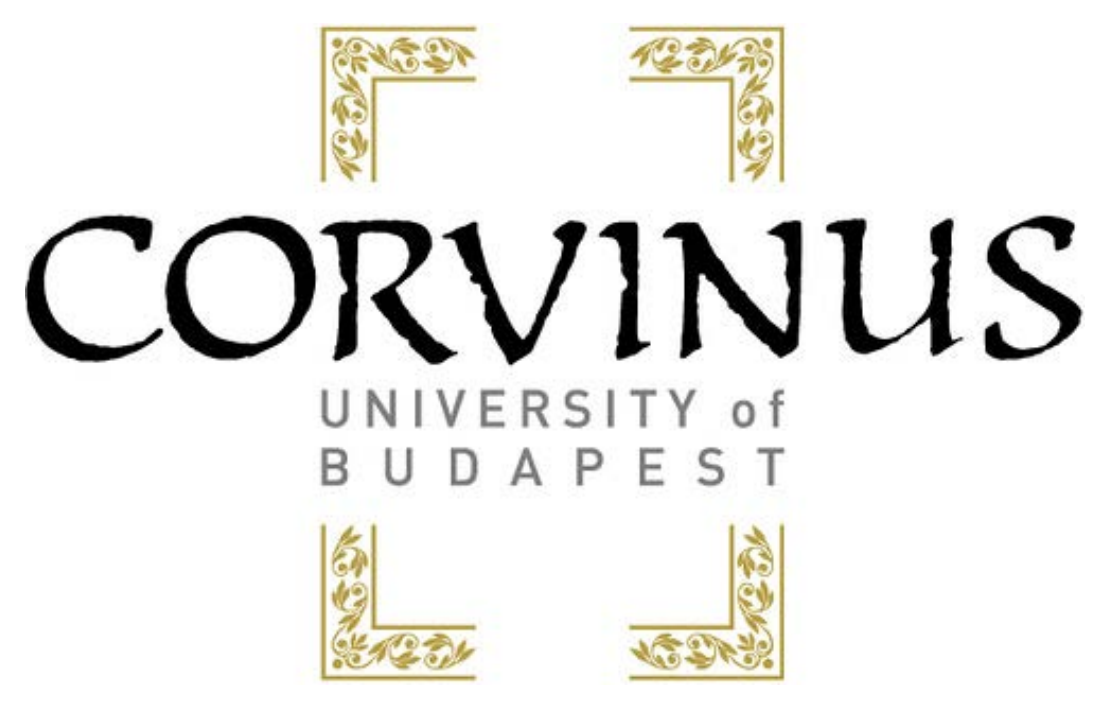


Estimado/a Señor/a:

Con la presente encuesta le solicito información sobre algunas actividades que lleva a cabo el Instituto de los Mexicanos en el Exterior como entidad responsable de coordenar las actividades del Gobierno Federal de México para mantener contactos con los mexicanos residentes en el extranjero.

Siendo becario de la Secretaría de Relaciones Exteriores en México en 2011 (en el Colegio Mexiquense de Zinacantepec, Estado de México), tuve la oportunidad de conocer el complejo sistema de acciones del Instituto de los Mexicanos en el Exterior. Los datos recogidos durante mi estancia han sido la base sobre la cual empecé a desarrollar mi tesis de doctorado.

Ahora, teniendo mi tesis de doctorado casi lista, quisiera pedir su cooperación para actualizar las informaciones que recogí en 2011. La encuesta que sigue tiene el único objetivo de recoger información para esta tesis, titulada "Migración, políticas de diáspora y desarrollo en América Latina”

Le doy las gracias anticipadas por su cooperación.

\section{Resumen de actividades de la política de diáspora mexicana}

Por favor, verifique las informaciones siguientes:

- ¿Siguen funcionando los siguientes programas hasta hoy día (septiembre 2015)? En caso de cambios, por favor añade su observación al cuadro "Notas".

- ¿Están correctamente marcadas las pertenencias institucionales (SRE, SEGOB, etc.)? En caso de cambios, por favor añade su observación al cuadro "Notas".

- ¿Existen más programas relacionados a la diáspora mexicana? En caso afirmativo, por favor añade su nombre al cuadro "Notas". 


\begin{tabular}{|c|c|c|c|}
\hline & $\begin{array}{l}\text { Institu- } \\
\text { ción } \\
\text { respon- } \\
\text { sable }\end{array}$ & Programa & Notas \\
\hline 1 & $\begin{array}{l}\text { SRE/ } \\
\text { IME }\end{array}$ & $\begin{array}{l}\text { - Programa de } \\
\text { Educación } \\
\text { Financiera para } \\
\text { Migrantes } \\
\text { Mexicanos } \\
\text { - Red } \\
\text { Talentos de } \\
\text { Mexicanos (Red } \\
\text { Global MX) } \\
\text { - Jornadas } \\
\text { Informativas } \\
\text { - Ventanillas de } \\
\text { Salud }\end{array}$ & $\begin{array}{l}\text { Todos los programas enumerados están } \\
\text { vigentes. A continuación una lista de } \\
\text { programas que también existen en el IME: } \\
\text { Programa de Plazas Comunitarias (Junto } \\
\text { con INEA) } \\
\text { IME- Becas } \\
\text { Programa de Donación de Libros de Texto } \\
\text { Gratuitos } \\
\text { Ventanilla de Oportunidades Educativas } \\
\text { Olimpiada Nacional } \\
\text { Acuerdos Bancos Consulados } \\
\text { Protección de los Derechos Agrarios de } \\
\text { las y los Ejidatarios y Comuneros } \\
\text { Migrantes (Junto con Procuraduría } \\
\text { Agraria) } \\
\text { IME-Estadísticas } \\
\text { Este es mi México } \\
\text { Tu Vivienda en México }\end{array}$ \\
\hline 2 & $\begin{array}{l}\text { SEGOB } \\
\text { / INM }\end{array}$ & $\begin{array}{l}\text { - } \text { Paisano } \\
\text { - Grupos Beta } \\
\text { de Protección a } \\
\text { Migrantes } \\
\text { - Menores } \\
\text { Repatriados } \\
\text { - Jornadas } \\
\text { Informativas }\end{array}$ & $\begin{array}{l}\text { Programa Paisano vigente. El IME } \\
\text { participa con insumos para la Guía } \\
\text { Paisano } \\
\text { http://www.paisano.gob.mx/index.php/pro } \\
\text { grama-paisano/124-guia-paisano } \\
\text { Se desconoce el estatus del resto de los } \\
\text { programas }\end{array}$ \\
\hline 3 & SEP & $\begin{array}{ll}\text { - Programa } & \\
\text { Binacional de }\end{array}$ & $\begin{array}{l}\text { Vigente. El IME funge como Secretaría } \\
\text { Técnica en el Programa. Del } 23 \text { al } 26 \text { de }\end{array}$ \\
\hline
\end{tabular}




\begin{tabular}{|c|c|c|c|}
\hline & & $\begin{array}{l}\text { Educación } \\
\text { Migrante México- } \\
\text { Estados Unidos }\end{array}$ & $\begin{array}{l}\text { septiembre de } 2015 \text { se realizará la XXVII } \\
\text { Reunión Binacional del PROBEM en la } \\
\text { Secretaría de Relaciones Exteriores. }\end{array}$ \\
\hline 4 & SS & $\begin{array}{l}\text { - Vete Sano } \\
\text { Regresa Sano } \\
\text { - Seguro } \\
\text { Popular de Salud } \\
\text { para Familias } \\
\text { Migrantes, } \\
\text { Repatriación de } \\
\text { Connacionales } \\
\text { Enfermos }\end{array}$ & Ambos programas están vigentes \\
\hline 5 & $\begin{array}{l}\text { SEDES } \\
\text { OL }\end{array}$ & $\begin{array}{l}\text { - Programa } 3 \mathrm{x} \\
1 \text { para Migrantes } \\
\text { - Programa } \\
\text { Opciones } \\
\text { Productivas }\end{array}$ & $\begin{array}{l}\text { Se desconoce el estatus del Programa de } \\
\text { Opciones Productivas. El Programa } 3 \times 1 \\
\text { sigue vigente. A continuación, enlace a } \\
\text { información al respecto: } \\
\text { http://www.sedesol.gob.mx/es/SEDESOL/ } \\
\text { Programa_3x1_para_Migrantes }\end{array}$ \\
\hline 6 & Otros & & \\
\hline
\end{tabular}

\section{EI Instituto de los Mexicanos en el Exterior}

2.1. ¿Aproximadamente cuántas personas trabajan actualmente en el IME?

Hay 46 empleados en las oficinas del Instituto de los Mexicanos en el Exterior, en la ciudad de México. Aunado a esto, hay un funcionario consular encargado de la Atención a Comunidades en cada Representación de México en el Exterior. 


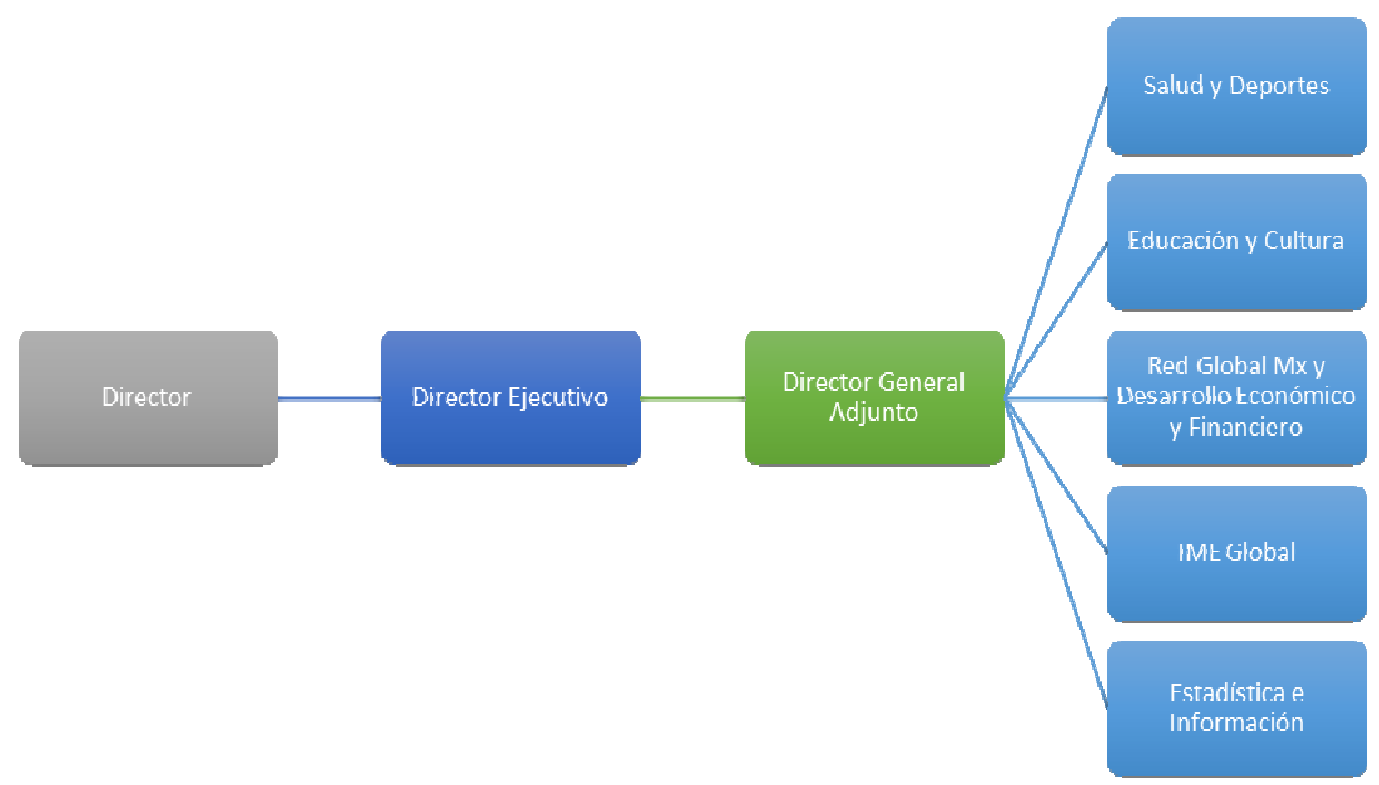

2.3. ¿Cuántos consejeros forman parte del CCIME (Consejo Consultivo del Instituto de los Mexicanos en el Exterior)?

Hasta 2014, el CCIME estaba integrado por 126 consejeros electos en las 56 circunscripciones consulares en Estados Unidos y Canadá. Sin embargo, la cuarta generaciónd e Consejeros del CCIME recomendó iniciar un proceso de replanteamiento del modelo.

A partir de 2015, el proceso de conformación del Consejo está enfocado a la presentaciónd e proyectos en favor de la comunidad mexicana en Estados Unidos y Canadá. Cada año, cualquier persona interesada en formar parte del Consejo debe presentar un proyecto específico al Consulado más cercano. A partir de estos proyectos, cada Representación Consular en América del Norte propone al IME la designación de hasta siete Consejeros Locales, por un periodo de 2 años.

Actualmente, el IME se encuentra en el proceso de evaluación de las propuestas de cada Consulado. A la fecha, se han recibido 167 proyectos de 40 representaciones consulares en Estados Unidos y Canadá.

2.4. ¿Quiénes son los integrantes del CNCME (Consejo Nacional para las Comunidades Mexicanas en el Exterior)? 
El CNCME nunca se reunió. No aplica.

2.5. ¿Existe una evaluación sobre las actividades del Instituto de los Mexicanos en el Exterior?

Existe una evaluación externa anual sobre las actividades el IME. Anexamos un folleto para mayor información.

\section{Programas coordinados por el Instituto de los Mexicanos en el Exterior}

3.1. En la página web del IME la última Jornada Informativa de la cual se encuentra información es la 100a, realizada en 2013. Desde entonces, ¿se han realizado más Jornadas Informativas?

Durante los primeros años del Instituto, la información sobre los diferentes programas se transmitía a la comunidad mexicana en el formato de Jornada Informativa. Actualmente, siguen realizándose muchos eventos como estos cada año, pero han dejado de nombrarse como Jornadas Informativas.

3.2. En cuanto al programa "Talento Mexicano en el Exterior", ¿existe una lista de proyectos realizados en el marco de este programa?

El programa es ahora la Red Global MX. Algunos ejemplos de proyectos son los siguientes:

Plataforma para la difusión del Sector europeo de Industrias Creativas - Capítulos Europeos: http://www.ic-rtm.org/

Libro Colaborativo Centenario de Octavio Paz - Capítulo Barcelona: http://www.icrtm.org/project/libro-colaborativo/

Britmex: Iniciativa organizada por el Capítulo Reino Unido y la Sociedad de exalumnos Chevening en el marco del Año Dual México-ReinoUnido, para impulsar alianzas entre los futuros líderes y emprendedores mexicanos y británicos. Boletíndeprensa: http://bit.ly/1dZLVNX

México expresando sus ideas "Mei": Salones globales, Foros Diplomados - Capítulo China. Vinculación con Aguascalientes y Zacatecas. 
Vinculación Académica México-Dallas, para fomentar el intercambio de estudiantes y profesores mexicanos hacia universidades estadounidenses en la región CapítuloDallas.

Modelo de Internacionalización de la Empresa Mexicana - Capítulo El Paso/Francia/Bélgica. (2darondaCONACYT)

Inspiring the Next Generation of Emerging Technology Leaders, Class of 2016Iniciativa del Capítulo Irlanda en donde colaboran miebros de la region europea: http://emtechub.com/emtechleaders/

Mexi-CanForum "Education,InnovationandEntrepreneurship“

Plataforma "Comunidad Mexicana en Venezuela", enfocada en la promoción cultural -CapítuloVenezuela: http://comeven.org/reddetalentos/

Brithack: Hackatón binacional para crear una aplicación o plataforma informática que proponga una solución a un problema social que compartan el ReinoUnido y México en el ámbito comercial o agrícola. La iniciativa cuenta con el apoyo de la oficina de la Coordinación de Estrategia Digital Nacional de la Presidencia de la República (octubre2015, premiación en el marco del Open Government Partnership).

3.3. En cuanto al "Programa 3x1 para Migrantes" (SEDESOL), ¿existe una evaluación reciente? En la página web de SEDESOL la más reciente es de 2009.

Las evaluaciones del programa 3x1 las realiza la SEDESOL, por lo que este Instituto no cuenta con ellas.

3.4. En cuanto al "Programa Opciones Productivas" (SEDESOL), ¿cómo pueden participar los migrantes? ¿Existe un esquema diferente de aplicarse a beneficios para migrantes?

El Programa Opciones Productivas tiene dos vertientes, una de las cuales es el programa 3x1 que está claramente dirigido a los migrantes.

3.5. ¿Existen actividades conjuntas de la IME y el Instituto Nacional de Migración? En caso de ambigüedades, ¿cuál es el principio para distribuir las tareas entre los dos Institutos? 
El objetivo del Instituto de los Mexicanos en el Exterior es promover estrategias, integrar programas, recoger propuestas y recomendaciones d elas comunidades de mexicanos en el exterior, sus organizaciones y órganos consultivos para fortalcer sus vínculos con México y fomentar su integración en las sociedades en las que residen y se desenvuelven.

El Instituto Nacional de Migración tiene como objetivos los delineados en el siguiente enlace: http://www.inm.gob.mx/index.php/page/Programas_del_INM

En general, el INM está más enfocado al proceso migratorio (el trayecto de un lugar a otro), mientras que el IME atiende a los mexicanos que ya se han establecido en el exterior.

3.5. Según su opinión, ¿cuáles serían las actividades más importantes que el Gobierno Federal de México podría hacer para mejorar sus contactos con los ciudadanos mexicanos en el exterior? Qué se necesitaría para desarrollar estas actividades?

Son muchas las actividaes que pueden realizarse en beneficio de los mexicanos en el exterior. En un primer momento, sería de suma importancia fortalecer los programas de Atención a Comunidades ya desarrollados por este Instituto en las áreas de Educación, Salud, Deportes, Educación Financiera y Empoderamiento Cívico.

\section{Otras preguntas}

4.1. Por favor, marque con una $\mathbf{X}$ entre las paréntesis donde corresponda.

Los ciudadanos mexicanos residentes en el exterior de manera permanente, al volver a México, tienen derecho a:

( ) exención fiscal si deciden invertir en el país (en caso afirmativo, por favor indique cómo):

( ) exención aduanera en importaciones y exportaciones (en caso afirmativo, por favor indique cómo):

( ) trato preferencial si deciden invertir en el país (en caso afirmativo, por favor indique cómo): 
( ) subvenciones estatales si deciden invertir en el país (en caso afirmativo, por favor indique cómo):

( ) otros beneficios (en caso afirmativo, por favor indique cuáles):

No hay beneficios que discriminen entre mexicanos que han vuelto al país y los mexicanos residentes en México.

Muchas gracias por su contribución a mi trabajo. Por favor, envíe el cuestionario rellenado a mi correo electrónico: soltesz.bela@gmail.com.

Le agradecería si pudiera enviármelo hasta el 15 de octubre de 2015.

Atentamente,

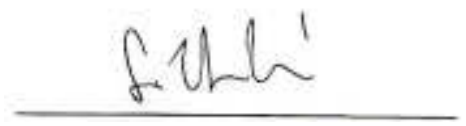

Licenciado Béla Soltész

Universidad Corvinus de Budapest, Hungría

Escuela de Doctorado en Relaciones Internacionales 
Encuesta sobre las actividades del Gobierno de la República del Perú para mantener contactos con ciudadanos peruanos residentes en el exterior

\section{Por: Licenciado Béla Soltész}

Universidad Corvinus de Budapest, Hungría

Escuela de Doctorado en Relaciones Internacionales

Título de la tesis de doctorado: "Migración, políticas de diáspora y desarrollo en América Latina”

Cuestionario enviado el 21 de septiembre de 2014

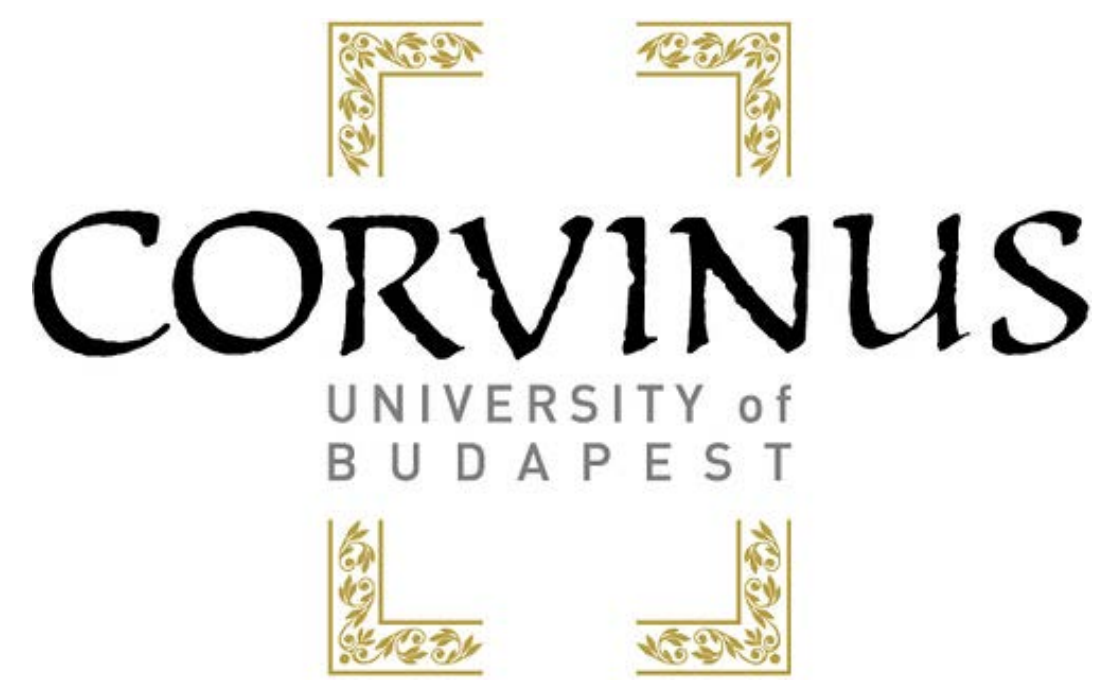


Estimado/a Señor/a:

Con la presente encuesta le solicito información sobre algunas actividades que lleva a cabo el Gobierno del Perú para mantener contactos con sus ciudadanos en el exterior.

La encuesta tiene el único objetivo de recoger información para mi tesis de doctorado que se trata de políticas de diáspora que promueven el desarrollo en América Latina. Es un tema en el cual Hungría puede aprender mucho de los gobiernos latinoamericanos. Para llenar el cuestionario se necesitarán unos 20 minutos aproximadamente, y con ello Usted ayudará mucho en desarrollar mi tesis y en facilitar el intercambio de conocimiento entre nuestros países.

En la encuesta, "peruanos en el exterior", "diáspora" y "migrantes" se entienden como conceptos sinónimos para el grupo de personas de origen peruano que viven fuera del Perú de manera permanente.

\section{Participación en elecciones desde el exterior}

1.1. Por favor, marque con una $\mathbf{X}$ entre las paréntesis donde corresponda.

Los ciudadanos de la República del Perú residentes en el exterior de manera permanente,

( $\mathrm{X}$ ) pueden participar en las elecciones presidenciales, pero solo en persona en los consulados.

( ) pueden participar en las elecciones presidenciales, en persona en los consulados o por vía postal.

( ) pueden participar en las elecciones parlamentarias, y votar a un diputado que representa a los ciudadanos en el exterior.

( $\mathrm{X}$ ) pueden participar en las elecciones parlamentarias, y votar a una lista de partido.

( ) pueden participar en referendums.

( ) no pueden participar en ningún tipo de elecciones.

Otras observaciones (por favor indique): 
El Congreso está debatiendo una ley que crea un distrito electoral para los peruanos que residen en el exterior para que puedan elegir parlamentarios que representen a la comunidad peruana en el exterior.

\section{Beneficios económicos para la diáspora}

2.1. Por favor, marque con una $\mathbf{X}$ entre las paréntesis donde corresponda.

Los ciudadanos de la República del Perú residentes en el exterior de manera permanente, al volver al Perú, tienen derecho a:

( ) exención fiscal si deciden invertir en el país (en caso afirmativo, por favor indique cómo):

( X ) exención aduanera en importaciones y exportaciones (en caso afirmativo, por favor indique cómo): ver otros beneficios

( ) trato preferencial si deciden invertir en el país (en caso afirmativo, por favor indique cómo):

( ) subvenciones estatales si deciden invertir en el país (en caso afirmativo, por favor indique cómo):

( ) otros beneficios (en caso afirmativo, por favor indique cuáles):

Ley de Reinserción Económica y Social para el Migrante Retornado

En cumplimiento del compromiso planteado en su Mensaje a la Nación en julio pasado, el Presidente de la República, Ollanta Humala, ha promulgado la Ley $\mathrm{N}^{\mathrm{o}}$ 30001, "Ley de Reinserción Económica y Social Para el Migrante Retornado”, cuyo propósito es facilitar la reinserción económica y social de los peruanos que, ante la situación de crisis económica internacional y el endurecimiento de políticas migratorias en los países de destino, hayan decidido o se hayan visto forzados a retornar al país. La norma contiene incentivos tributarios y contempla acciones de apoyo y orientación a favor de los retornados y sus familias.

De acuerdo a lo informado en la Nota de Prensa $N^{\circ}$ 086-13, se tiene previsto que, aproximadamente, veinte mil peruanos se beneficien anualmente con la citada Ley del Retorno la misma que se empezará a aplicar una vez que sea aprobado su Reglamento, el cual se está elaborando conjuntamente con otras 23 entidades, teniéndose prevista su culminación a más tardar el próximo 11 de junio. 
Los incentivos tributarios y las medidas para la reinserción socioeconómica de los peruanos retornantes están destinados a quienes hayan residido en el exterior sin interrupciones por un tiempo no menor de cuatro (04) años o que hayan sido forzados a retornar por su condición migratoria por el Estado receptor siempre que hayan permanecido en el exterior sin interrupciones por dos (02) años.

De conformidad con lo establecido en la Ley, los peruanos están liberados, por única vez, del pago de todo tributo que grave el internamiento en el país de los siguientes bienes:

Menaje de casa, conforme al Reglamento de Equipaje y Menaje de Casa, aprobado por Decreto Supremo 016-2006-EF, y las normas complementarias que se emitan para facilitar el retorno de los peruanos migrantes, hasta por treinta mil dólares americanos (USD 30 000,00);

Un (01) vehículo automotor, hasta por un máximo de treinta mil dólares americanos (USD 30 000, 00), según la tabla de valores referenciales, de la Superintendencia Nacional de Aduanas y de Administración Tributaria (SUNAT), siempre que se cumpla con los requisitos previstos en la normatividad vigente; y,Instrumentos, maquinarias, equipos, bienes de capital y demás bienes que usen en el desempeño de su trabajo, profesión, oficio o actividad empresarial, hasta por un máximo de ciento cincuenta mil dólares americanos (USD 150 000,00), siempre que presenten un perfil de proyecto destinado a un área productiva vinculada directamente al desarrollo de su trabajo, profesión, oficio o empresa que pretendan desarrollar en el país, o se trate de científicos o investigadores debidamente acreditados.

Igualmente, dicha iniciativa facilita la reinserción socioeconómica en el país, para lo cual los peruanos tienen derecho a solicitar apoyo y orientación de entidades del Estado en las áreas legal, educativa, de salud y de desarrollo económico, empresarial y laboral. De manera específica, el Estado brinda el acceso a programas de promoción del empleo, vivienda, salud, educación, productivos y creación de empresas, así como facilita el acceso a los beneficios derivados de los acuerdos suscritos para el reconocimiento de la seguridad social y el canje de la licencia de conducir por su equivalente en el Perú, entre otros. Asimismo, en el caso de los peruanos retornados que se encuentren en situación de vulnerabilidad económica, tienen derecho a solicitar el apoyo y la orientación de las entidades del Estado para acceder a los programas sociales y al régimen subsidiado de aseguramiento de salud, 
ambos dirigidos a contrarrestar situaciones de vulnerabilidad socioeconómica, conforme a los requisitos de la normatividad vigente.

2.2. ¿Existen programas de desarrollo implementados por el Gobierno del Perú en los cuales participan peruanos residentes en el exterior?

(Tengo conocimiento de: Programa "Solidaridad con mi pueblo" y "El Quinto Suyo”. ¿Existen otros? En caso afirmativo, por favor indique su nombre y una descripción muy breve o un enlace para una página web con más información):

\section{Instituciones relacionadas a la diáspora}

3.1. Dentro del Ministerio de Relaciones Exteriores de la República del Perú, ¿cuál es la unidad que se encarga de los asuntos de la diáspora?

Dirección General de Comunidades Peruanas en el Exterior y Asuntos Consulares

3.2. ¿Aproximadamente cuántas personas trabajan en esta unidad?

3.3. En su presente forma, ¿en qué año fue fundada esta unidad? Antes de esto, ¿qué unidad se encargaba de este tema?

3.4. ¿Cuáles son las actividades principales de esta unidad? Por favor, ponga una $\mathbf{X}$ entre las paréntesis donde corresponda.

( ) Organizar eventos y programas culturales para los peruanos en el exterior

( $\mathrm{X}$ ) Organizar eventos y programas sociales que ayudan a los peruanos en el exterior

( ) Organizar eventos y programas sociales que ayudan a los peruanos que están en el Perú, con la participación de los peruanos en el exterior

( ) Fomentar que los peruanos en el exterior inviertan en el Perú

( ) Otros, por favor indique:

La Dirección General de Comunidades Peruanas en el Exterior y Asuntos Consulares (DGC) es el área responsable de los asuntos consulares, las migraciones 
internacionales y la protección y asistencia de los peruanos en el exterior, en función a los objetivos y lineamientos institucionales.

Atiende a las comunidades peruanas en el exterior, fomentando activamente el ejercicio de su ciudadanía y su participación democrática a través de un servicio consular eficaz y de calidad.

Promueve la vinculación de los peruanos con el Perú desde una perspectiva productiva $\mathrm{y}$, al mismo tiempo, impulsa la inserción provechosa de nuestras comunidades en sus sociedades de destino. Igualmente fomentando la protección tanto como la asistencia legal y humanitaria de nuestros compatriotas en el exterior.

La Dirección General está integrada por funcionarios y expertos de alto nivel que laboran en dos áreas especializadas:

- $\quad$ Política Consular

- $\quad$ Protección y Asistencia al Nacional

- $\quad$ Consejo de Consulta de las Comunidades Peruanas en el Exterior

3.5. ¿Existe un consejo consultivo sobre el tema de las migraciones en el Perú, en el cual, fuera del Ministerio de Relaciones Exteriores, participan otros ministerios e instituciones? (En caso afirmativo, por favor indique cuáles, y a partir de qué año existe este consejo):

En el 2011, se creó la Comisión Multisectorial Permanente "Mesa de Trabajo Intersectorial para la Gestión Migratoria”. Forman parte:

- $\quad$ Ministerio de Relaciones Exteriores, que lo preside.

- $\quad$ Presidencia del Consejo de Ministros

- $\quad$ Ministerio de Trabajo y Promoción del Empleo

- $\quad$ Ministerio del Interior

- $\quad$ Superintendencia de Migraciones

- $\quad$ Superintendencia Nacional de Administración Tributaria

- $\quad$ Oficina de Normalización Previsional (ONP)

- $\quad$ Superintendencia de Banca, Seguros y AFPs (SBS)

- $\quad$ Ministerio de Educación

- $\quad$ Ministerio de la Mujer y Desarrollo Social

- $\quad$ Ministerio de la Producción 
- Ministerio de Justicia

- Instituto Nacional Penitenciario (INPE)

- Ministerio Público

- $\quad$ Ministerio de Salud

- $\quad$ Seguro Social de Salud (ESSALUD)

- $\quad$ Seguro Integral de Salud (SIS)

- Fondo MIVIVIENDA S.A.

- Instituto Nacional de Estadísticas e Informática (INEI)

El Decreto Supremo que crea dicha Comisión puede ser consultado en el siguiente enlace: http://www.consejodeconsulta.com/consecon/storage/Varios/DS-067-2011PCM.pdf

3.6. ¿Existen consejos consultivos con las organizaciones de peruanos en el exterior, en los cuales los migrantes pueden discutir los temas que consideren importantes, con miembros del cuerpo diplomático del Perú? (En caso afirmativo, por favor indique en qué países, y a partir de qué año existen estos consejos):

El Consejo de Consulta constituye una instancia asociativa representativa de la comunidad peruana residente en la jurisdicción de la oficina consular independientemente de su condición migratoria-, sin fines de lucro, autónoma, independiente y de duración indefinida. Su funcionamiento se regula mediante las Resoluciones Ministeriales Nos.1197 y 0687 de 8 de noviembre del 2002 y 21 de julio del 2004, respectivamente.

El Consejo de Consulta busca constituir un espacio de diálogo y cooperación con la oficina consular, en la identificación y solución de los problemas que le atañen directamente a la comunidad peruana como son: tareas de protección y asistencia a los nacionales en el exterior, desarrollo del vínculo nacional, promoción de la cultura, la inserción positiva de los connacionales en el país de acogida y participación en las actividades que desarrolle la Oficina Consular en beneficio de la comunidad peruana o a favor de obras de carácter humanitario a realizarse en el Perú. Adicionalmente, el Consejo de Consulta está prohibido de realizar actividades distintas a las que le confiere el reglamento; especialmente actividades políticas y de naturaleza lucrativa. 
Dado que el Consejo de Consulta no se encuentra dentro de la estructura orgánica del Estado peruano, no está autorizado a actuar en su representación ante las autoridades locales o terceros, ni efectuar gestiones en su nombre.

Ley N 29495 - Ley de los Consejos de Consulta de las Comunidades Peruanas en el Exterior:

http://www.consuladoperumadrid.org/descargas/Ley_29495.Consejos\%20de\%20Con sulta.pdf

Reglamento de la Ley $N^{\circ} 29495$ de los Consejos de Consulta de las Comunidades Peruanas en el Exterior:

http://www.consuladoperumadrid.org/descargas/DS-N\%BA057-2010-REREGLAMENTO\%20CONSEJO\%20DE\%20CONSULTA.pdf

\section{El futuro de la política de diáspora}

4.1. Según su opinión, ¿cuáles serían las actividades más importantes que el Gobierno del Perú podría hacer para mejorar sus contactos con los ciudadanos peruanos en el exterior? Qué se necesitaría para desarrollar estas actividades?

Muchas gracias por su contribución a mi trabajo. Por favor, envíe el cuestionario rellenado a mi correo electrónico: soltesz.bela@gmail.com.

Le agradecería si pudiera enviarmelo hasta el 20 de octubre de 2014.

Atentamente,

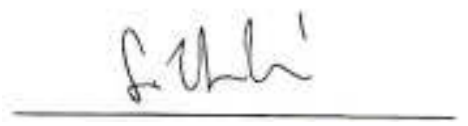

Licenciado Béla Soltész

Universidad Corvinus de Budapest, Hungría

Escuela de Doctorado en Relaciones Internacionales 
Encuesta sobre las actividades del Gobierno de la República Oriental del Uruguay para mantener contactos con ciudadanos uruguayos residentes en el exterior

Por: Licenciado Béla Soltész

Universidad Corvinus de Budapest, Hungría

Escuela de Doctorado en Relaciones Internacionales

Título de la tesis de doctorado: "Migración, políticas de diáspora y desarrollo en América Latina"

Cuestionario enviado el 21 de septiembre de 2014

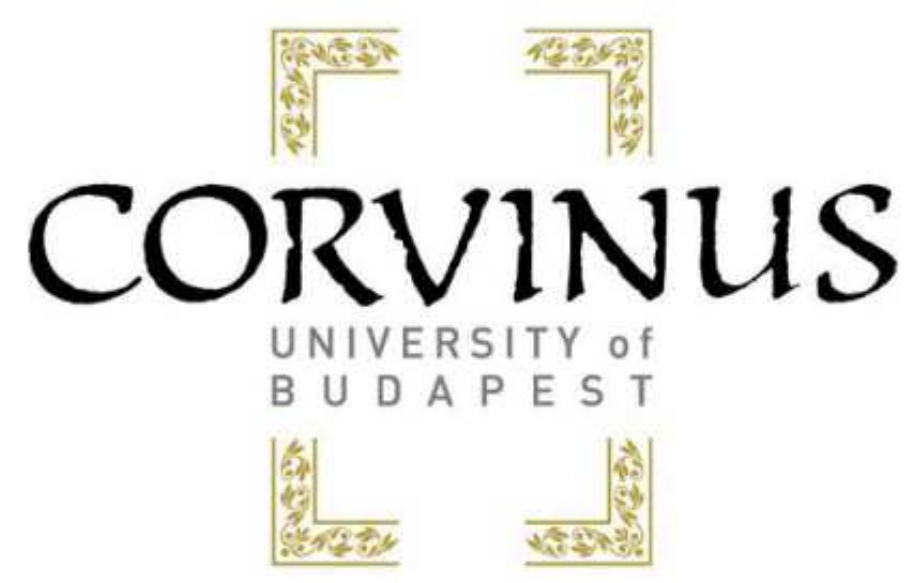

1 
Estimado/a Señor/a:

Con la presente encuesta le solicito información sobre algunas actividades que lleva a cabo el Gobierno de la República Oriental del Uruguay para mantener contactos con sus ciudadanos en el exterior.

La encuesta tiene el único objetivo de recoger información para mi tesis de doctorado que se trata de políticas de diáspora que promueven el desarrollo en América Latina. Es un tema en el cual Hungría puede aprender mucho de los gobiernos latinoamericanos. Para llenar el cuestionario se necesitarán unos 20 minutos aproximadamente, y con ello Usted ayudará mucho en desarrollar mi tesis y en facilitar el intercambio de conocimiento entre nuestros países.

En la encuesta, "uruguayos en el exterior", "diáspora" y "migrantes" se entienden como conceptos sinónimos para el grupo de personas de origen uruguayo que viven fuera de Uruguay de manera permanente.

\section{Participación en elecciones desde el exterior}

1.1. Por favor, marque con una $\mathbf{X}$ entre las paréntesis donde corresponda.

Los ciudadanos de la República Oriental del Uruguay residentes en el exterior de manera permanente,

( ) pueden participar en las elecciones presidenciales, pero solo en persona en los consulados.

( ) pueden participar en las elecciones presidenciales, en persona en los consulados o por vía postal.

( ) pueden participar en las elecciones parlamentarias, y votar a un diputado que representa a los ciudadanos en el exterior.

( ) pueden participar en las elecciones parlamentarias, y votar a una lista de partido.

( ) pueden participar en referendums.

(X) no pueden participar en ningún tipo de elecciones.

Otras observaciones (por favor indique):

En el mes de setiembre del presente año el Frente Amplio, partido político en el Gobierno, presentó en el Poder Legislativo un proyecto de Ley de Voto en el Exterior. Este proyecto de ley se pondrá en cosideración de una Comisión Legislativa para su estudio. Seguramente será discutido durante la próxima Legislatura que comienza en 2015 dado que Uruguay se encuentra realizando la elección de sus autoridades de gobierno y se apresta a llevar a cabo la $2^{\text {a }}$ Vuelta o Balotaje previsto en nuestro sistema electoral.

\section{Beneficios económicos para la diáspora}

2 
2.1. Por favor, marque con una $\mathbf{X}$ entre las paréntesis donde corresponda.

Los ciudadanos de la República Oriental del Uruguay residentes en el exterior de manera permanente, al volver a Uruguay, tienen derecho a:

( ) exención fiscal si deciden invertir en el país (en caso afirmativo, por favor indique cómo):

( $\mathbf{X}$ ) exención aduanera en importaciones y exportaciones (en caso afirmativo, por favor indique cómo): Quienes retornen a Uruguay con sus pertenencias (efectos personales, enseres del hogar, herramientas de trabajo, vehículo) quedan exentos de pagar los impuestos correspondientes que recauda la Dirección Nacional de Aduanas y quedan exonerados de abonar los costos correspondientes a la documentación presentada ante el Consulado uruguayo.

( ) trato preferencial si deciden invertir en el país (en caso afirmativo, por favor indique cómo):

( ) subvenciones estatales si deciden invertir en el país (en caso afirmativo, por favor indique cómo):

( $\mathbf{X}$ ) otros beneficios (en caso afirmativo, por favor indique cuáles): Convenio con la Administración de Servicios de Salud del Estado (ASSE) para la atención médica gratuita durante un año; Convenio con el Ministerio de Vivienda (MVOTMA) para conceder garantía para alquilar vivienda, en aquellos casos de alta vulnerabilidad se concede una subvención en el monto del alquiler de la vivienda; Convenio con el Banco Hiportecario del Uruguay (BHU) para compra de vivienda (se estudiará caso a caso); Convenio con el Correo Uruguayo para el envío de dinero desde España con destino a una cuenta de ahorro en el Banco Hipotecario del Uruguay (BHU) para la compra de Vivienda;Acuerdo con el Ministerio de Trabajo y Seguridad Social (MTSS) para enviar los curricúlums vitae a los Centros Públicos de Empleo dependientes de esa Secretaría de Estado; Acuerdo con las Cámaras Empresarial, de la Construcción y de Industrias para enviar los curricúlums vitae de quienes retornan; Convenio con la Facultad de Psicología para brindar una primera contención a los casos de retorno involuntario por deportación o inadmisión; coordinación con el Ministerio de Desarrollo Social (MIDES), Grupo Identidad, para proceder a la documentación de quienes están en situación de vulnerabilidad; Convenio con la Administración Nacional de Telecomunicaciones (ANTEL) a través del cual se le concede un chip (tarjeta sim) con una carga de $\$ 500$ por única vez, facilidades en la conección de telefónia fija en el hogar, acceso a Internet (fibra óptica), cursos de capacitación en instalación de fibra óptica; Convenio con la Universidad del Trabajo del Uruguay (UTU) para el reconocimiento de saberes adquiridos y para el dictado de cursos; Convenio con el Banco de Seguros del Estado para bonificaciones en los Seguors de vivienda (20\%) y de vehículos (15\%); etc.

2.2. ¿Existen programas de desarrollo implementados por el Gobierno de la República Oriental del Uruguay en los cuales participan uruguayos residentes en el exterior?

(Tengo conocimiento de: "Programa CUAC" y "Departamento 20". ¿Existen otros? En caso afirmativo, por favor indique su nombre y una descripción muy breve o un enlace para una página web con más información):

Hasta el momento esos son los dos grandes pilares de la Vinculación con nuestra Diáspora. El "Departamento 20" (que desde octubre de 2011 esa denominación identitaria ha sido concedida a la propia diáspora para su uso, ante lo cual la Dirección General para Asuntos Consulares y Vinculación 
actualmente se denomina "Soy Uruguay". El Programa de Circulación de Uruguayos Altamente Capacitados (CUAC) está siendo actualizado en estos momentos y se incoporan al mismo a las personas que se destacan en los ámbitos deportivo y cultural. El pilar más fuerte, por su cotidianeidad, es la vinculación con nuestras y nuestros compatriotas, la cual es permanente y cada vez abarca, atiende y soluciona más aspectos relacionados con las necesidades de nuestra diáspora. La mayor parte de los insumos para establecer políticas públicas relacionadas con la migración surgen del trabajo mancomunado entre la Dirección de Vinculación y la diáspora organizada en Consejos Consultivos y en Asociaciones.

\section{Instituciones relacionadas a la diáspora}

3.1. Dentro del Ministerio de Relaciones Exteriores de la República Oriental del Uruguay, ¿cuál es la unidad que se encarga de los asuntos de la diáspora?

Específicamente es la Dirección de Vinculación, pero pueden existir aspectos o necesidades que sean atendidas por otros sectores como lo son la Oficina de Retorno y Bienvenida, la Oficina de Asistencia al Compatriota o el Centro de Atención Ciudadana, sectores con los cuales interactúa la Dirección de Vinculación en forma permanente.

\section{2. ¿Aproximadamente cuántas personas trabajan en esta unidad?}

En la Dirección de Vinculación somos tres personas para atender una población que ronda la cifra de 600.000 personas, obvio que no se atiende a toda esa cantidad de personas pero existe una atención permanente y variada ya que un gran número de compatriotas se comunican con la Dirección de Vinculación por diferentes y variadas problemáticas o necesidades.

3.3. En su presente forma, ¿en qué año fue fundada esta unidad? Antes de esto, ¿qué unidad se encargaba de este tema?

La Dirección de Vinculación fue creada al principio del mandato del Dr. Tabaré Vázquez, quien asumió la Presidencia de la República en el año 2005. Antes de la creación de la Dirección de Vinculación no existía ningún área específica para la atención de la diáspora, en todo caso la Dirección de Asuntos Consulares podría tomar algún tema relativo a esta temática pero principalmente se dedicaba a las políticas consulares.

3.4. ¿Cuáles son las actividades principales de esta unidad? Por favor, ponga una $\mathbf{X}$ entre las paréntesis donde corresponda.

(X) Organizar eventos y programas culturales para los uruguayos en el exterior

( X ) Organizar eventos y programas sociales que ayudan a los uruguayos en el exterior

( X ) Organizar eventos y programas sociales que ayudan a los uruguayos que están en Uruguay, con la participación de los uruguayos en el exterior

( ) Fomentar que los uruguayos en el exterior inviertan en Uruguay 
( $\mathbf{X}$ ) Otros, por favor indique: Fundamentalmente se procura que las y los compatrios se organicen para que desde su propio contacto y conocimiento con el resto de la diáspora residente en el lugar puedan plantear las problemáticas y necesidades como así también las propuestas que entienden pertinente para llevar a cabo políticas públicas que puedan atender y solucionar esas problemáticas o carencias de nuestra colectividad.

3.5. ¿Existe un consejo consultivo sobre el tema de las migraciones en Uruguay, en el cual, fuera del Ministerio de Relaciones Exteriores, participan otros ministerios e instituciones? (En caso afirmativo, por favor indique cuáles, y a partir de qué año existe este consejo): La Ley № 18.250 (ley que actualizó el tema migratorio establecido en otra ley que databa de 1930) establece la formación de una Junta Nacional de Migraciones (JNM) integrada en sus inicios por los Ministerios de Relaciones Exteriores, del Interior y de Trabajo y Seguridad Social. Actualmente se incorpó al Ministerio de Desarrollo Social y un Representante del Sector de Población de la Presidencia de la República. Esta Junta esta asesorada por el Consejo Consultivo Asesor en Migraciones (CCAM) integrado por representantes de organizaciones sociales de uruguayas y uruugayos que trabajan con el migratorio pero también está integrado por organizaciones sociales de otras nacionalidades que representan a sus nacionales residentes en nuestro país. Este CCAM se reúne en el Ministerio de Relaciones Exteriores ya que tenemos el concepto de trabajar en forma conjunta con la sociedad civil organizada motivo por el cual les ofrecemos la infraestructura de esta Secretaría de Estado.

3.6. ¿Existen consejos consultivos con las organizaciones de uruguayos en el exterior, en los cuales los migrantes pueden discutir los temas que consideren importantes, con miembros del cuerpo diplomático de Uruguay? (En caso afirmativo, por favor indique en qué países, y a partir de qué año existen estos consejos): La mencionada Ley № 18.250 crea los Consejos Consultivos en el mundo, integrado por representantes de la colectividad uruguaya en el lugar de residencia. Ni su trabajo, discusiones, elaboraciones y propuestas no tienen ingerencia del Estado ya que son autónomos pero existe un trabajo directo y permanente con nuestaras Misiones Diplomáticas y Oficinas Consulares y con esta Dirección de Vinculación.

\section{El futuro de la política de diáspora}

4.1. Según su opinión, ¿cuáles serían las actividades más importantes que el Gobierno de la República Oriental del Uruguay podría hacer para mejorar sus contactos con los ciudadanos uruguayos en el exterior? Qué se necesitaría para desarrollar estas actividades?

Actividades importantes son todas y si bien se ha avanzado mucho desde la creación de esta Dirección de Vinculación aún falta mucho por hacer, por lo tanto hay que seguir mejorando y trabajando bajo el concepto de equipo entre el Estado y la sociedad civil. 
Muchas gracias por su contribución a mi trabajo. Por favor, envíe el cuestionario rellenado a mi correo electrónico: soltesz.bela@gmail.com.

Le agradecería si pudiera enviarmelo hasta el 20 de octubre de 2014.

Atentamente,

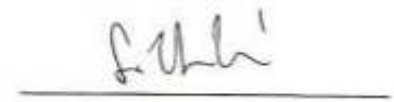

Licenciado Béla Soltész

Universidad Corvinus de Budapest, Hungría

Escuela de Doctorado en Relaciones Internacionales 


\section{Bibliography}

\section{Books and journal articles}

Acosta, P., Fajnzylber, P., López, H. [2008]. How Important Are Remittances in Latin America? In: Fajnzylber, P., López, H. (eds.) Remittances and development: lessons from Latin America. Washington DC: The World Bank, pp. 21-50. DOI: http://dx.doi.org/10.1596/978-0-8213-6870-1_ch02

Ager, A., Strang, A. [2008]. Understanding Integration: A Conceptual Framework. Journal of Refugee Studies, Vol. 21, No. 2: 166-191. DOI: http://dx.doi.org/10.1093/jrs/fen016

Agunias, D., Newland, K. [2012] Developing a Road Map for Engaging Diasporas in Development: A Handbook for Policymakers and Practitioners in Home and Host Countries. Washington DC: Migration Policy Institute.

Alarcón, R. [2006]. Hacia la construcción de una política de emigración en México. In: González Gutiérrez, C. (ed.) Relaciones Estado-diáspora: la perspectiva de América Latina y el Caribe. Mexico, D. F.: Miguel Ángel Porrua, UAZ, Secretaría de Relaciones Exteriores, Instituto de los Mexicanos en el Exterior, ANUIES.

Alba, F. [1999]. La cuestión regional y la integración internacional de México: una introducción. Estudios Sociológicos, vol. 17, núm. 51, septiembre-diciembre, pp. 611-631.

Alba, R., Nee, V. [1997]. Rethinking Assimilation Theory in a New Era of Migration. International Migration Review, Vol. 31, No. 4: 826-874.

DOI: http://dx.doi.org/10.2307/2547416

Alinsky, S. [1971]. Rules for Radicals: A Pragmatic Primer for Realistic Radicals. New York: Vintage.

DOI: http://dx.doi.org/10.2307/1959680

Anderle, Á. [2008] Magyarok Latin-Amerikában. Külügyi Szemle 20008/3, pp. 174-181.

Anderson, B. [1998]. Long-Distance Nationalism. In Anderson, B. [1998). The Spectre of Comparisons: Nationalism, Southeast Asia and the World. London: Verso.

Anzaldúa, G. [1987] Borderlands / La Frontera. The New Mestiza. San Francisco: Aunt Lute Books.

Aparicio, J., Meseguer, C. [2012]. Collective Remittances and the State: The 3x1 Program in Mexican Municipalities. World Development, Volume 40, Issue 1, pp. 206-222.

DOI: http://dx.doi.org/10.1016/j.worlddev.2011.05.016

Aparicio Gómez, R. [2011]. Participación ciudadana y asociaciones de inmigrantes. Madrid: Oñati socio-legal series, Vol. 1, No. 3, 2011.

Araujo, L., Eguiguren, M. M. [2009]. La gestión de la migración en los países andinos: entre la securitización y los vínculos diaspóricos. Andina Migrante, Boletín del Sistema de Información sobre Migraciones Andinas - FLACSO Sede Ecuador - N. 3 -Abril 2009, pp. 2-10.

Armstrong, J. [1976] Mobilized and proletarian diasporas. American Political Science Review, Vol. 70, no. 2, pp. 393-408.

DOI: http://dx.doi.org/10.2307/1959646 
Arteta, G., Oleas, D. [2008]. Migraciones internacionales: el caso de Ecuador. In: Andrés Solimano (ed.) [2008]: Migraciones internacionales en América Latina: Booms, crisis y desarrollo. Mexico, D. F. and Santiago de Chile: Fondo de Cultura Económica.

Atkinson, A. [2003]. New Sources of Development Finance. Oxford: Oxford University Press. DOI: http://dx.doi.org/10.1093/0199278555.001.0001

Ávila Molero, J. [2003]. Lo que el viento (de los Andes) se llevó: diásporas campesinas en Lima y los Estados Unidos. In: Degregori, C. I. (ed). Comunidades locales y transnacionales: cinco estudios de caso en el Perú. IEP Ediciones; Lima: 2003. pp. 167-261.

Baby-Collin, V., Cortes, G., Faret, L. [2008]. Migrant Remittances and Development in Bolivia and Mexico. A Comparative Study. In: Naerssen, Ton van et al. (eds.): Global Migration and Development. London: Routledge.

Baca Tavira, N. [2009]. Migración y gobierno. Atención a migrantes internacionales en el estado de México. Gaceta Laboral, vol. 15, núm. 3, septiembre-diciembre, 2009, pp. 5-35. Maracaibo: Universidad del Zulia.

Bakewell, O. [2008]. Perspectives from Governments of Countries of Origin and Migrant Associations. In: Castles, S., Wise, R. D. (eds) [2008]. Migration and Development: Perspectives from the South. Geneva: International Organization for Migration.

Balassa, B. [1989]. Comparative Advantage, Trade Policy and Economic Development. New York: Harvester Wheatsheaf.

Barilleaux, R. [1985] The President, "Intermestic" Issues, and the Risks of Policy Leadership. Presidential Studies Quarterly, Vol. 15, No. 4, Perspectives on the Presidency (Fall, 1985), pp. 754767.

Baumgartner, F., Jones, B. [1993]. Agendas and Instability in American Politics. Chicago, IL: University of Chicago Press.

DOI: http://dx.doi.org/10.7208/chicago/9780226039534.001.0001

Berg, U., Tamagno, C. [2005]. El Quinto Suyo: Conceptualizando la 'diáspora peruana' desde abajo y desde arriba. Política Internacional 80 (abril-junio).

Berg, U. [2010]. El Quinto Suyo: Contemporary Nation Building and the Political Economy of Emigration in Peru. Latin American Perspectives, Issue 174, Vol. 37, No. 5, September 2010, pp. 121-137.

DOI: http://dx.doi.org/10.1177/0094582x10380392

Berninghaus, S., Seifert-Vogt, H. [1988]. Temporary vs. permanent migration: a decision theoretical approach. Journal of Population Economy, 1988, 1(3), pp. 195-211.

DOI: http://dx.doi.org/10.1007/bf00161478

Berry, J. [1997]. Immigration, Acculturation and Adaptation. Applied Psychology: An International Review. Vol. 46, No. 1: 5-34

DOI: http://dx.doi.org/10.1080/026999497378467

Bhagwati, J. [1993]. The Case for Free Trade. Scientific American 269 (5): 18-23.

DOI: http://dx.doi.org/10.1038/scientificamerican1193-42

Biklen, D. [1983]. Community Organizing Theory and Practice. Englewood Cliffs, NJ: Prentice-Hall.

Black, R., Collyer, M., Somerville, W. [2011]. Pay-to-go Schemes and Other Noncoercive Return Programs. Is Scale Possible? Washington DC: Migration Policy Institute.

Blanco, J. (coord.) [2011]. The Cuban Diaspora in the 21st Century. Miami: Florida International University, Cuban Research Institute. 
Bonacich, E. [1973]. A Theory of Middleman Minorities. American Sociological Review Vol. 38, No. 5 (Oct 1973): 583-594.

DOI: http://dx.doi.org/10.2307/2094409

Borjas, G. [2006]. The New Economics of Immigration: Affluent Americans Gain; Poor Americans Lose. In Messina, A, Lahav, G. (eds.), The Migration Reader. Exploring Politics and Policies (pp. 318-328). London - Boulder, Colorado: Lynne Rienner Publishers, Inc.

Böröcz, J. [2001] Birodalom, kolonialitás és az EU keleti bővítése. Replika, 45-46(November): 1733.

Brettel, C., Hollifield, J. [2008]. Migration Theory: Talking across Disciplines. In: Brettel, C., Hollifield, J. (eds.), Migration Theory: Talking across Disciplines. New York: Routledge.

DOI: http://dx.doi.org/10.4324/9780203950449

Brown, M. [2002]. Intellectual Diaspora Networks: their Viability as a Response to Highly Skilled Emigration. Autrepart (22), $2002: 167-178$.

DOI: http://dx.doi.org/10.3917/autr.022.0167

Brubaker, R. [2005]. "The 'Diaspora' Diaspora." Ethnic and Racial Studies 28 [2005]: 1-19. DOI: http://dx.doi.org/10.1080/0141987042000289997

Buira, R. [2006]. Políticas de Estado-diáspora en Argentina. In: González Gutiérrez, C. (ed.) [2006]. Relaciones Estado-diáspora: la perspectiva de América Latina y el Caribe. Mexico, D. F.: Miguel Ángel Porrua, UAZ, Secretaría de Relaciones Exteriores, Instituto de los Mexicanos en el Exterior, ANUIES.

Canales Cerón, A. [2008]. Remittances and Development in Latin America: a Relationship in Search of a Theory. Migración y desarrollo, 2008 second semester.

Capetillo-Ponce, J. [2007]. From 'A Clash of Civilizations' to 'Internal Colonialism'. Reactions to the theoretical bases of Samuel Huntington's 'The Hispanic Challenge'. Ethnicities 2007/7, pp. 136134.

DOI: http://dx.doi.org/10.1177/1468796807073922

Cárdenas, M., Mejía, C. [2008]. Emigración, crisis y conflicto: Colombia 1995-2005. In: Andrés Solimano (ed.) [2008]: Migraciones internacionales en América Latina: Booms, crisis y desarrollo. Mexico, D. F. and Santiago de Chile: Fondo de Cultura Económica.

Castillo, K. [2010]. Por una propuesta de reforma constitucional. ¿Por qué no la Circunscripción de Peruanos en el Exterior? Revista del Observatorio Andino de Migraciones TukuyMigra, No. 4, 2010 september, pp. 2-17.

Castles, S., Miller, M. [2009]. The Age of Migration. International Population Movements in the Modern World. London - New York: Palgrave Macmillan.

DOI: http://dx.doi.org/10.1007/978-1-349-26846-7

Cerezo de Diego, P. [2011]. Migraciones, desarrollo, remesas y crisis económica internacional. Anuario Jurídico y Económico Escurialense, XLIV [2011], pp. 187-208.

Chenery, H. [1979]. Structural Change and Development Policy. Baltimore: Johns Hopkins University Press.

Cho, S. [2010]. The Demise of Development in the Doha Round Negotiations. Texas International Law Journal, Vol. 31, 2010, pp.572-601.

Cirasino, M., Guadamillas, M., Salinas, E. [2008]. Facilitating Remittances Flows and Security in the System. In: Fajnzylber, P., López, H. (eds.) Remittances and development: lessons from Latin America. Washington DC: The World Bank, pp. 299-334. 
DOI: http://dx.doi.org/10.1596/978-0-8213-6870-1_ch09

Cohen, R. [1997] Global diasporas: An introduction. Seattle, WA: University of Washington Press.

Dasgupta, P. [1995]. An Inquiry into Well-Being and Destitution. Oxford: Clarendon. DOI: http://dx.doi.org/10.1093/0198288352.001.0001

De Haas, H. [2009]. International migration and regional development in Morocco: a critical review of the literature. Journal of Ethnic and Migration Studies 35(10):1571-93.

DOI: http://dx.doi.org/10.1080/13691830903165808

Délano, A. [2011]. Mexico and its diaspora in the United States: policies of emigration since 1848. New York: Cambridge University Press.

DOI: http://dx.doi.org/10.1017/cbo9780511894848

Délano, A., Gamlen, A. [2014] Comparing and theorizing state-diaspora relations. Political Geography, 41, pp. $43-53$.

DOI: http://dx.doi.org/10.1016/j.polgeo.2014.05.005

Delgado, R., Márquez, H., Rodríguez, H. [2009]. Six Theses to Demystify the Nexus Between Migration And Development. Migración y Desarrollo, 2009 First semester: 27-49.

Devlin, R. - Ffrench-Davis, R. [1995]. The great Latin American debt crisis: a decade of asymmetric adjustment. Revista de Economía Política 15 (3). July-September 1995, pp. 117-142.

Didou, S. [2009]. From brain drain to the attraction of knowledge in Latin American social sciences. In UNESCO World Social Science Report. Paris: UNESCO.

Didou, S. [2009]: Movilidades académicas y profesionales en América Latina: entre la ignorancia y la polémica. Revista de la Educación Superior, vol. XXXVII, núm. 148, octubre-diciembre, 2009, pp. 71-85. Asociación Nacional de Universidades e Instituciones de Educación Superior, Distrito Federal, México

Dingemans, A. - Ross, C. [2012]: Free trade agreements in Latin America since 1990: an evaluation of export diversification. CEPAL Review 108, December 2012, pp. 27-48.

Dixit, A., Londregan, J. [1996] The Determinants of Success of Special Interests in Redistributive Politics. The Journal of Politics, Vol. 58, Issue 04, p. 1132

DOI: http://dx.doi.org/10.2307/2960152

Dore, C., Itzigsohn, J., Hernández Medina, E., Vázquez, O. [2003]. Cartografía del transnacionalismo dominicano: amplias y estrechas prácticas transnacionales. In: Portes, A., Guarnizo, L., Landolt, P. (eds.) La globalización desde abajo: Transnacionalismo inmigrante y desarrollo. México: FLACSO - Porrúa, pp. 159-191.

Dos Santos, T. [1970]. The Structure of Dependence. In: The American Economic Review, Vol. 60, No. 2, Papers and Proceedings of the Eighty-second Annual Meeting of the American Economic Association (May 1970), pp. 231-236.

Durand, J., Massey. D. [2003]. Clandestinos: Migración México-Estados Unidos en los Albores del Siglo XXI. México, D.F.: Editorial Porrua.

Durand, J. [2004]. Ensayo Teórico Sobre La Migración De Retorno. El Principio Del Rendimiento Decreciente. Cuadernos Geográficos, 35 (2004-2), pp. 103-116.

Durand, J. - Massey, D. [2010]: New World Orders: Continuities and Changes in Latin American Migration. The ANNALS of the American Academy of Political and Social Science, 2010, 630, pp. 20-52.

DOI: http://dx.doi.org/10.1177/0002716210368102 
Eriksen, T. [2007]. Complexity in social and cultural integration: Some analytical dimensions. Ethnic and racial studies 30(6): 1055-1069.

DOI: http://dx.doi.org/10.1080/01419870701599481

Escobar, A. [1995]. Encountering. Development: The Making and Unmaking of the Third World. Princeton, N.J.: Princeton University Press.

Escobar, A., Bean, F., Weintraub, S. [1999]. La dinámica de la emigración mexicana. Mexico, D. F.: CIESAS/Miguel Ángel Porrúa.

Escobar Latapí, A. [2008]. Mexican Policy and Mexico-U.S. Migration. In: Escobar Latapí, A., Martin, S.(eds.) Mexico-U.S. migration management : a binational approach. Plymouth: Lexington Books, pp. 179-216.

Eversole, R. [2005]. "Direct to the Poor" Revisited: Migrant Remittances and Development Assistance. In: Trager, Lilian (ed). Migration and Economy. Global and Local Dynamics. Oxford: Altamira Press, pp. 289-322.

Freyre, G. [1933] (1971). Casa-Grande e senzala. Rio de Janeiro: Aguilar.

Galeano, E. [1971] Las venas abiertas de América Latina. Montevideo: Monthly Review.

Gamlen, A. [2008] The emigration state and the modern geopolitical imagination. Political Geography, 27 (8), pp. $840-856$.

DOI: http://dx.doi.org/10.1016/j.polgeo.2008.10.004

Gamlen, A. [2010] Diasporas. Global Migration Governance, pp. 267 - 282. DOI: http://dx.doi.org/10.1093/acprof:oso/9780199600458.003.0012

Gamlen, A. [2014] Diaspora Institutions and Diaspora Governance. International Migration, Vol. 48, pp. $180-217$.

DOI: http://dx.doi.org/10.1111/imre.12136

García de Alba Tinajero, M., Jáuregui Casanueva, L., Nuñez Sañudo, C. [2006]. Liderazgos y nuevos espacios de negociación en el Programa 3x1 para Migrantes. El caso de Zacatecas. In: Fernández de Castro, R. (ed.). El Programa 3x1 para migrantes. Mexico: Editorial Porrua, pp. 223 248.

Ghosh, B. [2006]. Migrants' remittances and development. Myths, rhetoric and realities. Geneva: IOM

Giménez Romero, C., Martínez Martínez, J., Fernández García, M., Cortés Maisonave, A. [2006]. El codesarrollo en España. Protagonistas, discursos y experiencias. Madrid: Catarata.

Gindling, T. H. [2009]. South-South Migration: The Impact of Nicaraguan Immigrants on Earnings, Inequality and Poverty in Costa Rica. World Development, vol. 37(1), pp. 116-126, January. DOI: http://dx.doi.org/10.1016/j.worlddev.2008.01.013

Glick Schiller, N., Fouron. G. [2001]. Georges Woke Up Laughing: Long-Distance Nationalism and the Search for Home. Durham, NC: Duke University Press.

DOI: http://dx.doi.org/10.1215/9780822383239

Golte, J. [2007]. Migración y superación de la subordinación cultural de la población aborigen en los Andes Centrales. In: Dresler, W., Fahmel, B., Noack, K. (eds.) Culturas en movimiento. Contribuciones a la transformación de identidades étnicas y culturales en América. UNAM, México - Ibero-Amerikanisches Institut, Berlin, pp. 191-225.

González Gutiérrez, C. [2006]. Del acercamiento a la inclusión institucional: la experiencia del Instituto de los Mexicanos en el Exterior. In: González Gutiérrez, C. (ed.) [2006]. Relaciones 
Estado-diáspora: la perspectiva de América Latina y el Caribe. Mexico, D. F.: Miguel Ángel Porrua, UAZ, Secretaría de Relaciones Exteriores, Instituto de los Mexicanos en el Exterior, ANUIES.

Grindle, M., Thomas, J. [1991]. Public Choices and Public Policy Change: The Political Economy of Reform in Developing Countries. Baltimore: Johns Hopkins University Press.

Guarnizo, L. [2003]. The Economics of Transnational Living. International Migration Review, 37 (3), pp. 666-699.

DOI: http://dx.doi.org/10.1111/j.1747-7379.2003.tb00154.x

Guarnizo, L. [2006]. El Estado y la migración global colombiana. In González Gutiérrez, C. (ed.) [2006]. Relaciones Estado-diáspora: la perspectiva de América Latina y el Caribe. Mexico, D. F.: Miguel Ángel Porrua, UAZ, Secretaría de Relaciones Exteriores, Instituto de los Mexicanos en el Exterior, ANUIES.

Gunder Frank, A. [1966]. The Development Of Underdevelopment. New England Free Press, September 1966, pp. 1-15.

DOI: http://dx.doi.org/10.14452/mr-018-04-1966-08_3

Gunder Frank, A. [1969]. Capitalist Underdevelopment or Socialist Revolution. In: Gunder Frank, Andre: Latin America: Underdevelopment or Revolution. New York: Monthly Review Press, pp. 371-409.

Hagemann, H. [2009]. Solow's 1956 Contribution in the Context of the Harrod-Domar Model. History of Political Economy 41 (Suppl 1): 67-87

DOI: http://dx.doi.org/10.1215/00182702-2009-017

Hasmath, R. [2011]. Managing Ethnic Diversity: Meanings and Practices from an International Perspective. London: Ashgate.

Hausmann, R., Rodrik, D., Velasco, A. [2007]. Growth diagnostic. One Economics, Many Recipes: Globalization, Institutions, and Economic Growth. Princeton, N.J.: Princeton University Press.

Hesse, B. [2000]. Un/settled Multiculturalisms: Diasporas, Entanglements, "transruptions". London : Zed Books.

Hiskey, J., Orces, D. [2010]. Transition Shocks and Emigration Profiles In Latin America. Annals of the American Academy of Political and Social Science, 630(1)[2010], pp. 116-136.

DOI: http://dx.doi.org/10.1177/0002716210368106

Hollifield, J. [2006]. Migration, Trade and the Nation-State. The Myth of Globalization. In Messina, A, Lahav, G. (eds.), The Migration Reader. Exploring Politics and Policies: 170-198. London Boulder, Colorado: Lynne Rienner Publishers, Inc.

Howlett, M. [1998]. Predictable and Unpredictable Policy Windows: Institutional and Exogenous Correlates of Canadian Federal Agenda-Setting. Canadian Journal of Political Science, Vol. 31, Issue 03, September 1998, pp. 495-524

DOI: http://dx.doi.org/10.1017/s0008423900009100

Huddleston, T., Niessen, J. (with Ni Caoimh, E. and White, E.) [2011]. Migrant Integration Policy Index III. British Council, MPG, Brussels.

Huneeus, C. [2000]. Technocrats and politicians in an authoritarian regime. The 'ODEPLAN Boys' and the 'Gremialists' in Pinochet's Chile. Journal of Latin American Studies, Volume 32, Issue 02, May 2000, pp. 461-501.

DOI: http://dx.doi.org/10.1017/s0022216x00005812

Huntington, S. [2004]. Who Are We?-The Challenges to America's National Identity. New York: Simon \& Schuster. 
Imaz Bayona, C., Salcido Cañedo, P., Galeana Rodríguez, M. E. [2010]. Directorio de expertos en materia migratoria en México. Mexico DF: UNAM, Facultad de Ciencias Políticas.

Inglehart, R., Baker, W. [2000]. Modernization, Cultural Change, and the Persistence of Traditional Values. American Sociological Review, 2000, Vol. 65 (February): 19-51.

DOI: http://dx.doi.org/10.2307/2657288

International Development Association (IDA) [2007]: Aid Architecture: An Overview of the Main Trends in Official Development Assistance Flows. International Development Association Resource Mobilization (FRM), February 2007.

International Monetary Fund (IMF) [2008]. Balance of Payments and International Investment Position Manual, sixth edition.

Jessup, P. [1956] Transnational Law. New Haven: Yale University Press.

Kehoe, T., Levine, D., Romer, P. [1992]. On Characterizing Equilibria of Models with Externalities and Taxes as Solutions to Optimization Problems. Economic Theory 2, 43 - 68 (1992).

DOI: http://dx.doi.org/10.1007/bf01213252

Kingdon, J. [1984]. Agendas, Alternatives, and Public Policies. Boston: Little Brown.

Kováts, A. [2013] A bevándorlók társadalmi integrációja: Koncepciók és indikátorok. In: Kováts, A. (ed.) Bevándorlás és integráció: magyarországi adatok, európai indikátorok.

Budapest: MTA KI, pp. 9-24.

Kuhn, T. [1962]. The Structure of Scientific Revolutions. Chicago: The University of Chicago Press. DOI: http://dx.doi.org/10.7208/chicago/9780226458106.001.0001

Kymlicka, W. [1995]. Multicultural Citizenship: A Liberal Theory of Minority Rights. Oxford: Clarendon.

DOI: http://dx.doi.org/10.1093/0198290918.001.0001

Lal, D. [1985]. The Poverty of Development Economics. Cambridge, Mass. : Harvard University Press.

Letenyei, L. [2008] Inti Raymi Budapest. Az emigráns Andokbeli identitás szimbolikus reprezentációja Magyarországon. In: Letenyei, L. (ed) Tanulmányok az Andokról. Budapest, TeTT Consult, pp. 326-340.

Levitt, P. [2001]. The Transnational Villagers. Berkeley: University of California Press.

Levitt, P. [2007]. God Needs No Passport: Transnational Religious Life. New York: The New Press.

Levitt, P., Lamba-Nieves, D. [2011]. Social Remittances Reconsidered. Journal of Ethnic and Migration Studies, 37(1): 1-22.

DOI: http://dx.doi.org/10.1080/1369183x.2011.521361

Lewis, A. [1954]. Economic development with unlimited supplies of labour. Manchester School 22 (1954): 139-191

DOI: http://dx.doi.org/10.1111/j.1467-9957.1954.tb00021.x

Light, I. [1972]. Ethnic Enterprise in America. Berkeley: University of California Press.

Lilón, D. [2010] A Spanyolországba irányuló tömeges bevándorlás problémái. Külügyi Szemle 2010/3. pp. 114-129.

Long, N. [2008]. Translocal Livelihoods, Networks of Family and Community, and Remittances in Central Peru. In: Migration and Development Within and Across Borders. Research and Policy 
Perspectives on Internal and International Migration. Geneva: International Organization for Migration (IOM) and Social Science Research Council (SSRC), pp. 39-70

López, H., Molina, L., Bussolo, M. [2008]. Remittances, the Real Exchange Rate and the Dutch Disease Phenomenon. In: Fajnzylber, P., López, H. (eds.) Remittances and development: lessons from Latin America. Washington DC: The World Bank, pp. 217-252.

DOI: http://dx.doi.org/10.1596/978-0-8213-6870-1_ch07

López Segrera, F. [2011]: The Cuban Revolution: Historical Roots, Current Situation, Scenarios, and Alternatives. Latin American Perspectives, Issue 177, Vol. 38 No. 2, March 2011, pp. 3-30.

DOI: http://dx.doi.org/10.1177/0094582x10395891

Martínez Pería, M., Mascaró, Y., Moizeszowicz, F. [2008]. Do Remittances Affect Recipient Countries' Financial Development? In: Fajnzylber, P., López, H. (eds.) Remittances and development: lessons from Latin America. Washington DC: The World Bank, pp. 171-216.

DOI: http://dx.doi.org/10.1596/978-0-8213-6870-1_ch06

Massey, D. [1990]. The social and economic origins of immigration. In: Annals of the American Academy of Political and Social Science 510: 60-72.

DOI: http://dx.doi.org/10.1177/0002716290510001005

Massey, D., Arango, J., Hugo, G., Kouaouci, A., Pellegrino, A., Taylor, E. [1993]. Theories of International Migration: A Review and Appraisal. Population and Development Review 19, no. 3 (Sept. 1993): 431-466.

DOI: http://dx.doi.org/10.2307/2938462

McDonogh, G. [2009]: Other Worlds, Other Histories: Iberians and Exile. In: McDonogh, G.: Iberian worlds, pp. 243 - 271. New York: Routledge.

DOI: http://dx.doi.org/10.4324/9780203886410

Melegh, A. [2006] On the East/West Slope. Globalization, Nationalism, Racism and Discourses on Central and Eastern Europe. New York-Budapest: CEU Press.

Melegh, A. [2013] Net migration and historical development in Southeastern Europe since 1950. Hungarian Historical Review 1, no. 3-4 (2012): 144-182

Mignolo, W. [2005] The idea of Latin America. Oxford: Blackwell.

Migration and Remittances Factbook [2011]. The World Bank. DOI: http://dx.doi.org/10.1596/978-0-8213-8218-9

Mills, W. [1956]. The Power Elite. New York: Oxford University.

Moré, I. [2009]. Inmigración y remesas informales en España. Madrid: Ministerio de Trabajo y Asuntos Sociales.

Moreno Figueroa, M. [2010] Distributed intensities: Whiteness, mestizaje and the logics of Mexican racism. Ethnicities, 2010 10: 387, pp. 387 - 401.

DOI: http://dx.doi.org/10.1177/1468796810372305

Muñoz, C. [2013]. The Chicano Movement. Mexican American History and the Struggle for Equality. New York: The Rosa Luxemburg Foundation, New York Office, April 2013.

Nohlen, D., Zovatto, D., Orozco, J., Thompson, J. [2007]. Tratado de derecho electoral comparado de América Latina. México: FCE, Instituto Interamericano de Derechos Humanos, Universidad de Heidelberg, International IDEA, Tribunal Electoral del Poder Judicial de la Federación, Instituto Federal Electoral.

Nosthas, E. [2006]. Acciones del gobierno salvadoreño en torno a la migración. In González Gutiérrez, C. (ed.) [2006]. Relaciones Estado-diáspora: la perspectiva de América Latina y el 
Caribe. Mexico, D. F.: Miguel Ángel Porrua, UAZ, Secretaría de Relaciones Exteriores, Instituto de los Mexicanos en el Exterior, ANUIES.

Organisation for Economic Co-operation and Development (OECD) [2012]: Settling In: OECD Indicators of Immigrant Integration 2012. OECD Publishing.

DOI: http://dx.doi.org/10.1787/9789264171534-en

Orozco, M. [2005]. Transnationalism and Development: Trends and Opportunities in Latin America. In Maimbo, S., Ratha, D. (eds.), Remittances: Development Impact and Future Prospects: 307-329. The World Bank.

DOI: http://dx.doi.org/10.1596/0-8213-5794-8

Palma, E., Angeles, A. [2009]. Migración y políticas públicas. Una aproximación al Estado de México. In Baca, N., Herrera, F., González, R. [2009]. Migración, democracia y desarrollo: La experiencia mexiquense. Toluca : Instituto Electoral del Estado de México.

Parekh, B. [2002]. Rethinking Multiculturalism: Cultural Diversity and Political Theory. Cambridge, Mass. : Harvard University Press.

Piore, M. [1979]. Birds of Passage: Migrant Labor in Industrial Societies. Cambridge: Cambridge University Press.

DOI: http://dx.doi.org/10.1017/cbo9780511572210

Portes, A., Bach, R. [1985]. Latin Journey: Cuban and Mexican Immigrants in the United States. Berkeley: University of California Press.

Portes, A., Böröcz, J. [1989]. Contemporary Immigration: Theoretical Perspectives on its Determinants and Modes of Incorporation. International Migration Review. Vol. 23. No. 3: 606630.

DOI: http://dx.doi.org/10.2307/2546431

Portes, A., Zhou, M. [1993]. The New Second Generation: Segmented Assimilation and Its Variants. The Annals of the American Academy of Political and Social Science 530: 74-96.

DOI: http://dx.doi.org/10.1177/0002716293530001006

Portes, A., Guarnizo, L., Landolt, P. (eds.) [2003]. La globalización desde abajo: Transnacionalismo, immigrante y desarrollo. Mexico D.F.: FLACSO/Porrúa.

Prebisch, R. [1982]. The Crisis of Capitalism and the Periphery. Lecture at the United Nations Conference on Trade and Development, July 1982. United Nations, pp. 1-8.

Putnam, R. [1988] Diplomacy and domestic politics: The logic of two-level games. International Organization 42, 3, Summer 1988, pp. 427-460.

DOI: http://dx.doi.org/10.1017/s0020818300027697

Quijano, A. [2000] Coloniality of Power and Eurocentrism in Latin America. International Sociology, Vol. 15, Issue 2, pp. 215-232. DOI: http://dx.doi.org/10.1177/0268580900015002005

Radcliffe, S., Westwood, S. [1996]. Imagining the Nation / 'Race', State and Nation. In: Radcliffe, S., Westwood, S.: Remaking the Nation. Place, Identity and Politcs in Latin America. New York: Routledge, pp. $9-53$.

DOI: http://dx.doi.org/10.4324/9780203975558

Rédei, M. [2007] Hazautalások Kelet- és Közép-Európába. Statisztikai Szemle, 85/7, 581-601.

Richmond, Y. [2008] Practicing Public Diplomacy: A Cold War Odyssey. New York: Berghahn.

Rist, G. [1997]. The History of Development: From Western Origins to. Global Faith. London: Zed Books. 
Rostow, W. [1960]. The Stages of Economic Growth. A Non-Communist Manifesto. New York: Cambridge University Press.

DOI: http://dx.doi.org/10.1017/cbo9780511625824

Sabatier, P. [1999]. Theories of the Policy Process. Boulder, CO: Westview.

Sachs, W. [1992]. The Development Dictionary: A Guide to Knowledge as Power. London: Zed Books.

Said, E. [1977]. Orientalism. London: Penguin.

Sassen, S. [2006]. Foreign Investment: A Neglected Variable. In Messina, A, Lahav, G. (eds.), The Migration Reader. Exploring Politics and Policies: 596-608. London - Boulder, Colorado: Lynne Rienner Publishers, Inc.

Schierup, C., Hansen, P., Castles, S. [2006]. Migration, Citizenship and the European Welfare State. A European Dilemma. Oxford: Oxford University Press

DOI: http://dx.doi.org/10.1093/0198280521.001.0001

Schrover, M., Vermeulen, F. [2005]. Immigrant Organisations. Journal of Ethnic and Migration Studies Vol. 31, No. 5, September 2005, pp. 823-832.

DOI: http://dx.doi.org/10.1080/13691830500177792

Schwartz, S., Unger, J., Zamboanga, B., Szapocznik, J. [2010]. Rethinking the Concept of Acculturation: implications for theory and research. American Psychologist. Vol. 65. No. 4: 237251.

DOI: http://dx.doi.org/10.1037/a0019330

Sen, A. [1997]. Editorial: Human Capital and Human Capability. World Development, Vol. 25, No. 12: $1959-1961$.

DOI: http://dx.doi.org/10.1016/s0305-750x(97)10014-6

Sen, A. [1999]. Development as Freedom. Oxford: Oxford University Press

Sik, E. [2012] A migrációs burok jövője a globális-transznacionális világban. In: Sik, E. (ed.)

A migráció szociológiája 2. Budapest: ELTE TÁTK, 196-209.

Sjaastad, L. [1962]. The costs and returns of human migration. Journal of Political Economy 70S: 8093.

DOI: http://dx.doi.org/10.1086/258726

Skocpol, T. [1985]. Bringing the state back in: strategies of analysis in current research. In: Evans, P., Rueschemeyer, D. and Skocpol, P. (eds): Bringing the State Back In. Cambridge: Cambridge University Press.

DOI: http://dx.doi.org/10.1017/cbo9780511628283.002

Smith, R. C. [2006]. Mexican New York: Transnational Lives of New Immigrants. Berkeley: University of California Press.

Sokoloff, K. - Robinson, J. [2003]. Historical Roots of Inequality in Latin America and the Caribbean. In: Ferreira, F. et al [2003]. Inequality in Latin America: Breaking with History? World Bank Latin America and Caribbean Studies series. Washington DC: The International Bank for Reconstruction and Development / The World Bank, pp. 171 - 190.

Solimano, A. [2004]. Remittances by Emigrants: Issues and Evidence. In: Atkinson, A. B. (ed): New Sources of Development Finance. Oxford: Oxford University Press, pp. 177-199.

DOI: http://dx.doi.org/10.1093/0199278555.003.0009 
Solimano, A., Tokman, V. [2008]. Migraciones internacionales en un contexto de crecimiento económico: El caso de Chile. In: Andrés Solimano (ed.) [2008]: Migraciones internacionales en América Latina: Booms, crisis y desarrollo. Mexico, D. F. and Santiago de Chile : Fondo de Cultura Económica.

Solow, R. [1956]. A contribution to the theory of economic growth. Quarterly Journal of Economics 70 (1956): 65-94.

DOI: http://dx.doi.org/10.2307/1884513

Sørensen, N. N., Van Hear, N., Engberg-Pedersen, P. (eds.) [2002]: The Migration-Development Nexus. International Migration, vol. 40 (5), special issue.

DOI: http://dx.doi.org/10.1111/1468-2435.00211

Sørensen, N. N. [2004]. The Development Dimension of Migrant Remittances. IOM, Department of Migration Policy, Research and Communications.

Soto Priante, S., Velázquez Holguín, M. A. [2006]. El proceso de institucionalización del Programa $3 \times 1$ para Migrantes. In: Fernandez de Castro, R., Garcia Zamora, R. (ed.): El Programa 3x1 para Migrantes: Primera Política Transnacional en México? México, Porrúa, pp. 11-20.

Spanakos, A. [2011]. Citizen Chávez. The State, Social Movements, and Publics. Latin American Perspectives, Issue 176, Vol. 38, No. 1, January 2011, pp. 14-27.

DOI: http://dx.doi.org/10.1177/0094582x10384206

Stachowiak, S. [2009]. Pathways for Change: 6 Theories about How Policy Change Happens. Seattle: Organizational Research Services.

Stark, O. and Taylor, E. [1991]. Migration incentives, migration types: The role of relative deprivation. The Economic Journal 101: 1163-1178.

DOI: http://dx.doi.org/10.2307/2234433

Stefoni, C. [2011]. Migración, remesas y desarrollo. Polis (Santiago) 30/2011, pp. 495-521. DOI: http://dx.doi.org/10.4067/s0718-65682011000300023

Stiglitz, J., Sen, A., Fitoussi, J.-P. [2009]. Report by the Commission on the Measurement of Economic Performance and Social Progress. Technical Report. Paris: INSEE.

Stolcke, V. [1995]. Talking Culture: New Boundaries, New Rhetorics of Exclusion in Europe. Current Anthropology, Vol. 36, No. 1, Special Issue: Ethnographic Authority and Cultural Explanation (Feb. 1995): $1-24$.

DOI: http://dx.doi.org/10.1086/204339

Sunkel, O. [1969]. National development policy and external dependence in Latin America. The Journal of Development Studies. Volume 6, Issue 1, pp. 23-48.

DOI: http://dx.doi.org/10.1080/00220386908421311

Sumption, M. [2013]. Tackling Brain Waste: Strategies to Improve the Recognition of Immigrants' Foreign Qualifications. Washington, DC: Migration Policy Institute.

Szilágyi, Á. [2003] Magyarok Brazíliában és Portugáliában, régen és ma. In. Fischer, Ferenc (ed.) Iberoamericana Quinqueecclesiensis 1. Pécsi Tudományegyetem. Latin-Amerikai Központ.

Sznajder, M., Roniger, L. [2007]. Exile and the Politics of Exclusion in Latin America. Latin American Perspectives Vol. 34, No. 4, (Jul., 2007), pp. 7-30.

DOI: http://dx.doi.org/10.1177/0094582x07302891

Taylor, L., Bacha, E. [1976] The Unequalizing Spiral: A First Growth Model for Belindia. The Quarterly Journal of Economics, MIT Press, vol. 90(2), pages 197-218, May 1976.

DOI: http://dx.doi.org/10.2307/1884627 
Taylor, E. [1986]. Differential migration, networks, information and risk. In: Stark, O. (ed.) Research in Human Capital and Development, Vol. 4, Migration, Human Capital, and Development. Greenwich, Conn.: JAI Press, pp. 147-171.

Tedesco, L. [2008]. Inmigrantes latinoamericanos en España. Real Instituto Elcano, Anuario 2008, América Latina. Madrid : Real Instituto Elcano.

Texidó, E., Gurrieri, J. [2012]. Panorama Migratorio de América del Sur. Buenos Aires: IOM.

Todaro, M. [1969]. A model of labor migration and urban unemployment in less- developed countries. The American Economic Review 59: 138-48.

Todaro, M. [1976]. Internal Migration in Developing Countries. Geneva: International Labor Office. DOI: http://dx.doi.org/10.2307/2545164

Todaro, M., Smith, S. [2011]. Economic Development. Boston: Pearson.

Tóth, P. P. [2006]: Diasporisation and Population Development. In: Balogh, B., Ilyés, Z. (eds.) Perspectives of Diaspora Existence: Hungarian Diasporas in the Carpathian Basin - Historical and Current Contexts of a Specific Diaspora Interpretation and Its Aspects of Ethnic Minority Protection. Budapest: Akadémiai, pp. 99-105.

Tóth, J. [2010] Lehet-e normatív a migrációs politika? In: Hárs, Á., Tóth, J. (eds.) Változó migráció változó környezet. Budapest: MTA KI, pp. 193-220.

Tuirán, R. (ed.) [2000]. Migración México-Estados Unidos. Presente y futuro, Consejo Nacional de Población, México.

Tversky, A., Kahneman, D. [1981]. The Framing of Decisions and the Psychology of Choice. Science, 211(4481): 453-458.

DOI: http://dx.doi.org/10.1126/science.7455683

Urquidi, V. [2005]. Otro siglo perdido: las políticas de desarrollo en América Latina, 1930-2005. Mexico, D. F.: El Colegio de México.

Valenzuela, M. B. [2001]. Las condiciones de llegada y asentamiento de nuevos inmigrantes en ciudades globales. El caso de los mexicanos en el Harlem hispano de Nueva York. Papeles de Población, vol. 5, núm. 22, octubre-diciembre, pp. 69-103, Universidad Autónoma del Estado de México, México

Vargas, Y. [2011]. Dominicanos en el exterior: de la participación a la representatividad. Observatorio Político Dominicano, Unidad de Partidos Políticos.

Vega, J. A. [2011]. Hacia la construcción de una política integral de gestión migratoria en el Perú. Revista del Observatorio Andino de Migraciones TukuyMigra, Pontificia Universidad Católica del Perú, No. 5, Junio 2011, pp. 2-9.

Waldinger, R. [2013]. Immigrant transnationalism. Current Sociology September 2013, Vol. 61, No. 5-6, pp. 756-777. DOI: http://dx.doi.org/10.1177/0011392113498692

Wallerstein, I. [1979]. The capitalist world-economy. Cambridge : Cambridge University Press.

Wang, W., Fan, C. [2006]. Success or failure: selectivity and reasons of return migration in Sichuan and Anhui, China. Environment and Planning, 2006, Volume 38, pp. 939-958. DOI: http://dx.doi.org/10.1068/a37428

Weyland, K. [2001]. Clarifying a Contested Concept: Populism in the Study of Latin American Politics. Comparative Politics, Vol. 34, No. 1 (Oct 2001), pp. 1-22.

DOI: http://dx.doi.org/10.2307/422412 
Williamson, J. [1990]. What Washington Means by Policy Reform. In: Williamson, J. (Ed.). Latin American Adjustment: How Much Has Happened? Washington: Institute for International Economics.

Zelinsky, W. [1973]. The Cultural Geography of the United States. Upper Saddle River, NJ: Pearson Education.

Zhou, M. [2004]. Revisiting Ethnic Entrepreneurship: Convergences, Controversies, and Conceptual Advancements. International Migration Review 38 (3): 1040-1074.

DOI: http://dx.doi.org/10.1111/j.1747-7379.2004.tb00228.x

Žižek, S. [1997]. Multiculturalism, or, the cultural logic of multicultural capital. New Left Review (225): 28-51.

\section{Working papers and other analyses}

Agunias, D. [2010]. The Future of Diaspora Policy. WMR 2010 Background Paper. Geneva : International Organization for Migration.

Retrieved from http://publications.iom.int/system/files/pdf/wmr2010_future_diaspora_policy.pdf, accessed on 29 December 2013.

Aparicio, J., Meseguer, C. [2009]. The Electoral Determinants of Collective Remittances: The Mexican 3x1 Program for Migrants. IBEI Working Papers, CIDOB, Barcelona, 2009/22.

Retrieved from http://investigadores.cide.edu/aparicio/Aparicio\&Meseguer_3x1_IBEI_09.pdf, accessed on 10 January 2012.

Boccagni, P., Lagomarsino, F. [2009]. Enough to get back, or still better overseas? Recession, migration policies

and the prospects for return in Ecuador. Centre on Migration, Policy and Society, University of Oxford Annual Conference 2009.

Retrieved from https://www.compas.ox.ac.uk/fileadmin/files/Events/Annual_conferences/ conference_2009/B_Boccagni_Lagomarsino_Ecuador.pdf, accessed on 11 February 2012.

Boubtane, E., Coulibaly, D., Rault, Ch. [2011]. Immigration, Unemployment and Growth in the Host Country: Bootstrap Panel Granger Causality. Analysis on OECD Countries. IZA Discussion Paper No.5853, July 2011, Bonn : Institute for the Study of Labor (IZA) in Bonn.

Retrieved from http://ftp.iza.org/dp5853.pdf, accessed on 14 September 2013.

Capelli, C., Vaggi, G. [2014]. A better indicator for standard of living: The Gross National Disposable Income.

Centre for Economic Policy Research - VOX Portal.

Retrieved from http://www.voxeu.org/article/better-measure-standard-living, accessed on 25 September 2015.

Castillo Pavón, A. [2011]. Impacto socioeconómico de la entrega del capital semilla del Programa Fondo Concursable "El Cucayo" a personas migrantes retornadas y a las expectativas de de su proyecto de retorno. Thesis, Instituto de Altos Estudios Nacionales, Maestría en Alta Gerencia, Quito, Ecuador. Available at Retrieved from http://repositorio.iaen.edu.ec/bitstream/24000/2586/1/TESIS\%20IAEN-ANA\%20LUCIA $\% 20$ CASTILLO \%5b1\%5d.pdf, accessed on 26 February 2014.

Cattaneo, C., Fiorio, C., Peri, G. [2013]. What Happens to the Careers of European Workers When Immigrants “Take Their Jobs"? IZA Discussion Paper No.7282, March 2013, Bonn : Institute for the Study of Labor (IZA) in Bonn.

Retrieved from http://ftp.iza.org/dp7282.pdf, accessed on 29 December 2013. 
Centeno, M. A. [2005]. Leviatanes y Coyotes: Migración y Estado. No. 373, Working Papers from Princeton University, Woodrow Wilson School of Public and International Affairs, Center for Migration and Development.

Retrieved from https://ideas.repec.org/p/pri/cmgdev/wp0502p.html, accessed on 5 December 2012.

Ceriani, P. [2013] Migration, Citizenship and Free Movement in South America: A Rights-Based Analysis of Regional Initiatives. Draft paper prepared for the UNRISD Conference of Regional Governance of Migration and Socio-Political Rights: Institutions, Actors and Processes. 14-15 January 2013, Geneva, Switzerland

Retrieved from http://www.unrisd.org/80256B3C005BCCF9\%2F(httpAuxPages)\%2F174 C45EB44BF92D1C1257D6C0029E0CB\%2F\$file\%2FCeriani_Migration,\%20Citizenship\%20and\% 20Free\%20Movement\%20in\%20South\%20America.pdf, accessed on 10 October 2015.

Chaparro, F., Jaramillo, H., Quintero, V. [2004]. Aprovechamiento de la Diáspora e Inserción en Redes Globales de Conocimiento: El Caso de la Red Caldas. Informe preparado para el Banco Mundial (para el Knowledge for Development Program del Instituto del Banco Mundial) Bogotá, Colombia.

Retrieved from http://siteresources.worldbank.org/EDUCATION/Resources/2782001126210664195/ 1636971- 1126210694253/Colombia_Diasporas.pdf, accessed on 11 February 2012.

Comisión Nacional para la Protección y Defensa de los Usuarios de Servicios Financieros (CONDUSEF) [2015] 200 dólares, ¿Cuánto te cuesta enviar desde Estados Unidos a México? Retreived from http://mexicanosenelexterior.condusef.gob.mx/PDF-s/remesas/rem-comparaantes.pdf, accessed on 27 October 2015.

Czaika, M., de Haas, H. [2011]. The effectiveness of immigration policies: A conceptual review of empirical evidence. DEMIG/IMI Working Paper. Oxford, International Migration Institute, University of Oxford.

Retrieved from http://www.imi.ox.ac.uk/pdfs/wp/wp-33-11.pdf, accessed on 11 November 2013.

De Haas, H. [2008]. Migration and development. A theoretical perspective. Working Paper 9, International Migration Institute, James Martin 21st Century School, University of Oxford., 2008. Retrieved from http://www.imi.ox.ac.uk/pdfs/wp/wp-09-08.pdf, accessed on 10 October 2013.

De Haas, H., Fokkema, T., Fihri, M. [2009]. Return migration as failure or success? The determinants of return migration intentions among Moroccan migrants in Europe. Paper presented at XXVI IUSSP International Population Conference, 2009.

Retrieved from http://www.ncbi.nlm.nih.gov/pmc/articles/PMC4486414/, accessed on 28 December 2013.

De Haas, H. [2010]. Migration transitions: a theoretical and empirical inquiry into the developmental drivers of international migration. Working Paper 24, International Migration Institute, James Martin 21st Century School, University of Oxford.

Retrieved from http://www.imi.ox.ac.uk/pdfs/imi-working-papers/wp24-migration-transitions-1, accessed 14 September 2013.

De Haas, H. [2011]. The determinants of international migration: Conceiving and measuring origin, destination and policy effects. DEMIG/IMI Working Paper. Oxford, International Migration Institute, University of Oxford.

Retrieved from http://www.imi.ox.ac.uk/pdfs/wp/wp-32-11.pdf, accessed on 5 April 2013.

Deligdisch, R. [2008]. An Analogy Study of the Social Integration of Immigrants: The case of the German Jews in Argentina and Argentine Jews in Israel.

Retrieved from http://www.israel-sociology.org.il/uploadimages/immigration7.pdf, accessed on 28 December 2013.

Escobar, C. [2012]. Colombian and Dominican Immigrant Transnational Organizations and Development. Paper prepared for the Transnational Immigrant Organizations Network Conference. Princeton University, May 11-12, 2012. 
Retrieved from https://www.princeton.edu/cmd/working-papers/2012TransnationalMeeting/2012Colombia-Dominican.pdf, accessed on 9 December 2013.

Flores Jovel, B. [2011]. Análisis de la Iniciativa Unidos por la Solidaridad del Fondo de Inversión Social para el Desarrollo Local (FISDL) como modelo de gestión de codesarrollo en El Salvador, durante el periodo 2005-2010. Tesis de grado, Universidad de San Salvador, El Salvador, Octubre de 2011.

Retrieved from http://ri.ues.edu.sv/2894/1/An\%C3\%A1lisis\%20de\%20la\%20iniciativa\%20 unidos $\% 20$ por\%201a\%20solidaridad\%20del\%20fondo $\% 20 \mathrm{de} \% 20 \mathrm{inversi} \% \mathrm{C} 3 \% \mathrm{~B} 3 \mathrm{n} \% 20$ social $\% 20$ para $\% 20$ el $\% 20$ desarrollo $\% 20$ local $\% 20$ (FISDL) $\% 20$ como $\% 20$ modelo $\% 20$ de $\% 20$ gesti $\%$ C3\%B3n $\%$ $20 \mathrm{de} \% 20$ codesarrollo\%20en\%20El\%20Salvador,\%20durante $\% 20 \mathrm{el} \% 20$ periodo\%20\%2020052010..pdf, accessed on 10 January 2012.

Gamlen, A. [2006]. Diaspora engagement policies: What are they and what kinds of states use them? (Working Paper 06-32). Oxford, UK: COMPAS, University of Oxford. Reprinted in: Topic 19 Remittances, Diasporas, and States. Brooklyn NY: Social Science Research Council, March 2009. Retrieved from http://www.ssrc.org/workspace/images/crm/new_publication_3/\%7B0a6ab1518050-de11-afac-001cc477ec70\%7D.pdf, accessed on 18 January 2012.

Garzón, L. [2007]. Argentinos y ecuatorianos en Barcelona y Milán: trayectorias, dimensión urbana y capital cultural. Barcelona : Universitat Rovira i Virgili.

Retrieved from http://ddd.uab.cat/pub/papers/02102862n85/02102862n85p195.pdf, accessed on 28 December 2013.

Goldring, L. [2002]. Re-thinking Remittances: Social and Political Dimensions of Individual and Collective Remittances. Working paper, York University.

Retrieved from http://www.yorku.ca/cerlac/documents/Goldring.pdf, accessed on 12 March 2011.

González Ortiz, F., Rivera Sánchez, L. [2004]. Migrantes y políticas públicas. Apuntes desde la experiencia del programa „Iniciativa Ciudadana Tres por Uno” en los estados de México y Puebla. El Colegio Mexiquense, Zinacantepec, Colección Documentos de Investigación.

Goto, J. [2006]. Latin Americans of Japanese origin (Nikkeijin) working in Japan: A survey. Kobe: Kobe University.

Retrieved from http://www.rieb.kobe-u.ac.jp/academic/ra/dp/English/dp185.pdf, accessed on 28 December 2013.

Helliwell, J., Putnam, R. [1999]. Education and Social Capital. NBER Working Paper W7121. Cambridge: National Bureau of Economic Research.

Retrieved from http://college.holycross.edu/eej/Volume33/V33N1P1_19.pdf, accessed on 20 February 2014.

Herrera, W. [2011]. La construcción de la política de emigración del Estado ecuatoriano: el caso de las Casas Ecuatorianas en el exterior. Lecture at the IV Congress of the International Migration and Development Network:"Global Crisis and Migratory Strategies: toward the Redefinition of Migration Policies”, FLACSO, Quito, Ecuador, 19 May 2011.

Retrieved from http://rimd.reduaz.mx/ponencias_flacso/PonenciaWilliamHerrera.pdf, accessed on 26 February 2014.

Immigration Equality [2014]. Immigration Basics: Voluntary Departure.

Retrieved from http://immigrationequality.org/issues/law-library/lgbth-asylum-manual/voluntarydeparture/, accessed on 26 February 2014.

International Organization for Migration (IOM) [2008]. Migration and Climate Change. MRS $\mathrm{N}^{\circ} 31$, prepared for IOM by Oli Brown, International Organization for Migration, Geneva.

Retrieved from http://publications.iom.int/bookstore/free/MRS-31_EN.pdf, accessed on 14 September 2013.

Kahan, B. [2008]. Review of Evaluation Frameworks. Prepared by Kael Consulting for the Saskatchewan Ministry of Education, March 2008 
Retrieved from http://idmbestpractices.ca/pdf/evaluation-frameworks-review.pdf, accessed on 3 February 2014.

Kunz, R. [2010]. Mobilising Diasporas: A governmentality analysis of the case of Mexico. Glocal Governance and Democracy Series Working Paper 3, University of Lucerne.

Retrieved from https://www.unilu.ch/fileadmin/fakultaeten/ksf/institute/polsem/Dok/Diasporagoverning_-wp03.pdf, accessed on 28 March 2011.

Kuznetsov, Y. [2007]. Leveraging Talent Abroad for Home Country Development: Lessons from Asia and Europe for Pilot Diaspora Networks in Latin America. Lecture at the Knowledge for Development Program. Inter American Development Bank, 8 February, 2007.

Retrieved from http://web.worldbank.org/WBSITE/EXTERNAL/WBI/WBIPROGRAMS/KFDLP/ 0,,contentMDK:21202804 menuPK:2882115 pagePK:64156158 piPK:64152884 theSitePK:4611 98,00.html, accessed on 11 April 2011.

Laglagaron, L. [2010] Protection through Integration: The Mexican Government's Efforts to Aid Migrants in the United States. Washington, DC: Migration Policy Institute. Retreived from www.migrationpolicy.org/pubs/IME-Jan2010.pdf, accessed on 26 October 2015.

Ljungkvist, E. [2011] Remittances and Development in Ecuador. Thesis, Linnaeus University, School of Management and Economics.

Retrieved from lnu.diva-portal.org/smash/get/diva2.../FULLTEXT01, accessed on 26 February 2014.

Meyer, J. [2007]. Building Sustainability: The New Frontier of Diaspora Knowledge Networks. Working Papers - Center on Migration, Citizenship and Development; 35. Bielefeld: COMCAD.

Retrieved from https://www.uni-bielefeld.de/tdrc/ag_comcad/ downloads/workingpaper __35_ Meyer.pdf, accessed on 3 March 2012.

Manual del Regreso [2013] Manual del Regreso para Chilenos en el Exterior. Santiago: DICOEX IOM. Retreived from http://chileabroad.gov.cl/files/2013/04/MANUAL-DEL-REGRESO.pdf, accessed on 26 October 2015

Moncayo, M. [2011]. El plan "Bienvenid@S a Casa": Estudio sobre la experiencia del Fondo "El Cucayo". FLACSO Sede Ecuador, Quito - Fundación Carolina, Madrid. Serie Avances de Investigación $n^{\circ} 51$.

Retrieved from http://www.fundacioncarolina.es/wp-content/uploads/2014/07/Avance Investigacion_51.pdf, accessed on 13 February 2012.

Multilateral Investment Fund (MIF) [2012]. Remittances to Latin America and the Caribbean in 2012: Differing Behavior among Sub-regions.

Retrieved from http://www5.iadb.org/mif/en-us/home/knowledge/developmentdata/remittances .aspx, accessed on 12 February 2014.

Niessen, J., Huddleston, T. [2007]. Setting up a system of benchmarking to measure the success of integration policies in Europe. A study requested by the European Parliament's committee on Civil Liberties, Justice and Home Affairs.

Retrieved from http://www.migpolgroup.com/public/docs/18.Benchmarking_Integration_ EN_01.07.pdf, accessed on 28 December 2013.

O'Donnell, G. [1993]. Delegative Democracy? Kellogg Institute Working Paper \#192 (April 1993).

Retrieved from https://kellogg.nd.edu/publications/workingpapers/WPS/172.pdf, accessed on 7 March 2014.

Orozco, M., Rouse, R. [2007]. Migrant Hometown Associations and Opportunities for Development: A Global Perspective. Inter-American Dialogue, February 2007.

Retrieved from http://www.migrationinformation.org/feature/display.cfm?ID=579, accessed on 15 February 2014. 
Poletti, A. M. [2007]. Análisis comparativo sobre el derecho al voto, nacionalidad y migraciones en América Latina.

Retrieved from www.cristianbosch.com/downloads/analisisVoto.doc, accessed on 28 December 2013.

Portes, A., Escobar, C., Radford, A. [2005]. Immigrant Transnational Organizations and Development: A Comparative Study. Princeton University, August 2005, CMD Working Paper \#05-07.

Retrieved from https:/www.princeton.edu/cmd/working-papers/papers/wp0507.pdf, accessed on 5 February 2014.

Procuradoría Federal del Consumidor (PROFECO) [2015] Quién es quién en el envío de dinero. Retreived from http://www.profeco.gob.mx/envio/envio.asp, accessed on 26 October 2015.

Ramsey, G. [2012]. Tracing the Roots of El Salvador's Mara Salvatrucha. Insight Crime, 20 August 2012. Retrieved from http://www.insightcrime.org/news-analysis/history-mara-salvatrucha-elsalvador, accessed on 26 February 2014.

Reyes, M. [2013]. El Presupuesto Público Federal Centralizado para los Estados del país y el Distrito Federal, 2012-2013".

Retrieved from http://www.diputados.gob.mx/cedia/sia/se/SAE-ISS-05-13.pdf, accessed on 25 February 2014.

Romero Sánchez, J. [2004]. Migración y Aprovechamiento de Remesas: Un análisis sobre el impacto del Programa de Desarrollo Iniciativa Ciudadana 3x1 en Los Pilares, Santa María Texcalac y Lázaro Cárdenas en el estado de Tlaxcala. Tesis profesional. Puebla, Universidad de las Américas.

Sagarnaga Villegas, M. (ed.) [2004]: Evaluación del Programa Iniciativa Ciudadana 3x1, 2003. Cuarto Informe Red de Consultores Nacionales, S.C. México.

Retrieved from http://www.2006-2012.sedesol.gob.mx/work/models/SEDESOL/Evaluacion Programas Sociales/2003/EE_3X1_2003/Informe_final_3x1.pdf, accessed on 23 February 2012.

Secretaría General Iberoamericana (SEGIB) [2006]. Unidos por las migraciones. Encuentro Iberoamericano sobre Migración y Desarrollo. Madrid: SEGIB.

Retrieved from http://segib.org/documentos/esp/libromigraciones2008-web2.pdf, accessed on 11 February 2012.

Solimano, A. [2003]. Workers Remittances to the Andean Region: Mechanisms, Costs and Development Impact. Paper prepared for the Multilateral Investment Fund-IDB's Conference on Remittances and Development, May 2003, Quito-Ecuador.

Retrieved from https://publications.iadb.org/bitstream/handle/11319/744/Workers\%20Remittances $\% 20$ to $\% 20$ the $\% 20$ Andean\%20Region\%3A\%20Mechanisms, \%20Costs\%20and\%20Development\% 20Impact.pdf?sequence=1, accessed on 29 December 2013.

Solimano, A., Allendes, C. [2007]. Migraciones internacionales, remesas y el desarrollo económico: la experiencia Latinoamericana. CEPAL Informes 59, Santiago de Chile : División de Desarrollo Económico

Retrieved from http://repositorio.cepal.org/bitstream/handle/11362/5426/S0700878.pdf ?sequence $=1$, accessed on 28 December 2013.

Stiglitz, J. [2002] Whither Reform? Towards a New Agenda for Latin America. Prebisch Lecture, delivered at the Economic Commission for Latin America and the Caribbean, in Santiago, Chile, on 26 August 2002. 67 pages.

Retrieved from http://www.cepal.org/prensa/noticias/comunicados/1/10891/Stiglitzversion120603.pdf, accessed on 2 August 2013.

Vertovec, S. [2005]. The political importance of Diasporas. Working paper 13, Centre on Migration, Policy and Society (COMPAS): University of Oxford.

Retrieved from https://www.compas.ox.ac.uk/fileadmin/files/Publications/working_papers /WP_2005/Steve\%20Vertovec\%20WP0513.pdf, accessed on 12 October 2013. 
Vertovec, S. [2006]. Diasporas good? Diasporas bad? Working paper 41, Centre on Migration, Policy and Society (COMPAS): University of Oxford.

Retrieved from https://www.compas.ox.ac.uk/fileadmin/files/Publications/working_papers/ WP_2006/ WP0641-Vertovec.pdf, accessed on 12 October 2013.

\section{News articles}

Aguilar, J. [2015] New Consul Takes on Mexico's Texas Diaspora. 24 June 2015. Retreived from http://www.texastribune.org/2015/06/24/carlos-gonzalez-gutierrez-tt-interview/, accessed on 27 October 2015.

Departamento19.hn [2015] A fin de año hondureños en EEUU podrán contar con matricula consular. 8 June 2015. Retreived from http://departamento19.hn/index.php/portada/69-actualidad/29781-afin-de-ano-hondurenos-en-eeuu-podran-contar-con-matricula-consular.html, accessed on 27 October 2015.

El Ciudadano [2011]. Fondo Cucayo, una alternativa de producción para los migrantes. El Ciudadano, Periódico Digital del Gobierno de la Revolución Ciudadana, 7 February 2011.

Retrieved from http://www.elciudadano.gov.ec/index.php?option=com_content\&view=article\&id=21169: fondocucayo-una-alternativa-de-produccion-para-los-migrantes- $\&$ catid=4:social $\&$ Itemid=45, accessed on 4 March 2012.

El Comercio [2009a]. El Fondo Cucayo nutre a 61 proyectos. El Comercio, Cuenca, Ecuador, 24 August 2009. Retrieved from http://www.elcomercio.com/noticias/Fondo-Cucayo-nutreproyectos_0_103789630.html, accessed on 4 March 2012.

El Comercio [2009b]. Pocas ideas recibe el Fondo Cucayo. El Comercio, Ecuador, Corresponsal en Madrid, 20 September 2009.

Retrieved from http://www.elcomercio.com/noticias/Pocas-ideas-recibe-Fondo-Cucayo_0_ 119988131.html, accessed on 4 March 2012.

El Mercurio [2010]. Fondo Cucayo ayuda a reiniciar vidas. El Mercurio, Cuenca, Ecuador, 4 March 2010. Retrieved from http://www.elmercurio.com.ec/233080-fondo-cucayo-ayuda-a-reiniciarvidas.html, accessed on 4 March 2012.

El Telegrafo [2014] Retornados: de agentes económicos a generadores de conocimiento. Interview with María Isabel Moncayo, 6 June 2014. Retrieved from http://www.telegrafo.com.ec/economia/ masqmenos/item/retornados-de-agentes-economicos-a-generadores-de-conocimiento.html, accessed on 27 October 2015.

Elpais.com.uy [2014] Uruguayos podrán solicitar la tarjeta consular en todo Estados Unidos. 24 September 2014. Retreived from http://www.elpais.com.uy/informacion/uruguayos-podransolicitar-tarjeta-consular.html, accessed on 27 October 2015.

Expreso Latino [2010]. Presentan plan Cucayo para retorno a Ecuador. Rome, 10 March 2010. Retrieved from http://www.expresolatino.net/comunidad/ecuador/635-presentan-plan-cucayo-pararetorno-a-ecuador.html, accessed on 4 March 2012.

Mena Erazo, P. [2009]. Migrantes: historias de regreso a casa. BBC Mundo, Quito, 27 September 2009. Retrieved from http://www.bbc.co.uk/mundo/economia/2009/09/090927_1716_ecuador _regreso_migrantes_jrg.shtml, accessed on 4 March 2012.

Mena Erazo, P. [2011]. El inmigrante ecuatoriano busca otras tierras para afrontar la crisis. El País Internacional, 21 October 2011.

Retrieved from http://internacional.elpais.com/internacional/2011/10/21/actualidad/1319186484_ 883225.html, accessed on 4 March 2012. 
Radiolaprimerisima.com [2013] Unos tres mil nicas ya tienen tarjeta de identidad en EEUU. 25 April 2015. Retreived from http://www.radiolaprimerisima.com/noticias/140637/unos-tres-milnicas-ya-tienen-tarjeta-de-identidad-en-eeuu, accessed on 27 October 2015.

Remesas.org [2008]. Bolivia y Colombia cobrarán \$10 millones en 2007 a sus emigrantes en España con impuestos a las remesas.

Retrieved from http://www.remesas.org/impuesto.html, accessed on 15 January 2012.

Reyes, C. [2010]. "Razú", otro negocio ganador del fondo Concursable El Cucayo. Radio Sucre, 9 April 2010. Retrieved from http://radiosucre.com.ec/portal/index.php?option=com_content\&task =view\&id=24130\& Itemid=2, accessed on 4 March 2012.

Rosero, H. [2009]. Fondo Concursable para el retorno digno y sostenible "El Cucayo". Empresario Migrante, Red de Empresarios Migrantes, 9 December 2009.

Retrieved from http://www.empresariomigrante.com/el-cucayo.html, accessed on 4 March 2012.

\section{Government websites}

Colombianosune.com [2015] Sistema de servicios. Retreived from http://www.colombianosune.com/ejes/servicios-colombianos-exterior, accessed on 17 October 2015.

Proyecto Cidesal [2008]. Programme description.

Retrieved from http://www.msh-m.fr/IMG/Proyecto_CIDESAL_version_espanol_.pdf, accessed on 10 April 2012.

Redescolombia.org [2012]. Programme description.

Retrieved from http://www.redescolombia.org/quienessomos/colombianosune/ejesdetrabajo/ altamentereconocidos, accessed on 10 April 2012.

SENAMI [2011]. Secretaría Nacional del Migrante, Ecuador.

Retrieved from http://www.senami.gob.ec/proyectos/incentivo-a-la-inversion/fondo-cucayo.html, accessed on 4 March 2012.

\section{Other websites}

Bankofamericaboycott.com [2015] Bank of America boycott. Retreived from http://www.bankofamericaboycott.com/banklist/index.shtml, accessed on 27 October 2015.

DolarToday.com [2015] Noticias de Venezuela y Dólar Paralelo. Retreived from https://dolartoday.com/, accessed on 16 October 2015.

Keytlaw.com [2015] Customer Identification Program (CIP) Under the United States of America Patriot Act. Retreived from http://www.keytlaw.com/usrealestatelaw/open-us-bank-account/, accessed on 27 October 2015.

WorldSalaries.org [2006] International Average Salary Income Database. Retreived from http://www.worldsalaries.org/, accessed on 27 January 2012. 


\section{Data tables}

IATA Timatic Web Database [2015].

Retrieved from http://www.iata.org/ps/publications/Pages/tim.aspx, accessed on 15 September 2015.

\section{Latinobarómetro [2013].}

Retrieved from http://www.latinobarometro.org/latOnline.jsp, accessed on 27 September 2015.

The Maddison Project [2013].

Retrieved from http://www.ggdc.net/maddison/maddison-project/home.htm ， 2013 version, accessed on 19 September 2015.

United Nations [2013]. Trends in International Migrant Stock: Migrants by Destination and Origin (United Nations Department of Economic and Social Affairs database, POP/DB/MIG/Stock/Rev.2013).

Retrieved from http://www.un.org/en/development/desa/population/migration/data/estimates2/ estimatesorigin.shtml, accessed on 15 September 2015.

United Nations Population Database [2013]. World Population Prospects: The 2012 Revision. Retrieved from http://data.un.org/Data.aspx?d=PopDiv\&f=variableID\%3A85, accessed on 15 September 2015.

United Nations Development Programme [2014]. Human Development Report - Statistical Tables. Retrieved from http://hdr.undp.org/en/data, accessed on 15 September 2015.

United Nations Population Database [2015a]. World Population Prospects: The 2015 Revision. File POP/1-1: Total population (both sexes combined) by major area, region and country, annually for 1950-2100 (thousands).

Retrieved from http://esa.un.org/unpd/wpp/DVD POP/DB/WPP/Rev.2015/POP/F01-1, accessed on 5 October 2015.

United Nations Population Database [2015b]. World Population Prospects: The 2015 Revision. File POP/2: Average annual rate of population change by major area, region and country, 1950-2100 (percentage).

Retrieved from http://esa.un.org/unpd/wpp/DVD POP/DB/WPP/Rev.2015/POP/F02, accessed on 5 October 2015.

United Nations Population Database [2015c]. World Population Prospects: The 2015 Revision. File POP/7-1: Total population (both sexes combined) by five-year age group, major area, region and country, 1950-2100 (thousands).

Retrieved from http://esa.un.org/unpd/wpp/DVD POP/DB/WPP/Rev.2015/POP/F07-1, accessed on 5 October 2015.

World Bank [2014]. Country classification for 2015.

Retrieved from http://data.worldbank.org/news/2015-country-classifications, accessed on 2 October 2015.

World Bank [2015a]. Foreign direct investment, net inflows (BoP, current US\$)

Retrieved from http://data.worldbank.org/indicator/BX.KLT.DINV.CD.WD, accessed on 5 October 2015.

World Bank [2015b]. GDP per capita (current US\$)

Retrieved from http://data.worldbank.org/indicator/NY.GDP.PCAP.CD, accessed on 5 October 2015.

World Bank [2015c]. GDP (current US\$)

Retrieved from http://data.worldbank.org/indicator/NY.GDP.MKTP.CD, accessed on 5 October 2015. 
World Bank [2015d]. Industry, value added (\% of GDP)

Retrieved from http://data.worldbank.org/indicator/NV.IND.TOTL.ZS, accessed on 5 October 2015.

World Bank [2015e]. Net migration

Retrieved from http://data.worldbank.org/indicator/SM.POP.NETM, accessed on 5 October 2015.

World Bank [2015f]. Personal remittances, received (current US\$)

Retrieved from http://data.worldbank.org/indicator/BX.TRF.PWKR.CD.DT, accessed on 5 October 2015.

World Bank [2015g]. Unemployment, total (\% of total labor force) (modeled ILO estimate)

Retrieved from http://data.worldbank.org/indicator/SL.UEM.TOTL.ZS, accessed on 5 October 2015.

World Bank [2015h]. Urban population (\% of total)

Retrieved from http://data.worldbank.org/indicator/SP.URB.TOTL.IN.ZS, accessed on 5 October 2015.

World Bank [2015i]. Worldwide Governance Indicators, the 2015 update.

Retrieved from www.govindicators.org, accessed on 11 October 2015.

\section{Laws, decrees and other legal and policy documents}

Organization of American States (OAS) [1954]. Caracas Convention on Diplomatic Asylum. Retrieved from http://www.oas.org/juridico/english/treaties/a-46.html, accessed on 28 December 2013.

Vienna Convention on Consular Relations [1963] Retreived from http://legal.un.org/ilc/texts/ instruments/english/conventions/9_2_1963.pdf, accessed on 19 October 2015.

Vienna Convention on Diplomatic Relations [1961] Retreived from http://legal.un.org/ilc/texts/ instruments/english/conventions/9_1_1961.pdf, accessed on 19 October 2015.

\section{Argentina}

- $\quad$ Migration Law ( $\mathrm{N}^{\circ} 25.871$, in 2004)

- New Argentine Migratory Policy (Nueva Política Migratoria argentina, NPMA, on immigration only, in 2003)

\section{Bolivia}

- $\quad$ Migration Law ( $\mathrm{N}^{\mathrm{o}} 370$, in 2013)

\section{Brazil}

- Alien Statute Law (No 6815, in 1980)

- Proposal for a Migration Law, Bill (Projeto de Lei) 288/2013

Chile

- Decree-Law on Alien Affairs ( $\mathrm{N}^{\circ} 1094$, in 1975)

\section{Colombia}

- Law on the National Migration System( $\mathrm{N}^{\circ} 1465$, in 2011)

- Law on Return Migration ( $N^{\circ} 1565$, in 2012)

- Decree on the National Intersectorial Commission on Migration ( $\mathrm{N}^{\circ} 1239$, in 2003)

- Decree on the Modification of the Structure of the Ministry of Foreign Affairs $\left(\mathrm{N}^{\circ} 3355\right.$, in 2009)

- Integral Migration Policy (Política Integral Migratoria, Document $\mathrm{N}^{\mathrm{o}} 3603$ CONPES, in 2009) 


\section{Costa Rica}

- Law on Migration and Alien Affairs (No 8764, in 2010)

- " 'Integral Migratory Policy" (Política Migratoria Integral) document by the National Council of Migration (in 2013)

\section{Cuba}

- Decree-Law on Migration ( $\mathrm{N}^{\mathrm{o}}$ 302, in 2013)

\section{Dominican Republic}

- $\quad$ Migration Law ( $\mathrm{N}^{\mathrm{o}} 285$, in 2004)

\section{Ecuador}

- $\quad$ Migration Law (in 2005, modified several times)

- National Plan on Ecuadoreans Abroad (Plan Nacional de Ecuatorianos en el Exterior, in 2001)

- National Plan on Human Development for Migrations (Plan Nacional de Desarrollo Humano para las Migraciones 2007-2010, in 2007)

- Plan of Return for the Ecuadorean Migrant (Plan de Retorno para el Migrante Ecuatoriano, in 2008)

- $\quad$ Proposal for a Law on Human Mobility (Proyecto de Ley de Movilidad Humana)

- Proposal for an Organic Law on Protection and Equality of Rights of Ecuadorean Migrants Residing Abroad (Ley Orgánica de Protección e Igualdad de Derechos de los Migrantes Ecuatorianos Residentes en el Exterior)

\section{El Salvador}

- $\quad$ Migration Law (in 1959)

- Special Law for the Protection and Development of the Salvadorean Migrant Person and his/her Family (Ley Especial para la Protección y Desarrollo de la Persona Migrante Salvadoreña y su Familia, in 2011)

- Institutional Policy of Protection and Linkage for the Migrant Salvadoreans (Política Institucional de Protección y Vinculación para los Salvadoreños Migrantes, in 2014)

\section{Guatemala}

- $\quad$ Migration Law (in 1999)

\section{Honduras}

- $\quad$ Law on Migration and Alien Affairs (Decree $\mathrm{N}^{\circ} 208$, in 2003)

- Law on the Protection of Migrant Hondurans and their Families (Ley de Protección de los Hondureños Migrantes y sus Familiares, Decree $\mathrm{N}^{\circ}$, in 2013)

\section{Mexico}

- $\quad$ Migration Law (in 2011)

- Decree creating the Institute of Mexicans Abroad (Decreto por el que se crea el Instituto de los Mexicanos en el Exterior, con el carácter de órgano administrativo desconcentrado de la Secretaría de Relaciones Exteriores, D.O.F. 16 abril 2003, in 2003)

- Proposal for a Law on Attention to and Protection of Mexicans Abroad (Proyecto de Ley de Atención y Protección de los Mexicanos en el Exterior)

\section{Nicaragua}

- $\quad$ Migration Law ( $\mathrm{N}^{\circ} 761$, in 2011)

- Special Law on [Return] Migration Incentives (Ley especial de Incentivos Migratorios, $N^{\circ}$ 535, in 2005)

- Proposal for a Law on Attention to and Protection of the Nicaraguan Migrant Abroad (Proyecto Ley de atencion y proteccion al migrante nicaraguense en el exterior)

\section{Panama}

- Decree-Law on the National Migration Service (Decreto-Ley que crea el Servicio Nacional de Migración, la Carrera Migratoria y dicta otras disposiciones, in 2008) 


\section{Paraguay}

- $\quad$ Migration Law ( ${ }^{\circ}$ 978, in 1996)

\section{Peru}

- $\quad$ Migration Law (Legislative Decree $N^{\circ} 1236$, in 2015)

- Law on the Consultative Concils of Peruvian Communities Abroad (Ley de los Consejos de Consulta de las Comunidades Peruanas, Law N² 29495, in 2012)

- Law on the Economic and Social Reinsertion of the Returned Migrant (Ley de reinserción económica y social del migrante retornado, $N^{\circ} 30001$, in 2013)

- Resolution of the Minister of Foreign Affairs No.1197 of 2002

- Resolution of the Minister of Foreign Affairs No. 0687 of 2004

\section{Uruguay}

- Law on Migration and Return ( $\mathrm{N}^{\circ} 18.250$, in 2008)

\section{Venezuela}

- Law on Alien Affairs and Migration ( $\mathrm{N}^{\circ} 37.944$, in 2004)

- Proposal for a Law of Repatriation of Goods of Venezuelans Abroad (Ley de Repatriación de Bienes de venezolanos en el exterior) (or an emigrant tax)

\section{Own Survey (Diaspora Unit Survey among Latin American Governments, DUS)}

DUS Argentina (received on 17 November 2014)

DUS Brazil (received on 6 November 2014)

DUS Chile (received on 13 October 2014)

DUS Colombia (received on 7 May 2015)

DUS Costa Rica (received on 3 October 2014)

DUS Ecuador (received on 14 October 2014)

DUS Guatemala (received on 16 April 2015)

DUS Mexico (received on 16 October 2015)

DUS Peru (received on 30 September 2014)

DUS Uruguay (received on 1 November 2014) 


\section{List of related publications of the author}

Soltész, B. [2016] Migration - challenge or opportunity? (forthcoming)

Book chapter, in: Balázs, P. (ed.): The changing world order and its implications for the "wider Europe" series - Book No. 2 "Sectoral policies for a broader EU". Budapest : Central European University - Center for EU Enlargement Studies (CENS)

Soltész, B. [2015] Politikai átmenetek - migrációs átmenetek? Kelet-Európa és Latin-Amerika migrációs átmeneteink összehasonlítása [Political Transitions - Migration Transitions? A Comparison of Eastern European and Latin American Migratory Processes]. Journal article, Tér és Társadalom [Space and Society], 2015/4. pp. 5-26.

Soltész, B. [2015] Kivándorlás és diaszpóra-politika Latin-Amerikában [Emigration and diaspora policies in Latin America].

Journal article, Külügyi Szemle [Hungarian Foreign Policy Review], 2015/2. pp. 42-62.

Soltész, B., Szakál, D. [2015] Migránsok instrumentális kapcsolathálójának feltérképezése: egy szituációs névgenerátor [Mapping the instrumental network of migrants: a situational name generator]

Book chapter, in: Kováts, A., Várhalmi, Z. (eds.): Integrációs kutatások módszertana [Methodology for migrant integration research.] Budapest : The Interdisciplinary Centre for Comparative Research in the Social Sciences (ICCR)

Soltész, B. [2015] Latin-amerikai migrációs körkép [Migration in Latin America: an overview] Book chapter, in: Tarrósy, I., Glied, V., Vörös, Z. (eds.): Migrációs tendenciák napjainkban [Contemporary tendencies in international migration]. Pécs : IDResearch.

Gödri, I., Soltész, B., Bodacz-Nagy, B. [2014] Immigration or emigration country? Migration trends and their socio-economic background in Hungary: A longer-term historical perspective.

Working paper, 77 pages, Working Papers on Population, Family and Welfare, No. 19, Hungarian Demographic Research Institute, Budapest.

Soltész, B., Zimmerer, G. [2014] Migration between the EU, V4 and Eastern Europe: the present situation and possible future. The perspective of Hungary.

Book chapter, in: Jaroszewicz, M., Lesińska, M. (eds.): Forecasting migration between the EU, V4 and Eastern Europe - Impact of visa abolition. Ośrodek Studiów Wschodnich im. Marka Karpia / Centre for Eastern Studies, pp. 122-138.

Soltész, B. [2014] Data Sources on International Migration in the Eastern Partnership and the Visegrad Countries

Book chapter, in: Erőss, Á., Karácsonyi, D. (eds.): Discovering migration between Visegrad countries and Eastern Partners: Czechia, Hungary, Poland, Slovakia, Belarus, Georgia, Ukraine and Moldova on the eastern edges of the Schengen area. Budapest : Hungarian Academy of Sciences, Research Centre for Astronomy and Earth Sciences - Geographical Institute, pp. 12-39.

Kiss, A., Soltész, B. [2013] Technikai és pénzügyi segítségnyújtás migráns szervezeteknek Portugáliában [Technical and financial assistance for migrant NGOs in Portugal]

Book chapter, in: Bodolai, A., Kováts, A. (eds.): A nyelvtanulástól a politikai részvételig. Bevándorlók integrációját támogató programok az Európai Unióban [From language learning to political participation. Migrant integration programmes in the European Union]. Budapest : The Interdisciplinary Centre for Comparative Research in the Social Sciences (ICCR), pp. 61-84.

Soltész, B. [2013] Migránsok: A nemzetközi fejlesztési együttmüködés új szereplői? [Migrants: The New Actors in International Development?]

Journal article, Kül-Világ, No. 2. [2013], pp. 16-34.

Available at: http://www.kul-vilag.hu/2013/02/soltesz.html 
Soltész, B. [2013] Migración, remesas y desarrollo en América Latina [Migration, remittances and development in Latin America]

Book article, in: Fischer, F., Lilón, D. (eds.): Iberoamericana Quinqueecclesiensis No. 11. Pécs : University of Pécs, Ibero-American Centre

Soltész, B. [2012] Clandestino. Egy év Latin-Amerikában [Clandestino. One year in Latin America] Book, 314 pages, Pécs : Publikon.

Soltész, B. [2012] Migráció és fejlődés: mit tehet az állam? [Migration and Development: What Can a Government Do?]

Journal article, Délkelet-Európa - South-East Europe, 2012/1.

Available at: http://www.southeast-europe.org/pdf/09/DKE_09_M_N_Soltesz-Bela.pdf

Soltész, B. [2011] Latin-Amerika: Integrációk túlkínálata [Latin America: An Excess Supply of Integrations].

Journal article, Fordulat, 2011/4 , pp. $124-143$.

Soltész, B. [2011] A dél-amerikai horvát emigráció [The Croatian Emigration to South America]. Journal article, Délkelet-Európa - South-East Europe, 2011/1.

Available at: http://www.southeast-europe.org/pdf/5/DKE_05_M_M_SB.pdf

Soltész, B. [2010] Globális kihívás, globális válasz, lokális ellenállás? Az ENSZ Migráns munkavállalók és családtagjaik jogainak védelméről szóló nemzetközi egyezményének kudarca. [Global Challenge, Global Response, Local Resistance? The Failure of UN's International Convention on the Protection of the Rights of All Migrant Workers and Members of Their Families] Journal article, Grotius - A BCE Nemzetközi Tanulmányok Intézetének tudományos folyóirata [Scientific Journal of the Institute of International Studies of the Corvinus University of Budapest], 28 June 2010

Available at: http://www.grotius.hu/publ/displ.asp?id=RHLKDX

Soltész, B. [2010] Az UNASUR. A Dél-Amerikai Nemzetek Uniójának perspektívái és kihívásai. [UNASUR - Perspectives and Challenges of the Union of South American Nations]

Book chapter, in: Palánkai, T. (ed.): Tanulmányok a regionális integráció témaköréből, 2. Regionális integrációk - összehasonlító tanulmányok [Essays on Regional Integration 2. Regional Integrations - Comparative Analyses]. Savaria University Press, Szombathely.

Soltész, B. [2008] A demokratikus Spanyolország Latin-Amerika-politikája [Spanish Foreign Policy towards Latin-America after Franco].

Journal article, Grotius - A BCE Nemzetközi Tanulmányok Intézetének tudományos folyóirata [Scientific Journal of the Institute of International Studies of the Corvinus University of Budapest], 13 May 2008

Available at: http://www.grotius.hu/publ/displ.asp?id=CAIOAA 